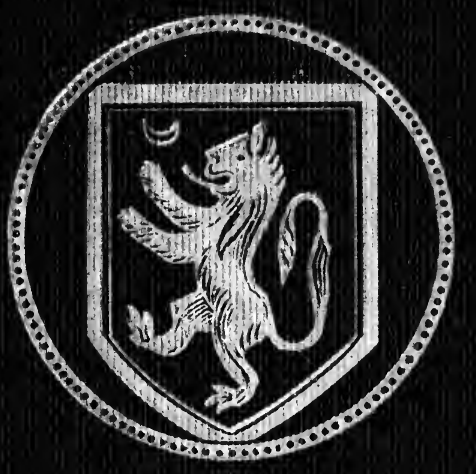

tho: Dwohy. 


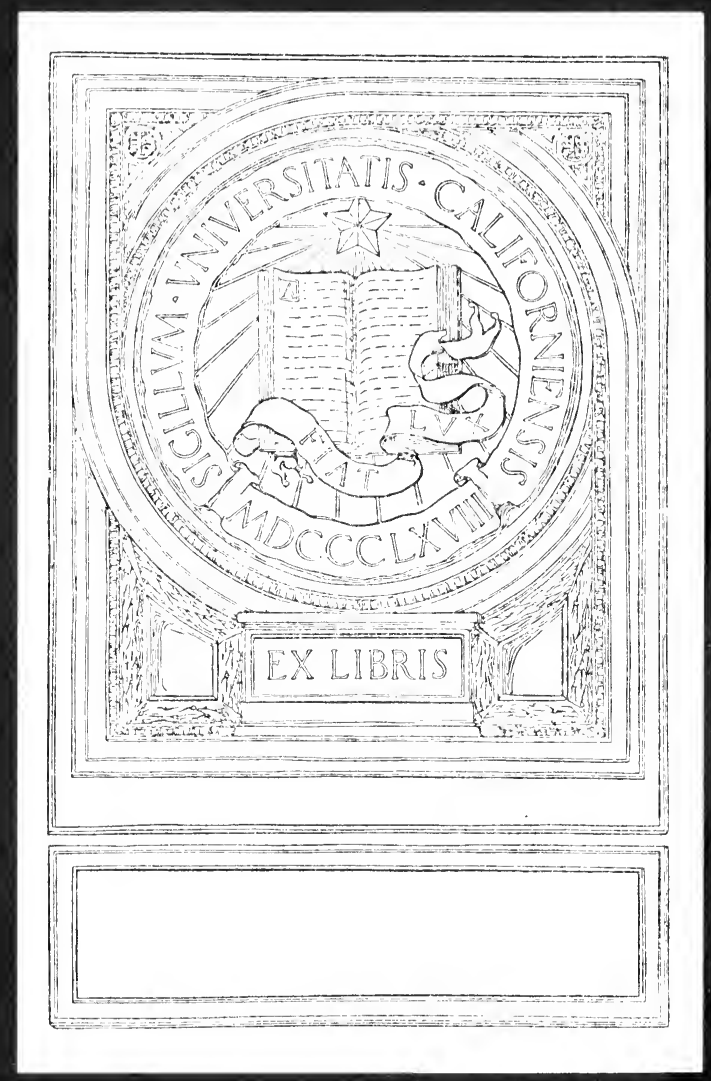




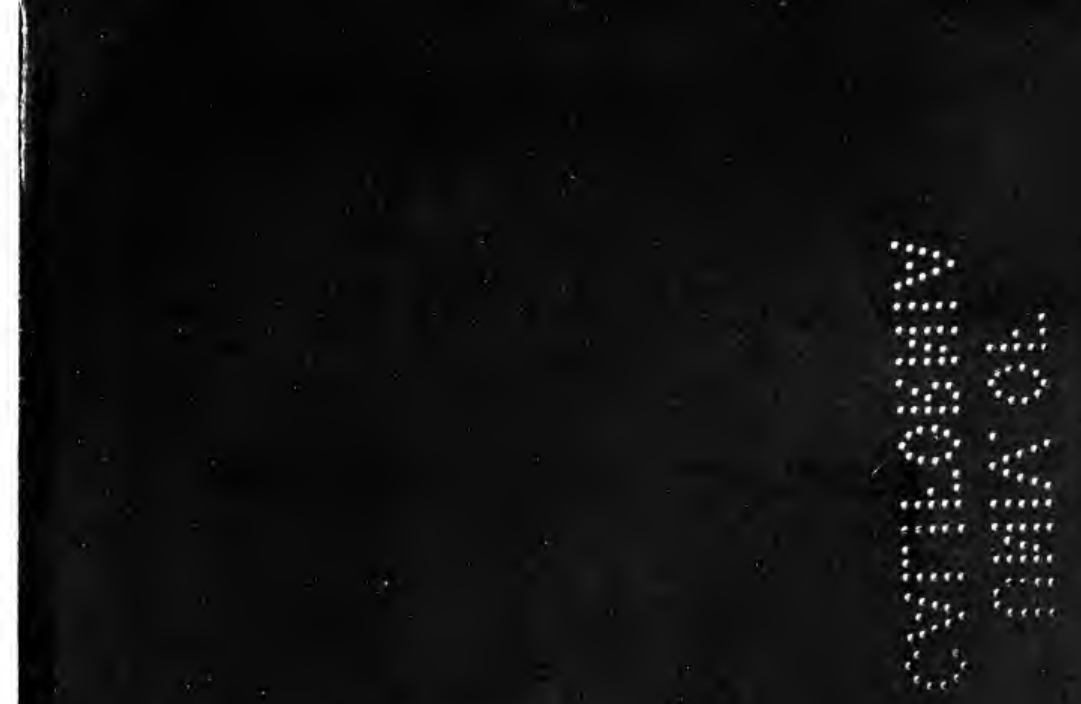




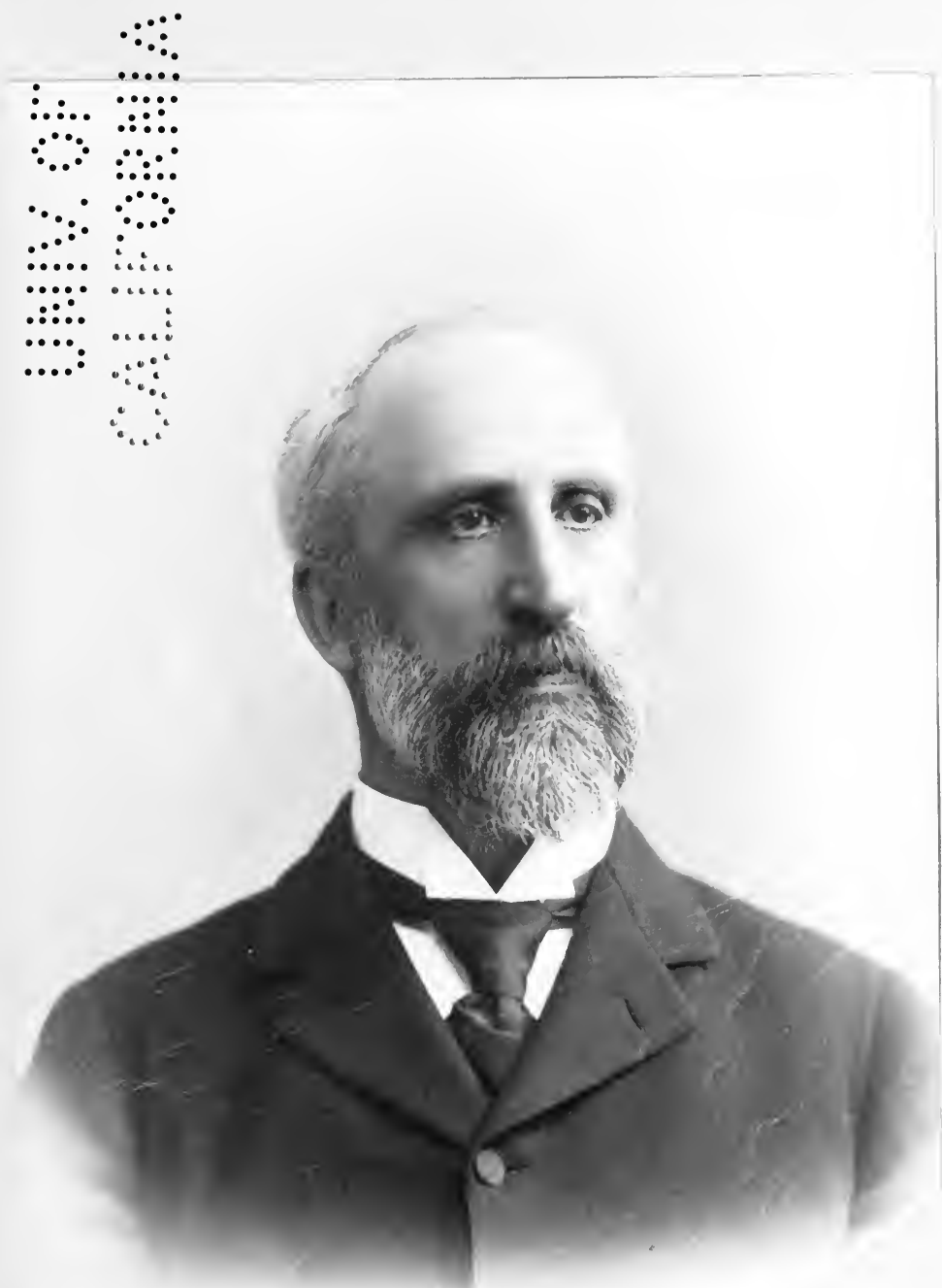




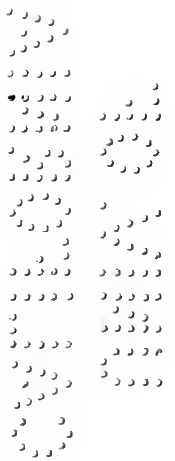




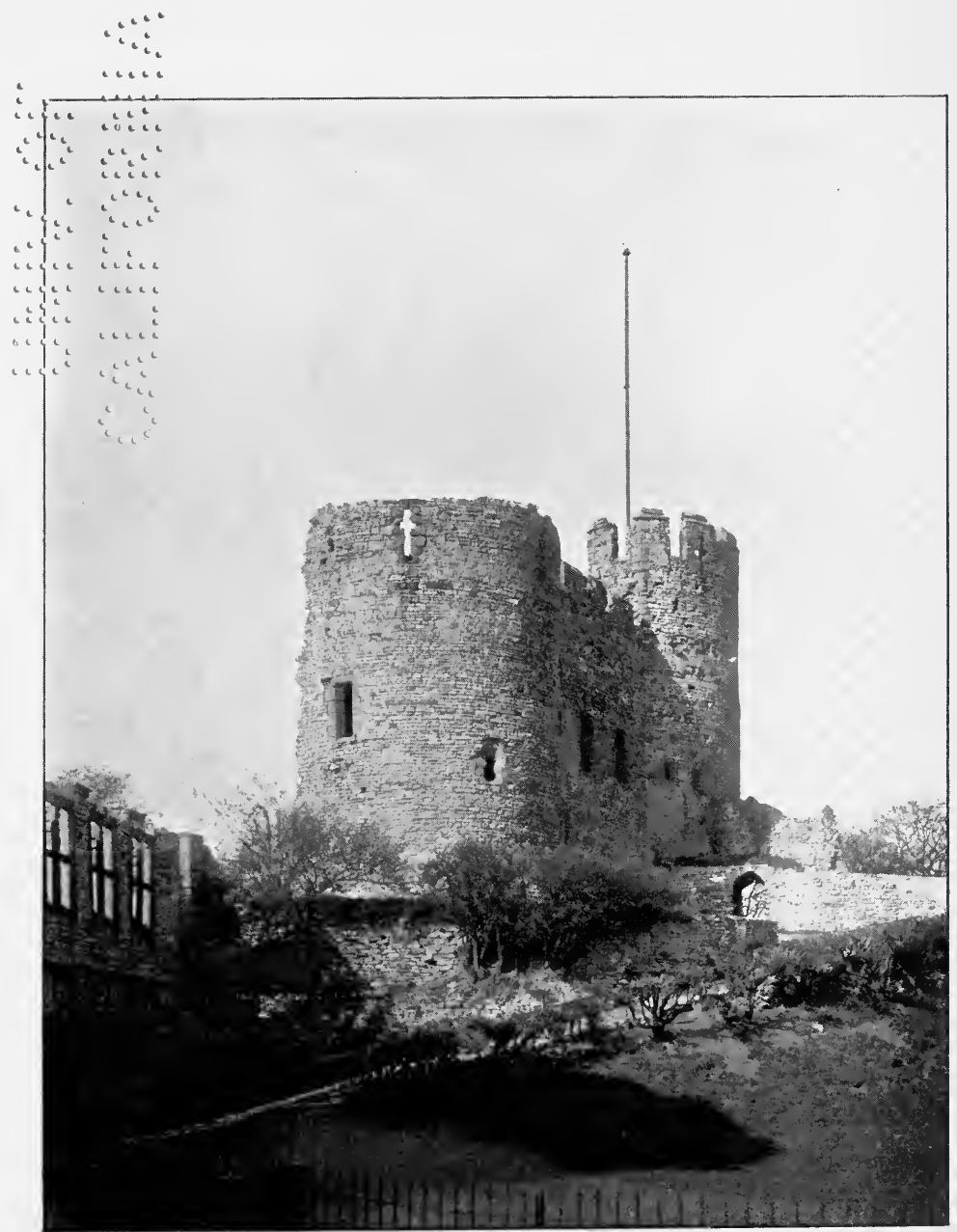

DUDLEY CASTLE (Page 6) 


\title{
THE LIFE AND WORK OF
}

\section{*THOMAS DUDLEY}

\author{
THE SECOND GOVERNOR OF
}

MASSACHUSETTS

BY

\section{AUGUSTINE JONES, A.M., LL.B.}

MEMBER OF THE RHODE ISLAND HISTORICAL SOCIETY AND OF THE NEW ENGLAND HISTORIC GENEALOGICAL SOCIETY

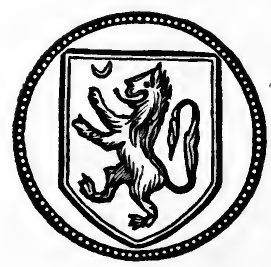

BOSTON AND NEW YORK

HOUGHTON, MIFFLIN AND COMPANY

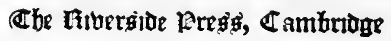




\section{F 67 \\ I8 236}

COPYRIGHT, 1899, BY AUGUSTINE JONES

ALL RIGHTS RESERVED

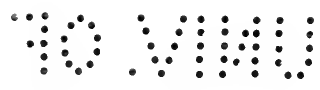

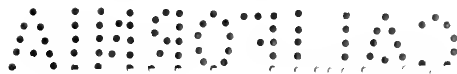


To

The Honorable Thomas B. Reed, Ll. D.

Whose illustrious career, in a more conspicuous public service, distinguished for patriotism, foresight, and wisdom, is in striking accord with that of him whose personal history at the beginning of the Republic is here delineated, this work is inscribed by his sincere friend and classmate,

AUGUSTINE JONES. 



\section{PREFACE}

THis Life of Governor Thomas Dudley has been written, especially so far as it pertains to Massachusetts, upon the authority of the public records, while the earlier portion, describing his career in England, has been produced chiefly from the literature which appeared immediately after his time.

We have not overlooked those writers who, during more than two centuries, have recorded with great unanimity their opinions respecting the bigotry of Dudley.

We indulge the hope that the thoughtful reader will conclude with us that an injustice has been done to the memory of an excellent man, who cordially welcomed truth from every source.

Dean Stanley has truly said, "Every one is familiar with the reversal of popular judgments respecting individuals or events of our own time. It would be an easy, though perhaps an invidious task, to point out the changes from obloquy to applause." 1

Our explanation of the adverse opinions and offensive epithets applied to Dudley is well expressed by the poet Prior. ${ }^{2}$

Dudley was as liberal in religion and politics as the public

1 Hist. Mem. Canterbury, by A. P. Stanley, 59.

2 "Till their own dreams at length deceive 'em, And oft repeating they believe 'em."

(Alma, iii. Canto 30.) 
sentiment of his age allowed, and nothing beyond this can be required. He was not then regarded as intolerant, and the judgment of his neighbors and peers is the only reasonable one.

The difficulties of our undertaking are set forth so fully in the first chapter that it is not essential to enlarge upon them here. The Puritanic quality of our theme has led us into some digression, in search for the social life in the midst of which Puritanism flourished.

It is said that Cromwell possessed a "massive stature; big, massive head, of somewhat leonine aspect ; wart above the right eyebrow ; nose of considerable blunt-aquiline proportions," 1 and that when a limner attempted to improve on nature in painting his portrait, he impatiently exclaimed, "Paint me as I am."

Thomas Dudley had the same unaffected, rugged character. He would say to us if he could, "I lived and acted regardless of praise or blame. I appeal from the unfair and incomplete judgments of biased men, to that unerring judge who knew my motives, inspired and led me in life. I ask neither apologies nor explanations respecting my life work. But if I am to be painted, ' paint me as I am,' for I say with Othello, 'Speak of me as I am; nothing extenuate, nor set down aught in malice.' "

The aim of the author has not been chiefly vindication, but to present the notable career of an eminent founder of New England, a public servant whose honest, healthful methods in public life are at present worthy of imitation. We must return with all possible speed to the same faithful, intelligent administration of the affairs of state which distinguished Dudley, to protect ourselves from great evils and

1 Carlyle's Speeches and Letters of Cromwell, ii. 287. 
political corruptions, which at present menace our institutions.

Mr. Moses Coit Tyler, says: "Doubtless we shall be ready to say with Nathaniel Hawthorne: 'Let us thank God for having given us such ancestors; and let each successive generation thank him not less fervently for being one step removed further from them in the march of ages.' "

Human progress in recent centuries has been sufficient to awaken the gratitude of thoughtful men for having been born into modern society with its light and culture.

A few hundred years later our descendants will be commiserating us on the intolerable evils of society in our day. They will also bring us into comparison with themselves, pluming themselves over our records, deriding our inhumanity to man, our cruelty to animals, and entertaining themselves with our antique foolishness. We shall be fortunate if our service to the world, with a perspective of as many years, is as creditable under examination as that of the Puri$\tan$ founders of New England.

We heartily approve of the first clause of the quotation, "Let us thank God for such ancestors." We neither adopt all of their theology nor all of their practices. We have a similar hesitancy respecting some of the teachings of Moses, the great lawgiver of antiquity. Both the Puritans and that eminent Hebrew were lights in the world in the greatest of all concernments, and are to be judged in the wisdom and intelligence of their respective periods and environments. The fundamental truth of all pure religions, indeed of the universal religion itself, which was proclaimed to the Samaritan woman at Jacob's well, was the groundwork, enduring and life-giving, of both manifestations of truth. ${ }^{1}$

1 The family of Thomas Dudley was undoubtedly more important in 
We tender our grateful acknowledgments to the Governor Thomas Dudley Association of Boston, Mass., for their important assistance in this undertaking.

We are greatly indebted to the valuable "History of the Dudley Family," by Dean Dudley, Esq., and also to the invaluable services of Caroline Rathbone Jones, whose earnest labors have entered into this work with unfaltering energy.

the affairs of Massachusetts during her first hundred years, or until a quarter of a century previous to the Declaration of Independence, than any other family of the original undertakers, assistants, or governors. A democratic revolution at the close of that period was under perpetual agitation advancing towards a crisis of separation from the mother country. The Dudleys, who had been so long and powerfully under royal prerogative, were then sent into retirement. (Appendix B, C, D, $\mathrm{E}, \mathrm{F}, \mathrm{J}, \mathrm{K}$.) 


\section{CONTENTS}

CHAPTER $\quad$ PAGE

I. The childhood and family of Thomas Dudley, 1576-

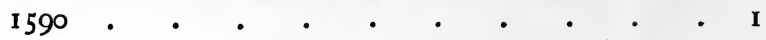

II. His youth and pagehood at the home of Lord Compton, including war in France, I590-1598 . . . I 2

III. His marriage; clerkship with Judge Nicolls, 1598I6r6 . . . . . . . . . . $\quad$. 24

IV. Steward of Theophilus Clinton, fourth Earl of Lincoln, 1616-1628 . . . . . . . . . 3I

V. His residence at Sempringham, Boston, and Clipsham, England, I6I6-1630 . . . . • . 43

VI. Emigration to America, I630 . $\quad . \quad$ • $\quad .54$

VII. The transfer of the First Charter of Massachusetts to America, I630 . . . . . . . . 66

VIII. The experiences of the emigrants in America, I630 . $76^{\circ}$

IX. Construction of government and personal disagreement between Winthrop and Dudley, r63I-1632 . 90

$\mathrm{X}$. Differences further considered, also strictures on Dudley, I632 . . . . . . . . 106

XI. Church and state, union of ; need of religion in the

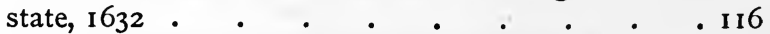

XII. Settlement and fortification of Cambridge, Mass., by Dudley, I631 . . . . . . . . . 123

XIII. Roger Williams, Gardiner, and others in Massachusetts, I63I-I632. . . . . . . .

XIV. Answer to Gardiner not subscribed by Dudley; the setting up of the king's colors on the fort, I63II 636

$\mathrm{XV}$. Fortifications in Boston and Cambridge; Dudley governor, I634 •

XVI. First use of the ballot; government by the people secured, 1634 . 6 . $\quad$. $\quad$. $\quad$. I64

XVII. The Hocking case; Dudley on the side of Plymouth,

1634 . . . . . . . . . 173 
XVIII. Preparation for war with England; influence of learned men; sumptuary laws; Hooker and his congregation desire to emigrate to Connecticut,

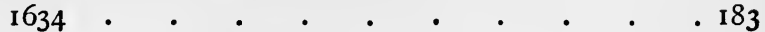

XIX. Roger Williams, departure of ; Winthrop and Dudley, 1634 . . . . . . . . . . . . 192

$\mathrm{XX}$. Code of laws considered; the fisheries; Dudley faction in politics; Winthrop in trouble; vindication of Dudley; discreditable false story in the matter of Marmaduke Matthews; Hooker emigrates to Connecticut; Standing Council formed; Dudley a member of it, $\mathrm{I}_{3} 6$. $\quad . \quad$. $\quad . \quad . \quad .202$

XXI. Ann Hutchinson; Harry Vane governor; the Synod and Antinomians; Dudley and Antinomians, also his poetry; his residence in Ipswich, Mass., 16341636 . . . . . . . . . 216

XXII. Lechford's book; the founding of Harvard College and Dudley's connection with it, 1636-1637 . . 233

XXIII. Winthrop and Dudley at Concord; the printing press; home of Dudley in Roxbury, Mass.; improved roads, $1638-1639$. $\quad . \quad . \quad . \quad . \quad .248$

XXIV. Dudley governor; law-making; refusal to deal with Rhode Island, I640-I64I

XXV. Dudley declines to be assistant, but suffers himself to be persuaded; name of king left out of oath, 1642

XXVI. The Standing Council; Dudley commissioner to the Confederacy; helped form its articles; civil war in England; matter of Samuel Gorton in Rhode Island, $1642-1643$

XXVII. Miantonomoh; the negative voice; D'Aulnay Commission; Rogers and Dudley; decease of Mrs. Thomas Dudley, I643

XXVIII. Dudley Sergeant Major General; Rev. John Eliot and Dudley; free school of Roxbury; slavery in Massachusetts; Hingham trouble; Uncas; Winthrop's " Little Speech," I644-1645 • • • • · 323

XXIX. Dudley governor; assembly of divines at Westminster and Cambridge Synod, and the Independents; Winslow's instructions ; D'Aulnay and La Tour, 1643I645 . . . . . . . . . 340

XXX. Declarations of the Confederacy respecting heresy, religion, and the state; harsh laws; Rev. John Eliot; death of Hooker, I646-1647 . • • • 353 
XXXI. Common schools; New Netherland; Governor Peter Stuyvesant; Connecticut River and Springfield, 1647-1648 . . . . . . . . . 366

XXXII. Witchcraft; long hair; death of Winthrop; execution of Charles I.; Indians; Hon. Robert Boyle; Book of Discipline, 1648-1649 . . . . . 382

XXXIII. Dudley governor; charter granted to Harvard College; Lex Mercatoria; Bozoun Allen and Dudley; Lord Cromwell and Ireland, 1650 . $\quad . \quad$. 393

XXXIV. The Baptists; John Clarke; aristocracy and democracy; the Bible in the Commonwealth; theocracy; coinage of shillings ; education; decease of Dudley,

Conclusion 1650-1653.

\section{APPENDIX}
A. Thomas Dudley's Letter to the Countess of Lincoln • . 437
B. Governor Joseph Dudley . . . . . . . 4453
C. Governor Simon Bradstreet and his wife, Anne . . . 464
D. Major-General Dennison and his wife, Patience • . .465
E. Rev. Samuel Dudley . . . . . . . . . 467
F. Rev. John Woodbridge and his wife, Mercy . . . 468
G. Captain Jonathan Wade and his wife, Deborah . . . 469
H. Sarah Pacey . . . . • . . . . . 469
I. Paul Dudley • • • • • • • • • 4772
J. Chief Justice Paul Dudley, grandson of Thomas Dudley • $\quad .472$
K. Colonel William Dudley, grandson of Thomas Dudley • 475 



\section{ILLUSTRATIONS}

Dudley Castle in the County of Worcester, England. Frontispiece

Compton-Winyates, Warwickshire. • • . • . $\quad$ I2

Castle Ashby, Northamptonshire . • . . . . . 16

Westminster Hall, London . • • • • • • 24

Court of Common Pleas, Westminster Hall, London . $\quad$ - 28

Doorway to St. Andrew's Church, on the south side . . 36

St. Andrew's Church, at Sempringham, Lincolnshire . . . 40

Interior of St. Andrew's Church • • • • • . 46

Church of St. Botolph, Boston, England . . . . 50

Interior of Church of St. Botolph • $\quad$ • $\quad$ • $\quad$ • $\quad$ - 52

Willows on the line of Dudley's Palisade in Cambridge, Mass. . I 26

First Charter of Massachusetts . . . . . . . 184

"Two Brothers," on the Bank of the Concord River, Bedford, Mass. • . . . . . . . . . . 252

Charter of Harvard College of 1650 , bearing the Sign Manual

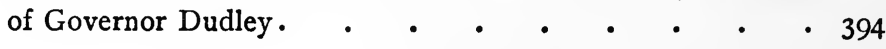





\section{THE LIFE AND WORK OF THOMAS DUDLEY}

\section{CHAPTER I}

IT may be reasonably questioned whether any single character in American history was more devoted to right doing, or has been more thoroughly made to appear to be what he was not, or more completely undervalued and neglected by his friends and traduced by the indifferent, since his own generation, which highly appreciated and honored him, than the second governor of Massachusetts, whose life work we propose to sketch.

Thomas Dudley, a Puritan second only to Governor John Winthrop in founding the Colony of Massachusetts, and in its history from I630 until I653, was born at Northampton, England, in the year 1576 , it is said near the residence of the Earl of Northampton. ${ }^{1}$ But since there was no Earl of Northampton until August 2, 161 8,2 it must be intended that he was born near Castle Ashby, ${ }^{3}$ the home of Henry Compton, or Baron Compton, whose son William became the first Earl of Northampton in 1618, as above mentioned. We shall have a special interest in this first Earl, because Governor Dudley was for many years in the highly honorable position of page to him.

It is the duty of every public man to write his autobiography, and give to mankind his own interpretation of events. Without this, the only person who knew the reasons for his

1 J. B. Moore's Memoirs of Am. Governors, 273.

2 Burke's Peerage, ro36.

${ }^{8}$ S. C. Hall's Baronial Halls of England, i. 
action in a given case cannot be heard, while enemies and rivals are left unanswered to color the story of his life work, as their memory, tinged possibly with personal prejudice, may dictate. Without such autobiography, persons seeking in the most impartial and judicial spirit to do justice to him are forced to conjecture and theorize as to his motives, and, with otherwise needless labor, to reproduce the different parts of his story, to render the whole as consistent as possible without the connecting links, which he held as a secret never imparted to the world. ${ }^{1}$

Governor John Winthrop did not make this mistake, but, with that prudent regard for the good opinion of posterity which signalized his thoughtfulness in securing the esteem of his contemporaries, he left an elaborate journal, so just in its delineations, even of his own faults and mistakes, that general credence has been given to it, in his account of the conduct of his political rivals in the heat of action. If we were sure that this truly noble man was without mortal frailty, and that his fairness of statement was nowhere intended to win our confidence, but merely designed to do ample justice to his own side of controverted subjects, we might never seek the side-lights of history, or search to find the missing links between the differing historic accounts. ${ }^{2}$

Governor Thomas Dudley was the only son of Captain

$$
1 \text { " And on me }
$$

Frown not, old ghosts, if I be one of those

Who make you utter things you did not say,

And mould you all awry and mar your worth ;

For whatsoever knows us truly, 'knows

That none can truly write his single day,

And none can write it for him upon earth."

(Tennyson's Memoirs, vol. i. xi.)

2 Mr. J. A. Doyle testifies that Winthrop is "not always a trustworthy authority." (J. A. Doyle's English in America, i. 239 note.) If self-interest made him untrustworthy on the heretics of Rhode Island, would not the same thing influence him in portraying the passions or avarice of his political rival? There is no other contemporaneous account of the passions or of the avarice of Thomas Dudley. The exact extent of them may therefore be a matter of doubt. 
Roger Dudley, who was killed, it is said, in the battle of Ivry, in which, in I 590, Henry IV. of France gained a decisive victory over Mayenne. ${ }^{1}$

Captain Dudley fought that day doubtless under Lord Willoughby, who is said to have commanded the English Protestants in that battle, and whose life five years before, on the field of Zutphen, Sir Philip Sidney saved but sacrificed his own, Sidney's death being one of the most memorable in the annals of the world. ${ }^{2}$ There is a well-supported tradition in the Dudley family that Captain Roger Dudley was connected by birth with Sir Philip Sidney.

It was singular that Captain Roger, and later his son Thomas Dudley, who was still later the stanch Massachusetts Puritan, were both fighting at different periods, with commissions as captains in the British army granted to them by Queen Elizabeth, to place Henry of Navarre, the first Bourbon, upon the throne of France, who, regardless of the Protestants in the ranks of his army, exchanged his religion for a royal crown.

We have not at present satisfactory knowledge of the ancestry of Governor Dudley beyond his father, Roger Dudley; but George Adlard says, in "The Sutton-Dudleys of England and the Dudleys of Massachusetts," 47, that "from the investigation I have made in relation to this family, I arrive at the conclusion that, though Governor Dudley was not descended in the direct line from John Dudley, Duke of Northumberland, yet that both were descended from the same ancestry. Both use the same coat of arms." This seems to be the most reasonable result yet attained.

Dean Dudley says : "Captain Roger Dudley flourished in the time of Robert Dudley, Queen Elizabeth's famous Earl of Leicester, and appears to have been one of the soldiers sent over by the queen to aid Henry of Navarre to establish his throne.... The Dudleys of the Dudley Castle race were ever inclined to a military life. Captain Roger doubt-

1 Dean Dudley's History of Dudley Family, i. 24.

${ }^{2}$ H. R. Fox Bourne's Sir Philip Sidney, 342. 
less belonged to this branch of his family." Mr. Dean Dudley says also that the wife of Roger Dudley "was a kinswoman of Augustine Nicolls of Faxton in Northamptonshire," and he thinks that Governor Thomas Dudley was drawn towards Puritanism by his mother's family." 1 Mr. Jacob Bailey Moore informs us that "there is a tradition among the descendants of Governor Thomas Dudley, in the eldest branch of the family, that he was descended from John Dudley, Duke of Northumberland, who was beheaded 22 February, 1553." 2 Dudley "was a man of a great spirit, as well as of great understanding, suitable to the family he was, by his father, descended from." ${ }^{3}$ We do not think that he was descended from the Duke of Northumberland, but that they had a common ancestry as stated by Adlard.

Anne Bradstreet, the daughter of Governor Thomas Dudley, "who wrote the first volume of poems published in New England," 4 declared in I64I, when the means of complete information were within her reach (for it was during her father's lifetime, who doubtless knew his ancestry), that she had the selfsame blood in her veins as Sir Philip Sidney. And with this abundant light on the subject she wrote, in her elegy upon Sir Philip Sidney (whose mother was the Lady Mary, eldest daughter of the above-named Duke of Northumberland, of the house of Dudley), as follows :-

"Let, then, none disallow of these my strains,

Which have the selfsame blood yet in my veins."

She subsequently changed these lines, it is said, so that they now are :-

"Then let none disallow of these my strains

Whilst English blood yet runs within my veins."

This change has been considered by some persons a revocation of her claim to relationship. ${ }^{5}$ The modification does

1 Dean Dudley's History of Dudley Family, i. 17.

2 Memoirs of Am. Governors, 273.

8 Cotton Mather, Proc. Mass. Hist. Soc. 220.

4 See Duyckinck's Cyclopædia of Amer. Lit., i. 52.

${ }^{5}$ J. H. Ellis's Works of Anne Bradstreet, Int. xii. 
not, however, seem to be a retraction of the claim. She may not have liked the personal, possibly boastful, allusion; it was certain to be distasteful to her father. He did not indulge in that sort of thing; he particularly concealed those matters which were of private concernment, and among them his ancestry. The change is in the direction of true art, of strict adherence to her theme.

She had, in the lines before these, enumerated the great merits of Sidney's work, mentioned the large esteem in which he was held, and lastly called attention to the love that England owed to him. It was not in good taste to exalt her own strains, for the reason that she was related to Sidney; or to draw attention to herself, or to withdraw public thought from the far greater achievements of her hero. She had failed in these lines of her first edition to carry out her poetic conception to completion, and, like a sensible woman, when her next edition appeared she had corrected them. I am unable to find a word written by Anne Bradstreet disclaiming her relationship to Sidney. She knew from her father, her husband, and her family the fact which she had so simply related. We must cherish her significant testimony, for she was an actor in those busy scenes, and speaks as one having authority. The light of truth streams through her first verses.

Anne Bradstreet's claim to relationship is confirmed by the coats of arms both of Governor Thomas Dudley, placed on his last will by himself, and of Governor Joseph Dudley. They were a lion rampant, with a crescent for difference. These, it is asserted, belonged to only two branches of the Dudley family, both descended from the first Baron Dudley, who died in 1488 .

Massachusetts was then English territory, and the laws of that country regulated and restricted the use of heraldic arms. They were then a distinguishing mark between noble families, and no high-minded person like Governor Dudley would assume the arms of another family, and no dishonest man would dare to do it. 
Titles to estates in England were held by virtue of the arms and escutcheons of ancestors; they proved marriages and descent by them sometimes. ${ }^{1}$

How well informed Governor Dudley was respecting his descent will be evident upon a moment's reflection. John Sutton, the first Baron Dudley of Dudley Castle, died only eighty-eight years before the birth of Thomas Dudley. Two successive barons, Edward the second and John the third Baron Dudley, had during that brief period lived and died; while, within the same exact duration of time, Edmund Dudley, the merciless extortioner of Henry VII., who furnished a theme for Sir Thomas More in the "Utopia," ${ }^{2}$ John Dudley, Duke of Northumberland, and Lord Guilford Dudley, his son, descending by another line from the same first Baron Dudley, flourished and disappeared.

Sir Philip Sidney, the son of Mary Dudley, died at Zutphen when Thomas Dudley was ten years of age; and Robert, Earl of Leicester, the favorite of Queen Elizabeth, died when he was twelve years old.

We can easily conceive Governor Dudley to have known. individuals who had met every one of the above-named persons, from the first Baron Dudley down to his own times. If we recall his social relation in England, his thoughtful, scholarly habits, and, in advanced life, his extended public career, we may be morally certain that the history of every one of these personages was familiarly considered by him, and his personal relation to them thoroughly understood.

When, therefore, in 1653 , he used the Sutton-Dudley seal on his will, he was not ignorant of his rights. $\mathrm{He}$ was trained to the law, and had long been a judge of it, and was always obedient to it in an exemplary manner. When he applied that coat of arms to his last will and testament, now preserved with probate records of Suffolk County, Mass., - one of the most solemn acts of his life, and nearly the final one, - he in effect affirmed that he was descended in

1 Sutton-Dudleys of England, 5 I ; N. Am. Rev., c. 19 I.

2 Hume's Hist. Eng., iii. 387, 41 I , 4 I 2. 
direct lineage from the barons of Dudley Castle. ${ }^{1}$ If, with his experience and knowledge, he did it wilfully with a purpose to cheat and to deceive as to his family, to claim what did not belong to him, to represent himself to be what he was not, or even to give to himself the benefit of a doubt, then that single last act of his life is in conflict with all the rest of his honest record.

His use of this seal under the circumstances tends, so far as the testimony of one honest man can go, to sustain the claim that he rightly appropriated it. The importance of this act on his part is greatly increased by the fact that it is the only known instance in which, after years of concealment and reserve, he suffered his ancestry to be revealed by himself in America. It seems to have been the solitary departure from a fixed purpose. His right is corroborated by his children, and by other evidence above mentioned.

The heralds may not recognize the claim, but the knowledge of Thomas Dudley himself is of far greater weight than their theories about the title. They may indeed refuse it, but it will not be the first time that legal titles have been lost by neglect, while the claim survives with every attribute except technicality and the letter of law.

Mr. John Fiske says : "Thomas Dudley came of an ancient family, the history of which, alike in the Old and in the New England, has not been altogether creditable." This is strictly true of every other family. It is harmless enough at first thought, but as you read and consider you feel that injustice is in it. It leaves a strong inference that the record of the family is dishonored below the average of ancient families, which we do not believe to be the fact.

There is much certainly to be satisfied with in the family history. Sir Philip Sidney said: "Though in all truth I may justly affirm that I am by my father's side of ancient and always well-esteemed and well-matched gentry, yet I do acknowledge I say that my chiefest honour is to be a Dud-

1 J. Timbs's Abbeys, Castles, etc., of England, 502; Penny Mag., xii. 83. 
ley." 1 And his father, Sir Henry Sidney, wrote to the same purport in his famous letter of advice to Philip at school: "Remember, my son, the noble blood you are descended of by your mother's side; and think that only by virtuous life and good action you may be an ornament to that illustrious family." 2

Governor Joseph Dudley has been both greatly praised and greatly blamed, chiefly because he was an Episcopalian and a royalist with Andros, although he was in fair repute later during thirteen years. We shall observe afterwards that some of his public services have added to the renown of himself and family.

His son, Chief Justice Paul Dudley, was very distinguished and beyond reproach, ${ }^{3}$ and recognized as an eminent scholar on both sides of the ocean. Among the noted descendants of Governor Thomas Dudley, though not bearing his name, are to be mentioned Dr. William Ellery Channing, Joseph Stevens Buckminster, Richard H. Dana (father and son), Dr. Oliver Wendell Holmes, Wendell Phillips, and Charles Eliot Norton. The fame of the family is safe with these names. ${ }^{4}$

We are not, however, unmindful that the greatness of Governor Dudley arose not so much from his distinguished ancestry as from his own eminent life work.

Far above "the boast of heraldry, the pomp of power," is the imperishable renown of being one of the foremost among the founders of this great nation, dedicated to liberty, to the freedom of human thought, to the worth and excellence of individual character. It was, indeed, a memorable achievement to bring into this wilderness in the seventeenth century a civilization, laws, customs, and social life the most advanced in the world, and to plant them with such vigor and stability that they continue to flourish through all con-

1 Julia Cartwright's Dorothy Sidney, 4.

2 Ib., 4.

8 Excepting the association of himself with his father by the enemies of both.

4 Dean Dudley's History of Dudley Family. 
flicts, with constantly extending potency over the continent, and in turn to react in unmeasured energy upon the progress and destiny of the Old World. "Let us praise famous men," saith the wise son of Sirach ; "the Lord hath wrought great glory by them through his great power from the beginning." 1

If Governor Dudley and his descendants may not claim kindred to the Sidneys, and have that claim allowed (which we do not admit), it is enough that he was an eminent founder of New England. There is no other epoch in human history from which so many great events have taken a turn.

It seems almost incredible to us that Governor Dudley should wish so utterly to burn all the bridges behind himself, sever all connection with his kindred and the land of his nativity, when he came to America to stay. He was, however, a Puritan, and regarded all human distinctions founded on family and blood as worthless. They had left the Old World to establish a new government in which only church members were to rule. Utopia was to be created, society was to appear in perfection. In this new, strange life the church, government, and social orders all underwent a rigid inspection to discern if there were any evil ways in them. In each institution they saw how vast the possibilities, and that, while tender memories and sacred associations attracted them to fatherland, with its endearing homes, matchless landscapes, and cultured life, yet they must forsake all these, restricted henceforth to the rugged but constantly broadening path of duty.

There seems to have been a prevalent disregard of descent and genealogies among these Puritans. Examination of the

1 "The true marshaling of the degrees of sovereign honor," says Lord Bacon, " are these : in the first place are 'conditores imperiorum,' founders of States and Commonwealths; . . . in the second place are 'legislatores,' 'lawgivers,' which are also called second founders, or 'perpetui principes' (perpetual rulers), because they govern by their ordinances after they are gone." (Lord Bacon's Essays, lv.) Thomas Dudley is included in both of these classes. 
lives of the governors of New Plymouth from I620 to I692, and of the governors of Massachusetts Bay from 1630 to I689, consisting of sixteen biographical sketches, discloses only two governors, John Winthrop and Sir Henry Vane, whose descent J. B. Moore, in his "Memoirs of the American Governors," has traced beyond the second generation. In the instance of Winthrop we have only three Adam Winthrops in succession. A striking illustration of this dearth of genealogy among these people has been the but recently successful effort to ascertain who the father of Roger Williams was, or where he himself was born. These instances, and many more which might be given, show that these Puritans took no interest in such matters, indeed entertained an aversion to them. It is probable that they were too busy with the real concerns of life. In some cases, moreover, they had been disowned and discarded by their families because they had become Puritans. It may have been so on the Dudley side of Governor Dudley's family, if the theory is correct that he was influenced by his mother's family to become a Puritan. In all such cases it would be a painful subject to revert to, and the severance from their former home and kindred had been so absolute that they had no heart to open that closed and forever sealed volume of their lives.

Governor Dudley lost his mother in infancy, it is said, and his father at fourteen years of age. His mother's name has not been preserved for us. He had one sister, probably younger than himself, of whom we know only that she survived their parents, and the orphans seem to have been left to the care of kind friends. Cotton Mather says Thomas Dudley "might say in his experience, that when he was forsaken of father and mother, then God took him up, and stirred up some friends that took special charge of him even in his childhood. 'T was said that there was five hundred pounds left for him in an unknown hand, which was not so long concealed but that it came to light in due time, and was seasonably delivered into his own hands after he came to man's estate; but before that time passed through many 
changes wherein he found the goodness of God, both in way of protection and preservation, by all which experiences he was the better prepared for such eminent services for the Church of God which he was in after time called unto." 1

Mather adds that, in the minority and childhood of Dudley, "It pleased God to move the heart of one Mrs. Puefroy, a gentlewoman famed in the parts about Northampton for wisdom, piety, and works of charity: by her care he was trained up in some Latin school, wherein he learned the rudiments of his grammar, the which he improved afterwards by his own industry to considerable advantage, so as he was able even in his age to understand any Latin author as well as the best clerk in the country that had been continually kept to study, which made it the more remarkable in the observation of some ministers, in whose hearing he was sometimes occasioned to read something out of a Latin book, who, by his false pronunciation, gathered he did not understand what he read, but upon further search and enquiry they found that he understood the language as well as themselves, although for want of school literature he missed the true pronunciation according to the rules of grammar to which children are exactly held at school; and probably after the decease of his parents he had not opportunity of that advantage, so long as many children under their parents' wings failed to enjoy it." 2 It appears that the Puefroys were connected by marriage with the Dudley family, and this no doubt accounts for the assistance rendered to Dudley in his education by Mrs. Puefroy. Mather is so impressed with the wisdom and piety of Mrs. Puefroy that we can seem to see that she was in sympathy with his Puritanic thought, and that her influence may early have given direction to the religious sentiments of the boy, who was full of gratitude to her for extending a helping hand to him, and assisting him to an education which otherwise he could never have secured.

1 Proc. Mass. Hist. Soc., 1870, 207; Sutton-Dudleys, 24.

2 Ib., 208 ; Sutton-Dudleys, 24. 


\section{CHAPTER II}

Cotton Mather informs us that so soon as ever Thomas Dudley "had passed his childhood he was by those that stood his best friends preferred to be a page ${ }^{1}$ to the Earl of Northampton, under whom he had opportunity to learn courtship and whatever belonged to civility and good behavior; with that earl he tarried till he was ripe for higher services." 2 The year is not mentioned when his period of childhood was passed and over, but we may well understand it to have been in about his fifteenth year. And although it is contrary to Cotton Mather, we have some reason to think that he continued in this occupation six years, more or less, until his majority.

If we are correct, there was no Earl of Northampton until long after this time, when Thomas Dudley was about fortytwo years old. We find in "Burke's Peerage" that William Compton, second lord, K. B., lord president of the Marches and dominion of Wales, who succeeded his father in 1589 , as Baron Compton of Compton, was created Earl of Northampton August 2, 1618, and that he died in 1630, the year that Dudley came to America. His great-grandfather, Sir William Compton, Knt., was the page of Henry VIII., and was with him at the Field of the Cloth of Gold, and in 1522 went on a special embassy to the Emperor Charles V. He built the house Compton-Winyates, near to Edge Hill, and nearer to the village of Brailes, in Warwickshire, England. This was one of the stately homes of the Comptons, where

1 The page of Dudley's period in England, as will appear later in the present chapter, was of gentle blood, and held a position of honor, as is there shown by a quotation from Ben Jonson.

2 Proc. Mass. Hist. Soc., I870, 208. 
, 2,

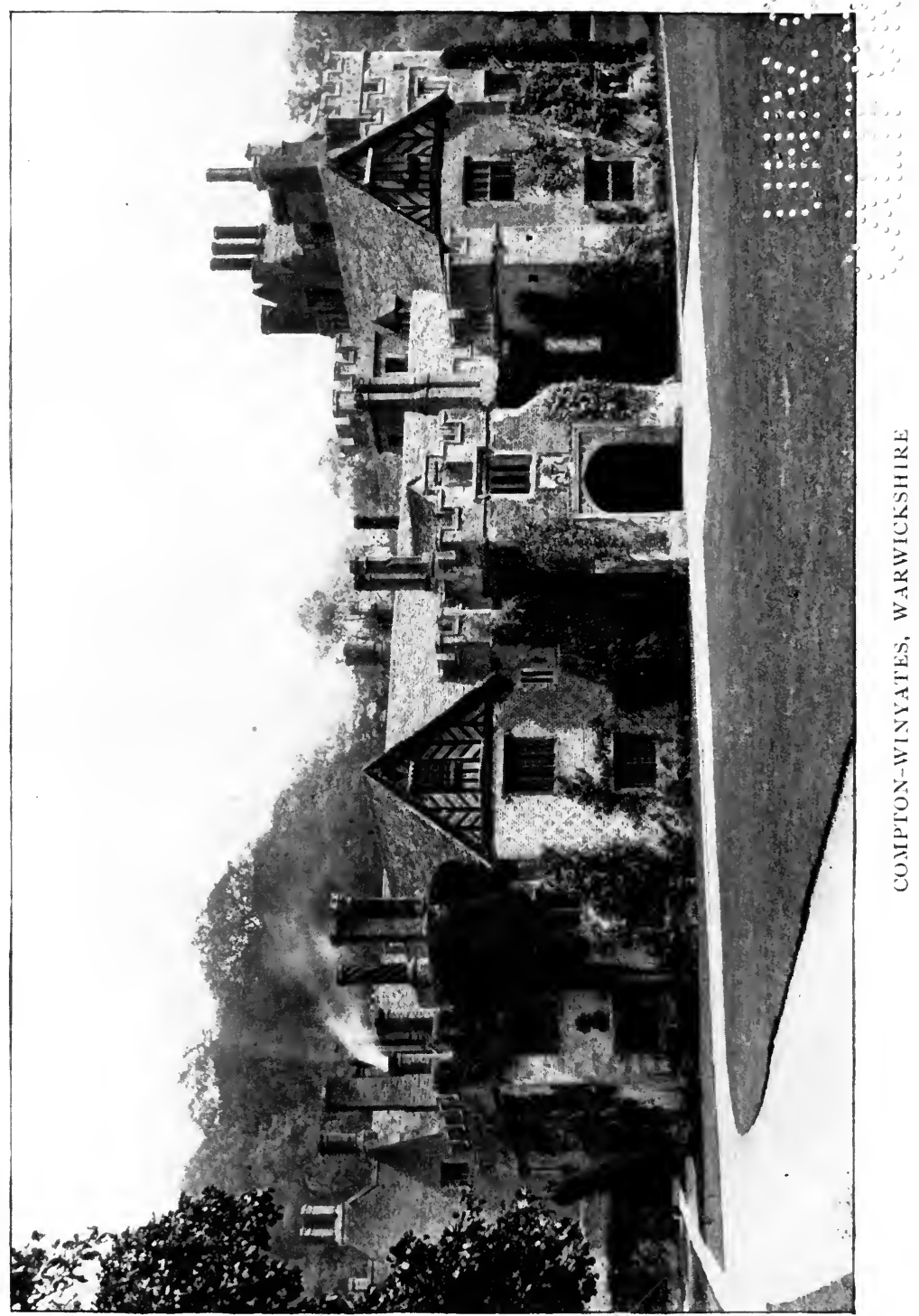




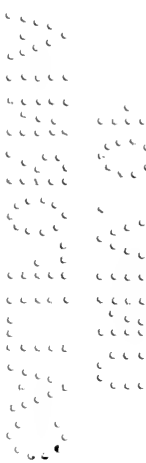


it is probable that Thomas Dudley lived a portion of the time that he was with the family. It is now standing, beautiful in ruins. ${ }^{1}$ There is another home of the Comptons, Castle Ashby, eight miles southeast of Northampton, the title to which was in Sir William, but it was not much occupied by the Compton family before the second Lord Compton, the friend of Thomas Dudley, took his bride there, Elizabeth, daughter and heir of Sir John Spencer, Knt., lord mayor of London. They were married in $1593 .{ }^{2}$ One of the requests of the rich heiress of Spencer to her lord was to "build up Ashby House." And the original pile may be presumed to have been completed when King James I. and his queen favored its noble owner with a visit in $1605 .^{3}$ Castle Ashby is at present the deeply interesting seat of the Marquis of Northampton, where visitors are kindly welcomed twice each week to view the pure Elizabethan architecture, plain and massive, the paintings, and exquisite marbles.

Perhaps there is no house in the kingdom which is placed in a more hidden and out-of-the-world situation than Compton-Winyates. It stands in a deep hollow of the Edge Hill range in Warwickshire, surrounded with ponds and woods.

It is quite evident that the youth of Dudley was spent in the midst of wealth, luxury, and splendor. We linger with delight oxer every place and thing which we feel quite certain that his eyes have seen, because all of these, however small, contributed to make him what he was, and to fit him for the great mission before him beyond the sea. "These armorial insignia, thistles, roses, and unions of thistle and rose, record the loyalty of the house in the reigns of Henry VIII. and James I., in which the Comptons received distinguished marks of the royal grace." 4 It cannot be extravagant, to

${ }^{1}$ Wm. Howitt's Visits to Remarkable Places, Visit to ComptonWinyates.

2 Northampton, Burke's Peerage, I037.

8 S. C. Hall's Baronial Halls of England, i. Castle Ashby.

4 Howitt's Visits to Remarkable Places, I27. 
say that here also in those days might be seen all the gayety and gallantry of Vanity Fair.

The Comptons were not Puritans ; they intensely enjoyed the good things of life. Here, in all the excess of fashion and of gleeful joviality, Dudley, in robust youth and even to vigorous manhood, took his leading share.

When in later years Thomas Dudley was governor of Massachusetts, a Puritan of Puritans, with grave responsibilities, in peril from enemies at home and abroad, and above all with a burning zeal for the welfare of Zion, the hope of the world, when all his "serious thoughts had rest in heaven," how often he must have recalled his childish ways, and recurred to those frivolous days at Compton-Winyates and at Ashby Castle! How changed at last from the splendor of his first estate, and yet in the current of human events how vastly greater was the last than the first! He survives in the memory of men, because he has served mankind by his sufferings and privations, while the gay throngs who joined him in the dance are forgotten.

There is little if any doubt that the family of Dudley was friendly to the Compton family. How intimate they were we do not know, but Sir Henry, the first Lord Compton, was knighted by the Earl of Leicester in $1566 .^{1}$

We are in doubt what the exact duties were of Dudley as page of the second Lord Compton, but we may fairly judge that they were such as would be usual in the homes of people of his rank at that period. We have full accounts of his great fortune, and we may conclude, from the magnificence of the homes still extant, something of the elegant life which abounded there. We can easily accept as very truthful the words of Cotton Mather, that, as page of Lord Compton, "he had opportunity to learn courtship and whatever belonged to civility and good behavior," 2 It is quite important that we should note these words, and the elegance in which he lived

1 S. C. Hall's Baronial Halls of England, i. Castle Ashby ; History of Dudley Family, i. 42, 43.

2 Proc. Mass. Hist. Soc., I870, 208; Magnalia, i. I 20. 
in this early period of his life, at the time when they would make the most indelible impression upon his character.

I think that we cannot too thoughtfully consider these matters in his early education, since many persons have been inclined to disparage his manners, and to allege that he was neither courteous nor well-bred. Certainly, if any one in the colony had been schooled in courtly ceremony and knew the respectful and gracious usages of society, it was Thomas Dudley, trained as he had been in this home, and later in the family of the Earl of Lincoln. These two were among the very first families in the kingdom; and it must have been a perpetual education in refinement to have had, during the period of an ordinary lifetime, the entrée to these homes, and, more than that, to have taken up one's abode in them.

There can be no doubt that Dudley used vigorous English sometimes in expressing his abhorrence of wrong-doing, his convictions of right, and we are thankful that he exercised that becoming freedom.

It is quite evident that Dudley belonged to a distinguished family from his having this position of page. He would have been apprenticed to learn a trade had he been of humble parentage. But, instead of this, he took a position which is sought by youths of rank, sons of nobility. The story of pagedom is an interesting one, and although we cannot enter fully upon it here, yet to make it evident how far removed it was from menial service, and yet how near and bordering to it in some of its offices, we must venture a little into its functions and duties. ${ }^{1}$

1 Ben Johnson, who was born two years earlier than Dudley, has given us a fine contemporaneous account of pagehood:-

"by a line

Of institution, from our ancestors

Hath been derived down to us, and received

In a succession for the noblest way

Of brushing up our youth in letters, arms,

Fair mien, discourses civil, exercise,

And all the blazon of a gentleman!

Where can he learn to vault, to ride, to fence,

To move his body gracefully, to speak 
It appears to have had its origin largely in knighthood, beginning with the Crusades. The squire and the page were both in training for knighthood, but the first had advanced farther than the second. A chivalrous education demanded successive stages of boyhood and youth, while knighthood was reached in early manhood.

Every feudal court and castle was in fact a school of chivalry. The page made a beginning in his service and training when he was between seven and eight years old; and during his novitiate of seven or eight years, he was the constant personal attendant of both his master and his mistress. $\mathrm{He}$ waited on them in their hall, attended in the chase, served the lady in her bower, and followed the lord to the camp. "From the chaplain and his mistress and her damsels he learned the rudiments of religion, of rectitude, and of love; from his master and his squires, the elements of military exercise."

When he was between fifteen and sixteen the youth became a squire, but continued to wait at dinner with the pages, though in a more dignified manner. He served, carved, and helped the dishes. He offered the first or principal cup of wine to his master and his guests, and carried to them the ewer and napkin before and after meals. He laid the tables for games, and shared in the pastimes for which he had prepared. His military training consumed more and more his time and thought. Skill in horsemanship was one of his great accomplishments. ${ }^{1}$ At length he took his sword to the priest, who laid it on the altar, blessed it, and returned it. It was the squire's duty to display and guard in battle the banner of the baron or the pennon of the knight, to supply him with his own horse if his was disabled, to receive and keep his prisoners, to fight by his side if he was unequally

The language pure, or to turn his mind, Or manners, more to the harmony of nature,

Than in these nurseries of nobility ?"

1 Hist. of Bayard, the good chevalier sans peur et sans reproche, chap. iii., iv. 


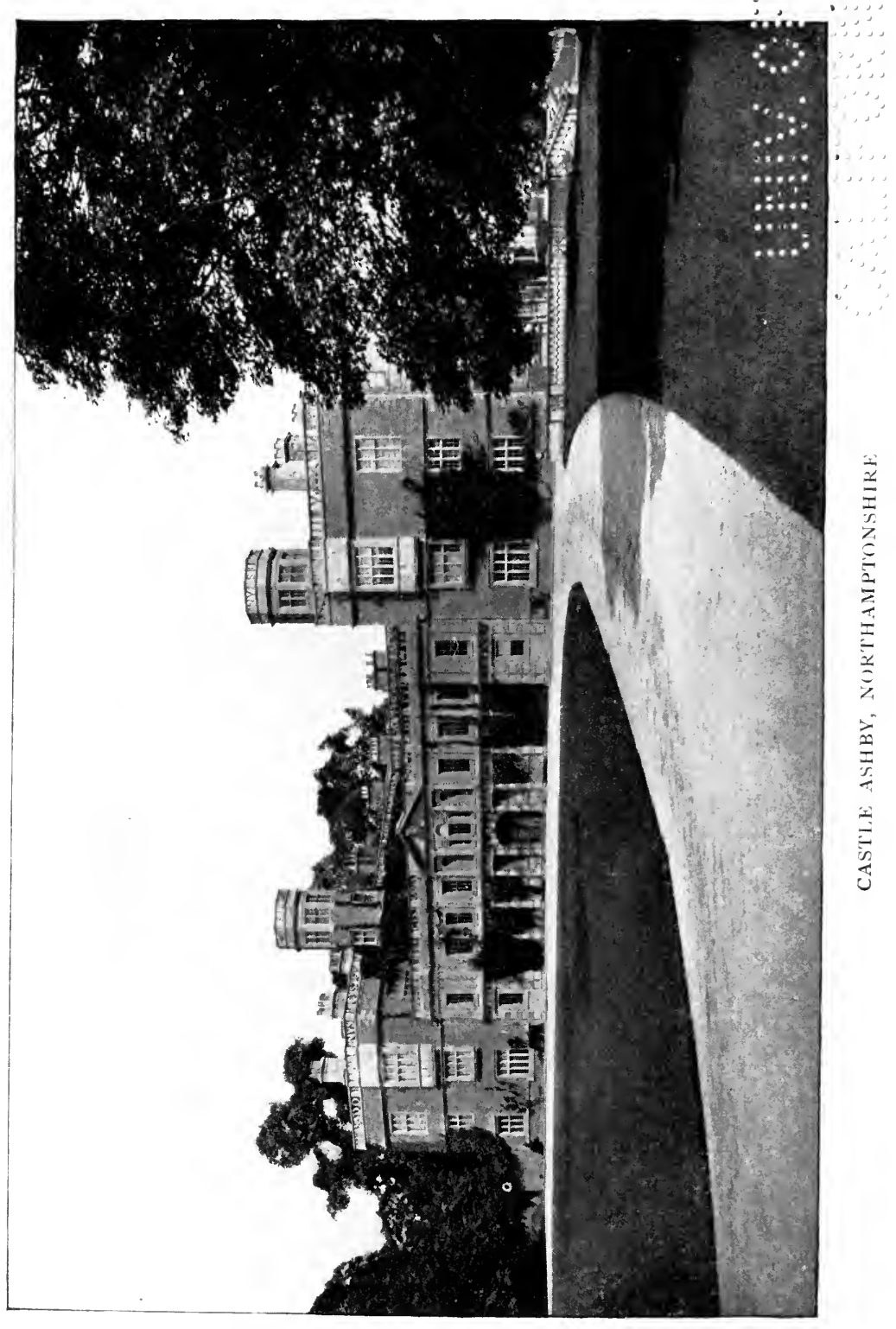



matched, to rescue him if captured, and bury him honorably when dead. If he had borne himself well for six or seven years, our squire was dubbed a knight. ${ }^{1}$

If we are correct in our theory that Dudley left the service of Lord Compton in his twenty-first year, and then, with a commission from Queen Elizabeth, went to take part in the war in France, we may regard it the natural step in his advancement from a page to a soldier. It is also reasonable to conclude that Lord Compton assisted him in obtaining his commission as captain, because he showed his earnest friendship years after this by recommending Thomas Dudley to the Earl of Lincoln. It was certainly a very honorable position which he held as the page of so distinguished a man. The influence from association so early in life, for so many years, with the family of Lord Compton, and with their eminent friends, must have been constant during his life.

The seventy-seven years of Dudley's life, from I 576 to

1 Knighthood: Ency. Brit., 9th ed., p. I 7 ; Sainte Palaye, Memories, i. 36 ; Mills, Hist. of Chivalry, i. chap. ii. The office of page, like everything else, changed with new customs. It survived longest in France, down indeed until the Revolution. Queen Victoria now has pages, but they are servants who are recompensed in money, and not purely by love and honor, sometimes by commissions in the army. "The most graceful volunteer page that ever existed was Edward, the Black Prince, who, when the noble, valiant, and unfortunate John, King of France, was captive in the tent of the prince's father, King Edward, waited on the illustrious prisoner as he sat at table, pouring out his wine, and handing to him his napkin. When the parents of George III. of England, the Prince and Princess of Wales, were at dinner, Prince George and his brother Edward used to stand apart and wait upon their father and mother." (Temple Bar Mag., No. 42, p. 92.)

Antinous, the beautiful page of Hadrian, in the second century, long before the age of chivalry, gave his life for his master, as it is thought. It was believed by the ancients to be a most noble instance of altruism. Hadrian enrolled him among the gods, and caused statues of him to be set up in almost every part of the world ; oracles were delivered in his name. "A star between the eagle and the zodiac, which the courtiers of the emperor pretended had then first made its appearance and was the soul of Antinous, received his name, which it still bears." (Smith's Dict. Gr. and Rom. Biog. and Mythology, i. 192.) 
1653, were very important in the world's history. But the events of the one or two preceding centuries had been preparing the way in Europe for an accelerated advancement in almost everything pertaining to human life and civilization. This period was conspicuous in improved agriculture and manufactures, in the more general diffusion of knowledge among the masses of the people, in individual freedom of opinion in politics and religion, tending toward democracy, all of which resulted no doubt largely from a reformation in religion. ${ }^{1}$

The invention of the mariner's compass in 1302 , of gunpowder in 1320 , Wickliffe's translation of the Bible in 1380 (only in manuscript until I73I), of printing with movable type in 1440, the discovery of America in 1492, and the revival of learning from I 450 to I 550 , were some of the events which led up to greater activity, and to higher living and thinking.

Of the importance of the period in which Dudley lived, it is enough to say that it began in the Elizabethan age, glorious in English literature. He was contemporary with Galileo, Spenser, Sir Philip Sidney, Raleigh, Shakspere, Spinoza, Jonson, Beaumont and Fletcher, Lord Bacon, Lord Coke, Milton, Herbert, Herrick, Richard Hooker, John Bunyan, Donne, Dryden, Evelyn, Hobbes, Law, Locke, Marlowe, Sir Isaac Newton, Pepys, Selden, Tasso, Temple, Sir William Waller, and Walton.

The Geneva Bible was translated and completed in 1576 , the year that Dudley was born; while the authorized King James translation appeared in I6II, when he was thirty-five years of age. Countless thousands of vernacular Bibles were printed, and in a short time were in the hands, and inspiring the minds, of the masses, creating a new Europe, which, regenerated, was destined to colonize America.

1 "There never was anywhere," says Lord Jeffrey, "anything like the sixty or seventy years that elapsed from the middle of the reign of Elizabeth to the Restoration." (Botta's Hand-book Universal Lit., 450. See also T. W. May's Democracy in Europe, p. Ixv. ; 2 Ib., 375, 376.) 
Dudley had now, in 1597 , reached the ripe age of twentyone years, which date Mather is supposed to refer to when he said that he tarried till he was ripe for higher services. ${ }^{1}$ He no doubt tenderly and proudly cherished the memory of his heroic father, and the old Protestant cause, for which the father had died in a foreign land, far from his kindred; recollections calculated to arouse his enthusiasm, and kindle his deepest emotions.

His inborn martial spirit, descending from generations of heroes, was in readiness for action, and eager for mortal combat.

The announcement was made that the queen must have soldiers to fight the armies of Philip II. of Spain, the Leaguers, or their successors. They were to be commanded by the gallant Henry of Navarre, under whose daring leadership Dudley's noble father had fallen seven years before. The young men of Northampton, accustomed to such invitations, gave little heed to this call for troops, until Dudley, with that undaunted spirit which always characterized him, came to the front, and attracted them to his leadership. $\mathrm{He}$ held, through the influence of friends, a commission as captain from Queen Elizabeth; he had also character, prestige, and public confidence. It is of great importance, in studying the quality and character of a man, to observe carefully the estimate of him by his youthful associates. No other opinion of his gifts and qualities will ever be more thorough or more permanent, although the subsequent growth and development in some persons have astonished their early friends. ${ }^{2}$

He had, in the unconscious days of boyhood before he had taken on the mask which humanity later in life assumes to hide its motives and its inmost thoughts, won the golden opinions, and, more than that, the firm confidence, of his comrades, to such an extent that they prepared to risk everything in foreign war under his intrepid leadership.

1 Proc. Mass. Hist. Soc., I870, 208.

2 "Childhood shows the man as morn the day." (Milton.) 
Mather"says : "The young lads about Northampton were none of them willing to enter into the service till a commission was sent down to this young gallant to be their captain, and then presently there were fourscore that were willing to list themselves under him as their captain. With these he was sent over into France, which, being at that time an Academy of Arms as well as of Arts, he had opportunity to furnish himself with such military skill as fitted him to command in the field as well as on the bench. The service that he and his company were put upon in France was to help Amiens, before which city the King Henry IV. at that time lay."

It is an incident of interest that ten years previous to this date the beautiful Mary, Queen of Scots, had been executed at Fotheringay Castle, less than thirty miles north of his home, when Dudley was eleven years of age. She was an unfortunate victim in that same war which deprived him of his father three years later, and which he himself was now about to enter. 1

We are already informed by Mather that King Henry lay before Amiens, and that Dudley had gone to assist him. The city had been captured by the Spaniards in I 597 through a stratagem so petty that it was more unbearable than a downright battle and defeat. It was retaken without bloodshed, however, by King Henry, Dudley and his company participating in the siege, which ended six months later, in September, in its capitulation. ${ }^{2}$

1 John Hosack's Mary, Queen of Scots, ii. 410; H. M. Baird's Huguenots and Henry of Navarre, i. 284.

2 There were many notable events in the history of Amiens, which would make it an attractive place to visit after the siege was over; and Dudley himself, by his delay there, has invested the place with a new fascination for those of us who are interested in his life work. Peter the Hermit, who preached the first Crusade and kindled Europe with his burning zeal, was born here in the middle of the eleventh century. William of Malmesbury says: "The Welshman left his hunting, the Scotchman his fellowship with vermin, the Dane his drinking party, the Norwegian his raw fish." The statue of Peter stands in front of 
Amiens is divided by eleven beautiful trout streams, and was styled by Louis XI. "the little Venice" of France. It was natural that Ruskin, who had characterized the Cathedral of St. Mark in Venice as the Book-Temple which "shone from afar off like the star of the Magi," ${ }^{1}$ should designate this cathedral as the "Bible of Amiens." We have, perhaps, lingered too long over this interesting locality; our excuse is that here is a structure which keeps its youth. If Thomas Dudley entered the portals of this temple, trod its pavement, or looked up into its fretted vaults, or studied its three magnificent rose-windows, or if the early influence of Puritanism restrained him from seeking the buildings dedicated to Popery and idolatry, which we do not believe, since Puritanism came to him after his return home (see Mather); if he gazed every succeeding day, as he must have done, upon its noble exterior, and saw its lofty spire, four hundred and twenty-two feet in height, - all the strength, beauty, and grandeur which we behold in it to-day was then visible to him. The perpetuity of this great work of men's hands seems to extinguish time, and make succeeding generations of men contemporary; they all seem in imagination to walk the same streets and pavements with us.

This siege was of great importance, because here was the last resistance of Philip II. The city was completely block-

the great cathedral, which dates from 1220 , "and is the crowning glory of Gothic art." (Charles H. Moore's Gothic Architecture, 74.) It has been well said that an "abbey church of the thirteenth century ... is matchless, priceless, sacred; such as man on this earth will never replace, nor ever again see." (Frederic Harrison's The Meaning of History, 437.) John Ruskin asks: "Who built it, shall we ask? God, and Man, is the first and most true answer. The stars in their courses built it, and the nations. Greek Athena labors here, and Roman Father Jove, and Guardian Mars. The Gaul labors here, and the Frank; knightly Norman, - mighty Ostrogoth,_ and wasted anchorite of Idumea." (Our Fathers have Told Us, The Bible of Amiens, sec. 12, p. 371.) "But of all, simplest, completest, and most authoritative in its lessons to the active mind of North Europe, is this on the foundation stones of Amiens." (Ib. sec. 57, p. 410.)

1 Stones of Venice, ii. chap. ix. sec. lxxi. 
aded by the French and allied lines; and the Spaniards, despairing of relief, at length capitulated on the $25^{\text {th }}$ of September, I597. On April I 5, I 598, Henry IV. issued the memorable Edict of Nantes, which protected Protestants for nearly a century; and finally, on May 2, I 598, the Peace of Vervins was signed. ${ }^{1}$

The year I 598 was, in France, an eventful one. She then, on May 2, at the Peace of Vervins, began her record in modern history, and left behind her mediæval annals. Her monarchy was thenceforth concentrated and absolute, and a number of great ministers came forth in succession to direct her course: Sully, Richelieu, and Colbert. Thomas Dudley, the second governor at the beginning of this epoch, was only an humble captain in her army, whose great commander had been false to the Queen of England, and to the Protestant cause. Nevertheless, it was a notable era in human history, and furnishes a graphic episode in the personal record of the subject of this biography. ${ }^{2}$

Lord Macaulay has given us a comprehensive statement of the political situation at this important juncture. "Dur-

1 H. M. Baird's Huguenots and Henry of Navarre, ii. 400-42I.

2 Henry of Navarre, for some months previous to his assassination, May I4, I6Io, was seriously engaged, without success, in uniting fifteen states of Europe into one magnificent Christian republic. Queen Elizabeth of England was said to be in sympathy with this enterprise. (H. M. Baird's Huguenots and Henry of Navarre, ii. 49I, 492 ; Memoirs of Sully, v. 62; Works of Charles Sumner, ii. 233.)

It is said in the Convention of 1787 , which framed our national Constitution, that "the project of Henry IV. and his statesmen was but the picture in miniature of the great portrait to be exhibited" in our Federal Republic. (James Madison's Papers, by Henry D. Gilpin, ii. 956.)

We do not claim that Dudley, who was a captain in the army of Henry in $1597-98$, brought to our shores the dreams of federation so dearly cherished by the King of France. It was, however, a memorable occurrence, that he, as a commissioner, assisted in the organization of the New England Confederacy in 1643, that beginning of the union of colonies here which, with its accessions of territory, became in the fullness of time the United States of America. (Richard Frothingham's Rise of the Republic of the United States, 33-7I.) 
ing the greater part of Elizabeth's reign, therefore, the Puritans in the House of Commons, though sometimes mutinous, felt no disposition to array themselves in systematic opposition to the government. But, when the defeat of the Armada, the successful resistance of the United Provinces to the Spanish power, the firm establishment of Henry the Fourth on the throne of France, and the death of Philip the Second, had secured the state and the church against all danger from abroad, an obstinate struggle, destined to last during several generations, instantly began at home." 1

Peace being now concluded, and his services no longer required, with his company Dudley returned to England, only to enter upon new, very important, and as yet untried fields in his career.

1 Macaulay's Hist. Eng., i. 47. 


\section{CHAPTER III}

DUDLEY was unexpectedly discharged as a soldier, without fighting, but he had obtained valuable education and discipline in his preparation, and in the expedition to France, which were destined to be of important service to him in future years. It was doubtless a great disappointment both to him and to his company to retire without a sight of battle, or an opportunity to win undying glory. They were none of them brimful of experience, like the Duke of Wellington when he exclaimed, "Take my word for it, if you had seen but one day of war, you would pray to Almighty God that you might never see such a thing again."

Marriage was the next important business which claimed Dudley's attention on his return to England. War and love each require courage; faint hearts cannot win in either.

He was married to Miss Dorothy Yorke, the daughter of Edmond Yorke of Cotton End, in the county of Northampton, England. Their son, Samuel Dudley, was baptized the 3oth day of November, 1608, at All-Saints', Northampton. ${ }^{1}$

Cotton Mather says that "after Captain Dudley returned into England, he settled again about Northampton, and there meeting with a gentlewoman both of good estate and good extraction, he entered into marriage with her, and then took up his habitation for some time in that part of the country, where he enjoyed the ministry of Mr. Dodd, Mr. Cleever, and one Mr. Winston, who was a very solid and judicious divine as any thereabouts, though he never published anything in print as some others did." 2

Captain Dudley appears to have been six years older than

1 Dean Dudley's History of Dudley Family, App., ii. 24.

2 Proc. Mass. Hist. Soc., 1870, 209. 


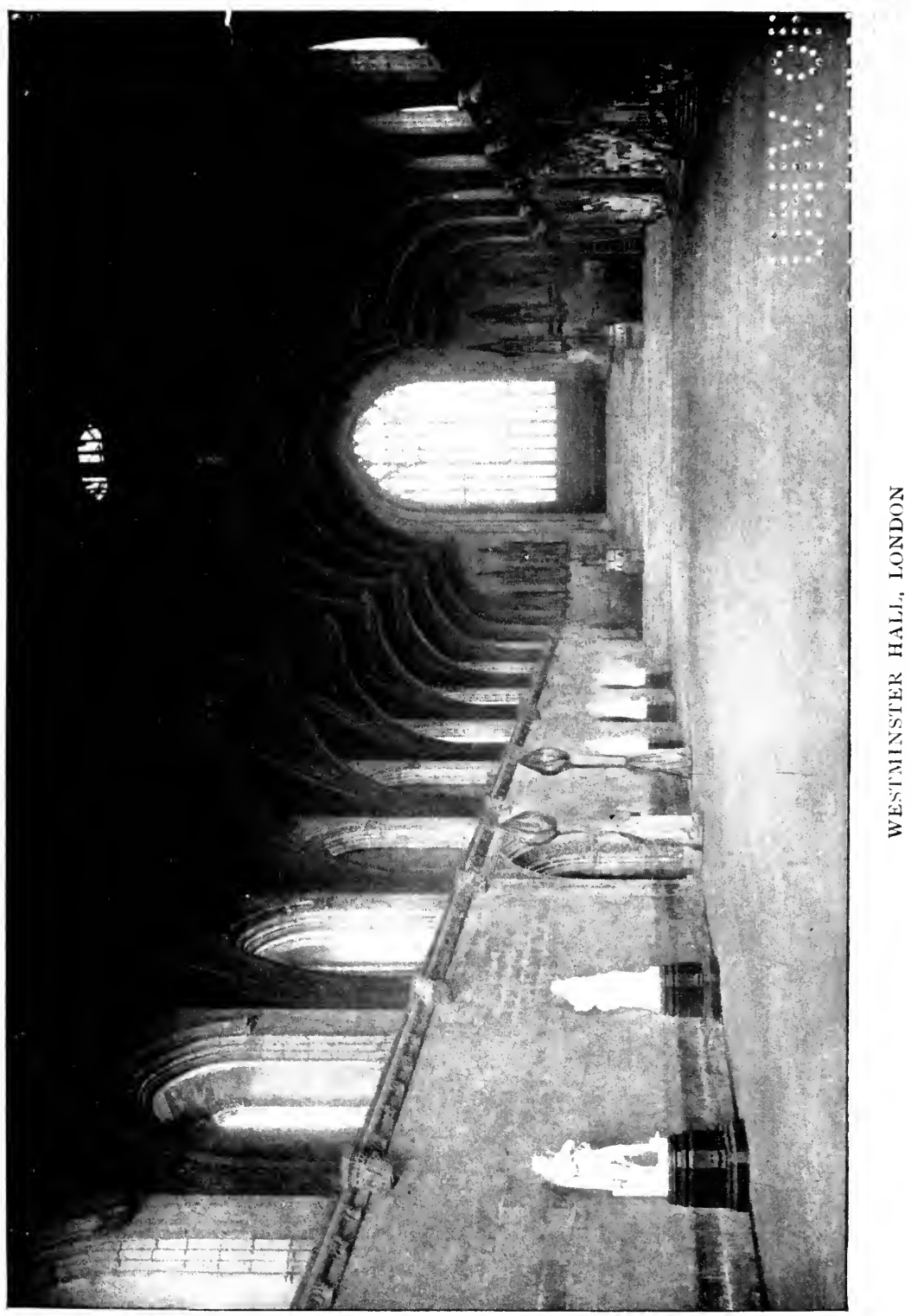




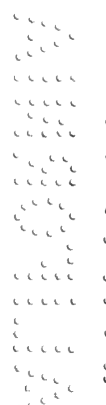


his wife, who must have been born in 1582 , since she is said to have died at the age of $6 \mathrm{r}$ at Roxbury, Mass., in $1643 .{ }^{1}$ There were five children by this marriage.

It interests us to note that Mrs. Dudley was a "gentlewoman both of good estate and good extraction," because, although it may not establish his social position, it carries a strong probability that he also was of "good extraction," and this is confirmed by all of the authorities, who agree that he was of gentle blood.

Mather says that Dudley "was taken by Judge Nicolls to be his clerk, who, being his kinsman also, by the mother's side, took more special notice of him; and from him, being a prompt young man, he learned much skill in the law, and attained to such abilities as rendered him capable of performing a secretary's place, for he was known to have a very good pen, to draw up any writing in succinct and apt expressions, which so far commended him to the favor of the judge, that he would never have dismissed him from his service, but have preferred him to some more eminent and profitable employment under him, but that he was prevented by death." 2

We are unable to determine what year Dudley went with Judge Nicolls. Mather evidently tells us that it was before he went to war in France (we think that it was after), but he also assures us that the judge was so much pleased with the services of Dudley that only death itself could and did separate them. We are informed that Judge Nicolls died in August, I6ıб. We thus conclude that Thomas Dudley certainly was his clerk in 1616 , or eighteen years after the war. That he was his clerk before the war is improbable.

We may reasonably understand, as we have already mentioned, that Dudley did not leave Lord Compton until he was twenty-one years old. He reached his majority, as we have seen, the year he went to France, I 597, where he remained a year or more.

1 Dean Dudley's History of Dudley Family, i. 276.

2 Proc. Mass. Hist. Soc., I870, 208; also Sutton-Dudleys, 25. 
We cannot give too much attention to the life and character of the Hon. Augustine Nicolls, because he must have had a marked influence upon the character of Dudley.

It is said that "Nicolls entered at the Middle Temple in London, November 5, 1575 ; that he became a reader or lecturer there in 1602 , and in the same year was summoned to take the degree of the Coif, which, in consequence of the death of Elizabeth, was renewed by King James, by whom he was knighted; that his arguments in Westminster Hall are reported both by Coke and Croke for the next nine years, till 1612, when he was elevated to be judge of the Common Pleas. Three years after, he was appointed chancellor of Charles, Prince of Wales. Four years he sat and judged with much success, and then died suddenly at Kendall, county of Westmoreland, August, 16 6 , while on the summer circuit. He was buried there, and has a monument in the Kendall church." 1

1 Foss's Judges of Eng.; History of Dudley Family, i. 44, note; R. Thompson's Historical Essay on the Magna Charta, 197, 198.

I quote in full the account of the judge by Thomas Fuller, written in the seventeenth century, as it appears in Fuller's History of the Worthies of England: "Sir Augustine Nicolls, son to Thomas Nicolls, Sergeant at Law, was born at Eckton in this County (Northampton). Now according to the rigour of our fundamental premises, he cometh not within our cognizance under this title, yet his merit will justify us in presenting his character.

"He was bred in the study of the Common Law, wherein he attained to such knowledge that Queen Elizabeth made him a King James his own Sergeant; whence he was freely preferred one of the Judges of the Common Pleas; I say freely King James commonly called him 'the Judge that would give no money.'

"Not to speak of his moral qualifications and subordinate abilities, he was renowned for his special judiciary endowments; patience to hear both parties all they could say, a happy memory, a singular sagacity to search into the material circumstances; exemplary integrity, even to the rejection of gratuities after judgment given.

"His forbearing to travail on the Lord's day wrought a reformation on some of his own Order. He loved plain and profitable preaching; being wont to say, 'I know not what you call Puritanical sermons; but they come nearest to my conscience.' 
The exalted position of Judge Nicolls and his eminent judicial endowments are assured. And it goes far in aiding us to determine the powers and qualities of Dudley, that this able judge, who was educated to appreciate the qualifications and fitness of men, employed Dudley as his clerk. We shall have occasion hereafter to notice in the documents and letters of Dudley the qualities ascribed to him in composition by Mather. ${ }^{1}$

It must, on the other hand, always be accounted good fortune on the part of Dudley, and creditable to his discernment and incorruptibility, that in the midst of so much wickedness in high places he made choice of such a friend and patron as Judge Nicolls, of whom it could be said freely that he was of "exemplary integrity, even to the rejection of gratuities after judgment given." And by King James he was commonly and freely called "the judge that would give no money." This was about the time that the Lord Chancellor of England, Sir Francis Bacon, was found guilty of bribery of the most flagrant sort.

It would be difficult indeed to overestimate the effect upon Dudley of association with such a lawyer and upright judge of the Court of Common Pleas, in and about Westminster, at that eventful period in English history when many of the leading cases in the common law were tried by great masters like Coke, as precedents to guide the succeeding generations of jurists ; and also of being, year after year, at the very heart and centre of the religious and political agitations of that remarkable period, when and where the doctrine of the Divine Right of Kings was entering upon its life-anddeath contest with that modern teaching that government

"The speech of Cæsar is commonly known, 'Oportet Imperatarem stantem mori ;' which Bishop Jewell altered, and applyed to himself, 'Decet Episcopum conscionantem mori;' of this man it may be said, 'Judex mortuus est Jura dans,' dying in his calling as he went the Northern Circuit; and hath a fair monument in Kendall church in Westmoreland."

I Sutton-Dudleys, 25. 
is by the consent of the governed; which latter doctrine was only the individualism, including the right of private judgment, of the Reformation, transferred to the domain of politics. It is simply the Christian view of the great value and importance of each individual soul both in religion and politics. Puritanism was both the cause and effect of this sort of agitation.

There were other scarcely less wonderful things happening in that same little city of London, containing only at that time about one hundred and sixty thousand inhabitants. King James's translation of the Bible was being made in the Jerusalem Chamber at Westminster Abbey. Francis Bacon, who ranks in the very first order of genius in the history of the English-speaking people, was effecting in science a revolution which will always be regarded among the highest achievements of the human intellect; while at the Globe and Blackfriars theatres were being produced by Shakspere and played, with him as an actor, the most powerful and complete dramas which have appeared in any language.

Shakspere must have been a familiar personage, well known by name at least to Dudley, and doubtless often seen by him on the streets of London. The city was small; most persons knew by sight every notable person. Dudley is not believed to have yet become so subdued by Puritanism as to look upon amusements as dangerous which were furnished with great historic teachings, or exhibited human passion under proper social limitations. It might have been otherwise after 1630, when he was a leading Puritan emigrant. There were no newspapers and few books, and the plays of Shakspere must have then had an immense attraction, because of the newness of such historic dramas, and because his associations and family and his own terse and comprehensive style of composition leads one at once to think that Dudley of all persons would delight in those marvelous works of genius, until his religious prejudice, caught up from the age in which he lived and the air which he breathed, might question their usefulness. 


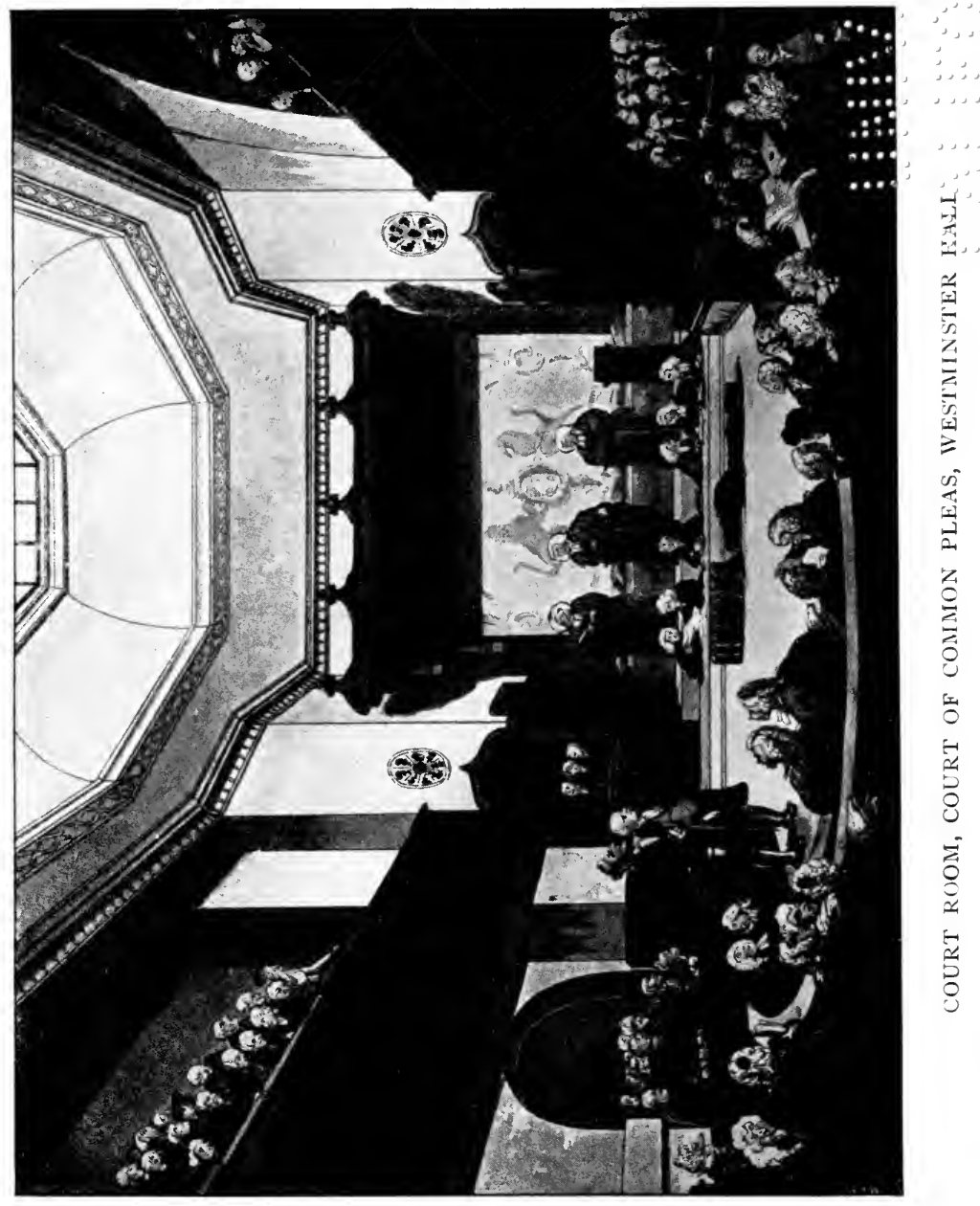



The mind of Dudley was both capacious and retentive, and this review of the larger influences operating with concentrated force during the years of early manhood will help to connect and interpret the few and scattered particulars of his life, and furnish us with an explanation of many matters in his subsequent career.

There are many ancient historic buildings which to-day in our walks about London attract our earnest attention, because within their antiquated walls the greatest scenes and events in the annals of our mother country have been enacted. Thomas Dudley knew them thoroughly. Westminster Abbey is, for example, the Walhalla of England, under whose protecting roof repose her great men who have filled history with their deeds and the earth with their renown. Its beautiful chapter house became the Parliament house of England in the thirteenth century, and thence down to the dissolution of the religious orders.

Westminster Hall ${ }^{1}$ is another, with the largest and grandest deeply and beautifully framed timber roof in the world, dating from $\mathrm{I} 397$, and the Hall itself from William Rufus. Here is indeed hallowed ground. All of the great men in English history for the last eight hundred years have paced to and fro within its glorious walls. Here the British sovereigns have held their coronation feasts. Here David of Scotland and John of France were entertained in their captivity by the chivalrous Edward III. And beneath this far-famed roof the noblest and bravest men of our race have nerved themselves against bitter fate and the edicts of inexorable despots. Where shall we find worthier martyrs than Sir William Wallace; the wise and good Sir Thomas More; the noble-minded Lord Protector Somerset; Lord

1 The court-room of the Court of Common Pleas was entered from Westminster Hall, by a door on the west side nearly half way down the hall. Dudley probably passed here daily for many years with Judge Nicolls, always excepting vacations and the times they were on the circuits. The picture of the court-room is the best attainable, the persons as seen in it are caricatures. 
William Russell ; and the great democratic hero and patriot, Algernon Sidney?

The Temple Church, completed in II85, with its nine monuments of Templars of the twelfth and thirteenth centuries ; and the monument of Robert de Ross, one of the barons to whom England owes Magna Charta, is also memorable in the annals of London and of the nation, and, descending from hoary antiquity, has long survived destruction and decay. The same is true of several old churches and buildings in the city.

But Father Thames is older than these, yet with less vestige of age, upon whose banks Dudley wandered in the morning, at evening, or floated often upon its tide. Its waters were then more limpid, its shores more green, but it still keeps its youth and its identity. How often at Westminster, at Temple Gardens, at Richmond Hill, Coopers Hill, or at Windsor, he visited its winding shores!

Dudley viewed these historic piles, sacred temples, and this majestic river as we do; association with them reminds us of him; he regarded them with the same admiration for Englishmen, and for their achievements in the world, which now kindles the enthusiasm of visitors from every zone who cherish a sincere affection for the land of their fathers. 


\section{CHAPTER IV}

Dudley had in 1616 , in which year his benefactor and friend Judge Nicolls died, reached the age of forty years, and was destined to remain in England fourteen more years, full of service and experience, before he led the great emigration to America.

He was during most of this time the steward of Theophilus Clinton, the fourth Earl of Lincoln, at or near Sempringham, in Lincolnshire. Here his duties were varied, including the management of a large number of estates, the collection of rents and other incomes.

This was an eventful period in English history. Dudley was at Sempringham, in the midst of the most congenial religious and political associations. His mother's family is said, as we have noticed, to have inclined towards the Puritans. Judge Nicolls, who had no doubt influenced, as greatly as any one, his views and character, was in sympathy with the Puritans ; and the household of the fourth Earl of Lincoln was the very hotbed of Puritanism and of resistance to kingly prerogative. Cambridge University was near by, at which the most advanced and revolutionary thought and doctrines were welcomed and disseminated broadcast; while at Boston and in all the surrounding towns were to be found the most learned and able Puritan ministers, busily engaged in stirring the hearts of the people with political and religious principles which could only vindicate themselves against the tyranny of the Stuarts by a merciless civil war. "By the ministry of eminent scholars," Mather informs us, "as likewise of Mr. Hildersham, a man famously known all England over by his writings, it pleased the Almighty to season this Mr. Dudley's heart with the saving knowledge of the 
truth, so as ever after he became a serious Christian, a great lover of religion, and follower of those ministers that either preached, professed, or practiced it. And those ministers before named, of whom he was a constant hearer, being such as were then called Puritans or Nonconformists, Mr. Dudley was himself also moulded into the knowledge and persuasion of that way, so as he became a zealous asserter thereof, but yet so as they were only sober, orthodox divines and Christians, that he chose always to consort himself with; for there was no man that more hated fanatics and wild opinionists than he did, notwithstanding he was so strenuous an oppugner of conformity and the ceremonies of the Church of England." 1 Mather says also that "Mr. Dudley began to be well known in those places where his abode was, and by being a follower of Mr. Dod, he came into the knowledge of the Lord Say and Lord Compton, and other persons of quality, by whose means he was afterwards commended to the service of the Earl of Lincoln, who was then a young man and newly come into the possession of that earldom, with the lands and hereditaments that belonged thereunto." 2 Since Dudley had long been the page and attendant of Lord Compton, it does not seem probable that he stood in need of commendation from Mr. Dod, but Mather never neglects an opportunity of exalting the importance of ministers.

It seems, as we have already said, to be of the first significance, in our examination of the life and character of Dudley, to enter as much as we can into a knowledge of the people who were nearest to him. If we find them intelligent and at the head of advanced thought in the kindred subjects of religion and of politics, and that their social life was the best their age afforded, these discoveries will go far in determining Dudley's real character. We strive, therefore, to give to these persons their true historic proportions, and then to measure him by them as standards; to view him and his character and qualities as they viewed them, to discover to what extent and in what matters they reposed unwavering 1 Proc. Mass. Hist. Soc., 1870, 209.

2 Ib., 2 I I. 
confidence in him; and thus, assisted by light reflected from them, we hope to present him as he was. We must also carefully and thoughtfully note the scenery and associations of his daily life, and, so far as possible, the influence upon him of architecture, noble trees, wide moors, the fens, and sea. The Earl of Lincoln and his home of Sempringham are of preëminent importance, therefore, at this era in the life of Dudley.

We learn from "Collins's Peerage" that the family of the Earl of Lincoln came in with William the Conqueror. It has recently been said of it, that "for seven hundred years it has poured out a scarcely intermitted succession of men who have spent their lives in the furtherance of England's greatness and policy. If it has never had a genius, it has also never produced a traitor; and if it has never risen to the lofty position of one or two of its rivals, it has not in its annals chapters which it would give estates to conceal." 1

The fourth Earl came to his title on the death of his father, January 15, 1618-19, at the age of nineteen, having been made a Knight of the Bath, along with Prince Charles (afterwards Charles I.), in I6I6. "He was a warm patriot on the parliament's side in the civil war, but, after the captivity of the king, being inclined to moderation, was imprisoned and accused of treason by the usurping power of the army, which subverted, under Cromwell's direction, all the principles of the Constitution." 2

He thus fell at this time into the hands of the army, and was with other Presbyterian peers impeached by the Commons, on the eighth day of September, I647. The impeachment was, however, allowed to drop. He took no prominent part in the time of the Commonwealth, acquiescing in it. " He performed the office of carver at the coronation of Charles II." 3

I Sanford and Townsend's Great Governing Families of England, 212.

2 Winthrop, i. 34, Savage's note.

8 Burke's Peerage, Newcastle Family, I024. 
The first notable act of which we have a record in the life of the Earl of Lincoln was that "he became colonel of a regiment of foot and two troops of horse, which were a part of 12,000 men raised by Count Mansfeld in England to assist the Palatine in the 22d of James I. ; but neither France, Holland, nor Brabant allowing the troops to land on their shores, they were decimated by pestilence, and scarce one half reached Germany. His share in this expedition shows the political leanings of the Earl of Lincoln, the Puritans being deeply interested in the Palatine's enterprise; but these were displayed more decidedly at the rupture between the king and parliament, when he espoused warmly the Puritan side, attaching himself to the Presbyterian party." 1

Mather informs us that "towards the latter end of King James his reign, when there was a press for soldiers to go over into Germany with Count Mansfeld, for the recovery of the Palatinate; when the matter was first motioned, the Earl of Lincoln, who was zealously affected toward the Protestant interest, was strongly inclined to have gone over with the said earl or count, and should have been a colonel in the expedition, yet resolving not to go without Mr. Dudley's advice and company ; and therefore he sent down to Boston, in Lincolnshire, where Mr. Dudley then sojourned, to come forthwith to London, to order matters for this enterprise, and to be ready to accompany him therein. Mr. Dudley knew not how to refuse to wait upon his lordship, yet thought it best, as well for himself as for the earl, to take the best counsel he could, in a concern of so high a nature, not being unmindful of what Solomon said, 'with good advice make war.' Therefore he resolved with himself, in his passing up to London, to take Cambridge in his way, that he might advise with Dr. Preston about the design, who was a great statesman as well as a great divine, at least was conceived very well to understand the intrigues of the state in that juncture; and he altogether dissuaded Mr. Dudley, or the

1 Sanford and Townsend's Great Governing Families of England, 208. 
earl, from having anything to do in that expedition, laying before them the grounds of his apprehensions on which he foresaw the sad event of the whole, as did really soon after come to pass. Dr. Preston, by reason of his frequent intercourse with the Earl of Lincoln's family, was free to discover to Mr. Dudley all that he knew, and he improved it thoroughly to take off the earl's mind from the enterprise." 1

The next year, 1626, the earl appeared in resistance to the forced loan demanded by Charles I., who, when he found that his subjects were averse to giving him money, concluded that he would make them lend instead, the result being the same, no payment being intended in either case. ${ }^{2}$

Dean Dudley says : "But the Earl of Lincoln's opposition to the loan was most conspicuous. According to his wont, he quickly took action in the matter, and probably by the aid of his former steward and counselor, Mr. Thomas Dudley, prepared and published an abridgment of the English statutes for free distribution. The fact of Dudley's having a hand in this proceeding, if not, indeed, being the chief adviser of it, is sufficiently evident from many circumstances, says the historian. . . . The king was not unacquainted with this proceeding of the earl, who had distributed his

1 Life of Thomas Dudley, by Mather, Proc. Mass. Hist. Soc., 1870, $214,215$.

${ }^{2}$ It is related,in the diary of Walter Yonge, from 1604 to $I 628$, that "December, 1626, the king having determined heretofore to demand of all his subjects so much money by way of loan as they are set in subsidy, viz., he that's set at twenty pounds in subsidy to lend unto the king twenty pounds, the judges were urged to subscribe. They paid their money, but refused to subscribe the same as a legal course; for which Sir Randall Crew, chief justice of England, had his patent taken from him, and he was displaced, Ter. Michael. 1626, anno 2 Caroli. The privy council subscribed; the lords and peers.subscribed, all except fourteen, whereof six were earls, viz., Earl of Essex, Earl of Warwick, Earl of Clare, Earl of Huntington, Earl of Lincoln, and the Earl of Bolingbroke, being Lord St. John." (Diary of Walter Yonge, 98; The John Forster's Debates on the Grand Remonstrance, 220, note I.) The earl continued steadfast in this cause. (John Forster's Arrest of the Five Members, 37, note, in the year 1642.) 
book all over his county at least, if not over the whole realm; and the royal power was rigorously used to suppress the abridgment, the great object of the king's resentment. .. . Theophilus was proceeded against in the Star Chamber, and was soon made a close prisoner in the Tower, where he was kept in custody for some years." 1

The cherished seat of the Earl of Lincoln at this time, as we have already intimated, was the ancient, historic Sempringham. He possessed other estates, some of which will be named hereafter, because Dudley is supposed to have had the immediate care of them. The manor of Sempringham is distant about three miles southeast from Folkingham. The village of Sempringham is noted in the monastic annals of England as the birthplace of St. Gilbert de Sempringham, who founded a novel religious order, indeed the only English order, and settled it at his native place.

St. Gilbert lived to be 106 years old, and to see thirteen monasteries erected, in which were 700 men and 1300 women. So noted did the order of the Gilbertines become that, in the reign of Edward I., Vincilian, daughter of Llewellyn, King of Wales, was a nun of the convent of Sempringham. ${ }^{2}$

In Gilbert's time the land to the east of Sempringham was

${ }^{1}$ History of Dudley Family, i. 57, 58.

${ }^{2}$ St. Gilbert was lord of the manor of Sempringham and rector of the parish. The Gilbertine was the only purely English order ever established. Sempringham Priory was always considered the chief house of the order, and was the place in which all their grand chapters were held. It grew and flourished for nearly four hundred years.

When Thomas à Becket fled from the anger of Henry II., in I I64, he was accompanied by two monks of Sempringham, and was received (in disguise) at various Gilbertine houses, for which acts St. Gilbert was summoned to appear at Westminster for high treason. He was, however, shortly released and returned to Sempringham.

King Henry afterwards entertained an almost superstitious reverence for Gilbert. He attributed to his prayers the prosperity of his kingdom and his general success. And after Gilbert's death the king exclaimed, "Verily I knew that he was passed away, and my misfortunes have found me out now that he is no longer present." 


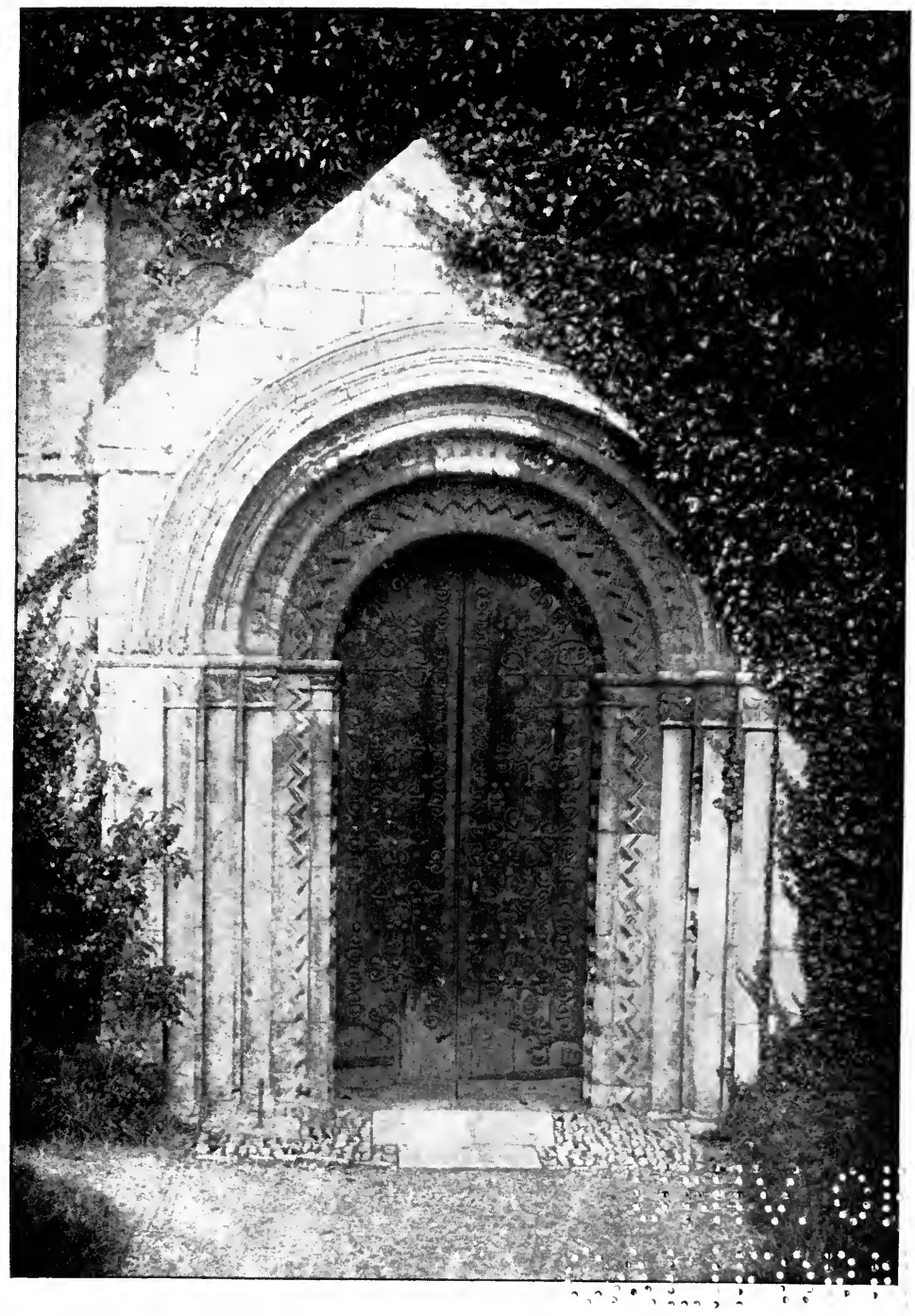

SIIE DOOR, SAINT ANIOREW'S CHLRCH 


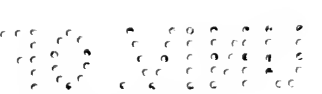

a 
one vast, dismal, dreary, dangerous swamp which extended northward to Lincoln, eastward to the sea, and southward to Spalding, Crowland, Peterborough, and Ely. But through the skill and energy of the inmates of the monasteries situated in these fens, and their dependents, supplemented by the superior engineering ability of later days, these fenny swamps have become some of the most fertile land in the kingdom. It was in these swamps that the last stand of the Saxon against the Norman took place under Hereward, Lord of Bourne. ${ }^{1}$

Every semblance of a house has long since vanished. The old Church of St. Andrew's, however, remains among the graves of the monks and the nuns, and the desolation of their home, preserving at least some of the features upon which they gazed.

Through that magnificent doorway which is yet in the south side, almost as perfect as when it left the workman's hand, many a time has passed the good St. Gilbert at the head of his chapter; and those fine old fir doors, so splendidly ornamented with iron scrolls, have closed upon them while they worshiped or deliberated upon the business of their order. How often, also, during many years they have closed upon the noble earls of Lincoln, upon Isaac Johnson and Lady Arbella, upon Governor Thomas Dudley and his family!

1 Charles Kingsley's Hereward, the Last of the English; Hist. of the County of 'Lincoln, ii. 285; Architectural Reports, ii. 138, also xi. I 1 and xiv. I 79.

At the dissolution of the monasteries the inmates of Sempringham all dispersed, and their house was given by Henry VIII. to Edward, Lord Clinton, who built a beautiful mansion out of its ruins. Lord Clinton was greatly distinguished as admiral of the fleet at the victory of Musselburgh, on the coast of Scotland, in 1547 . He was created Lord High Admiral in June, $155 \mathrm{I}$, and the first Earl of Lincoln in May, 1572. He married Elizabeth, daughter of Gerald, Earl of Kildare, the far-famed Geraldine, the heroine of the verses of Thomas Howard, the accomplished Earl of Surrey. (Chambers's Ency. of Eng. Lit., i. 46.) 
There is not a road within two or three fields of the church, and the glory of Sempringham long ago departed. It is now in the midst of a country of green fields, treelined hedgerows, with here and there, above the level landscape of redeemed fenlands, the tower of one of those grand Norman churches for which the county is famous, each worthy to be the cathedral of a diocese, and each with its red-tiled hamlet nestling near to it, undoubtedly little altered in itself or its surrroundings for five hundred years.

The Sempringham Church of St. Andrew's was entered by Dudley, when, according to Mather, he said, "Now I must return to the church to hear Dr. Preston," who then preached before the Earl of Lincoln. ${ }^{1}$

We have already noticed what influence Dr. Preston had, both with the Earl of Lincoln and with Dudley, in the matter of the proposed expedition to the Palatinate. Here we are able to judge of them by their relations with so eminent a man, and from their wisdom in seeking his learned counsel. It adds to our high opinion of both the Earl of Lincoln and of Mr. Dudley, that they were satisfied with nothing inferior to the opinions of the greatest and best persons of their period, for this at once reveals their own quality of character. It has been said by some one that we cannot appreciate with enthusiasm a great work of literature or of art unless we have in ourselves the same qualities in a degree which the composer possessed. It is quite evident that our estimate of great qualities in men depends upon what we are.

Dr. Preston, D. D., was a fellow of Queens College, Cambridge ; later chaplain to Prince Charles, Master of Emanuel College. And here he was preaching in St. Andrew's Church (which, standing alone, still overlooks the fens) the doctrines and heresy of John Calvin over the sacred ashes of St. Gilbert, while the same ancient vaulted roof, the identical antique arches and Norman pillars, reverberate his words and accents as freely as when, centuries before, they had resounded the voice of him who sleeps between the altars of

1 Proc. Mass. Hist. Soc., 1870, 213. 
the Virgin and St. Andrew, at the east end of the church, undisturbed by mutations of doctrine and faith.

But the change was broad and unconfined throughout the land. Thomas Carlyle tells us that "already (in I624) either in conscious act or in clear tendency, the far greater part of the serious Thought and Manhood of England had declared itself Puritan." 1

The Nonconformists were certainly in the ascendency in Lincolnshire and the neighboring counties. The thralldom in which the minds and hearts of the masses had been held for centuries was being dissolved by the swift and perpetual diffusion of a new light into souls aroused by long-suffering to welcome and use it.

It would be of great service to us if we knew the extent of the property and estates which were under the care of Dudley as steward of the Earl of Lincoln. We fortunately do know the names of the estates which descended with the title to the earl's father, the third Earl of Lincoln, and they were quite likely included under the stewardship of Dudley. ${ }^{2}$

Mather has left to us a very brief statement of the difficulties which Dudley encountered as steward of the Earl of Lincoln, and they seem to have been great, and to have been heroically struggled with, and successfully overcome, by him.

Mather's statement is that "the grandfather of this present

1 Carlyle's Cromwell's Letters and Speeches, i. 48 ; Froude's Bunyan, chap. ii.

2 They were "the manor of Aslackby and Temple Aslackby, the castle and manor of Tattershall, the house and site of the monastery of Sempringham, with the manor of Sempringham and the advowson of the church, the manor of Billingborough, rectory of the church, and advowson of the vicarage, the manors of East and West Claughton, the honor, castle, and manor of Folkingham, and manor of Thirkingham, and advowson of the churches, the manors of Thorp and Kirby Byrne, Roughton, Marton-juxta-Thornton, Conisby, Billingay, Walcottjuxta-Billingay, Burthorp, and Kirksted, alias Crested." (Sanford and Townsend's Great Governing Families of England, 207, 208.)

Dean Dudley visited the manor of Tattershall in 1850 , and obtained valuable items from the old parish register, but nothing concerning Dudley or his family. (History of Dudley Family, i. 53, 57.) 
earl was called Henry, who, being a bad husband," that is to say, a feeble economist, "had left his heirs under great entanglements, and his son, named Thomas, had never been able to wind out of that labyrinth of debts contracted by his father, so that all the difficulties were now devolved upon Theophilus, the grandchild, who was persuaded therefore to entertain Dudley as his steward to manage his whole estate, who, though it were so involved with many great debts, amounting to near twenty thousand pounds, yet by his prudent, careful, and faithful management of the demesnes of that family, he in a few years found means to discharge all those great debts, wherein the young earl was so engulfed that he saw little hope of ever wading through them all. But with God's blessing on Mr. Dudley's pains and industry, he was soon freed of them." 1

Mather continues on p. 214: "The earl, finding him so to be, would never, after his acquaintance with him, do any business of moment without Mr. Dudley's counsel of advice."

Dudley came to America in I630, and the earl lived thirtyseven years after that without much, if any, of his counsel or advice. These words of Mather are nevertheless very significant. They present Dudley in his true character; they show plainly the estimation in which he was then held by the Earl of Lincoln, who had tried and proved him so thoroughly as to leave no doubt of his integrity and ability. He was then, as he was always and everywhere subsequently, a "trusty pillar," a firm and reliable support and guide, in business, in church, and in state.

How truly Dudley was a man directed by conscience and guided by conviction in the ordinary affairs of life, as well as in greater matters of state later in his career, is shown in the following extract from Mather $\mathbf{~}^{2}$ "Some of those that overlooked his [Dudley's] manuscripts found such an expression as this, not long after he left the earl's family: ' $I$ found the estate of the Earl of Lincoln so much and so much in debt, which I have discharged, and have raised the rents so many
1 Proc. Mass. Hist. Soc., 1870, 212.
2 Ib., 2 I 4. 


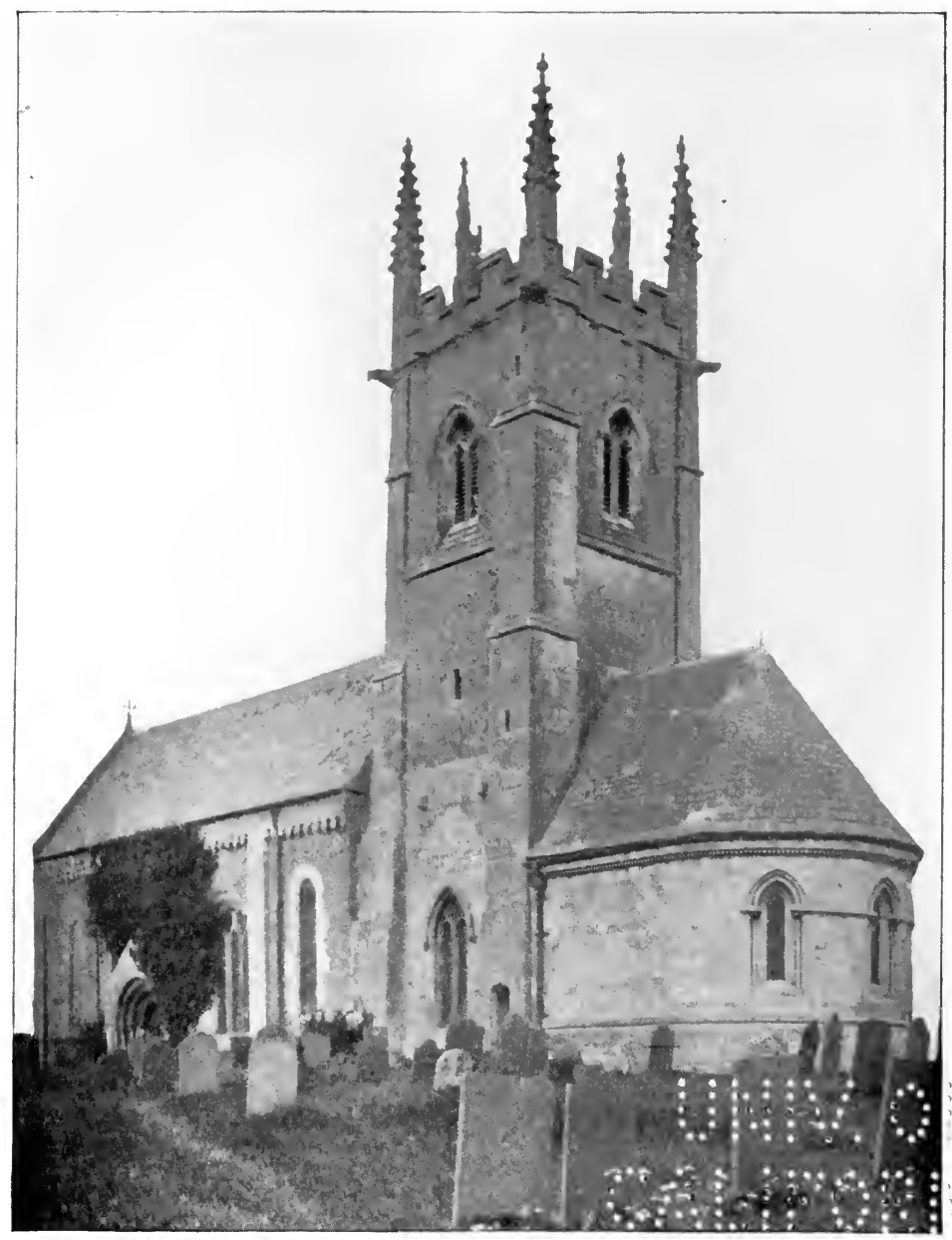

SAINT ANIREW'S CHURCH, AT SEMPRINGHAM, LINCOLNSHIRE 
hundreds per annum. God will, I trust, bless me and mine in such a manner as Nehemiah sometime did, appealing unto the judgment of God, that he knew the hearts of all men, that he had walked in the integrity of his heart before God, to the full discharge of the duty of his place.'"

We know nothing of the pecuniary resources of the earl in the hands of Dudley, aside from the estates above mentioned, with which he achieved this great success. We are not instructed as to the details of the claims, or how they were liquidated. We do know that others tried to free the estates from debt, and failed to do it. We know that the debts amounted to about $\$ 100,000$, which required a net profit every year of more than $\$ 10,000$ above and beyond payments of interest, household and other expenses, to attain to the crowning achievement in this management. We learn also that in this time he not only discharged these mountains of debt, but that he did greater things, for he raised the rents many hundreds of pounds per annum, and sent the earl and his estates on their way rejoicing in prosperity, and yet "he had all the time walked in the integrity of his heart before God." If Dudley had never accomplished more than this, he would have been entitled to a very worthy place among business men. Our surest measure of his effort is found in the opinions of his contemporaries. The most trustworthy light comes to us from their judgment, shown both in their words and actions. They surely accounted his success to be very extraordinary. Perhaps one of the most marvelous features in it, after all, was that he acquired such an ascendency over the fourth Earl of Lincoln that he allowed him to limit and restrain his expenditures within the lines of prudence, and taught him the secret of self-restraint, self-sacrifice, and economy, and in it and through it all retained the earl's abiding confidence in his ability and integrity, together with the highest esteem for the excellent qualities of his character, and a due and constant deference to him and his opinions until his departure across the Atlantic.

Dudley was intrusted even, as we have already observed, 
with the delicate and diplomatic service of "procuring a match between the daughter of the Lord Say and this Theophilus, Earl of Lincoln, who was so wise, virtuous, and every way so an accomplished lady, that she proved a great blessing to the whole family." 1 It is by no means certain whether it was the earl or the steward who first discovered the perfections of Lady Bridget, Countess of Lincoln, but the overture was made by the steward, who was excluded from the fortune of John Alden in "The Courtship of Miles Standish."

It is an impressive episode in history that Dudley, long years after this event, conferred enduring immortality upon the countess by writing to her a letter, from his desolate and comfortless home in this American wilderness, which will be read thoughtfully, tenderly, and gratefully by citizens of the United States forever, while the other brilliant women, her companions in society, are forgotten, - a letter which Young declares to be "the most interesting as well as authentic document in our early annals;" ${ }^{2}$ while Drake says, in the "History and Antiquities of Boston:" "With this paragraph ends the invaluable letter of Dudley. No document in the annals of Boston will compare in importance with it, and no one can successfully study this period of its history without it." 3

1 Mather, Proc. Mass. Hist. Soc., 1870, 212.

2 Chron., 340.

3 Page 122, note. 


\section{CHAPTER V}

Sempringham had a very close and intimate connection with the great emigration to America in 1630 , which, although not the first, was one of the most important. We have, therefore, most excellent reason to cherish the home of St. Gilbert as one of those memorable cradles in our old English home where a great undertaking was thought out, nurtured, and matured in the minds of the founders of the Massachusetts Colony, and whence those seminal ideas of liberty and equality taught at Geneva and in the Netherlands, and now diffused throughout England, took their departure for this continent, to become vital and fundamental in the Constitution and laws of the greatest and most enlightened nation which exists.

The Earl of Lincoln himself, as we have observed, had resisted forced loans and the tyranny of Charles I. $\mathrm{He}$ had suffered loss of property and caste; he had endured impeachments and imprisonment in the Tower, and later the insolence of a despotic Parliament. And Sempringham, like the cave of Adullam, became a resort for those who dared to think and speak the words of freedom, of soberness, and reason.

Roger Williams, the founder of Rhode Island, wended his way thither. He says in his "Bloudy Tenent yet more Bloudy:" "Master Cotton may call to mind, that the discusser [Roger Williams] riding with himself [viz., with John Cotton] and one other of precious memory, Master Hooker, to and from Sempringham, presented his arguments from Scripture, why he durst not join with them in their use of Common Prayer." 1 We can easily divine the purpose of

1 Pub. Narr. Club, iv. 65. 
this pilgrimage to Sempringham. Dudley, in his letter to the Countess of Lincoln, has furnished a motive for this and of all similar visits by other New England planters.

We like to dwell upon the quaint picture of these three great historic New England worthies, the founders of almost as many states, riding together across the plains and fens of Lincolnshire, disagreeing as they did, in all their subsequent lives, about doctrine and the meaning of Scripture. And, strange to say, no man can assure us whence they came to Sempringham and whither they went when they departed. It is fortunately unimportant.

Dudley says in his letter to the Countess of Lincoln, not for her information, because she knew it already, but for the instruction of emigrants: "Touching the Plantation which we here have begun, it fell out thus. About the year I627, some friends, being together in Lincolnshire, fell into discourse about New England, and the planting of the Gospel there; and after some deliberation we imparted our reasons, by letters and messages, to some in London and the west country, where it was likewise deliberately thought upon, and at length with often negotiation so ripened, that in the year 1628 we procured a patent." 1

Governor John Winthrop, "the father of Massachusetts," was drawn to Sempringham as well as the other planters. The following letter from him is excellent and to the point :-

" July 28: 1629. My Bro : Downing \& myselfe ridinge into Lincolnshire by Ely, my horse fell under me in a bogge in the fennes, so as I was allmost to the waiste in water; but the Lorde preserved me from further danger. Blessed be his name."

The Hon. Robert C. Winthrop remarks that this letter indicates, "beyond a question, that Winthrop and Downing were on their way to Sempringham to visit Isaac Johnson, and consult with him about the great Massachusetts enterprise. There is a letter, from Johnson to Downing, found 1 Young's Chron., 309. 
among Winthrop's papers, dated just twenty days before, inviting them to do so." 1

We cannot think, upon an examination of Mr. Johnson's letter, that they made the journey to Sempringham solely to consult with him. The whole household, including many members, like a busy hive, was thoughtfully and deeply pondering immediate emigration to America; each one who was not about to depart was full of solicitude for the impending fate of those who were. They were studying and reflecting upon the loss of much that was as dear to them as life itself, by this separation from the home of their childhood. They were thinking of perils by sea, of perils in the wilderness, of manifold privations, of furious wild beasts, of unknown diseases, of merciless savages; all of these dangers, and many others, kept them anxious and perplexed by day, and sleepless by night. And still, above all this solicitude concerning personal safety and comfort, the thoughts of a land of freedom to worship God, a country where a new government might arise, divested of the worn-out, cumbersome systems descending from earlier and darker ages, took possession of their souls, and made them anxious and restless to be on their journey "Westward," whither "the course of empire takes its way."

How great the interests of this enterprise were in this family and household will appear if we carefully note the individuals who were in it, and the parts they acted in the early history of Massachusetts. No other family is so conspicuous.

Mather says the "times began to look black and cloudy upon the Nonconformists, of which Mr. Dudley was one to the full." 2 Isaac Johnson, the brother-in-law of the earl, gave in his name for the expedition to the American wilder-

1 Life and Letters of John Winthrop, i. 304, 2d ed.; Mass. Hist. Coll., 4th series, vi. 29. This was probably Emanuel Downing, who was of the Inner Temple, and married a sister of Governor Winthrop. (Young's Chron., 97.)

2 Proc. Mass. Hist. Soc., I87o, 216. 
ness. He was the largest financial adventurer. His saintly wife, the beautiful Lady Arbella Johnson, whose praises have been sung during two and one-half centuries, joined him to take her full share of privations and sufferings in founding this nation. She had been tenderly reared at Sempringham, and most of her cherished memories of childhood and youth clustered about it. It is quite possible that the old church which remains was the place of her marriage; we are sure that it was her place of worship.

Hubbard says that "she came from a paradise of plenty and pleasure, which she enjoyed in the family of a noble earldom, into a wilderness of wants," and that "she took New England in her way to heaven." She arrived in America in June, 1630, and died in the following August, and her husband survived her only one month.

Lady Susan Humphrey also was a sister of the Earl of Lincoln. She must have left her native land with deep misgivings in 1632, following with a forlorn hope her sister Arbella to her last earthly abode. She and her husband came with their children. Her husband, John Humphrey, was one of the six original patentees to whom the grant of Massachusetts Bay was made by the Council of Plymouth. $\mathrm{He}$ was the first deputy governor of Massachusetts. He was also an original patentee of the Colony of Connecticut. They returned to England in I64I with a dark shadow on their lives by reason of a cruel misfortune which overtook their little daughters in America. ${ }^{1}$

Lady Frances Gorges, wife of John Gorges, was another sister of the Earl of Lincoln, whose husband had large landed interests in New England even prior to the emigration of 1630 .

The eminent William Fiennes, Lord Saye and Sele, greatly distinguished in the Revolution, was connected with this family by marriage, for his daughter Bridget was the accomplished Countess of Lincoln, who presided at Sempringham through all this stormy period in English annals.

'Lewis and Newhall's Hist. of Lynn, 152. 


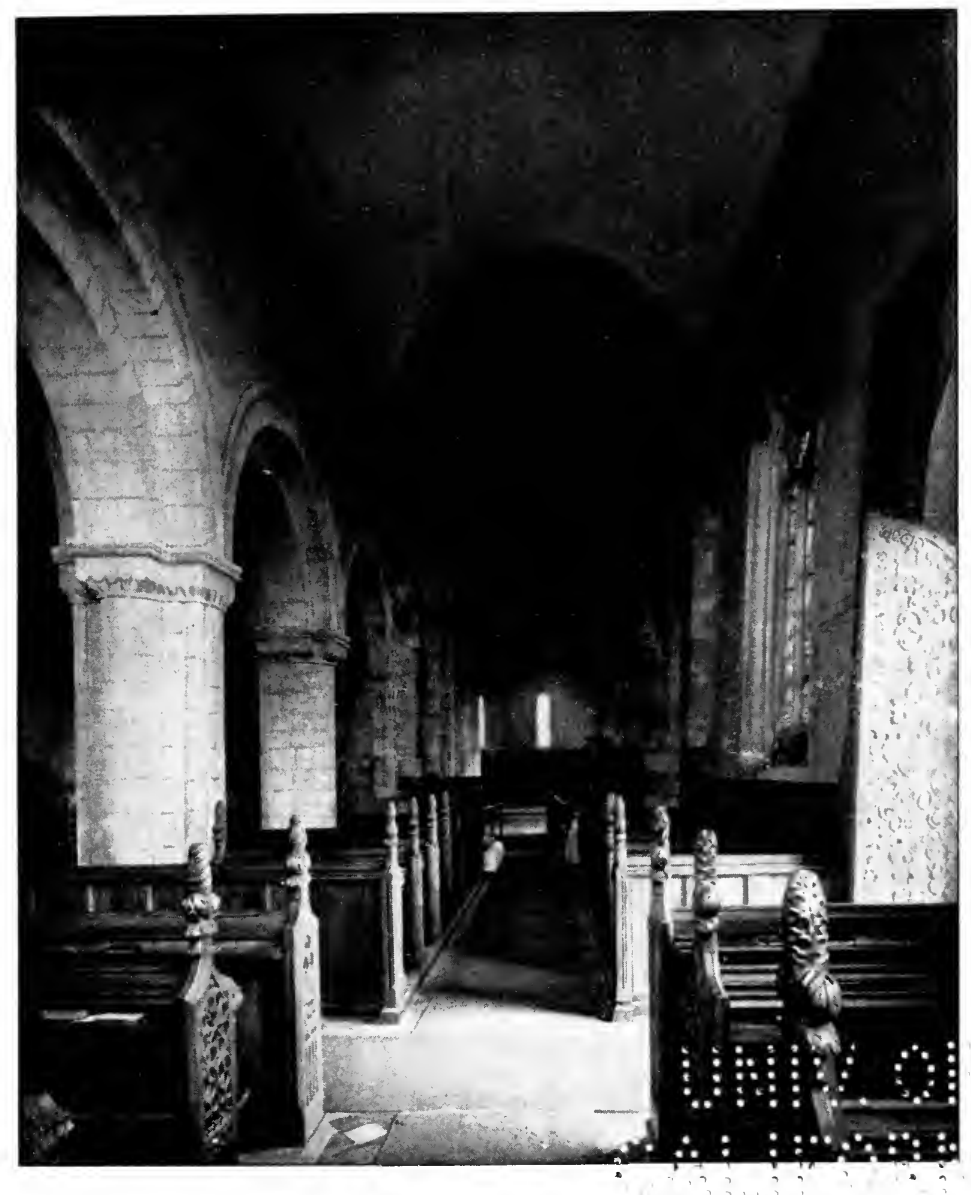

INTERIOR OF SAINT ANDREW'S CHURCH 
10 
He was a large proprietor in New England and the West Indies. Saybrook in Connecticut takes a part of its name from his title. He intimated to the government of Massachusetts that he would come there to reside if only the hereditary dignity of a peerage was permitted to him. It was politely declined, and he remained in England and took an active part in the struggle for freedom. ${ }^{1}$

Mr. Young says, "This family of Lincoln had a more intimate connection with New England settlements, and must have felt a deeper interest in their success than any other noble house in England." Cotton Mather describes the family in "Magnalia," i. I 26, as religious, and " the best family of any nobleman then in England."

It attaches still more strongly the beginning and development of New England to this ancient Sempringham, and to this illustrious house of Lincoln, that Dudley and his distinguished son-in-law, Simon Bradstreet, were both at different times stewards during many years in this home, and subsequently were both a long time magistrates and governors of Massachusetts.

All things had seemed to be in preparation for many generations for this very hour. The intellectual, religious, social, and political revolution in Holland; the great movement of spiritual and intellectual life culminating in the Reformation ; the vitalizing force of Calvinism, charged with Christian power, which had everywhere manifested itself in Europe, and later in America, as above all other religious teaching fruitful in individual liberty (although its doctrines were harsh and its methods narrow), - were each and all conspicuous in human progress. Liberty has flourished most where Calvinism has predominated.

This doctrine took a deep and permanent hold of the minds of the people who inhabited that region of country north of London on the eastern side of England, including Lincolnshire. That territory was always, from the time of

1 Bancroft's Hist. of U. S., i. 385 ; Hutchinson's Hist., 42 ; Palfrey's History of New England, i. 389, note. 
the Reformation, inhabited by bold, independent, thoughtful, and industrious citizens. Henry VIII. found Lincolnshire independent and its people thoughtful, for he called them "the most brute and beastlie of the whole realm."

They were in close proximity to the Netherlands, where spiritual and intellectual freedom had achieved their most signal triumphs, and where were to be found the finest manufactured fabrics, the most skilled artisans in the world, and the most perfect and scientific agriculture known at that time. Holland was, in the fifteenth and sixteenth centuries, at the head of the commerce of the world. It was later the asylum and retreat of brave people of every race who had political or religious ideas dangerous to prerogatives of tyrants, or hostile to so-called divine rights to rule in church or state, and of individuals who felt their personal responsibility to God, but none to priest or pope.

Englishmen crossed the Channel; they fought in the Low Countries side by side with the soldiers of the Netherlands in the good old Protestant cause; they brought, on their return to England, the invigorating spirit from the land of their sojourn. In addition to this, the white sails of commerce, then as now, were carrying the light from more favored nations to those which sit in darkness.

And, in turn, "the Flemings (in I 570) crowded across the Channel in tens of thousands, and brought with them their arts and industries, and while the rich looked to the East for the silk and satins ... . the artisans, the laborers, and the farmers were clothed from the looms which had been brought from Ghent and Bruges to their own doors." 1

"The low districts about the Humber and the Wash, reclaimed from the ocean by the Hollanders, were always hotbeds of Nonconformity: here was the original Boston; near by was Cambridge, the home of Puritanism." 2

1 Froude's Hist. of Eng., x. 106.

2 Douglas Campbell's The Puritans in Hol., Eng., and Amer., i. 495; Fourth Earl of Bedford, Lodge's Portraits, iv. 299; Carlyle's Cromwell, i. 89; Chamb. Ency., vi. 139. 
Men from the other side of the Channel educated the English in manufactures. They were descended from an ancestry which for generations had resisted the sea in the Low Countries, and they helped to redeem and reclaim the fens of Lincolnshire and its neighborhood. Devout people reared aloft in 1309 the tower of St. Botolph, the parish church of Boston, two hundred and ninety-one feet above the pavement, resembling the majestic tower of the Cathedral of Antwerp, suggestive at least, almost prophetic, of the wonderful service which the emigrants from the Netherlands would render centuries later in delivering from the thralldom of the sea these wide fields, rich now with harvests, and picturesque with thousands of sheep and cattle grazing peacefully over their broad acres; because, whenever the eyes of these delvers and dike-builders, during many centuries, turned to the tower, visible forty miles over land or sea, it smote upon their hearts with a message of home, of childhood and youth, of early loves and early friends.

Dudley retired to Boston ${ }^{1}$ at one time, and made it his home, that he might listen in this very church to the preaching of the Rev. John Cotton, ${ }^{2}$ who afterwards for a long period was the most noted preacher in Boston, Massachusetts.

Dudley dwelt later, probably for a short time only, near to Isaac Johnson, at Clipsham in Rutlandshire; but Sempringham, fifteen miles away, was always the centre of his thought and interest. Nothing of importance, Mather assures us, could be done at Sempringham without him, whether it were to direct an expedition that he and the earl might go in two days from Sempringham to the Hague, "by reason of an interview of some great princes that were then to be present," and there by his tact and judgment to preserve the earl from misfortune, or to render to him and to his estate, day after day, invaluable and most highly appreciated services at Sempringham.

We have sought to show the environment in which Dud-

1 Palfrey, i. 367, note 3 ; Proc. Mass. Hist. Soc., Jan. 1870, 216.

2 See Letter of Dudley to Cotton, p. 257 of this volume. 
ley's career was set, the society and people most influential in shaping his course in life. He possessed the friendship and the confidence of Judge Nicolls, of Lord Compton, of Lord Saye and Sele, of the Earl of Lincoln, Isaac Johnson, John Humphreys, and a great number of the most eminent and learned ministers of his time.

These friends were the friends of, and associates with, Cromwell, Hampden, and Pym. They were, take them for all in all, among the ablest men of their period. Many of the great soldiers and heroes of the Commonwealth came from this neighborhood; Cromwell, Milton, Hampden, and Fairfax, for example. The Ironsides of Cromwell were, it is said, from the region of the fens. This vicinity was as prolific in heroes and armed men as if Jason had sown the fens with dragons' teeth.

We have felt particularly desirous to establish in the mind of the reader, as firmly as possible, the character of Dudley in England in private life and among his friends and associates, because, if we are quite sure that we have found his leading characteristics, and that they were sound and consistent year after year up to fifty-four (the age at which he emigrated), we may feel very certain that the rest of his life was of the same general nature and course. This view is strengthened by the very firm intellectual and moral fibre and constitution of the man. He was 'strong and stable by his very nature, and not easily turned from a habit once fixed, or an opinion once carefully and thoughtfully made up, so that as we have known him in the past we shall find him to be in the future. What he was therefore in England, and what were his characteristics there, are very important, for the reason that in America we must depend upon descriptions of his doings sketched by political rivals, or by persons controlled, whether they knew it or not, by a personal or political bias. Dudley has not, as we have seen, written his own defense and explanation of matters and causes which are, and have been for more than two centuries, used to detract from his just fame and merit; therefore it is with great satis- 


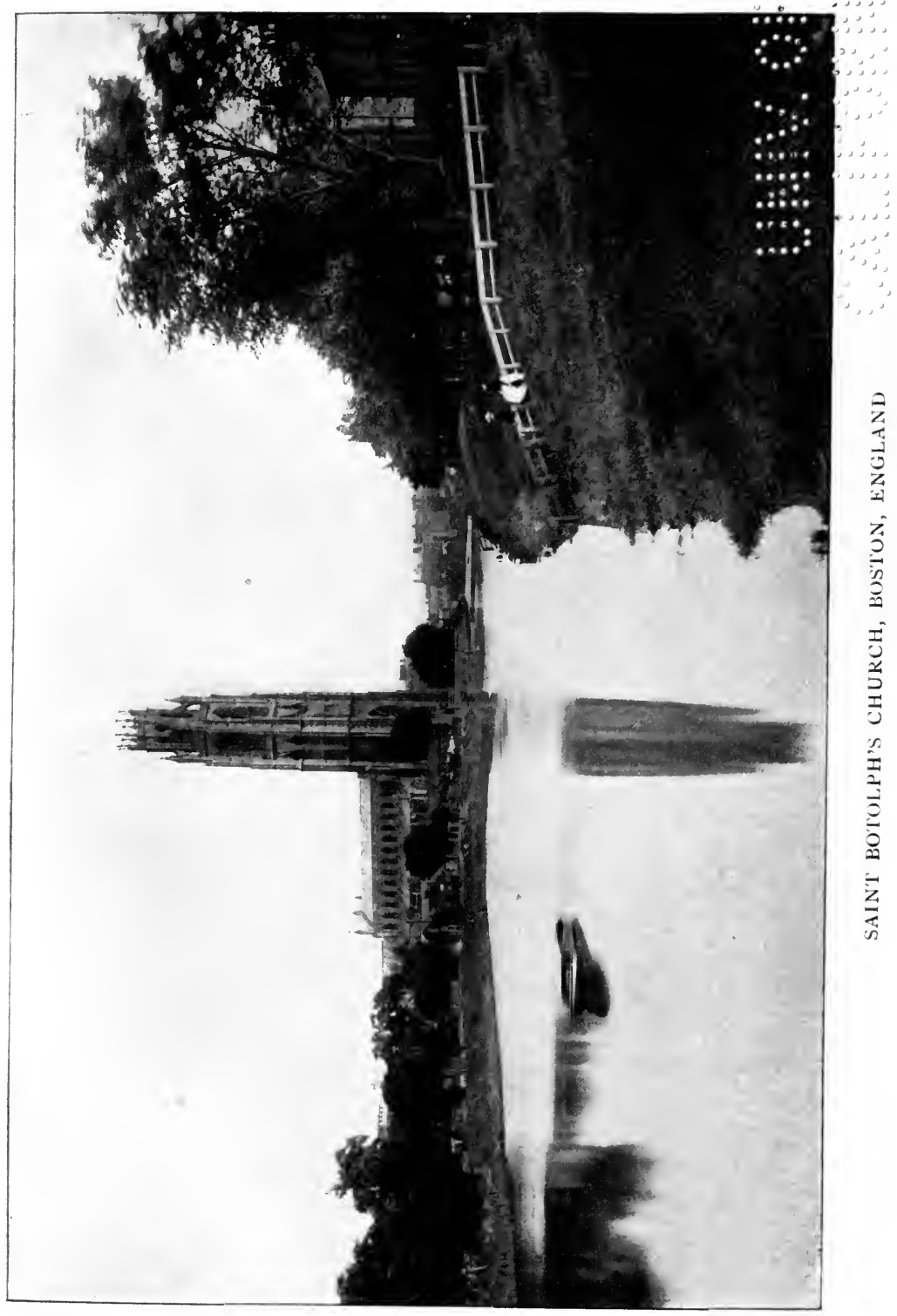



faction and confidence that we look back upon a long life the other side of the sea, round, complete, and full, and everywhere distinguished for ability, integrity, and wisdom, to aid us in doing substantial justice to his career in America. While we think of him as a man who adhered to his convictions, like St. Paul, Luther, or John Hampden, we are assured that he was kind of heart, and just to the rights of all persons. As we have seen, he was of "gentle blood," was long a page in the elegant home of Lord Compton, and must have been a master and a guide in the ways of polite society and accomplished manners. He was associated for years with a distinguished judge of the Court of Common Pleas, during which years Sir Edward Coke was chief justice of that very court. And it must have been his constant duty, as clerk, either himself to give expression to the opinions of the judge or to study them as given; in any event, he had ever before him justice between man and man, and the golden rule as his constant guide and inspiration. Here in this occupation he must have become well seasoned with justice and mercy. His views of life had been early broadened by a sojourn in the army of Henry IV. His business life had been unusually successful. His social position had been all that could be desired. And with the advantage of great connection, of wide and varied observation in life, brimful of the best quality of experience in every direction, in his ripe mature age he joined the great emigration. "The past at least is secure." And the future will be like unto it.

Dudley had no need to make a business adventure three thousand miles over the ocean. He was already, in England, retired from business, and was probably one of the most affluent men in the colony during his lifetime. If the real indispensable things of life did not draw him from fatherland, from the culture and luxury of Old England in which he had been reared, what were the all-sufficient motives determining his future course?

Whether he had bread in England or not, there are greater things in this world than bread, although it is the staff of life. 
"Man shall not live by bread alone." So soon as he was assured that the Massachusetts Charter would go to America with them, and that the possibilities of a regenerated and purified church and state lay before them, he consulted not flesh and blood but cast in his lot with the adventure. $\mathrm{He}$ risked in this comfortless enterprise not only himself and his property, but, what was far dearer to him, the lives and fortunes of his wife and five children, the oldest of whom, Samuel, was only twenty years of age. ${ }^{1}$

Mather no doubt stated the situation well when he said that "the times began to look black and cloudy upon the Nonconformists, of which Mr. Dudley was one to the full." These people were reasonably convinced that the only true and safe course was to break at once totally with the past, taking the best of everything that it had produced, and to transplant it on virgin soil beyond the sea, a glorious heritage for succeeding generations. It was now the way of least resistance. The king was glad to be rid of them, although it has been said and disputed that Cromwell and Hampden were detained and never came.

Freedom to worship God was before them, in a Puritan English Church cleansed from all the defilements clinging to the ancient church through the dark periods of history. The Puritans, says Lowell, "were the most perfect incarnation of an idea the world has seen." They were leaving behind them the wornout and cast-off vesture of church and state, kingcraft and priesthood. ${ }^{2}$ Behind them also were war-clouds, dark and ominous, charged with revolution, which was soon to drench the land in fraternal blood.

Dudley had twenty-three wonderful years before him; they were a glorious remnant of life, full of noble, self-sacrificing privations and sufferings, upon which he entered "with firmness in the right as God [gave him] to see the right," to secure the blessings of civil and religious liberty to posterity.

There is a sadly sweet remembrance that lingers over all

1 History of Dudley Family, i. 276.

2 Quincy's Hist. Boston, 324. 


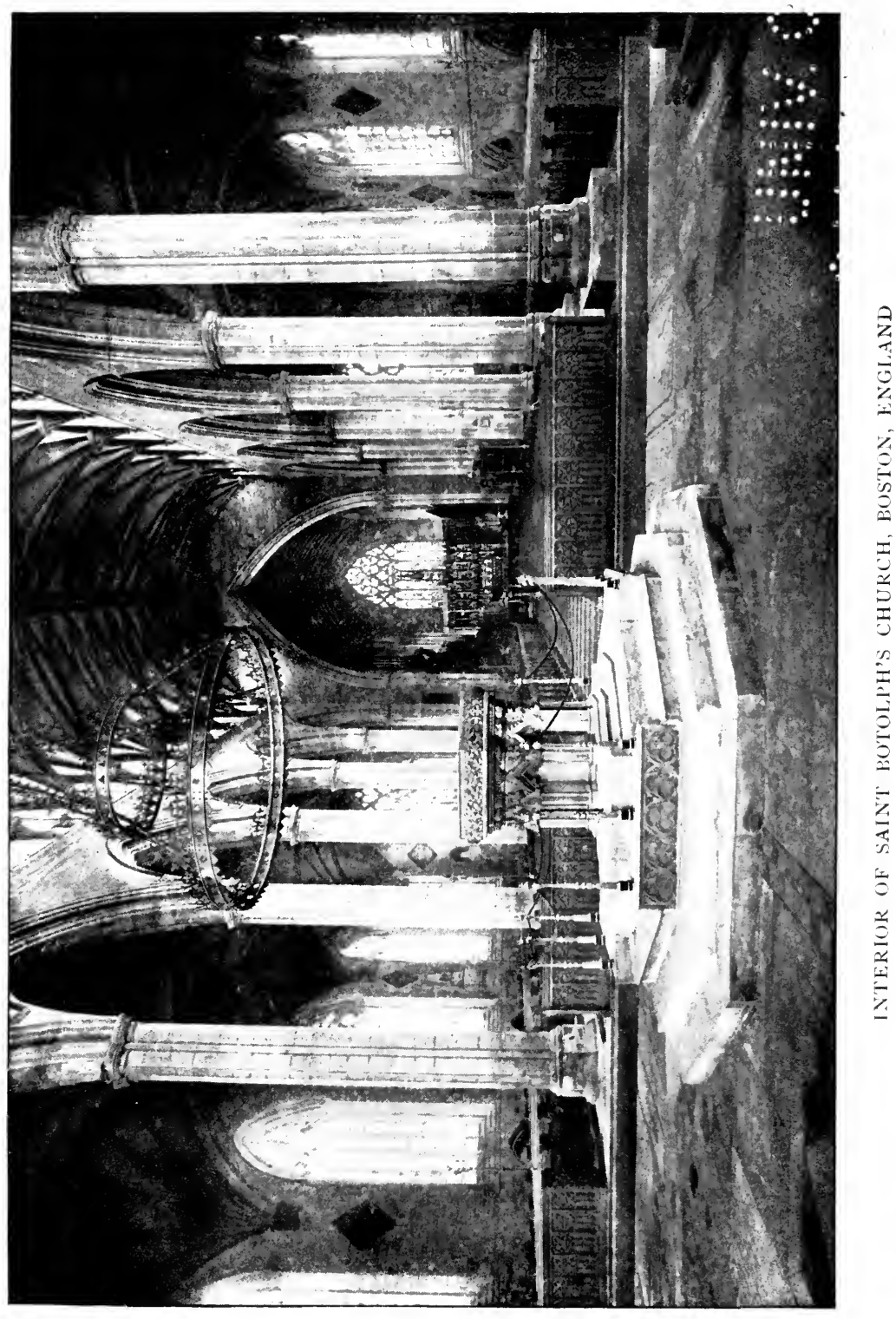



of these ancient highways, these fens stretching far away to the sea, and over all the smiling tract of Lincolnshire and its surroundings, because it was in these sacred scenes that Thomas Dudley, the second governor of 'Massachusetts, thoughtfully and prayerfully, as he went to and fro, considered the founding of the Colony of Massachusetts during the five years from 1625 to 1630 . The scene is almost unchanged, except in the more highly cultivated fields; there are the same church towers, roads, dwellings, the same varieties of birds and flowers. ${ }^{1}$

Here he wandered, while one great thought was slowly taking possession of him, - that his departure was at hand, and that never in all his life would he revisit these dear old ways and haunts, or see their like again.

1 Dudley was an executor of the will of Isaac Johnson, wherein he is mentioned as of Clipsham, in the county of Rutland, March, I629, O. S., from which we conclude that he had removed from Boston, and was residing during his last days in England, near the home of Isaac Johnson and Lady Arbella. He may have been led to this in order to be helpful in closing up their affairs, preparatory to emigration." (Mass. Hist. Soc. Coll., 3d series, viii. 245.) 


\section{CHAPTER VI}

Religion stands on tiptoe in our land, Ready to pass to the American strand.

Herbert.

THE most important emigration to America which was ever made, and, it is sometimes said, which has ever been made in the history of the world, was about to be undertaken, and Dudley was to have a leading part in it, and in the colony.

Mather says that, "when the enterprise for New England began to be set forth, Mr. Dudley embraced that opportunity, and so resolved to leave England and travel over the sea into the deserts of America, that there he might with other Nonconformists enjoy his liberty to the utmost of what he desired. Mr. Dudley was not among the first of them that embarked in the design for New England, which is the reason why he was not numbered among the patentees." 1

There had been many attempts by the English before this period to found colonies on the shores of Massachusetts Bay, without success, and Mather attributes their failure to the fact that their design was to advance some "worldly interests." He means, no doubt, such as to catch fish or to seek gold. 2

He informs us also that good news from the Plymouth plantation "inspired the renowned Mr. White [Rev. John White], minister of Dorchester, to prosecute the settlement

1 Proc. Mass. Hist. Soc., Jan. I870, 216.

2 Mather's Mag., i. 6I. It has been said that, if gold had been found in New England and the cultivation of the soil and manufactures neglected, democracy would not have subsisted here. (Atlantic Monthly, lxxii. 816.) 
of such another plantation here for the propagation of religion. This good man engaged several gentlemen, about the year 1624, in this noble design; and they employed a most religious, prudent, worthy gentleman, one Mr. Roger Conant, in the government of the place." He made choice of Salem as a refuge for the exiles of religion. Mr. Conant and his three companions were "the sentinels of Puritanism" in Massachusetts. " "This man was inspired, as it were, by some superior instinct," and thus made a beginning in 1626 .

The deed from the Council of Plymouth, in England, to Sir Henry Roswell, Sir John Young, Thomas Southcoat, John Humphrey, John Endicott, and Simon Whetcomb, bearing date March 19, 1628, conveyed the land extending three miles south of the river Charles and the Massachusetts Bay, and three miles north of every part of the river Merrimac, from the Atlantic to the Pacific Ocean. The grantees received as associates Sir Richard Saltonstall, Isaac Johnson, Matthew Cradock, Increase Nowell, Richard Bellingham, Theophilus Eaton, William Pynchon, and others." 2

A royal charter was granted incorporating the Governor and Company of Massachusetts Bay, March 4, I628 (29). But Endicott had gone in September, 1628, to Salem, Mass., with six vessels containing emigrants, supplies, cattle, and other needful things. They established at Salem a church by mutual covenant, with Skelton as pastor and Higginson as teacher, and sent men to begin another settlement at Charlestown.

Dudley, after giving some account of the various former expeditions to Massachusetts to obtain fish and beaver, proceeds to give his account of the colonization of that neighborhood, in which he himself took a great part. He says (as we have previously mentioned, p. 44): "Touching the plantation which we here have begun, it fell out thus : About the year 1627, some friends, being together in Lincolnshire, fell into discourse about New England, and the planting of

1 Bancroft's Hist. U. S., i. 339.

2 Mather's Mag., i. 62, 63. 
the gospel there; and after some deliberation we imparted our reasons, by letters and messages, to some in London and the west country; where it was likewise deliberately thought upon, and at length with often negotiations so ripened, that in the year 1628-29 we procured a patent from his Majesty for our planting between the Massachusetts Bay and Charles River on the south, and the river of Merrimac on the north, and three miles on either side of those rivers and bay; as also for the government of those who did or should inhabit within that compass. And the same year we sent Mr. John Endicott [June, 1628] and some with him to begin a plantation, and to strengthen such as he should find there, which we sent thither from Dorchester ${ }^{1}$ and some places adjoining. From whom the same year receiving hopeful news, the next year, 1629, we sent divers ships over, with about three hundred people, and some cows, goats, and horses, many of which arrived safely.

"These, by their too large commendations of the country and the commodities thereof, invited us so strongly to go on that Mr. Winthrop, of Suffolk, (who was well known in his own country, and well approved here for his piety, liberality, wisdom, and gravity,) coming in to us, we came to such resolution that in April, 1630, we set sail from Old England with four good ships. And in May following eight more followed; two having gone before in February and March, and two more following in June and August, besides another set out by a private merchant." 2

It has been said that, "while all the forty counties of England were more or less represented among the emigrants to Massachusetts, the shires on the eastern side contributed far more than all the rest. It is estimated that two thirds of the American people (emigrants) came from these, one sixth from Devon, Dorset, and Somerset, and the remaining one sixth from all other parts of England." 3

1 Young's Chron., 23-29.

2 Ib., 309-3II.

8 John Brown's Pilgrim Fathers of New England, 266. 
The spring of 1630 was an eventful season. A large number of people, amounting to about fifteen hundred persons, were contemplating a final departure to America. All through the months of January, February, March, and April these Puritan exiles were closing up their worldly affairs as if about to make their final adieu to this planet. They were collecting and thoughtfully considering what needful things should be taken by them over the sea. In those March days they began to wend their way towards Southampton, the place of embarkation, whence ten years before the Mayflower and the Speedwell had sailed for Plymouth, freighted with hopes of future years and with unmeasured destiny, for the Massachusetts Colony took inspiration from Plymouth.

They would naturally pass in their journey ancient Winchester, the old-time capital of the kingdom, the capital of the British, the Saxon, and the Norman kings, and the beloved resort of English kings and queens until long after the departure of the Puritans to America. These Puritans have sometimes been spoken of as the rising and triumphant remnant of that Saxon race which, vanquished at the battle of Hastings under Harold, and in the fens of Lincolnshire, had returned to grind to powder in succeeding years the residue of the feudal system, with its oppressive tenures, and to preserve this continent from its baneful tyranny.

Whether it meant anything to these proscribed people, who were then filing through the streets of the old capital, or not, it was fit and proper that they should pay their last reverent homage at the grave of Alfred the Great, ${ }^{1}$ and at the resting-place of the other Saxon kings, before their withdrawal to plant on another continent that liberty denied to them at home, which their ancestors had struggled and died for, under the kings whose ashes were treasured up in yonder cathedral, and are still preserved as the heritage of the English-speaking nations. ${ }^{2}$

1 F. W. Farrar's Cathedrals of England, 278.

2 And that they should remember that Alfred the Great "left behind him in his will, as an immortal legacy to his country, the sentiment - 
They would find at Southampton, if they sought for it in the New Forest, the oak, then more than five hundred years old, which was said to have turned the arrow sped from the bow of Walter Tirel to the heart of William Rufus, the Norman king, August 2, I 100. "The arrow, by whomsoever shot, set England free from oppression such as she never felt before or after at the hand of a single man." 1

There were four ships of the fleet ready, and they sailed from Southampton, March 22, I630. Leaving behind the Mayflower, and six other ships to follow, they ran across the Southampton Water and the Solent to Cowes, on the Isle of Wight (the distance of an hour's sail by the steamer of to-day), and a week later, on March 29, again proceeded a little on their way.

We are especially interested in the Arbella. She was a ship of three hundred and fifty tons, carrying twenty-eight guns and fifty-two men. Peter Melbourne was her master, and owned a share in her. The excellent and beautiful Lady Arbella Johnson, sister of the Earl of Lincoln, and her husband, Isaac Johnson, were on board this ship. Governor John Winthrop and two of his sons were passengers of the first importance, also Sir Richard Saltonstall, with three sons and two daughters ; the Rev. George Philips and wife; William Coddington and wife, afterwards of Rhode Island; Thomas Dudley, deputy governor of Massachusetts, with his wife, Dorothy Dudley, with one son, Samuel, and four daughters, - Anne, sixteen years old, the youthful bride of Simon Bradstreet, who was with her, and her sisters, Patience, Sarah, and Mercy.

As the Arbella moved over that extensive bay called how glorious from the heart of a great and victorious king! - that 'it is just that the English should forever remain as free as their own thoughts.'" (Howitt's Visits to Remarkable Places, Winchester, I77; Lappenberg's Hist. of Eng. under the Anglo-Saxon Kings, 99.)

It is because these emigrants cannot be as free as their thoughts, in the kingdom once ruled over by Alfred the Great, that they are now making haste to bid farewell to the home of their ancestors.

1 E. A. Freeman's Reign of William Rufus, i. 337. 
Southampton Water, if the wonderful tides served on that 22d day of March, 1630, there was hardly any more beautiful sheet of water set in more lovely shores. The farewell view of Old England presented to their lingering gaze was in the midst of the most exquisite scenery that land, water, hills, dales, and woods ever formed. On either side are beautiful villas, the walls of old and ivy-covered towers, and the ruins of ancient abbeys.

It is not possible for us to penetrate the veil which hid the deep feelings and well-springs of thought in the minds of these people, however active our imagination, however much we may seek to do it. It is an unusual experience to go forth with no hope of returning; it is like bidding farewell to mortal affairs. They were assured that this was their last view of home, and ruins, and ivy-mantled towers, of historic associations connected with their ancestors for thousands of years. But deeper, more heart-rending than all, was the severing of tender ties of family and friendship. There could be no future meetings, and for the multitude little or no correspondence. There may, it is true, have been many who had been weaned from intense love of fatherland by what they had suffered, and who hailed their hour of deliverance with joy. There may have been others who were so inspired by that vista of religious and political freedom beyond the sea, by their visions of a Utopia towards which they were now tending, that the mighty past became as nothing in comparison with the future which lay before them. Nevertheless, to one and all of them there surely came moments when the tide of feeling had its way, and their hearts were true and tender with thoughts of home and early friends.

The last meeting of the Court of Assistants on English soil was at Southampton four days before they sailed. ${ }^{1}$ The Arbella was on March 23 riding at Cowes. Here on board the ship, at a Court of Assistants, Thomas Dudley was chosen deputy governor in place of John Humphrey, who

1 Mass. Col. Rec., i. 69. 
had decided not to embark then, but who came to America later.

Dudley held this same office by annual elections thirteen different years. This was the very last record in England of the Massachusetts Company, and its purpose was to confer honor and responsibility upon Dudley. The four ships sailed from Cowes on the 29th of March, and were soon at Yarmouth in the Isle of Wight. They were delayed there more than a week by contrary winds. This gave the emigrants the privilege of a visit, on April 6, from the captain of Yarmouth Castle, who took breakfast with them. They were also honored with a visit the same day from Matthew Cradock, the first governor of the company, who never came to America. He had once before at their embarkation bidden them farewell, but his interest was so deep in the enterprise that he had followed them to their last anchorage on the coast of.Europe.

Governor Winthrop informs us that "Lady Arbella and the gentlewomen, and Mr. Johnson and some others, went on shore to refresh themselves." No doubt it was a great delight to them to be permitted unexpectedly once more, and for the very last time, to step upon the soil of Old England, and Yarmouth will always have the honor of being the place of this farewell.

But the next day a more important event in human history transpired, when the following letter, signed by the most notable men in the cabin of the Arbella, setting forth their affection and loyalty toward the Church of England, "their dear mother," went forth from this village of Yarmouth, giving it a lasting place in the memories of men :-

“The Humble Request of His Majesty's Loyal Subjects, the Governor and the Company late gone for New England; To the rest of their Brethren in and of the Church of England. For the obtaining of their Prayers, and the removal of suspicions, and misconstructions of their Intentions :- 
"Reverend Fathers and Brethren, - The general rumor of this solemn enterprise, wherein ourselves with others, through the providence of the Almighty, are engaged, as it may spare us the labor of imparting our occasion unto you, so it gives us the more encouragement to strengthen ourselves by the procurement of the prayers and blessings of the Lord's faithful servants. For which end we are bold to have recourse unto you, as those whom God hath placed nearest his throne of mercy; which, as it affords you the more opportunity, so it imposeth the greater bond upon you, to intercede for his people in all their straits. We beseech you, therefore, by the mercies of the Lord Jesus, to consider us as your brethren, standing in very great need of your help, and earnestly imploring it. And howsoever your charity may have met with some occasion of discouragement through the misreport of our intentions, or through the disaffection or indiscretion of some of us, or rather amongst us (for we are not of those that dream of perfection in this world), yet we desire you would be pleased to take notice of the principals and body of our Company, as those who esteem it our honor to call the Church of England, from whence we rise, our dear mother; and cannot part from our native country, where she specially resideth, without much sadness of heart and many tears in our eyes, ever acknowledging that such hope and part as we have obtained in the common salvation, we have received in her bosom, and sucked it from her breasts.

"We leave it not therefore as loathing that milk wherewith we were nourished there; but, blessing God for the parentage and education, as members of the same body, shall always rejoice in her good, and unfeignedly grieve for any sorrow that shall ever betide her, and while we have breath, sincerely desire and endeavour the continuance and abundance of her welfare, with the enlargement of her bounds in the Kingdom of Christ Jesus.

"Be pleased, therefore, reverend fathers and brethren, to help forward this work now in hand; which if it prosper, you shall be the more glorious, howsoever your judgment is 
with the Lord, and your reward with your God. It is a usual and laudable exercise of your charity, to commend to the prayers of your congregations the necessities and straits of your private neighbours : do the like for a Church springing out of your own bowels. We conceive much hope that this remembrance of us, if it be frequent and fervent, will be a most prosperous gale in our sails, and provide such a passage and welcome for us from the God of the whole earth, as both we which shall find it, and yourselves, with the rest of our friends, who shall hear of it, shall be much enlarged to bring in such daily returns of thanksgivings, as the specialties of his providence and goodness may justly challenge at all our hands. You are not ignorant that the spirit of God stirred up the Apostle Paul to make continual mention of the Church of Philippi, which was a colony from Rome; let the same spirit, we beseech you, put you in mind, that are the Lord's remembrancers, to pray for us without ceasing, who are a weak colony from yourselves, making continual request for us to God in all your prayers.

"What we entreat of you that are the ministers of God, that we also crave at the hands of all the rest of our brethren, that they would at no time forget us in their private solicitations at the throne of grace.

"If any there be who, through want of clear intelligence of our course, or tenderness of affection towards us, cannot conceive so well of our way as we could desire, we would entreat such not to despise us, nor to desert us in their prayers and affections, but to consider rather that they are so much the more bound to express the bowels of their compassion towards us, remembering always that both nature and grace doth ever bind us to relieve and rescue, with our utmost and speediest power, such as are dear unto us, when we conceive them to be running uncomfortable hazards.

"What goodness you shall extend to us in this or any other Christian kindness, we, your brethren in Christ Jesus, shall labor to repay in what duty we are or shall be able to perform, promising, so far as God shall enable us, to give 
him no rest on your behalfs, wishing our heads and hearts may be as fountains of tears for your everlasting welfare when we shall be in our poor cottages in the wilderness, overshadowed with the spirit of supplication, through the manifold necessities and tribulations which may not altogether unexpectedly, nor, we hope, unprofitably, befall us. And so commending you to the grace of God in Christ, we shall ever rest

Your assured friends and brethren, "John Winthrop, Gov., Richard Saltonstall, Charles Fines, George Phillipps,

$\& c$. ISAAC JOHNSON, Thomas Dudley, William Coddington, \&c.

"From Yarmouth, aboard the Arbella, April 7, 1630." 1

The fact that Winthrop's name as governor appears first in this letter among the signers of it would not seem to give any assurance that he was the author. Mr. Robert C. Winthrop dwells with some satisfaction upon his possible authorship of it. The pathetic parts seem more like the work of a minister than of Governor Winthrop or of Governor Dudley, although neither of them was wanting in emotional power of expression when the occasion demanded, as we shall hereafter discover. It is not probable that any person in the colony in the time of Governor Dudley had greater power in drawing public letters and documents in apt words and terse forms of expression than himself. He had given years to this very difficult occupation under the instructions of Judge Nicolls, a great master in that art.

The authorship is unimportant, and it need not be assumed for either of them without evidence. They may all have the credit of a joint composition, and each may be held responsible for all that appears in the letter, and each and all have the credit of every worthy and exalted sentiment contained in it. 
The particular value of this letter is in their clear and unrestricted declaration of perfect loyalty to the Church of England and most deep and sincere attachment to it. They were not yet Separatists. They were hereafter to be trained in a rugged school, until step by step their dear and early church affiliations would disappear and leave them only inflexible Independents. When they signed this letter, they were Puritans, who were constantly saying to the Established Church, "Thou ailest here and here," but their cry was soon unavailing, and they went their own way. They had said, "We do not go to New England as Separatists from the Church of England, though we cannot but separate from the corruptions in it ; but we go to practice the positive part of Church reformation, and propagate the Gospel in America." They set sail in earnest for their long voyage across the Atlantic, Thursday, April 8, about six in the morning, and before ten they were through the Needles, which will always recall, to persons interested in the exiles on those ships, their very last adieu but one to their native land. Those pointed rocks were then as beautiful as to-day, with the same curious " effect produced by the wonderfully colored cliffs, contrasted with the glittering masses of the snowy Needles," visible to all who pass along this great highway of nations, century after century.

As they were sailing along the coast of England on the first day, they were made very anxious because eight sail astern of them seemed to be Dunkirkers, hostile to England and dangerous to them. They put themselves and their ships in fighting trim with great courage and calmness; "the Lady Arbella and the other women and children were removed into the lower deck, that they might be out of danger. All things being thus fitted, we went to prayer upon the upper deck. It was much to see how cheerful and comfortable all the company appeared; not a woman or child that showed fear, though all did apprehend the danger to have been great, if things had proved as might well be expected, 
. . . but our trust was in the Lord of Hosts." 1 The ships proved to be friendly and harmless, but it reveals to us what manifold perils they were exposed to at all times.

They were on Sunday, the I Ith of April, past the Scilly Isles, where thirty years after Sir Harry Vane, fourth governor of Massachusetts, was a state prisoner. ${ }^{2}$ They had a small accident, and the minister and the people were sick, and they were all out of order that day, and could have no sermons.

The next day, Governor Winthrop says, "our children and others, that were sick, and lay groaning in the cabins, we fetched out, and having stretched a rope from the steerage to the mainmast, we made them stand, some of one side and some of the other, and sway it up and down till they were warm, and by this means they soon grew well and merry." 3

1 Winthrop, i.

${ }^{2}$ J. B. Moore's Memoirs of Am. Governors, 332.

3 Winthrop, i. *9. 


\section{CHAPTER VII}

WE have not mentioned that the first charter of Massachusetts was on board the Arbella, and being transported to America, a fact often unjustly declared to be due to sharp practice on the part of the Puritans, the grantees. We most heartily join these critics in disapproving of the sentiments of the Greek poet, that "unrighteousness might be fittingly practiced in order to obtain a crown, but that righteousness should be practiced in all other times and places." 1

This theory of virtual deception on the part of the Puritans has been assumed and argued long and fervently by persons who have been searching for their transgressions, and who have not always been embarrassed by worship of ancestors, but only afflicted with an ambition to champion the thrice-popular cause of liberty, often themselves simply indifferent to religion or to limitations which the best standards in this generation approve, and which the Puritans deemed most sacred and binding upon them. There has been a reaction in Puritan Boston, and the pendulum, in swinging away from the intolerance of the seventeenth century, has gone to the other extreme, and persons to the manor born have prided themselves in casting overboard the founders of the old Commonwealth as Jonahs who made an unseemly record, and whose memory ought not to be much cherished in modern thought. A notable exception is made of John Winthrop, who for prudential reasons is usually let off mildly, with extenuating particulars, which leave little to blame in his truly heroic record. There have been, it is true, some noble lawyers who have honestly argued

1 Eurip. Phøn., 534; Freeman's Hist. of the Norman Conquest, i. 290. 
that the charter ought never to have come to America, and that it was not constructed for the use it was put to, and it would seem to follow from their position that what was done in America under the charter was illegal and unwarranted.

Fortunately, we are not driven to these painful conclusions. The action of the Puritans in this matter has been fully vindicated by careful students who have given their lives to the investigation of charter rights. ${ }^{1}$ Chief Justice Joel Parker, Royall Professor of Law in Harvard University, said, February 9, I869, "The grantees professed, in all they did, to act under the charter, and, as they contended, according to the charter. We are to look to the terms of the charter, therefore, and to a sound construction of its provisions, to ascertain what rights of legislation, religious or otherwise, were possessed by the grantees.

"From a careful examination of it, I have no hesitation in maintaining five propositions in relation to it. [We quote only three of them.]

" $\mathrm{r}$. The charter (bearing date March 4, I629) is not, and was not, intended to be an act for the incorporation of a trading or merchants' company merely. But it was a grant which contemplated the settlement of a colony, with power in the incorporated company to govern that colony.

" 2 . The charter authorized the establishment of the government of the colony within the limits of the territory to be governed, as was done by the vote to transfer the charter and government.

" 3. The charter gave ample powers of legislation and of government for the plantation or colony, including power to legislate on religious subjects, in the manner in which the

1 The considerations by the Supreme Court of Massachusetts of charter rights have special interest. (Commonwealth $v$. Roxbury, 9 Gray, 480, 48I.) The notes of Chief Justice Gray, respecting the removal of the charter from England, are particularly valuable and conclusive in favor of the right of transfer. (Ib., 510, 5 II ; Quincy's Hist. of Boston, 329-339, notes.) 
grantees and their associates claimed and exercised the legislative power." 1

This removal of the charter was sanctioned at the time by the best legal advice; the Privy Council did not question the lawfulness of the act of transfer; it was approved by the attorney-general. The chief justices Rainsford and North mention the "charter as making the adventurers a corporation upon the place." Chief Justice Parker has shown that it was a practical impossibility to have carried on the government of the colony with the charter and General Court in England; that the theory that such was the original intention is reduced to an absurdity by a construction of all the parts of the charter together. Since no place was mentioned, why was not Boston, in English America, more fitting than London in England, and why was not the choice left to the grantees? We say it was! Besides, similar patents were granted to colonies later, showing that the government found nothing to complain of in this precedent when afterwards it granted charters to Rhode Island and Connecticut, with full liberty to transport them, and to other colonies as well. No, the ruts of condemnation are easy to travel, for those who seek them, but they are not profitable unless there is more substantial cause. We are fortunately not left to the interpretations of the charter by lawyers and historians, in the decision of this much-controverted matter, because recently discovered original documents quite conclusively close the argument. Winthrop, in a paper which came to light in

1 Massachusetts and its Early History, Lowell Institute Lectures, I 869, 364-384.

Mr. James Bryce, in speaking of the authority contained in the charters of Massachusetts, says : "We have therefore . . . in the charter of $1628-29$, as well as in that of 1691 , the essential and capital characteristic of a rigid or supreme constitution, - viz., a frame of government established by a superior authority, creating a subordinate law-making body, which can do everything except violate the terms. and transcend the powers of the instrument to which it owes its own existence. . . . The trading company grows into a colony, and the colony into a state." (The Amer. Commonwealth, i. 4I3-4I 5.) 
I860, and which shows that the removal was expected by the British government, says : "The last clause (in the charter) is for the governing of inhabitants within the plantation. For it being the manner for such as procured patents for Virginia, Bermudas, and the West Indies, to keep the chief government in the hands of the company residing in England (and so this was intended and with much difficulty we got it abscinded)." This reveals to us the reason why the place of administering the charter is not mentioned in it. It seems to settle the controversy. ${ }^{1}$

The removal was unique at the start no doubt, but from it follow such important and necessary consequences that it now really seems to have been the natural and inevitable course that the charter and the governor and company should come together, and be inseparable until the foundation of this nation was laid upon bed-rock broad enough to support the superstructure, still rising under the guidance of succeeding generations into higher civilization, giving no indication that the principles cherished by the Puritans in the beginning are not destined to be sufficient.

The import of the removal of the charter was vastly augmented by two things which may or may not have been foreseen by the Puritans. The first was the distance of three thousand miles, with nothing more swift of transit than slow sailing-vessels, requiring from six weeks to three months for the passage; the second was the Puritan revolution at home, which demanded the attention of the government so completely that it had no time to give thought to its independent and unrestrained child in America.

These two circumstances contributed to make the otherwise unimportant transit of the charter really the first declaration of independence from British supremacy. This severance began at the very start, as the Arbella moved out of Southampton Water with the charter, and culminated on the $4^{\text {th }}$ of July, I776, in the American Revolution.

1 Life and Letters of John Winthrop, ii. 443; George E. Ellis's Puri$\tan$ Age, 47. 
Perhaps we can never overestimate the great importance, in this wonderful emigration, of the quality of the most prominent men among the undertakers. They were men of mark at home, men successful in life, with ample possessions, persons of high social standing, the natural leaders of society, possessing strong personal influence. And they not only drew a following after themselves; they also controlled and guided it in the right way. They never, in the first generation at least, lost their influence until the Puritan commonwealth was firmly knit together, and had entered upon its never-ending career of usefulness.

It must be evident to all persons who study the records, that such emigrants never would have abandoned home and friends and native land and gone into the wilderness, unless they had been assured beyond a doubt that the charter and the government would go with them, and that it would be lawful in all respects. They were not going for trade or for travel; they and their children were seeking a permanent home in America: the charter must secure their rights, it must be legal, it must have a legal transfer. Without all this, there was no safety in the enterprise ; it would be unutterable risk without hope. They watched every point of legal technicality, and did not venture until they felt absolutely secure. Without this assurance the undertaking could have no interest for them.

But their own records are the best evidence of their profound solicitude. The record of the General Court for the 28th of July, I629, is as follows, viz. :-

"And lastly, Mr. Governor read certain propositions conceived by himself, viz., that for the advancement of the plantation, the inducing and encouraging persons of worth and quality to transport themselves and families thither, and for other weighty reasons therein contained, to transfer the government of the plantation to those that shall inhabit there, and not to continue the same in subordination to the company here, as now it is. This business occasioned some debate; but by reason of the great many and considerable 
consequences thereupon depending, it was not now resolved upon; but those present are desired privately and seriously to consider hereof, and to set down their particular reasons in writing pro and con, and to produce the same at the next General Court; where they being reduced to heads, and maturely considered of, the company may then proceed to a final resolution thereon; and in the mean time they are desired to carry this business secretly, that the same be not divulged." 1

It may be that this injunction of secrecy is one of the little things that seem to the enemies of the Puritans so Jesuitical, and indicate that they meant to avoid and cheat the spotless and credulous Charles I. and his unsuspecting ministers. But it was really only a matter of business prudence, usual in all corporations, not to divulge vital matters until they are matured and the parties know their own minds. It is notable that the secrecy is only "in the mean time" of one month, until they can debate and deliberate among themselves.

Less than one month after the above meeting, viz., August 26, I629, the following agreement was entered into at Cambridge, in England, signed by only one person who was present at the General Court when the subject was first introduced, viz., Increase Nowell. Another interesting and significant fact is that the names of Governor Winthrop and Governor Dudley appear here, and not in the General Court record until the September and October following. The real Moses and Joshua who were to lead the colony joined it upon express condition, legal and sure beyond question, that the charter, the very palladium of liberty and of safety, was to go with them legally. Every precaution was taken to be sure that they were right. They could not afford, as we have said, to be wrong; they had too much at stake. Perhaps persons who are so sensitive about the honor of the Puritans in this matter think that they ought to have been frank, and asked Charles I. or his ministers openly if it was intended that the General Court and charter were to be taken

1 Mass. Col. Rec., i. 49. 
to Massachusetts. Not one of those men, if a charter were granted to them to-day, would ask the government what they meant when they issued it ; and if they did, the answer would have no value. They would seek the best counsel as to its meaning and wait the order of the courts, which have the final authority to decide these matters. And that was exactly what the Puritans did, as appears by the record, only, as is now known, they "had abscinded from the charter" the usual statement of administration in England, and were therefore safe in that respect. ${ }^{1}$

The true copy of the Agreement at Cambridge, August 26, 1629, is as follows: "Upon due consideration of the state of the plantation now in hand for New England, wherein we, whose names are hereunto subscribed, have engaged ourselves, and having weighed the greatness of the work in regard of the consequence, God's glory and the Church's good; as also in regard of the difficulties and discouragements which in all probabilities must be forecast upon the prosecution of this business; considering withal that this whole adventure grows upon the joint confidence we have in each other's fidelity and resolution herein, so as no man of us would have adventured it without assurance of the rest: now, for the better encouragement of ourselves and others that shall join with us in this action, and to the end that every man may without scruple dispose of his estate and affairs as may best fit his preparation for this voyage ; it is fully and faithfully agreed amongst us, and every one of us doth hereby freely and sincerely promise and bind himself, in the word of a Christian, and in the presence of God, who is the searcher of all hearts, that we will so really endeavor the prosecution of this work, as by God's assistance, we will be ready in our persons, and with such of our several families as are to go with us, and such provision as we are able conveniently to furnish ourselves withal, to embark for the said plantation by the first of March next, at such port or ports of this land as shall be agreed upon by the company, to the end to pass

1 John Winthrop's Life and Letters, ii. 443. 
the seas (under God's protection), to inhabit and continue in New England: provided always, that before the last of September next, the whole government, together with the patent for the said plantation, be first, by an order of Court, legally transferred and established to remain with us and others which shall inhabit upon the said plantation: and provided also, that if any shall be hindered by such just and inevitable let or other cause, to be allowed by three parts of four of these whose names are hereunto subscribed, then such persons, for such times and during such lets, to be discharged of this bond. And we do further promise, every one for himself, that shall fail to be ready through his own default by the day appointed, to pay for every day's default the sum of $£ 3$, to the use of the rest of the company who shall be ready by the same day and time. This was done by order of Court, the 29th of August, I629.

Richard Saltonstall,

Thomas Dudley,

William Vassali,

Nicholas West,

ISAAC JOHNSON,

JoHN Humfrey,
Thomas Sharpe,

INCREASE NOWELL,

JOHN WINTHROP,

William Pinchon,

Kellam Browne,

William Colbron."1

It will be noticed that they assert that they have "weighed the greatness of the work in regard of the consequence, . . . as also in regard of the difficulties," and that they make this proviso, upon which condition all their future course depends : "Provided always that before the last of September next, the whole government, together with the patent for the said plantation, be first, by an order of Court, legally transferred and established to remain with us and others which shall inhabit upon the. said plantation." Governor Dudley, who may have written this agreement (it is quite like his work), speaks kindly and gratefully of the British

1 Young's Chron., 281, 282. There are no ministers among these names nor at the meetings of assistants; they are lawyers, men of affairs, statesmen. 
government in his letter to the Countess of Lincoln : "But we do continue to pray daily for our sovereign lord the king, the queen, the prince, the royal blood, the council, and whole state, as duty binds us to do, and reason persuades others to believe. For how ungodly and unthankful should we be, if we should not thus do, who came hither by virtue of his Majesty's letters patent, and under his gracious protection; under which shelter we hope to live safely." 1

The vote of the General Court upon the question of the transfer of the charter is instructive, and was three days after the above Agreement, August 29, I629, as follows :-

"As many of you as desire to have the patent and the government of the plantation to be transferred to New England, so as it may be done legally, hold up your hands : so many as will not, hold up your hands.

"Where by erection of hands, it appeared by the general consent of the company, that the government and patent should be settled in New England, and accordingly an order to be drawn up." 2

At a General Court, September 29, I629, “it was propounded that a committee should be appointed to prepare the business; to take advice of learned counsel whether the same (the transferring of the charter) may be legally done or no; by what way or means the same may be done, to correspond with, and not to prejudice the government here [in its action, not in the mind of the British government]; to consider of the time when it will be fit to do it." 3

The well-established characters of John Winthrop, Isaac Johnson, Richard Saltonstall, Thomas Dudley, and John Humphrey are a guaranty of the good faith and integrity of their action, and of their conviction at least that they were acting wisely and honestly, and with no purpose to take advantage of, or deceive, the English government. Dudley appears nowhere in the record until October I 5, I629, almost two months after the vote was passed that the patent and government should be settled in New England; but he

1 Young's Chron., 331. $\quad 2$ Mass. Col. Rec., i. 5 I. $\quad 8$ Ib., i. 52. 
had signed the Cambridge Agreement August 26, with the condition for removal of charter in it. This does not exonerate him if there was a wrong done in that transfer. $\mathrm{He}$ was a party to it. But there was no wrong in it, the opinions of great and wise men to the contrary notwithstanding.

The Arbella, after an unusually rough voyage, arrived safely off Salem harbor, Mass., June 22, I630, with the Governor and Company of Massachusetts Bay and the first charter, about to enter upon a life in the New World, the results of which were far to transcend any conception they ever entertained of it in their most visionary moments.

It has not seemed needful at every mention of events to call attention to Dudley's part in them, it being always understood that he is a central figure in all that is presented here, and that in every one of the stirring incidents mentioned he was a principal actor, although not named. A man of strong sensibility and quick feeling, no one of that throng left Old England with a more reluctant step, or yet with a firmer purpose to give up all questions of personal comfort and selfish considerations, to make way for the cause of truth, for the blessing of liberty to the church, to the state, and to posterity.

If you would learn how devoted he was to this enterprise and to the cause which dominated it, follow him through the records of the Colony of Massachusetts Bay during the twenty-three years of life which was granted to him here, and note that he was present at every session but one, when his own cause was in hearing, both of the General Court and of the Court of Assistants, until his final sickness and disability in 1653 , and that therefore there is not a recorded act, great or small, which does not bear his illustrious imprint. If there was any glory or shame, or praise or blame, he shared it all, in the beginning of Massachusetts, New England, and the United States. ${ }^{1}$

${ }^{1}$ Mr. Savage, in his notes to Winthrop, i. *51, has well said of Dudley, that "his history must be embodied in that of his country." 


\section{CHAPTER VIII}

THE arrival of those emigrants in June, I630, was a great event in human history. They settled by their numbers and quality, as well as by their energy and enterprise, that the undertaking was not to be an uncertain experiment of adventurers. A fixed purpose was at the heart of every one of them to make their homes in this wilderness, and devote their lives to the setting up of Christ's kingdom, and to the construction of a pure and noble state.

It was natural that these heroic men should then recall the first establishment of Christianity in Macedonia, on the very spot where, a century before it was planted, the fate of the world had been decided $;^{1}$ that they should remember "a man of Macedonia, who came to plead the spiritual wants of his country," and that they should write on the colonial seal, and stamp on every colonial act, that perpetual cry of heathendom, "Come over and help us." Did they call to mind the mission of Augustine to heathen England in 616 , and the words of Gregory to him respecting his treatment of pagans, when he said that "for hard and rough minds it is impossible to cut away abruptly all their old customs, because he who wishes to reach the highest place must ascend by steps, and not by jumps." This was a humane rule to guide them in their treatment of Indians, which, in any event, they followed. As they were far removed from their English home in the prosecution of their Christian mission, they might have reflected that that very English church and state which had driven them forth had arisen

1 See Company's Humble Request, April 7, I630, already mentioned. Philippi in Macedonia was the scene of the decisive battle in which Brutus and Cassius were defeated by Augustus and Antony, в. с. 42. 
by degrees from the beginnings of Augustine at Canterbury, the first English Christian city. It is notable that, in both England and America, Christianity had been planted before the arrival of the masterful spirits who were destined to achieve its first real conquests. Dudley, in his letter to the Countess of Lincoln, in I63I, sends forth the same Macedonian cry in behalf of the colonists themselves which they at first had put into the mouths of the Indians. He says that, "if there be any (in England) endued with grace and furnished with means to feed themselves and theirs for eighteen months, and to build and plant, let them come over into our Macedonia and help us, and not spend themselves and their estates in a less profitable employment." 1

Dudley informs the Countess of Lincoln that "our four ships which set out in April arrived here in June and July, where we found the colony in a sad and unexpected condition, above eighty of them being dead the winter before, and many of those alive weak and sick; all the corn and bread amongst them all hardly sufficient to feed them a fortnight, insomuch that the remainder of a hundred and eighty servants we had the two years before sent over, coming to us for victuals to sustain them, we found ourselves wholly unable to feed them, by reason that the provisions shipped for them were taken out of the ship they were put in, and they who were trusted to ship them in another failed us and left them behind; whereupon necessity enforced us, to our extreme loss, to give them all liberty, who had cost us about $£ \mathrm{I} 6$ or $£ 20$ a person, furnishing and sending over.

"But bearing these things as we might, we began to consult of the place of our sitting down; for Salem, where we landed, pleased us not." 2

It was most natural and reasonable that Salem should not please them, for eighty persons out of the little colony had died there the previous winter; others were sick ; the terror of famine was in their minds, and all were sad and miserable.

1 Young's Chron. 325 ; see, also, Appendix A, this volume.

2 Ib., 3 I I . 
Sickness began to spread, and during that autumn Dudley informs us that two hundred of the recent emigrants had fallen victims to diseases due largely, no doubt, to exposure and unaccustomed hardships.

The governor went, after a few days of rest, with a number of persons, in search of a more satisfactory abode and suitable place for a capital town. ${ }^{1}$

Our acquaintance with Dudley in England assures us that he was active at this important juncture. $\mathrm{He}$ was able, thoroughly a business man, eminently qualified to be a leader in the moments of selection, which were of great importance in their consequences. He was not an idle spectator, but an efficient actor. He was called, at the close of his career, a "pillar" to support state, church, and society. $\mathrm{He}$ and Governor Winthrop were both men of decided convictions, as competent men always are, for the experience of life has taught them safely to rely upon their judgments carefully made up.

Dudley proceeds to tell us that, in this very important exploration for a place to settle; "some were sent to the Bay," that is, Boston harbor, "to search up the rivers for a convenient place; who, upon their return, reported to have found a good place upon Mistick, but some other of us, seconding these ;" that is to say, following or supplementing these, to determine whether "to approve or dislike of their judgment, we found a place [that] liked us better, three leagues up Charles river," probably Cambridge. ${ }^{2}$ It appears from this that two expeditions went on these journeys of inquiry, and that Winthrop led the first and Dudley the second; that neither selection was satisfactory to both leaders, and that they settled on Charlestown. as a compromise. The next year the stanch and still unconvinced governors were each dwelling in his own house on the very spot of his own first choice, - the one at Mistick, the other at Newtown (Cambridge). The name Mistick was changed in 1649 to Malden. Winthrop and several of the patentees (including Dudley) 1 Prince, 308.

2 Young's Chron., 312, note. 
"dwelt in the Great House, which was last year built in this town [Charlestown] by Mr. Graves [Thomas Graves, engineer], and the rest of their servants." 1 This Great House became the public meeting-house of Charlestown from 1633 until 1636 , and was afterwards a tavern or ordinary, and in I 7 I was called the "Great Tavern." It stood wholly in the Square, opposite the lane by the "Mansion House." It was probably destroyed when the town was burnt by the British, June I7, $1775 .^{2}$

This removal to Charlestown was on July I2, I630. ${ }^{3}$ Their place of assembling for divine worship was a spreading tree, since the "Great House" would not contain all, or indeed a small part, of the emigrants. ${ }^{4}$

It must have been a picturesque scene at the hour of worship. The learned divines, trained at the great universities of England, exiles, proclaiming beneath a canopy of green the unsearchable riches of Christ to a most notable company of seed sowers. There sat in the foreground, about the ministers, Governor Winthrop, Sir Richard Saltonstall, Isaac Johnson, Thomas Dudley, Roger Ludlow, Increase Nowell, William Pynchon, Simon Bradstreet, and their families; while in groups down the slope of the hill were scattered heroic people, whose hearts were full of the missionary spirit, and instinct with the purpose of making the pagan wilderness before them blossom as the rose, under the light and power of Christian civilization. There lay spread out before them the whole smiling tract of Massachusetts Bay, with its lovely islands in the midst, and its shining shores glorious with adornment of primeval forest, as yet undisturbed by the violence of man. Trimountain, now Boston, towered on the right, while behind them rose a gentle stretch of hill, where, a little more than a century later, their descendants would struggle with England, in one of the most important battles in human history, to complete that severance from,

1 Young's Chron., 378. 2 Ib., 375, note.

3 Drake's Antiq. of Boston, 92.

4 J. B. Moore's Memoirs of Amer. Governors, 245. 
and independence of, their native land, which they had inaugurated when they brought away the first charter in the Arbella. How much of interest to us and to humanity clustered about this little hillock and these devout and earnest servants of God!

The situation of these people was dismal in the extreme. Hunger, and not improbable starvation, were impending as the result of want of proper precaution in shipping sufficient provisions upon their departure from England; the water of Charlestown had proven bad and unhealthy, because they would only use running water; later the water of that place was found to be goỏd and wholesome. Fever and various maladies were rapidly reducing their numbers. The devout leaders, in their deep and exceeding need, doubtless remembered that "if any of you lack wisdom, let him ask of God, that giveth to all men liberally and upbraideth not; and it shall be given him." And they set apart the 3oth of July, I630, as a day of fasting and prayer.

It is uncertain whether they were gathered under the same wide-spreading branches of a tree, or were within the walls of the "Great House" of the colony, constructed for a residence, for defense, storage, and public gatherings not over-large. But here and now, at the conclusion of the religious exercises, Governor Winthrop, Deputy Governor Dudley, Isaac Johnson, and John Wilson, with many others, both men and women, put their names to the following covenant :-

"In the name of our Lord Jesus Christ, and in Obedience to His holy will and Divine Ordinance, -

"We whose names are hereunder written, being by $\mathrm{His}$ most wise and good Providence brought together into this part of America in the Bay of Massachusetts, and desirous to unite ourselves into one congregation or Church, under the Lord Jesus Christ our Head, in such sort as becometh all those whom $\mathrm{He}$ hath Redeemed and Sanctified to Himself, do hereby solemnly and religiously (as in His most holy Presence) Promise and bind ourselves to walk in all our ways 
according to the Rule of the Gospel, and in all sincere Conformity to His holy Ordinances, and in mutual love and respect each to other, so near as God shall give us grace." 1

Winthrop relates that on the 27th of August, I630, they completed their church organization, afterwards the First Church of Boston. He says: "We of the congregation kept a fast, and chose Mr. Wilson our teacher, and Mr. Nowell an elder, and Mr. Gager and Mr. Aspinwall, deacons. We used imposition of hands, but with this protestation by all, that it was only a sign of election and confirmation, not of any intent that Mr. Wilson should renounce his ministry he received in England."

This mode of church institution was not in accord with the Church of England. It was like the Separatist method in the Plymouth Colony. The members pledged Conformity to Christ, and not to the Church of England. The earlier church at Salem was impressed with the same independency, and doubtless suggested a model at this time.

Already, at Salem, the disuse of the "Common Prayer and of other ceremonies" had alienated the excellent brothers John and Samuel Browne, who were more deeply attached to the Church of England, and Governor Endicott had sent them back to England, because they were not in harmony and fellowship in New England.

Doyle says: "If the colony was to become what its promoters intended, unity, not merely of religious belief, but of ritual and of ecclesiastical discipline, was, at least for the present, a needful condition of existence. We must not condemn the banishment of the Brownes unless we are prepared to say that it would have been better for the world if the Puritan colony of Massachusetts had never existed." 2

The church now formed set aside the liturgy, prayers "read from a book," all church days except the Sabbath,

1 George E. Ellis's Puritan Age in Massachusetts, 58 ; Drake's Hist. Boston, 93 ; Mr. Foxcroft's sermon, August 23, $173^{\circ}$; Memorial Hist. of Boston, i. I 4 .

2 English in America, i. I29. 
and responsive services. They went, as they thought, directly to the Scriptures, and in the exercise of right reason believed themselves led and guided to lay hold upon the essential and fundamental truth and practice of the mother church, divested of its lifeless and traditional customs and teachings.

"Hail to the spirit which dared

Trust its own thoughts before yet

Echoed him back by the crowd!" I

They seemed not to have realized how far they had wandered away from the Church of England until a half century later, when certain of her members appeared in the colony for recognition and brotherly consideration, and were not welcomed. It is thought that all the Congregational churches in America have taken their form of construction from the one under consideration. How many great and lasting institutions came forth in a few brief years from the heavenappointed hands of this group of men, who were moulding, like huge. Titans, the destiny of men and states!

Many have thought that the Puritans were false in their expressions of regard for the Church of England in their letter sent from the Arbella to the dear mother church. They clung, however, sincerely and earnestly to the "Thirty Nine Articles and to the sacred Scriptures." They must have been profoundly impressed when they came suddenly into the new light and freedom of America, when they listened to the experience of their brethren of Salem and Plymouth, who had thought out the simple religious requirements in this first planting. It was not yet, and could not be for generations, a place for cathedral service, for all the pomp and splendor of the State Church of England. The times, the place, the irresistible conditions of environment, predetermined that the modes of life, manners, customs, and worship as well, must be reduced to the simplest form. They must march in the lightest armor to fight successfully the battles before them.

1 Matthew Arnold, "Brontë." 
We may be certain of one thing : the world has never seen a group of men more ingenuous and sincere than these leading men. We have known them before, and we shall see them in many vicissitudes of life, artless and open-hearted. They manifested always a depth of conviction, a profound and constant sense of duty and of regard to an all-seeing eye which viewed constantly every act of their lives, and would literally bring every work and every secret thing into judgment, so surely that they became men of deep integrity, penetrated with holy purposes, and hypocrites never. ${ }^{1}$ They did some things which we cannot approve, but they did them in obedience to what they found in the very oracles of God, read and interpreted from their standpoint ; and however much we may doubt the authority for the act which they read in or out of the sacred texts, we need not, nor cannot, question the sincerity or downright honesty of the men.

The records of Charlestown state "that in the mean time they went on with their work for settling. In order to which they, with Mr. John Wilson, one of the ministers, did gather a church, and chose the said Mr. Wilson pastor, the greatest number all this time intending nothing more. than settling in this town; for which the governor ordered his house to be cut and framed here. But the weather being hot, many sick, and others faint after their long voyage, people grew discontented for want of water, who generally notioned no water good for a town but running springs. . . . The death of so many was concluded to be much the more occasion by this want of good water." 2 There is a thrilling account of the sufferings and sickness of these people by Edward Johnson, who was one of them. ${ }^{3}$

It appears that there was a wide distribution of the people

1 Men have sneered at Puritans, but, Macaulay says, "no man ever did it who had occasion to meet them in the halls of debate, or cross swords with them on the field of battle."

2 Young's Chron., 399.

${ }^{8}$ See Mass. Hist. Coll., xii. 37 ; Young's Chron., 380, note. 
into the country in different directions in search of good water, resulting in many permanent settlements.

We find in the Charlestown records that "in the mean time Blackstone, dwelling on the other side of Charles River alone, at a place by the Indians called Shawmutt, where he only had a cottage, at or not far off from the place called Blackstone's Point, he came and acquainted the governor of an excellent spring there; withal inviting him and soliciting him thither ; . . . whither also the frame of the governor's house, in preparation at this town [Charlestown], was also (to the discontent of some) carried, where people began to build their houses against winter; and this place was called Boston. ... But this [search for water], attended with other circumstances, the wisdom of God made use of as a means of spreading his Gospel and peopling of this great and then terrible wilderness; and this sudden spreading into several townships came to be of far better use for the entertainment of so many hundreds of people, that came for several years [until I640] following hither in such multitudes from most parts of Old England than if they had now remained all together in this town." 1

It seems reasonable to believe that Dudley and his family passed their first winter in Boston. ${ }^{2}$ The greatest part of the church removed thither ${ }^{3}$ with the governor. Dudley did not remain in Charlestown, for the list is given of those who were not scattered abroad, ${ }^{4}$ and his name is not found in it, neither is the name of his son-in-law, Mr. Bradstreet, there. And we know that he did not build his house in Cambridge until the next year, and that many of the more distinguished assistants accompanied the governor to Boston and remained until spring. Mr. Dudley has himself

1 Young's Chron., 380-382.

2 His letter to the Countess of Lincoln, dated March 12, 1630, which was I63I N. S., was written from Boston, and, as it would seem, in the only room occupied by himself and family in his own house there. (Drake's Hist. and Antiq. of Boston, 9I, note.)
8 Young's Chron., 38r.
4 Ib., 382, 383. 
given a very graphic account of the dispersion, but he does not state the object of it to have been a search for pure water; quite likely what the above record calls a "circumstance," he considered the chief and perhaps only cause.

He says in his letter to the Countess of Lincoln : "But there [at Charlestown] receiving advertisements by some of the late-arrived ships, from Lincoln and Amsterdam, of some French preparations against us (many of our people brought with us being sick of fevers and the scurvy, and we thereby unable to carry up our ordnance and baggage so far), we were forced to change counsel, and for our present shelter to plant dispersedly, some at Charlestown, which standeth on the north side of the mouth of Charles River; some on the south side thereof, which place we named Boston (as we intended to have done the place we first resolved on) [for a capital]; some of us upon Mystick, which we named Medford; some of us westwards on Charles River, four miles from Charlestown, which place we named Watertown; others of us two miles from Boston, in a place we named Roxbury; others upon the river of Saugus, between Salem and Charlestown; and the western men four miles south from Boston, at a place we named Dorchester.

"This dispersion troubled some of us; but help it we could not, wanting ability to remove to any place fit to build a town upon, and the time too short to deliberate any longer, lest the winter should surprise us before we had builded our houses.

"The best counsel we could find out was to build a fort to retire to, in some convenient place [which Dudley did at Cambridge], if any enemy pressed us thereunto, after we should have fortified ourselves against the injuries of wet and cold. So ceasing to consult further for that time, they who had health to labor fell to building, wherein many were interrupted with sickness, and many died weekly, yea, almost daily. Amongst whom were Mrs. Pynchon, Mrs. Coddington, Mrs. Phillips, and Mrs. Alcock, a sister of Mr. Hooker's. Insomuch that the ships being now upon their return, some 
for England, some for Ireland, there was, as I take it, not much less than a hundred (some think many more), partly out of dislike of our government, which restrained and punished their excesses, and partly through fear of famine, not seeing other means than by their labor to feed themselves, which returned back again; and glad were we so to be rid of them." 1

Dudley's account of the distribution of inhabitants in all directions seems to suggest that, since they could not build and fortify a town and place their ordnance in such a position as to be effective, it was better to make no exhibition of numbers and strength to tempt the enemy, but to fold their tents and silently steal away, and wait for spring and health and prosperity. The fortitude of these men was stupendous in the face of starvation and death, without houses or homes, and winter rapidly approaching, the merciless ocean in front of them and the unknown and mysterious forest behind them, their ranks daily decimated by disease, and, last of all, seeing the departure and desertion of a hundred at a time, in total discouragement and disgust, of persons who had consecrated their lives to this enterprise, and who now like cowards were madly seeking a place of retreat and safety. This is an exhibition of heroism which matches anything the history of the world can show even in "facing fearful odds" on the fields of martial glory; for there the conflict is brief, here it was long and arduous and unremitting, endured mostly for mankind, for posterity. Certainly it was so with Dudley. He left a prosperous, happy home in England. His life was approaching its decline. He was not a persecuted clergyman, without visible support, fleeing from the fury of the bishops.

Isaac Johnson fell a victim to disease and privation on the 3oth day of September, I630. His lovely wife, Arbella, for

1 Young's Chron., 321-324, App. "Dudley and Winthrop seem to have been less impressed with the heroism of those who stayed than with the faint-heartedness of those who fled." (J. A. Doyle's English in America, i. 136.) 
whom their ship was named, the heroine of the emigration, had left them a month before for the life beyond. Johnson was the largest shareholder, the most wealthy man, in the company. But his loss to the colony was not in money; in sterling character he left a void that never could be filled. We can well understand something of the bereavement sustained by Dudley in the demise of Isaac and Lady Arbella Johnson. He could say with sincerity that the return of indolent adventurers to England was a blessing to the colony. But the departure of these persons was another thing. They were members of the noble house of Lincoln; they were family friends. The loss of such wealth of character in any community, no matter how rich it might be in distinguished people, would be irreparable; but in this forlorn situation, wherein character and leadership were of consummate importance, the bereavement was overwhelming. Dudley had been a member of the household for many years, and had been a stay, counselor, and business director in the family; he may have influenced these persons, by his words or his example, to risk every earthly hope in this emigration; they were nearer to him, and he to them, than any other persons in the colony, - we need not except his son-in-law, Bradstreet, who was younger. He must have felt keenly the demise of Lady Arbella, the cherished sister of his patron and dear friend, the Earl of Lincoln. He had a sympathetic, compassionate heart beneath his dignified, judicial, and martial bearing. This appears in his affectionate letters, in his ardent response to kindness shown to him by Governor Winthrop at unexpected moments, when his intrinsic nature was shown in all its strength. Dudley, we cannot doubt, did all that human aid could accomplish to console and comfort the heart of Mr. Johnson during that brief thirty days in which

" he try'd

To live without her, lik'd it not and dy'd."

Dudley has given to us his own beautiful description of the situation, full of pathos and personal emotion. He says : 
"This gentleman was a prime man amongst us, having the best estate of any, zealous for religion, and the greatest furtherer of this plantation. He made a most godly end, dying willingly, professing his life better spent in promoting this plantation than it could have been any other way." $\mathrm{He}$ then writes one of his comprehensive, terse sentences, full of discernment of the worth they had lost. "He left to us a loss greater than the most conceived." He then describes their stripped and desolate condition. "There were left [by the end of October, I630] of the five undertakers but the governor, Sir Richard Saltonstall and myself, and seven other of the assistants. And of the people who came over with us, from the time of their setting sail from England, in April, 1630, until December following, there died by estimation about two hundred at the least : so low hath the Lord brought us!

"Well, yet they who survived were not discouraged, but bearing God's corrections with humility, and trusting in his mercies, and considering how, after a lower ebb, he had raised up our neighbors at Plymouth." 1

Edward Everett has so touchingly described the events in this chapter that we quote his words :-

"The Massachusetts Company arrived at the close of June. No vineyards, as now, clothed our inhospitable hillsides; no blooming orchards, as at the present day, wore the livery of Eden, and loaded the breeze with sweet odors; no rich pastures, nor waving crops, stretched beneath the eye along the wayside, from village to village, as if Nature had been spreading her flowers with a carpet, fit to be pressed by the footsteps of her descending God! The beauty and the bloom of the year had passed. The earth, not yet subdued by culture, bore upon its untilled bosom nothing but a dismal forest, that mocked their hunger with rank and unprofitable vegetation. The sun was hot in the heavens. The soil was parched, and the hand of man had not yet taught its secret springs to flow from their fountains. The

1 Appendix A. 
wasting disease of the heartsick mariner was upon the men; and the women and children thought of the pleasant homes of England as they sank down from day to day, and died at last, for want of a cup of cold water in this melancholy land of promise." 


\section{CHAPTER IX}

WE have attempted to present these emigrants as they were in the autumn of 1630 , with their trials, and wild, strange environment.

It is of the greatest importance, when we have discovered their real status and associations, to ascertain what they did, particularly what they produced which has come to us and entered into our social fabric. This leads us at once to the study of their legislation. For, view it as we will, in their laws we find the life and inwardness of a people, the highwater mark of their progress, fixed and unalterable. It is true laws are sometimes in advance of public sentiment, but in general they are the product of the intelligence of the majority. "History is past politics and politics is present history," says Freeman. Politics is the theory and practice of obtaining the ends of civil society as perfectly as possible.

It is certain that these people properly regarded their charter as the foundation and constitution of a government. It has been said, without sufficient authority, that they had no right to assume it to be such. Certainly the fathers did not intend to be deceived, and took every precaution to be certain, as we have seen. Even if they were mistaken, time has healed the injury. We think that their interpretation of the charter was reasonable and correct, one which protected them, and secured the blessings of liberty to themselves and their posterity. It ill becomes us to waste sympathy on the tyrannical government which issued the charter, and to charge double-dealings upon our heroic fathers, - godly men, intrusted in the providence of God with greater human interests, more important to their race, than were ever given to the keeping of any other body of people in history, - a trust performed with the utmost fidelity. 
The first Court of Assistants was held at Charlestown, August 23, 1630, probably in the "Great House," at which Dudley was present. The first business considered was the maintenance of the ministers in the most comfortable manner their circumstances allowed. This seems to manifest at the very beginning an appreciation of their importance, and how much depended upon their faithful services in this undertaking. The rate of wages to be paid to various mechanics and laborers employed in building was also determined; it is quite evident that carpenters and masons were taking advantage of the immediate necessity for houses, all persons impatiently desiring them at once. The next Court of Assistants was held at the "Great House" at Charlestown, September 7, I630. Ludlow, Rossiter, and Pynchon are fined a noble (6s. 6d.) apiece for their absence from the Court after the appointed time. Herein Dudley furnished to his associates for years a creditable example; he was almost never absent or tardy at Court. This is a trifle, but it indicates his business habits of attention and punctuality. Whatever was done by the Court in his lifetime, whether it was action that was wise and reasonable or otherwise, it was his, he was a part of it, for his thought was in it, either to create, direct, and guide or to modify it. The doings of the Courts, therefore, since he left no biography or diary, are the most permanent memorials of his life work from I630 to I653. Whoever seeks his monument must search the records of the Colony of Massachusetts Bay in New England. ${ }^{1} \mathrm{He}$ was too intent upon the momentous duty of the hour to study the far-off effects and perspective views of posterity upon his work. He came to America and cut all the bridges behind him; had severed himself from his family, excepting his wife and children, as completely as if a deluge had separated them; and he would naturally give little heed to the presentation of his doings and himself to the judgment of later generations. It was not that he was thoughtless of those who were to follow him. These twenty-three

1 See Savage's note to Winthrop, i. *5I. 
years, the crowning days of his life, were devoted freely and unselfishly to the establishment of an asylum and refuge for the oppressed of future times. It has often happened that men of action have had little regard for their fame, or the interest of posterity in them.

Thomas Morton, of Wollaston, received at this Court welldeserved punishment, ${ }^{1}$ resulting in his being sent to England, then the Botany Bay of the colony, which transportation, if the colony had used more, and some other punishments less, it would have, in the opinion of more humane ages, added to its lasting merits. It was ordered that "Trimountain shall be called Boston," a change in name not due to the Rev. John Cotton, as it has been said, for he was not yet in the country. Dudley says that they had intended in advance to name the "place Boston that they first resolved on," - we suppose he means for a capital. If that view is correct, they decided on the name of Boston, and the place for a capital, September 7, 1630, then in the following December changed their minds, and resolved that Newtowne (Cambridge) should be the capital, then subsequently changed back to Boston permanently, with a brief exception, in 1634-35.

The Court refused to permit any Indians to use any "Peece" (musket) upon any occasion or pretense whatsoever. It also began on the same 28th day of September its temperance crusade, for it ordered "that all the strong water of Richard Clough shall presently be seized, for his selling a great quantity was the occasion of much disorder." This Court was active also in the determination, as a matter of law, of the amount each mechanic should receive as daily wages, which still seems to indicate a purpose among these house-builders to take advantage of the needs of the people. But if that were so, it was not confined to them, for it was ordered at the same time "that laborers in general shall not take above I6d. or I2d. a day for their work." Sir Richard Saltonstall was fined four bushels of malt for his absence from the Court. He soon grew weary of the exacting life in ${ }^{1}$ See Young, 32I, and note. 
America, and returned to England in less than a year after he left it.

A meeting of the General Court under the provisions of the charter was held in Boston on the Igth day of October, 1630. This General Court was made up out of three elements. First, the governor and the deputy governor were the executive, although the second body, known as assistants, acted with the executive as a council, as the governor to this day has a council. This body of assistants was in the course of years developed into an upper house, called at present the Senate. It was also from the first a court of judicature, like the House of Lords in Parliament. Then there remained another element called the freemen, which included all male persons of age who had taken the oath of allegiance to the colony and the laws, and had been admitted into membership in the company by a direct personal covenant and agreement, - in other words, had been accepted by the company, and naturalized into it. The lower house, known at present as the House of Representatives, must include all of these freemen, or else a small body of representatives chosen from them, and given all the powers of legislation which the whole body of freemen possessed. Thus we have, first, governor or deputy governor; second, assistants ; third, freemen or their representatives.

The first business that came before the General Court, held as above, was the establishment of the government. A hundred and eighteen persons had asked to be made freemen; a number of the assistants had died, and others had gone home to England, as we have already noticed. This left the governor, deputy governor, and assistants in great anxiety, lest their government should be overthrown or dominated by the more numerous freemen, who had not, as they thought, the knowledge or wisdom to manage this sacred enterprise, the hope of religion and the world. It was a crisis sharp and dangerous. They might be engulfed at once by an unreasonable democracy, and their holy experiment totally wrecked, to the great and everlasting joy of the 
Philistines, without an opportunity to teach its impressive lesson to mankind. They had lived under a very autocratic government in England; they had a conservative and natural dread of democracy pure and simple. Even now the corruption and fickleness of political parties may raise a reasonable doubt in thoughtful minds how far the masses, with indifferent education and morals, may be trusted, and where a free government is to land our succeeding generations. They had not then two and a half centuries of democracy in America, to inspire confidence in a government of the people, which Abraham Lincoln had when he said in his first Inaugural Address, "Why should there not be a patient confidence in the justice of the people? Is there any better or equal hope in the world?" No, if the people are wise and virtuous! But if they are ignorant and immoral, it admits of doubt.

The Puritan Fathers, with commendable prudence, dispensed power and responsibility to these newly enfranchised citizens as they proved their fitness for self-government, by their knowledge and virtue, and not by their hungry clamor for it. This they did, not in an arbitrary manner, but by convincing the majority of the justice and wisdom of their action.

It was therefore arranged at this first General Court in Boston, by the free suffrages of assistants and freemen together, that for one year the sole and only power left with the freemen should be to choose the assistants to serve one year. During the year the whole legislature and officerappointing powers were vested in the governor, deputy governor, and assistants. ${ }^{1}$

The charter contemplated that a share in legislation should be taken by the freemen, and this power, belonging to them under the charter, they requested the governor and assistants to exercise as their representatives, for a year at a time; and after four years they resumed it to themselves, May 14, $1634{ }^{2}$ This double representative service, rendered for 1 Mass. Col. Rec., i. 79.

2 Ib., i. I 8 . 
and on behalf of the freemen, has given without reason an unwarranted excuse to call the government an oligarchy, and the governor, deputy governor, and assistants, oligarchs, a name which, viewed from the standpoint of their representative character, is radically and intrinsically false. ${ }^{1}$

It is unjust to the government, and discreditable to the country of which their action and record is a distinguished part, to associate them by name and inference with the petty tyrants of antiquity. This is especially evil because they acted in a most patriotic and unselfish manner. The power and trusts they held they never perverted to private uses, nor did they employ them to secure their own reëlection, but served their country; and the ends of justice which they sought would have excused a departure from the letter of the law, even if they had exceeded the authority of the charter. It is not what is done so much as the spirit in which it is done. In this instance the law was not violated.

Thomas Dudley was the principal founder of Newtowne; the name was changed to Cambridge in 1636 . There arose a great disagreement between Winthrop and Dudley out of the settlement of this town. Governor Hutchinson says that "on the sixth of December, Governor Winthrop and the assistants met, and agreed to fortify the neck between Boston and Roxbury, and orders were given for preparing the materials ; but at another meeting, on the twenty-first [day of December, 1630] they laid that design aside, and agreed on a place [Newtowne] about three miles above Charlestowne,

1 The governor and assistants were not absolute rulers; they had by their office powers under the charter. They were also made representatives of the freemen, the source of power coming through them to the assistants. Oligarchy is an evil misnomer which reminds us of no other thing so much as the note of Mr. James Savage upon the word "Antinomian," which name always inflicted a qualm upon him. He says that "Welde and other inquisitors have trusted much to the influence of an odious name. It is the most common artifice of the "exquisite rancor of theological hatred." (Winthrop, i. 215, note I.) It went out of existence with the political uprising which made Dudley governor the first time. 
and most of them engaged to build houses there the next year." $1 \mathrm{He}$ says further that "in the spring of $16_{3} \mathrm{I}$, they pursued their design of a fortified town at Newtowne. The governor set up the frame of a house; the deputy governor finished his house and removed his family." $2 \mathrm{He}$ further informs us that an Indian chief visited Governor Winthrop about this time and assured him that there was no need of fortifications, which seems to have influenced him to make his home in Boston instead of Cambridge, for Hutchinson says that "the apprehensions of danger lessened by degrees, the design of a fortified town went off in the same proportion, until it was wholly laid aside. The governor [Winthrop] took down his frame and carried it to Boston. Mr. Dudley, the deputy, was offended, and persisted for some time in his first determination of residing at Newtowne." 3 "It was ordered ${ }^{4}$ there should be threescore pounds levied out of the several plantations within the limits of this patent towards the making of a palisade about Newtowne, and viz. : Watertowne $£ 8$, Newtowne $£ 4$, Charlestowne $£ 7$, Medford $£ 4$, Saugus and Marble Harbor $£ 6$, Salem $£ 4$ ios., Boston $£ 8$, Roxbury $£ 7$, Dorchester $£ 7$, Wessaguscus [Weymouth] $£ 5$, Winettsem 30 ."

This record assists us to understand how complete the distribution of inhabitants had been in such a short time, and the relative importance of these places early in I63I. Dudley's military knowledge and foresight has been questioned, in his selection of Cambridge, instead of Boston, for the purpose of fortification and protection. Some, at least, of his reasons were that in case of attack from the sea it was far safer to be in the interior, out of range of guns on shipboard. They were not in a condition yet to fortify the harbor of Boston, and could only throw up an embankment and erect simple palings into a palisade in a central place, which would not be a defense against the artillery of Europe,

1 Hutchinson, i. 22.

2 Ib., 23.

8 Ib., 23.

4 At a meeting of assistants in Boston, February 3, 1631. (Mass. Col. Rec., i. 93.) 
but only a protection against wild beasts and the darts of savages. This did not require hills and elevations. Besides, Cambridge was on the west side of most of the plantations, and thus would be an outlying fortification in the direction of the enemy, and a defense to all the towns except Watertown, which is near to it. It had an advantage, also, of not being so near to the sea as to enable the enemy to hem them in and thus destroy them. However persons may differ about the wisdom of the selection of Cambridge, it certainly was not an unreasonable policy to fortify it, as Dudley did. One thing which seemed to have taken from the importance of a fort was the fact that if they retired into it, they must abandon their houses and homes to destruction by the savages. The remains, it is said, of Dudley's fortification might recently have been seen at Cambridge. ${ }^{1}$

It is quite certain, from Winthrop's diary, that he and Dudley did not live in the most harmonious relations with each other between the spring of 1631 and the spring of 1632. And however officially they may have tried to respect the position and importance of each other, there existed a hardness, which grew until it culminated at last in an open rupture in Court between them. The character of Dudley, as it is made to appear in the record of his opponent and rival, has suffered in the good opinion of all the generations since. And if we had not a knowledge of him previously as well as subsequently to guide us, the seeming judicial fairness of Winthrop's delineations in these disputes, as we have already noticed, would create in us, as it has in others, a prejudice against Dudley. It is not intended to raise a question as to the purpose of Winthrop to be fair, but it is not in human nature, even when seasoned with grace, to be absolutely just to an opponent in a contest, particularly where there is constitutional vigor on both sides, and blows to take and blows to give. There is no doubt that these two men were at the head of this colony during

1 T. W. Higginson's Oration, 250th Anniversary, December, 1880; Holmes's Hist. of Cambridge. 
the first twenty years. They had very few estrangements, but the major part of their official lives was passed in a friendship as beautiful as that of Saul and Jonathan, without, as it would seem, a flaw to disturb their perfect harmony and unity of spirit.

Nevertheless, until they learned to esteem and appreciate each other they had troubles which we cannot pass over in silence, however willingly we would do so.

The first matter which disturbed them was the refusal of the governor and assistants to dwell at Cambridge, establishing the capital there.

Winthrop had withdrawn unfairly, as it appeared to the elders, upon an examination, and Dudley, who regarded the obligations of a contract as extremely sacred, was deeply hurt at the manner in which Winthrop had removed his house from Cambridge, without giving him notice.

Winthrop says that "At a Court at Boston, the deputy, Mr. Dudley, went away before the Court was ended, and then the secretary delivered the governor a letter from him, directed to the governor and assistants, wherein he declared a resignation of his deputyship and place of assistant ; but it was not allowed." Mr. Savage well says, "It is remarkable that the colony records give no account whatever of this resignation, or of another event, which seems to have been a limitation of the power of the governor or the consideration thereof." This is said to have been done April 3, I632. ${ }^{1}$

Dudley was made to appear rash, angry, and unreasonable, not by anything said against him, but by being left without any explanation or setting forth of his side of the case from his own standpoint. It is true we have more details later, but they take their color from the same source.

We do not know from Dudley himself what he suffered from

"The insolence of office, and the spurns

That patient merit of the unworthy takes;"

1 Winthrop, i. *72. 
but so far as the record indicates, by its omissions at least, he was not rash. The most important trouble of the removal of the house had made him unhappy for a year, and, as it proved, Winthrop had done him a wrong and yet he had borne it a year with a constant accumulation of distress, no doubt, because when alienation begins in friendship, it must be healed, or the divergence constantly increases.

Finally it had become so intolerable that he was willing for the sake of peace, and for the harmony of the Court, to relinquish his share in an enterprise which had drawn into it himself and his estate, his hopes for his children, and what was more, the paramount cause to him of righteousness in the earth, and the holiest experiment of government in the world. He had taken a year to think it all over, and in his struggle; alternating between hope and fear, at last calmly, and to avoid an exhibition of passion, he placed his resignation in writing in the hands of the secretary. It is a notable fact, which ought not to be overlooked, that from these pages of Winthrop, which seem so candidly to state the truth, a new character undeserved has been given to Dudley, unknown to his contemporaries, which has led recent writers to apply to him adjectives not suited to his record established in England, and not borne out in Winthrop's Journal, after the first years in Massachusetts. It is true that Roger Williams, and a few others who tested his methods of justice, did not approve of him, and these men have contributed to the ill opinion that has been promulgated sometimes by men who are quite willing to see the ancient theology ground to powder, upon which the fathers built so nobly.

"The Puritans were narrow; in other words they had an edge to them, as men that serve in great emergencies must, for a Gordian knot is settled sooner with a sword than beetle." 1 But in another view they were very liberal ; they laid broad foundations of education and of politics, considering their historic period, upon which one of the most perfect superstructures in human history has arisen. "The bigoted 
Mr. Dudley" 1 is a character which is not on the whole just to him.

It is instructive to examine the terms applied to him by his contemporaries and personal acquaintances. $\mathrm{He}$ was declared by them to be a "Trusty Pillar," "Worthy," "Much honored," of "Sound judgment," "Like honored," "An erect, honored, and long-continued champion for the truth, as it is in Jesus," "The honored, aged, stable, and sincere servant of Christ, zealous for his truth." Winthrop said of Dudley, long years subsequent to their troubles, and after he had much opportunity to learn his worth, although he was his political rival: "Besides, this gentleman was a man of approved wisdom and godliness, and of much good service to the country, and therefore it was due to share in such honor and benefit as the country had to bestow." 2 These are weighty words from a political rival, bursting forth at the moment of triumph over himself. We shall quote later

1 Mr. James Savage, who can neither endure the word Antinomian nor the name Dudley, in his note to Winthrop's Journal i. *21 5, has clearly shown great solicitude when reproachful epithets are affixed to the names of characters admired or cherished by him, while he seems far less concerned about the fortunes of other worthy names.

He says, for example, that "similar and often much heavier artillery of reproach is too often employed in that fortress within which the brave defenders fear no answer of an adversary's fire." This has been strikingly true of Dudley for many years; he has had no one to defend him or call a halt to his detractors. Mr. Savage says further, and very pertinently, particularly when the treatment Dudley has received is kept in mind, "An odious name is the most common artifice of the exquisite rancor of theological hatred." We will test the odious names and sentences which have appeared often where the name of Dudley is written: "With a hardness in public, and rigidity in private life," Savage; "Testy;" "Bigoted ;" "Narrow;" "Austerest of Puritans ;" "Irascible Dudley;" "Bigoted Dudley;" "Man of blood," - this is a sufficient assortment with which to exhibit the "exquisite rancor of theological hatred." Savage says, "Welde and other inquisitors have trusted much to an odious name." Does he mean to style all men inquisitors who ruthlessly detract from the memory of the just by the use of evil epithets? We think he is correct.

2 Winthrop, ii. 3. 
many other persons whose testimony supports the same excellent character. We do not overlook the fact that certain persons resist the testimony of these associates, the only persons who knew the character of Dudley, because they regard the Massachusetts Puritans to have been all of the same sort, merely members of a mutual admiration society. But they were all honest men, and were the heroes who founded Massachusetts, forever worthy of veneration and immortal honor.

But returning to the antagonism between Winthrop and Dudley, we find in Winthrop's Journal, under date of May I, 1632, page *73, the following: "Governor and assistants met at Boston to consider of the deputy his deserting his place." "Deserting" is a strong word to express a retirement with a request for permission to depart in peace. A deserter is one who quits duty without right or permit. We must go behind the words of Dudley's rival. "The points discussed were two: the Ist, upon what grounds he did it; 2 d, whether it were good or void. For the Ist, his main reason was for public peace; because he must needs discharge his conscience in speaking freely; and he saw that bred disturbance," etc. How admirable! It has often been accounted creditable in a minister of state to resign his office to produce harmony in a cabinet and unity in its action. "For the $2 \mathrm{~d}$, it was maintained by all that he could not leave his place, except by the same power which put him in; yet he would not be put from his contrary opinion, nor would be persuaded to continue till the General Court, which was to be the gth of this month."

He was doubtless most heartily sick of his disagreeable situation, and having made up his mind to be free, and having counted the cost and taken his stand, he was not an unstable politician, to be coaxed and placated. Patience had ceased to be a virtue, and he had highly resolved to be out of his unendurable sufferings. We can find only commendation for both his spirit and manner. This was not petty conduct in him. His life before and after assures us of the 
judicial judgment upon which in general he rested his actions. He had been all his life a man of moral and religious calibre, fearing God and attentive to duty. This established record assists us to estimate how he would act under given conditions of trial and misfortune. True character is the one thing in this world that outrides at last all storms and misrepresentations. Truth is in the keeping of the Almighty Father himself. Men may gloss and obscure, but the light finds a rift in the clouds at last, and comes streaming through.

"Truth crushed to earth shall rise again, The eternal years of God are hers;

But error, wounded, writhes with pain, And dies among his worshipers." 1

We must, however, follow Winthrop's arraignment of Dudley, not because the charges amount to anything in themselves, for they do not, but because they are the nebulous stuff out of which persons who do not approve of the vigorous methods of the Puritans have chosen to give a character to Dudley which does not accord with what is known of him.

"Another question fell out with him [Dudley] about some bargains he had made with some poor men, members of the same congregation, to whom he had sold seven bushels and an half of corn to receive ten for it after harvest, which the Governor [Winthrop] and some others held to be oppressing usury, and within the compass of the statute; but he [Dudley] persisted to maintain it to be lawful [as he was bound to do if he thought so, and he was not the man to do it unless he did so think], and there arose hot words about it." We are not told which was most effective with hot shot, but inasmuch as Dudley was the one charged with grinding the face of the poor of his own family in the church, the presumption intended to be raised in the mind of the reader is that he was most in wrath and most in fault. If Winthrop has quoted fairly the words of Dudley on that occasion, we are

\section{Bryant.}


inclined to regard them as very moderate and calm, and, so far as they reflect upon Winthrop's charges, very true and just. For, as Savage shows in his note to this passage, Dudley was only doing, if we admit the trade to have been made, what was and is usual among farmers, "he telling the governor that, if he had thought he had sent for him to his house to give him such usage, he would not have come there; and that he never knew any man of understanding of other opinion; and that if the governor thought otherwise of it, it was his weakness." 1

"The governor took notice of these speeches, and bear them with more patience than he had done, upon a like occasion, at another time." It was evidently assumed by the governor that he was the injured man, for the reasonable and truthful remarks of Dudley, given it may be with a little natural earnestness, because he considered the charges of the governor to be trivial nonsense, as they were, gave the governor an opportunity to exhibit the distinguishing grace of ancient Job, in a degree somewhat in excess of his previous record, and, what is more, to write it down in such a good-natured and genial form, that his own excellent qualities are not neglected.

But divested of all drapery, it is an attempt to magnify nothing into something, a molehill into a mountain, and like the charge following it, it takes from the august majesty of Winthrop. Idealization of the qualities of great men is one of the noblest powers we have. Our heroes, thus invested with ideal perfections, stimulate us always to advance to greater attainment. But it is healthful to turn the searchlight upon them, and view them in the real conflicts of life, divested of the supernatural qualities with which we have canonized them.

We are called to note another instance of Winthrop's fostering care of Dudley and the colony. He says, "Upon this there arose another question about his [Dudley's] house. The governor having formerly told him, that he did not well to 
bestow such cost about wainscoting and adorning his house, in the beginning of a plantation, both in regard of the necessity of public charges, and for example, etc., his answer now was, that it was for the warmth of his house, and the charge was little, being but clapboards nailed to the wall in the form of wainscot." 1

Dudley asked to be allowed to resign, because he could not peaceably and conscientiously speak and act without creating a disturbance. And this privilege of departure was denied to him, and the governor proceeds, thus out of the kindness of his spirit, adding two more grievances to his miserable mischance. If there is a blessing assured to peacemakers among the Beatitudes, as there certainly is, Dudley in this Court seems to have done very much to deserve it, and is entitled to universal sympathy.

The question of the removal of the governor's house from Cambridge, together with a charge on the part of Dudley that the governor was taking too much authority upon himself, came up by agreement before the elders at Charlestown, August 3, 1632. Dudley said that he had grievances which under advice he should let pass, and confine himself to two. Ist. "That the governor did not build at Newtowne as agreed, and that he thus made a breach of his promise." The governor answered that " he had a house up, and seven or eight servants abiding in it, by the day appointed, and for the removing of his house, he alleged that, seeing that the rest of the assistants went not about to build, and that his neighbors of Boston had been discouraged from removing thither by Mr. Deputy himself, and thereupon had (under all their hands) petitioned him, that (according to the promise he made to them when they first sat down with him at Boston, viz. that he would not remove, except they went with him) he would not leave them;- this was the occasion that he removed his house. Upon these and other speeches to this purpose, the ministers went apart for an hour; then returning, they delivered their opinions, that the governor was in

\section{Winthrop, i. *73.}


fault for removing of his house so suddenly, without conferring with the deputy and the rest of the assistants; but if the deputy were the occasion of discouraging Boston men from removing, it would excuse the governor a tanto but not a toto." 1 It is well to observe here that the ministers do not decide the question whether the deputy had discouraged the Boston men. They did, however, afterwards decide in favor of Dudley. They do find Winthrop at fault in the removal of his house, and later ${ }^{2}$ adjudge that he shall furnish a minister to Cambridge because thereof. This was a serious matter. Dudley had gone to Cambridge with the express agreement that the government and the capital were to be removed there. It was with great difficulty that he could reconcile himself to his unexpected misfortune; it was the work of years, and finally he left Cambridge himself in 1636 , to reside in Ipswich, and ultimately at Roxbury.

1 Winthrop, i. *83.

${ }^{2}$ See p. I 12 of this volume. 


\section{CHAPTER $\mathrm{X}$}

Winthrop, it seems by the accounts of Dudley and Hutchinson, had promised, on the 2 Ist day of December, 1630, to build his house in Cambridge the next year. $\mathrm{He}$ now argued that he performed the letter of his promise, but the ministers decided that he did not perform the spirit of it, and was in fault. Winthrop thereupon, in great condescension and deference to the "wise and godly ministers," but without any change of opinion on his part, said something which conceded nothing, and which he hoped would be taken as a full reparation for all his fault to him, the deponent, unknown. His skillful words were, "The governor, professing himself willing to submit his own opinion to the judgment of so many wise and godly friends, acknowledges himself faulty." He continued of the same opinion himself. He had promised both to go to Cambridge and to Boston, and when the hour of reckoning overtook him, he went in the direction of least resistance. Moreover, we have only his own version of this disagreeable business. Dudley left not a word of justification, and his reputation must abide the result. The conclusion of the whole matter is that the ministers, who were the judges in the case, found Winthrop guilty, although he lets himself down very easily in his own diary, and there is no other account of the affair. They took a recess before entering upon the next and more serious complaint. "After dinner the deputy [Dudley] proceeded in his complaint, yet with this protestation, that what he should charge the governor with, was in love, and out of his care of the public, ${ }^{1}$ and that the things which he

1 We may feel confidence that, if he used those words, he meant what he said, for he was " too honest or too proud to feign a love he 
should produce were but for his own satisfaction, and not by way of accusation. Then demanded he of him the ground and limits of his authority, whether by the patent or otherwise." This was an important and fundamental question, and we shall observe later that other persons in the colony were solicitous respecting the course of the government in this matter of excess of authority. They had tasted tyranny before they came to America, and had a dread of one-man power. Dudley realized the importance of obedience to law in the officers and governors of the people, and more particularly so until the government was firmly rooted and grounded in the respect and confidence of the masses. Winthrop was subsequently impeached on this ground, and, although he came out of the contest with credit to himself, the charges indicated the public anxiety respecting him. Dudley stands well in this respect. He was four years governor, and thirteen years deputy governor, and although constantly in public life, and always under the inspection of the people, no reflection rests upon his career that he sought to secure or retain power. He was, it is true, a member of the discredited council for life, with others, but that was ornamental, and never vexed the liberties or rights of the people by any unfortunate doings. "The governor [Mr. Winthrop] answered, that he was willing to stand to that which he propounded, and would challenge no greater authority than he might by the patent. The deputy [Mr. Dudley] replied, that then he had no more authority than every assistant (except power to call courts, and precedency

never cherished." He shared with others a reasonable solicitude respecting Winthrop's arbitrary use of authority, which might, if suffered in silence, soon extend over all the affairs of the government. The disagreeable duty of calling a halt fell naturally and by necessity to Dudley, and we cannot fail to note the tender way in which he approached this duty; and also that he is free from jealousy, or a petty wish to annoy the governor, or to supplant him. For although we have so little of the record, and that little from such a source, yet we have enough in various other ways to enable us to determine the probable limits of his conduct. 
for honor and order). The governor answered he had more ; for the patent, making him a governor, gave him whatsoever power belonged to a governor by common law or the statutes, and desired him to show wherein he had exceeded, etc.; and speaking this somewhat apprehensively, the deputy began to be in passion and told the governor that if he were so round he would be round ${ }^{1}$ too." 2 Winthrop evidently discovered wrath in the person of Dudley, before it began so to glow in himself as to reach his consciousness. But he had certainly surprised Dudley, when he sent him through all the statutes of the realm and the body of the common law, to find the limits of gubernatorial power and authority, which Dudley had supposed until that moment were contained in the patent, except certain incidental and implied powers which naturally inhere in the office by common consent. This was not consistent with the uniform practice, which was to avoid as much as possible foreign law and foreign appeals. ${ }^{3} \mathrm{He}$ had reason to think that Winthrop magnified his office in words, as he had already done in acts. The governor admits that he spoke "somewhat apprehensively." He means, perhaps, sensitively, or with feelings bordering on resentment. They had both reached the dan-

1 The word "round," as here used, means harsh, severe, and shows how Dudley regarded what he conceived to be the haughty manner of the governor, when, as a citizen and as a patriot, he called his attention, among friends in council, to certain matters, in which he was believed by others, accidentally or otherwise, to have exceeded his powers; it was giving him an opportunity in a quiet way to explain and allay the natural solicitude. The deputy felt for the instant as if the moment for revolt had arrived. They had left Charles I. in England, to fall into the hands of a ruler who claimed to be responsible, in large part, to the courts beyond the sea, and to be guided by statutes and foreign interpretations of the law, rather than the patent as understood in the colony, although Winthrop was the first to deny the force of foreign statutes and the jurisdiction of English courts in other cases.

2 Winthrop, i. *83.

3 Rhode Island Hist. Soc. Coll., ii. 124, 125, 201 ; Elliot, i. 268, 284 ; Winthrop, ii. *279, *282, *289; John Child's New England's Jonas, Marvin ed., pp. xxx., xxxi.; Mass. Col. Rec., i. I75. 
ger line, approaching from opposite directions, one from the seat of authority, the other from the people.

"The governor bade him be round [harsh, severe], if he would. So the deputy [Dudley] rose up in great fury and passion." 1

Dudley always began the trouble, as Winthrop related it; he was the cause and effect of all the wrong. He had been, however, disciplined in a life of experience in judicial service and earlier in the army, and above all he was accustomed to situations of dignity. He was, moreover, under the powerful restraints of religion. He was in his day accounted both "wise and godly." These few pictures of passion, drawn by his rival, were intended no doubt to be truthful, but nevertheless they are both inconsistent with his education, his honest profession, and the record of a lifetime before, and many official years subsequent to this. There is such a thing as holy wrath and righteous indignation. The governor grew very hot also (Dudley, we are left to infer, was the cause why the governor, being "much enforced, showed a hasty spark"), "so as they both fell into bitterness, but by mediation of the mediators [the ministers] they were soon pacified. Then the deputy proceeded to particulars as followeth :-

"Ist. By what authority the governor removed the ordnance and erected a fort at Boston?

" 2 d. By what authority he lent twenty-eight pounds of powder to those of Plymouth?

" 3 d. By what authority he had licensed Edward Johnson to sit down at Merrimack?

" 4 th. By what authority he had given them of Watertown leave to erect a weir, upon Charles River, and had disposed of lands to divers, etc. ?

1 Even if he was a little excited, he had the great example of Cromwell. " His [Cromwell's] temper was exceeding fiery, as I have known, but the flame of it kept down for the most part or soon allayed with those moral endowments he had." (Letter of Maidstone to Winthrop, Jr., Mass. Hist. Soc. Coll., 3d series, i. 193.) 
" 5th. By what authority he had given license to Ratcliff and Grey (being banished men) to stay within our limits?

" 6 th. Why the fines were not levied?

" 7 th. That when a cause had been voted by the rest of the Court, the governor would bring new reasons, and move them to alter the sentence!" 1

To each of these several questions the governor gave reasons which were sufficient, without doubt, to have caused the Court to direct the same action which Winthrop took in the premises, so that the conduct of Winthrop was intrinsically correct; but as a rule his actions ought regularly to have followed an order of Court, which they did not. The governor ought to have stood ready to answer such proper questions, not "apprehensively," but directly and squarely, without mental reservations, particularly to the deputy governor and without any resentment because of the liberty taken or the interrogatories propounded. "No man is wise at all times," and this was one of the instances in which Governor Winthrop does not appear at his best, even with the great advantage of being allowed to tell the story with no opportunity for the other side to be heard.

The governor proceeded now to give his thoughts and opinions respecting the situation, with so much seeming candor that the world in general has accepted the description, as clearly showing the contrast in character between the two men, not always to the advantage of Dudley.

"The deputy having made an end, the governor desired the mediators to consider whether he had exceeded his authority or not." The mediators were silent, and did not decide until a subsequent meeting. ${ }^{2}$ It is not unreasonable to believe that they thought, as we think, that the matters charged were not important or injurious, but that the governor was taking things into his own hands in a manner which ought to be checked at once. However, since the deputy had administered the needful caution, and since a

$$
1 \text { Winthrop, i. *84, *85. } \quad 2 \text { Ib., i. } 88 .
$$


word to the wise is sufficient, they adroitly kept out of the business, but subsequently sustained Dudley. ${ }^{1}$ They were not a tribunal which was bound to come to judgment; they were only a group of mutual friends intent upon the best interests of the colony. "And how little cause the deputy had to charge him with it; for if he had made some slips in two or three years' government, he ought rather to have governed them [it was not the things done, so much as it was the assumption of growing power and authority], seeing he could not be charged that he had taken advantage of his authority to oppress or wrong any man, or to benefit himself; but, for want of a public stock, had disbursed all common charges out of his own estate, whereas the deputy would never lay out one penny," etc. Here the generosity and patriotic, self-sacrificing character of the governor appear in contrast to the selfishness of Dudley. He had already prepared us to expect this in his graphic picture of Dudley "selling seven bushels and an half of corn to receive ten for it after harvest." And so far as I have been able to learn, it is from these two passages that the false story of Dudley's stingy character originated.

It must be admitted without question that in money matters Dudley was prudent and careful. He could not have lifted the estate of the Earl of Lincoln out of poverty without that quality and the power which came from it. It was then thought to be greatly to his credit. He was the business man of the colony. Dudley lived and acted according to the doctrine and philosophy of Burns :-

"To catch dame Fortune's golden smile, Assiduous wait upon her; And gather gear by ev'ry wile

That's justified by honor; Not for to hide it in a hedge, Nor for a train-attendant; But for the glorious privilege Of being independent."

1 Page 112 of this volume. 
Dudley's trades in corn, as we have said, were not unusual or unfair, and have long since been the custom. Besides, the great scarcity of seed corn at that time made the rate more reasonable, and if we had the facts, it might be shown that Dudley really did the thing as a special favor to his friends, and that if he had been mean, he would have retained the seed corn and used it himself. It was no doubt an act of kindness, in part, from his standpoint. His side of this episode has not been told, at least not by himself.

Dudley served the public twenty-three years faithfully and honestly, and never came under condemnation in office, and never received anything, so far as appears on record, except a gratuity now and then towards the end of his career, declared always to be no just payment of the value of the service. So Dudley might have claimed to be a generous public benefactor, but he never did. ${ }^{1}$

We are permitted now and then to catch a glimpse of the real nature of Dudley, of far greater interest than any direct efforts of Governor Winthrop himself, or anybody else, to describe him. Because in the study of character every day, the view when persons are off guard, when the mask is up, when their thought is far away from themselves, enables one to penetrate deepest into their interior life.

The ministers tried later to reconcile these persons, and the account by Winthrop is as follows :-

"The ministers afterwards, for an end of the difference between the governor and deputy, ordered that the governor should procure them a minister at Newtown, and contribute somewhat towards his maintenance for a time; or, if he could not by the spring effect that, then to give the deputy, toward his charges in building there, twenty pounds. [Dudley stands ahead in this dispute; there was probably a stronger case for him than appears in the Journal of Winthrop.] The governor accepted this order, and promised to perform it in one of the kinds. But the deputy, having received one part of the order, returned the same to the

1 Morton's New England's Memorial, 166. 
governor, with this reason to Mr. Wilson, that he was so well persuaded of the governor's love to him, and did prize it so much, as, if they had given him one hundred pounds instead of twenty pounds, he. would not have taken it." 1 Here is the same elevation of soul, the same Christian magnanimity, and no one can read these words and not feel that a wrong has been done to Dudley by the epithets which have been applied to him.

Winthrop says further, "Notwithstanding the heat of contention, which had been between the governor and the deputy, yet they usually met about their affairs, and that without appearance of any breach or discontent; and ever after kept peace and good correspondency together, in love and friendship."

There is an entry in the Journal, page * I 7 , November, 1633, which makes this last quotation a trifle premature, but it is correct in the main. The entry is as follows :-

"Some differences fell out still, now and then, between the governor and deputy, which yet were soon healed. It has been ordered in Court that all hands should help to the finishing of the fort of Boston, and all the towns in the bay had gone once over, and most the second time; but those of Newtown being warned, the deputy would not suffer them to come, neither did acquaint the governor with the cause, which was, for that Salem and Saugus had not brought in money for their parts." Dudley felt that there was a wrong which could only be remedied by holding out until it was righted. And he may well have presumed that the governor knew and understood it. "The governor, hearing of it, wrote friendly to him, showing him that the intent of the Court was, that the work should be done by those in the bay, and that, after, the others should pay a proportionable sum for the house, etc., which must be done by money; and therefore desired him that he would send in his neighbors. Upon this, Mr. Haynes and Mr. Hooker came to the governor to treat with him about it, and brought a letter from 
the deputy full of bitterness and resolution not to send till Salem," etc. We do not know what was in the letter, but we can feel sure that after he had been deeply disappointed that Cambridge was not the capital of the colony, and after he had at great patriotic and personal labor and cost constructed the palisade there for the defense of the entire colony, and since, moreover, he did not believe in either the present settlement of Boston or the fortification of it, and all the inhabitants of Cambridge felt as he did, that he would advance cautiously. We can under these circumstances have some charity for the people of Cambridge, and some sympathy, when they said other towns as remote, and needing this more, must do their part, and then they would do their part also. "The governor told them it should rest till the Court, and withal gave the letter to Mr. Hooker with this speech: I am not willing to keep such an occasion of provocation by me." Which speech does great credit to Governor Winthrop.

Now the politic Winthrop thought that as Dudley was exceedingly in need of hogs, he would test him; and would couple two of the deputy's dearest friends in the temptation. Bread and meat are ancient temptations. Let him tell the story :-

"And soon after, he wrote to the deputy (who had before desired to buy a fat hog or two of him, being somewhat short of provisions) to desire him to send for one (which he would have sent him, if he had known when his occasion had been to have made use of it), and to accept it as a testimony of his good-will [Whittier has beautifully said a 'genuine token of love and good-will has no limitations of time, and is never out of place']; and lest he should make any scruple of it, he made Mr. Haynes and Mr. Hooker [who both sojourned in his house] partakers with him.

"Upon this the deputy returned this answer: 'Your overcoming yourself hath overcome me. Mr. Haynes, Mr. Hooker, and myself do most kindly accept your good-will ; but we desire without offense to refuse your offer and that 
I may only trade with you for two hogs ;' and so very lovingly concluded." 1

Misers and niggards are made of sterner, more unrelenting stuff than this. His great, chivalrous heart welcomed the touch of kindness and reconciliation as the hart the water brook. It was not lucre, but love, which reached him; he was not sordid, he had his conversation in heaven, where all is love. We are left to guess as to the attitude and feelings of Dudley. We have not a line about all this over his signature, and must spell out all we can between the lines of his rival's Journal.

It is delightful to remember that after 1633 we hear of no more disputes or dissensions between these great leaders, the two foremost men in this most important emigration in the tide of time. They lived and wrought together sixteen more eventful years in beautiful harmony, without a record of strife or variance, until Governor Winthrop died, in I649. Who can find the heart to inveigh against or disparage the memory and record of either of them? They both belong to the illustrious school of Cromwell, Hampden, Pym, and their coadjutors on the other side of the sea. Their honor and renown is a part of the wealth and heritage of their country, and it is not a patriotic service to detract from the character of either of them.

There is a beautiful picture presented of these noble men, by Hon. Robert C. Winthrop, worthy of perpetual remembrance, mentioned elsewhere. It is a lasting covenant of love and good-will between them at Concord, Mass., April 24, 1638 .

1 Winthrop, i. * 118. 


\section{CHAPTER XI}

A CHURCH was soon established at each of the various settlements of Boston, Charlestown, Dorchester, and of other towns, on the same model as that of Salem. Every hardship was endured by these heroic men and women during their first bitter winter in America. Hunger, privation, and disease reduced their numbers constantly, weighed down their spirits with unrelenting anxiety, and unnerved them in the inevitable struggle into which each was forced daily to preserve themselves and their friends. The fortitude of these people, and their unruffled contentment in the midst of sufferings and perils, have never ceased to receive the merited admiration of thoughtful people. Winthrop wrote to his wife out of the depths of his overwhelming trouble, "I thank God I like so well to be here, as I do not repent my coming. I would not have altered my course, though I had foreseen all these afflictions. I never had more content of mind." And Dudley, after saying in his letter to the Countess of Lincoln, that up to December, 1630, "there died by estimation about two hundred at the least; so low hath the Lord brought us!" manifests the same sweet resignation in the following words: "Well, yet they who survived were not discouraged, but bearing God's corrections with humility, and trusting in his mercies, and considering how after a lower ebb he raised up our neighbors at Plymouth, we began again in December to consult about a fit place to build a town upon." And later in the same letter he says: "Yet many of us labored to bear it as comfortably as we could, remembering the end of our coming hither, and knowing the power of God, who can support and raise us again, and useth to bring his servants low that the meek may be made glo- 
rious by deliverance." 1 Everything which was now done at the very beginning by these remarkable people in this new and strange land will always have an extraordinary attraction for the zealous student of American history.

They came to America in a large measure to Christianize the Indians; they sought liberty for themselves and their posterity, and also to redeem the wild aborigines from darkness to light. ${ }^{2}$ The experience of the English in Virginia had already assured them that these sons of the forest were not to be implicitly confided in and trusted. It was a difficult and delicate matter to establish and maintain just relations with them. Even two and one half centuries later Indians are accounted only wards of the government. It is to the honor of the colony that during this early period they paid the Indians for their lands. The Court of Assistants thought it inexpedient to trade in money with them. It may have been in part because with the money they might procure arms and ammunition from the enemies of the colony, but most probably the Court took this position because all the money in the colony was far too little to do its legitimate business. They also deemed it unsafe to employ them as servants in their households. ${ }^{3}$ They seem to have administered justice without respect of persons. Sir Richard Saltonstall was fined at one Court for his absence from Court, and two months later for whipping two several persons without the presence of another assistant. $\mathrm{He}$ was required to give to Sagamore John a hogshead of corn for the hurt his cattle had done to the Indian in his corn.

Every page of the records of Massachusetts Bay in the early years of its history reveals the manifold crimes and misdemeanors of servants and adventurers, who with nothing to lose, and a possible opportunity to win a fortune, attached themselves to this emigration.

1 Young's Chron., 320, 321.

2 Conversion of the Indians. Young's Chron., I33, 142, 202, 21 , $215,258,273,364$.

3 Mass. Col. Rec., i. 83. 
The Court is called upon at one time to consider the conduct of masters and servants towards each other, to punish ill speeches of servants to masters, to restrain drunkenness and the immoderate use of strong water; at another time to set up ferries, boundaries between towns, and to name them; to make rules for the restraining of cows, horses, goats, and swine; to impanel juries; to satisfy Indians who had been overreached by white men; to punish wicked Indians and venders of quack and worthless medicines; and to order bad and useless people to be returned to England. These are a few of the matters coming constantly before the Court, and at every session Governor Dudley had a conspicuous share in their settlement. There were also questions about the price of commodities and of labor to be fixed, where no sufficient market determined such matters, and persons were therefore inclined to take advantage of the freedom from restraint in which they suddenly found themselves. It was indeed this newborn freedom, which all recently enfranchised persons are wont to esteem to be unbridled license to do what they please, which gave the Court its greatest anxiety and kept it busy with manifold new, unheard-of, and before unadjudicated questions.

We have already considered the action of the General Court in October, 1630, by which it was provided that freemen should choose the assistants, and that the assistants from among their own number should select the governor and deputy governor, who with assistants should make the laws and appoint officers to execute them, without any further aid from the freemen, who had thereby delegated for a short period their law-making powers to the assistants.

The freemen were then few, and possessed by a profound sense of their. insufficiency and lack of qualifications for legislators (a feeling of self-depreciation which has rarely been known to enter the human mind in any previous or subsequent age in human history).

The General Court in a measure confirmed the above in May, I63I, and added to it a provision, annexed to and in 
continuation of this act, which has been the subject of more relentless criticism still. "And to the end the body of the Commons may be preserved of honest and good men, it was likewise ordered and agreed that for the time to come no man shall be admitted to the freedom of this body politic, but such as are members of some of the churches within the limits of the same." 1 The standard in Rhode Island was ownership of land. ${ }^{2}$

If the motive was the one expressed in the act itself, viz. : that the "body of the Commons may be preserved of honest and good men," most persons, in the light of more recent politics, would be inclined to approve of the ideal aimed at by the fathers, even if they could not commend their method of advance towards it. The result of this rule was that in three years there were in the colony three hundred and fifty voters, while the aggregate population was three or possibly four thousand persons.

The expediency of the union of church and state has now been under discussion many years, and great light has in recent centuries been derived from the experience of nations, both with and without such union. The Puritans had no such experience to reveal the way to them. Their ideas of government were derived from England and Holland, their charter, the rules of the English common law, and the Bible.

It certainly was not their original purpose to use their government primarily to disseminate new religious ideas. They were considering only the purification of the Church of England. They wanted to divest her of the Romish traditions and usages, which in their opinion were no essential part of her, and greatly retarded her usefulness. They knew no state without union with religion. It does not yet appear that any state can survive without religion. ${ }^{3}$ The experiment was indeed attempted in the French Revolution,

1 Mass. Col. Rec., i. 87 ; Story on the Const. of the United States, ii. §§ $1846-1850$.

2 Narr. and Critical Hist. of America, iii. 338.

${ }^{3}$ De Tocqueville's Democ. in Amer. i. 44, 334, 337. 
and signally failed. The church should be secondary and subject to the temporal power in civil matters, but in its own realm in matters of belief, conscience, and worship, it should be supreme. This should be accorded to all alike, to individual men, to associations whose usages and services are conformable to good morals and pure government, and the civil authority must in all cases be the final judge in this cause. It is an immense satisfaction that in the highest form of spiritual worship no man or court has power to intervene or intercept the service. It has been claimed, with much reason, that since the ministers received the various candidates into the church membership, the power was ultimately reposed in them to determine who should be eligible as freemen and entitled to vote. It must not be overlooked, however, that the personal interests of the ministers lay in the direction of extending their membership and the growth of their flocks. It does not appear that any were excluded from entrance to the church on political grounds. And if there were to be a religious test as a gateway to politics, it may be reasonably doubted whether anything more just could have been substituted for the learned, sagacious ministers who were busy sifting the population to discover the willing, obedient, and elect.

These Puritans, in their true allegiance to the English church and throne at the start, had not yet thought of a separation of church and state. Their ministers were learned in the Scriptures, which they regarded as the great ultimate source of law and justice, and some of them were also the most learned men in the English common law in the colony. And while they were not received into the positions of assistants, or of the Commons, or into executive or judicial stations, they were exceedingly well prepared to instruct and inform the government and all persons interested as to the meaning of Biblical and common law.

Disability to hold office in England continued against Jews to the middle of this century, and against Catholics and Friends to the early part of it. The first legislative body in 
America, which sat at Jamestown, July 30, I619, was elected by all the adult male inhabitants of the colony, a policy which has continued nearly everywhere, to the extent of excluding both from the franchise and from public office the women, one half of the population of the country, who bear their share of the burdens of government. The political dogma that the franchise, or the right to hold political office, is a natural right, like life, has received in this country almost universal disapproval. It is declared not to be a right for anybody, but a privilege conferred upon persons and classes by the state, according to its own will, in the most arbitrary exercise of its own judgment. Not even the Constitution of the United States guarantees the right to vote. It is no privilege or immunity secured to American citizenship by virtue of that document. If this is the correct theory in this matter, then it follows that the General Court of Massachusetts, on May 30, I63I, was both by precedent and subsequent franchise fully justified in the exercise of its discretion, in saying that none but church members shall be admitted into the body politic. What better class was there in the colony, if they were to select one?. Their work for thirty years justifies the wisdom of their choice. They did unwise and unjust things during that period, we freely admit ; but their great constructive work nevertheless remains as a monument of their integrity, breadth of understanding, and enlightened conceptions of the state which was gradually being evolved under their guiding hands.

It is popular in some quarters now to characterize their action as intolerant, bigoted, and despotic. But it bears the mark of none of these things. They then had, as we now have, a numerous population of recent immigrants who had no conception of the importance and magnitude of this great undertaking in the interests of humanity, who were only adventurers seeking opportunities to secure a living, without interest in politics or religion, or the fortunes of the enterprise beyond themselves.

A portion of our recent population from Asia we have 
found undesirable, and have limited further immigration. We have proceeded in like manner with the paupers of Europe, and have assured their governments that they are in no way useful to us, and have requested them to retain them at home. We are aware that the people excluded by the Puritans were as a rule respectable, neither paupers nor inferior races ; but the right to exclude is of universal application. And still our shores are swarming with poor, ignorant, and often criminal immigrants, whom we cannot in three generations assimilate with our native population to become worthy, educated American citizens. Are we required in the name of our religion, of justice, humanity, or right reason, to place political power, the government of ourselves, of our families, and the fortunes of our country in the keeping of these persons, and to turn over our institutions, the most sacred hope of mankind, to these miserable creatures, who were the very peril of government at home before they came, the material for mobs and revolutions the world over? Does not all history justify the exercise of arbitrary discretion by our fathers? The Puritans had no confidence in these people without religion, and with a conviction that possessed our fathers also in the days of Washington, they said, the foundation of this nation must be laid upon the intelligence and virtue of the rulers. And what safer line could they draw between the classes of population, to secure intelligence and virtue in the rulers, than to set apart the church members, who had this magnificent undertaking at heart as the mere enterprising fortune-hunter had not? The whole matter is creditable to the thoughtful foresight and prudent wisdom of these wonderful, divinely guided men, the founders of Massachusetts. No man can successfully take exception to this fundamental action of the Puritans until he is prepared to show that the world would have been in a better condition if this colony had been planted by other persons, of other tenets, other education, and other convictions - a thing which we believe, with all earnestness, to be impossible. 


\section{CHAPTER XII}

IT may justly be accounted a distinguished honor to have been the founder of a city which contains within its limits the greatest university in America; which for two and onehalf centuries has been incessantly pouring its healthful stream of influence into the life-currents of our republic; which also has drawn into its inclosure scholars, poets, orators, and statesmen, who have been great literary, social, and political leaders in our history, and have contributed vastly to the best quality of our national character and literature. Dudley and his son-in-law, Bradstreet, were the first to settle at Cambridge, in the spring of $1631^{1}$ Dudley was then the more eminent of the two, and manifested such zeal in securing the residence of the governor and assistants at Newtown, both before and after his own settlement there, that he seems entitled to the ever-increasing merit of being the founder of the University City on the Charles River. His house was placed between the river and the present site of the university, at the northwesterly corner of Dunster and South streets, near its southern termination at Marsh Lane. ${ }^{2}$ It was very near to the first house for public worship, erected in 1632 (with a bell on it), on the corner of Dunster and Mt. Auburn streets. It is probable that neither was the chimney built of wood nor the roof covered with thatch, which were materials often used for such purposes. ${ }^{3}$

The capital was retained in Boston until Dudley was chosen governor, May 14, 1634, in place of Winthrop, but upon this change it was at once removed to Cambridge, and

1 Paige's Hist. Camb., 8.

2 Holmes's Hist. Camb., 8, note.

3 Paige's Hist. Camb., 247; Winthrop's Journal, i. *49. 
all the Courts were holden there for two years, during the administration of both Governor Dudley and of Governor Haynes, and until the election of Governor Vane, in $1636 .^{1}$

Governor Winthrop, and the greater part of the assistants, in I63I, did not make Cambridge their place of residence, yet they seem to have regarded it on the whole, being more interior, as a safer place for the capital in case of danger from the sea. It is in any event a notable fact, whatever their reasons might have been, that they caused George Maisters to make a water passage by the enlargement of a creek from Charles River up into the heart of the settlement. This waterway was made twelve feet broad and seven feet deep, and on the 5 th of July, I6 31 , there was levied on the other towns, excepting Newtown, the sum of thirty pounds to pay the cost thereof. ${ }^{2}$ "This canal still exists on the westerly side of College Wharf, from Charles River nearly to South Street. It was a natural creek, enlarged and deepened thus far, from which point, turning westerly, it extended along the southerly and westerly sides of South and Eliot streets, and crossed Brattle Street, where the town ordered a causeway and foot-bridge to be constructed, Jan. 4, 1635-36." 3 Passengers and freight could by this channel be conveyed to almost every door in the settlement, in boats from the sea, by its connection with the river, as the houses and homes of Venice are approached by canals. The residence of Governor Dudley seems to have been beside this watercourse, near its greatest curve. Here, in 1633, might often have been seen John Haynes, who was the third governor of Massachusetts and the first governor of Connecticut; the Rev. Thomas Hooker, who was the first minister of Cambridge, and as a pioneer led his flock in 1636 to the settlement of Connecticut, and who, it is said, more than "any other man, deserves to be called the father of American democracy;" and with these two distinguished founders of states, also Thomas Dudley, taking
1 Mass. Col. Rec., i. I 16, 173.
2 Ib., i. 88,90 .
8 Paige's Hist. Camb., 9, note. 
boat for the Court in Boston, or for errands of business or deeds of charity, or on missions of mercy to neighboring settlements, for Haynes and Hooker sojourned on their first

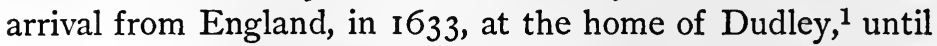
they had homes of their own at or before 1635 , when they are known to have built separate houses.

But the public interest in Cambridge, or possibly the safety of the colony at large, called forth a more munificent expenditure there by the Court of Assistants, February 3, I631. " "It was ordered there should be threescore pounds levied out of the several plantations within the limits of this patent, towards the making of a palisade about Newtowne,

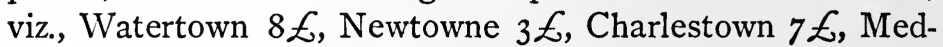
ford $3 £$, Saugus and Marble Harbor $6 £$, Salem $4 £$ ios., Boston $8 £$, Roxbury $7 £$, Dorchester $£ 7$, Weymouth $5 \mathcal{E}$, Winisemet 30s." The influential leadership of Governor Dudley in the affairs of Cambridge is shown by his impaling there a thousand acres of land without the order of court, to protect the inhabitants and their flocks from the ravages of wild beasts, and the sudden and unexpected attacks of savages. ${ }^{3}$ "This fortification was actually made; and the fosse which was then dug around the town, was in some places visible in this century. It commenced at Brick Wharf (originally called Windmill Hill), and ran along the northern side of the present Common in Cambridge, and through what was then a thicket, but now constitutes a part of the cultivated grounds of Nathaniel Jarvis, beyond which it cannot be distinctly traced. It inclosed above a thousand acres." 4

We find a more complete account in Paige's " History

1 Winthrop's Journal, i. *I 8 .

3 Winthrop, i. *85.

${ }^{4}$ Colonel T. W. Higginson, the orator on the two hundred and fiftieth anniversary of the settlement of Cambridge, held December 28, 1880, said, "It [Cambridge] is to be a fortified village, created after some delays, and under the inexpressive name of Newtown. Even after Winthrop has abandoned the new settlement, stout Dudley secures an appropriation of sixty pounds to build a ' pallysadoe, or stockade, around 
of Cambridge," page Io, note, as follows : "The location of the greater part of this fence, or 'pale,' is designated with tolerable accuracy by the ancient records of possessions and conveyances. Commencing in the present college yard, near the northwesterly angle of Gore Hall, and extending eastwardly, it passed very near the junction of Ellsworth Avenue with Cambridge Street to the line between Cambridge and Charlestown (now Somerville), at its angle on Line Street, near Cambridge Street, and thence followed that line to the creek, a few rods easterly from the track of the Grand Junction Railroad. Commencing again at the point first mentioned, the fence extended southwardly to the marsh near the junction of Holyoke Place with Mount Auburn Street. The kind of fence erected in the colony later is indicated in an order passed Dec. 5, 1636: "That the common pales in all places, to be made after this day, shall be done with sufficient posts and rails, and not with crotches.'" There is a beautiful and picturesque group of willows still standing, it is thought, as stated by Higginson and others, on a part of the line of this palisade and fosse. We have entered thus into the several accounts of its structure and history, because it seems to have been so directly the work of Dudley, or at least he appears to have been the

it.' A thousand acres are ordered to be thus impaled with trees set in the ground; a mile and a half of trees being thus placed, at the very lowest estimate (that of Wood), ... the stockade not including the side toward Charles River. What a task for the men of this little settlement to fell, remove, and plant these thousands of trees, and to dig round them a fosse or trench, so well executed that I remember parts of it still existing as a ditch in my boyhood! The willows on the football ground of the students, at the edge of Oxford Street, are the last memorial of that great labor undertaken two centuries and a half ago. ... The pallysadoe keeps the new village safe." (Exercises in Celebrating the Two Hundred and Fiftieth Anniversary of the Settlement of Cambridge, 46, 47.)

The identity of this fosse and palisade has been questioned, but the authority of Holmes and Higginson, sustained by a clear tradition reaching over only two centuries and a half, seems quite sufficient. (Prince, ii. 57 ; Rev. Abiel Holmes's Hist. Camb., 9.) 


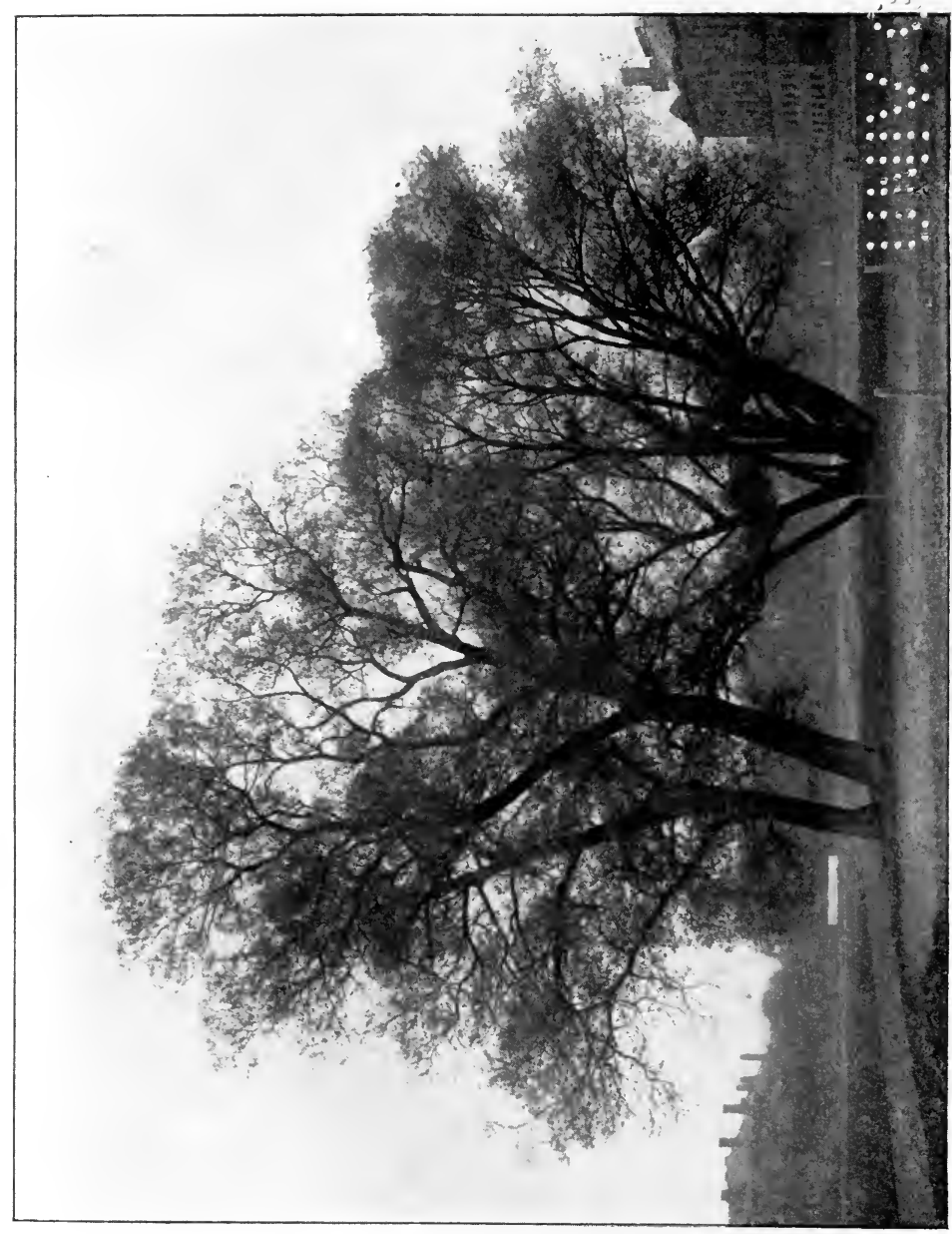

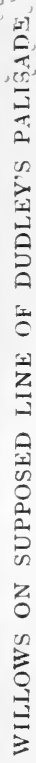



chief projector. That he had the influence to carry the Court of Assistants with him to raise this large sum to defend the plantation and the colony, and that he had the energy in a public emergency to do the needful service and assume the risk of being able to convince his associates of its expediency, are conclusive facts as to his executive force and weight of character at this period in the history of the colony.

But it is generally thought that matters of far greater importance than the payment for the palisade resulted from this action of the assistants. When Watertown received the warrant for its portion of this tax, "the pastor and elders, etc., assembled the people, and delivered their opinions that it was not safe to pay moneys after that sort, for fear of bringing themselves and posterity into bondage." Here is supposed to appear the right of the more direct representatives of the people in the House of Commons or House of Representatives in the legislature to originate tax bills and assessments of money. And in confirmation of this view, although the pastor of Watertown was immediately reduced to submission by the Court, at the next General Court, May 9, 1632, " "It was ordered that there should be two of every plantation appointed to confer with the

$1 \mathrm{Mr}$. J. A. Doyle evidently regards Winthrop as the chief oligarch at the beginning of Massachusetts, because he disposed of the people so summarily in the Watertown matter (Winthrop, i. *7o), and on other occasions when they appealed to him or to the government (Winthrop, i. *I 28, *I 29). He says : "We may be sure, too, that in fact the men of Watertown were contending against an oligarchical spirit, which was probably made all the more dangerous by the conspicuous personal merit of the man in whom it was embodied." (The English in Amer., i. I40.) Dudley was made governor in 1634 by the triumphant party which then secured the law that "none but the General Court hath power to raise monies and taxes." (Mass. Col. Rec., i. I I7.) It seems to us that the word "oligarch" is not justly applied here. The supreme power was not vested in a small and exclusive class, but in all church members. If it be said that at one time they constituted a small portion of the population, the same is true, in the United States to-day: the women, minors, unnaturalized persons, and others, have civil rights, 
Court about raising of public stock;" and singularly enough, the names of Oldeham and Masters, both of Watertown, were the first on the committee. Watertown was vindicated, truth crushed to earth had arisen, and Prince says an "embryo parliament" had appeared. ${ }^{1}$ The incipient idea of a House of Representatives in the legislature of Massachusetts had been evolved through Dudley's venture to impale a thousand acres at Cambridge, and trust the Court and people to indemnify him. But it did not extend to a share in the making of laws until May I4, I634.

All this jealousy of the government had resulted from the power given by the freemen, October I9, I630, to the governor and assistants to make laws and choose officers to execute them. ${ }^{2}$ Experience with new power in the hands of the assistants almost at once aroused the suspicion of the freemen that they had committed an error, and rendered them jealous of the exercise of authority. Savage and others seem to consider the action of the assistants as a usurpation, unauthorized by the charter. ${ }^{3}$ We have already considered this question, but a few new observations are desirable in this connection.

It would appear that the views of the Court at that time, giving contemporary opinions, are entitled to much weight, although influenced a little, possibly, by a desire to sustain themselves and their own action; yet from what we know of them, we can believe that their chief solicitude was to be right, not only because of their great personal integrity, but because every act and every secret thing was in constant

but not political privileges, and are a large portion of the population. The representatives of the people who make the laws at present are few compared to the whole number; we do not now call them an oligarchy. When in 1632 the Court of Assistants made laws and appointments, it was by the authority of the General Court, as the agents or representatives of all the people who had any rights under the charter. And opprobrious epithets do not apply to them.

1 Prince, ii. 60; Winthrop, i. *70, *76; Mass. Col. Rec., i. 93-95.

2 Mass. Col. Rec., i. 79.

3 Winthrop, i. *7o, note by Savage. 
danger of being brought into vigorous examination by the home government, and of putting in peril the whole undertaking.

Governor Winthrop told the people in effect that they had by their own action created a parliament of one house for one year, and they must abide by its action until the time had expired, when they might change it, which they did not wholly until May 14, 1634. ${ }^{1}$ This is said to be in violation of the charter, but they were good lawyers and knew the charter. ${ }^{2}$ It distinguishes Dudley that he became governor under the political change which elevated the freemen as representatives to the legislature.

There are a few notes from the town book of Cambridge

1 Mass. Col. Rec., i. I 8 ; Winthrop, i. I28, Savage's note.

2 The only words of the charter which appear to relate to legislative action are as follows: "That the governor, or, in his absence, the deputy governor, of the said company for the time being, and such of the assistants and freemen of the said company as shall be present, or the greater number of them so assembled, whereof the governor or deputy governor and six of the assistants, at the least to be seven, shall have full power and authority to choose, nominate, and appoint such and so many others as they shall think fit, and that shall be willing to accept the same, to be free of the said company and body, and them into the same to admit, and to elect and constitute such officers as they shall think fit and requisite for the ordering, managing, and dispatching of the affairs of the said governor and company and their successors. And to make laws and ordinances for the good and welfare of the said company, and for the government and ordering of the said land and plantation, and the people inhabiting and to inhabit the same, as to them from time to time shall be thought meet."

Thus it would appear that the governor or deputy and six of the assistants were fully authorized and empowered under the charter to elect freemen and to make laws, order as to the land, and govern the people. That there was no law against the participation of all the freemen in legislative action, nor on the other hand was there any law requiring them to participate, or rendering the laws or ordinances invalid if they were not present by themselves or their representatives, appears clear. There seems to have been in the case considered the required number of seven, therefore their action was valid. As to its expediency, there may have been, and may still be, reasonable doubt, but we can discover none as to the validity of the action of the assistants in assessing the tax. 
which have a special interest in the daily life of Dudley on and after 1632-33. It is still extant, and begins with "An agreement made by general consent, for a monthly meeting. Imprimis, That every person undersubscribed shall [meet] every first Monday in every month, within [the] meeting house, in the afternoon, within half [an hour] after the ringing of the bell $;^{1}$ and that every [one] that makes not his personal appearance there [and] continues there, without leave from the [ ] until the meeting be ended, shall forfeit [for each] default xii. pence : and if it be not paid [before the next] meeting, then to double it, and so until [it be paid]." The historian of Cambridge says that "although a general subscription seems to have been contemplated, only two signatures are appended, namely, Thomas Dudley and John Haynes; and Mr. Haynes must have subscribed his name several months after the order was adopted, as he did not arrive until Sept. 3, I633. At the first meeting holden in pursuance of this 'agreement,' several municipal arrangements were made to secure the beauty and safety of the town, to wit : Jan. 7, $1632-3$. 'It is ordered, that no person whatever [shall set] up any house in the bounds of this town [without] leave from the major part. Further, it is agreed, by a joint consent, [that the] town shall not be enlarged until all [the vacant] places be filled with houses. Further, it is agreed, that all the houses [within] the bounds of the town shall be covered [with] slate or board, and not with thatch.' "

It must assist us very much in discovering how fully the influence of Governor Dudley entered into the plans and government of Cambridge at its very beginning, if we note his words in his letter to the Countess of Lincoln, March 28, I63I, on this subject: "For the prevention whereof in our new town, intended this summer to be builded, we have ordered that no man there shall build his chimney with wood, nor cover his house with thatch." 2 . . . "Further it is

1 Page 123 of this volume.

2 Young's Chron., 339; Paige's Hist. Camb., I\%, I 4. 
ordered that all [the houses shall] range even, and stand just six [feet on each man's] own ground from the street." Dudley is the only one who had subscribed at the date of the several orders herein mentioned. This provision about setting houses back from the street, although not far, is an evidence of his and their taste and regard to picturesque effects, in the early beginning, in the laying out of that little town, which was destined to become a renowned and beautiful city. The town was constructed from the first with a view to elegance, the streets being arranged in nearly parallel lines, the houses regularly placed, the whole symmetrical and compact, suitable for the future seat of government. It was bounded "northerly by Harvard Street and Square, westerly by Brattle Square and Eliot Street, southerly by Eliot and South streets, and easterly by Holyoke Street, which was then very crooked." 1

William Wood, who was in the colony the first year, in his "New England's Prospect," says : "This place was first intended for a city; but upon more serious considerations it was not thought so fit: being too far from the sea being the greatest inconvenience it hath. This is one of the neatest and best compacted towns in New England, having many fair structures, with many handsome contrived streets. The inhabitants, most of them, are very rich, and well stored with cattle of all sorts, having many hundred acres of ground paled in with one general fence, which is about a mile and a half long, which secures all their weaker cattle from the wild beasts." 2

It is probable that while Wood presents in the above extract Governor Winthrop's reason for his preference for Boston, so Johnson, in his "Wonder-Working Providence," sets forth Governor Dudley's opposite choice as follows : "Wherefore they rather made choice to enter farther among the Indians, than hazard the fury of malignant adversaries, who in a rage might pursue them, and therefore chose a

1 Paige's Hist. Camb., I8, note I.

2 Young's Chron., 402. 
place situated on Charles River, between Chiarles Town and Watertown, where they erected a town called New Town, now named Cambridge. ... It hath well ordered streets comely completed with the fair building of Harvard College, their first pastor was the faithful and laborious Mr. Hooker, whose books are of great request among the faithful people of Christ." 1

This was probably one of Dudley's reasons, as we have before mentioned, for the earnest effort which he made to establish the capital at Cambridge. There are very few capital cities in the world which are not situated on rivers or bays less exposed from the sea than Boston; the anxiety of Dudley in this instance is therefore no matter of surprise.

The New England town and town meeting have for many years justly received a great amount of careful consideration from students of American history. The town has been sometimes designated as the unit in our system of government. Any description of Cambridge which overlooked the political organization of the town would therefore be very incomplete.

Power was early in 1634 delegated to a few persons, first styled "townsmen," later "selectmen," to transact "the whole business of the town." February 3, 1634-35, "At a general meeting of the whole town, it was agreed upon by a joint consent, that seven men should be chosen to do the whole business of the town, and so to continue until the first Monday in November next, and until new be chosen in their room: so there was then elected and chosen John Haynes, Esq., Mr. Symon Bradstreet," and five other persons. Dudley is not on this list because of more exalted public duties. $\mathrm{He}$ was a few days later elected governor of the colony. There is little reason to doubt that he had an important share in the doings of the meeting. At this meeting, "It is further ordered, by a joint consent, [that] whatsoever these townsmen, thus chosen, shall do, in the compass of their time, shall stand in as full force as if the whole town

1 Wonder-Working Providence, chap. xxviii. 6I, Pool's ed. 
did the same, either for making of new orders, or altering of old ones." 1

The Court in June, 1632 , ordered "that there shall be two hundred acres of land set out by marks and bounds, on the west side of Charles River, over against the New Town, to enjoy to Thomas Dudley Esq., deputy governor, to him and his heirs forever." 2 This land was mostly included within a great bend of the Charles River, directly south of the headquarters of General Washington on Brattle Street, afterwards from I 837 to I 882 the home of the poet Longfellow, who has hallowed this turn in the river.

Dudley was again chosen to the place of deputy governor, May 9, I632, which shows that although he had aroused the solicitude of Watertown and of the rest of the colony by impaling Cambridge at the public cost, he was nevertheless popular, and had public confidence. We do not overlook the oft-asserted opinion of persons who seem to think that the magistrates combined to retain the offices in their immediate possession, and that sometimes it was fortune, more than merit or popularity, which secured the leading positions to these men. But if the favor of Dudley with the people at this period is questioned without reason, very soon after this time it was clearly in the ascendant, and he was in the full tide of public regard.

1 Paige's Hist. Camb., 21.

2 Mass. Col. Rec., i. 96. 


\section{CHAPTER XIII}

THE Rev. Mr. Wilson, minister of Boston, made a visit to England in the spring of $163 \mathrm{I}$, and in that connection we make the following quotation from Winthrop, i. * 50 , viz. : "About ten of the clock Mr. Coddington and Mr. Wilson, and divers of the congregation, met at the governor's, and there Mr. Wilson, praying and exhorting the congregation to love, etc., commended to them the exercise of prophecy in his absence, and designed those whom he thought most fit for it, viz., the Governor Winthrop, Mr. Dudley and Mr. Nowell the elder." It is evidently the opinion of Mr. Paige that there were no meetings "held in Cambridge for religious worship" before August 14, 1632. We may understand him to mean that there was no regularly established church service. We may easily suppose, with no other authority for it than this quotation from Winthrop, that Dudley, and possibly all of the settlers of Cambridge, attended service at the First Church in Boston during their first year of residence at New Town. The chief importance of this passage is its high testimony to the exemplary and religious character of Dudley. He certainly could not have been one of the three most fit to preach in Boston unless either he was a very good man, or the average moral and religious condition of the inhabitants was of so low a grade that good men were wanting, which we are not prepared to believe. Because if Winthrop was in fact the only really good man in Boston at that time, since Wilson ruled in three as the best, and Savage has excluded two of these, which leaves Winthrop alone, then there truly was a nearer resemblance between Boston and Sodom, which had not ten righteous men, than has been heretofore suspected. We can, with great consideration for Mr. James 
Savage, be convinced that he truly thought that the "instructions of Dudley and Nowell were probably rendered less serviceable by their severe tempers than the mild wisdom of Winthrop." Who has given evidence of the ungoverned rage of Dudley except Winthrop himself, and in matters where he himself was a party and a rival ?

Yet, strange to say, Savage coldly depreciated Dudley. We should expect Savage to be partial to Winthrop; we should expect him to proclaim that, "Where MacGregor sits, there is the head of the table." But prejudice we should not look for in him, and do not care to assume it. Bolingbroke once said of prejudice, "Some must labor on in a maze of error because they have wandered there too long to find their way out."

The character which Savage has attributed to Dudley we have clearly shown in foregoing pages is utterly inconsistent with his record. He was a man of warm heart and affections, tender towards his children, and the poor and suffering. When he had judgment against Governor Winthrop in court, and might have enforced it against him, he would not do it, and freely gave to him the amount. Did that seem penurious in him? When Governor Winthrop adroitly presented him with hogs to win his friendship, he tenderly responded to the act of friendship, but paid for the hogs. Did that seem to be penurious? If he had been a selfish, sordid man, he never would have crossed the ocean, and devoted the remnant of life to Massachusetts.

If it should appear that he spoke courageously and directly what he thought, in the cause in hearing, we ought to honor him for his honesty. We admire transparent character, uprightness, and courage of convictions, in official station and in private life. Heartless courtesy, the robes pretense is wearing, and all the panoply of false life and falsehood are alike hateful to honest men.

Roger Williams, the founder of Rhode Island, arrived in Boston, February 5, I63I, and Winthrop says, "At a Court holden at Boston (upon information to the governor that 
they of Salem had called Mr. Williams to the office of teacher) a letter was written from the Court to Mr. Endicott to this effect: 'That whereas Mr. Williams had refused to join with the congregation at Boston, because they would not make a public declaration of their repentance for having communion with the Church of England, while they lived there; and besides had declared his opinion, that the magistrate might not punish the breach of the Sabbath, nor any other offense, as it was a breach of the first table; therefore they marveled they would choose him without advising with the Council ; and withal desiring him, that they would forbear to proceed till they had conferred about it.' " Men who all their lives had fellowshiped with excellent religious people of the same tenets and creed as their own, who had not repented of that earlier connection, were unworthy of him, and repudiated by him. It was not enough that they had placed the ocean between them and their former associates, or even that possibly in some instances they silently regarded it a misfortune ever to have known their church brethren in Europe, but he required a public avowal of repentance for their innocent and no doubt very useful church connection. This was a test of soul-liberty, not by the magistrate, but by the priest, who is quite as dangerous to it. The next teaching by this remarkable man is also a little strange, viz. : "That the breach of the first table of the Law the magistrate might not punish."

The first table of the Law is as follows :-

"r. Thou shalt have no other God before me.

"2. Thou shalt not make to thee any graven image.

"3. Thou shalt not take the name of Jehovah thy God in vain.

"4. Thou shalt remember the Sabbath day, to keep it holy.

"5. Thou shalt honor thy father and thy mother." 1

The first four precepts forbid idolatry or atheism, perjury, blasphemy, and Sabbath-breaking.

And we are now so averse to this sort of liberty, and to this indifference to religious precepts, that there are well

\section{Exodus xx.}


recognized statutes in force for the punishment of most of these offenses on our books to-day. So Williams was not only in advance of the Puritans, but away ahead of, or behind this generation also. We cannot ourselves complain of the Puritans.

Massachusetts has a statute against perjury, and so has Rhode Island. Massachusetts has a statute against blasphemy, and so has Rhode Island. Massachusetts has a statute against Sabbath-breaking, and so has Rhode Island. Blasphemy is indictable at common law. ${ }^{1}$ The same author says in effect that there is reason to believe that Sabbathbreaking is a common law offense. ${ }^{2}$ But he says further that "the Lord's Day is so fully enforced by statutes, both here and in England, that it is of little importance to inquire about indictments at common law." The consensus of opinion, with two and one half centuries added, is against Williams. ${ }^{3}$

It will always be a matter of curious conjecture what he would have done if he had possessed a powerful civil government, and found himself overwhelmed with what he deemed idolatrous Catholics. He never had the temptation and power, and it is of little value to attempt to guess as to what he would have done; this is rendered of less interest because he was quite certain to do the erratic and unexpected thing. ${ }^{4}$

He seems sometimes to enjoy a vision of a good strong government. Thus he holds out to his "Impartial Reader," whom he takes into his own sacred companionship, heir to the same great privileges as himself, as follows: "Yet shalt thou see Him, reign with Him, eternally admire Him, and enjoy Him, when He shortly comes in flaming fire to burn up millions of ignorant and disobedient." 5

1 Bishop's Crim. Law, ii. § 74 .

2 Ib., i. \$ 499, and note.

B The exception of such "cases as did disturb the public peace," Winthrop, i. *162, was unimportant, as idolatry, perjury, blasphemy, and Sabbath-breaking are all against the public peace.

4 Staples's Annals of Providence, 45.

5 Pub. Narr. Club, i. 318. 
His contemplated joy, when the Lord shall burn up millions of ignorant people, is an indication that he had as little sympathy with suffering humanity as the most stubborn Puritan in the colony. It would not have been safe to give to him extensive power over his fellow-creatures. This may be the reason why the people trusted him so little with authority in his own colony of Rhode Island, for he was governor for only a very brief period, and even this was due no doubt to his successful labors, through his friend Harry Vane, in securing the charter of that colony.

His "violent and tumultuous carriage against the charter of Massachusetts," which was for half a century their constitution, the very bulwark and safeguard of their liberties, was startling.

I have here called attention to Roger Williams in Massachusetts, because Dudley was somewhat active in his banishment to England, for which Williams himself adroitly substituted Rhode Island; and the important question to be considered hereafter in this connection is whether Dudley manifested that kindness, forbearance, and Christian courtesy towards Williams which his own profession of religion and his official position demanded of him, or whether Williams, by his conduct, forfeited his right to sojourn in Massachusetts, and rendered himself not only an unworthy but dangerous inhabitant, to such an extent that Dudley and his associates were fully justified in sending him out of their jurisdiction. We shall at the proper time and place address a few words to this issue. ${ }^{1}$

1 The contrasts, changes, and reversals in circumstances and history would have a comical side to them, if it were not for their intense seriousness in the career of the actors themselves; for example: Rhode Island, on September 9, I897, permitted the mayor and police of Providence to banish to Massachusetts, or elsewhere, Emma Goldman, an anarchistic declaimer, who sought to relieve her burdened mind of doctrines believed by the authorities to be destructive of existing law and order. The teachings of Roger Williams were believed by the ancient authorities in Massachusetts to be subversive of law and order. We approve heartily of the action of the mayor. 
The following orders of the General Court are interesting : The Court, in June, I63I, established the rule that no person shall travel out of the patent without leave from the governor, deputy governor, or some assistant, so that they were equally prepared to retain and adhere to persons, or reject them, according as they approved of them or otherwise, which was a privilege of no little importance at the planting of a colony. The sifting of the population at that period, the exclusion of tares, and retaining of the pure wheat were alike important so long as the manner of doing it was legitimate and just.

On June I4, I63I, the Court ordered "that Philip Ratcliffe shall be whipped, have his ears cut off, be fined forty pounds, and banished out of the limits of this jurisdiction, for uttering malicious and scandalous speeches against the government and the church of Salem, \&c., as appeareth by a particular thereof proved upon oath." 1

This punishment seems to us, in the light of our methods and ideas, both very cruel and vindictive. We at once see, however, that it is needful to consider public sentiment at that period, and the criminal and social conditions which of necessity influenced their action. ${ }^{2}$

It is claimed that the common law of England never recog-

1 Mass. Col. Rec., i. 88.

${ }^{2}$ It aids us in a charitable opinion of the punishments inflicted by these people, if we note how nearly barbarous punishments have descended to our own period in history; neither ought we to overlook the cruelty inflicted in modern warfare, which is only a means of dealing out punishment to selfish, unyielding, and unreasonable nations. The pillory was abolished by 7 William IV. and I Vict., c. 23; the stocks and the burning in the hand for felony; by 19 George III., c. 74. See Torture, Encyc. Britannica, 9th ed., 495. There are two quite recent cases in which the United States court has decided that whipping as a punishment for crime is not an unusual or cruel punishment under the Constitution of the United States. (Desty's Fed. Const. Dig., 325.) It was only one or two years after the Court of Massachusetts had inflicted their cruel edict upon the ears of Ratcliffe that William Prynne lost both of his ears by a decree of a British court, on account of publishing his book, Histrio-Mastix, against plays. 
nized torture as legal. The peine forte et dure was not, however, far removed, which was inflicted on Giles Corey in Salem, Mass., in 1692. And there was a case in England in 1726.1

Old Testament punishments are set forth in the Encyc. Bib. Lit., viii. Freeman says in his history of the Norman Conquest of England, vi. 106: "In fact, in an age which had few jails and no penal colonies, it may well have seemed that the best way to deal with a sinner who was not to be put to death was to make him personally incapable of sinning again."

It is important, in this comparison of public sentiment at two periods, to note as illustrative of the feeling at that time that even Bacon, who was only fifteen years older than Thomas Dudley, and died only four years before the great emigration to America, "compares experiment in nature to torture in civil matters as the best means of eliciting truth."

We have given more attention to this matter, because there are several instances of punishment in the Massachusetts record which cannot fail to shock every one in this era, and to seem cruel and unjustifiable. But we have no right to take people out of their age and environment and hold them accountable to the ideals and sentiments of subsequent times. They may always be pointed to for comparison and instruction, but with the attendant thought that they came earlier, and saw "through a glass darkly," and that we should be charitable to them and consider their day and generation, as we hope for consideration on our own doings at the hands of later and yet more enlightened ages.

Dudley gives an account in his letter to the Countess of Lincoln of Sir Christopher Gardiner, which has considerable importance, since Gardiner soon appeared in England as an enemy to the colony. Dudley writes as follows, viz. : "Likewise we were lately informed that one Mr. Gardiner, who arrived here a month before us, and who had passed here for a knight, by the name of Sir Christopher Gardiner, all this

1 Encyc. Britannica; xxiii. 466. 
while was no knight, but instead thereof had two wives now living in a house at London, ${ }^{1}$ one of which came out September last from Paris in France (where her husband had left her years before) to London, where she had heard her husband had married a second wife, and whom, by inquiring, she found out. And they both condoling each other's estate, wrote both their letters to the governor, (by Mr. Peirce, who had conference with both the women in the presence of $\mathrm{Mr}$. Allerton, of Plymouth,) his first wife desiring his return and conversion, his second his destruction for his foul abuse, and for robbing her of her estate, of a part whereof she sent an inventory hither, comprising therein many rich jewels, much plate, and costly linen. This man had in his family (and yet hath) a gentlewoman, whom he called his kinswoman, and whom one of his wives in her letter names Mary Grove, affirming her to be a known harlot, whose sending back into Old England she also desired, together with her husband. Shortly after this intelligence we went to the house of said Gardiner (which was seven miles from us), to apprehend him and his woman, with a purpose to send them both to London, to his wives there. But the man, who having heard some rumor from some who came in the ship, that letters were come to the governor requiring justice against him, was readily prepared for flight, so soon as he should see any crossing the river or likely to apprehend him, which he accordingly performed. For he dwelling alone, easily discerned such who were sent to take him, half a mile before they approached his house; and, with his piece on his neck, went his way, as most men think, northwards, hoping to find some English there like to himself. But likely enough it is, which way soever he went, he will lose himself in the woods, and be stopped with some rivers in his passing, notwithstanding his compass in his pocket, and so with hunger and cold

1 A writer in the March number of Harper's Monthly, I883, has discovered a non sequitur here, and evidently does not think that a knighthood is an equivalent to two wives in London; he is correct beyond a doubt. 
will perish before we find the place he seeks. His woman was brought unto us, and confessed her name, and that her mother dwells eight miles from Boirdly, in Salopshire, and that Gardiner's father dwells in or near Gloucester, and was (as she said) brother to Stephen Gardiner, Bishop of Winchester, and did disinherit his son for his twenty-six years' absence in his travels in France, Italy, Germany, and Turkey; that he had (as he told her) married a wife in his travels, from whom he was divorced, and the woman long since dead; that both herself and Gardiner were Catholics till of late, but were now Protestants; that she takes him to be a knight, but never heard when he was knighted. The woman was impenitent and close, confessing no more than was wrested from her by her own contradictions. So we have taken order to send her to the two wives in Old England, to search her further." 1

Young says, "There seems to be a mystery hanging over Gardiner as well as Morton of Merry Mount which it is difficult to clear up. They appear to have had no definite object in view in coming to New England, but seem actuated by a spirit of adventure and an unaccountable love of frolic. Morton says that Gardiner 'came into those parts, intending discovery.' It is not unlikely, however, that they were both in the employment of Sir Ferdinando Gorges, who claimed a great part of the Bay of Massachusetts, and had been sent over as his agents or spies. We know that Gorges corresponded with them both, and by his intercepted letters it appears that he had some secret design to recover his pretended right, and that he reposed much trust in Gardiner. On his return to England, Gardiner was very active in coöperating with Gorges and Morton in their endeavors to injure the colonists, and deprive them of their patent. These attempts, however, were defeated by the friends of the colony in England."

This man interests us chiefly from the fact that he was conspicuous in an attempt to destroy the charter and over-

1 Young's Chron., 334, 335. 
throw the colony in 1632, although he declared himself very grateful for the "great courtesy" which he had received in Massachusetts in his late visit. There seems to be no reasonable doubt that the Puritans were fully justified in sending him away, either as a spy, or as a man immoral and unworthy. Either reason was a sufficient cause for retiring him. There has been some attempt among certain historians and essayists to trifle with Dudley's sincere words in giving a description of these people, and an undue sympathy for the malefactors themselves may be discovered between the lines of these writers. This spirit is abroad in the world everywhere. The worst felons always find some one to send flowers and messages of condolence to their cells. It is creditable to our humanity, doubtless, that no souls are ever lost in historic annals so utterly as not to find in after ages persons to admire them. The unvarnished account in Dudley's letter of Gardiner and of Mary Grove, derived from investigations both in Europe and America under the direction of the government of Massachusetts, continues to be the most authentic and trustworthy information extant concerning these miserable people. 


\section{CHAPTER XIV}

THIS mysterious man, Gardiner, proved himself able to do the colony considerable injury, as we have noticed, upon his return to England. The records of the Privy Council show that on the I9th of December, I632, several petitions were "offered by some planters of New England, and a written declaration by Sir Christopher Gardiner, Knt., when upon long debate of the whole carriage of the plantations of that country" the matter "was referred to a committee of twelve Lords," to examine how the patents of the said plantations have been granted, and how carried." Winthrop relates that "We had intelligence from our friends in England, that Sir Ferdinando Gorges and Capt. Mason (upon the instigation of Sir Christopher Gardiner, and Morton, and Radcliff) had preferred a petition to the lords of the Privy Council against us, charging us with many false accusations; but through the Lord's good providence, and the care of our friends in England ... their malicious practice took not effect." The delicate situation, and the peril attaching to the colony from the violent words of such outspoken separatists as Roger Williams, is evident in the following words of Winthrop: "The principal matter they had against us, the letters of some indiscreet persons among us who had written against the church government in England," etc. ${ }^{1}$

The order of the Privy Council, adopted January 19, I633, contained, however, the following, among other favorable allusions to the government of Massachusetts, viz.: that their Lordships "have thought fit, in the mean time, to declare that the appearances were so fair, and the hopes so great, that the country would prove both beneficial to this 
kingdom and profitable to the particular adventurers, as that the adventurers had good cause to go on cheerfully with their undertakings, and rest assured, that if things were carried as was pretended when the patents were granted, and accordingly as by the patents is appointed, his Majesty would not only maintain the liberties and privileges heretofore granted, but supply anything further that might tend to the good government of the place and prosperity and comfort of his people there." 1

This investigation, no doubt, had a powerful tendency to strengthen and establish more firmly the government in America. "The whole carriage of the plantation" had been under the fierce examination of the British government, instigated and stimulated by the bitterest enemies of the colony at home and abroad, who each had a several grievance to present to, and to be heard by the Council. "The whole carriage" must of necessity have included the much mooted question of the transfer of the charter to America, if any one then had a doubt about the propriety of that action, which is not probable. It was left mostly for debating societies of a later period to exercise their wits upon this question, when time, the great corrective in human affairs, had healed all the defects, and the government, with a new and independent life, had gone far on the way of its magnificent destiny. Every favorable decision of an important court strengthens and confirms a patent to-day, and the same no doubt was true then of patents.

The colonists were so solicitous about the charges against them before the Privy Council, that they "sent an answer to the petition of Sir Christopher Gardiner, and withal a certificate from the old planters ${ }^{2}$ concerning the carriage of affairs," etc. ${ }^{3}$ Winthrop, on the next page of his Journal,

1 Orders in Council, January 19, 1632-33, and Memorial Hist. of Boston, i. 337 .

${ }^{2}$ Savage thinks we may conjecture the names to be Blaxton, Jeffries, Maverick, Thomson, and perhaps Bursley, Conant, and Oldham.

${ }^{3}$ Winthrop, i. 106. 
has given an account of the objections of Dudley to the answer to the above petition of Gardiner, which have been freely used to depreciate and discredit Dudley, and we think it a duty carefully to examine, and if possible to discover, the real reasons for Dudley's course in this matter. The statement is as follows, viz.: "There is mention made before of the answer, which was returned to Sir Christopher Gardiner his accusations, to which the governor and all the assistants subscribed, only the deputy [Dudley] refused. He made three exceptions: I. For that we term the bishops reverend bishops; which was only in repeating the accuser's words. 2. For that we professed to believe all the articles of the Christian faith, according to the Scriptures and the common received tenets of the churches of England. This he refused, because we differed from them in matter of discipline, and about the meaning of Christ's descension into hell; yet the faithful in England (whom we account the churches) expound it as we do, and not of a fatal descent, as some of the bishops do. 3. For that we gave the king the title of sacred majesty, which is the most proper title of princes, being the Lord's anointed, and the word a mere civil word, never applied in Scripture to any Divine thing, but sanctus used always. ${ }^{1}$ Yet by no reasons could he be drawn to yield to these things, although they were allowed by divers of the ministers and the chief of Plymouth."

This account has drawn out very strikingly the pity and commiseration of Mr. J. A. Doyle ${ }^{2}$ for Winthrop, who was compromised by such "bigoted" men with such "impenetrable minds" as Dudley possessed. He seems to think that Dudley was the most benighted Puritan on record among the prominent settlers of Massachusetts.

It does not appear that any one in this period of history is qualified to judge respecting this action of Dudley in declining to subscribe to the answer, because no one has seen the document or knows its substance even. Dudley was as well

1 Mr. Knox called the queen of Scotland by the same title.

2 J. A. Doyle's English in America, i. 159. 
qualified as any man in the government to measure the force of apt words, and to determine whether it was consistent with his views and convictions that he should subscribe. He determined that he ought not to do it, and we are bound to respect his judgment and his opinions. As to the first objection of Dudley, "For that we term the bishops reverend bishops : which was only in repeating the accuser's words." Winthrop, and Doyle following in his train, undertake to inform us that the repeating of "the accuser's words" was harmless, because they were his sentiments, and not of necessity those of the subscriber. But Dudley, against the magistrates and the wisdom of Plymouth, thought otherwise, and was justified in acting on his opinion, which from his education was as likely to be correct as that of the majority.

There is a certain dignity and nobility of position in the attitude taken by Dudley in this case. He was the last man to crouch and cringe and call a bishop reverend, that is to say, "entitled to respect mingled with fear and affection," when he knew how wicked, cruel, and merciless they as a class had been towards the Puritans; that they "had introduced to the Parliament a bill making it felony to maintain any opinion against the ecclesiastical government; and had succeeded in carrying it through the upper house." There is a long list of their doings which made them very abhorrent to New England Puritans, and Thomas Dudley could no more apply adjectives of reverence or endearment to them, than a Jew could offer such epithets to a Samaritan or a Philistine. If the words to which he was asked to subscribe did not carry that meaning in fact, he felt that they compromised his profession and testimony, and that they would be construed to mean that in effect, and therefore he would avoid the "very appearance of evil." We know that he was deeply anxious to have Gardiner and his associates answered, and that if he could have seen his way clear, he would have instantly joined his name to the answer. That he hesitated shows that we do not know the purport in full of that docu- 
ment nor his reasons for declining to sign it; we can trust his judgment safely in that sort of a thing.

The next thing that staggers him is, according to Winthrop, "that we profess to believe all the articles of the Christian faith, according to the Scriptures and the common received tenets of the churches of England." This, Winthrop says, Dudley refused on the ground that "we differ from them in matter of discipline." He was correct; they differed as far as Congregationalists and Episcopalians are separated in church discipline to-day. Had they not at Charlestown, on that 3oth day of July, I630, under the "Great Tree," or in the "Great House," put their names to the church covenant which separated them from the mother church? Was not this the fundamental beginning of that church institution which, alienated from the Church of England, has extended everywhere? Was not this organization of the First Church the model for all the others across the continent?

And to quote more, "about the meaning of Christ's descent into hell." Perhaps the best method to apply to the consideration of this question is to refer to the examination of the Puritan, the Rev. Thomas Settle, minister of BQxford in Suffolk, before Archbishop Whitgift and his colleagues in commission. "The charge was that Settle denied that the soul of the Saviour went to the regions of the damned." $\mathrm{He}$ answered, "I confess it to be my opinion, that Christ did not descend locally into hell, and in this opinion I am supported by Calvin, Beza, and other learned men." 1 It was said as recently as in 1859, that the doctrine of the "Protestant Episcopal Church, as given in the Liturgy and Homilies, can only be reconciled with that of the creed and Articles by a liberal construction of the creed. And this has been done by the American church herself in the rubric prefixed to the creed, in which she substitutes the words, 'He went into the place of departed spirits,' as of equivalent import.

1 Hopkins's Puritan, 34, and note. 
The terms in which this substitute is couched are quite general and indefinite." 1

And now comes the political issue in which Dudley, whom Winthrop on another occasion had declared to be wise, just, and brave, evidently is in advance of them all. "For that we gave the king the title of sacred majesty, which is the most proper title of princes, being the Lord's anointed." The Puritans gave their judgment respecting the "divinity" which "doth hedge a king" when, in 1649, they beheaded Charles I. America, receiving its impulse from the Puritans, repudiates all fictions and superstitions respecting heavenly anointed kings, and declares that government is of the people, by the people, and for the people. "The Americans equally detest the pageantry of a king and the supercilious hypocrisy of a bishop." 2 "It [Calvinism] established a religion without a prelate, a government without a king." 3 "There was a state without king or nobles; there was a church without a bishop; there was a people governed by grave magistrates which it had selected, and by equal laws which it had framed." 4 It might be made to appear to minds not "impenetrable" that Dudley was the most liberal and progressive man in that great and famous group; that he was nearest to the stature of the true and typical American. He would not bow the knee to Baal. Possibly he was the noblest Roman of them all. He has been called bigoted in this matter. The first meaning of bigot is hypocrite, but he was not that ; it is the other people who are subscribing to what they do not believe for the noble purpose of being polite. Society is replete with persons of a craven spirit who will deny their principles, to be agreeable. "It is an amiable weakness." Thomas Dudley , "was made of sterner stuff." As to the other definition of

1 McClintock and Strong's Cyc. of Bib. Theolog. and Eccl. Lit., iv. 172.

2 Junius, Letter XXXV., Dec. 19, 1739.

3 George Bancroft.

4 Rufus Choate, Dec. 22, I843. 
bigotry, he may be said to be equally clear. $\mathrm{He}$ has been charged with intolerance; that we must consider later. We then hope to show that he contended with, and refused to tolerate, only religious teachings which were subversive of their social, political, and religious undertaking, teachings which an organized government and established institutions, with seventy-five millions of inhabitants, may easily and safely leave to be absorbed, or run their harmless course. The early tender plant of government could not endure, but must at first be protected from the fury of fanatics. How important it was to mankind that the Puritan commonwealth should have been what it was, let history relate, and on its testimony we will rest secure.

The authors who have so easily detected the narrowness of Dudley in comparison with Winthrop have, if we may be permitted to anticipate, failed to note the liberality and enlightenment manifested by Dudley in the instance of the setting up of the king's colors, early in the administration of Harry Vane. We will let Winthrop tell it : "We replied, that for our part we were fully persuaded, that the cross in the ensign was idolatrous, and therefore might not set it in our ensign; but because the fort was the king's, and maintained in his name, we thought that his own colors might be suspended there. So the governor [Vane] accepted the colors of Captain Palmer, and promised they should be set up at Castle Island. We conferred over night with Mr. Cotton, etc., about the point. The governor [Vane], and Mr. Dudley, and Mr. Cotton were of opinion that they might be set up at the fort upon this distinction, that it was maintained in the king's name. Others [including himself], not being so persuaded, answered, that the governor and Mr. Dudley, being two of the council, and being persuaded of the lawfulness, etc., might use their power to set them up. Some others, being not so persuaded, could not join in the act, yet would not oppose, as being doubtful," etc. ${ }^{1}$ "The colors were given us by Captain Palmer, and the gov-

1 Winthrop, i. 188. 
ernor [Mr. Vane] in requital sent him three beaver skins. But the deputy [Winthrop] allowed not of this distinction." 1

We find the following just and very satisfactory comments upon this dispute in vol. iv. of Sparks's "American Biography," page I 16: "So far as the character of the conflicting parties is to be inferred from the transaction just related, it is impossible not to recognize a more liberal and enlightened spirit in Vane and Dudley than was manifested by the other members of the Court." And here the author is caught by the cherished ideal of Winthrop, viz. : that he, like the king, can do no wrong, and so he invents a theory for his seeming error, which, if it expresses the facts, derogates much more from the character of Winthrop than the first simple unexplained action. It is, in effect, a charge that he was capable of mean jealousy and treachery against the government, and bad faith towards his associates. To vindicate his intelligence, it robs his heart and moral reputation. Away with such excuse. We proceed to quote: "Thè jealousy which had for some time actuated the leading men towards Vane, [observe that this does not include Dudley among the 'leading men,'] and their hostility to his principles, gave a prevailing direction to their course on this occasion, which cannot otherwise be explained. Nothing but the disturbing influence of sentiments of this sort could have induced such a man as Winthrop to oppose the governor, on the strength of a scruple so far-fetched and excessive, as that which led him to join with others in refusing to recognize the king's authority in his own dominions, on his own fort, by an innocent ceremony, which was requested for the avowed purpose of preserving peace and harmony, and preventing a misunderstanding between the colony and the people of England, under circumstances that would certainly have been highly injurious, and might have become utterly ruinous to the former."

It is more probable that the popular current was setting strongly against the existence of the cross in the ensign and 1 Winthrop, ii. 344 . 
against Governor Vane, and that Winthrop clearly saw that it was the beginning of the downfall of Vane in the colony, and he was too discerning a politician to drift on to rocks and reefs exposed to his view at every change of the popular tide. Winthrop, like Abraham Lincoln, waited for the opinions of the people. The Emancipation Proclamation came forth when the people were convinced of its expediency and necessity. So Winthrop always, with one hand on the public pulse, was forecasting the future. $\mathrm{He}$ was Vane's successor in office. He could risk misunderstandings with England three thousand miles away, which could be easily condoned by many plausible explanations, in investigations long subsequent to the unfortunate event in question. And he was not the man to attach himself to a falling star, and be dragged down and out of public attention.

Endicott had, two years before, cut the cross out of the ensign, as an emblem of Popery, and the General Court had for this rashness, uncharitableness, and indiscretion, and for exceeding the limits of his calling on the part of Endicott, censured him to be sadly admonished of his offense, and, what was doubtless far more unbearable, disenabled him from holding office in the commonwealth for and during one entire year. The question has been raised, to what degree the sensitive conscience of Williams was affected by the cross on the king's coin in his own pocket ? ${ }^{1}$

These events disclose the royal and sterling independence of Dudley, standing side by side with Harry Vane, the great martyr of liberty.

${ }^{-1}$ Mass. Col. Rec., i. 146; Palfrey's Hist. New Eng., 427. This was suggested by the theory which once prevailed, that Williams was the instigator of this action of Endicott, which is not proven. 


\section{CHAPTER XV}

THE acts of the Courts from time to time furnish a lively account of the doings and opinions of these people, and give a striking illustration of the dominant public opinion and social life of the period.

"It is ordered, that Thomas Dexter shall be set in the bilboes, disfranchised and fined 40 s. for speaking reproachful and seditious words against the government here established, and finding fault to divers with the acts of the Court, saying, this captious government will bring all to naught, adding that the best of them was but an attorney," etc. ${ }^{1}$

Free speech and the sacred privilege of fault-finding were restrained until the infant colony had strength and independence enough to be beyond their influence. Such a rule now, well enforced, would nearly or quite deprive orators and the public press of their lucrative occupations.

The relative importance of the six towns in 1632 appears in the rate of taxation. Boston is assessed $£ 5$, Charlestown $£ 4$, Roxbury £6, Watertown $£ 6$, New Town $£ 6$, Medford $£ 3$, for the maintenance of Captain Underhill and Captain Patrick for half a year; they were then the military commanders of the colony. "The price of corn, formerly restrained to six shillings the bushel, is now set at liberty to be sold as men can agree." The price for breach of promise to marry was more moderate then than now. "It is ordered, that Joyce Bradwick shall give unto Alexander Beck the sum of twelve shillings for promising him marriage without her friends' consent, and now refusing to perform the same." ... " John Winthrop was chosen governor, and Thomas Dudley, deputy governor, at a General Court held at

1 Mass. Col. Rec., i. Io3. 
Boston, May 29, 1633, manifested by a general erection of hands." 1

The prohibitory law was introduced early. "It is ordered, that no person shall sell either wine or strong water without leave of the governor, or deputy governor. This order to take place a fortnight hence, and after the constable of the same plantation hath published the same, and that no man shall sell, or (being in a course of trading) give any strong water to any Indian." 2

They had something which seems like involuntary bankruptcy, for, "It is ordered that the goods of Thomas Walford shall be sequestered and remain in the hands of Anchient Gennison, to satisfy the debts he owes in the Bay to several persons." 3

The proclamation for a general thanksgiving, issued at a Court holden at Boston, October I, I633, is pathetic: "In regard of the many and extraordinary mercies which the Lord hath been pleased to vouchsafe of late to this plantation, viz., a plentiful harvest, ships safely arrived with persons of 'special use and quality, etc., it is ordered, that Wednesday, the I 6 th day of this present month, shall be kept as a day of public thanksgiving through the several plantations. And whereas it is found by common experience that the keeping of lectures at the ordinary hours now observed in the forenoon to be divers ways prejudicial to the common good, both in the loss of a whole day and bringing other charges and troubles to the place where the lecture is kept, it is therefore ordered, that hereafter no lecture shall begin before one o'clock in the afternoon." 4

"It is ordered, that there shall be $£ 400$ collected out of the several plantations to defray public charges, viz. - Boston $£ 48$, Roxbury $£ 48$, New Town $£ 48$, Watertown $£ 48$, Charlestown $£ 48$, Dorchester £80, Saugus $£ 36$, Salem $£ 28$, Winetsemet $£ 8$, Medford $£ 12$, Aggawam $£ 8$, Sum total $=£ 412 . " 5$

1 Mass. Col. Rec., i. I03, 104. 4 Ib., i. Iog.
2 Ib., i. 106.

5 Ib., i. I Io.
3 Ib., i. I07. 
This is of importance, since it shows the relative standing of the eleven towns in October, 1633. We have already given considerable attention to the contest between Winthrop and Dudley over the question whether Cambridge or Boston should be the capital of the colony. It is quite evident that the struggle continued longer, and was deeper and more influential in the lives of these men and their relations to each other than a mere superficial research might lead one to suspect.

We have also dwelt upon the matter of Dudley's palisade around Cambridge, and upon the fact that the House of Representatives ${ }^{1}$ is claimed to have indirectly resulted from the taxation of Watertown for its share of the expense of the work. It seems that Winthrop began the fortification on Fort Hill, in Boston, at the same time nearly, that is to say, two months after this tax was assessed in February, 1632. Winthrop says, " "The fortification upon the Corn Hill [afterwards called Fort Hill, begun May 24, 1632], that Charlestown men came and wrought upon it the 25th of May. Roxbury the next, and Dorchester the next." It is to be observed that New Town does not appear here, and at first had nothing to do with it. August 3, 1632, Dudley is said by Winthrop to have asked him by what authority he had moved certain ordnance, and erected a fort at Boston, and that Winthrop replied to this "that the ordnance lying upon the beach in danger of spoiling, and having often complained of it in the Court, and nothing done, with the help of divers of the assistants, they were mounted upon their carriages, removed where they might be of some use : and for the fort, it had been agreed, above a year before, that it should be erected there: and all this was done without any penny charge to the public." Dr. Shurtleff, in his "Topographical and Historical Description of Boston," page 164, says:

1 The oldest representative body in America excepting that of Virginia, which first met June 19, 1619. Plymouth had none until I639. (Hutchinson, ii. 46.)

2 Winthrop, i. *77. 
"These extracts clearly show that Governor Winthrop originated the project of erecting the fortifications upon the hill, and actually accomplished the undertaking, in which he was opposed by Dudley, the deputy governor." And it helps to disclose a contest between them in these matters that Winthrop charges back upon Dudley, on the $3 \mathrm{~d}$ day of August, as follows: "But the deputy had taken more upon him, in that, without order of Court, he had empaled, at New Town, above one thousand acres, and had assigned lands to some there." Winthrop's argument seems to be, I am no worse than you are, which has the merit at least of equality. Winthrop and the Boston influence were no doubt at work to fix the permanent capital in that town, and to that end, and for their own proper security, they were very solicitous about the fortifications of the harbor. Hence it was ordered "by the General Court, May 29, I633," that the "fort at Boston shall be finished with what convenient speed may be, at the public charge." 1 And the Court, in September of that year, enforced the above order as follows: "It is ordered, (according to a former order at the General Court) that every hand (except magistrates and ministers) shall afford their help to the finishing of the fort at Boston, till it be ended." 2 New Town did not respond to this order. It is charged in Winthrop's Journal that Dudley was the man who resisted it. He was no doubt the most influential citizen of New Town at that time, and was opposed to spending money or labor on the fortifications of Boston, not because he was selfish or morose, but because the work did not commend itself to his better judgment as of sufficient importance. He still believed that New Town would be the capital, and that fosses and palisades were the best defense against Indians, bears, and wolves; that they were not in condition yet to build forts to resist the artillery of Europe. But it would no doubt be a mistake to assume that Dudley was alone in this opinion. There is some reason to believe that this struggle between Boston and New Town was participated in by Governor Haynes as
1 Mass. Col. Rec., i. I05.
2 Ib., i. 108. 
well, and Governor Ludlow, and that it may have contributed something to the antagonism between Cotton and Hooker, which is thought to have been the reason why the latter left Massachusetts and settled in Connecticut. Whether there is any connection or not between the two events, the departure came at that exact time when Boston triumphed over Cambridge and the capital went there forever. We are aware that a few Courts were held in Cambridge later, but only in time of violent public disturbance. The battle was won for Boston, and Winthrop, Cotton, and Vane were victorious over Dudley, Haynes, and Hooker. Was this rivalry between these towns, and the personal animosity created thereby, the cause? It may at least have been a potent influence; perhaps it will never be known to what extent they played a part in those important movements.

But to return to the record a little further : "It is ordered, that when all the plantations in the Bay hath done two days' work apiece at the fort, there shall order go forth to Salem, Aggawam, and Saugus, to send in their money for three days' work towards it for every man, except magistrates and ministers." This action was at the Court in November of the same year, and requires Winthrop's explanation ${ }^{1}$ to make it clear how high the feeling ran between the towns and between the worthies. It seems expedient to mention in this connection that this Court, and one other, viz., June 2, I640, are the only two recorded Courts of either kind that Dudley did not attend until the very end of his life. As we have already mentioned, this indicates his interest, his faithfulness, and his important share in all the doings of that noble bench of magistrates during twentythree years, which bench in impelling and directing power has hardly been exceeded in importance by any other body of men of equal numbers and station in life in the world's history. Why did not Dudley attend this particular Court? We do not know; he may have been ill; but we suspect that he felt that he was in the minority and could do no good,

1 Winthrop, i. *II 7 . 
and might make himself and others unhappy; and like a prudent man that he was, he heeded the injunction of Shakspere, "Beware of entrance to a quarrel." It might have been better if he had considered this wise suggestion earlier. We are informed by Winthrop "that those of New Town being warned, the deputy [Mr. Dudley] would not suffer them to come." The only account of this matter is from Winthrop. It seems a little strange that Dudley could thus resist the order of Court, and the Court take no notice of it. There is positively no account of it in the records of the colony. It seems also doubtful whether Salem and Saugus, as represented, were the real reason. If it was as Winthrop says, and in the main no doubt it was, Dudley's objection lay deeper and went against the whole scheme of fortification at Fort Hill. Winthrop says further, "The Court being two days after, ordered, that New Town should do their work as others had done." Which we understand to be included in the general order of November 5, above quoted. We hear nothing more about the fortification of Boston; the Boston party has carried the day and Dudley is reconciled, but not convinced, after all, of the expediency of the action. For so soon as he is governor, in I634, the capital is instantly removed to Cambridge, and remains there during his administration and that of Governor Haynes, his friend and successor in office, also a citizen of Cambridge. Then the Boston party comes into the ascendency in the person of Harry Vane. The Cambridge party, in 1635 , the year before, had probably arrived at a profound convincement that the tide of public sentiment had permanently set in favor of Boston, for they began that year to leave Cambridge. They considered Ipswich and Connecticut, both then in Massachusetts, as places of residence. Governor Haynes and Hooker went to Connecticut. Dudley was unwilling to go so far from the seat of government, and therefore went with his family and son-in-law, Governor Simon Bradstreet, and others, to Ipswich. There he remained three or four years, until he was again candidate for gov- 
ernor, when he removed to Roxbury, to be nearer to the seat of government, and also to be under the preaching or ministry of his friend, John Eliot, the Indian missionary. Here he remained immovable all the rest of his life. Winthrop and Dudley, after the supremacy of Boston was assured, had no more troubles which have descended to us. They were no doubt welded together in their contests with Roger Williams and with Antinomians, and with the discontented and ever-growing and surging forces of democracy and fanaticism, which must be bridled and curbed and kept in place, until they could be educated and trusted to go alone without the leading strings of babyhood. Their families intermarried, and most of the important matters mentioned, which awakened their solicitude and tried their courage, wisdom, and patience, occurred while Dudley resided at Ipswich, from I635 to I639.

It would be difficult to overestimate the great stability and force of character which these two men contributed to this commonwealth, and thence directly to the commonwealth of England. Allow all honor to John Cotton and tho ministers in general, as an advisory force and guide to the meaning of the Scriptures, and even of the law, and yet the executive wisdom was in the magistrates, to discern the right way and to walk, and direct others to walk, therein with fidelity, and a courage which could withstand the anointed ministers if reason dictated that course, and tell them to keep their allotted places and reign in their own bailiwick. There remained, as early as 1636 , only three of that Court of Assistants which met on board the Arbella, March 23, 1629, the last Court in England which elected Dudley deputy governor. These were Winthrop, Dudley, and his son-in-law, Bradstreet, who was the last governor under the first charter in 1679, and was young and of less weight until the ancient worthies had disappeared. Winthrop went to his final rest in I649, and Dudley survived him four years, and was governor again in 1650. But how these two men tower in importance above all the others in the colony! 
They were so constantly in office, and so united and combined in the service of the commonwealth, that their labors and achievements are absolutely inseparable. Then let no American citizen willingly and voluntarily "abate the tithe of a hair from the just character and just fame" of either illustrious magistrate. "These were honored in their generation and were the glory of their times." 1

The election on May I4, I634, was an exceedingly important one. Dudley up to this time had lived and labored always under the shadow of Winthrop. He had been constantly second, and Winthrop first. He had been only the deputy heretofore, but now he was elevated by the suffrages of the people above Winthrop, in the governorship. This indorsement by the people was of special importance to him, because it was a vindication of himself in his controversy with Winthrop. He was jealous of Winthrop, it is asserted, and wanted his high place for himself. This view is unjust to Dudley. He was very much disturbed at the unwarranted assumption of power and authority on the part of Winthrop, as appears in his charges against him. ${ }^{2}$ It was not for himself that he contended; it was for the cause of causes, it was for the state, that he was anxious.

"Why, man, he doth bestride the narrow world

Like a Colossus. . . .

Upon what meat doth this our Cæsar feed,

That he is grown so great?" 3

Thus thought the people of Winthrop at this election, and Dudley was at their head and was their choice for governor, and their verdict then was a conclusive judgment in favor of Dudley and against Winthrop, running back over the controversies of 1632 and 1633 down to this period. It is to be said that the political lines were not the same as in former years, yet it is true that the supposed usurpations of Winthrop were at the foundation of all controversies, early and late. The Rev. Mr. Cotton was an earnest supporter of

1 Son of Syrach. See Rom. xii. 7, 8.

2 Winthrop, i. *83-*86.

8 Julius Cæsar, act $\mathrm{I}$, scene 2. 
Winthrop. The Rev. Mr. Hooker, who did not cherish Cotton with great warmth, was no doubt on the side of Dudley. Both Hooker and Haynes lived at Cambridge, as we have noted, with Dudley, and were no doubt his friends and supporters. And this same spirit between the same persons continued until Hooker retired to Connecticut in 1636 , and Dudley to Ipswich in 1635. The Hutchinson and Williams struggles in 1636 united the factions against their common enemies; and we hear nothing more about unpleasantness and jealousies between Winthrop and Dudley. It is well to observe that Dudley believed with all his heart in rotation in office. They had escaped from a land of hereditary and one-man power, and had espoused the government by the whole church-going people, who were believed to contain the virtue and intelligence of the community, and he was anxious that they might not drift back into their old ways of office for life, which seemed to be the idea of Cotton and also of Winthrop. It was this, it may be safely believed, which kept Dudley out of the office of governor, with the exception that he returned about every five years. He was governor in $1634,1640,1645,1650$, and these periods of absence from office so regular, coupled with his firm adherence to the doctrine of rotation in office, accounts fully for his continued action during his whole life in Massachusetts.

"This election was held in the old First Meeting House, and the courteous, but defeated Winthrop, entertained at his own house Dudley and the assistants, as he usually had done after his own election in former years, during the three days of the session." Nothing has in it greater power of reconciliation than an hospitable reception and a good dinner. "If thine enemy hunger feed him." Winthrop's residence was on Washington Street, ${ }^{1}$ a little north of the Old South Church, and here the worthy magistrates feasted May I4, I5, and 16, 1634, and never more told the world at large their quarrels, if they had them.

1 In I $_{3}$ I he brought his house from Cambridge, and placed it by the Old South. (Old Landmarks of Boston, 225.) 
The Rev. Mr. Cotton, "at the General Court, preached and delivered this doctrine, that a magistrate ought not to be turned into the condition of a private man without just cause, and to be publicly convict, no more than the magistrates may not turn a private man out of his freehold, etc., without like public trial, etc. This falling in question in the Court, and the opinion of the rest of the ministers being asked, it was referred to further consideration." 1 It does not appear that Winthrop was displeased with Cotton's single-man government doctrine. Cotton was himself only made a freeman at this Court, and was so recently from the autocratic ideas of England, and so in fellowship with Winthrop, his administration and fortunes, that he soon discovered himself to be quite on the unpopular side in the politics of the period, without even the support of the ministers.

The freemen were evidently very much agitated over the doings of Governor Winthrop and the Court of Assistants, and proposed to examine at once into their own charter rights, and having found them, to maintain them at any cost. When the notice was issued for the great election at the May meeting of the General Court, they were on the alert. Two of them from each town met and "desired a sight of the patent," in April previous to the session of the General Court, " and conceiving thereby that all their laws should be made at the General Court, repaired to the governor [Winthrop] to advise with him about it, and about the abrogating of some orders formerly made, as for the killing of swine in corn," etc. Swine from time to time became the proximate cause of some very important revolutions in the interests of liberty in the colony. The governor said to this committee of towns that "for the present they were not furnished with a sufficient number of men qualified for such a business, neither could the commonwealth bear the loss of time of so many as must intend it." He very adroitly suggested that they might do divers and sundry things, only they must not make new laws. ${ }^{2}$ Winthrop's treatment of this committee, in this very

1 Winthrop, i. * ${ }^{*} 32$.

2 Ib., i. * ${ }^{*} 28$. 
important inquiry and critical juncture of political affairs, reveals the imperious and lordly assumption he was capable of, until the discipline of dealing with a free people taught him to be more considerate. Here we see him as he was, and can well understand the character that Dudley was united with for years. And we can well believe that his patience was tried to a hair's breadth, when Winthrop, a man of less years and experience in life, took matters into his own hands, and took no trouble to say, "By your leave, I do this and that." Winthrop had to be called to account, and taught a vigorous lesson, beginning with the golden rule, and then that the people were thenceforth and forever to be sovereign in America. It is remarkable that Winthrop, who charges Dudley with jealousy of him, nowhere seems to suggest that Dudley had stirred the freemen to the point of resistance to his continuance in office. We do not believe that Dudley ever sought to displace Winthrop. We know he was desirous that he should consult the government more in the administration. We also know that he approved of rotation in office. It is certainly creditable to Dudley that Winthrop found no occasion to say of him that his own temporary overthrow was due in any manner to the intrigue of himself. Nor does he even insinuate that Dudley had cultivated the dear people to obtain votes which would elevate himself to the governorship in his place. It is evident that Dudley, by his very mental structure, was incapable of that service to himself. 


\section{CHAPTER XVI}

THE thoroughness with which this Court did its work is simply marvelous, and its effect no man can estimate. Savage says, "No country on earth can afford the perfect history of any event more interesting to its own inhabitants than that which is here related." 1 The first thing done in the General Court, as the record stands, was a change of the oath of freemen, and also a retroactive provision changing the obligation of the former oath upon the freemen of earlier date. The latter part of this oath was a healthful and suggestive preparation for the resistance they were about to undertake in politics against the present firmly seated government, including possibly the ministers and magistrates. It is impossible to state how the party division ran at this time. We know that the majority were bent on reducing Governor Winthrop. The following is a part of the oath, which has the most important bearing on the situation, viz.: "Moreover, I do solemnly bind myself in the sight of God, that when I shall be called to give my voice touching any such matter of this state wherein freemen are to deal, I will give my vote and suffrage, as I shall judge in mine own conscience may best conduce and tend to the public weal of the body, without respect of persons, or favor of any man. So help me God, in the Lord Jesus Christ." 2

This kind of oath would be a useful reminder to the thoughtless in our present elections. It is well adapted also to the integrity and independence of the candidate who received a majority of the votes at the election. For Winthrop said of Dudley in 164I, "Who being a very wise and just

1 Winthrop, i. *129, note I.

2 Mass. Col. Rec., II 7 . 
man and one that would not be trodden under foot of any man." When Winthrop said that, he knew Dudley by a living experience, close and intimate, in temptation, under fiery trials of every sort; and it is exceedingly strong testimony from the lips of a rival. Dudley would hardly succeed as a politician in some known localities to-day with such characteristics.

There was, at this election, a determined purpose to bring out the independent vote, and to preserve its independency until the issue was settled whether there should be a change in the government. The ballot, or voting "by papers," was used, the secret ballot, that permitted each freeman to make his choice without exposure to the scrutiny of politicians or ministers. It has been thought that this use of the ballot was a return after fifteen hundred years to the Roman system in the time of Trajan. But it is now shown to have come to America by the way of the Netherlands. ${ }^{1}$

It is also said that the ballot had a prior service in Salem, Mass., in church elections. But the important question is whether, in all the history of representative government, the election of Dudley was not the first wherein the free people cast their vote by ballot direct for the chief magistrate. This would have far greater historic importance than the use of the ballot by churches, by corporations, or by deliberative and legislative bodies. It would be the introduction of a system which is not yet in use in England except as to representatives, and not even in that particular instance until I872. It does not yet exist in all of the American States. The Congress of the United States has provided that all votes for representatives in Congress shall be by written or printed ballots. $^{2}$ The citizen who votes directly for governor or representatives acts for himself, not by delegative authority, and has a right to keep to himself, and guard his private independent choice. It is no doubt vastly for the public

1 Douglas Campbell's Puritan in Holland, England, and America, ii. 430-440.

${ }^{2}$ Revised Statutes of the U. S., p. 5, § 27. 
good that he be so protected as to exercise this privilege freely, but the representative in legislature or in Congress is in another relation; he has constituents. He votes for them, and they have a reasonable and just right to know by a viva voce vote exactly how he voted on all questions.

It does not yet appear that, with these proper limitations, the vote for Dudley was not original in form and unique in all history. Hooker was doubtless in favor of Dudley in this election. He belonged to the Cambridge, and not to the Boston, faction. He did not in general side with Cotton, who was an earnest Winthrop man. We have observed his association with Dudley from his first arrival in the colony. $\mathrm{He}$ had lived three years in Holland, and we may reasonably suppose that he had there learned something of the use of the ballot. At any rate, he placed it permanently in the famous constitution of Connecticut, five years subsequent to this election. Did he have a hand in guiding the political fortunes of Dudley on that eventful I4th day of May, I634? Or did he learn then the value of the ballot in Massachusetts, and later enrich that constitution, as he did in many other particulars, through his experience and observation in the older commonwealth ? ${ }^{1}$

It is pleasant and very interesting to read Hubbard's excuse for and thoughtful explanation of Winthrop's failure of reëlection: "The freemen, that they might not always burden one person with the yoke of the government, nor suffer their love to overflow in one family, turned their respects into another channel." $2 \mathrm{He}$ also wrote kind and appreciative words of Dudley's promotion to the gubernatorial office. Savage, in his note, ${ }^{3}$ asks what induced this concert of action among the towns, by which their delegates proceeded to interrogate Winthrop, and to examine the charter, to learn their rights and powers? He himself answers this question by the suggestion that the assistants had become

1 Douglas Campbell's Puritan in Holland, England, and America, ii. 439.

${ }^{2}$ Hist. and Antiq. of Boston, 169.

3 Winthrop, i. *129. 
weary of power, and devised this method of shifting a portion, at least, of the responsibility upon the deputies, which is quite a departure from the theory expressed by Hubbard. It appears to us that the theory of Savage, so far as Winthrop is concerned, is improbable, if not impossible. He had clearly shown, at his interview with the committee a month before, that he did not consider them competent to take the responsibility either to make laws or to execute them. He was evidently desirous of retaining all the position and power he had attained to so far, and of keeping the freemen in their proper place, which he considered subordinate. This had been his constant method, manifested in his words and in his actions.

The more reasonable view of his political reverse is that certain thoughtful men in the colony, including possibly Hooker and Nathaniel Ward, were quietly agitating certain changes and reforms in the arbitrary government by the Court of Assistants ; that, influenced by them, these delegates put a few questions kindly to Governor Winthrop, and learned that he had no sympathy with them, and that being already convinced by the learned among them that the assistants were determined to govern, so long as they were permitted to do so, the delegates began, under the inspiration of some one to us unknown, who had something of the spirit of 1776 , seriously to ponder the great thought that "eternal vigilance is the price of liberty."

The Court of Assistants had ordered, ten months before this date, "that it shall be lawful for any man to kill any swine that comes into his corn." 1 Six months before, the same Court ordered: "Further, it is agreed that no man shall give his swine any corn but such as, being viewed by two or three neighbors, shall be judged unfit for man's meat. . . Also, that every plantation shall agree how many swine every person may keep, winter and summer, about the plantation."

When the honorable deputies appeared before Governor 1 Mass. Col. Rec., i. 106. 
Winthrop for information and sympathy, he says that they wished to advise with him about "the abrogating of some orders formerly made, as for killing of swine in corn," etc. This Court organized May 14, 1634, and then settled some constitutional questions, and began to do the ordinary business of the Court by passing the following act : "All former orders concerning swine are repealed; and it is agreed that every town shall have liberty to make such orders about swine as they shall judge best for themselves." The delegates had approached Governor Winthrop and presented their grievances, and he in turn alluded to some matters which he considered no doubt the more important, but he either disregarded or overlooked the question respecting swine, and gave them no satisfaction. We do not seek to magnify this or any other matter beyond its due and relative importance. It is, however, evident that these citizens from a land of severe laws and oppressive government were beginning to feel the impulses of liberty in a new social life, and the democratic spirit awakened in them was constantly stimulating them to a close inspection of the laws of government under which they were living. They were searching, as we are to-day, for the unattained, the ideal theory and practice of government, the royal highway and method of advance, to which was then, as now and always will be, by agitation.

Political agitation had been invoked in the question of the conflict between Cambridge and Boston, respecting the choice of one of them as the capital town, and also as an incidental matter the fortifications of Boston harbor. Several of these contests had set the people in battle array to contend for their liberties, and thereupon aroused a spirit which never slumbers in America, but has appeared in every struggle and period in our annals.

Winthrop, in the judgment of the majority of the freemen, as we think, was growing into the conviction that he was to be governor at least during. good behavior, and that he and his immediate associates would for a long time be 
tolerated in the high places of power in the colony; that the true course of the government was to curb the "vaulting ambition" of the people, and keep them in the subordinate ranks of obedient subjects, neither law-makers nor judges of the laws created by their superiors.

Dudley was raised to the chief magistracy upon the popular tide which created a representative government outside of the charter, ultra vires; not indeed the first, but the second representative body in America, - not second, however, in importance in the history of the United States. Ought the colony properly to have applied to England for a change of charter enabling them to make this extension in their government ? 1

One thing is evident : that the government of the people made a great and permanent advance, and that in this movement Dudley was at the front, while the swine question was surely quite fundamental in the agitation among the people which developed this great political advance. Dudley had himself first called public attention to the complacent, self-assured methods of Winthrop's administration, no doubt because he was by his prominent position best prepared for this service; but at this election the freemen themselves were fully awake to the growing importance of rotation in office in a free government. Dudley therefore was, by his election upon this issue, at this moment vindicated respecting his arraignment earlier of the one-man government of Winthrop, and he had also the proud distinction of being borne into office in this progressive movement of the freemen towards that democratic freedom which is the noblest characteristic in our government to-day.

We can never know whether the twenty-four freemen enrolled at that General Court, May 14, I634, acted as and for the whole body of freemen in the election of Mr. Dudley, the others being fully notified, but having failed to appear, or whether there were others present not named in the record. We know that the twenty-four names were the

1 Grahame's Hist. U. S., i. 229. 
representative body when the Court was finally organized. We also know that the governor was not to be elected by the representatives, but by the whole Court, governor, deputy governor, assistants ; and the election would proceed now, except that it would be in town meeting, by the freemen or such portion thereof as might come after due and lawful notice to all. ${ }^{1}$ It is ordered, "that there shall be four General Courts, held yearly, to be summoned by the governor, for the time being, and not to be dissolved without the consent of the major part of the Court." They did not intend to leave any prerogative with the executive to prorogue or dissolve Parliament at its pleasure. The people were sovereign, and intended to continue to be. They now began to reserve in themselves all powers, as they have since done, not specifically granted, and to extend even the contemplated methods of the charter in the interests of liberty and political progress. For without special authority or direction under the charter, though not in violence to it, "It was further ordered, that it shall be lawful for the freemen of every plantation to choose two or three of each town before every General Court, to confer and prepare such public business as by them shall be thought fit to consider of at the next General Court. $^{2}$ And that such persons shall be hereafter so deputed by the freemen of the several plantations, to deal in their behalf, in the public affairs of the commonwealth, shall have the full power and voices of all the said freemen, derived to them for the making and establishing of laws, granting of lands, etc., and to deal in all other affairs of the commonwealth wherein the freemen have to do, the matter of election of magistrates and other officers only excepted, wherein every freeman is to give his own voice." 3 This is very fundamental, and seems to contain the germ of the present organized government of Massachusetts, and of the other States as well, and indeed of the United States.

1 Mass. Col. Rec., i. I 18.

2 This looks like a sort of caucus, for conference at least.

8 Mass. Col. Rec., i. I I8. 
The people, having thus established the manner of election of their governor and legislative officers, proceed in the full exercise of their assumed powers of government to secure to themselves and to their posterity "the free liberties of a freeborn people of England." Although they do not at this one effort secure the whole of the most celebrated thirty-ninth of Magna Charta, or trial by jury in all its provisions, they nevertheless make a very important beginning in that direction. "It was further ordered that the constable of every plantation shall, upon process received from the secretary, give timely notice to the freemen of the plantation where he dwells, to send so many of their said members as the process shall direct, to attend upon public service; and it is agreed, that no trial shall pass upon any, for life or banishment, but by a jury so summoned, or by the General Court." 1 We cannot fail to note that this is a continuation of the struggle of the people towards liberty by an instinct of freedom. The intrinsic motive in the minds of these people, and of all other people who seek for trial by jury, is its relations to the rights of the people. Judges in the past, at least, were appointed by sovereigns, and were often their servants against the interests of the people; but a jury of one's peers was a cherished bulwark of liberty, and protection from the abuse of power and prerogative in high places.

Forebodings of calamities arising from ungovernable democracy and a population which was not trusted with power, but which was being constantly increased by the arrival of every ship from Europe, were influencing Winthrop and the other assistants, and made them hesitate before they recognized the sovereignty of the masses, and transferred the most important powers to untutored citizens. Nevertheless, that transfer, however slowly evolved, was the meaning in history of the great emigration to America, and this three days' session of the General Court was the very dawn of the new era, and notice was here served by the people, that 1 Mass. Col. Rec., i. 118. 
they proposed to enter at once upon their inheritance from which they had been ousted since time immemorial. We ought most highly to appreciate the good fortune of Dudley in being elevated to the first place in the commonwealth and in the gift of the people at this period. We have not always found writers of history regarding him as a student of law and of English liberty, the associate in England with the greatest and most advanced spirits of the age, and such historians would never observe how gladly he welcomed the progress of political freedom, and gave to it his sympathy and warm approval. Dudley, Nathaniel Ward, and Thomas Hooker were kindred spirits of the true American type, and the colony derived from them more, perhaps, than history has distinctly chronicled. Winthrop, on the other hand, has received his share of honor for all that was then achieved, because he left a diary, in which events take a shade and color from his own objective point of view, and because his illustrious descendants have honorably guarded his cherished memory. 


\section{CHAPTER XVII}

AN important matter absorbed the attention of the government. The Plymouth Colony claimed under their grant a monopoly of the Indian traffic on the Kennebec River, and one John Hocking, of Piscataqua, agent for Lords Say and Brooke, undertook, in May, 1634, to intercept the canoes which came down the river and to divert the trade to himself. A dispute at once arose, which resulted in the death of Hocking, and also of a Plymouth man by the name of Moses Talbot. Hocking was no doubt the one chiefly at fault. ${ }^{1}$ Palfrey says that "the business, as threatening mischief to all the colonies, was taken up by the General Court of Massachusetts." 2 The Massachusetts Court record is as follows : "Upon a complaint made to John Winthrop, Esq., then governor, by a kinsman of John Hocking, lately slain at Kennebec, by one of the Plymouth Plantation, desiring that justice might be done upon the offender, the Court, taking into consideration the same, hath ordered that $\mathrm{Mr}$. John Alden (being there present when the said Hocking was slain) shall be detained here, till answer be received from those of Plymouth, whether they will try the matter there or no, or that sufficient security shall be taken that he, the said John Alden, shall not depart out of the limits of this patent, without leave from the Court or governor." It seems that John Alden gave the security. ${ }^{3}$ Goodwin relates that "Alden was found at large on bail, and on Standish's presentation of the case Alden and his sureties were fully discharged. Yet the new governor, Dudley, committed the

${ }^{1}$ Hutchinson, ii. 474, note; Goodwin's Pilgrim Republic, 38 r.

2 Palfrey, i. 338.

8 Mass. Col. Rec., i. II 
fresh indignity of putting Standish under bonds to appear before the Massachusetts Court in two weeks and make oath as to Plymouth's rights, as well as to the special facts of the Hocking case. At the time set, Standish returned to Boston, bearing a letter sent by Prence (who was governor in I634), but written by Bradford. This note was probably of the thorough and severe nature which the case demanded, for Dudley answered it unofficially, and made an effort to dispose of the matter by private diplomacy; nor did he disclose Bradford's letter, even to his council. But the bluff Standish discomfited him by demanding that a reply be given him in open court. Dudley was then forced to produce the letter in court, where it seems to have given much offense, but the members finally evaded the matter by declaring that, as it was only an answer to one of Dudley's, it did not require a reply.

"Standish and Alden then went home, bearing Dudley's private note. This pleaded for harmony, and made some talk about the honor of suffering wrong patiently, - a subject upon which the irascible Dudley can have known little; ... Plymouth was too weak to redress her wrongs by force. When her righteous indignation had somewhat cooled, the excellent Winthrop, to allay the storm aroused by his bitter rival, Dudley, induced Plymouth to request all the plantations to send delegates, including their clergy, to meet at Boston, and, after hearing all who chose to appear, decide the Hocking case, with full power, but without 'prejudice of the liberties of any place.' . . . These, however, after reviewing the case with care, formally and fully exonerated the Plymouth men, and declared that Hocking alone had been to blame. The Bay officials also undertook to satisfy the English lords of the justice of this decision, - an effort in which they succeeded." 1 Dudley and Winthrop both wrote to England "to mediate peace." 2 "Lord Say and Brook replied to Mr. Dudley." 3 Bradford adds, "Thus

1 Goodwin's Pilgrim Republic, 383.

${ }^{2}$ Winthrop, i. I37. $\quad 8$ Ib., i. 145. 
'was their love and concord renewed,' - an expression which admits that it had been suspended." 1

We have introduced this long account of a not very remarkable matter in itself, because it seemed to be another instance in which Dudley has been misunderstood and misrepresented. It is important at the start to remember that the government of the colonies was at this time in special danger of being reorganized by the home government. And this, if it were accomplished, meant the destruction of all that the Puritans held most sacred in America. Hence they were deeply solicitous to avoid such a catastrophe. Winthrop has given us in pathetic language his conviction of the danger. He says : "And besides had brought us all and the gospel under a common reproach of cutting one another's throats for beaver." 2 The author from whom we quote evidently thinks that the intermeddling of Massachusetts in the affairs of the other colonies was officious. $\mathrm{He}$ assures us that the "excellent Winthrop" came forth serene from retirement "to allay the storm aroused by his bitter rival, Dudley."

The colonies were, however, so connected with the mother country and with each other that their interests very soon forced them into a union for common defense. The arrest of Alden and Standish were attempts to make assurance doubly sure that a satisfactory examination should be entered into, either in Plymouth or in Massachusetts, that they might have a reasonable explanation ready when called upon by the government in England and by Lords Say and Brooke. The importance of this is more manifest when we recall that the wicked Laud was at the helm of state.

But the most singular feature of this case is the undoubted fact that Dudley was the one, and only one, among his associates who did not.approve of the action of Massachusetts in this affair. He seems to have been censured for opposition to Plymouth in the matter, when he was always really on her

1 Goodwin's Pilgrim Republic, 382-384.

2 Winthrop, i. I3I. 
side of it. He was clear-sighted enough to discover earlier than his associates what they all saw and accepted at last, that Hocking was himself wholly in fault. The action of Dudley in enforcing, as the executive, the opinion of a majority of the Court must not be regarded as declaring his own personal opinion. We have, fortunately, evidence to direct us in discovering his own views of this case, which Bradford calls "one of the saddest things that befell them since they came."

Cotton Mather was almost contemporary with Dudley, and knew many men who had taken part in these matters. The following is believed to be his statement: "When it was thought meet to make a change, the lot of advancement fell in the first place upon Mr. Dudley, who was the first that succeeded Mr. Winthrop in the governor's place, into which he was chosen at the Court of Election in the year 1634 ; in which year there falling out some occurrences of more difficulty than before, Mr. Dudley was in a needful hour called to the government ${ }^{1}$ for in the case that concerned Hocking, of [Piscataway] who was slain at Kennebec by some of Plymouth, Mr. Dudley differed from all the rest of the bench, and yet was concluded afterwards to be in the right ${ }^{2}$ and peradventure, if he had not been so steadfast fixed to his own principles and judgment, but to have been swayed by the bias of other men's inclinations, some inconvenience might have fallen out; for the person murdered was one that belonged to the Lord Say, who was better known to Dudley than to any other gentleman upon the bench, yet that did not sway him to alter his judgment when he saw he had reason on his side $;^{3}$ yet, did he not passionately [or, we think,

1 Mather seems to consider it fortunate that in this unusual difficulty the clear head of Dudley was at the helm of state.

2 If this is correct, Dudley was in favor of Plymouth and against Hocking from the first, and in opposition to the other members of the General Court; the friends of the Pilgrims have therefore unjustly censured him and failed to comprehend his real position in this case.

${ }^{3}$ This seems to show that he was firmly against Hocking and on the side of Plymouth. 
'irascibly'] oppose those that differed from him, but placidly [as was his general custom and excellent judicial manner] bore their dissent. ${ }^{1}$ Dudley's wisdom in managing this business will best be understood by his own beautiful letters, [two in number,] to Mr. Bradford, the ancient governor of Plymouth, though at that time another [Prence] was in place."

Letter of Thomas Dudley to Governor William Bradford of Plymouth Plantation :-

Good Sir, - I have received your letters by Captain Standish, and am unfainly glad of God's mercy towards you in the recovery of your health, or some way thereto. For the business you write of, I thought meet to answer a word or two to yourself, leaving the answer of your governor's letter to our Court, to whom the same, together with myself is directed. I conceive (till I hear new matter to the contrary) that your Patent may warrant your resistance of any English from trading at Kennebec, and that blood of Hocking, and the party he slew, will be required at his hands. Yet do I with yourself and others sorrow for their deaths. I think likewise that your general (public) letters will satisfy our Court, and make them cease from any further intermeddling in the matter.

I have upon the same letter set Mr. Alden at liberty, and his sureties, and yet, least I should seem to neglect the opinion of our Court and the frequent speeches of others with us, I have bound Captain Standish to appear the third of June at our next Court, to make affidavit for the copy of the Patent, and to manifest the circumstances of Hocking's provocations; both which will tend to the clearing of your innocency. ${ }^{2}$

1 Proc. Mass. Hist. Soc., 1870, 217.

2 It is evident that Dudley's sympathies are strongly with Plymouth; but with executive responsibility, the terror of Archbishop Laud and his commission for regulating plantations, the wrath of Lords Say and Brooke, and the well-known opinions of the General Court impending 
If any unkindness hath been taken from what we have done, let it be further and better considered of, I pray you ; and I hope the more you think of it, the less blame you will impute to us. At least you ought to be just in differencing them, whose opinions concur with your own, from others who were opposites; and yet I may truly say, I have spoken with no man in the business who taxed [accused or censured] you most, but they are such as we have many ways heretofore declared their good affections towards your plantation. I further refer myself to the report of Captain Standish and Mr. Alden; leaving you for this present to God's blessing, wishing unto you perfect recovery of health, and the long continuance of it. I desire to be lovingly remembered to Mr. Prence, your governor, Mr. Winslow, Mr. Brewster, whom I would see if I knew how. The Lord keep you all. Amen. Your very loving friend in our Lord Jesus,

Thomas Dudley.

NewTown, the 22 of May, $1634 \cdot^{1}$

If we are correct, Dudley, as executive, had in the interests of peace and good neighborhood sent a letter to the Plymouth government, asking the important question, "whether they will try the Hocking case themselves at Plymouth, do justice in the case, and relieve both colonies from English resentment. ${ }^{2}$ And he had received, in answer, a very disagreeable letter, which was of such an inflammable nature that he did not deem it wise in the interests of peace and good-fellowship to read it publicly; he was certain that the bitterness contained in it would tend to interrupt intercolonial friendship and comity, as it did, in fact, when finally

over him, he felt it a solemn duty to take security that Plymouth would have the case determined according to the law and evidence for the safety of all the colonies and protection against their common enemies in England. It was of vital importance to Massachusetts that nothing bordering on lawlessness might furnish excuse for English interference with their government.

1 Bradford's Hist. Plym. Plant., §§ 200, 201.

2 Mass. Col. Rec., i. IIg. 
presented. He appears in this transaction in the noble attitude of a peacemaker and Christian gentleman, doing all in his power to prevent a further breach between the sister colonies. Dudley, bent upon this course, withheld as long as he reasonably could from the Court of Massachusetts the discourteous answer which he had received from Plymouth. He was, however, forced by the warlike Standish at last to present it and take the consequences. The purport and drift of this answer is manifest from the satisfaction of Standish in calling for the reading of it, and the wrath which it called forth in the Court of Massachusetts. The forethought and wisdom of Dudley in this matter are clearly vindicated. He was convinced that his friend Lord Say had no case, and that the needful thing was for both parties to possess themselves in patience, and that perfect reconciliation would follow their sober second thought ; and the event proved that he was correct. The manly dignity and strength of Dudley among his contemporaries is revealed in this case clearly and distinctly. We possess, fortunately, another letter of Dudley, which we think fully sustains the theory which we have presented of his position:-

SiR, - I am right sorry for the news which Captain Standish and other your neighbors and my beloved friends will bring unto Plymouth, wherein I suffer with you by reason of my opinion which is different from others, who are Godly and wise amongst us here; the reverence of whose judgments causes me to suspect mine own ignorance, yet must I remain in it, till I be convinced thereof. ${ }^{1}$ I had thought not to have shown your letter to any, but to have done my best to reconcile differences betwixt us, in the best season and manner I could; but Captain Standish requiring an answer thereof publicly in the Court, I was forced to produce it, and that

1 It appears that he was suffering alone with Plymouth, and on its side of the question, yet without conceit of opinion, and even with reverence for the judgments of his opponents. His attitude is most excellent, devoid of any diplomatic effort to win favor to himself. 
made the breach so wide, as he can tell you. [This result Dudley strove in vain to avoid.] I propounded to the Court to answer Mr. Prince's letter, your governor, but the Court said it required no answer, it being an answer to a former letter of ours. I pray you certify Mr. Prince so much, and others whom it concerneth (that no neglect or ill manners be imputed to me) thereabout. ${ }^{1}$ The late letters I received from England, wrought in me divers fears of some trials which are like to fall upon us; and this unhappy contention between you and us, and between you and Piscataqua, will hasten them, if God with an extraordinary hand do not help us. To reconcile this for the present will be very difficult, but time cooleth distempers; and a common danger approaching to us both, will necessitate our writing again : I pray you therefore, Sir, set your wisdom and patience at work and exhort others to the same, that things may not proceed from bad to worse. So making our contentions like the bars of a castle, ${ }^{2}$ by that a way of peace may be kept open, whereat the God of peace may have entrance in his own time. If you suffer wrong it shall be your honor to bear it patiently; but I go too far needlessly in putting you in mind of these things. ${ }^{3}$ God hath done great things for you, and I desire his blessings may be multiplied upon you more. I will commit no more to writing; but commending myself to your prayers, I am your truly loving friend in our Lord Jesus,

Newtown, June 4 th, $1634^{4}$

Thomas Dudley.

1 This solicitude respecting good manners is characteristic of him. We desire always to emphasize the fact that the usages of good society became him as a part of his nature.

2 The words "bars of a castle" are from Prov. xviii. 19: "A brother offended is harder to be won than a strong city; and such contentions are like the bars of a castle."

$8 \mathrm{Mr}$. Goodwin, the historian of Plymouth, evidently regards this last Christian teaching of Dudley as insincere, sentimental cant. We think, on the contrary, that he spoke words of soberness and reason, springing from an earnest purpose to do justice.

4 Bradford's Hist. Plym. Plant., § 201 . 
Mather further relates, that " By this letter it appears that Mr. Dudley was a very wise man, and knew how to express his mind in apt and gentle expressions, not willing to provoke others, although he were never so confident that he was in the right; for by his wise and moderate proceedings in the case, he satisfied their neighbors at Plymouth, who thought they were injured by the unnecessary intrusion of the jurisdiction of the Massachusetts, in a matter which did not really concern them, and maintained peace at home amongst them that so much differed from him in the case then depending before them." 1

Governor Bradford is very charitable to the action of Massachusetts in this matter. ${ }^{2}$

We think it is quite proper at this point to ask whether it was the "excellent Mr. Winthrop" who did the most to allay this storm, or the wise, deliberate, peace-loving Dudley? And again, whether it is not quite certain that "Mr. Dudley did not at all arouse the storm ?" Also if it is not, on the whole, reasonably clear that heretofore great injustice has been done in this case to the patriotic services of Dudley?

The great reconciliation with Plymouth was completed, and happiness restored on this side of the ocean; but from England, louder, clearer, and more ominous were the mutterings of discontent towards the colonies, and in particular towards Massachusetts.

Archbishop Laud and other members of the Privy Council had been informed by disaffected persons, who were always busy in stirring up the English government against New England and the charter of Massachusetts, that the Puritans, among other wrong-doings, were setting up in America an independent church and state; hence in February, 1634, a number of ships departing from England were intercepted, and their passengers required to take the oath of allegiance to the English crown, and to promise conformity with the Prayer-Book.

1 Proc. Mass. Hist. Soc., Jan. I870, 218.

2 Bradford's Hist. Plym. Plant., § 202. 
But on the 28 th day of April, I634, a commission was issued, with Laud at the head of it, to take charge of the American colonies, to hear complaints, to secure conformity, to make laws, "ordinances and constitutions, concerning the state public of the said colonies or utility of private persons, and their lands, goods," etc. There were twelve of these commissioners, and they were further directed as follows : "And we do, furthermore, give unto you, or any five or more of you, letters patent, and other writings whatsoever, of us or of our royal predecessors granted, for or concerning the planting of any colonies, in any countries, provinces, islands or territories whatsoever, beyond the seas, and if, upon view thereof, the same shall appear to you, or any five or more of you, to have been surreptitiously and unduly obtained, or that any privileges or liberties therein granted, be hurtful to us, our crown or prerogative royal, or to any foreign princes, to cause the same, according to the laws and customs of our realm of England, to be revoked, and to do all other things which shall be necessary, for the wholesome government and protection of the said colonies and our people therein abiding." 1 Here was unlimited power over the fortunes of the colony in the hands of its most relentless and malignant enemies.

1 Hutchinson, App., i. 502-505. 


\section{CHAPTER XVIII}

WE constantly note the compassion of writers for Winthrop; he was worthy of it, but it is a mistake to reverence him as the entire government of the colony, in these trying times when the little state had to prepare to defend itself against the tyranny of a nation possessing the most powerful naval force in the world. We ought to regard with admiration the heroic energy, the Spartan bravery, the sublime trust in God and a righteous cause, which nerved these patriots to arm themselves in the autumn of 1634 to defend their liberties and their new-made homes on the shores of Massachusetts Bay. Neither will the world soon forget who was the governor of the old commonwealth in this hour of her trial. American oratory for more than a century has, on the annual national festival of the Fourth of July, set forth the magnificent fortitude of our fathers in the Revolution, in arms against the same Britons ; but there were more than four millions of Americans then, while Governor Dudley ruled over only four thousand Engtishmen in 1634 .

Their records tell the pathetic story of their solicitude for the preservation of that which was dear to them, and which the world is beginning at last to see was of priceless value in the enfranchisement of our race.

The General Court ordered, September 3, 1634, "That there should be a platform made on the north east side of Castle Island, and an house built on the top of the hill to defend the said platform. It was further ordered, that warrants shall be sent to the constable of every plantation, to send in money or workmen to make that which they have already done, three days apiece towards the fort at Boston, both of new comers and others for every hand able to work 
(except magistrates and ministers) that are behind, to be delivered to Captain Underhill, before the next Court of Assistants." 1 And on the same day power was given to impress men for the public works. The colony now seemed like one armed camp, "facing fearful odds" and shrinking from no responsibilities, for their faith was in Jehovah himself, whose breath withered the hosts of Sennacherib. They proceeded to fortify Boston, Dorchester, Charlestown, Castle Island, and Salem.

"It is ordered, that the captains shall train their bands once every month, giving a week's warning before (except in July and August), and that the captain shall have liberty to train all such unskillful men as are at their own hands, so often as they please, provided they exceed not three days in a week." 2

They appointed a committee with power to manage war for a year, and we find some writers declaring Winthrop to have been at the head of this committee; but Dudley was now first in war. "It is ordered, that the present governor [Thomas Dudley], John Winthrop Senior, John Haynes, John Humfrey, and John Endicott, Esq., shall have power to consult, direct, and give command for the managing and ordering of any war that may befall us, for the space of a year next ensuing, and till further order to be taken herein." 3 Dudley was the foremost soldier in the colony. He was in I644 chosen sergeant major general, or commander-in-chief, of the forces of the colony.

The Court proceeds further in preparations for war, and orders a beacon forthwith on "the sentry hill [Beacon Hill] at Boston, to give notice to the country of any danger, and that there shall be a ward of one person kept there from the first of April to the last of September, and that upon the discovery of any danger, the beacon shall be fired, an alarm given, as also messengers presently sent by that town where the danger is discovered, to all other towns within this jurisdiction." 4

1 Mass. Col. Rec., i. 123. ${ }^{2}$ Ib., i. 124. $\quad 3$ Ib., i. 125. $\quad{ }^{4}$ Ib., i. I37. 



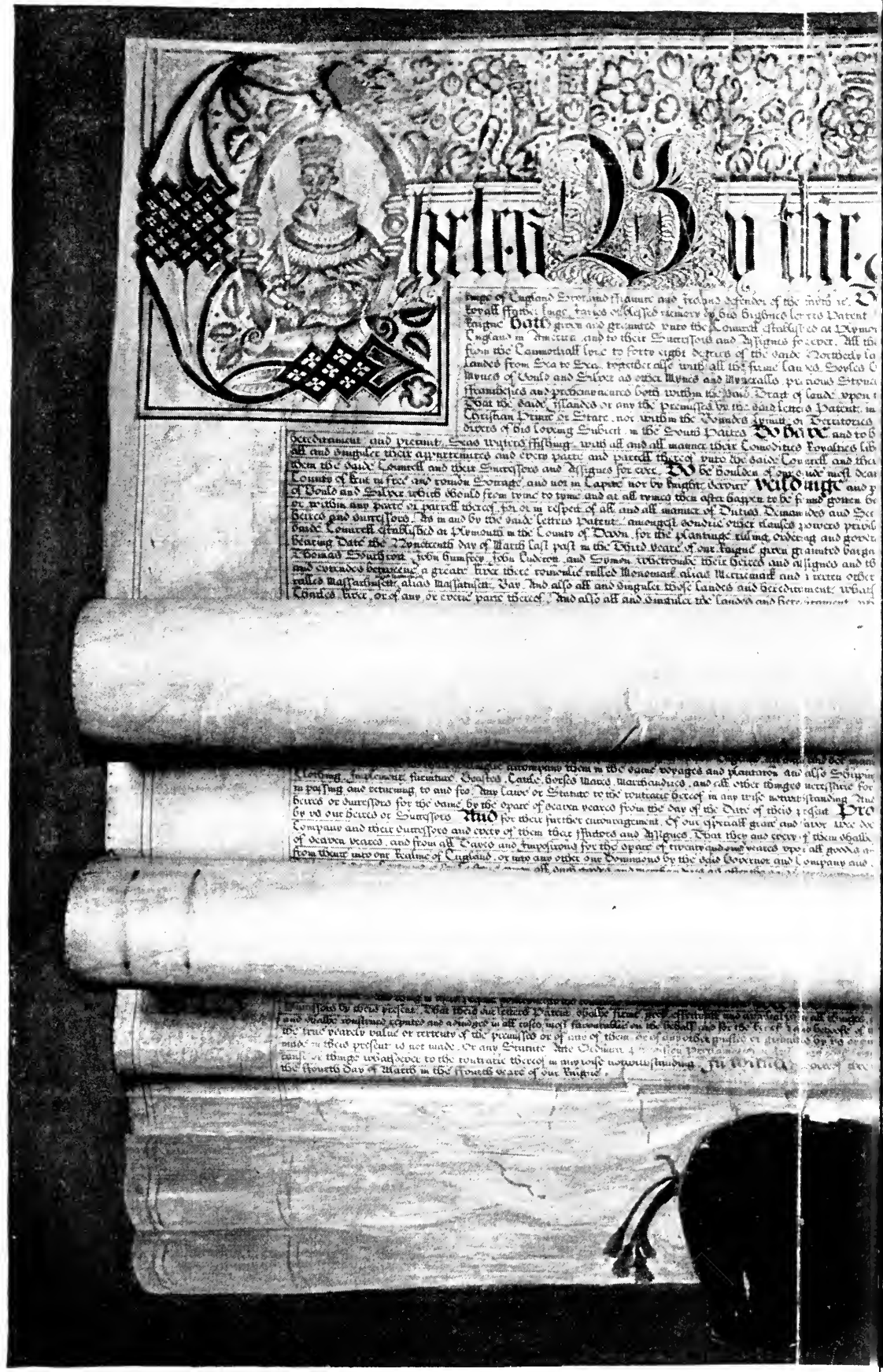



Massachusetts was now ordered to lay its charter before the Privy Council, with the purpose if it was once there, no doubt, to extinguish it.

Winthrop says, "Mr. Cradock wrote to the governor [Mr. Dudley] and assistants, and sent a copy of the Council's order, whereby we were required to send over our patent. Upon long consultation whether we should return answer or not, we agreed, and returned answer to Mr. Cradock, excusing that it could not be done but by a General Court, which was to be holden in September next." 1

And thus, by first one excuse and then by another, they put off the sending of the charter, delaying with Fabian policy for a more convenient season, which never came. "A writ of quo warranto was issued against the charter, and it was declared null and void, and Gorges was created viceregal governor of New England. But death swept off their arch-enemy Mason at a critical moment, and the British government found all it could attend to henceforth for some time, in caring for the discontented factions at home." 2

"The elements that gave energy to a commonwealth, in peace or war, are strikingly disclosed and illustrated in the history of Massachusetts under the first charter. A more efficient government for the preservation of order, security, and the common welfare has never existed; and the rapidity with which the public resources were brought to bear in military movements, while it was repeated at the opening of the war of Independence, has never been surpassed, even in our day, which has witnessed the uprising in their might of a great people to save the national life." 3

The unpopularity of Winthrop at this time appears in the appointment of a committee at the first Court after his departure from office, " to take an account of John Winthrop, Esq., for such commodities as he hath received of the com-

1 Winthrop, i. * 137 .

2 Maverick's Brief Description of N. E., I660, I8.

8 Mass., Its Early Hist., Lect. Lowell Inst., by Charles W. Upham, $245,246$. 
mon stock. ${ }^{1}$ The account of Governor Winthrop is duly recorded on the Court record the next September. ${ }^{2}$ Hutchinson says, "After he was out of the chair, he was questioned in such a manner, as appears to have been disagreeable to him, concerning his receipts and disbursements for the public during his administration. Having discharged himself with great honor ..." 3 Robert C. Winthrop says in regard to this that he is not disposed to complain of the request for an account. "It exhibits the scrupulous exactness which was demanded of the servants of the commonwealth in those early days, and inculcates a lesson of responsibility which may well be studied by their successors." 4 It was not, however, the request for the account that disturbed the mind of Governor Winthrop. No honest man would object . to that; it was the manner in which it was done, it was the critical spirit which was abroad, it was "ingratitude, more strong than traitors' arms," that went to his heart. He nobly vindicated himself, and in that effort gave an interior view of his service to the public which is priceless.

The friends and admirers of Governor Dudley may well congratulate themselves that nowhere on the public records is to be found any attempt to put him under investigation, or his administrations, civil, military, or judicial, which in whole or in part continued through the twenty-three most important years, under the first charter.

The Court turned aside from the consideration of a fearful foreign war and preparations to resist cruel enemies, to make war upon the vain fashions of society, as follows: "The Court, taking into consideration the great, superfluous, and unnecessary expenses occasioned by reason of some new and immodest fashions, as also the ordinary wearing of silver, gold, and silk laces, girdles, hat bands, etc., hath therefore ordered that no person, either man or woman, shall hereafter make or buy any apparel, either woolen, silk, or linen, with

1 Mass. Col. Rec., i. 120.

2 Ib., i. 130.

${ }^{3}$ Hutchinson, i. 40.

4 Life and Letters of John Winthrop, ii. 123. 
any lace on it, silver, gold, silk or thread, under the penalty of forfeiture of such cloths, etc.

"Also that no person, either man or woman, shall make or buy any slashed clothes, other than one slash in each sleeve, and another in the back; also all cutworks, embroidered or needle-work caps, bands, and rayles, are forbidden hereafter to be made and worn, under the aforesaid penalty; also, all gold or silver girdles, hatbands, belts, ruffs, beaver hats, are prohibited to be bought and worn hereafter under the aforesaid penalty, etc.

"Provided, and it is the meaning of the Court, that men and women shall have liberty to wear out such apparel as they have now provided of (except the immoderate great sleeves, slashed apparel, immoderate great rayles, long wings, etc.) ; this order to take place a fortnight after the publishing thereof." 1

"It is further ordered, that no person whatsoever shall either buy or sell any tobacco within this jurisdiction after the last of September next." 2 "Whereas complaint hath been made to this Court that divers persons within this jurisdiction do usually absent themselves from church meetings upon the Lord's day, power is therefore given to any two assistants to hear and censure, either by fine or imprisonment (at their discretion), all misdemeanors of that kind committed by any inhabitant within this jurisdiction." 3

It certainly is matter of surprise that even among these Puritans, in the administration of Dudley, something of the "vain pomp and glory of this world" appears in the following: "Further it is ordered, that at every General Court there shall be six men appointed by the governor for the time being, out of the town where he lives, to attend, with halberts and swords, upon the person of the governor, and the rest of the members of the Court, during the space of the first day of every General Court, and that there shall be two men appointed by the governor to attend, in like manner, at every particular Court, at the public charge." 4
1 Mass. Col. Rec., i. 126.
2 Ib., i. 236.
8 Ib., i. I40.
4 Ib., i. 142. 
The question which caused the greatest trouble to the Court in this September session was the desire of Hooker and his church to remove to Connecticut, which they accomplished two years later. Different reasons have been assigned for their anxiety to depart. It has been thought that Cotton and Hooker were in the way of each other, and that they did not agree well. It has been suggested that the approaching Antinomian troubles hastened their departure. These do not appear on the record as the causes, and are a matter therefore of inference. Winthrop says :-

"The principal reasons for their removal were, I. Their want of accommodation for their cattle, so as they were not able to maintain their ministers, nor could receive any more of their friends to help them; and here it was alleged by Mr. Hooker, as a fundamental error, that towns were set so near each to other. 2. The fruitfulness and commodiousness of Connecticut, and the danger of having it possessed by others, Dutch or English. 3. The strong bent of their spirits to remove thither.

"Against these it was said, I. That, in point of conscience, they ought not to depart from us, being knit to us in one body, and bound by oath to seek the welfare of this commonwealth, etc." 1 "Upon these and other arguments the Court being divided, it was put to vote; and of the deputies, fifteen were for their departure, and ten against it. The governor [Thomas Dudley] and two assistants were for it, and the deputy [Roger Ludlow] and all the rest of the assistants were against it (except the secretary, ${ }^{2}$ who gave no vote); whereupon no record was entered, because there were not six assistants in the vote, as the patent requires. ${ }^{3}$

1 Winthrop, i. * I 40.

2 Simon Bradstreet, son-in-law of Dudley, who was with him from Cambridge, where the petitioners resided.

8 It is quite possible that Governor John Haynes voted with Governor Dudley and the Cambridge faction, to let these people depart for Connecticut; both he and Governor Ludlow joined the emigrants when they finally went. 
Upon this grew great difference between the governor [Thomas Dudley] and assistants, and the deputies. They would not yield the assistants a negative voice, and the others [that is, the governor and assistants], considering how dangerous it might be to the commonwealth, if they should not keep that strength to balance the greater number of the deputies, thought it safe to stand upon it." 1

The negative voice became a vital question in the politics of the colony in I643. The colony was powerless to let Hooker and his associate emigrate to Connecticut, so they all turned to the ministers for light and consolation, and waited two years for the way to open, and for Massachusetts to learn how foolish it was to hold unwilling and restless people who were constantly considering the perfection of the place where they wished to be, and could find no contentment until they had freedom to go and abide on that desired spot of earth.

Dudley saw the uselessness of the effort to retain these people from the first, and did what he could to set them free; but he had to yield to the opinion of the majority and wait for the people of Massachusetts to learn that they could not retain them for a long time against their fixed determination to depart. He exercised at all times distinguished patience with the adverse opinions of other people. This ennobled his life, and rendered his character greater in the minds of his contemporaries, and ought to extend its influence more and more in public estimation.

He was at the head of the colony in this most remarkable and revolutionary period, when the people were contending for and securing their share in the government, when perils at home were only surpassed by far more ominous perils from abroad. There was at the helm of state then a man both vigilant and sagacious; there was neither doubt nor confusion in the administration, and we discover no mistakes which lie at the door of the governor. It is sometimes thought that the most able man in the colony at that time

1 Winthrop, i. *I4I. 
was the Rev. John Cotton, and that its success was due to his wisdom. But no minister was permitted to hold civil office; he could only advise, and had no living voice or vote in the government. Dudley did not affiliate very much with him in America, although they were warm friends in England, and he appears to have been the only magistrate who had the courage to say to Cotton and to the other ministers, in a polite, graceful, and most convincing manner: Please to attend to your own legitimate calling.

Governor Dudley was, first, conscientious ; second, utterly fearless; third, remarkably gifted with common sense, liberal in politics, guided by principles of permanent importance rather than by temporary expedients. Indeed, he and other Puritans believed that by adhering to the literal words of the Old Testament, regarded as a statute book, they were certain to be right, since they were guided by the Eternal and Unchangeable, indeed by Truth itself.

The attempt has been made to detract from his public importance, on the ground that he was permitted to hold the office of governor only four terms of one year each, while Governor Winthrop enjoyed the public confidence for longer periods. This comparison of popularity has no force, since the people had only just begun to govern themselves, and rotation in the office of governor was a cardinal topic at the end of Governor Winthrop's first term as it never had been before. Dudley himself, as I have already pointed out, was no doubt a strong advocate of this rule, for he took to himself the office of governship not oftener than once in five years. His friend and neighbor, John Haynes, of the same Cambridge faction, succeeded him after his first term in office, while Dudley was elected at once an assistant. If any one is inclined to account it a day of small things, and to belittle the conspicuous characters in this undertaking in Massachusetts, it would be well for him to remember that " the guiding and directing force was supplied by an element which was itself moulded on the banks of the Cam and the Isis, under the influence and refinements of the best 
culture which the England of that day could give." 1 Dudley, it is true, was not himself a university man, but he was a very studious and scholarly person, who on both sides of the sea removed from place to place to be the companion and pupil of the first men of the university, and thus brought himself in touch with the best learning of his period throughout his mature years. But above and beyond this appears the conclusive fact that, without deceit or political subterfuge he sustained himself in the high places of power, retaining to the very end of life the confidence and reverence of the wisest and best men among his contemporaries. Nothing less than great gifts, great acquirements, and great virtues could have achieved such success.

1 Franklin B. Dexter's Influence of the English Universities in the Development of New England. 


\section{CHAPTER XIX}

We delight to think of the assistants at this September Court, I634, entertained at the house of Governor Dudley, in Cambridge, as they had been received by Governor Winthrop during his long administration at his home in Boston, when the Court sat in that town. ${ }^{1}$

Governor Dudley was now in his prime, affluent in worldly possessions, rich in experience, full of information gathered from books, his mind stored with incidents connected with the great men and events of two wonderful generations in English history. Here he then sat at the age of fifty-eight years, at the head of his table, with a generous, dignified manner, dispensing colonial hospitality and entertaining the nobility of Massachusetts with the good things of life.

These people were accustomed to society and fond of good cheer. They must have been excellent company, at least for each other, scoffers to the contrary notwithstanding. Anne Bradstreet assures us that her father was "A Prizer of good Company." 2 The Rev. Nathaniel Rogers, who was personally acquainted with Dudley, said of him :-

"A table-talker, rich in sense, And witty without wit's pretense." 8

Human nature has much in common under all conditions and disguises. Wise, learned, experienced, and good men have abundant resources for entertainment, especially if they possess culture, social arts and graces, sincerity in speech and manner, - qualities which surely distinguished the governor in the drawing-room and at the head of his table.

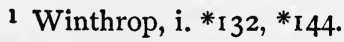

2 Epitaph on Thomas Dudley, by Anne Bradstreet.

3 History of Dudley Family, i. 83; Mather's Magnalia, i. I23. 
Governor Dudley and the Court did what they could to reconcile the Indian tribes to each other, and to induce them to make peace, instead of stimulating their warlike natures to destroy each other. This shows the humane and excellent quality of these Christian people, when their selfish interests, in the estimation of those who seek only power and are influenced by the greed of gain to revel in the destruction of weaker races, would have been best subserved by their ruin. They regarded them as wards committed under divine appointment to their care and protection.

They furnish us in this instance with a lovely picture of the power and influence of our holy religion over the petty and base elements in human nature. ${ }^{1}$

A favorite method of reducing the relative importance and merit of Governor Dudley is to compare him and match him with Governor Endicott. But the resemblance between them in education, in refinement, in temper, or in any other respect, was slight and to the advantage of Dudley; they were both indeed resolute, vigorous Puritans. Governor Dudley could not have been induced, as Endicott was, to have defaced "the cross in the British ensign at Salem." 2

He was not, like Endicott, "rash and without discretion, taking upon him more authority than he had, and not seeking the advice of the Court." 3 Dudley was never in contempt of court for his rashness, and forced, like Endicott, to make his submission and acknowledgment of his offense. ${ }^{4}$

Governor Dudley was also too large a man to allow the arguments against the cross in the ensign to prevent him from unfurling it with Harry Vane in $1636 . \mathrm{He}$ had marched with it at the head of his column in war, and was not in a mood to share in its mutilation or destruction. The conduct of Governor Winthrop in this matter of the ensign in 1636 , and also the doubt and the fear of the whole Court of Assistants in this miserable business, render it certain

1 Winthrop, i. *I 49; Knowles's Memoir of Roger Williams, 97.

${ }^{2}$ Mass. Col. Rec., i. 137, 145, 146; Winthrop, i. * ${ }_{150}{ }_{5}{ }_{15} 58$, and note.

8 Winthrop, i. * ${ }^{*} 58$.

1 Mass. Col. Rec., i. 157. 
that Dudley was less fanatical than the Court, than Winthrop or Endicott, and that he was more dignified and sensible than any of them.

The last official act of Governor Dudley, according to Winthrop, in his administration as governor in $1634-35$, was as follows: "The governor and assistants sent for Mr. Williams, the occasion was, for that he had taught publicly, that a magistrate ought not to tender an oath to an unregenerate man, for that we thereby have communion with a wicked man in the worship of God, and cause him to take the name of God in vain. He was heard before all the ministers, and very clearly confuted. Mr. Endicott was at first of the same opinion, but he gave place to the truth." 1 Winthrop seems to leave the inference that Williams did not give place to the truth, but clung to his error.

Cotton Mather says: “The Court, about a year before they proceeded unto the banishment of this incendiary, sent for the pastors of the neighboring churches, to intimate unto them their design, of thus proceeding against him; which yet they were loath to do, before they had advised the elders of it, because he was himself an elder. Mr. Cotton, with the consent of the other ministers, presented a request unto the magistrates, that they would please to forbear prosecuting of him, till they themselves, with their churches, had in a church-way endeavored his conviction and repentance; for they alleged, that they hoped his violences proceeded rather from a misguided conscience, than from a seditious principle. The governor [Thomas Dudley] foretold unto them, you are deceived in the man, if you think he will condescend to learn of any of you; however the proposal of the ministers was approved and allowed. .. He renounced them all as no churches of our Lord Jesus Christ." 2

Dudley was correct in his estimate of Williams and of the absence of the childlike, teachable spirit in his constitution. He was certain that they might as well argue with the north

1 Winthrop, i. * 158.

2 Mather's Magnalia, ii. bk. vii. chap. ii. § 5, 43I, 432. 
wind, and this opinion of him was fully vindicated. The untenable position taken by Williams in this matter shows how little he comprehended the forces of civil government. The oath is made even now, and has been ever since that day, the formal cement which binds every officer of government, professed Christian or otherwise, from the president of the republic down to the petty officer of the smallest school district, except a few who are permitted to affirm. It is in constant use in court. We know that patriotism, conscience, and reverence for truth are the real forces underlying, but it will be long before these uses of oaths will disappear, or the question of regeneration will be a condition precedent to the administering of them to officers-elect or to witnesses in court. It may be claimed still that Williams was in this matter of oaths centuries in advance of his age, but such an assumption is not important. Dudley, who in his judicial service was in the constant use of oaths, was justified in regarding these doctrines as full of public peril ${ }^{1}$ and tending towards anarchy. We are required to examine carefully the share Dudley had in dealing with Williams, because most writers who defend Williams find it needful to say bitter things of Dudley, to paint him with dark colors, because he has now become the standard in literature representing the bigotry of the Massachusetts Puritans.

Governor Winthrop entered earnestly and argumentatively into the reasons for the action of the colony and Court in their treatment of Williams, and one can discover in reading his Journal no disapproval of the attempt of the Court to send Williams to England. We learn, however, from the letters of Williams that Winthrop had at that very same time, certainly not in very good faith toward his associates in the government of Massachusetts, put it into the head of Williams that Rhode Island was his best place of escape. ${ }^{2}$

1 The author deems it to be his duty to remark that he personally neither adopts the public estimate of the value of oaths, nor the peculiar opinions of Williams.

2 Knowles's Memoir of Williams, 74 . 
That refuge the Massachusetts Court was anxious to keep Williams out of, and therefore sought to send him to England, lest he should from his near vantage ground sow tares and heresy in Massachusetts. This adroit conduct, if we are correct, may call forth hosannas from the friends of Williams, but it was too costly a price for Winthrop to pay for their approval. ${ }^{1}$

Winthrop's loyalty to the Court is in his Journal made to appear firm and consistent. ${ }^{2}$ The Court thereupon sent an officer to Salem to arrest Williams, who had escaped and gone towards Rhode Island with at least the probable knowledge of Winthrop, who had aided and abetted his escape, and directed him to Rhode Island, which place he might never have known of, or found at all, but for Winthrop and Winslow, and might have been safely returned to England.

Williams says: "It pleased the Most High to direct my steps into this bay, by the loving, private advice of the everhonored soul, Mr. John Winthrop, the grandfather, who, though he were carried with the stream for my banishment, yet he tenderly loved me to his last breath." He evidently understood Winthrop to have approved of his departure.

But Williams wrote in a letter to Major Mason, of Connecticut, which appears in the Massachusetts Historical Society's Collections, i. $275^{3}$ as follows : "When I was unkindly and unchristianly, as I believed, driven from my house and land, and wife and children, in the midst of an New England winter, now about thirty-five years past, at Salem, that everhonored governor, Mr. Winthrop, privately wrote to me to steer my course to the Narragansett Bay and Indians, for many high and heavenly and public ends, encouraging me, from the freeness of the place from any English claims or patents. I took his prudent motion as a hint and voice from

1 We have heretofore detected Winthrop in the matter of placing his house in Cambridge; making promises both to the citizens of Cambridge and of Boston so in conflict with each other that faith had to be broken with one party in order to perform promises made to the other, -a course of conduct which is not commendable. (P. 96, this volume.)

2 Winthrop, i. * ${ }^{*} 70,{ }^{*}{ }_{175},{ }^{*}{ }^{2} 76 . \quad{ }^{8}$ Pub. Narr. Club, vi. 335. 
God, and waiving all other thoughts and motions, I steered my course from Salem."

A commission was sent to Captain Underhill to apprehend Williams at Salem, to have him returned to England. Underhill went to Williams's house in Salem, and found that he had been gone three days. Winthrop appears to have had reasonable cause to believe that Williams had gone to Rhode Island under the suggestion of his own secret letter to him. But he continues in his Journal as follows: "But when they came to his house they found [just as though he did not know the fact in advance] that he had been gone three days before, but whither they could not learn." Can there be a reasonable doubt that Winthrop knew all this time well enough what road Williams had taken under his own personal direction?

Blackstone, who left England, as he said, "to avoid the Lord Bishops, and Massachusetts to be free from the Lord Brethren," had preceded Williams to Rhode Island, having sold his Boston estate. Perhaps Winthrop thought Williams could not do a wiser thing than to follow Blackstone into Rhode Island. It is important to remember that the sufferings of Williams in his immigration to Rhode Island arose from his own choice of place. The Court desired his comfortable passage to England instead of privations in the wilderness among Indians.

Winthrop says further: "It was agreed to send him [Williams] to England by a ship then ready to depart. The reason was, because he had drawn above twenty persons to his opinion, and they were intended to erect a plantation about Narragansett Bay, from whence the infection would easily spread into these churches." 1 Thus he, entertaining, or claiming to entertain, such sentiments, secretly conspired by his letter to spread this infection in the churches, and to thwart the very efforts being made by his associates to protect them. He united with the Court, as one who believed the influence of Williams an infection, which they had wisely

1 Winthrop, i. ${ }^{*}{ }_{175},{ }^{*}{ }_{176}$ 
concluded, first, to quarantine in Salem six months, and, finding this useless, had resolved to send to Europe. Winthrop not only deceived the Court intentionally or otherwise; he deceived all the world by these remarkable entries in his diary, and the truth would never have been known but for the letter of Roger Williams.

Nevertheless there will be found persons who will approve of his humane motive in his concealed effort to aid Williams. But we are unable to discover a reasonable excuse for him.

The satisfaction that some persons find in charging the misfortunes of Williams to Dudley and Haynes is indeed quite remarkable. They speak of "the mild and amiable Winthrop, who was the ablest as well as the most liberal man of his age and place." 1 Arnold says : "The bigoted Dudley had succeeded to the chief magistracy as the leader of the most restrictive party in Massachusetts. The persecution of Williams is to be attributed to a policy of which Dudley and his successor Haynes were the exponents." 2 It seems never to have entered the minds of these writers that it was the colony that was being persecuted, and that Williams was the intolerant man. They seem to forget that Williams might be at fault in part, as well as the honest government which was calmly trying to maintain its existence in the face of its enemies. Mr. Arnold finds, on page 147 , an opportunity to use still more bitter language respecting Dudley, although when he has once used the word "bigoted," he has nearly exhausted the ancient stock of vituperation. That word covers more malignity in the opinion of some persons than any other epithet of its class ; it may, however, be strengthened by the addition of the word " narrow."

We are thoroughly convinced on the authorities that Williams was induced to depart from Massachusetts solely on political grounds, simply on a question of public policy, which had nothing to do with religious liberty. Soul liberty was an afterthought with him. ${ }^{3}$

1 S. T. Arnold's Hist. R. I., i. 46.

2 Ib., i. 46.

8 Pub. Narr. Club, ii. 4-8; Ellis's Puritan Age, 267-29I ; Palfrey, 
What had the alleged bigotry of Dudley to do with the question of his departure, or how could it complicate it in any way? Was it not a departure from propriety and justice to attribute to Dudley disagreeable names which had nothing to do with the issue? The order for the so-called banishment ${ }^{1}$ of Williams fortunately is matter of record, and shows for itself the whole sad story. It is as follows: "Whereas Mr. Roger Williams, one of the elders of the church of Salem, hath broached and divulged divers new and dangerous opinions against the authority of magistrates, as also written letters of defamation, both of the magistrates and churches here, and that before any conviction, and yet maintaineth the same without retraction, it is therefore ordered, that the said Mr. Williams shall depart out of this jurisdiction within six weeks now next ensuing, which, if he neglect to perform, it shall be lawful for the governor and two of the magistrates to send him to some place out of this jurisdiction, not to return any more without license from the Court." 2

The government had only two ways of protecting itself completely against persons dangerous to society, - those were either capital punishment or banishment. They had

i. 414; Dexter's As to Roger Williams, 79. Neither he, nor either of the thirteen proprietors signed the famous compact, "only in civil things." (R. I. Col. Rec., i. 14, 20 ; Baptist Quar., x. 199; Pub. Narr. Club, vi. 5.)

1 Banishment in the case of Williams is, if it be proper to call it that, at least peculiar. He was sentenced, September 3,1635 , "to depart out of this jurisdiction within six weeks" (Mass. Col. Rec., i. I6r); subsequently he obtained "permission to remain until spring," but would not refrain from teaching in his own house, contrary to the understanding of the Court when it granted the respite; it therefore resolved to send him to England, but he escaped and went to Rhode Island. Consequently the orders of the Court were neither of them ever executed upon him by its own officers. Williams's journey to Rhode Island was not in obedience to the Court, but was exactly what they most feared. We cannot state the occurrence more strongly for his side than to say that he was influenced indirectly to exile himself.

2 Mass. Col. Rec., i. I60, I61 ; Pub. Narr. Club, ii. 8. 
no prisons, reformatory institutions, or asylums. Williams is represented as liberty enlightening the world, and Dudley as a restrictive, soul-bound bigot. There is no question that Dudley was conspicuous in sustaining a reliable government in Massachusetts, which won confidence everywhere, drew emigrants, and made the other New England colonies possible, and has been the generic model in a large measure both in the construction of American States and of the general government itself. Roger Williams, whose greatest work was the securing of the parliamentary charter of Rhode Island, - not a satisfactory one, - through the friendship of Harry Vane, the Earl of Warwick, and others, was a kindhearted, good, even great man, but he could not endure restraint; he would not live even in church limitations which he had created himself. His writings, for two centuries and more, have greatly contributed to human freedom. He did not reach the head of government in his own town of Providence until near the end of the first generation, when Winthrop and Dudley were gone. He held power only two years and eight months, from September, 1654, to May, I657, during which the government was feeble and unstable. ${ }^{1}$

We freely grant that Williams was a great agitator, was an apostle of soul liberty in religion and politics, but not the discoverer of that doctrine, not constructive in statecraft. $^{2}$ At the same time we must claim with equal assurance that Dudley, the creator, guardian, fearless defender, and executive of that righteous law without which liberty

1 He said himself in a letter to the General Court of Massachusetts after he had been in office one year, "Honored Sirs, I cordially profess it before the Most High, that I believe it, if not only they (the families at Pawtuxet and Warwick, under the rule of Gorton), but ourselves and all the whole country, by joint consent, were subject to your government, it might be a rich mercy." (Pub. Narr. Club, vi. 205 ; Knowles's Memoir of Roger Williams, 282, 283, 285.)

2 Rhode Island took from its small beginning an impregnable position in defense of religious liberty and of civil freedom. It did not originate the doctrines, it merely exemplified them. (Crosby's Hist., Appendix to vol. ii.; Cong. in Lit., by H. M. Dexter, IOI-I03, 704.) Individualism was so intense there that every element for a while 
cannot exist, was in character his equal, his superior in administrative power.

seemed to repel every other in the community, each person and plantation became a political entity, avoiding entangling alliances, but the terror of being absorbed either into Plymouth or Massachusetts was the leading centripetal force that finally established the union into one colony. (Staples, Annals of Providence, 69, 70, 86, 89, 99, 100, 1 19, 1 36.)

There was really no stable government until the royal charter of I663, ten years after the decease of Dudley; he never knew the colony, therefore, except in its unsettled beginning. This was the first charter which guaranteed soul liberty in Rhode Island, and was not secured by Williams, but by Dr. John Clarke, of Newport, who has received the distinguished designation of being called the "Father of Rhode Island." This charter recites: "Whereas, we have been informed, by the humble petition of our trusty and well beloved subject John Clarke, on behalf of Benjamin Arnold" and others. This charter was the Constitution of Rhode Island until the Dorr war in I843. (Staples, I27.) It was then the oldest constitutional charter in the world. (Arnold's Hist. of Rhode Island, i. 294.) Williams was never governor under this charter, although he lived twenty years after it was granted. It is said, but not proven, that Clarke wrote those memorable words in the code (R. I. Col. Rec., i. I90) of laws under the Rhode Island Confederacy of 1647 , when Williams's first charter, which met with little success, was adopted as the form of government for the colony. The words were: "And otherwise than thus what is herein forbidden, all men may walk as their consciences persuade them, every one in the name of his God. And let the saints of the Most High walk in this colony without molestation, in the name of Jehovah, their God, for ever and ever." Clarke said in addressing the king with regard to his colony, "It is much on their hearts, if they may be permitted, to hold forth a lively experiment, that a most flourishing civil state may stand, and best be maintained, and that among our English subjects, with a full liberty in religious concernments." (Preston's Documents, I12 ; Baptist Quarterly, x. I87, 27I ; Coll. Mass. Hist. Soc., 4th series, ii. III ; Hist. Baptists, by Backus, i. 280, 349-35 I.) Neither John Clarke in Rhode Island, nor Thomas Dudley in Massachusetts, has yet received the attention from the public which their important services merit. If enmity against Massachusetts and the Puritans, or sympathy with the kind-hearted, magnanimous Roger Williams, be at the bottom of that public sentiment which appears on his side of the question, then Clarke has a stronger claim, for he was sentenced to pay a fine or be whipped, and was in prison in Boston more than three weeks, bearing testimony to his Baptist faith in July and August, 1651. (Ill Newes from New England, Coll. Mass. Hist. Soc., 2d series, ii. 3I-37.) 


\section{CHAPTER XX}

Winthrop informs us that "divers jealousies, that had been between the magistrates and deputies, were now cleared, with full satisfaction to all parties." But a little later he says, "The deputies having conceived great danger to our state, in regard that our magistrates, for want of positive laws, in many cases, might proceed according to their discretion, it was agreed that some men should be appointed to frame a body of grounds of laws, in resemblance to a Magna Charta, which, being allowed by some of the ministers and the General Court, should be received for fundamental laws." 1 The governor, deputy governor, John Winthrop, and Thomas Dudley, Esq., are deputed by the Court to make a draft of such laws as they shall judge needful for the well ordering of this plantation, and to present the same to the Court. ${ }^{2}$

The people were desirous of having established and wellknown laws, and of avoiding as much as possible the personal discretion of the magistrates in judicial decisions. They were convinced that without law there is no just condemnation, and that every citizen ought to have an opportunity to know in advance the law which furnishes protection to his person and property, and raises the presumption that every man knows the law "except the judges, who must be instructed by the lawyers." And, further, that ignorance of the law might be no excuse, they saw, as we see, the paramount importance of written laws.

This subject was not suffered to rest long by the people, who had far more solicitude about it than the magistrates, who thought that laws were more valuable when they grew

1 Winthrop, i. * ${ }_{1} 60$.

2 Mass. Col. Rec., i. 147. 
one by one out of experience and the necessities of the occasion, than when constructed on theory in advance of their usefulness.

The agitation went on, however, until $164 \mathrm{I}$, when the Court approved of the famous Body of Liberties, which is the foundation of Massachusetts legislation in construction of statutes.

The ministers were conspicuous in the creation of this code, as was natural and proper. If the Bible was the chief source to be drawn from, who were more learned in that volume than the men who had devoted their lives to the study of it? It is notable that the greatest divine in the colony, John Cotton, tried his hand at it and failed; and that the distinguished men learned in English common law, Dudley, Winthrop, and Bellingham, were invited to inspect, supervise, and improve, but not to construct the code to be prepared. This important work was left to Cotton and to Nathaniel Ward, of Ipswich. Ward was first a lawyer, second a minister, and third a poet. He produced the organic law, which was amended, improved, and illuminated by all the legal and clerical wisdom of the fathers until it was duly perfected.

The Puritans were almost as hostile to lawyers, as such, as they were towards heretics. Their aversion to them was as strong as that of Peter the Great, who, seeing them in England, said " that he had only one lawyer in his empire, and that he intended to hang him as soon as he arrived in Russia." They did not admit the profession to be a legitimate business, as poor Lechford learned to his sorrow. But Ward had been a lawyer, and was now first and foremost a minister, and had been so seasoned with the Bible, with grace, and with poetry, and withal was so well qualified, that the codification and construction of the laws was left in his hands, and by him completed, to the satisfaction of the Court. ${ }^{1}$

1 William H. Whitmore's Colonial Laws of Mass., containing also, The Body of Liberties of $1641,5-9,29-64$. 
The position of Dudley on nearly all of these committees as counselor, from 1635 till $164 \mathrm{I}$, shows us how important his judgment and wisdom were deemed to be in this beginning of the laws. He was probably the oldest man in the service, therefore the work of compiling and research came mostly to others; but in the supervision and final determination of the text we may well believe, from what we know of his judicial record, that no one had a greater influence than himself. ${ }^{1}$ Ward was residing at Ipswich during the years I635 to 1636 inclusive, and Dudley was no doubt a constant attęndant on his preaching at that place. They are believed to have been sincere friends, and it is thought that one of the motives of Dudley in going to reside at Ipswich was to be near to Ward and to attend his church.

The General Court in I635 enacted, "that Mr. Thomas Dudley, Mr. Beecher, Mr. Waltham, Mr. Duncom, Mr. Tylley, and Mr. Peirce, these forenamed gentlemen or any three of them, whereof $M r$. Dudley always to be one, shall have power to consult, advise, and take order for the setting forwards and after managing of a fishing trade, and upon their account all charges of diet or otherwise, at the times of their meeting to be allowed out of the fishing stock." 2 Our attention is thus attracted again to the business qualities of Dudley, thus recognized in the colony, capabilities which had distinguished him in England. The fisheries were for many years the most important and lucrative interest in the commerce of Massachusetts ; therefore we are not surprised that the business judgment of Dudley was to enter every transaction, no matter who his associates were. This is a fine contemporary testimony to his capacity, integrity, and to the public confidence in him.

Fish at one time in I63 I was the only food of the people. ${ }^{3}$ Cape Ann was peopled by fishermen. ${ }^{4}$

In the time of great scarcity of food at Plymouth, their

1 Mass. Col. Rec., i. I6I, 194.

2 Ib., i. 158.

3 Wonder-Working Providence, by Edward Johnson, chap. xxiv.

4 Ib., chap. xx., I64I. 
little boat saved them. "It helped them to improve the net, wherewith they took a multitude of bass, which was their

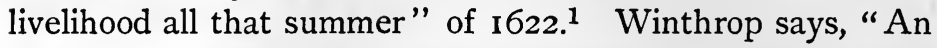
order was made, that all stocks employed in fishing should be free from public charge for seven years." Fishermen were free from military duty. He informs us further how lucrative the fisheries were in 1639 : "Here was such store of exceedingly large and fat mackerel upon our coasts this season, as was a great benefit to all our plantation. Some one boat with three men would take, in a week, ten hogsheads, which was sold at Connecticut for $£_{3}$ I2s. the hogshead." 2 This industry led to shipbuilding. ${ }^{3}$

The whale and cod fishing in Massachusetts, we are told, amounted in 1750 to $\$ 1,250,000$ per year. The importance of the codfish to Massachusetts in its early history is sufficient reason for the emblem now suspended in the popular hall of the legislature of that State, that the representatives of the people, when they assemble to make laws, may not be unmindful of the source of prosperity and even of sustenance of their predecessors, ${ }^{4}$ just as the lord chancellor of England is required to sit on the wool-sack, to remind the noble lords that wool was once the staple production of the kingdom.

These circumstances assist us to realize what an important figure in the business circles of the Bay the excellent citizen was whose life work claims our attention.

It taxes severely our courage to question the opinions of Mr. Savage, but we are quite convinced that he misapprehended the intent of the complaint against Winthrop, by Vane, Peters, Hooker, and others, set forth in Winthrop. ${ }^{5}$ If we are correct, he not only went astray here, but he has caused many rejoicing adherents to the same love of Winthrop, and aversion to Dudley, to fall into the like error with himself.

1 Hubbard, 80.

${ }^{3}$ Palf. Hist. N. E., i. 55.

5 Vol. i. *I 77-*I79, note I.
2 Winthrop's Journal, i. *307, 308.

4 Memorial Hist. of Boston, 47, note. 
It was made to appear at the meeting; it seems, that there was a Dudley faction and a Winthrop faction. Dudley had been governor in 1634, and had, with the energy of a business man, trained in the regular and correct methods of Judge Nichols at Westminster, and also with the strict discipline of a soldier, set an example in the method of doing the public business which many people approved, and it became the subject of talk and of comparison not favorable to the administration of Winthrop. The Cambridge faction, with Haynes, Hooker, and other leading men in it, desired more dignity and less looseness in the management of affairs, according to approved precedents in well-organized governments. The proceedings at this meeting had no connection with soul liberty, or with Winthrop's being lax or harsh with tender consciences or deluded fanatics. It pertained strictly to general rules and orders, regardless of the religion, politics, or parties which were to guide the conduct of the officers of court in all cases. Its trend was neither on the one hand in the direction of bigotry, nor on the other of latitudinarianism. It was absolutely neutral in religion. All of which we think will clearly appear from a careful perusal of the fifteen rules of court. ${ }^{1}$ Savage says, "The general result of this conference must, I think, be, regretted. When the administration of Winthrop was impeached by Governor Haynes for too great lenity, it seems natural that such severe tempers as Dudley, Vane, and Peters should unite in the attack." He succeeds in introducing the "severe temper" of Dudley. Mr. Savage could not easily pass Dudley in any event without striking him, neither would he fail to emphasize the meekness and gentleness of Winthrop. Yet the words of Dudley on that occasion were gentle, loving, excellent. He said, in the words of Winthrop's account, "Though there had been formerly some differences and breaches between them, yet they had been healed, and for his part he was not willing to renew them again; and so left it to others to utter their own complaints." He was out of it, he was 1 Winthrop, i. * ${ }_{178}, *_{1} 79$. 
not the man to ask others to do his own disagreeable duties, he made no complaint, and must not be held as attempting to improve Winthrop's business habits. There have been persons who dated Winthrop's downfall into bigotry from the influence of this meeting and who charged the responsibility of his declension upon the innocent Dudley. Thus Dudley is made to bear the sins of both, and to go evermore double freighted with opprobrium, in the estimation of people who seek to visit the sins of Winthrop upon others. It would be as reasonable to charge the Rules and Orders of the Massachusetts Legislature of I 899 with persecution in 1635 and 1636 , as the Rules of Practice and Procedure agreed upon at the meeting in 1635 . This affair and its consequences broadens, however, in the mind of Mr. Savage, until he includes the dreadful clergy as particeps criminis, with all the concentrated bigotry believed to have been in them. He regards Vane, Peters, and Dudley only as simple tools of the shepherds. Subsequent writers, as we have said, have freely taught that Winthrop took at this fatal juncture a proclivity towards bigotry totally unlike anything ever observed in him in England, and that the change is due to Dudley. So little is known of Winthrop's life in England that such statements do not amount to much. There is a difficulty about these allegations that Dudley was constantly leading Winthrop from sweetness and light to bigotry and darkness. If they were true they would manifest a docility and want of backbone in Winthrop which would be degrading and in no way creditable to him. It is claimed that Winthrop did not recover from this evil influence until near the close of life, when the two "upon whom the weight of affairs did lie" 1 were for the last time brought together. Winthrop is declared to have passed out of life a changed man, having broken forth into clear light just before his departure, while Dudley continued in the darkness of bigotry and in the gall of bitterness.

We are told that "during this last illness Winthrop was 1 Winthrop, i. * ${ } 77$. 
waited upon by Thomas Dudley, the deputy governor, and pressed to sign an order for the banishment of a person who was deemed heterodox, but that he refused, saying that he had done too much of that work already." 1 This intensely dramatic scene has no foundation whatever, so far as we can discover. There is no known witness of the alleged event ; it is corroborated by no testimony whatever. George Bishop, in "New England Judged," page 226, made a charge similar to this respecting Marmaduke Matthews, who is said to have been the subject of this traditional story, which story in any event could not possibly have been true. Matthews, at the time of the death of Winthrop, was regarded as a godly minister at Hull and later at Malden. His name first appears in the Colonial Record, May, I649, iii. I53. But Winthrop died March 26, 1649. ${ }^{2}$

The authority for this false tradition usually relied on is Hutchinson, i. I 5 I. But it appears first of all, as we have said, in "New England Judged," by George Bishop, published in I66I, at London, more than a century before the publication of Hutchinson's history. Mr. J. A. Doyle, as usual, seems to relish this reflection on Dudley. He says : "The tradition is so unlike what a New Englander would have invented for the glorification of his countryman that I am inclined to believe it." 3 Doubtless his inclination to believe disagreeable traditions respecting Dudley will continue, although they emanate from George Bishop, of Bristol, England, and not from "New Englanders."

If, however, this story were strictly true, such official action of the deputy governor would not have been personal, he would be there by the order of the Court, in the discharge of his sworn duty. If Winthrop was incapacitated and physically unable to perform the duties of his office, for that reason the deputy governor ought not to be held up to the

1 R. C. Winthrop's Life and Letters of John Winthrop, ii. 393.

2 See Pool's Introduction, Wonder-Working Providence, cx., note 2; Winthrop, i. *273.

8 English in America, i. 395, note. 
execration of the world in comparison with the compassionate Winthrop, who, in health and vigor, having no veto power, would not have hesitated to execute the order of the Court. The comparisons between these noble men, who in most things were of one mind and of one heart, which are intended to injure the character of Dudley, are constructed, like this one, out of nebulous material and disappear upon examination. Massachusetts ought, with a grateful sense of obligation, to see to it that tardy justice is done to the memory of all her heroic founders. It is too much the modern habit to traduce them, to judge their acts by the standards of other centuries, or by the ideals of pamphlet writers who knew nothing of their responsibilities, nor could themselves for a week have enforced their dreams of impossible things.

One memorable feature of the meeting, described in the early part of this chapter, was the fact that Winthrop had never discovered "any breach between his brother Dudley and himself, ... neither did he suspect any alienation of affection in him." Nor was there any, and whoever seeks to establish the reverse is a public enemy.

Another still more important fact was revealed on this occasion, and cannot be too much considered. It is that this group of the foremost men among the founders - two of them (Vane and Peters) conspicuous afterwards in England, both indeed martyrs of liberty in the struggles of the English commonwealth, while one (Haynes) was then governor of Massachusetts, and was to be the first governor of Connecticut, busy actors in the very scenes themselves - then left on record "that Dudley and Winthrop were those upon whom the weight of the affairs did lie." 1 Memorable words, worthy of inscription on a tablet at the Capitol in Washington, beside the monument of the illustrious Winthrop, the noble representative of Massachusetts character and greatness, to keep in the memory of men, "while rivers run and grass grows green," these brothers, who were first 1 Winthrop, i. * ${ }_{177}$. 
and foremost in laying the foundations of the model commonwealth.

There was, as we have noticed, at Cambridge, in 1635 and 1636 , great discontent among the people. The entire church of Thomas Hooker was, with himself, determined to emigrate. Connecticut, Ipswich, and other places were considered as places of residence. The reason given by these people was that they had not sufficient land. "Besides the need for fresh soil, it was thought that the personal ambition of Hooker, the pastor of Cambridge, made him eager for greater freedom and authority than he could enjoy in Massachusetts." One New England chronicler indeed tells us that "two such eminent stars, such as were Mr. Cotton and Mr. Hooker, both of the first magnitude, though differing influence, could not well continue in one and the same orb." 1

The pilgrimage of these people to Connecticut is a very attractive subject, but we cannot enter upon it. They ruled by magistrates during the first three years, and in 1639 formed their government. Connecticut and Rhode Island were both overflows from Massachusetts. John Haynes, the first governor of Connecticut, as we have seen, had been the friend, neighbor in Cambridge, and successor in the gubernatorial office of Dudley, in Massachusetts, in 1635. We have already observed how he held Winthrop strictly to account in office while he himself resided in Cambridge.

Dudley, who did not differ materially in his ideas of church, state, or toleration from these associates, was relied upon when emergencies arose in any direction. He wrote no tracts explaining the motives of his actions, but Massachusetts is the answer to all detractors; she is the result of their combined labors; "she needs no encomiums ;" twentythree years of his greatest and best work are in the earliest elements of her construction.

$\Gamma$ Dudley caught with his friends also the spirit of wander-

1 Hubbard, I73; J. A. Doyle's English in America, i. 207; George L. Walker's Thomas Hooker, 90. 
ing. He could not find it in his heart to go so far away as Connecticut; he was too deeply interested in the holy experiment of liberty in Boston, and was under obligation to stand firmly by Massachusetts. 1

Dudley, in I635, sold his home in Cambridge to Roger Harlakenden, who had come with the Rev. Mr. Shepard, the new minister, who took the place of Hooker in August of that year. ${ }^{2}$ He went with his son-in-law, Bradstreet, as he had gone with him to Cambridge in 1631 , also with his son-in-law, Major-General Daniel Denison, and with his oldest son, Samuel Dudley, to Ipswich, in I635. Other citizens of Cambridge went with them. Dudley remained there only four years, and then removed to Roxbury, where he would be nearer to the seat of government, and there resided during the remainder of his life. This last change of home took place the year before he was again governor, in I640, which political office may have influenced somewhat his removal to Roxbury.

We find an account of some of these people in "The Hammatt Papers concerning the Early Inhabitants of Ipswich, published by Augustine Caldwell and Arthur Dodge, Ipswich, I88I." There is an account of Governor Dudley on pages 80 and 82 of No. 2, from which we take the following: "Granted to Thomas Dudley, Esq., in October, I635, about nine acres of land between Goodman Cross, on the west, and a lot intended to Mr. Bradstreet on the east, upon which Mr. Dudley hath built a house. . . . All which the said Thomas Dudley, Esq., hath sold to Mr. Hubbard. ${ }^{3}$ The spot where Mr. Dudley's house probably was placed must have been one of the most desirable situations for a gentleman's residence which could be found in this region. It had a copious spring of pure water, which gave name to the street. It was sheltered on the north and the east by the

1 Proc. Mass. Hist. Soc., Jan. 1870, 219.

2 Young's Chron., 517, note.

3 Whether the following applies to the home of Governor Dudley, or his son, is not quite certain. 
hill, and open towards the south and southwest on an uncom. monly beautiful landscape."

Three hundred pounds were levied, March 3, 1636, out of the several plantations for public use, and from the assessments we learn that Cambridge, at the time that Dudley left it, was the most wealthy in the colony, and that of the thirteen towns Ipswich was the sixth in respect to property. ${ }^{1}$

It was ordered, March 3, 1636, that the General Court from time to time, as occasion shall require, "shall elect a certain number of magistrates for the term of their lives, as a standing council, not to be removed but upon due conviction of crime, insufficiency, or for some other weighty cause; the governor for the time being to be always president of this council, and to have such further power out of court as the General Court shall, from time to time ... endue them withal." It is thought that this council was created to induce the nobility and eminent people of England to come to America, and was designed to open the way for the enjoyment of titles of rank and nobility in this country. This was repugnant to the sentiments of the great body of middle-class people who had settled on these shores. The Constitution of the United States, in the same spirit, a century and a half later, gives expression to the democratic republican genius of the American people, and allows neither titles of rank nor of nobility in the republic. This council had no public importance after three years, and its power constantly dwindled under the blows of the people, jealous and watchful over its progress from the beginning. It bears quite largely the impress of the Rev. John Cotton and John Winthrop. When, in 1634, Dudley succeeded Winthrop as governor, Cotton, a strong partisan of Winthrop, preached, at the General Court, "that a magistrate ought not to be turned into the condition of a private man without just cause, and to be publicly convict, no more than the magistrates may not turn a private man out of his freehold, etc., without

1 Mass. Col. Rec., i. 165, 166. 
like public trial," etc. ${ }^{1}$ The council for life is more august, but it is of the same political sort. It was that conflict between authority and the people in which our institutions were moulded and formed on both sides of the sea. The account of this council given by Winthrop is very instructive, not only respecting its rise but its fall as well. ${ }^{2}$. It was probably Cotton's address which, by its anti-American sentiments, aroused the people still more against the Standing Council ; however that may be, they proceeded without more ado to wrest from it every semblance of authority or power in $1639 .^{3}$ There were never but four members of this council : Vane, Winthrop, Dudley, and Endicott. ${ }^{4}$

Richard Saltonstall, a former neighbor of Dudley at Ipswich, even wrote a book to reveal "wherein the institution of the Standing Council was pretended to be a sinful innovation." 5 Dudley, into whose safe keeping this book had been placed, had found some very unsound, reproachful, and dangerous passages in it, and he proceeded at once to disarm them of their power to do harm, for which service he was exceedingly well qualified. The sympathy of Dudley was in general on the side of the people, and we are sure that neither he nor Winthrop sought the power and authority which had been so signally bestowed on them, because they were ex-governors par excellence. Yet they being made members of the Standing Council, perhaps to make place for Vane, especially by the political efforts of Cotton first, and the elders next, were not to be traduced and misrepresented by the ignorant and wrong-headed, not while Dudley had the facts in his memory and keeping. We could well and heartily wish that he had been also alive in these recent centuries to vindicate public services against the detraction of modern writers and annotators. Some persons who have gone in and out before their fellow creatures would, we are persuaded, be astonished at their own opinions in the light of honest truth. In this connection it goes to one's heart to read his thoughts

1 Winthrop, i. *132.

Ib., i. *302.
2 Ib., i. *I 85.

3 Ib., ii. *64, *65. 
while living, expressed in his letter to the noble Countess of Lincoln. "But we do desire, and cannot but hope, that wise and impartial men will at length consider that such malcontents have ever pursued this manner of casting dirt, to make others seem as foul as themselves, and that our godly friends, to whom we have been known, will not easily believe that we are so soon turned from the profession we so long have made in our native country." 1 This quotation indicates how important his early life in England, to the age of fifty-four years, is as a key to his subsequent life in America, always to be considered in connection with the records of Massachusetts during his period, and with the books and tracts composed by his rivals or hostile contemporaries and all subsequent detractors.

All these controversies about the Standing Council and other matters had not in the least diminished the stable popularity of Dudley with the people, which he had won by faithful, self-sacrificing service from the beginning to the end, and thus when his usual gubernatorial year approached in 1640 , he was elevated into the exalted station for the second time. It ought not to be overlooked, however, that the election of Winthrop and Dudley by the General Court of the colony to the Standing Council, set them apart as the two most eminent persons at that time in Massachusetts, with the possible exception of Governor Vane. This honor crowned six years of faithful service, in which they had attained to the fullest and highest confidence of the people. Winthrop was certainly able, wise, and amiable; Dudley was rugged, just, courageous, untiring in energy. He had little patience with windy discussions and arrogant nonsense, which characteristic is admirable, worthy of his dignity and position. He was preëminently a man of action, and belongs to that class of men in history who with sincere convictions, clear heads, and iron nerves have achieved the best things in this world. These men ought to be judged by the average public sentiment of their period. We freely admit 1 Young's Chron., 33I. 
that Dudley entertained a childlike belief in special providences which would not in general be acceptable to this generation, yet perhaps in the course of time and the progress of human mutations his ideas may be in fashion again; and even now, we know that there are multitudes of excellent people who are in perfect accord with his opinions in these matters.

It was ordered furthermore, on March 3, 1636, "that hereafter there shall be only two General Courts kept in a year, viz., that in the third month, called May, for elections and other affairs, and the other the first Wednesday in October, for making laws and other public occasions of the commonwealth." This system was established, no doubt, by reason of the new county courts created this very session. This had in it the further extension of local government from the capital to the counties, and the distribution of justice as nearly as possible to the places where persons are to be tried by their peers. These excellent provisions came from the method and example found in the mother country. 


\section{CHAPTER XXI}

THE May election in the year 1636 was unique and of great historic interest. Sir Henry Vane, whose father, Sir Henry Vane, the elder, had filled some of the highest state offices during the reigns of James I. and Charles I., arrived in Boston the previous year. He was a man of education, although he left the university before completing his course there, and going abroad reinforced his Puritanism at Geneva, one of the exhaustless sources whence these doctrines were to be imbibed. He was everywhere welcomed in the colony by reason of his distinguished family and personal attainments. He was at once the subject of all praise, and so excited were the people with their newly discovered franchise, and so anxious to have a change and break the monotony of things, that, regardless of all other considerations, they instantly set aside the old founders, comforting them meanwhile with a councilship for life; and believing that nothing in this wilderness could be too great or too excellent for this youth born in the purple, elevated him, after a sojourn here of six months, at the age of twenty-four years, to the chief magistracy of Massachusetts.

The people soon found, however, cause to regret their rash and inconsiderate action. Winthrop, whether with a tinge of envy does not appear, relates that, "because Governor Vane was son and heir to a privy councilor in England, the ships congratulated his election with a volley of great shot." 1 This is said to have been the first instance of such great honor to a governor-elect.

It must have been a disheartening scene to those of the colony who remained behind, when one hundred of their best 1 Winthrop, i. 187. 
people, with one hundred and sixty cattle, began their journey to Connecticut May 3I, one week after this election. We have already considered, without much success, some of the causes of this democratic secession. ${ }^{1}$ It was probably made in search for more space to expand in, for liberty in general. But great men are the wealth of any community, and two of them, Hooker and Haynes, departed at the head of this emigration. Dudley probably felt this separation more than any one else, since they had been his associates, neighbors, and political friends, and now he was left to the tender mercy of the triumphant Boston faction. The question soon arose whether the government in Boston would set up the colors on the fort, and thereby evince their loyalty to the mother country, or whether they would decline to do it, because the royal cross of St. George within it was believed by many Puritans to be an emblem of Roman idolatry, for which reason Endicott had cut the cross out of the ensign in Salem. It is interesting to note in the writings of Rev. Mr. Hooker that he did not approve of the cutting the cross out of the English ensign by Governor Endicott. He therefore was in accord with Governor Vane and Governor Dudley. 2

The ensign was duly set upon the fort by the order of Governor Vane, sustained only by Governor Dudley. This act shows in a striking manner the quality of Dudley. $\mathrm{He}$ was large enough to make the needful distinction in the midst of the prejudice about him, and his life abounds in just such breezy exhibitions of obedience to conviction.

The Indians killed John Oldham, of Watertown, Mass., and brought on the dreadful Pequot war, which resulted next year almost in annihilation of the tribe, perhaps the strongest and bravest in New England. This war was precipitated

1 Mr. George E. Ellis says the Antinomian troubles in Massachusetts were the cause. Sparks's Am. Biog.; Rev. R. Stansby to Rev. J. Wilson, Mass. Hist. Coll., 4th series, vii. I0, II ; Walker's Life of Hooker, 88-90; Hubbard, 165, I66.

2 Walker's Life of Hooker, 8 I, 82. 
upon the little colony of Connecticut mostly, which had less than two hundred men, who had been there less than a year, while the Pequots had one thousand men. But the hero of the colony, Captain John Mason, closed the war in one battle. The number of men to be furnished for this war by the towns of Massachusetts was one hundred and sixty, of which Boston had the largest number, while Cambridge, reduced by the emigration to Connecticut, had now less than one half as many in her quota. The most serious question which arose during the administration of Governor Vane was the Antinomian controversy. Winthrop relates that one "Mrs. Hutchinson, a member of the church of Boston, a woman of a ready wit and bold spirit, brought over with her two dangerous errors: I. That the person of the Holy Ghost dwells in a justified person. 2. That no sanctification can help to evidence to us our justification. From these two grew many branches; as I. Our union with the Holy Ghost, so as a Christian remains dead to every spiritual action, and hath no gifts nor graces, other than such as are in hypocrites, nor any other sanctification than the Holy Ghost himself." 1

Ann Hutchinson was a very gifted woman, who in 1636 was at the head of a woman's association or club, where the sermons of several of the leading ministers of the colony were reviewed by her with considerable critical severity, the substance of the teaching of this club being that the ministers in general, except Cotton and Wheelwright, were blind leaders, holding views and teaching doctrines which might have been quite correct and proper in the Garden of Eden, when and where our first parents were under a covenant of obedience, but not so now in the last days of the new dispensation; we have now instead a covenant of grace and faith, and may safely do what to us seemeth good without regard to law. ${ }^{2}$

The magistrates of Massachusetts permitted this woman

1 Winthrop, i. 200.

2 Mather's Magnalia, ii. bk. vii. chap. iii. §§ 8, 9, p. 447. 
with her associates ${ }^{1}$ to remain in the colony until 1638 , and tolerated her teaching and influence before they banished her. Many writers do not seem to realize the anxiety of the Puritans both in England and America, at this time and before, respecting the doctrines of the Antinomians, Enthusiasts, Familists, and German Anabaptists, which they believed upon examination to be contained in the teachings of Ann Hutchinson and of the Woman's Club. How intense their solicitude was is manifest in the writings of nearly every Puritan of importance in the colony whose works are extant. $^{2}$

There certainly was great reason to fear those persons who claimed to act under the authority of personal visions from Heaven, like the fanatical John of Leyden, not that they had yet attempted to legalize polygamy and unbridled profligacy, as had been done in the previous century at Münster and other places. The doctrine of justification by faith and the right of private judgment, so dear to Protestants, were interpreted by John of Leyden to mean that whatever a saint thought or did, was the will of God wrought by him and in him; the moral law, the social law, the civil law, all laws, were indeed abrogated, and each individual was a law unto himself, each had a special dispensation from Heaven to commit sin without restraint, for in them it was not $\sin$, because they were not " under the law, but under grace." 3

The Puritans in England, as we have mentioned before, were moreover seriously tainted with this subtle, dangerous heresy. The watchful, clear-sighted, brave founders of Massachusetts saw this plague-spot, full of deadly influences, which

1 Mass. Hist. Coll., 4th series, vii. Ioo, II I, note.

2 Mather's Magnalia, ii. bk. vii. chap. iv. § 7, p. 477; John Winthrop and T. Welde's Short Story of the Rise, Reign, and Ruin of the Antinomians, Familists, and Libertines that infected the Church of New England, 40; Hutchinson, ii. App., 513, 514, 516; Ann Hutchinson, Sparks's American Biog., 2d series, vi. I99.

${ }^{8}$ See Anabaptists, Cyclo. of Bib. Theolog. and Ecc. Lit., by McClin tock and Strong; also Encyc. Britannica, i. 
had ruined the Christian life at Münster, ${ }^{1}$ extending from Mrs. Hutchinson and Boston over their fair commonwealth, to pollute and destroy their cherished institutions. They determined finally, after two years, that they must join in the issue, and contend for self-preservation, for social existence, and for religious liberty. Dudley in after years left his testimony that they were too long in arriving at this determination for the public good. Their solicitude was more, no doubt, as to the future fruits and influence of this false doctrine than to the evils springing from it in their generation. Yet it is important to remember in this connection that Captain Underhill and the Rev. Mr. Knollys, ${ }^{2}$ disciples

1 Their fear of the German heresy is seen in the act of disarming. (Mass. Col. Rec., i. 2I r.)

2 Since writing the above, our attention has been called to the subsequently excellent, useful, and eminent career of Knollys in England. We have noted the attempt in certain directions to discredit the accounts of Winthrop, Hubbard, and Belknap respecting his alleged conduct in Dover, N. H., in 164I. Savage in his notes sustains Winthrop. Hubbard was contemporary and was then twenty years old. Hugh Peters says in a letter to Winthrop in 1640, Mass. Hist. Coll. (4th series, vi. I06), speaking of the troubles at Dover: "I conceive that two or three men sent over may do much good at this conflux of things." He says further: "I think this work falls naturally under the care of the council." Winthrop informs us that the next year, in I64I, "The governor and council considered of their petition, and gave commission to Mr. Bradstreet, one of our magistrates, Mr. Peter and Mr. Dalton, two of our elders, to go thither and to endeavor to reconcile them, and if they could not effect that, then to inquire how things stood and to certify us," etc.

The letter of Peters quoted above, which has been said to sustain the reputation of Knollys, was a year before the discovery of his error, if we are correct. He confessed in open church. The commissioners of Massachusetts investigated. A suit for slander instituted by Knollys is used to defend him, but he did not have the courage to prosecute it, and at the best it is of doubtful importance. Winthrop had the best means of information from the commission and otherwise. He is very explicit in the details, and if he is discredited in this, a matter of such public celebrity, we must be in doubt respecting his general trustworthiness. "The tempter hath a snare for all." Knollys had experience, repented, lived a noble and useful life, and, like St. Augustine and a 
and followers of Ann Hutchinson, put in practice at once the same disgusting and repulsive conduct which distinguished the fanatics of Münster." Winthrop said, "What may they breed more if they be let alone ?" 2

It was also Winthrop and T. Welde - and there are no stronger authorities - who said, in "A Short Story of the Rise, Reign, and Ruin of the Antinomians," etc., pages 42, 43 : "So it hath been in the churches of Rome, and others, and so we may justly fear in these churches in New England, however that many that now adhere to these familistical opinions are indeed truly godly, and (no doubt) shall persevere to the end, yet the next generation which shall be trained up under such doctrines, will be in great danger to prove plain familists and schismatics. This discovery of a new rule of practice by immediate revelations, and the consideration of such dangerous consequences which have and might follow thereof, occasioned the Court to disarm all such of that party, as had their hands to the petition."

Winthrop said at another time, "But God will teach them by immediate revelations, and this hath been the ground of all these tumults and troubles, and I would that those were all cut off from us that trouble us, for this is the thing that hath been the root of all the mischief." The following extract from the account of the trial of Mrs. Hutchinson presents Governor Winthrop as of the same opinion expressed by him before.

"COURT. We all consent with you.

"Governor Winthrop. Ey, it is the most desperate enthusiasm in the world." 3

"I am persuaded that the revelation she brings forth is delusion." 4

host besides, is entitled to our admiration and confidence. "The end crowns the work." (Hubbard, Mass. Hist. Coll., 2d series, vi. 363, 364; N. E. Reg. xix. I3I ; Christian Review, xxiii. 438; Cong. Quarterly, xiii. 38 .)

1 Winthrop, ii. 27-29; Mather's Magnalia, ii. 477.

2 Hutchinson, ii. App., 5 I4. $\quad 3$ Ib., ii. App., 513, 5 I4.

4 Ib., i. App., 515. 
The following passage, believed to be the composition of Winthrop, is highly instructive as to his opinion: "So that the Court did clearly discern, where the fountain was of all our distempers, and the tragedy of Münster (to such as had read it) gave just occasion to fear the danger we were in, seeing (by the judgment of Luther writing of those troublous times) we had not to do with so simple a devil, as managed that business, and therefore he had the less fear of him: but Satan seemed to have commission now to use his utmost cunning to undermine the kingdom of Christ here (as the same Luther foretold he would do, when he should enterprise any such innovation under the clear light of the Gospel), so as the light has not been known in former ages, that so many wise, sober, and well-grounded Christians, should so suddenly be seduced by the means of a woman, to stick so fast to her, even in some things, therein the whole current of Scripture goeth against them, and that notwithstanding her opinions and practice have been so gross in some particulars, as their knowledge and sincerity would not suffer them to approve, yet such interest hath she gotten in their hearts as they seek cloaks to cover the nakedness of such deformities." 1

The vigorous position taken by the United Colonies of New England in I644, in contending against this Antinomian heresy, removes this issue out of a mere local struggle confined to Massachusetts, and reveals a general solicitude respecting the danger from it, which is entitled to full consideration, and cannot be lightly passed over. We quote as follows from the record: "That Anibaptism, Familism, Antinomianism, and generally all errors of like nature which oppose and undermine and slight either the Scriptures, the Sabbath, or other ordinances of God, and bring in and cry up unwarrantable revelations, inventions of men, or any carnal liberty, under a deceitful color of liberty of conscience,

1 A Short Story of the Rise, Reign, and Ruin of the Antinomians, Familists, and Libertines, etc., 1644, 40. 
may be seasonably and duly suppressed, though they wish as much forbearance and respect may be had of tender conscience seeking light as may stand with the purity of religion and the peace of the churches." 1

The writers who take the side of Mrs. Hutchinson, and regard her as the brilliant forerunner of the present accomplished woman, social and political leader, are inclined to the opinion that Winthrop had little sympathy with her prosecution, and to allege that Dudley was the bigot who sought her destruction. But in the record of her trial in Hutchinson's "History of Massachusetts" (which account is thought to have been constructed in her interest and to misrepresent the Court), Winthrop took positive action, presided at the trial, did most of the summing up of the evidence, formulated the judgment of the Court, and was more conspicuous than any one else, and if the doings of that Court are to be condemned, he cannot escape his full share of the responsibility. The quotations, however, already made, exhibit him in the strongest light against Mrs. Hutchinson, and leave no room for doubt. There is sufficient evidence that the fathers of Massachusetts, with great forbearance and long delay, sought to deal justly with Mrs. Hutchinson. They were at that time under unusual embarrassments, for on one side they were preparing for the dreadful Pequot war, while on the other they were constantly expecting a crushing blow from the hostile and vindictive Archbishop Laud, which might annihilate their holy experiment of government in America. They are surely entitled to our sympathy in their afflictions. They had faults, they were human and without large experience in affairs of statecraft, but their record is secure in its essential features, and demands neither defense nor apology. Their love of justice is notable in the very beginning of their investigation into this heresy. They first called a synod at Cambridge, which met August 30, 1637, presided over by the very distinguished Rev. Thomas Hooker, then of Hartford,

1 Plymouth Col. Rec., ix. 81, 82. 
Conn., and the Rev. Peter Bulkley, of Concord, Mass. The purpose of this synod was not to try persons for heresy, but to examine and test by the standard of the Scriptures, doctrines believed to have been disseminated or approved by Mrs. Hutchinson or her club.

This synod ${ }^{1}$ discovered eighty-two well-recognized errors afloat in the community, chargeable in general to Mrs. Hutchinson or her association. The synod attached to each of these errors a passage of Scripture, believed to be a sovereign antidote for the poison contained in it. For Cotton Mather asserts with assurance that they "did unto reasonable men immediately smite the error under the fifth rib." These eighty-two errors, with the Scripture so attached, are to be found in "A Short Story of the Rise, Reign, and Ruin of the Antinomians," etc.

The citizens of Boston cannot forget that she commended herself to Harry Vane, the governor, the Rev. John Cotton, to Rev. Mr. Wheelwright, and to the church and town of Boston in general. Cotton and Wheelwright both recanted soon, ${ }^{2}$ saw their errors, and were restored to the faith and to their brethren. The great name of the overrated Governor Vane has done very much to support Mrs. Hutchinson in the public estimation, and to create a strong aversion towards the government of Massachusetts which banished her. This opinion seems to demand that we should scrutinize with care the character and peculiar qualities of mind of Governor Vane. Investigation will remove, we believe, all surprise respecting the ascendency of Mrs. Hutchinson over him, for he was constitutionally susceptible to her Antinomian ideas and visions. His biographer, James K. Hosmer, says " that he was after a strange fashion a dreamer, devoted, when he could find leisure for it, to rhapsody and abstruse discussion, unintelligible to the men of his time, and the despair of those of the present day who seek to follow him." Thomas Car-

1 The leaders were not ignorant peasants, but university men.

2 Mass. Col. Rec., ii. 67; Winthrop, ii. 162. This has been denied (Backus, i. 131), but the authority seems to sustain the text. 
lyle has set forth this fatal weakness in his character in his usual vigorous manner. ${ }^{1}$

Clarendon informs us that "Vane was not to be described by any character of religion, in which he had swallowed some of the fancies of every sect." 2 Hutchinson pronounces Vane to have been "obstinate and self-sufficient," and says further that "he craftily made use of the party which maintained these peculiar opinions in religion, to bring him into civil power and authority, and draw the affections of the people from those who were their leaders into the wilderness." 3 Gardiner has given to us the conclusion of the whole matter in the following: "Vane coming to Massachusetts at a time of unexampled difficulty, found that Ann Hutchinson, voluble, ready, earnest, uttered doctrines which attracted strongly his mystical temperament. The absolute character of his intellect made him careless about expediency." 4 It has been said that "the departure of Vane was hailed as an inexpressible relief" to the government of Massachusetts.

The founding of Harvard College is almost the only constructive work in legislation during his term of office, but it was enough to redeem the time lost in controversy. It was perhaps the most important single event which transpired in the commonwealth during the century.

"The Court agreed to give four hundred pounds towards a school or college, whereof two hundred pounds to be paid the next year and two hundred pounds when the work is finished, and the next Court to appoint where and what building." The next year "the college is ordered to be at Newtown." 5

The departure of Governor Vane insured the downfall of the party of Mrs. Hutchinson. It is proper to mention in conclusion that Clarendon says "that the reason and understanding of Vane in all matters without the verge of religion was inferior to that of few men." The world will never for-

1 Cromwell's Letters and Speeches, ii. part 7 of Int.; The Rump, 227; also Letter 188, 250.

2 Clarendon, vi. 2957.

4 Hist. Eng., viii. 174.

${ }^{8}$ Hutchinson, i. 73.

5 Mass. Col. Rec., i. 183, 208. 
get that he was one of the greatest of the democratic republican martyrs, who received in his own person the vengeance of the Stuarts, and fell in the struggle for human freedom.

We have extensively considered this Antinomian question, perhaps occupying too much space with it, because Governor Thomas Dudley has received a large share of censure in modern times, bestowed upon the magistrates who banished Mrs. Hutchinson. We have believed that justice could not be done to him without reviving thoughtfully the influences and public sentiments which prevailed before and at the time when the Court took action in this case. We also think that he has been made unduly prominent in this affair by the misfortune of having left some lines of poetry in his pocket, found after his decease, which have been much quoted on the supposition that they contain the concentrated bigotry of the seventeenth century.

Dudley was deputy governor at the time, and was no doubt, next to Winthrop, the most influential in the overthrow of Mrs. Hutchinson.. He said at her trial, "These disturbances that have come among the Germans [meaning especially at Münster] have been all grounded upon revelations, and so they have vented them, have stirred up their hearers to take up arms against their prince, and to cut the throats of one another, and these have been the fruits of them." 1

1 Hutchinson, ii. App., 514. Dangerous, extreme, and fanatical pretensions of special endowment and guidance of the Holy Spirit are now and have been made for centuries with blasphemous presumption. They are neither new nor strange, although some persons have regarded Ann Hutchinson as unique in history. The danger which menaces a population of seventy millions from a few scattered irrational enthusiasts is insignificant; it was otherwise in Boston in 1636.

Mr. George E. Ellis, who wrote the Life of Ann Hutchinson, and has given the Antinomians the benefit of able and faithful service, says, "The struggle was one of the series of strifes and assaults which aimed at the very life of the Biblical commonwealth." $\mathrm{He}$ also remarked, "But the Antinomian controversy was most threatening of convulsion, disaster, and of a final overwhelming catastrophe." He says further, "The reason given for this civil interposition, though consistent with the theocratic principle, was that Antinomian doctrines threatened civil 
There are two or more versions of Dudley's poetry, but the following is believed to be the most approved:-

"Let men of God in courts and churches watch

O'er such as do a toleration hatch,

Lest that ill egg bring forth a cockatrice,

To poison all with heresy and vice.

If men be left, and otherwise combine,

My epitaph 's, I di'd no libertine."

This poetry seems to have been the vehicle which has preserved the intense feelings of that epoch, and transmitted them, antiquated indeed, to our own times, and for these reasons we ought to read between the lines, and catch the real thought intended then to be expressed by it, and not to translate a new meaning into it.

The usual method in the treatment of this poetry is to begin by depreciating the quality of it, which we at present cannot find time to defend. It is enough that Mather thought it to be creditable. Next, an important concession is made as to the substance and truthfulness of the matter contained in it, to the effect that it well expresses the bigotry of the age and neighborhood. This may certainly be considered exalted praise, because there is a vast amount of alleged poetry in the world which does not express anything. Dudley may not have "married immortal verse to tune" with the beauty and perfection of the great poets, but he certainly has had the exceptional fortune to have gathered into a single stanza, if these persons are correct, the sentiments of his associates, to have transmitted them to the coming generations, and to have been more quoted (which is said to be an indication of genius in poetry) than any contemporary; and it is probable that he will con-

order and pure morals. This justification was not wholly unsupported by thoroughly sincere reasons and apprehensions incident to the time and circumstances of the strife." He says also, "The immoralities and abominations of fanatical Antinomians in Germany in the previous century had not passed from memory, nor from living reference to them." (The Puritan Age in Massachusetts, 359, 360.) 
tinue to receive the same deference so long as the history of Massachusetts shall claim the attention of mankind.

But unfortunately this composition has cruelly recoiled on Dudley, and has stimulated modern writers to hold him up as the chief bigot of his age. Every mention of him recalls to them his deathless lines.

The first difficulty about the stanza is that there does not appear to be any real evidence that he wrote it. Mather says, to be sure, that they were "lines of his own composing." But the general contemporary testimony is only that they were found in his pocket. They have, however, been so long attributed to him that we may as well consider them his own.

This poetry must be read in the light of the Antinomian controversy. Every line of it is instinct with the issues of that struggle. How clearly the prevailing dread of anarchistic revelations, making every one a law unto himself, appears in the "ill egg," which suggests a life of poison not yet in existence! It was the fruit, the influence, of his age in disseminating this error, which the writer feared would blight their holy experiment, the hope of the world.

Toleration, which ought sometimes to be translated indifference about religion, is a very popular word. It appeared in the above lines and seemed to be a prayer to Heaven, the last appeal of a Massachusetts man who had "fought a good fight and kept the faith," to save the commonwealth from the Antinomian rocks on which a sort of Christian democracy was shattered at Münster.

The word "libertine" creates a disagreeable sensation, because it is conceived to include the modern liberal thinker. Its meaning was not that when used by Dudley: it was to identify the membership of one of an order of heretics of the Münster type. Webster defines the word as "one of a sect of Anabaptists, in the fifteenth and early part of the sixteenth century, who rejected many of the customs and decencies of life, and advocated a community of goods and of women." We ourselves in recent times took Dudley's 
side of this same question, and approved of the dispersion of the Mormons, and we would no more have "combined" with libertines than Dudley himself would have done it.

Mr. Savage appears very anxious to relieve Governor Winthrop from the disgrace of having used the term Antinomian, which seems to be particularly offensive to him. ${ }^{1}$ But Winthrop, unfortunately for this position, applied the more disreputable term to them, viz., "Familistical persons." 2 The book, "A Short Story of the Rise, Reign, and Ruin of the Antinomians," said to have been written by Winthrop and T. Welde, ${ }^{3}$ contains all the names ever applied to these people. Certainly there is no "exquisite rancor of theological hatred" in the use of terms which express the exact historic doctrines professed and held by people. Such names are given to designate, not to defame. The word "libertine," in the lines quoted, characterizes that class of heretics called also Antinomians and Familists, which at one time was supposed to threaten the complete destruction of the Massachusetts Colony.

We affirm that we do not persecute, and we wonder how those good people of the seventeenth century could have thought themselves consistent with their claims to have emigrated in search for liberty. The boundary line between what may safely be tolerated and what may not, changes with different periods. We now persecute people, not in the same manner but with the same spirit, using social ostracism ; we "boycott" them, we keep them out of our clan, or club, or church; we make them feel, wherever we meet them, that we do not approve of them socially, religiously, or politically. The spirit in us is the same that has always been active in our race; we are neither much wiser nor better than our fathers. There are now many dogmas in science and religion which are fighting their way against public opinion, and meeting opprobrium which, to the sensitive natures

1 Winthrop, i. 21 5 , note 1 .

2 Ib., i. 256.

${ }^{3}$ Ib., i. 249, note ; Dexter's Cong. in Lit., App., 50, No. 972. 
of their sincere advocates, may be as oppressive and painful to endure as the ruder censures of two centuries ago.

Thomas Dudley and his associates deemed it their duty to the church and state to extinguish what they thought to be dangerous, as we now consider ourselves under obligation to crush polygamy, vivisection, the liquor traffic, or the distribution of indecent literature. Our methods are different; our motives are the same. We seek, as they sought, to keep poison from the people by the power of the state. "The rigid uniformity of belief enforced in Geneva, or in Massa. chusetts, was enforced, partly at least, on political grounds, to insure a sufficient amount of cohesion in small communities struggling for their liberty. Such communities cannot afford to tolerate those who only ask for toleration till they are strong enough to seize the government and refuse toleration to others." 1

Sometimes toleration, which is only in any instance enduring what we do not approve, marks the decay of faith and the substitution of indifference or insensibility to matters once esteemed vital. It is quite possible to permit liberty of opinion, of the press, or in religion, when the government is firmly established. "Only those who feel themselves secure can afford to tolerate a tax upon themselves, and toleration is then their wisest course." The Supreme Court, in the case of Reynolds $v$. United States, declared that "Congress was deprived by the Constitution of all legislative power over mere opinion, but was left free to reach actions which were in violation of social duties and subversive of good order." Opinions charged with "soul liberty" are safe under this decision, but immediately when the thought appears in action, if the legislature in the exercise of its discretion deems the action subversive of good order, it may freely exercise the power of repression.

If the people have revelations like Mrs. Hutchinson, and keep them to themselves, the Constitution and the court will protect them; if, on the other hand, they express them

1 Ritchie's Natural Rights, i. 178. 
in action, and such action is by the legislature deemed subversive of good order, they are liable to suppression, or, as they may call it, persecution.

This was the exact ground of the Puritans. They did not, like the Church of Rome, seek to force their opinions into the minds of people by violent measures, nor to punish persons for their belief, but only for teaching or practicing heretical opinions. The Supreme Court, therefore, in our own time and the Puritans of the seventeenth century seem to be in essential accord and agreement in their principles.

No person can have candidly examined these various records without deep sympathy for Thomas Dudley. "Let not the land once proud of him insult him now." Burke once said, "Respecting your forefathers, you would have been taught to respect yourselves." He worshiped the one true God, as we worship Him, in a liberal, faithful, consistent obedience, which is worthy of modern imitation. $\mathrm{He}$ was as free from superstition as the most intelligent of his age. He could not have been narrow-minded in a general way, and at the same time "wise and just, . . . in books a prodigal, they say, a living Cyclopædia." We have already observed that both in England and America he sought the foremost scholars for his teachers and companions, men educated in all the wisdom of the great English universities. We shall have occasion to note later his active part in establishing Harvard College, an institution of liberal learning. These and many other labors and characteristics of Dudley are convincing evidence that his mind was open to truth from all quarters. He was a great reader of books. But perhaps his political record is as convincing as anything which we possess as to his breadth and scope of thought. For we must consider him as one of the wise, political master-builders; he had a share in all the progressive work in the construction of the Puritan commonwealth in Massachusetts, which has not ceased to be the admiration of the world. "We know ... what workmen wrought thy ribs of steel." If he was liberal in this work, it goes far to show 
that he was as broad all around as his associates. Men are seldom wise and liberal in state matters who are much contracted in religious thought.

In conclusion, the fathers sent away Ann Hutchinson because they traced directly to her, as they thought, a claim to dangerous revelations inciting to acts subversive of the law and the gospel, which had overthrown church and state at Münster $;^{1}$ they sent her away as a matter of public policy, but not until they had found, by means of a synod, eighty-two specimens, attributed to her influence, of the Münster poison, afloat in an infant state struggling into existence and not yet grown to such manly vigor that it could resist and cast out noxious influences without forcible remedies.

1 "There stands upon record a most shocking instance of this [Anabaptist delusion] in the dreadful commotions that were excited at Münster, in the year I 533, by certain Dutch Anabaptists, that chose that city as the scene of their horrid operations. . . Münster was to be the seat of this new and heavenly Jerusalem, whose ghostly dominion was to be propagated from thence to all the ends of the earth. . . . John of Leyden, the Anabaptist king of Münster, had taken it into his head that God had made him a present of the cities of Amsterdam, Deventer, and Wessel. . . . The progress of this turbulent sect in almost all of the countries of Europe alarmed all that had any concern for the public good. . . . It may be safely affirmed, that, had it not been for the vigor and fortitude of this active and undaunted reformer [Martin Luther] the Lutheran Church would, in its infancy, have fallen a miserable prey to the enthusiastic fury of these detestable fanatics." (Mosheim's Eccl. Hist., iv. 305, 437, 438; Kostlin's Life of Luther, 304-324.) Such was the dread in Massachusetts of this Antinomian doctrine, that men declared in their wills that they died free from its contamination. (See the wills of Dudley and Robert Keayne.)

The British Parliament on the second day of May, 1648 , passed an ordinance against Antinomians more severe than anything which ever appeared in America. This was more than ten years after Ann Hutchinson's banishment. (Neal's Hist. Puritans, iii. 418-42I.) Sir Harry Vane was a member, probably present. (Hosmer's Young Sir Harry Vane, 297, 298.) 


\section{CHAPTER XXII}

IT was ordered in October, 1636 , that all the military men in this jurisdiction, including the whole colony, shall be ranked into three regiments: Governor Vane to be commander-in-chief, John Winthrop to be colonel, and Thomas Dudley lieutenant-colonel of the first regiment. It is not quite apparent why Dudley, who was more of a military man, was placed second in command, or why, as he now resided in Ipswich, he was not in the third regiment instead of the first. The election for governor and deputy governor in May, 1637, was an occasion of much anxiety. Religious and political interests combined to create great public excitement. The Boston faction was determined to return the present governor, Vane. The towns outside of Boston were dissatisfied with him, among other reasons because he was of the Antinomian party. Winthrop, the honored first governor, had now been out of office three years, rotation in office having been well exemplified; in these stormy times of division and party faction he appeared to be the safest man, particularly with Dudley in the second place.

As early as March the Court decided that it would not be expedient to hold the election in Boston, and selected Cambridge as the most convenient place. This action was a great mortification to Governor Vane. One thing which influenced the Court against Boston was a petition already mentioned, signed by many prominent citizens of that town, condemning the Court for its proceedings against Wheelwright, the Antinomian.

When the Court of Election opened at Cambridge at one P. M., May 17, 1637, another similar petition was offered, which Governor Vane wanted read, but which Deputy 
Governor Winthrop objected to as being out of order; the first business being the election under the charter, it must take precedence of all other matters. Still the governor would not proceed to election, and the deputy, Winthrop, called for a division of the members on that question. The majority voted to proceed to election. The governor, after more useless delay, at last submitted, and they proceeded. Winthrop was chosen governor and Dudley deputy.

Vane and the Antinomian party were left out, and the cause of Mrs. Hutchinson in Massachusetts was forever lost. Hutchinson has an interesting note respecting this election, which must not be omitted. It is as follows: "Mr. Wilson, the minister, ${ }^{1}$ in his zeal gat up upon the bough of a tree (it was hot weather and the election like that of parliament men for the counties of England was carried on in the field), and there made a speech, advising the people to look to their charter and to consider the present work of the day, which was designed for the choosing the governor, deputy governor, and the rest of the assistants, for the government of the commonwealth. His speech was well received by the people, who presently called out, 'Election, election,' which turned the scale." 2

"In some of the first years, the annual election of the governor and magistrates of the colony was holden in this town [Cambridge]. The people, on these occasions, assembled under an oak-tree, which stood on the northerly side of the Common in Cambridge, a little west of the road leading to Lexington. The stump of it was dug up not many years since." 3 This was probably the tree which furnished Wilson a commanding position, whence he turned the tide against Mr. Vane and his party, and carried the Great and General Court for Winthrop and Dudley. ${ }^{4}$

1 Of Boston, violently hostile to Antinomianism, the colleague of Cotton in the First Church, and also antagonistic to him in the Hutchinson controversy.

2 Hutchinson, i. 6I, note.

8 Mass. Hist. Soc. Coll., vii. 9.

4 Paige's Hist. Camb., 23, 24, note. 
"There was great danger of violent tumult that day. The speeches on both sides were fierce, and they began to lay hands on one another, but the manifest majority on one side was a restraint to the other. . . The sergeants, who used to attend Mr. Vane, laid down their halberds and went home as soon as the new governor was elected, and they refused to attend him to and from the meetings on the Lord's day as had been usual. They pretended that this extraordinary respect was shown to $\mathrm{Mr}$. Vane as a person of quality. The Court would have appointed others, but Winthrop took two of his own servants to attend him. Mr. Vane professed himself ready to serve the cause of God in the meanest capacity. He was, notwithstanding, much mortified, and discovered his resentment; although he had sat at church among the magistrates from his first arrival, yet he, and those who had been left out with him, placed themselves with the deacons, and when he was invited by the governor to return to his place he refused it."1

Mr. Savage does not think that a discourtesy was intended to Winthrop by the sergeants, but that their term of office had expired, and they had no authority to act or serve Winthrop. ${ }^{2}$ Hutchinson does not seem to accord with Savage in this, neither does Mather. ${ }^{3}$

The next matter to attract notice is an order of the Court to keep out of the colony such persons as, in the opinion of the magistrates, might be dangerous to it. This called forth a long controversy between Winthrop and Vane, and furnished Vane with some discipline and some serious considerations respecting individual rights and the obligations of states, which had a place, and were valuable to him in the struggle for liberty in England, soon to follow after his return thither." "The twelfth of the eighth month was ordered to be kept a day of public thanksgiving to God for his great mercy in subduing the Pequots, bringing the

${ }^{1}$ Hutchinson, i. 6r, 62.

8 Mather's Magnalia, i. II4.

4 Winthrop, i. *224; Mass. Col. Rec., i. 193. 
soldiers in safety, for the success of the conference, ${ }^{1}$ and good news from Germany."

They were all the while following with intense feeling the fortunes of the Thirty Years' War. Absorbed deeply in their own contentions and political evolutions, and anxious about the revolution in England, which was vital to their welfare in all directions, still they sympathized with the old Protestant cause, its heroes and defenders in Germany, and set apart a day, and returned thanks to Almighty God for the success of the soldiers of liberty, who have registered from age to age on fields of mortal combat the steps of human progress. The Puritans themselves had forsaken their homes in England, and come to this far-off wilderness to construct, maintain, and enjoy free institutions. No persons, therefore, in the habitable world had a more vivid sense of the importance of that freedom which had been achieved in the German wars. Thomas Dudley has experienced as a soldier all that an earnest man can, who has enlisted and taken the risks of war because his heart was engaged in the objects of the struggle, because he loved and believed in the cause in which, moreover, he had lost in infancy his lamented father. He could never cease to remember their family sacrifices, the associations connected with continental war, and, above all, its purposes, objects, and results. And he, indeed, reinforced by vigorous and living experience, could heartily join in thanksgivings and hosannas ascending from the new world in behalf of the old.

The following letter of Dudley to Winthrop furnishes some interesting suggestions respecting the religious controversies at that time.

SiR, - Since my coming home, I have read over Mr. Lechford's book and find the scope thereof to be erroneous and dangerous, if not heretical according to my conception.

His tenet being that the office of Apostleship doth still

1 The synod which had discovered eighty-two particular Antinomian poisonous heresies. 
continue, and ought so to do until Christ's coming, and that a church hath now power to make Apostles as our Saviour Christ had when he was here, other things there are but I pray you consider of this, and the inseparable consequences of it. I hear that Mr. Cotton and Mr. Rogers know something of the matter, or man, with whom you may if you please confer. I hear also that he favoreth Mr. Lenthall and hath so expressed himself since Mr. Lenthall was questioned by the ministers. It is easier stopping a breach when it begins than afterward. We saw our error in suffering Mrs. Hutchinson too long. I have sent you the book herewith, that instead of putting it to the press, as he desireth, it may rather be put into the fire as I desire. But I pray you let him know that I have sent the book to you and after you have read it (which I think you said you had not done) it may be restored to him. I received yesterday a letter from my loving friend Mr. Burdett to excuse himself of the slander laid upon him for baptizing any; with some high strains of other matter, which I have answered. This is all I have at present; with due respect therefore I take leave, resting, Yours,

ROXBURY, Dec. II, 1638.

Tho : Dudley.

P. S. I suppose the book to be rather copied out than contrived by Mr. Lechford, he being I think, not so good a Grecian and Hebretian as the author undertakes to be. There was one here to-day of Weymouth to buy treacle (as I hear) who reported that there are sixty persons sick there of the spotted fever except three of them of the small-pox. If this be true the plague is begun in the camp for this sin of people. ${ }^{1}$

Dudley, in a letter to Winthrop, written eighteen days after the former one, refers again to some of the matters contained in his first letter :-

1 Labeled "Brother Dudley about Mr. Lechford's Book." (Proc. Mass. Hist. Soc., I855-58, 31 I, 312.) 
To the Right Worshipful John Winthrop, EsQR., Governor at Boston.

Sir, - I thank you for your gammon of bacon, the outsides whereof I was forced to cut off, it smelled so restily of the old Saxon reesings. I meant in my censure of your last book no resurrection of unreasonable individuals, but a continuance of those, or some of them which should be alive at the consummation, which I think is the same with your species. The breaking open of your letters was presumptuous if not hostile. For Mr. Gibbins, I think I shall satisfy you at my next coming to Boston. For Mr. Lechford and his book you say nothing, and I have since heard that the worst opinion in his book (which I think I shall prove to be heresy) is taken up by others. Now seeing that this is the way Satan invades us by (viz. new opinions and heresies), it behooves us to be the more vigilant and to stir up our zeals and stop breaches at the beginning least forbearance hurt us as it did before. I desire to see the letter Capt. Underhill wrote to Mr. Cotton. I take leave, resting ready to do your service.

Dec. 29: 1638.1

Tho : Dudley.

This Thomas Lechford named in the letters was the first lawyer who practiced in New England, and returned under many difficulties to England in 164I, dissatisfied with his experience in America. We have previously noticed the dislike of the Massachusetts Puritans for lawyers. Lechford published in 1642, in London, "Plaine Dealing; or, Newes from New England." - And it is no doubt this book that he presented to Dudley in manuscript for his examination and approval. Dudley was more critical and solicitous respecting heresy, evidently, than Lechford had supposed. Neither was he willing to pass upon a matter so vital to the public interest without consulting his associate Winthrop. This course was not agreeable to Lechford, who wrote to Hugh

1 Indorsed by Governor Winthrop, "My Brother Dudley." (Mass. Hist. Soc. Coll., 4th series, vii. 100, II I.) 
Peters in January, I639, "After the court here ended I delivered (my book) of prophesie to Mr. Deputy [meaning Dudley] to advise thereof as a private friend, as a godly man, and a member of the church, whether it were fit to be published. The next news I had was, that at first dash he accused me of heresy, and wrote 'to Mr. Governor that my book was fitter to be burned." It is very evident from Dudley's letter first above quoted, that he did not regard the placing of the book in his hands as matter of personal confidence. He undoubtedly thought that he was allowed to inspect Lechford's book, because he would not otherwise have said in his letter, "But I pray you let him know that I have sent the book to you, that after you have read it . . . it may be restored to him." It seems very certain that Dudley understood that Lechford desired the opinion of persons in influence and authority respecting his book, and therefore Dudley passed it over in good faith into the hands of the most important person in the colony, providing at the same time for its safe return, after examination, to Lechford.

It was certainly greatly to the credit of Dudley that he detected so soon the heresy of Lechford, which denied the right of the people to elect their own rulers, and also the validity of any non-Episcopal ordination. He thus became prominent in detecting that which was soon apparent to all in authority. We find in a sketch of J. H. Trumbull's "Life of Lechford," page 25 , the following statement: "That he [Lechford] should have been permitted, for two years and a half, to hold his course unchecked, and that his unconcealed and somewhat aggressive dissent should have so long escaped censure, proves that the founders of Massachusetts were not incapable of the exercise of toleration, even though they might not give it a place among the virtues."

Dudley says, it will be remembered, in the above letter, "I hear that he also favoreth Mr. Lenthall and hath so expressed himself." Winthrop says, "This man Lenthall was found to have drank in some of Mrs. Hutchinson's opin- 
ions," whereupon he was required by the Court to make a recantation at Weymouth. ${ }^{1}$

George Burdett, mentioned in one of the letters quoted, found his way to Dover, N. H., after he had preached at Salem, but he was discovered at last to be a spy in the service of Archbishop Laud. He was an enemy to the Puritans, and had a contention at Dover with Knollys, the Antinomian. He was so imprudent in a letter to Winthrop that he would have been brought to Boston to answer for contempt, but for the influence of Dudley, who was fearful that if he became hostile to Massachusetts he might do greater injury to her interests in England. For Winthrop says, "As the governor [Winthrop] says he was purposed to summon him [Burdett] to appear at our Court to answer his contempt, but, advising with the deputy [Dudley] about it, he was dissuaded from it, the rather for that, if he should suffer him this cause it would ingratiate him more with the Archbishop (with whom he had intelligence, etc.), but his counsel was rather to undermine him by making him thoroughly known," etc.

It is difficult to understand why Dudley speaks of Burdett in such terms of affection, calling him "My loving friend, Mr. Burdett." The most natural explanation would seem to be that he had not then discovered that he was an enemy of the colony and an English spy in the employ of Archbishop Laud. Burdett had evidently, somewhere and somehow, won the confidence of Dudley, and misled him for a while, until his eyes were opened to the true nature of the man and his mission.

But this circumstance is greatly to our advantage, for it furnishes an opportunity for us to observe the method and action of Dudley when required to take responsibility in a crisis. His reserve, coolness, and forethought, when even Winthrop was impassioned, was truly admirable. $\mathrm{He}$ advised to wait patiently, and thus undermine the enemy slowly and surely, step by step. The two great leaders are thus

1 Winthrop, i. 288 ; Mass. Col. Rec., i. 254. 
brought before us side by side in an important exigency, that we may see and compare them, and form our own opinions as to which exhibited the greater qualities, and their methods.

The following letter of Sir Richard Saltonstall to the Rev. Mr. Wilson and the Rev. Mr. Cotton throws further light upon the Christian firmness of Dudley in matters of heresy. He says :-

"When I was in Holland about the beginning of the wars, I remember some Christians there, that then had serious thought of planting in New England, desired me to write to the governor thereof to know if those that differ from you in opinion, yet holding the same foundation in religion as Anabaptists, Seekers, Antinomians, and the like, might be permitted to live among you, to which I received the short answer from your then governor Mr. Dudley, 'God forbid (said he) our love for the truth should be grown so cold that we should tolerate errors,' and when (for satisfaction of myself and others) I desired to know your grounds, he referred me to the books written here between the Presbyterians and Independents, which if that had been sufficient, I need not have sent so far to understand the reasons of your practice. I hope you do not assume to yourselves infallibility of judgment, when the most learned of the Apostles confesseth that he knew but in part, and saw but darkly as through a glass, etc.

"Your truly and most affectionate friend in the nearest union,

$$
\text { "Ric: Saltonstall. }
$$

"For my Reverend and worthily much esteemed friends, Mr. Cotton and Mr. Wilson, preachers to the church which is at Boston in New England."

The next matter on the record which attracts attention is the first appearance, possibly, of American hotel-keeping, which is naturally unique and curious. Sumptuary laws are at best rigid, and not altogether agreeable reading, for at 
every turn they excite our commiseration for those excellent people who had so few of the comforts and almost none of the luxuries of life.

"And whereas complaint hath been also made that divers poor people, who would willingly content themselves with mean diet, are forced to take such diet as is tendered them at twelve pence the meal or more, it is now ordered that every keeper of such inn or common victualing house shall sell and allow unto every of their guests such victual as they call for, and not force them to take more or other than they desire, be it never so mean and small in quantity, and shall afford the same and all other diet at reasonable prices, upon pain of such fine as the Court shall inflict according to the measure and quantity of the offense." 1

As we have already noticed, the college is ordered to be at Newtown by the General Court, November I 5, 1637, and on the 2oth day of the same month the Court appointed a committee "to take order" for a college at Newtown. ${ }^{2}$

"For the college, the governor, Mr. Winthrop, the deputy, Mr. Dudley, the treasurer, Mr. Bellingham, Mr. Humfrey, Mr. Herlakenden, Mr. Stoughton, Mr. Cotton, Mr. Wilson, Mr. Davenport, Mr. Wells, Mr. Shepard, and Mr. Peters, these, or the greater part of them, whereof Mr. Winthrop, Mr. Dudley, or Mr. Bellingham, to be always one to take order for a college at Newtown." 3

We have quoted this entire act, to show how conspicuous the three men, Winthrop, Dudley, and Bellingham, were at the inception of this institution. Our special interest is at present centred in Dudley, one of the three, and the peer of either of them in all-round practical knowledge and information.

President Josiah Quincy tells us that "the year ensuing

1 Mass. Col. Rec., i. 214.

2 "To take order" is an obsolete phrase, and means to take "suitable action in view of some particular result or end ; care preparations; measures." (Century Dict., 4143.)

3 Mass. Col. Rec., i. 217. 
(1637), the General Court appointed twelve of the most eminent men of the colony to take order for a college at Newtown, all of them names dear to New England, on account of their sacrifices, their sufferings and virtues." While these men were contemplating the laying of the foundation of the college, John Harvard died, in 1638 , and was found to have bequeathed one half of his whole property, and his entire library to the institution.

We have not found that this committee was changed until 1642 , and it is therefore safe to conclude that the whole government and construction of the college was in their care until that date. The college was chartered in 1642 , and again received a new charter in 1650 , with the signature of Governor Thomas Dudley. "A copy of the original, engrossed on parchment, under the signature of Governor Dudley, with the colony seal appendant, is in the custody of the President and Fellows of Harvard College." 1 Governor Dudley did not cease to be on the Board of Overseers of the college during nearly sixteen years, from that 20 th day of November, 1637 , until his death.

His family, also, was destined later to serve the college in time of special need. It appears that Governor Joseph Dudley, the son of Governor Thomas Dudley, "who held between May and December, in the year I686 [just before the arrival of Governor Andros], the commission of president of the colony, and William Stoughton, who held during the same time that of deputy president, availed themselves of their transitory power to place the college on a basis adapted to the uncertainty which hung over its destinies, in common with those of the colony," at that critical period. President Josiah Quincy said, "Of all the statesmen who have been instrumental in promoting the interests of Harvard College, Joseph Dudley was most influential in giving its constitution a permanent character."

There had for a long time been a desire for a new charter for the college from the crown, since the charter of the 1 Josiah Quincy's Hist. of Harv. Univ., i. 59r. 
colony had been annulled. It did not seem possible of attain. ment, but Governor Joseph Dudley, with a bold movement, secured that which served as a substitute.

He furnished at once "the long-sought charter for the college, and fulfilled the utmost desire of his friends, in a form not requiring the sanction of the crown, and deriving all its efficacy from the authority of the provincial legislature. ... This measure had, probably, its origin in the depths of Dudley's own mind, and is marked with boldness and sagacity eminently characteristic of him. It is hardly probable that any other person would have ventured to propose a course so full of responsibility."

$\mathrm{He}$, in 1707 , "in defiance of all recognized principles, had the boldness to consent to revive the college charter of 1650 [the very charter his honored father, Thomas Dudley, had signed fifty-seven years before], and thus established a charter, contrary to the will of the British sovereign. . . . He took the great responsibility of a dangerous policy, and he deserves all the credit of its success.

"It is also certain, that the measure received the almost universal approbation of the people of Massachusetts; that the act of 1650 , thus revived by a legislative resolve, has been ever since recognized as the charter of the college ; that, during the continuance of the colonial relation, it received the uniform support of judicial decision and legislative sanction; and that, on the adoption of the state Constitution, in I 780 , it was ratified and confirmed. Thus, by virtue of uniform judicial construction, successive legislative sanction, and ultimate constitutional ratification, the charter of 1650 [signed by Thomas Dudley] has been established on a firm and now incontrovertible basis." 1

It is a great pleasure to follow thus the united services of these two governors throughout the charter life of the college to the present day. Governor Joseph Dudley was a courtier and a politician very different in character from his honored father. He has been the subject of bitter and often

${ }^{1}$ Josiah Quincy's Hist. Harv. Univ., i. 158-16r. 
undeserved denunciation. He was an Episcopalian who did not always please the Mathers, and in his sworn duty to the mother country did not always act in a manner to satisfy the selfish, and possibly sometimes the legitimate, wishes of his countrymen in America. The colonial governors, if nativeborn Americans, certainly if not Puritans in religion, were at best between two fires, and are entitled to some consideration. It is only fair to say of Joseph Dudley that certain of his contemporaries in America eulogized both his character and services in the strongest terms, while others, then and since, have been equally free in censuring him. It is the reward of politics. He is said to have been the first nativeborn American who ever sat as a member in the British Parliament.

The college had yet one more benefactor in this family in Judge Paul Dudley, the son of Governor Joseph Dudley, and grandson of Governor Thomas Dudley. He was attorneygeneral of Massachusetts sixteen years; a judge of the superior court, the highest in the colony, twenty-seven years, and chief justice of the same court six years, thus making in all a round judicial service of forty-nine years, almost half of the century. He founded the Dudleian lectures by a bequest of one hundred pounds to the college, which donation has in one important direction quite outgrown its usefulness.

We are not informed that Governor Thomas Dudley made any donations whatever to the college. And many persons have no doubt thought, from what has been said and written about him, that it was not in his nature to have given money. This is a gross mistake, unfair to his life work of Christian philanthropy and self-sacrifice. He gave his valuable services.

Cotton Mather, who was not more fond of the Dudley family than Christian obligation required, said of him, "That which crowned all was his sincere piety, exact justice in his dealings, hospitality to strangers, and liberality to the poor." 1

Dudley's dominant thought appears in his letter to the 1 Proc. Mass. Hist. Soc., Jan. 1870, 221. 
Countess of Lincoln. "If any come hither to plant for worldly ends, that can well live at home he commits an error, of which he will soon repent him, but if for spiritual, and that no particular obstacle hinder his removal, he may find here what may well content him. ... If any godly men, out of religious ends, will come over to help us in the good work we are about, I think they cannot dispose of themselves nor of their estates more to God's glory and the furtherance of their own reckoning." Lowell has said, "There never was a colony, save this, that went forth, not to seek gold, but God."

This is a picture of his own self-sacrificing missionary enterprise across the sea, leaving a life of comfort and luxury to do good.

We must not permit Winthrop's charge, in a quarrel about letting grain on shares, or the eulogistic poetry quoted by Governor Belcher, "A bargain is a bargain," to be wrested from their original purpose to convince us that Dudley was a hard and penurious man. Morton says, in "New England's Memorial," "His love to the people was evident in serving them in a public capacity many years at his own cost, and that as a nursing father to the churches of Christ."

He was thrifty, but he was also honest and just. He did not publish his deeds of charity. He concealed them, as he did his ancestry and himself. We have no wish to give him credit for donations to the college which were not made, but knowing how little he sought the applause of men, we cannot fail to remember that men contributed to it who were unwilling to have their names recorded. Mather tells us, "But as I find one article to run thus, a gentleman not willing his name should be put upon record, gave $50 £$; thus I am so willing to believe that most of those good men that are mentioned were content with a record of their good deeds in the book of God's remembrance," that he does not name them. ${ }^{1}$

President Quincy says that in making donations to the 1 Mather's Magnalia, ii. bk. iv. §3. 
college, "the magistrates caught the spirit, and led the way by a subscription among themselves of two hundred pounds, in books for the library. The comparatively wealthy [of whom Mr. Dudley was one] followed with gifts of twenty and thirty pounds. The needy multitude succeeded, like the widow of old, casting their mites into the treasury."

We shall have occasion hereafter to witness the liberality of Dudley, who was the most prominent founder in $1645-46$ of the Roxbury Latin School. His hand appears indeed in every good work, in founding churches, schools, wholesome laws, the commonwealth, and the union of the colonies.

His daughter, Mrs. Bradstreet, knew her father well, and if we regard her testimony with less confidence because of her filial affection, still she was honest, and her simple declarations are convincing. She writes:-

"High thoughts he gave no harbor in his heart, Nor honors puffed him up, when he had part:

Those titles loath'd, which some too much dolove For truly his ambition lay above.

His humble mind so loved humility,

He left it to his race for legacy:

And oft and oft, with speeches mild and wise,

Gave his in charge, that jewel rich to prize.

No ostentation seen in all his ways,

As in the mean ones, of our foolish days,

Which all they have, and more still set to view,

Their greatness may be judged by what they shew.

His thoughts were more sublime, his actions wise,

Such vanities he justly did despise." 1

The jewels of Fair Harvard, like those of Cornelia, the brave mother of the Gracchi, are her illustrious children, some of the noblest of whom have descended from Thomas Dudley.

1 The Works of Anne Bradstreet, ed. by J. H. Ellis, 366. 


\section{CHAPTER XXIII}

LAW-BUILDING is a matter of the greatest human interest, not only because it demands the highest qualities of intellectual endowment and knowledge of social order, but, what is of more interest in general, the laws created are supposed to gather into themselves the regular steps of advance in human thought and progress, and are therefore a concentrated history of our race during the periods included by them. The laws of this colony are of especial interest, because they were made at the beginning of political and social life unlike anything in the previous history of the world. The General Court, on the I 2 th day of March, I638, enacted as follows: "For the well ordering of these plantations, now in the beginning thereof, it having been found by the little time of experience we have had here, that the want of written laws has put the Court into many doubts, and much trouble in many particular cases, this Court hath therefore ordered that the freemen of every town (or some part thereof chosen by the rest) within this jurisdiction shall assemble together in their several towns, and collect the heads of such necessary and fundamental laws as may be suitable to the times and places where God by his Providence hath cast us, and the heads of such laws to deliver in writing to the governor, for the time being, before the fifth day of the fourth month, called June next, to the intent that the same governor, together with the rest of the Standing Council [that is, Dudley and Endicott] and Mr. Richard Bellingham, Esq., Mr. Bulkley, Mr. Philips, Mr. Peters, and Mr. Shepard, elders of several churches, Mr. Nathaniel Ward, Mr. William Spencer, and Mr. William Hawthorne, or the major part of them, may, upon the survey of such heads of laws, make a 
compendious abridgment of the same by the General Court in autumn next, adding yet to the same or detracting therefrom what in their wisdom shall seem meet, that so the whole work being perfected to the best of their skill, it may be presented to the General Court for confirmation or rejection as the Court shall adjudge.

"And it is also ordered, that the said persons shall survey all the laws and orders already made, and reduce them into as few heads as they may, and present them unto the General Court for approbation or refusal, as aforesaid." 1

In taking a general survey of the condition of the colony, resulting from all of its action, in repression and otherwise, we are forced to admit that its course in the matter of good government, and its suppression of intruders included, had the effect to draw emigrants, for three thousand settlers were attracted; no other colony had anything like such prosperity. This seeming public commendation goes far to vindicate the wisdom and political sagacity of the Puritans of Massachusetts, if the growth and magnitude of a colony are the surest indications of successful planting, as they are usually regarded. No doubt the great increase in population was due very much to the disturbed political and religious forces in England; but when the unhappy people looked across the sea for an asylum, they evidently regarded Massachusetts as the land of strong and safe government, the abode of law and order, the one spot in all the world where English scholars, who had lost confidence in their own institutions and rulers, were beginning to rally and to experiment on virgin soil, with new ideals of government.

It was in fact the inauguration of a new era of liberty in the world. Mather informs us that "It was for a matter of twelve years together, that persons of all ranks, well affected unto church reformation, kept sometimes dropping, and sometimes flocking unto New England, though some that were coming into New England were not suffered to do so. . . . Among those bound for New England, that were so stopt,

1 Mass. Col. Rec., i. 222. 
there were especially three famous persons, whom I suppose their adversaries would not have so studiously detained at home, if they had foreseen events ; those were Oliver Cromwell and Mr. Hampden, ${ }^{1}$ and Sir Arthur Haselrig." 2

Mr. James Grahame, in his history of the United States, adds the name of Pym to this roll of notable persons. It will always afford a very interesting and striking, but useless subject for human speculation, how the course of events in both England and America would have turned, if those master minds of the English commonwealth had really emigrated and found here useful occupation in subduing forests and Christianizing savages. James Russell Lowell has given to us in a beautiful poem the supposed thoughts of these two men, Hampden and Cromwell, as they were deeply considering whether the cause of human freedom would be most served by their emigration to America or by their remaining to aid the coming revolution in England.

"The fate of England and of freedom once

Seemed wavering in the heart of one plain man:

One step of his, and the great dial-hand,

That marks the destined progress of the world

In the eternal round from wisdom on

To higher wisdom, had been made to pause

A hundred years. That step he did not take, -

He knew not why, nor we, but only God, -

And lived to make his simple oaken chair

More terrible and grandly beautiful,

More full of majesty than any throne,

Before or after, of a British king." 3

It is important to mention in this connection that modern investigators, who seem determined upon destroying the very fabric of history itself, have not overlooked this beautiful story, but have found occasion to doubt it altogether.

1 Hampden, Winthrop, and Dudley were the executors of the will of Isaac Johnson, also of one before the last one, a fact which suggests their intimate relations. (Mass. Hist. Coll., $3 \mathrm{~d}$ series, viii. 244; Hutchinson, i. 16.)

2 Mather's Magnalia, i. bk. i. § 7, p. 73.

8 Lowell's "A Glance Behind the Curtain," Poems, Household ed., 49. 
Winthrop was chosen governor and Dudley deputy governor in May, 1638. This was no doubt an era of excellent good feeling; popular enthusiasm and approval abounded, for the Court at that very session enacted as follows: "It is ordered, by this present Court, that John Winthrop, Esq., the present governor, shall have twelve hundred acres of land, whereof one thousand was formerly granted him, and Thomas Dudley, Esq., the deputy governor, his one thousand acres granted to him by a former Court, both of them about six miles from Concord, northward; the said governor to have his twelve hundred acres on the southerly side of two great stones, standing near together, close by the river side that comes from Concord, and the deputy governor to have his thousand acres on the northerly side of the said two great stones, (which stones were lately named the Two Brothers)." 1

Those very stones remain there in the town of Bedford, little changed, and the Bedford Historical Society, in I894, cut in large letters the name of Winthrop in the stone which was, in 1638 , next to his land, and in the same manner the name of Dudley in the other stone, with the same date, 1638, and thus Winthrop and Dudley here confront each other. ${ }^{2}$ This society, which has placed the inscriptions on these ancient landmarks, is justly entitled to public gratitude. This spot is of deeper interest possibly than we at first suspect. Winthrop has left in his Journal the following: "The governor [Winthrop] and deputy [Dudley] went to Concord [April 24, 1638] to view some land for farms, and, going down the river about four miles, they made choice of a place for one thousand acres for each of them. They offered each other the first choice, but because the deputy's was first granted, and himself had store of land already, the governor yielded him the choice. So, at the place where the deputy's land was to begin, there were two great stones,

1 Mass. Col. Rec., i. 229.

2 For an account of the Two Brothers, see Henry A. Hazen's Hist. of Billerica, 4, 5, 10. 
which they called the 'Two Brothers,' in remembrance that they were brothers by their children's marriage, and did so brotherly agree, and for that a little creek near those stones was to part their lands." 1

The Hon. Robert C. Winthrop has written his own graceful and beautiful impression of this event. "Certainly it was a felicitous coincidence that Concord should have been the scene of this charming exhibition of mutual concession and fraternal love. Since the quarrel of Brutus and Cassius, which Shakspeare has rendered so memorable in his immortal dialogue, it would be difficult to find one more vividly described or more happily ended. Who would undertake to reopen the record in order to decide who was right and who was wrong in such a disagreement? Let it stand, without mutilation and without commentary, as a beautiful illustration of the manner in which two of the fathers of New England conducted the controversies which sometimes sprung up among them. There were no challenges to personal combat. 'They were angry but sinned not.' . . . The contentious statesmen of modern times may well take an example from this early chapter of New England history, and this original record of New England controversy." 2

A lovely scene is spread out before you, as you stand beside the "Two Brothers," and look up and down the Concord River. ${ }^{3}$ Far up, the river is obstructed by a beautiful

1 Winthrop, i. *264.

2 R. C. Winthrop's Life and Letters of John Winthrop, ii. IoI, Io2.

3 Nathaniel Hawthorne knew this river well and loved it dearly. He has left to us the following description of it in one of his own classic pictures: "We stand now on the river's brink. It may well be called the Concord, the river of peace and quietness; for it is certainly the most unexcitable and sluggish stream that ever loitered imperceptibly towards its eternity - the sea. Positively, I had lived three weeks beside it before it grew quite clear to my perception which way the current flowed. It never has a vivacious aspect, except when a northwestern breeze is vexing its surface on a sunshiny day. From the incurable indolence of its nature, the stream is happily incapable of becoming the slave of human ingenuity as is the fate of so many a wild, free mountain torrent. . . . It slumbers between broad prairies, kissing 


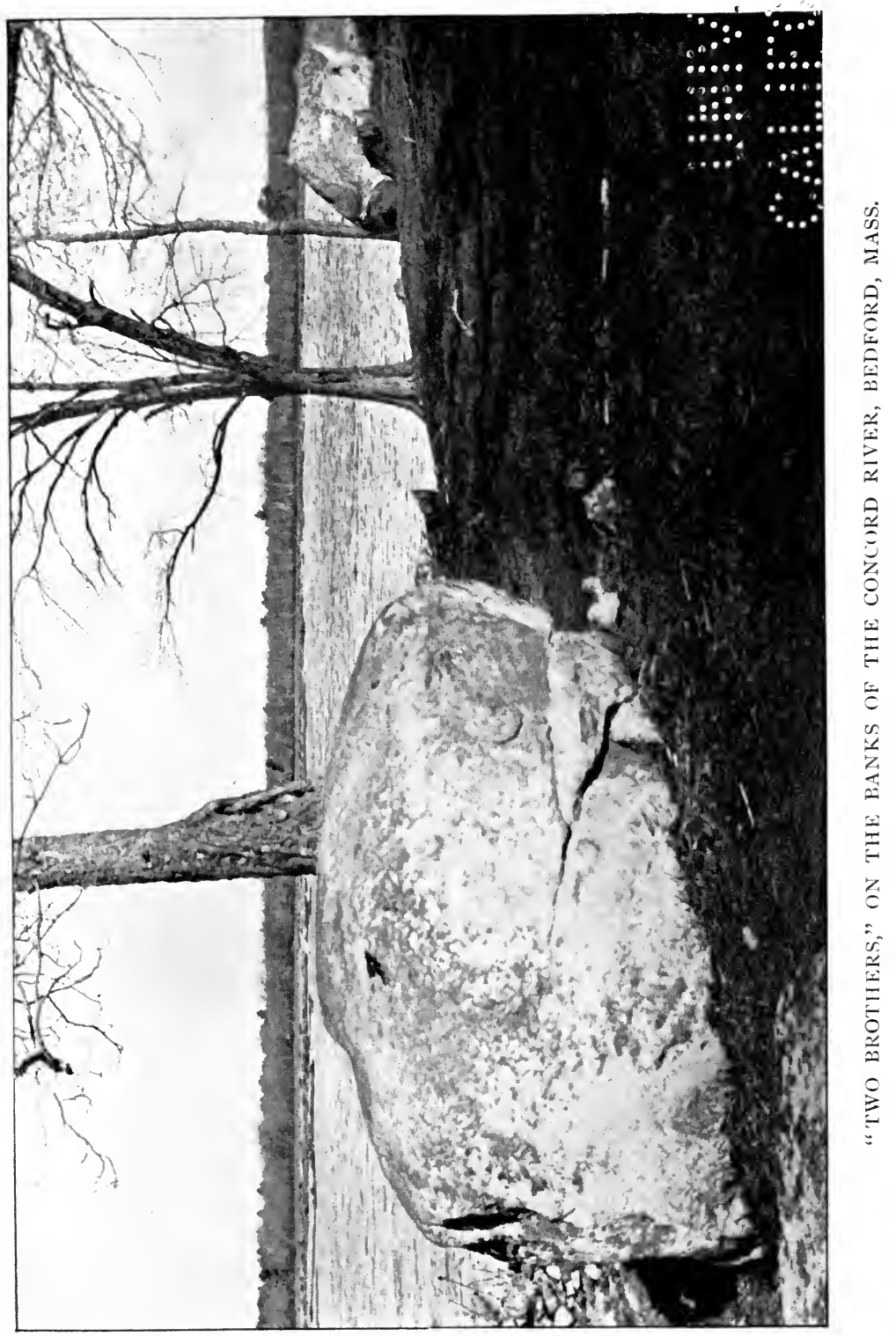




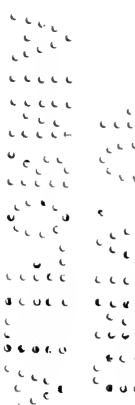


bridge with many arches, while below, after a long sweep by the winding of its course it disappears. Across the stream the view stretches away over boundless meadows to the broken lines of distant hills.

One hundred and thirty years subsequent to this memorable visit of the two most eminent planters of New England, but a few miles nearer towards the source of this stream,

"The embattled farmers stood, And fired the shot heard round the world."

Labor, wages, and prices perplexed and embarrassed the colony, as in modern life they vex society, and as during long ages to come they are destined to disturb the social life of nations. "Whereas there hath been divers complaints made concerning oppression in wages, in prices of commodities, in smith's work, in excessive prices for the work of drafts [moving loads by drawing], and teams and the like, to the great dishonor of God, the scandal of the gospel and the grief of divers of God's people, both here in this land and in the land of our nativity, the Court taking into consideration, hath ordered it, that it shall be duly considered by Mr. Endicott [and others constituting a committee of about thirty persons], whom the Court hath desired in that particular, and to bring into the next General Court their thoughts, for the remedying of the same." 1

Captain Robert Keayne, who was the first commander of the Ancient and Honorable Artillery of Boston, and whose unworthy son, Benjamin, was the husband of Dudley's daughter Sarah, was disciplined both by church and state for selling his merchandise at excessive profits. He left a will, very many pages of which are devoted to the proper vindica-

the long meadow grass, and bathes the overhanging boughs of elder bushes and willows or the roots of elms, and ash trees and clumps of maples. Flags and rushes grow along its plashy shores; the yellow water-lily spreads its broad, flat leaves on the margin; and the fragrant white pond-lily abounds." (Hawthorne's Mosses from an Old Manse, chap. i. I4.)

1 March 12, 1638. Mass. Col. Rec., 1. 223. 
tion of himself and his character, appealing to the serious and unbiased reflections of mankind.

Dudley and Captain Keayne were both military men, for which reason, and because of the intermarriage of their children, we may confidently suppose them to have been friends, at any rate until the subsequent unhappiness of their children; and we have no evidence that their friendship was not well-established and permanent to the end of life.

The General Court, in June, I639, declared the now famous Council for Life to have no power of judicature whatever, nor in the magistracy, and to be in fact ornamental only. ${ }^{1}$

The General Court gave its attention in September of this year, on the one hand to superfluity and exuberance in dress, and on the other hand to its improper contraction and to its reduction. It is ordered that tailors are not to "set lace or points upon any garment. And that hereafter no garment shall be made with short sleeves, whereby the nakedness of the arm may be discovered .. . sleeves not to be more than an ell in the widest place," and more about immoderate great sleeves, knots of ribbon, broad shoulder bands, double ruffles and cuffs.

It would be a great satisfaction to us to know what part Dudley took in all this quaint and curious legislation. We know that he was present and took a share at all the meetings whose records have claimed our attention, but whether he voted with the majority in favor of sumptuary laws, or was hopelessly lost with the minority, we cannot tell. Since, however, he was so popular, and retained the places of first importance among the people so many years, it is reasonable to conclude that in general he was with the majority, and that his personal influence went as far as that of any one in directing on which side the majority would be found, upon every question before the Court. This in any event matters but little ; the decision arrived at included the majority and minority; all members are therefore equally entitled to the credit or dishonor of each and every act. No one can go

1 Mass. Col. Rec., i. 264. 
behind the curtain to discover individual action, and to fix individual responsibility; all is merged in the final recorded statute or judgment.

They ordered at this September Court that records of the doings of the Court should be carefully kept, also of probate matters, marriages, births, deaths, and of houses and lands.

Improved roads and the means of cheap, easy, and rapid transit and communication between one part of a state and the other have at least, since the construction of the wonderful ancient Roman roads, been little by little winning the attention and confidence of men. No effort now is required to convince intelligent people that if intercourse and commerce through the agencies of the air, water, steam, electricity, and horse-power were extinguished, a very short period would show a rapid relapse towards that night of barbarism from which we have slowly emerged. When the General Court, therefore, at this session ordered "that all highways shall be laid out before the next meetings of the Court, so as may be with most ease and safety for travelers," and made provision therefor, it had moved in the right direction towards the development of the colony and country. It would need centuries of vigorous labor to complete only a portion of this herculean undertaking, but then and there the work of the Titans began, and it required only the improved skill and abounding energy of the coming generations of intelligent freemen, assisted, indeed, by foreign labor and capital, to overlay the continent with highways of steel.

Another material change was made this year in the Court, transferring important judicial powers from the General Court to the Court of Assistants ; county courts were also created, and an essential advance made towards the system which has prevailed ever since. ${ }^{1}$

We have previously noticed the founding of Harvard College and the connection of Dudley with it, but the public system of education of the whole people was very funda-

1 Washburn's Judicial Hist. of Mass., 27, 31 ; Pub. Narr. Club, ii. 184. 
mental in the formation of our government, and the source from which it was principally derived was the college, coupled with the watchful, intelligent purpose of the founders. Educated men from Oxford and Cambridge, ministers and others, went into the wilderness, each bearing a torch, carrying the gospel and the saving light of learning to the remotest and ever-extending boundaries of the colony. This was the seed-sowing for a government of the people, in which sovereign people must be educated in virtue, and trained in everything which contributes to true nobility of character. The common school was produced by spread of learning from the college to the people, and therefore we are not to regard the university as the product of the common schools, but as being itself in a large degree the source and fountain of such schools in our system. This thought ought very much to awaken our appreciation of the foresight and sagacity of the fathers of New England, who took the first welding heat on our institutions, and began by founding a college.

The printing press, moreover, came to Cambridge in 1639 , by far the most powerful engine in the general distribution of knowledge. Here they were together, the college and the press, on the extreme eastern shore of the continent, beginning to force "westward the course" of democratic republican empire.

"The earliest effort of the Cambridge press, apparently, was to print in 1639 the oath required from all freemen. In the next year the so-called Bay Psalm-Book was printed. . . . The Almanac, which from 1639 was an annual production, was as yet nothing 'more than a bare calendar, with blank spaces to serve as a diary. With the next generation it took higher rank, and may in fact be looked on as the earliest form of light literature recognized in New England." 1

This year Dudley changed his residence to Roxbury, which was his home during the remainder of his life. Cotton Mather gives the reasons for this change, as follows : "The country soon found a need of his wisdom to help to

1 Doyle's The English in America, ii. I I9, I 20. 
strengthen them in that storm of trouble that began to arise immediately after his removal [to Ipswich in I635], so as the necessity of the government and importunity of friends, enforced him to return back two or three years after his going away. The town he returned unto was called Roxbury, within two miles of Boston, where he was near at hand to be counseled or advised with in any exigency; divers of which did presently appear, after his return; of him it was verified what the poet said, "Virtutem presentem odimus, sublatam ex oculis quærimus invitis.'" 1

The following letter of Thomas Dudley to Rev. John Cotton shows what perplexing questions disturbed the souls of the founders : -

Reverend Sir, - I appointed my brother Dennison, the bearer hereof, to have been with me at the Court at Boston, about what I now write, but it fell out otherwise. The uprightness I perceive to be in him stirreth me up to desire his reconciliation to the Church, and one thing that hindereth is his opinion about the first evidence: He granteth that the Spirit can give no first evidence without it work grace, and I assent that there can be no grace until the Spirit work it, which agreeth with what passed at my house between yourself and me: therein I perceive no difference between them. But when these premises are drawn to a conclusion, then he draws back and affirmeth that yet the Spirit gives the first evidence without the sight of grace.

If two things go together neither of which is first or last, and if the Spirit work not grace, that Spirit is delusory, then I cannot know it to be the Spirit of God until I see it hath wrought them even, for evidence (about which the question is) implieth sight within the signification and ordinary use of the word: I am not able to see but that he contradicteth himself.

If you so conceive I pray you, Sir, help him. This I would ${ }^{1}$ See Horace, bk. iii. ode 24; Proc. Mass. Hist. Soc., Jan. 1870, 219, 220. 
this day have spoken to you if I had not been hindered: you see how bad my page is, and it is time for the bearer to be gone towards Boston.

I pray you bear with hasty, page, \&c. I shall understand by my Bro: Dennison at his return without your trouble of writing what you say. I therefore forbear your further trouble, resting -

Your old unprofitable friend,

Tho: Dudley.

ROXBURY the 21 of the I Month 1638.1

We are quite certain that the Brother Dennison mentioned in this letter was William Dennison, constable of Roxbury, whose son, Daniel Dennison, had married Dudley's daughter, Patience. We know that it was the custom to call each other brothers when their children intermarried. Dennison was disarmed with other Hutchinsonians, November 20, I637, and in I639, June 4, "had liberty till the next Court." This explains Dudley's interest in Dennison. The letter above was written while Dennison was disarmed; it is about grace and other Antinomian doctrine, and bears its own evidence of the cause which produced it. The beautiful altruism of Dudley is manifested in the concluding lines of the letter.

It has also been said that Dudley "removed to Roxbury to place himself under the ministration of Eliot," the apostle to the Indians ; their houses were on opposite sides of the same street, and, also, under the ministration of Mr. Weld, they were associated in the same church." "The Dudley homestead, containing between five and six acres, lay between what are now Washington and Bartlett streets, on the south, and Roxbury Street, on the north, extending from Guild Row to Putnam Street, the eastern boundary of the

1 The original of this letter is in the Boston Public Library, Prince Collection, Cotton Papers, S. 21-1, ii. 15.

The letter was written about the time that Dudley removed from Ipswich to Roxbury, and is for that reason inserted here.

2 Mass. Col. Rec., i. 212. 
land of the First Parish. Smelt Brook was originally the eastern boundary of the homestead." 1

The house and home of Dudley was on the site long occupied by the First Universalist Church; his well is said to have been under it. ${ }^{2}$ This was the house on which Dudley, in I646, secured a perpetual tribute to the Roxbury Latin School at its foundation. ${ }^{3}$ Drake, the historian of Roxbury, assures us that "in its day this was one of the best houses in the town. . . . And that we may be certain that during the entire colonial period no New England mansion entertained a larger number of visitors of distinction." Here, in the next year, 1640, when Dudley was governor, he well entertained "the brave and magnanimous Miantonomoh, the Sachem of Narragansett." Perhaps we ought to say, on the authority of the United Colonies, the treacherous Miantonomoh. ${ }^{4}$

We are admitted into the interior of this Roxbury home, and with lively interest pass from room to room, and are informed what furniture and personal effects once used by these excellent people were found in the various apartments, including two parlors, a parlor chamber, a hall chamber, study, and other rooms. The library attracts us in the study. Here, more than in any other room, we seem to feel the presence and the personality of "the sturdiest support and ornament of New England," the pillar of church and state. The library of a person, selected by himself, with the means given to him to exercise his taste and choice from time to time, becomes in a sense the mirror of his mind, culture, and development. To this end, the number of books is far less important than the quality. A few books and much reflection have been the means and method of the giants of learning.

1 Francis S. Drake's Town of Roxbury, 238.

2 The church was burned a few years ago, and now small shops in part occupy the site.

8 C. M. Ellis's Hist. of Roxbury, 39.

* Winthrop, ii. *8, * 5 . 
The first book on his list but one is the "General History of the Netherlands." The Netherlands, more than any other country except their native land, and Geneva, had contributed to the Puritan ideas of liberty, education, and religion. This book, next to the Bible, the laws of Moses and dealings of the Almighty with ancient Israel, may have been his constant study, his morning and evening text-book and guide. The "Turkish History" indicated breadth and liberality in reading and investigation. His copy of the "reserved and thoughtful" Tacitus denotes his vigorous and classical taste, respecting which Cotton Mather has informed us. Camden's "Annals of Queen Elizabeth" would be of personal interest to him because he was an Englishman; because, also, he had been a subject during her reign, and had gone as a soldier to France, bearing her commission; besides, the book itself reflects credit on its owner, even if it was unreliable as to Queen Mary of Scotland, and too favorable to Elizabeth. Selden has declared that "Camden's 'Annals of Elizabeth' and Bacon's 'History of Henry VII.' are the only two Lives of the sovereigns of England which come up to the dignity of the subject, either in fullness of matter or beauty of composition."

The "Commentaries of the Wars of France" doubtless included the war in which his father died, and in which he himself had a part in the struggle of Henry IV. of France. Scotland also was dear to the Puritan heart, because Presbyterianism triumphed there, both over papacy and at last over prelacy. George Buchanan also was unfavorable to' Mary, Queen of Scots, but his "History of Scotland" was a famous book. "It cannot be denied but Buchanan was a man of admirable eloquence, of rare prudence, and of exquisite judgment; he has written the history of Scotland with such elegance and politeness that he surpasses all the writers of his age ; and he has even equaled the ancients themselves, without excepting either Sallust or Titus Livius." 1 
As Dudley was himself a lawmaker, "An Abstract of Penal Statutes" must have been to him a useful book ; besides, he was very much of a lawyer. But what was the significance of "Piers Plowman" in this library, a satire upon church and state? It was indeed very marked. For that book contains, in epitome and outline, the doctrines which produced the Reformation, and no man of his period was more strongly imbued with those teachings, extended even to the perfection of Puritanism, than he.

It represents a literary and political revolution in which the Saxon is over the Norman. And the battle won at Hastings was lost at Marston Moor. The victorious Saxon was uppermost alike in the commonwealth of England and in the other one of Massachusetts. One of the principal founders of the last, moreover, was the student who in this library daily and constantly sought light and wisdom upon his responsible work. Campbell says that "the general object of 'Piers Plowman' is to expose, in allegory, the existing abuses of society, and to inculcate the public and private duties both of the laity and clergy." No man in all the world had these things more at heart, and no man had therefore a better right to the perpetual companionship with Piers Plowman, than our honored governor.

We find in this room, also, the writings of Calvin, Cotton, Rogers, and Norton; books on history, law, theology, religion, and education. Every one of these books has an essential characteristic of himself in it, and is in the library because of his own exceeding need. His greatness and liberality of mind are reflected in the quality of these silent friends and associates.

A list of Dudley's books - there were fifty or sixty volumes inventoried at his decease - is to be found in the Suffolk Probate Records, lib. ii. fol. I33; Hist. Gen. Reg., xii. 335, 336 ; also Dean Dudley's Hist. of the Dudley Family, i. 84,85 .

The Rev. Nathaniel Rogers wrote of Dudley : "A devourer of books, in himself a choice collector, a compend of sacred 
history." Captain Edward Johnson says, in "WonderWorking Providence," that he was "a man of sound judgment in matters of religion, and well read, bestowing much labor that way." 1 His daughter, Mrs. Bradstreet, records that he was "a magazine of history."

"The old mansion was razed to the ground a few days after the battle of Bunker Hill, and its brick basement walls, facing north and east, made the angle of the work that was erected by the Americans. The intrenchments at this point included the garden, and extended to the hill east of the meeting-house." 2

If the glorious old Saxon was permitted to witness that desolation of his home and hearth, that invincible spirit which inspired his life work responded, Grind it as fine as dust to construct bulwarks to resist the tyranny of the British throne and defend American liberty!

It is mentioned in the "Memorial History of Boston" that "by far the most eminent citizen of colonial Roxbury was Thomas Dudley, founder of a family that furnished two governors, a chief justice, and a speaker of the House, all of whom played conspicuous parts in the affairs of New England." ${ }^{3}$

His daughter, Anne Bradstreet, distinguished, as we have before remarked, as the earliest poet of her sex in America, herself the ancestor of at least two eminent poets, is worthy to be named among the celebrated members of that family. Her volume of poetry was the first published in America.

1 Poole's ed., 52.

2 F. S. Drake's Roxbury, 237.

3 Memorial Hist. Boston, i. 4I 7 . 


\section{CHAPTER XXIV}

AN extensive reorganization of the courts was made between 1636 and 1640 . It seems that previous to that time the General Court had exercised the whole powers, both legislative and judicial, throughout the colony, and had jurisdiction both in civil and criminal cases. But now county courts were created, which have continued, with change of names, to the present time. The principal judicial powers of the General Court were transferred to the Court of Assistants.

The county courts were held by one or more of the assistants or magistrates who resided in the county where the court was to sit, or by magistrates appointed from time to time by the General Court, aided by commissioners who were nominated by the freemen of the county and appointed by the General Court. The commissioners and magistrates were to be five in number; but three of them, if one were a magistrate, were competent to hold a court. This court had no jurisdiction in matters of divorce, of life and limb, or banishment. ${ }^{1}$

Although they denied all rights of appeal to England from their courts, and insisted upon this with great firmness, yet they manifested their loyalty to the throne in many ways. The following is an instance of it : "Further, it is ordered that, in all the aforesaid places of judicature, the King's Majesties arms shall be erected so soon as they can be had." 2 .

Dudley was constantly a magistrate during all this con-

${ }^{1}$ Mass. Col. Rec., i. 175, 169; Washburn's Judicial Hist. of Mass., 27, 31,37 .

2 Mass. Col. Rec., i. I75. 
structive period of the courts, and both long before and long after. His. handiwork is in it all. He not only executed the laws and interpreted them with his associates, but with them he also created the laws, since they were together the legislative body of Massachusetts. ${ }^{1}$

As we have already noticed, the people were anxious because there was no general system of laws. Although the laws of England were supposed to be the authority on which sentences were grounded, yet it was felt that far too much was left to the authority and discretion of the courts. For this reason steps were taken in 1635 as follows: "The governor [John Haynes], the deputy governor [Richard Bellingham], John Winthrop and Thomas Dudley, Esquires, are deputed by the Court to make a draught of such laws as they shall judge useful for the well ordering of this plantation, and to present the same to the Court." 2

The first thing that attracts our notice in this act is the prominent position given to Dudley and a few other men in the constructive work in law-making. $\mathrm{He}$ is everywhere present at the laying of the foundation of Massachusetts and her laws. This is confirmed by the fact that Dudley was a member of a similar committee appointed in 1636 , I637, and another in 1639 , which was directed to peruse all those models which have been, or shall be, further presented to this Court, or to themselves, concerning a form of government and laws to be established, and shall draw them up. And although these committees have left little or nothing on record of their labors, and there are some reasons to suppose that the magistrates and elders were inclined to delay the framing of a code of laws, yet an advance was made, for at the General Court, May 13, 1640, it was voted: "Whereas a Breviate of Laws was formally sent forth to be considered by the elders of the churches and other freemen of the commonwealth, it is now desired that they will endeavor to ripen their thoughts and counsels about the same

1 Mass. Col. Rec., i. I I 7, ri8.

2 Ib., i. 147. 
by the General Court in the next Eighth Month." This refers to Mr. Ward's Body of Liberties, which became the foundation of the laws of Massachusetts, not, however, until it had been referred to the people and improved by amendments at the General Court, in which Dudley, with others, took an active part.

The reason why the magistrates had been careful about establishing regular statutes was the fear that their enemies would censure them and attempt to prove the statutes repugnant to the laws of England, and thus give them new cause to expect foreign interference. But if their laws were merely the interpretations of customs which arose step by step in the development of the country, they would attract less notice and have greater stability than theoretical codes of laws.

There were two models of laws prepared: one by the Rev. John Cotton, supported by texts of Scripture, the other by the Rev. Nathaniel Ward, who was not only a clergyman but a lawyer who had practiced in the courts of the common law in England; and since the Bible was accounted the supreme law of the land, it gave him a great advantage to have been educated thoroughly in both professions. Ward's model was soon found to be of greater practical use and advantage, and in December, I64I, three weeks were employed by the General Court in considering his system, which, with amendments, as we have said, was adopted as the Body of Liberties of the Massachusetts Colony. "This," Bancroft says, "for its liberality and comprehensiveness, may vie with any similar record from the days of Magna Charta." He says further, these laws "exhibit the truest picture of the principles, character, and intentions of that people and the best evidence of its vigor and self-defense."

A few features of these laws are worthy of special notice, as indicating real progress in government and individual freedom.

The representatives to the General Court were to serve but one year unless reëlected. The Assembly could not be 
dissolved or adjourned without the will of the majority. Every town had power of self-government, subject to the public laws of the country; power also to choose selectmen annually, "to order the prudential occasions of the town according to instructions to be given them in writing."

This town government has since been recognized as the unit in our system, and as being nearer in influence and in control of the individual citizen than the state government itself. "It abolished feudal servitudes of the soil, children inherited under it equally the property of intestate parents, all officers were annually elected, jury trial was secured, married women were protected, fugitives from tyranny or oppression were welcomed, and no person was required to pass the limits of the plantation in an offensive war."

The capital crimes, which were then under the English common law more than forty in number, were reduced to twelve. "There shall never be any bond slaverie, villinage, or captivitie amongst us, unless it be lawful captives taken in just wars, and such strangers as willingly sell themselves or are sold to us. And these shall have all the liberties and Christian usages which the law of God established in Israel."

Notwithstanding this provision, slavery continued within the commonwealth down to 1780 . Rights of person and property were secured, no one was to be tried twice for the same offense, public records were open to inspection, public money was only to be disbursed with the consent of the taxpayers, cruel punishments were forbidden, judicial proceedings were defined and the privileges and duties of freemen. Elisha Hutchinson says that "Mr. Bellingham of the magistrates and Mr. Cotton of the clergy had the greatest share in this work." We have seen that he was wrong as to Cotton; but Bellingham undoubtedly served on nearly all the committees, as did Winthrop and Dudley. ${ }^{1}$

There may be a question in some minds why the Court in I639 placed the important service of producing a code of laws in the hands of two persons, Cotton and Ward, instead

1 William H. Whitmore's Mass. Col. Laws, 18. 
of a larger committee, and that the commission did not include the prominent men, Winthrop and Dudley. As in the case of the former committees, the explanation undoubtedly is that they recognized that small committees are more efficient, that the code ought to be the work of one mind, to give to it unity and symmetry in its proportions, and greater vigor, because of the individual responsibility of its author. Dudley was occupied fully as governor during most of the time when Ward was upon this work. Both he and Winthrop had important judicial engagements, as appear by the records, but these laws underwent their careful personal inspection during weeks of vigorous examination.

The work of preparation was both constructive and clerical. The elements of the laws were largely from the common law, and they required judicious and wise selection and reconstruction. The people in all the towns had contributed their mites, to be used or declined by the wise master-builders in forming the new code. But at last it had to pass and receive its crowning perfection from the sanction of the most eminent founders of the commonwealth.

The standard of public morals in England was at this time very low indeed, and it was no wonder, therefore, that the Puritans were disgusted, and sought in every way to exemplify the purity and worth of that Christianity which they were professing with great sincerity. ${ }^{1}$

There arose at once a conflict, therefore, between the Puritans and state and church of England, respecting the immoral influence of the drama.

In connection with the above it may be worth while to advert to the fact that on the 27th of September, I63I, being Sunday, the play of the Midsummer Night's Dream was privately performed in the Bishop of Lincoln's house in London.

The Puritans had influence to get this affair inquired into and visited with punishment, and there is something rather humorous in what was decreed to the performer of

1 Palfrey's New England, i. 276; Barry's Mass., i. 324. 
Bottom the weaver: "We do order that Mr. Wilson, as he was especial plotter and contriver of this business, and did in such a vigorous manner act the same with an ass's head, shall upon Tuesday next, from six o'clock in the morning till six o'clock at night sit in the porter's lodge at my Lord Bishop's house with his feet in the stocks and attired with an ass's head, and a bottle of hay before him and this inscription on his breast :-

'Good people, I have played the beast, And brought ill things to pass;

I was a man, but thus have made, Myself a silly ass." " 1

We have in remarkable contrast to the gay life and drama in England in the Stuart period, the New England Sunday, even a century and a half later, in I78I : "Sunday is observed with the utmost strictness; all business, how important soever, is then totally at a stand, and the most innocent recreations and pleasures prohibited. Boston, that populous town, where at other times there is such a hurry of business, is on this day a mere desert; you may walk the streets without meeting a single person, or if by chance you meet one you scarcely dare to stop and talk with him. A Frenchman that lodged with me took it into his head to play on the flute on Sundays for his amusement; people upon hearing it were greatly enraged, collected in crowds around the house and would have carried matters to extremities in a short time with the musician, had not the landlord given him warning of his danger and forced him to desist. Upon this day of melancholy you cannot go into a house but you find the whole family employed in reading the Bible; and indeed it is an affecting sight to see the father of a family surrounded by his household hearing him explain the sublime truths of this sacred volume. . . . Piety is not the only motive that brings the American ladies in crowds to the various places of worship. Deprived of all shows and pub-

1 Halliwell's Shakspere, v. 12; The Book of Days, i. 556; Charles Kingsley's Plays and Puritans, 9, 10, 20. 
lic diversions whatever, the church is the grand theatre where they attend to display their extravagance and finery. There they come dressed off in the finest silks, and overshadowed with a profusion of the most profuse plumes." 1

The church in New England furnished the chief attraction and entertainment in the seventeenth century.

Some account of the service appears in Samuel Whiting's "Life of the Rev. John Cotton," minister of Boston in 1632. Mr. Cotton "was marvelous successful in his ministry, till he had been twenty years there, and in that twenty years' space, he, on Lord's day on afternoons, went over thrice the whole body of divinity in a catechistical way, and gave the heads of his discourse to those who were young scholars, and others, in that town, to answer, his questions in public in that great congregation; and after their answers, he opened those heads of divinity, and sweetly applied all to the edification of his people, and to such strangers as came to hear him.

"In the morning on the Lord's day he preached over the first six chapters of the Gospel by John, the whole book of Ecclesiastes, the Prophecy of Zephaniah, and many other Scriptures ; and when the Lord's Supper was administered (which was usually every month), he preached upon I Cor. xi., and the whole thirtieth chapter of the 2 Chronicles, and some other Scriptures about the Lord's Supper.

"On his lecture days, he preached through the whole Ist and 2 d Epistles of John, the whole Book of Solomon's Song, the Parables of our Saviour, set forth in Matthew's Gospel to the end of chapter I 3 th, comparing them with Mark and Luke. He took much pains in private and read to sundry young scholars that were in his house. . . . Beside his ordinary lecture on the fifth day of the week, he preached thrice more on the week days, on the fourth and sixth days, early in the morning, and on the last day, at three of the clock in the afternoon. ... He was frequent in duties of humilia-

1 Abbé Robin, N. B. Shurtleff's Top. and Hist. Descript. of Boston, 69-7I. 
tion and thanksgiving, in which I have known him in prayer and opening the word and applying it, five or six hours." 1

Winthrop informs us that in 1639 , "Mr. Hooker being to preach at Cambridge, the governor [Mr. Winthrop] and many others went to hear him (though the governor did very seldom go from his own congregation upon the Lord's day). He preached in the afternoon, and having gone on with much strength of voice and intention of spirit about a quarter of an hour, he was at stand, and told the people that God had deprived him both of his strength and matter, etc., and so went forth, and about half an hour after returned again, and went on to very good purpose about two hours.

"There was at this time a very great drought . . . whereupon the General Court conferred with the elders, and agreed upon a day of humiliation about a week after.

"The very day after the fast was appointed there fell a good shower, and within one week after the day of humiliation was passed, we had such store of rain and so seasonably as the corn revived and gave hope of a very plentiful harvest." 2

Thomas Dudley was elected governor for the second time, in I640. Winthrop says: "Some trouble there had been in making way for his election and it was obtained with some difficulty, for many of the elders labored much in it, fearing lest the long continuance of one man in the place should bring it to be for life, and in time hereditary. Besides, this gentleman [Dudley] was a man of approved wisdom and godliness, and of much good service to the country, and therefore it was his due to share in such honor and benefit as the country had to bestow." 3

This, as we have before said, is remarkable testimony to the worth and character of Dudley from a political rival, at the end of more than ten years of constant intercourse and most difficult business relations. Johnson says, in "WonderWorking Providence," that "for to govern and rule this little

1 Young's Chron., 424, 425.

2 Winthrop, i. *304, *305.

8 Ib., ii. *3. 
commonwealth, was this year chosen the valiant champion for the advance of Christ's truth, Thomas Dudley, Esq., and Richard Bellingham, Esq., deputy governor." 1

Alden Bradford, speaking in 1822 of this election, says, "Dudley was a man of great integrity and piety, but bigoted and intolerant in his theological views. . . . Winthrop was passed by, not from any disesteem or want of confidence of the people, but to relieve him of the cares of government, and probably in accordance with the republican maxim of rotation in office." 2

In comparing the actions of these two foremost men of that period, it is quite evident that Winthrop made what effort he could to be reëlected, but the popular current, for democratic reasons, was against him and in favor of Dudley. As we have said before, it was no doubt a matter of principle with Dudley, on account of his regard for rotation in office, not to occupy the governor's position oftener than once in five years.

Many important laws were passed during this year. About this time there was a struggle for power between the magistrates and the ministers. Cotton preached that the priesthood ought to be consulted in all civil and military affairs. This doctrine met the indignant opposition of Governor Dudley. He was glad to welcome any instruction or information from the ministers in the new and untried experiment of government, in which the Bible was made the supreme law of the land, but he was equally opposed to their holding any official station or any place of power in the civil government. And he, above all other men, stood ready to confront them if they undertook in any manner to cross the dividing line which separated the functions of the state and of the church. He seems to have been only anxious to do right, and fearless of both ecclesiastical and political influence which might assail him or his fortunes, but always watchful of any influences, near or remote, which might inflict an injury upon Massachusetts.

1 Chap. xvi. 138.

2 Bradford's Hist. of Mass., 45. 
It is very agreeable to note the care which they all entertained respecting their wards, the Indians, and the protection which they afforded to them. "It was ordered this year that the English settlers shall keep their cattle from destroying the Indians' corn, and if any of their corn be damaged for want of fencing or herding, the town shall be liable to make satisfaction."

Acts were also passed for the encouragement of the manufacture of linen, woolen, and cotton cloth. The colony was afflicted at this time with that great common need, the want of money. On account of the scarcity of money, it was ordered that debts might be paid in corn, cattle, fish, or other commodities, at such rates as the General Court should from time to time establish, but this applied only to debts contracted before a certain date.

An important law was passed "for avoiding all fraudulent conveyances, and that every man may know what estate or interest other men may have in any houses, lands, or other hereditaments they are to deal in." And also the appointment of persons to take acknowledgments of deeds. ${ }^{1}$ This order, together with the following order, made the next year, was a great advance in the law of conveyance: "It is also ordered, and by this Court declared, that all our lands and heritages shall be free from all fines and licenses upon alienations, and from all heriots, wardships, liveries, primer seisins, year day and waste, escheats, and forfeitures, upon the deaths of parents or ancestors, be they natural, casual, or judicial. All persons which are of the age of twenty-one years, and of right understanding and memories, whether excommunicate or condemned, shall have full power and liberty to make their wills and testaments and other lawful alienations of their lands and estates." 2

Lowell says: "The men who gave every man a chance to become a landholder, who made the transfer of land easy, and put knowledge within the reach of all, have been called

1 Mass. Col. Rec., i. 306, 307.

2 Body of Liberties, I64I, Nos. 10, II, Whitmore's ed., 35. 
narrow-minded, because they were intolerant. But intolerant of what? Of what they believed to be dangerous nonsense, which if left free would destroy the last hope of civil and religious freedom." 1

One of the remarkable events in the official life of Dudley this year was his reception of Miantonomoh, the eminent sachem of Narragansett, at his home in Roxbury. This chief has an important place in the history of this period, because he was supposed to be, and probably was, the friend of Roger Williams and of Gorton, while he was finally believed by the United Colonies to be the crafty enemy of the English, and conspiring secretly for their entire destruction, as King Philip did a quarter of a century later. They were so thoroughly convinced of his treachery towards them and their allies that they suffered him to be destroyed by Uncas. Much has been written in testimony against the United Colonies for their action in this matter, which is unjust to them, for they acted reluctantly and upon careful examination, and only allowed extreme measures when they regarded them needful for the preservation of the whole English enterprise in America.

Winthrop has left an interesting account of this visit of the chief to the home of Dudley. ${ }^{2}$

Mr. Savage, in his note to Winthrop, thought that Dudley manifested more resolution than good policy in his treatment of Miantonomoh. But Dudley says that he thought it a dishonor to give way to him, and he was not the man to barter honor for anything. His judgment at the time ought to be conclusive, particularly since it was sustained by the General Court, that this magnificent savage needed to be instructed to respect the dignity and authority of Massachusetts.

This year, I640, was an important one in England, for the Puritans were coming into power, and the liberty which they were seeking in America was now becoming possible at home; there were indications also of a revolution which they

1 J. R. Lowell's Among my Books, i. 242.

2 Winthrop, ii. * ${ }^{2} 5, *$ I 6 . 
could not honorably flee from, and which they felt it a religious duty to share in. The emigration to Massachusetts from England had been so large, that in the ten years previous to this period it is estimated that twenty thousand English Puritans had come to the colony. The great rebellion stopped this influx of people, and from that time to the American Revolution it is said that more men returned to England from America than came thence to this country.

This feature is not to be disregarded, because from this it is evident how large a portion of the inhabitants of America was native, and not foreign born, in a few generations.

The Long Parliament was now assembled, and the great rebellion begun, and Massachusetts was left mostly to herself for many years. Palfrey says: "The Puritan party in England, which did so many wonderful things, was at the start distinctly a party of -reform and not a party of revolution or separation in church and state." 1

We can hardly conceive what it meant for our forefathers to be set at liberty, three thousand miles away, from the dictation and influence of English politicians and of the established church.

These Puritans were conservative people; no body of men was ever less fanatical. "It is to Puritanism that we mainly owe the fact that in England religion and liberty were not dissevered amid all the fluctuations of fortune." 2

Barry says: "Liberty in England existed but in name; and for its revival that nation is largely indebted to the efforts of the Puritans. It has long been the fashion to deride this sect and to brand it as an embodiment of cant and hypocrisy. Few have comprehended the importance of its mission, fewer have awarded it its just meed of praise. It is so easy to misjudge, it is so easy to join in the sneer against principles which are despised and condemned, that the spirit which animated the body of the Puritans has been undervalued and lost sight of by those whose prejudices

1 Palfrey, i. 304.

2 Lecky's Rationalism in Europe, ii. I73; De Tocqueville, i. 43, 44. 
incline them to speak lightly of everything not according with their own views and opinions." 1

Froude has beautifully said of them: "These men were possessed of all the qualities which give nobility and grandeur to human nature, men whose life was as upright as their intellect was commanding, and their public aims untainted with selfishness, unalterably just where duty required them to be stern, but with the tenderness of a woman in their hearts, frank, true, cheerful, humorous, as unlike sour fanatics as it is possible to imagine any one, and able in some way to sound the keynote to which every brave and faithful heart in Europe instinctively vibrated. This is the problem : grapes do not grow on bramble bushes." 2

Governor Winthrop mentions in March, 1639, that a "Printerie was begun at Cambridge by one Stephen Daye. The first issues from that press was an oath for freemen to sign, and Pierce's Little Almanack, followed in 1640 by the publication of 'The Whole Book of Psalms' in English Meter, for the Use, Edification and Comfort of the Saints in New England." 3 Soon a new translation was confided to Richard Mather, "whose voice was large and big, who was associated in this work with Rev. John Eliot and Rev. Thomas Welde, ministers at Roxbury." 4

The General Court confirms the grant to Dudley of a farm in Ipswich, as follows: "The farm (granted by Ipswich to the present governor) [Dudley] which Mr. Whitingham possessed is confirmed so far as it is in the Court's power." 5

Winthrop says, "We received a letter at the General Court from the magistrates of Connecticut and New Haven and of Aquiday, wherein they declare their dislike of such as would have the Indians rooted out, as being of the cursed race of Ham, and their desire of our mutual accord in seek-

1 Barry's Hist. of Mass., i. 322.

2 J. A. Froude's Short Studies on Great Subjects, 2d series, I4, 52.

8 Winthrop, i. 289.

4 Mag. of Amer. Hist., xxiii. 384.

5 Mass. Col. Rec., i. 304. 
ing to gain them by justice and kindness, and withal to watch over them to prevent any danger by them, etc. We returned answer of our consent with them in all things propounded, only we refused to include those of Aquiday in our answer, or to have any treaty with them." 1

It seems desirable to quote in full the Court record in this matter, which is as follows: "It is ordered, that the letter lately sent to the governor [Dudley] by Mr. Eaton, Mr. Hopkins, Mr. Haynes, Mr. Coddington and Mr. Brenton, but concerning also the General Court, shall be thus answered by the governor [Dudley], that the Court doth assent to all the propositions laid down in the aforesaid letter, but that the answer shall be directed to Mr. Eaton, Mr. Hopkins, and Mr. Haynes, only excluding Mr. Coddington and Mr. Brenton as men not to be capitulated withal by us, either for themselves or the people of the island where they inhabit, as their case standeth." 2 Mr. Savage, in his note upon the extract from Winthrop's Journal made above, grows very much heated, and says, "By giving the order of Court, to which our text refers, I shall not deserve the condemnation of exposing the nakedness of our fathers." The special thing which disturbs him is the exclusion of Coddington and Brenton, both of Newport, and Antinomians, in the above order. He continues further: "This is the most exalted triumph of bigotry." This word bigotry does not come gracefully from Mr. Savage, who says that Welde and other inquisitors have trusted much to the influence of an odious name. It is "the most common artifice of the exquisite rancor of theological hatred." 3

This was not bigotry; it was the dignified, proper course of the General Court to take in a matter in which they were dealing with colonies, and not so much with individuals.

These two persons had been separated and lost their citizenship in Massachusetts, and had been hostile to her in a very trying time. They did not represent any colony with 
a charter which Massachusetts recognized, neither did she regard them later otherwise than a community which ought to be attached either to herself or to Plymouth.

They could not consistently have dealings with them as a colony, and yet Mr. Savage has suffered himself to continue his note as follows: "Papists, Jews, Mussulmans, Idolaters, or Atheists may be good parties to a civil contract, but not erroneous Protestant brethren, of unimpeachable piety, differing from us in explication of unessential or unintelligible points of doubtful disputation." It does not appear that the difficulty about contracting was a question of nationality or of piety, and it may not have been at all a difference in belief. There may be good and sufficient reasons, satisfactory to one's self, why he should not enter into a contract or alliance even with his own brother or friend; he certainly has the right to judge for himself whether he will or will not, and it does not seem to be the business of other people.

"It was not enough that the common charities of life were broken off, but our rulers proved the sincerity of their folly by refusing connection in a just and necessary course of policy ${ }^{1}$ which demanded the concurrence of all the plantations on our coast.". It might demand the action of Massachusetts and of the separate plantations, but the necessity for concurrence in action does not appear. We will not claim that these words of Mr. Savage, to use his own quoted expression, are the "artifice of the exquisite rancor of theological hatred," but they do seem to be inspired by a partisan and prejudiced spirit which manifests itself in many places in his notes.

It is painful to notice in this connection how easily this prejudice infects successive'writers, and that even so faithful a man as J. A. Doyle has suffered himself to commend and approve this wrong, and, finally, unjustly to concentrate the whole force of his discreditable charges upon Dudley, as follows: "It is consolatory to those who reverence the mem-

1 The policy might be just, but how necessary, except to Rhode Island, that they should join her in it, is not evident. 
ory of the great New England statesman, that Dudley, and not Winthrop, was the governor when this outburst of fanatical malignity was recorded." 1

Arnold says: "The governor of Massachusetts at this time was the bigoted Dudley, the man upon whose person there was found, when on his death-bed, this original couplet, which embodies the prevailing sentiment of the age :-

'Let men of God in courts and churches watch O'er such as do a toleration hatch.'

A verse no doubt considered equally creditable to the piety and the poetic genius of the author. We think it was."

Mr. Arnold, after quoting those remarkable lines, which have such a fascination for some persons, and reflecting upon both the piety and poetic genius of Dudley, which is usual in these cases, concludes with these words full of prejudice: "That such a governor should adopt such a course might be expected." It is only needful to give heed to the order of the Court, which has been quoted and which is the foundation of all this bitterness, to discover that the governor, Dudley, had no choice in this matter, was only the presiding officer sworn to execute the orders of the General Court, which were that the answers shall be directed to certain ones only, excluding Mr. Coddington and Mr. Brenton as men not to be capitulated by them.

It is further to be noted that Winthrop, who they find such consolation in remembering was not governor at the time, and so, they declare, free from blame in this and other instances of intolerance, was present at this Court, and took part in constructing this order alleged to be full of bigotry.

Arnold heaps all the supposed opprobrium of this matter upon Dudley, to whom he alludes with sentiments of contempt which are unjust and unreasonable. ${ }^{2}$

1 J. A. Doyle's The English in America, i. 309.

2 Felt, i. 457 ; Arnold's Hist. R. I., i. 147. 


\section{CHAPTER XXV}

OuR excuse for introducing the following mere business note from Dudley to Winthrop is that every original document which connects these distinguished men possesses a public interest.

To my hONORED BRother, John Winthrop, EsQ., at his house at Boston.

Sir, - I have received the 20 li., 1 sent now by your man, for which I thank you. The truth is, I owe the whole 50 li. to be paid the end of this month, and have no other money to pay it. The money is not yet gathered up here for you, and how much will be in money I yet know not: for the other things you write of I likewise return thanks and purpose to confer thereof with you at my coming to Boston, and in the mean time and ever shall rest,

Your very assured

ROXBURY, 4 month: 15 day, 1640.2

Tho : Dudley.

It is enacted this year that the preliminary election should be held in the towns, the lists of votes to be sent to Boston by the deputies, and the candidates who stood highest in the list were the required number to be voted for or against by the whole body of freemen. ${ }^{3}$

Richard Bellingham was chosen governor at the election in 1641 , he having six more votes than Winthrop. There

$1 \mathrm{Li}$. is probably an abbreviation of libra, a pound. (Century Dict., 4657; Ency. Brit., 9th ed. 655.)

2 Indorsed by Governor Winthrop, "Bro: Dudley, Governour." (Mass. Hist. Coll., 4th series, vii. I Io; Winthrop Papers, pt. II.)

${ }^{8}$ Mass. Col. Rec., i. 293. 
were, however, some persons who were said not to have voted who now desired to do so, but were refused because they had not voted regularly at the door. Bellingham was a lawyer, and had an equal share with Winthrop and Dudley in framing the colonial laws.

This election seems to have greatly disturbed Winthrop, who undoubtedly felt that if the election had been fairly held he himself would have been elected governor. It was the democratic spirit of the period and a desire for rotation in office, rather than personal hostility to Winthrop, which elected Bellingham at this time. It is evident that in the years following the Antinomian controversy party spirit was high, and that there were church factions, political factions, and disturbing party influences. The alleged informality in the election resulted at once in the unpopularity of Bellingham, because they at once passed a vote to repeal "the order formerly made for allowing a hundred pounds to the governor." 1

Winthrop says, “The governor, Mr. Bellingham, was married. (I would not mention such ordinary matters in our history, but by occasion of some remarkable accidents.) The young gentlewoman was ready to be contracted to a friend of his, who lodged in his house, and by his consent had proceeded so far with her, when of the sudden the governor treated with her, and obtained her for himself. He excused it by the strength of his affection, and that she was not absolutely promised to the other gentleman. Two errors more he committed upon it: Ist, That he would not have his contract published where he dwelt, contrary to an order of Court; $2 \mathrm{~d}$, That he married himself contrary to the constant practice of the country." 2

Savage says: "The people were scandalized at such a breach of order in their chief magistrate."

Winthrop says also: "There fell out a case between Mr. Dudley, one of the council, and Mr. Howe, a ruling elder of

1 Mass. Col. Rec., i. 319.

2 Winthrop, ii. * 43 . 
the church of Watertown, about a title to a mill. ${ }^{1}$ The case is too long here to report, but it was so clear on Dudley's part, both in law and equity (most of the magistrates also and deputies concurring therein), as the elders being desired to be present at the hearing of the case, they also consented with the judgment of the Court, before the case was put to vote, and some of them humbly advised the Court, that it would be greatly to their dishonor, and an apparent injustice, if they should otherwise determine. Notwithstanding, he [Bellingham] still labored to have the cause carried against Mr. Dudley." 2

Winthrop proceeds to describe the conduct of the governor on this occasion as being very unjust, unworthy, revealing a very hostile spirit toward Dudley.

There were other instances of improper conduct in Court, and Winthrop says: "Upon these and other miscarriages the deputies consulted together, and sent up their speaker, with some others, to give him [Bellingham] a solemn admonition, which was never done to any governor before, nor was it in their power without the magistrates had joined." 3

Winthrop continues: "These continual oppositions and delays, tending to the hindrance and perverting of justice, afforded much occasion of grief to all the magistrates, especially to Mr. Dudley, who being a very wise and just man, and one that would not be trodden under foot of any man, took occasion (alleging his age, etc.) to tell the Court that he was resolved to leave his place, and therefore desired them against the next Court of Elections to think of some other.

"The Cøurt was much affected with it, and entreated him with manifestation of much affection and respect towards him, to leave off these thoughts, and offered him any ease and liberty that his age and infirmities might stand in need of, but he continued resolute.

${ }^{1}$ Mass. Col. Rec., i. 344.

2 Winthrop, ii. *50, * 5 I.

8 Ib., ii. * 53 ; J. B. Moore's Memoirs Amer. Governors, 338. 
"Thereupon the governor [Bellingham] also made a speech, as if he desired to leave his place of magistracy also, but he was fain to make his own answer, for no man desired him to keep or to consider better of it." 1

It is a notable fact that Bellingham and Saltonstall were frequently found in hostile opposition to the older magistrates and their ideas. Nobody can read these accounts without discovering that Dudley was a far stronger man than Bellingham.

Bellingham has been described as a more thorough lawyer than Dudley, which may well be doubted, but he certainly exceeds Bellingham in manly dignity, in uprightness of character; for though Dudley was a man of strong emotions, and is sometimes represented as exhibiting righteous indignation when he felt that either he himself or his principles, or what he conceived to be the just course, were assailed, yet he never anywhere appears as a party in any discreditable or unworthy conduct or speeches. And this in a measure is true in comparing Dudley and Endicott.

The strength, dignity, and consistency of Winthrop and Dudley seem to raise them in intellectual and moral grandeur above their associates; and while they lived, all the others occupied a secondary place, and in general were recognized by the colony as ranking beneath them in importance and influence. We are able to discover in this description which Winthrop has left us of the feelings of the Court when Dudley tendered his resignation with great sincerity and without mental reservation, giving his reasons, that he was universally held in high esteem ; enjoying a popularity among his associates which any man might justly be proud of, having just left the office of governor and having been so many years constantly in the public eye ; and it adds weight to these words that they flow from the pen of his great political rival.

The Colonial Records contain the following: "Mr. Dudley [June 2, I64I] was entreated to answer Mr. Fenwick's Winthrop, ii. *55. 
letter according to the directions indorsed." 1 And we are interested to learn what it was about.

We have been unable to find any portion of this correspondence, but there is reason to believe that it refers to a controversy between Massachusetts, George Fenwick, ${ }^{2}$ and Connecticut respecting the true line between Massachusetts and Connecticut and the right to the Connecticut River, involving also the question whether Springfield was in one colony or the other. ${ }^{3}$

William Pynchon, Esq., had made a settlement already at Agawam, afterwards called Springfield. These rights were finally settled after much deliberation by the Confederacy of the United Colonies. Between the years I64I and I 643 the rights of the parties were constantly being considered and agitated, and in this controversy both Fenwick and Massachusetts took an active part.

It is interesting in this connection to remember that Fenwick was a delegate to the first Congress of the United Colonies at Boston, at which the Articles of Confederation were adopted.

Fenwick was afterwards famous in English history as a

1 Mass. Col. Rec., i. 3 I9.

2 "Minutes of the General Court, 2-4mo (June), 1641. 'For answer to Mr. Fenwick's letter written to Mr. Dudley, Mr. Dudley to answer according to the four heads indorsed on the letter : First, it is thought by many of the Court that it (Springfield) is within our patent; Second, our claim is from the Pequot conquest, if that (our Patent) fail, and the Pequot right is before your patent; Third, we know not whether it be within your patent or no, because we never saw it nor copy of it ; Fourth, for the division of the tribute we ( ); but ( ) that which was appointed for the river, your share was in it, a letter to Mr. Hunter to forbid him for setting up ( ) trading house up the river; and (if he) will not, the governor to send to pull it down and to write to him to send our proportion of the tribute.' (Mass. Archives, State House, Boston, vol. Ixxxvii. p. 25I.) Compared with the original, Jan. 28, г 898."

We have recently discovered these minutes in the Mass. Archives, which explain the letter.

8 Mass. Col. Rec., i. 323, 324 ; Trumbull's Conn., i. I18. 
colonel in the army of the English Commonwealth, and as one of the judges selected by Cromwell to try Charles the First. He had the wisdom, however, not to sit, and escaped the danger which subsequently attended members of that court. On the same second day of June "Mr. Symonds, Mr. Hubbard, Mr. Dummer, Mr. Bellingham, and Mr. Dudley were appointed to assist at Ipswich court." 1

On the same day, also, Batt, Dudley, and Winslow were appointed to order small causes for Salisbury, and one of them to see people joined in marriage and keep records. ${ }^{2}$ Governor Winthrop says : "Mrs. Hutchinson and those of Aquiday Island broached new heresies every year. Divers of them turned professed Anabaptists and would not wear any arms, and denied all magistracy among Christians, and maintained that there were no churches since those founded by the Apostles and Evangelist." 3 Samuel G. Arnold says with reference to this extract from Winthrop: "We prefer to quote him [Winthrop] because he was the most liberal man of his age and station, to citing the more bitter denunciations of Hubbard and Mather, or the many other writers of that and the succeeding century, whose Dudleian spirit would perhaps more truly portray the prevailing temper of the times." 4

It is evident that Arnold had been touched by the Dudleian poetry, but he also indirectly thus compliments Dudley with having been abreast of his age and with being the spirit or very incarnation of it. These were the most remarkable "times in the tides of men," the most fruitful in events and seed-sowing. Arnold, like Savage, is disturbed by the terms Anabaptists and Antinomians, and says that they "were used generally to designate all dissenters from the established faith." This is certainly a questionable statement; we do not think that these terms were applied to Presbyterians or other well-established sects. The General Court sets forth as follows :-

1 Mass. Col. Rec., i. 328.

3 Winthrop, ii. *38, *40.
2 Ib., i. 329:

4 Arnold's Hist. R. I., i. I 5 I. 
"It being found by experience that the course of elections had need to be brought into some better order, the freemen growing to so great a multitude as will be overburdensome to the country. . . . The way which this Court hath thought on is, that in every town which is to send a deputy to the Court, the freemen to meet before the Court of Election, and for every ten freemen to choose one, to be sent to the Court with power to make election for all the rest, and in this way to be at liberty whether they will join all together or vote severally, or to vote so as every one that hath ten votes shall be an elector, and magistrates and elders to put in their votes as other freemen." 1

The system of tens disappeared the next year. The towns were to elect one or two representatives, and these representatives formed a list of candidates, from which the freemen elected.

Winthrop writes in regard to the General Court of December, I64I : "This session continued three weeks, and established one hundred laws which were called the Body of Liberties. They had been composed by Mr. Nathaniel Ward (sometime pastor of the church of Ipswich; he had been a minister in England and formerly a student and practicer in the courts of the common law), and had been revised and altered by the Court, and sent forth into every town to be further considered of, and now again in this Court, they were revised, amended, and presented, and so established for three years, by that experience to have them fully amended and established to be perpetual." 2 It is evident from this that while Ward drew the outlines of the Body of Liberties, all the lawyers of the General Court examined, revised, and amended them, or had an opportunity to do so.

This code was the foundation of the legislation and laws of Massachusetts. We notice in No. 7I of the Body of Liberties, "The governor shall have a casting voice when-

1 Mass. Col. Rec., i. 333, 334.

2 Winthrop, ii. *55. 
soever an equi vote shall fall out in the Court of Assistants, or General Assembly, so shall the president or moderator have in all civil courts or assemblies." 1

This gave a new power and dignity to the governor, who previously had been first among his equals. "In the Constitution of the United States, and in those of many States of the Union, it is provided that the presiding officer thereby designated shall give the casting vote when the body over which he presides is equally divided." 2

We have already noticed the founding of Harvard College, and the fact that Dudley was from 1636 , during the remainder of his life, one of its patrons and overseers. George B. Emerson has said that "the people of Massachusetts at that time were poor, with all the hardships of new settlers in a savage country, clearing up the forests, building houses and barns and churches, enlarging their pastures, and bringing the earth into cultivation. ... One of the most remarkable things in the history of Harvard College is the fact that in all the constitutions of the college there is nothing illiberal or sectarian, nothing to check the freest pursuit of truth in theological opinions and in everything else; and this, too, while the founders of the college were severely and strictly orthodox, often exclusive in their own opinions." And yet these men are branded by some subsequent citizens as narrow and bigoted.

They have also been accounted broad and liberal, because they extinguished feudalism and created unlimited alienation of land, but greater glory is to be attributed to them for giving freedom of mind, and opening the ways of truth and life to all the generations of men which were to follow.

The device on the first seal was "Veritas." This was followed by "In Christi Gloriam" (To the Glory of Christ), and this soon after by the present motto, "Christo et Ecclesiæ" (To Christ and the Church). ${ }^{3}$

1 W. H. Whitmore's Col. Laws of Mass., I660 to 1672, 49.

2 Cushing's Law and Practice of Legislative Assemblies, §§ 298, 391.

${ }^{3}$ George B. Emerson, Mass. and its Early Hist., 468. 
The conditions for admission at Harvard College were higher, it is said, in 1642 than they have been since. The following requirement seems pretty severe: "Whoever shall be able to read Cicero, or any such like classical author at sight, and correctly and without assistance, to speak and write Latin, in prose and verse, and to inflect exactly the paradigms of Greek nouns and verbs, has a right to expect to be admitted into the college; and no one may claim admission without these qualifications." 1

Savage thinks that there were in the colony probably, in I638, forty or fifty sons of the University of Cambridge in Old England, one-for every two hundred or two hundred and fifty inhabitants, dwelling in the few villages of Massachusetts and Connecticut. The sons of Oxford were not few. $^{2}$ Mercy Dudley, the fifth child of Governor Thomas Dudley, married, in I64I, the Rev. John Woodbridge, ${ }^{3}$ of Newbury, Mass. He had been at Oxford, and was highly regarded by Dudley. The following letter to him, about one year after the marriage, is a valuable contribution, since it illustrates the affectionate character of Dudley, which is more important because we have very little knowledge of his domestic and family life, except through Mrs. Bradstreet, but are limited almost entirely in our study to his public career :-

Son WoODBRIDGe, - On your last going from Roxbury, I thought you would have returned again before your departure hence, and therefore neither bade you farewell, nor sent any remembrance to your wife. Since which time I have often thought of you, and of the course of your life, doubting you are not in the way wherein you may do God best service. Every man ought (as I take it) to serve God in such a way whereto he hath best fitted him by nature, education, or gifts, or graces required. Now in all these respects I conceive you to be better fitted for the ministry, or teach-

1 J. Quincy's Hist. Harv. Univ., i. 515.

2 Winthrop, i. *265, note 2.

3 App. F. 
ing a school, than for husbandry. And I have been lately stirred up the rather to think hereof by occasion of Mr. Carter's calling to be pastor at Woburn the last week, and Mr. Parker's calling to preach at Pascattaway, whose abilities and piety (for aught I know) surmount not yours. There is a want of schoolmasters hereabouts, and ministers are, or in likelihood will be, wanting ere long. I desire that you would seriously consider of what I say, and take advice of your uncle, Mr. Noyse, or whom you think meetest about it ; withal considering that no man's opinion in a case wherein he is interested by reason of your departure from your present habitation is absolutely to be allowed without comparing his reason with others.

And if you find encouragement, I think you were best redeem what time you may without hurt of your estate, in perfecting your former studies.

Above all, commend the case in prayer to God, that you may look before you with a sincere eye upon his service, not upon filthy lucre, which I speak not so much for any doubt I have of you, but to clear myself from that suspicion in respect of the interest I have in you. I need say no more. The Lord direct and bless you, your wife and children, whom I would fain see, and have again some thoughts of it, if I live till next summer.

Your very loving father,

Thomas Dudley.

ROXBURY, November 28th, 1642.

To my very loving son Mr. John Woodbridge, at his house in Newbury. ${ }^{1}$

This letter is of great value, because Dudley has herein honestly expressed his conviction of the secondary importance in this world of money-getting. He has often been represented, as we have seen, to have been avaricious and grasping, which was indeed quite contrary to his nature. That he was one of the wealthiest men in the colony may have contributed improperly to have given him a mercenary 1 Winthrop, ii. ${ }^{2} 253$, note. 
character. We know that he had habits of thrift and an aptitude for business which rendered him of great service to the estate of the Earl of Lincoln, and to Massachusetts. If he had been a miserly man he would never have emigrated to America. He must have been actuated by far higher motives than the acquiring of a fortune.

Dudley, in the second place, was a deeply religious man; he served God rather than mammon. His words in this letter strongly confirm our opinion of him in this respect. He says with great sincerity and deep pathos, in the most disinterested manner, to his son, "Above all, commend the case in prayer to God, that you may look before you with a sincere eye upon his service, not upon filthy lucre." These are not the words of a sordid man, but they strike the very keynote to the character and career of Dudley.

There is throughout this letter a flavor of liberal thought which is an answer to the unjust conception of his character which has been almost universally set forth in recent years.

The influence of the revolution which was going on in England seems at once to have reached Massachusetts, the colony, without much public manifestation of feeling, being deeply in sympathy with their Puritan brethren. They were bound to them not only by political or religious interests, but more strongly, if possible, by family bonds, intimate personal friendship, and acquaintance. They were persons with whom they had constantly consulted respecting the great emigration to America and the fortunes of the colony during twelve years. The two commonwealths on either side of the sea had much in common. They were both Saxon uprisings against feudalism and the Royalists. The one in England nearly failed of its purpose, while the other in America survives with ever-increasing possibilities.

This revolution revealed itself in this country by the omission in the oath of allegiance to the king so far as the magistrates and officers were concerned, leaving the words as follows : "It is ordered and declared to be the meaning of this Court, that no oath of magistrate or counselor or any 
other officer shall bind him any further or longer than he is resident or inhabiting within this jurisdiction." 1

This is quite different from "You swear to be faithful and loyal to our Sovereign, Lord, the King's Majesty and to his heirs and successors."

This was a very remarkable political severance from the mother country, and was a step far on the way towards independence. The growth in population which had taken place during twelve years was astonishing. There were twenty-one flourishing towns at this time, Boston being more than twice as large as any other town in taxable importance, a prominence in Massachusetts which she has always maintained.

Robert C. Winthrop says that "the year I642 saw Winthrop restored to chief magistracy of the colony ; not, however, it would seem, without some heart-burning on the part of his old rival, Thomas Dudley." There may have been two versions to this story, as there are to many others in literature. But, if there ever were two, only one has come down to us; and that is contained in the following passage from Winthrop, vol. ii. p. ${ }^{*} 63$, dated May I8, I642 :-

"The Court of elections was. Mr. Winthrop was again chosen governor, and Mr. Endicott, deputy governor. This being done, Mr. Dudley went away, and though he were chosen an assistant yet he would not accept it. Some of the elders went to his house to deal with him. His answer was, that he had sufficient reasons to excuse and warrant this refusal, which he did not think fit to publish, but he would impart to any one or two of them whom they should appoint, which he did accordingly. The elders acquainted the Court with what they had done, but not with the reasons of his refusal, only that they thought them not sufficient. The Court sent a magistrate and two deputies to desire him to come to the Court, for as a counselor he was to assist in the General Court. The next day he came, and after some excuse he consented to accept the place, so that the Court 1 Maverick's Description of N. E., 1660, 19. 
would declare that if at any time he should depart out of the jurisdiction (which he protested he did not intend), no oath, either of officer, counselor, or assistant, should hold him in any bond where he stood.

"This he desired, not for his own satisfaction, but that it might be a satisfaction to others who might scruple his liberty herein. After much debate, the Court made a general order which gave him satisfaction." 1

Robert C. Winthrop seems to have received the opinion that Dudley was a candidate in the above election and was defeated by Winthrop, and that he went away in wrath although he was chosen to a third place in the government, which he would not accept. It is quite possible that he is mistaken in this opinion. It appears in the same Journal, page $* 55$, that Dudley, who had now arrived at the age of sixty-five years, began to feel official duty to be a burden (and although he continued years after, a certain special freedom was granted to him), for less than a year before he had resigned from the said office of magistrate, and the offer was then made to him of " any ease and liberty that his age and infirmities might stand in need of." It may have been, and probably was, a question of infirmities or of some personal consideration entirely apart from jealousy of Winthrop, or rivalry, or any feeling on his part of want of appreciation of him by the people. His hold upon the public before, after, and during this period are a sufficient guarantee to us that he had no occasion whatever for "heartburning" over the momentary success of Winthrop, to which good fortune he doubtless heartily contributed, and with whom he had long ceased to contend. So far as the record goes they labored together as the leaders of the commonwealth; as the joint leaders, also, of a political party, without mean and selfish personal ambition for office. They were each thoughtful only of the prosperity or glory of Massachusetts. Dudley had known too much of the fortunes of politics to show ill temper and pout like a silly child over his defeat for an

1 R. C. Winthrop's Life and Letters of John Winthrop, ii. 268, 269. 
office which there is much reason to believe would have been a burden to him. It is noticeable in confirmation of this opinion that, "after much debate, the Court made a general order." Which order evidently was intended to extend his freedom in office and not to heal any petty grievance, arising from envy, over the fortunes of his "Brother" Winthrop.

J. B. Moore, in his "Memoirs of American Governors," page 289, alludes to this subject, but it does not seem that the interpretation of this passage from the Journal which Robert C. Winthrop has arrived at, occurred to him, for he says, "Dudley refused to accept that place in the latter year, unless the General Court would give him liberty to remove from their jurisdiction whenever it might suit his convenience, without being bound in any existing oath or regulation, either as an officer, counselor, or assistant. To these conditions the General Court readily assented."

Moore may be regarded as entirely impartial in this judgment. Finally, nothing ought to be taken as mere inference against the character of Dudley without positive evidence, which does not exist in this case. The presumption of his innocence of such petty conduct towards his great associate, in the presence of the Court, remains firm and unimpeachable. 


\section{CHAPTER XXVI}

THE public highways received the attention of the General Court. "It is declared by this Court, that the selected townsmen have power to lay out particular private ways concerning their own town only, so as no damage be done to any man, but due recompense be given by the judgment of said townsmen." 1 The further power at the very next Court was conferred upon the selectmen, sometimes called prudential committee, to see to the education of neglected children, especially that they have ability to read and understand the principles of religion and the capital laws of the country. ${ }^{2}$

It would be interesting to follow from 1633 the powers of selectmen in towns, until they became, as at present, the complete executive authority in the New England town, which was developed from each of these little villages, beginning with the village parish government as found in England. So strictly is this true that in many of the towns of Massachusetts the early town and parish records are united and are one and the same.

The subject of the Standing Council, or Council for Life, which was never composed of any persons except Winthrop, Dudley, the governor ex-officio, and later Endicott, was, June I4, I642, ${ }^{3}$ apparently brought out by the defeated Bellingham faction to irritate the triumphant party of Winthrop. For when Winthrop succeeded Bellingham, "a book was brought into the Court wherein the institution of the Standing Council was pretended to be a sinful innovation. The governor moved to have the contents of the book examined, and then if there appeared cause, to inquire after the author. But the greatest part of the Court having some intimation

1 Mass. Col. Rec., ii. 4.

${ }^{2}$ Ib., ii. 6, 9.

8 Ib., ii. 5-21. 
of the author, of whose honest intentions they were well persuaded," withheld their influence against the book. "Whereupon it was found to have been made by Mr. Saltonstall," who was the intimate friend of Bellingham, and usually joined him with the popular party against the other magistrates. It may be that for this reason the deputies felt under obligation to protect Saltonstall in exercising his freedom in abusing the council. The matter is quite insignificant, since the council had already been shorn of its power. The book had found its way into the hands of Dudley, who had prepared an answer to it. "The Court would not agree to any action except Saltonstall were first acquit from any censure."

There were various excuses made explaining his intentions in writing the book. "As that the council was instituted unwarily to satisfy Vane's desire, etc., whereas it was well known to many in the Court, as themselves affirmed, that it was upon the advice and solicitation of the elders, and after much deliberation from Court to Court. Other passages there were also which were very unsound, reproachful, and dangerous, and was manifested by an answer made thereunto by Dudley, and received at the next session of the Court, and by some observations made by Mr. Norris, a grave and judicious elder, teacher of the church in Salem (and with some difficulty read also in Court) who, not suspecting the author, handled him somewhat sharply according to the merit of the matter." 1 Dudley seems to have taken a leading part in this controversy in behalf of the Standing Council. He convinced Winthrop that the book was " unsound, reproachful, and dangerous," and it may be assumed that his argument had a strong influence, for the matter was referred to the elders, with the following result: "By the wisdom and faithfulness of the elders, Mr. Saltonstall was brought to see his failings in that treatise, which he did ingenuously acknowledge and bewail, and so he was reconciled with the rest of the magistrates." 2
1 Winthrop, ii. *65.
2 Ib., ii. * * I 6. 
Some of the arguments are preserved in Winthrop, vol. ii. pp. *9, *9I. There seems to be no copy of Dudley's answer to this book, which is much to be lamented, as it might throw light upon the pending political controversy.

The agitation in England which culminated this year in civil war showed itself at once in this country. An attempt was made to maintain allegiance to the king, which was rendered futile by the people. Massachusetts foresaw at once that she might have to defend herself, both against foreign and domestic enemies, and particularly against the royal party in England. She recognized that self-preservation is the first consideration, and that to this end she must husband every resource and become as independent of all governments and peoples as her circumstances would permit. She has told her own troublous story in the following pathetic words: "This Court, taking into serious consideration the great danger that this commonweal is liable unto by foreign and domestic foes, which we have just cause to conceive will be ready, as opportunity and means are put into their hands to practice against us, and being willing to lay hold on, and use all such means as God shall direct us unto, as may tend to the raising and producing such materials amongst ourselves as may protect the making of gunpowder, the instrumental means that all nations lay hold on for their preservation." ${ }^{1}$ Then follows in the order directions that every plantation shall proceed to produce saltpetre according to the directions therein given, placing the matter under the care of the military, that it may be executed promptly and faithfully.

"It was ordered that the twenty-first of the Fifth Month should be kept as a day of public humiliation throughout this jurisdiction, in regard of our own straits, and the foul sins broken out amongst us, and the distractions of our native country, Ireland, Holland, and the other parts of Europe." 2

This order shows how thoroughly the colonists were watch1 Mass. Col. Rec., ii. 17, 29.

2 Ib., ii. 16. 
ing the struggle in Europe and the advancement of liberty. Very special attention was given by the Court to the production of leather in the largest possible amount, which indicates that they already felt that they could not depend upon foreign commerce for the essentials of life, and that an early severance with the mother country was even now looming up before them.

That great modern system or artifice known as the political caucus appears in the following order, that every town shall choose one or two freemen, "who shall meet at Salem on a certain day, and shall there consider and agree" upon the most able and fit men to be put in nomination for magistrates at the next Court of Elections. This order may have arisen, and probably did, from jealousy of the magistrates.

Commissioners were sent on the 8th of September, I642, to Miantonomoh, with certain instructions to demand satisfaction of him upon twelve points set forth in writing, and among these the most prominent, that the Narragansett Indians have conspired with other sachems in making war upon the English. It was this fear and dread which resulted in the destruction of Miantonomoh the next year.

How important this matter was in the judgment of the colony will be seen by the following direction to Mr. Wannerton: "The General Court holden at Boston, the 8th of September, 1642 (upon creditable information of a general bloody design of the Indians against all the English in this country, and of great supply of powder and guns which they have from the English in the eastern parts, which living alone and under no government, cannot, by any ordinary way of justice be punished or restrained), have given power and commission to you to make seizure of all such powder." And their anxiety is further manifest as to the plot and conspiracies of the heathen among them, for they issue six specific directions to citizens of every town with reference to alarms to be given day and night, places for retreat for wives and children, and due preparation of ammunition fitting them for sudden occasions. "And that all watches throughout 
this country be set at sunset, at the beat of the drum, and not be discharged till the beat of the drum at sunrising." 1

The following was ordered: "Whereas by the order of Court in the Seventh Month, 1636, there was appointed and named six magistrates, and six elders, to order the college of Cambridge, of which twelve somewhat removed out of this jurisdiction, - it is therefore ordered that the governor and deputy for the time being, and all the magistrates of this jurisdiction, etc. . . . shall have from time to time full power and authority to make and establish all such orders, statutes, and constitutions, as they shall see necessary for the instituting, guiding, and furthering of the said college, and the several members thereof from time to time in piety, morality, and learning." As we have already noticed, Dudley was a perpetual member of this board ever after the founding of the college, during his life. Mr. J. A. Doyle has taken occasion to say that, "in their sobriety of thought and in their manly simplicity and force of language, the works of Bradford and Winthrop stand out as noble exceptions to the literature of Puritan New England." 2

It seems to us that he might well have included the writings of Dudley, especially his letter to the Countess of Lincoln. Even if its brevity seems to exclude it from the larger works of literature, composed by the persons mentioned, still in strength of English and clearness of statement it seems equal to the best work of either of them.

The most memorable event in the year I643 was no doubt the political confederation of the four principal colonies of New England. It has been thought that this confederacy was suggested by that of the Low Countries. However that may be, it was the Plymouth Colony which called the attention of the other colonies more directly to this subject.

We find the following act of the General Court on the Ioth of May, I643: "The governor, Mr. Dudley, Mr. Bradstreet, Mr. Treasurer, Captain Gibbons, and Mr. Hawthorne

1 Mass. Col. Rec., ii. 25, 26, 29.

2 English in America, i. 319. 
are chosen to treat with our friends of Connecticut, New Haven, and Plymouth about a confederacy between us." This confederacy was the prototype and first beginning of the United States of America.

It is therefore with unfeigned pride and satisfaction that we discover the name of Dudley on the first committee at the very inception of this remarkable and far-reaching experiment in government. The Articles of Confederation were subscribed on the Igth of May by the commissioners, save those of Plymouth, who subscribed a little later in the same year after consultation with the colony at home.

The preamble to these articles is as follows: "Whereas we all came into these parts of America with one and the same end and aim, namely, to advance the kingdom of our Lord Jesus Christ, and to enjoy the liberties of the Gospel in purity with peace; and whereas by our settling, by the wise providence of God, we are further dispersed upon the seacoasts and rivers than was at first intended, so that we cannot, according to our desire, with convenience communicate in one government and jurisdiction; and whereas we live encompassed with people of several nations and strange languages, which hereafter may prove injurious to us or our posterity; and forasmuch as the natives have formerly committed sundry insolences and outrages upon several plantations of the English, and have of late combined themselves against us, and seeing by reason of the sad distractions in England (which they have heard of), and by which they know we are hindered, both from that humble way of seeking advice, and reaping those comfortable fruits of protection, which at other times we might well expect; we therefore do conceive it our bounden duty, without delay, to enter into a present consociation amongst ourselves for mutual help and strength in all future concernment, that, as in nation and religion, so in other respects, we be and continue one, according to the tenor and true meaning of the ensuing articles." 1 Which articles were eleven in number.

I Winthrop, ii. *IoI, * Io6. 
It is said that the best account of the confederacy is in Hubbard's " History of New England." 1

The people of the several nations mentioned in this preamble include the French on their eastern boundary, the Dutch on their western, the Indians all about them; and in their thoughts, although not expressed in the preamble, is a dangerous faction in the mother country, which is liable at any time to exhibit its power in an attempt to reduce them to obedience to royal authority.

The colonies were represented by two persons from each of them, like the several state representations in the present Senate of the United States, and were therefore equal in the confederacy in the matter of voting and in power. Massachusetts was larger in population and in wealth than all the other colonies together; her moral influence had greater weight in directing the action of the confederacy than that of any other colony, a prestige which she has maintained far down in the history of the republic.

Winthrop was chosen president at the first session of the commissioners, and presided over the doings of that first congress. He was again chosen president of the confederacy in the year I645, an honor which was also twice conferred (namely in the years I647 and I649) upon Thomas Dudley. Thus it appears that either Dudley or Winthrop presided over the doings of this congress whenever it was held in Boston during their lifetime, and that no one else attained to this honor. This is another confirmation of the firmly settled conviction of the Massachusetts people that Winthrop and Dudley were their two foremost men ; and, moreover, that their eminence was recognized throughout the other colonies and had a national significance; for as between themselves they each received this honor from the United Colonies in equal and even measure.

It was claimed that "the four jurisdictions had a population of twenty-four thousand, living in thirty-nine towns, in 1642." The whole plantation was on this tenth day of May 1 Mass. Hist. Coll., 2d series, v. 465. 
divided into four counties containing thirty towns. "In September, I642, William Arnold, Robert Cole, William Carpenter, and Benedict Arnold, his company upon their petition, ${ }^{1}$ were taken under our government." "And they are to see to keep the peace in their lands." 2

These men were in conflict with Samuel Gorton and company at Pawtuxet, R. I. Thus says S. G. Arnold: "A foreign jurisdiction was set up in the very midst of the infant colony, which greatly increased the difficulties of its existence, and continued for sixteen years to harass the inhabitants of Providence." It was the established course of Massachusetts in other places, such as Maine, New Hampshire, Connecticut, as well as Rhode Island, to receive under her jurisdiction and government people and districts of territory, although outside strictly of her charter limits, upon condition that such people or some portion of them desired her care and protection, and solemnly covenanted to submit to her jurisdiction and her laws.

There was a reasonable cause for this. In the midst of enemies, she possessed the strongest and most conservative paternal government in New England, in which she was most strictly the representative English colony, and could not fail properly to take the deepest interest, and even control, in neighboring communities in which at any time disturbances might occur, the direct result of which would be injurious to Massachusetts.

Neither could she maintain her essential ideas in politics and religion if she permitted them in the very beginning to be conspicuously assailed and remain undefended on her border, more particularly if the danger proceeded from her own disaffected citizens, who had entered upon another jurisdiction only to secure a stronger vantage ground from which to attack her.

We who live in a greater light, with more perfect laws, claim the right even now to regulate our neighbors, to enforce

1 See, also, R. I. Hist. Soc. Coll., ii. ror.

2 Mass. Col. Rec., ii. 26, 27. 
Monroe doctrines and provisions beyond our borders, on the ground that our self-preservation demands the exercise of such liberty. Every civilized nation upon the globe assumes to dictate to other nations a policy which is consistent with its own alleged interest and safety. The present concert of Europe and combination of the great powers illustrates this freedom of the large states exercised toward the small ones in their own interest.

But in this controversy between Massachusetts and certain persons in Rhode Island the position of the colony is far stronger; because at this time there was no government at Pawtuxet which anybody recognized, either under charter or otherwise, except that Plymouth now and then claimed jurisdiction over this territory, and as often surrendered it to Massachusetts. They had, as Gorton claimed, an alleged title to land from the Indians, and pitched their tents there without authority from England. ${ }^{1}$

Two sachems, Pumham and Sacononoco, from near Pawtuxet, submitted themselves, on June 22, to the jurisdiction of Massachusetts, in a writing signed by them, with the following certificate attached: "This was signed, after clear interpretation of every particular by their own interpreter, Benedict Arnold, in the presence of us, whose names are subscribed, and many of the clders and others," - John Winthrop, governor, Thomas Dudley, Richard Bellingham, and others.

Winthrop says: "Sacononoco and Pumham having under them two or three hundred men, finding themselves overborne by Miantonomoh, the sachem of Narragansett, and Gorton and his company, . . . did desire we receive them under our government, . . . so it was agreed and they wrote to Gorton . . . how they had tendered themselves to come under our jurisdiction, and, therefore, if they had anything to allege against us they should come or send to our next Court. They invited Miantonomoh, who came to Boston, and being questioned in open court in public, whether he 1 S. G. Arnold's Hist. of R. I., I76. 
had any interest in the said two sachems, he could prove none. Cutshamekin also in his presence affirmed that he had no interest in them, but they were as free sachems as himself."

"Gorton and his company sent a writing to our Court, of four sheets of paper, full of reproaches against our magistrates, elders and churches, of familistical and absurd opinions, therein they justified their purchase of the sachem's land, and professed to maintain it to the death." 1

Winthrop says further: "Upon the complaint of the English of Pawtuxet, near Providence, who had submitted to our jurisdiction, and the two Indian sachems there, of the continual injuries offered them by Gorton and his company, the General Court sent for them, by letter only, not in way of command, to come answer the complaints, and sent them letters of safe conduct. But they answered our messages disdainfully, refused to come, but sent two letters full of blasphemy against the churches and magistracy, and other provoking terms, slighting all we could do against them.

"So that having sent three times, and receiving no other answer, we took testimonies against them, both of English and Indians, and determined to proceed with them by force. And because they had told our messengers the last time, that if we had anything to say to them, if we would come to them, they would do us justice therein, therefore we wrote to them to this effect, viz. :-

"To the end that our justice and moderation might appear to all men, we would condescend so far to them as to send commissioners to hear their answers and allegations, and if thereupon they would give us such satisfaction as should be just, we would leave them in peace, if otherwise, we would proceed by force of arms; and signified withal that we would send a sufficient guard with our commissioners. For seeing they would not trust themselves with us, upon our safe-conduct, we had no reason to trust ourselves with them, upon their bare courtesy, and accordingly we sent the next week, 
Captain George Cook, Lieutenant Atherton, and Edward Johnson, with commission and instructions (the instructions would here be inserted at large), and with them forty soldiers." 1

"The commissioner came to Providence and found the party of Gorton all in one house, which they had made musket proof. They undertook to parley," and then offered to refer their cause to arbitrators. The Massachusetts agents declined the arbitration for five reasons, which they set forth. ${ }^{2}$

A skirmish took place thereupon between the Boston party and Gorton and his followers, which resulted in the defeat of the latter. Only three of the Gorton party escaped; he and the rest were captured, taken to Boston, and committed to prison. ${ }^{3}$ Many attempts have been made in recent times to defend Gorton, and to present him as one of those unfortunate men who, being ahead of their age, and possessed powerfully with advanced and progressive thought, were consequently abhorred and persecuted by the Puritans, and are therefore justly entitled to be canonized and adjudged heroes in a humane and liberal era.

Compassionate men have, consequently, too often condemned the action of the government of Massachusetts in the Gorton affair. It is remarkable, also, that while Gorton has received so much attention, the little book by Governor Edward Winslow, which is an original and authoritative account from the Puritan side of the case, has not until recently been republished. Without this book the two sides can never be fairly presented. It is at present so rare that it can be consulted only by a very few persons. The title of this book is "Hypocrisie Unmasked." 4 Even Judge Staples had not found this book, nor had the use of it, in preparing his edition of Gorton's "Simplicitie's Defence."

1 Winthrop, ii. * 137 .

2 Ib., ii. * ${ }^{*} 39$; Coll. R. I. Hist. Soc., ii. II I.

8 Coll. R. I. Hist. Soc., ii. 190-202.

4 Moore's Am. Governors, 123, 124. 
A stimulating inquiry is naturally awakened, why so many unimportant books written at that period have been reproduced with so much care and expense, while "Hypocrisie Unmasked" has been suffered to go almost out of existence until recently.

We are informed in "Hypocrisie Unmasked" that "Gorton lived for a time at Plymouth, ${ }^{1}$ where his behavior was so turbulent and offensive both to the magistrates and others, as they were necessitated to drive him out of their jurisdiction. From thence he went to Rhode Island, where he began to raise sedition and to make a party against the authority there; for which he was apprehended and whipped, and so sent away. From thence (with some others whom he had gathered to his part) he removed to Providence, where Mr. Roger Williams then lived. He (with some others) opposed his sitting down there as an inhabitant, only in regard of his present distress, they gave way for his abode for a time. But being once housed, he soon drew so great a party to him, as it was beyond the power of Mr. Williams and his party to drive them out, or to rule them there; as both parties came armed into the field each against other, and had fought it out, had not Mr. Williams used means for pacification." 2

"Hereupon many of the chief of Providence sent messengers with a letter to the governor and council of the Massachusetts, desiring aid against Gorton and his company, but they were answered, that not being within our jurisdiction nor confederation, we had no ground to interpose in their quarrels.

"Soon after, some of those men tendered themselves and their lands to come under our government and were received. ... The two sachems were as free as Miantonomoh, but in awe of him. Gorton and Miantonomoh conspired to cheat

1 Hypocrisie Unmasked, I ; Morton's New England's Memorial, I36138, I 53 .

${ }^{2}$ Letter of Williams to Winthrop, March 8, I646, Pub. Narr. Club. vi. I4I, 142 . 
Pumham out of his land. They secured his mark, but he refused the consideration when tendered for the land, which in Indian custom binds the bargain.

"And Gorton and Miantonomoh abuse the Indians by taking possession of the land. And the Indians in distress tender their lands and themselves to Massachusetts. Miantonomoh appeared before the Massachusetts Court in answer to summons, and claimed these sachems to be his vassals, but it appeared clearly both by writing from Mr. Williams, and the testimony of some other English in those parts, and of divers other Indians no way related to them, that they were free sachems; so as Miantonomoh having nothing to reply, the Court received the two Indian sachems with their subjects and lands under the government and protection of the Massachusetts; and upon that writ to our neighbors of Providence, intimating the same to them, and advising Gorton and his company, that if they had any just title to the land they possessed, they should come, or send some to show the same to the Court and offered them safe-conduct. They of Massachusetts waited under the constant abuse of Gorton against state and church one half year, and then took the advice of the commissioners [of the United Colonies], who upon testimony of their insolent and injurious courses, and perusal of the letter they sent to us, left them to us to proceed according to justice. ${ }^{1}$

"Arbitration was impossible, first because they were in our power, second, because we were not parties, again they were no state or body politic, but a few fugitives living without law or government, and so not honorable for us to join with them in such a way of reference." Mr. Gorton came to the church in Boston and gave John Cotton some of his original thoughts as follows: "That in the church now, there was nothing but Christ, so that all our ordinances, ministers, sacraments, and so forth were but men's inventions, for show and pomp, and no other than those silver shrines of Diana." He said also "that if Christ live

1 Hypocrisie Unmasked, 2, 3, 4. 
eternally, then he died eternally," and other speeches of like kind. He thought that "Christ was incarnate in Adam and was the image of God when Adam was created." 1

"Their plea: I, Not within our jurisdiction. Ans., Were at least within the jurisdiction of our confederates who had referred them to us. If they were within no jurisdiction, then was there none to complain to for redress of our injuries in way of ordinary justice, and then we had no way of relief but by force of arms.

" $2 \mathrm{~d}$, As to persecution, we did not meddle with their consciences except as they had discharged them at us.

" $3 \mathrm{~d}$, As to the Indian lands, our title appeared good."

The sentences given to Gorton and the others were in part as follows : "And to wear an iron chain upon one leg." We have introduced this quotation because it is often said that they were loaded with heavy irons, but it appears from this that it was only a chain. ${ }^{2}$ Winslow says further, "We sent for their cattle to pay expenses, but left every of them a part for the support of their families." 3 Governor Winslow asserts that Gorton was "opposed to magistrates everywhere, ${ }^{4}$ also that he was against churches, ministers, the Word of God, sacraments, repentance, and against Jesus Christ himself." 5 When Gorton had been whipped by order of Coddington, he said "Christ Jesus had suffered." 6 Winslow says further that Miantonomoh had no right to the land as shown in Boston, and was not Prince of those parts. ${ }^{7} \mathrm{He}$ says that there was no ransom by the Narragansetts offered for Miantonomoh, ${ }^{8}$ and that Miantonomoh was put to death in a house and not on a marsh, as falsely related by Gorton. ${ }^{9}$

The record of the commissioners of the United Colonies on the subject of Gorton, referred to above, is as follows : "Whereas complaints have been made against Samuel Gorton and his company, and some of them weighty, and of

1 Winthrop, ii. * I 43. See, also, Coll. R. I. Hist. Soc., ii. 236-240.

2 See Hypocrisie Unmasked, 8. They had no secure prisons.
8 Ib., 9.
4 Ib., 43.
5 Ib., 47-49.
- Ib., 53 .
7 Ib., 69.
8 Ib., 74 .
9 Ib., 80. 
great consequence. And whereas, the said Gorton and the rest have been formerly sent for, and now lately by the General Court of Massachusetts with a safe-conduct both for the coming and returning, that they might give answer and satisfaction wherein they have done wrong. If yet they shall stubbornly refuse, the commissioners of the United Colonies think fit that the magistrates in the Massachusetts proceed against them according to what they shall find just ; and the rest of the jurisdiction will approve and concur in what shall be so warrantably done, as if their commissioners." 1

The fact that the commissioners of the United Colonies "think fit that the magistrates in Massachusetts proceed against" Gorton and his company furnishes a strong support to the action of the colony. These colonies were disinterested. The able commissioners from the other colonies are joined with those of Massachusetts in review of all the facts and particulars of this disagreeable business, at the very time and in the midst of the turmoil, and the character of these men and the dignity of this court ought to lift this whole affair out of the disgrace which is attempted in recent times to be heaped upon Massachusetts alone, fastening upon her, so far as this influence reaches from modern critics, the charge of petty tyranny, bigotry, and selfishness. ${ }^{2}$ Winslow was one of the commissioners of the United Colonies from Plymouth, before whom the case of Gorton was considered. This fact increases our confidence in his knowledge and judgment respecting the facts at issue. He was a party engaged in making the record of the confederacy already quoted. He was especially qualified from his judicial standpoint to write "Hypocrisie Unmasked," which book contains the force of his eminent character for ability and integrity, as well as the great weight of his position, all of which

1 Acts of the Commissioners of the United Colonies, Plymouth Col. Rec., ix. I 2.

2 Moore says that Winslow had "a standing such as no other New England man enjoyed." (Mem. Am. Governors, 129.) 
things, set off against the capricious character of Gorton, leave little to be desired in defense of the Puritans.

In order fairly to consider the incursion of Massachusetts soldiers into Rhode Island, and the claim of jurisdiction of the former colony there, we must first divest our minds of the present hard and fast State lines, and while regarding, indeed, the charter rights of that period, we must consider that Gorton and his company were only a few fugitives living without charter law, and if not within the jurisdiction of Massachusetts or Plymouth, they were within no jurisdiction this side of England.

We ought to remember, also, that the commissioners claimed that Gorton and his followers were within the jurisdiction of their confederates, and that they were thus subject to their government.

The records of the commissioners of the United Colonies show that while Plymouth claimed jurisdiction over the territory of Rhode Island, she also approved of the conduct of Massachusetts in dealing with Gorton.

We have entered very fully into this Gorton affair because Winthrop and Dudley were the prominent men who acted for and in behalf of Massachusetts in these matters, both in the General Court and at the session of the confederacy of United Colonies. If, therefore, there is any injustice or wrong-doing chargeable to Massachusetts in its treatment of Gorton, Dudley must be credited with a large share in it.

Massachusetts, during all that early formative period from 1630 to 1653 , is the standard of substantial, firmly knit government, obedient to the majesty of law, of order, and of supreme authority. She laid the foundation of her government on her charter on the common law of England, but she recognized the irresistible power of righteousness, of the higher law as revealed in the Holy Scriptures, and sought always to be guided by those persons who were most learned and best qualified to instruct her.

Dudley was, as we have said, a foremost leader in this ideal method of government, possessed of an unbounded 
faith that they were building a permanent structure which would be remarkable for liberal political qualities, mingled with a strong Christian element, which could not fail to be the greatest blessing to mankind. This was not a mere vision. It is quite evident that the mission of Massachusetts as a model in government in New England had a controlling influence in bringing order out of chaos, of preserving from anarchy the settlements about her; and that those States which are always manifesting unkindness towards her through the jealousy of their citizens, for intermeddling early in their affairs, have more reason to be grateful to her, that through her influence they were led forth, some of them slowly indeed, to stable government and honorable places finally in the sisterhood of States. 


\section{CHAPTER XXVII}

We have already observed that the General Court was fearful of, and indeed expected, a general uprising of Indians under the leadership of Miantonomoh, the information of such a conspiracy having for a long time been reaching them through the different colonies and the friendly Indians ; and they had placed the colony on a war footing and put on watches night and day. Miantonomoh made war upon Uncas, the sachem of the Mohegans, without giving notice of his intention. Uncas was victorious in the battle and captured him, and by the rules of Indian warfare his life was forfeited and he was at the mercy of Uncas. Winthrop says: “The news of Miantonomoh's captivity coming to Providence, Gorton and his company, who had bought of him the lands belonging to the sachems who were come under our jurisdiction, wrote a letter to Uncas, willing him to deliver their friend Miantonomoh, and threatened him with the power of the English if he refused, and they sent their letter in the name of the governor of Massachusetts." This use of the governor's name seems to have been a forgery on the part of Gorton. "Upon this Uncas carries Miantonomoh to Hartford to take the advice of the magistrates there, and at Miantonomoh's earnest entreaty he left him with them, yet as a prisoner. They kept him under guard, but used him very courteously, and so he continued until the commissioners of the United Colonies met at Boston, who, taking into serious consideration what was safest and best to be done, were all of opinion that it would not be safe to set him at liberty, neither had we sufficient grounds for us to put him to death. In this difficulty we called in five of the most judicious elders (it being in the time of the Gen- 
eral Assembly of the elders), and propounding the case to them then, all agreed that he ought to be put to death." ... It was agreed that the commissioners from Connecticut "should send for Uncas and tell him of our determination, that Miantonomoh should be delivered to him again, and he should put him to death so soon as he came within his own jurisdiction, and that two English should go along with him to see the execution, and that if any Indians should invade him for it, we would send men to defend him. If Uncas should refuse to do it, then Miantonomoh should be sent in a pinnace to Boston, there to be kept until further consideration. The reasons of this proceeding with him were these : I. It was now clearly discovered to us that there was a general conspiracy among the Indians to cut off all the English, and that Miantonomoh was the head and contriver of it. 2. He was a turbulent and proud spirit, and would never be at rest. 3. Although he had promised us in the open court to send the Pequot to Uncas, who had shot him in the arm with intent to have killed him (which was by the procurement of Miantonomoh, as it did probably appear), yet in his way homeward he killed him. 4. He beat one of Pumham's men and took away his wampum, and then bid him go and complain to the Massachusetts." 1 It appears that Miantonomoh was, as directed, slain by Uncas in the presence of the two Englishmen. Governor Winslow differs, in "Hypocrisie Unmasked," in his description as to the manner of execution from the usual account of it, which he says was Gorton's story.

It is only just in this case to the United Colonies to present their own decree from their own records, which is as follows: "The commissioners apparently see that Uncas cannot be safe while Miantonomoh lives, but that either by secret treachery or open force his life will be still in danger. Wherefore they think he may justly put such a false and bloodthirsty enemy to death, but in his own jurisdiction, not in the English plantations, and advising that in the manner

1 Winthrop, ii. * ${ }^{1} 33,{ }^{*}{ }^{1} 34$. 
of his death all mercy and moderation be shown contrary to the practice of the Indians who exercise tortures and cruelty." 1

Very bitter reflections have been made in recent years, particularly by the admirers of Gorton, upon the action taken by the commissioners of the United Colonies in the case of Miantonomoh.

It is important to note in the very beginning that his life was forfeited to Uncas in open war, and next to observe that the United Colonies, not Massachusetts alone, declare him to be "a false and bloodthirsty enemy." That they have not the specific charges and evidence before the commissioners to draw a clear indictment against him, and thus to arraign him and try him, is no part of this case.

They were not constituted as a court for such a purpose, but they had had a long acquaintance with him, such a knowledge of him and such direct reports from many sources, which Winthrop declares to have been reliable, that they certainly had a sufficient cause to turn him over to Uncas, with a provision that white men should see to it that no barbarous cruelty was inflicted upon him. It is necessary, in order to do justice to these men, to consider how many petty crimes and what small matters were then in Christian lands liable to capital penalty.

They had lived under laws in England which had provisions for the death penalty attached to more than forty crimes. ${ }^{2}$ Human life was not then regarded as important and sacred as it now is, or ought to be. And while the white men in New England exercised in general a remarkable forbearance and kindness toward the Indians, properly enough their lives were not more important than those of the white men of the colony; and if they were well satisfied that an outbreak on the part of the Indians was at hand, with Miantonomoh at the head of it, taking the part which King Philip

1 Plymouth Colony Records, ix., Acts of the Commissioners of the United Colonies, I I, 12.

2 W. D. Northend's Bay Colony, 96-98. 
did later, and they assure us with all the combined intelligence and character of all the colonies that such was the case, then they were justified in extreme measures as a matter of self-preservation, and in doing the greatest good to the most important numbers and persons.

We ought certainly, while we do justice to all, not to let our sympathies, even for the ideal noble red men, betray us into a cruel coldness against our fathers in the struggles in which they were engaged and in the perils to which they were exposed, with the regions peopled with savages in front of them, the ocean behind them, severed, as they were, from all hope of support or protection from their mother country. They certainly may be excused for having allowed some things, no occasion for which has ever risen in our national history since, and never will again.

The elders, it seems, agreed that under the Mosaic law Miantonomoh's life was forfeited. We are not informed under what provision of that law they arrived at that opinion. There is no ground to impeach their judgment without more knowledge of the facts presented to them, or to assail now that code which belonged to a very early age in human history, and which thę fathers, however ignorantly, believed to be absolutely binding upon them in letter and spirit. It is interesting to note how many red men and white men of that period lost their lives for the most trivial offenses, ${ }^{1}$ or for none at all, even this humane age recalling with little or no interest the story of their destruction, while friendship for Gorton and for the heroes of Rhode Island, the alleged home of soul liberty and unequaled personal freedom, has

1 The persons who are so disturbed over the conduct of the Puritans in dealing with Miantonomoh show no interest in the share Williams took in the execution of the Indian Chuff, August 25, 1676, after King Philip's war was ended and all danger from Chuff had departed with it. Nor are they troubled in conscience that Williams shared in the proceeds of the sale of Indian captives in that war. Not that any action of Williams is an excuse for the Puritans, but it only is evidence that very good men at that time did things our humane age cannot approve. (Knowles's Memoir of Roger Williams, 347, 348.) 
exaggerated the importance of Miantonomoh in history, all the more because of the assumption that Miantonomoh suffered at the hands of the English from the dislike which they bore towards Gorton and everybody else who was his friend or ally, an hypothesis which is not proven and cannot be maintained with any success. As for the share which Dudley had in all this business, while we cannot commend all the action taken upon the highest Christian ideals, yet we may well believe that he adopted that expedient and that judgment in the case which, according to the light he had, his conscience approved, and there we leave him.

As early as 1634 a very great difference arose between the governor and assistants on the one side, and the deputies, who were more numerous, on the other, upon the question whether any legislative action on the part of one might be properly and legally prevented and thwarted by the other. This aroused that ancient jealousy which in these modern times always exists on the part of the common people towards those in authority on the one side, and on the part of those in more stable position and long-delegated authority, lest little by little their prerogatives may be reduced or altogether taken away. ${ }^{1}$

This question took the form of the negative voice of the magistrates, and reappeared in a more vigorous form in 1643. But we must begin by an earlier explanation of a suit, out of which came most important results. Winthrop says, "At the same General Court there fell out a great business upon a very small occasion, Anno I636, there was a stray sow in Boston, which was brought to Captain Keayne: he had it cried divers times, and divers came to see it, but none made claim to it for near a year. He kept it in his yard with a sow of his own. Afterwards one Sherman's wife having lost such a sow laid claim to it, but came not to see it, till Captain Keayne had killed his own sow. After being shown the stray sow and finding it to have other marks than she had claimed her sow by, she gave out that he had killed her sow. 
The noise hereof being spread about the town, the matter was brought before the elders of the church as a case of offense ; many witnesses were examined and Captain Keayne was cleared." She then brought the case before the Inferior Court of Boston, and Captain Keayne was cleared again. Then it came before the General Court, seven days were spent in the trial of the case, and since there were nine magistrates and thirty deputies no sentence could pass without the greater number of both, and neither party had them. "For there were for the plaintiff two magistrates and fifteen deputies, and for the defendant seven magistrates and eight deputies." And because there was such laboring in the country upon a false supposition, that the magistrate's negative voice stopped the plaintiff in the case of the sow, one of the magistrates (Winthrop) published a declaration of the necessity of upholding the same. ${ }^{1}$ Winthrop says in 1643 , the sow business not yet being digested in the country, and many of the elders being yet unsatisfied, "the question came before them and after serious and careful examination they reached the very wise and judicious conclusion that ... they did not see any ground for the Court to proceed to judgment in the case, and therefore earnestly desired the Court might never be more troubled with it. To this all consented except Mr. Bellingham, who still maintained his former opinion, and would have the magistrates lay down their negative voice, and so the cause to be heard again. This stiffness of his and singularity of opinion, was very unpleasing to all the company, but they went on notwithstanding $\therefore$ to reconcile differences and take away offenses, which were risen between some of the magistrates by occasion of this sow business, and the treaties of Mr. Saltonstall against the council, so as Mr. Bellingham and he stood divided from the rest, which occasioned much opposition even in open court." 2

The conflict between Saltonstall and Bellingham on the one side and the other magistrates is here manifested again.
1 Winthrop, ii. *69-*72.
2 Ib., ii. * I I6. 
They seem, from jealousy, or from a desire to win popular favor, to be often on the side of the dear people against the magistrates, or in opposition in every contest where there is a conflict between them and the rich, or persons higher in social rank.

It seems that "Mr. Dudley also had let fall a speech in the Court to Mr. Rogers of Ipswich, which was grievous to him and other of the elders. The thing was this, Mr. Rogers being earnest in the cause between the town and Mr. Bradstreet [who was the son-in-law of Dudley], which also concerned his own interest [that is to say, the interest of Rogers], Mr. Dudley used this speech to him, 'Do you think to come with your eldership here to carry matters,' etc. Mr. Dudley was somewhat hard at first to be brought to see any evil in it, but at last he was convinced, and did acknowledge it and they were reconciled." It is certainly very refreshing to observe Dudley honestly declaring his real convictions as to the impropriety of the elders mingling in the action of the Court with the influence of their high office. We feel certain that he was right in his first position, and his acknowledgment must have been simply one of expediency and to secure harmony without the sacrifice of principle. $\mathrm{He}$ is the only one of the magistrates who seems to have had the courage to declare the whole counsel of the gods to the elders.

Winthrop says further, "The sow business had started another question about the magistrate's negative voice in the General Court. The deputies generally were very earnest to have it taken away." It was believed by the magistrates that this would lead to an unavoidable change into a democracy if the negative were taken away, and after writing several treatises and much discussion it was concluded to let it remain, as it has to this present time, with some modifications forty years after that date of sixteen hundred and forty-three.

There was, it is evident, a strong feeling in the minds of Winthrop and Dudley and other founders of Massachusetts 
against democracy pure and simple; and from this it has been claimed that they had no conception of the great democratic republic which they were contributing towards founding. Winthrop says that "democracy is among most civil nations counted the meanest and worst of all forms of government . . . and histories record that it has always been of least continuance, and fullest of troubles."

But there is a vast difference between a representative republic, with its organized system, its checks and counterchecks of one department of government upon another, even though all the departments are elected directly or indirectly by the votes of the people, and a simple democracy. The latter, if the citizens are not of the first quality in intelligence and virtue, a thing which has hardly yet been attained by any people in the history of the world, is a government liable to sudden outbursts of anarchy, without any conservative centralized power to control, and must be a very uncertain and unsafe form of government; indeed, it can have no practical existence, and must be unwieldy except in very small populations and to a very limited extent. We therefore may well agree with the dread of the fathers of democracy, and can well understand why they sought to limit the franchise, and to retain government in the hands of experienced and efficient men of the colony.

One thing is certain, that in the sow business the magistrates triumphed; they not only maintained themselves and the negative voice; they also, as we have seen, secured the right to sit in a separate chamber ever after, and thus won a double victory.

A sad bereavement came this year to Dudley in the loss of his wife, Dorothy. Mather says that she was "a gentlewoman whose extraction and estate were considerable." She had, during all these struggles, from the early part of the century to the day of her death, been the comfort and loving companion of Dudley. She had walked by his side through it all and taken her full share of the privations and suffering which were a part of this great undertaking. She was 
the mother of five of his children. The most that we know of the merits of this excellent woman is found in her epitaph, written by her distinguished daughter, Anne Bradstreet :-

\section{AN EPITAPH}

On my dear and ever honored Mother, Mrs. Dorothy Dudley,

Who deceased Decemb. 27, I643, and of her age, 6r ;

Here lyes, A worthy Matron of unspotted life, A loving Mother and obedient wife, A friendly Neighbor, pitiful to poor, Whom oft she fed, and clothed with her store;

To servants wisely aweful, but yet kind, And as they did, so they reward did find:

A true instructor of her Family, The which she ordered with dexterity. The publick meetings ever did frequent, And in her closet constant hours she spent; Religious in all her words and ways, Preparing still for death, till end of dayes: Of all her Children, Children, lived to see, Then dying, left a blessed memory. ${ }^{1}$

This epitaph reveals the sympathy which Mrs. Dudley must have had in the earnest religious life work of her husband, proving herself a most faithful and appreciative companion. We may well feel from these lines that her government in her household affairs was so strong that she also proved herself born to rule as well as he.

There is, moreover, a flavor of kindness and of tender charity for the suffering and the poor, which we most heartily believe was not borne by herself alone, but that it received the sincere approval and support of Governor Dudley as well, for it has been shown elsewhere that he had a heart full of sympathy toward his less fortunate fellow-creatures.

It doubtless would appear to many persons that the marriage of Dudley to Mrs. Catharine Hackburn, widow of Samuel Hackburn, of Roxbury, only a little over four months

2 J. H. Ellis's Anne Bradstreet, 369. 
after the death of his first wife, was too soon, and did not show a sufficient respect to her memory, or that tender thoughtfulness of her life work with him which would have been more creditable to his character. There are, however, often circumstances in life which may justify a course in these matters which otherwise would not be respectful or proper. And since we are not informed sufficiently we are unable to enter on any judgment in the premises, and can only fall back upon what we know of Dudley otherwise, and assume that he had what he thought to be good reasons for his peculiar conduct in this matter. It may also have been at that time a custom not to delay marriage, according to the present ideas. Life was more simple. There may have been a peculiar fascination about this widow, as we believe she married after the demise of Governor Dudley, with less intervening time. Governor Dudley had three children by this marriage. The most distinguished of these was Governor Joseph Dudley. Winthrop, after the death of Margaret Winthrop, in 1647, married his fourth wife about eight months later.

We have dwelt upon the difficulty which grew up between Cambridge and Boston. It may have been that Dudley and Hooker were on the one side opposed to Winthrop and Cotton on the other. That is to say, there was a Cambridge faction arrayed against a Boston faction in politics. All this had long since disappeared, and Dudley and Winthrop, in the great constructive work of forming the government, were united, laboring together against all factions and all opposition towards the onward progress of Massachusetts and her institutions. It is noticeable that nearly all writers in commenting upon the events of this period seem to consider the successes of Dudley as triumphs of the Winthrop party in politics. There is perhaps a natural tendency, without sufficient consideration, to include all the important services of Dudley in the great work of Winthrop without fully recognizing the former, who was, to say the least, a tower of strength and stability wherever he took part. 
But in 1644 the battle-ground had been changed. It was now a rivalry between the people of Essex and of Suffolk counties, between Ipswich and Boston. It was the Essex influence, no doubt, which gave to Endicott the governorship this year, displacing Winthrop. Ipswich was, next to Boston, the largest and most important town. Bradstreet resided there, who, although the son-in-law of Dudley, seems at this time to have been in political opposition to him, and Nathaniel Ward, who had prepared the draft of laws entitled "Body of Liberties," the first code of laws established in New England, adopted, as we have seen, in 1641. He was also the author of "The Simple Cobler of Aggawam," Agawam being the Indian name of Ipswich. Palfrey says that "the change now made [that is, of Endicott as governor and Winthrop as deputy governor, although they tried to introduce Bellingham] was a moderate one, but it indicated a reversal of the policy towards the rival Frenchmen [La Tour and D'Aulnay]. There was evidence of this, still more significant, when Bradstreet and William Hawthorn, the latter a young man rising into notice, were appointed to succeed Winthrop and Dudley as federal commissioners, while Saltonstall was designated to supply Bradstreet's place, in case a substitute should be needed. These were men of Essex County, except Saltonstall, and he was the fast friend of Bellingham. Winthrop was suspected of being unduly under the influence of the business men of Boston, in the favor which he had shown to La Tour. Palfrey says' further, "Two hundred years ago it seems Essex men were thought to be aspiring to rule the colony, as fifty years ago 'an Essex junto' was cried out against for its alleged ambition to rule the commonwealth." 1 Thus the scheming of politicians, inspired with local self-interest, was manifested from the very beginning of the history of this mother of commonwealths.

It was in 1643 that Parliament passed an ordinance to restrain unlicensed printing, which called forth the Areopa-

${ }^{1}$ Palfrey, ii. 156,157 ; Winthrop, ii. ${ }^{1}{ }_{171},{ }^{*}{ }_{172}$; Mass. Col. Rec., ii. 69 . 
gitica of John Milton, which William E. Channing says, and the world agrees, was "Milton's most celebrated prose work." This was "A Speech for the Liberty of Unlicensed Printing, a noble work indeed, a precious manual of freedom, an arsenal of immortal weapons for the defense of man's highest prerogative, intellectual liberty." 1

James Russell Lowell says, "that in this time in England every crotchet and whimsey, too, became the nucleus of a sect, and, as if Old England could not furnish enough otherwise-mindedness of her own, New England sent over Roger Williams and Gorton to help in the confusion of tongues. All these sects, since each singly was in a helpless and often hateful minority, were united in the assertion of their right to freedom of opinion and to the uncurtailed utterance of whatever they fancied that opinion to be. Many of them, it should seem, could hardly fail in their menial vagabondage to stumble upon the principle of universal toleration, but none discovered anything more novel than that liberty of Prophesying is good for Me and very bad for Thee. It is remarkable how beautiful the countenance of toleration always looks in this partial view of it, but it is conceivable that any one of these heterodoxies once in power, and therefore orthodox, would have buckled around all dissenters one strait waistcoat yet warm from the constraint of more precious limbs. . . Williams, as was natural in one of his amiable temper, was more generous than the rest, but even he lived long enough to learn that there were politico-theological bores in Rhode Island so sedulous and so irritating that they made him doubt the efficacy of his own nostrum, just as the activity of certain domestic insects might make a Brahmin waver as to the sacredness of life in some of its lower organisms." 2

Yet even Milton later became a censor of the press, and he never would have granted liberty either to Popery or Atheism to propagate itself. He says, in his history of Britain, "that liberty hath a sharp and double edge fit only to

1 William E. Channing, i. 28, 29.

2 Lowell's Prose Works, Latest Literary Essays, 94, 95. 
be handled by just and virtuous men; to bad and dissolute it becomes a mischief unwieldy in their own hands." Thus the Puritans of Massachusetts were in substantial accord in spirit with the Puritans in England and with their greatest exponent. 


\section{CHAPTER XXVIII}

THE civil war which was raging in England at this time was, as we have noticed, a subject of the deepest interest and solicitude in Massachusetts. Boston became almost a scene of battle between the two parties in May, 1644. There was in port at this time a Bristol ship laden with fish on her way to Bilboa; there was also a Parliament man-of-war of twenty-four guns in the harbor, commanded by Captain Thomas Stagg. Captain Stagg demanded the surrender of the Bristol ship within half an hour, and prepared to fire upon her if she refused. There was a great assemblage of people upon Windmill Hill to witness the contest, but the Bristol ship surrendered without battle. Deputy Governor John Winthrop wrote to Captain Stagg asking his authority for his conduct. Captain Stagg produced his commission from the Earl of Warwick, which was sent to Governor Endicott, at Salem. This event created a great disturbance in the colony, because there were Bristol merchants here who felt it to be an outrage. The elders in their pulpits regarded it as an invasion of the liberties of the people, and even the General Court was forced to consider the advantages and the perils to which they were exposed by the adherence either to the Parliament or to the Royalists. This was illustrated at a meeting of some of the magistrates and elders, at which they gave some of their reasons and convictions why they ought rather to sustain the action of Captain Stagg :- -

"I. Because this could be no precedent to bar us from opposing any commission or other foreign power that might indeed tend to our hurt and violate our liberty ; for the Parliament had taught us that salus populi is supreme lex. 
“ 2. The King of England was enraged against us, and all that party, and all the Popish states in Europe; and if we should now, by opposing the Parliament, cause them to forsake us, we could have no protection or countenance from any, but should lie open as a prey to all men. . . . Upon these and other considerations, it was not thought fit to oppose the Parliament's commission, but to suffer the captain to enjoy his prize." 1

We can well understand what a tremendous responsibility fell upon the most prominent men in Massachusetts at this time, when to make a mistake, either in one direction or in the other, might, as had so often happened in other nations, expose the colony to destruction from its enemies abroad. Nobody could tell at that moment which party would finally prevail in England, and thus they were exposed constantly to the uncertain fortunes of a foreign war, the issues of which otherwise were quite unimportant to them. We cannot overestimate the sound judgment and enlightened wisdom which entered into their method and conduct in this crisis. We know very well that Winthrop, Dudley, and Endicott were here foremost, the great leaders so long as they remained in the colony. When they were gone they were succeeded by others whom they had educated and prepared to fill their places.

Thomas Morton returned to this country in 1643 , having done what he could while in England to disturb the relations between Massachusetts and the home government, and having there published a hostile pamphlet, entitled "The New English Canaan," and written a letter which was scurrilous and bad in the extreme. He was brought before the Court, sent to prison for a year, then fined a hundred pounds, and set at liberty. He was shown mercy, because he was old and crazy. He died within two years. There are persons who have expressed great sympathy for Morton, but he does not seem to have merited by his character or his conduct much more consideration than he received. He early for-

1 Winthrop, ii. *180-1 83 . 
feited all right to the respect and confidence of the government of Massachusetts, and as her bitter enemy she was justified in holding him strictly responsible for his hostile efforts against her, for it was to her a matter of self-preservation, and her first duty to the extent of his importance and his influence.

A new office was created in 1644: Dudley was chosen sergeant major general, and was given the sole command of the militia, as fully empowered as the governor was at the head of the civil authority. Dudley was especially well qualified for this office, both by his early military career and by his long experience in the government. This appointment and organization of the militia is another evidence that the colony felt deeply the need, because of the civil war at home and savage Indians all around, to be constantly in readiness to defend and protect itself.

Great power was placed in the hands of the commanding general. He always had in the councils of war the casting vote, also the power to impress all materials and instruments fit for war. His commission says : "But for the ordering and managing of any battle in time of service, it is wholly left to yourself. Also yourself, together with the council of war, shall have power to make such wholesome laws, agreeable to the word of God, as you shall conceive to be necessary for the well ordering of your army." Indeed, he seems to have had no controlling power above him except the General Court, and was only limited in his actions as provided in his commission by the council of war. ${ }^{1}$

"It is desired that the Igth of the Ioth month shall be kept a day of public humiliation in regard of our native country, the prevailing of erroneous and corrupt opinions, the sore wars, and extreme wants of many there, with the weighty occasions in hand both there and here." 2

This record indicates to us the troubles which afflicted the colony and gave great anxiety to the administration.

1 Mass. Col. Rec., ii. 77, 78.

2 Ib., ii. 84 . 
It also shows, whatever we may think of it, the childlike dependence which they maintained toward an overruling Providence in all matters, both small and great. Their intense fear and dread of Anabaptists and of heresy leads them to bring the matter before the General Court, November 13,1644 , and to place on record an expression of their conviction that these false religions, by their infection, are a danger to the churches and to the whole commonwealth. ${ }^{1}$

Richard Andrews and two ladies of London, England, had made generous donations to the colony, and accordingly a committee was appointed to draw, transcribe, and send a letter from the Court returning the thanks of the Court and colony to these benefactors. Winthrop, Dudley, and Hibbins were the members of this committee. At the same Court, the same committee were appointed to answer for the colony in all such occasions as may be presented to the Parliament concerning us or our affairs. 2. To receive all letters and other dispatches of public nature. 3. To advise the Court of all such events as may happen touching the colony. 4. To receive all moneys for other things due to the colony from any person in England, by gift or otherwise, and to dispose of them according to direction under our public seal. The appointment of this important committee with such remarkable powers is conclusive evidence of the estimate which the Court then held on the character and gifts of its members. It is notable, first, that they are chosen to prepare with fitting words a graceful acknowledgment of foreign gifts, in the name and behalf of the Court, and that the members selected were the best qualified for this service; and, second, that they were intrusted by their other appointment with the powers of a cabinet and the unbounded confidence of the General Court.

The commissioners of the United Colonies gave advice that care be taken for the encouragement and maintenance of poor scholars in the college at Cambridge, and it is commended by the General Court that the deputies of the sev-

1 Mass. Col. Rec., ii. 85. 
eral towns shall undertake to do what has been done in some of the other colonies, that every family shall allow one peck of corn, or twelve pence in money for other commodity, to be sent to the treasurer for the college at Cambridge. ${ }^{1}$

A proposition was made, on account of the expense of " the over number of deputies, ... to have only five or six out of each shire, . . . and those to be prime men of the country." It was agreed that the magistrates should relinquish the negative voice, if the deputies were reduced to the same number as the magistrates, but the towns refused it, and the change was not made; and Palfrey says, "It was not till more than two hundred years after this time that the municipal corporations, as such, ceased to be constituents of the second house of legislature.".

It has been the custom from the very first, until I 884 , to have an election sermon, so called, preached before the legislature by some eminent minister, at or near the time of the annual inauguration of the new legislature. The purpose of this, no doubt, was to give them helpful Christian advice and direction at their entrance upon the important work of legislation for the year ensuing.

It happened in the year I64I, when Bellingham was made governor, on account of the unpopularity, in part, of Winthrop, because of the favor which he had shown La Tour, that the deputies had chosen for this service Nathaniel Ward, without consulting the magistrates, who, on account of ill feeling between the two branches of the legislature, waived their own supposed right of appointment to this office. In 1644 the deputies ordered the appointment of Mr. Norton, while the governor and magistrates selected Mr. Norris. The magistrates again surrendered to the deputies, and Norton performed the service. Norris was the minister of Goviernor Endicott, and this was used politically against him at the election in 1645. The Essex junto, no doubt, was active at this election, but Bellingham was defeated, and they in turn succeeded in preventing the elec-

1 Mass. Col. Rec., ii. 86; Winthrop, ii. *214. 
tion of Winthrop or Endicott. Dudley was, however, elected governor, and Winthrop deputy governor, which was in effect the triumph of the Winthrop-Dudley party, and a return to the ancient trusted leaders.

It was ordered by the Court on the fourteenth day of May, 1645, when Dudley was for the third time elected governor of the colony, that "all youth within this jurisdiction, from ten years old to the age of sixteen years, shall be instructed by some one of the officers of the band, or some other experienced soldier, ... in the exercise of arms, as small guns, half pikes, bows and arrows." This training was to secure their efficiency, even if they were destitute of powder. ${ }^{1}$

The Rev. John Eliot, the apostle to the Indians, relates in his diary that the following anagram was sent to Dudley two days after this election. Eliot dwelt upon the opposite side of the street from Dudley, in Roxbury. As we have observed, they were excellent friends. Charles M. Ellis, the historian of that town, evidently inclines to the opinion that Eliot was its author. He says, "Eliot was guilty of doggerel. This is in his vein. And it is hard to see why he should have questioned the best reading of a line, or noticed such a thing at all, or written it out at length, unless it was his own." 2

Dudley was then sixty-nine years of age. It has been inferred by certain persons whose esteem for Dudley is moderate, that these lines were sent to him, in his moment of success, by some insolent enemy, to temper his happiness and impede his joyousness.

It is possible, and indeed far more probable, that his friend Eliot, whose uppermost thought was the theme of these lines, may have feared that the governor might not at this moment sufficiently dwell upon the nothingness of mortal affairs, and a little reminder, couched in words ingeniously composed from his own name, with a remote flavor of poetry, might arrest his attention. They probably had an impor-

1 Mass. Col. Rec., ii. 99.

2 Ellis's Hist. of Roxbury, 104. 
tance in his estimation which it would be impossible for us to accord to them.

\section{THOMAS DUDLEY.}

Ah, Old, must dye.

A death's head on you, you would not weare ;

A dying head, you on your shoulders beare.

You need not one to mind you, you must dye.

You in your name may spell mortalitye,

Young men may dye, but old men they dye must.

Lord it can't be long ?

'T will not be long $\}$ before you turne to dust.

Before you turne to dust! Ah, Must, Old! dye!

What shall younge doe, when old in dust doe lye,

When old in dust lye; what shall New England doe?

When old in dust lye, it's best dye too. ${ }^{1}$

The paramount importance of education, both military and civil, had taken possession of the minds of these founders. Schools which have given, during the last two hundred and fifty years, immense force of culture to the mass of American citizenship, and have contributed as much as anything to the unparalleled intellectual and moral influence of Massachusetts in the republic, were founded now ; while the noble public school system was created two years later. ${ }^{2}$

Winthrop informs us that "divers free schools were created as at Roxbury (for the maintenance whereof every inhabitant bound some house or land for a yearly allowance forever), and at Boston (where they made an order to allow forever fifty pounds to the master and an house, and thirty pounds to an usher, who should also teach to read and write and cipher), and Indian children were to be taught freely, and the charge to be by yearly contribution, either by

1 Hist. of Roxbury, 103, 104; Eliot's Records, Hist. Genealog. Reg., Jan. 1879.

2 The historian of Dorchester, Mass., informs us that he believes that the "first public provision for a free school in the world by a direct tax or assessment on the inhabitants of a town "was made in Dorchester in 1639. For aught that we know, this may have been the pioneer movement in the most important concernment in the colonies next to religion. 
voluntary allowance, or by rate of such as refused, etc., and this order was confirmed by the General Court [blank]. Other towns did the like, providing maintenance by several means." 1

Savage says, justly no doubt, in his note to this passage, that " in her admirable system of free schools, or he greatly mistakes, Massachusetts is superior to all the rest of the world, unless those states, neighboring or remote, who have borrowed from her may divide the honor."

We have elsewhere mentioned that the free school of Roxbury was established upon an agreement of citizens, at the head of which contract the name of Thomas Dudley appears. C. M. Ellis says that there "is reason to suppose he drew the agreement for the free school." 2 And the same writer says also, "Governor Dudley is supposed to have given part of the lot where the old schoolhouse that was sold, stood, opposite to Guild Hall. Both he and his descendants made very large donations to the school." 3

This school still holds its rank among the very best schools in America.

If we except the statute in the Body of Liberties, the first protest of Massachusetts against African slavery was issued in October, 1645, during the administration of Governor Dudley. We have no evidence that this philanthropic movement, in which Massachusetts was destined at a later period to take such a leading part, originated with Dudley, but the noble effort contributed to render his reign illustrious.

The British policy at this period, and for more than a hundred years thereafter, was to establish the slave trade in her American colonies, and to secure to herself the spoils and the profits of this nefarious commerce. Massachusetts was powerless to resist her directly, but with her invincible love of liberty she wielded the reserved power that she retained to give freedom to the captive.

1 Winthrop, ii. *21 5 .

2 Hist. Roxbury, 37, 39, 101.

8 Ib., 50. 
The Court directed Williams, ${ }^{1}$ of Portsmouth, N. H., "that he forthwith send the negro which he had of Captain Smyth hither, that he may be sent home to [Guinea], which the Court doth resolve to send back without delay." 2

The record of the same Court the very next year on the fourth day of November, in another case, is yet more effective and certain.

"The General Court, conceiving themselves bound by the first opportunity to bear witness against the heinous and crying sin of man-stealing, as also to prescribe such timely redress for what is past, and such a law for the future as may sufficiently deter all others belonging to us to have to do in such vile and most odious courses, justly abhorred of all good and just men, do order, that the negro interpreter, with others unlawfully taken, be, by the first opportunity (at the charge of the country for the present) sent to his native country of Guinea, and a letter with him of the indignation of the Court thereabouts; and in justice hereof desiring our honored governor would please to put this order in execution." 3

1 "Boston, at the General Court, the I4th of the 8th Mo. I645.

"Mr. Williams: The Court understanding that the negroes which Capt. Smyth brought were fraudulently and injuriously taken and brought from Guinea, by Capt. Smyth's confession; and the rest of the company hath resolved to send them back, and so doth desire that the negro which you had of Capt. Smyth be forthwith sent hither, that he may be sent home without delay; and if you have anything to allege why you should not return him, to be disposed of by the Court, it will be expected you should forthwith make it appear, either by yourself or your agent, but not make any excuse or delay in sending of him.

GOV. WINTHROP.

"Consented to by the deputies and the governor, because of the present opportunity to send him directly home by Major Gibbon's vessel.

EDWARD RAwSON."

Boston, Jan. 28, 1898 . Compared with the original and found correctly copied, William M. Olin, Sec'y. (Mass. Archives, State House, Boston, 1x. 29I.)

2 Mass. Col. Rec., ii. I36.

8 Winthrop, ii. *244, *245, and App. M. 
The fathers were sublimely consistent in cherishing civil liberty. Where in human history are there earlier or more decided utterances against slavery? The nations of the earth were then indifferent to the evils or even the existence of slavery.

Sir John Hawkins, in I 562, attained to the infamy of tainting British commerce with the execrable and barbaric traffic in men, and Queen Elizabeth to the reproach of having knighted him for this despicable service. ${ }^{1}$

Lord Mansfield, in the case of James Somerset, declared, though not the first time in the history of English jurisprudence, that "the air of England has long been too pure for a slave, and every man is free who breathes it. Every man who comes into England is entitled to the protection of English law, whatever oppression he may heretofore have suffered, and whatever may be the color of his skin. 'Quamvis ille niger quamvis tu candidus esses.' Let the negro be discharged." This decision was on the $22 \mathrm{~d}$ of June, $1772 .^{2}$

"Slaves cannot breathe in England; if their lungs

Receive our air, that moment they are free!

They touch our country, and their shackles fall."

Massachusetts, in 1641, guaranteed in her Body of Liberties that "there shall never be any bond slavery, villenage or captivity amongst us unless it be lawful captives taken in just wars, and such strangers as willingly sell themselves or are sold to us." 3

Every child born in Massachusetts from that day has with its first breath drawn in the pure air of freedom, regardless of its parentage or the color of its skin. ${ }^{4}$

John G. Whittier has well said, "It was not the rigor of her northern winter, nor the unfriendly soil of Massachusetts, which discouraged the introduction of slavery during the first half century of her existence as a colony. It was the

1 Mass. and its Early Hist., Lowell Inst. Lect., 198.

${ }^{2}$ Lord Campbell's Lives of the Chief Justices, iii. 317.

3 Body of Liberties, Io, § 9; Whitmore's Col. Laws, 53.

4 Works of Charles Sumner, iii. 384; v. 281. 
recognition of the brotherhood of man in sin, suffering, and redemption; the awfil responsibilities and eternal destinies of humanity; her hatred of wrong and tyranny, and her stern sense of justice, which led her to impose upon the African slave trade the terrible penalty of the Mosaic code." 1

The question of domestic service vexed these people as it does ourselves at the present time, for the spirit of democratic equality at once seized all the English servants whom they imported, and made them immediately aspire to become prosperous citizens, rather than humble servants. Therefore it is highly creditable to the virtue and justice of the Court, that from principle they resisted all selfish and mercenary considerations.

The temptations in this respect offered to individuals, as is evident in the literature of the period, were very great, and furnish strong side lights revealing a profound sense of justice and a steadfast integrity in the leaders of society and the rulers of the colony. We have, for example, a letter of Emanuel Downing, brother-in-law of Winthrop, illustrating the view already presented, furnishing to us a quality of him, however, which is far less humane and enlightened than the public sentiment of the community where he dwelt. $\mathrm{He}$ wrote to Winthrop this very year I645 as follows :-

"A war with the Narragansetts is very considerable to this plantation, for I doubt whether it be not sin in us, having power in our hands, to suffer them to maintain the worship of the devil which their powwows often do; truly, if upon a just war the Lord should deliver them into our hands, we might easily have men, women, and children enough to exchange for Moors, which will be more gainful pillage for us than we conceive, for I do not see how we can thrive until we get into a stock of slaves sufficient to do all our business, for our children's children will hardly see this great continent filled with people, so that our servants will still

1 Wilson's Hist. of the Rise and Fall of the Slave Power in America, i. 7 . 
desire freedom to plant for themselves, and not stay but for very great wages. And I suppose you know very well how we shall maintain twenty Moors cheaper than one English servant." 1 Downing's exceeding need of Narragansett Indians as merchandise is a refreshing argument, conclusive indeed that they ought to be preserved from devil worship.

Pesecus, the brother of Miantonomoh, no doubt influenced by Gorton, continued with his allies to meditate war upon Uncas for a long time, but he was restrained from that purpose by the United Colonies. ${ }^{2}$

Hutchinson says that Uncas, being dismissed in 1638 , "with a present, went home joyful, carrying a letter of protection for himself and men through the English plantations, and never was engaged in hostilities against any of the colonies, although he survived Philip's war, and died a very old man after the year 1680." 3

This was the conclusion of the long, cruel war. A treaty was signed August 30, 1645, which was satisfactory to the commissioners of the United Colonies. The colonial army was disbanded September 4, and that day, which had been set apart as a fast day, was triumphantly and joyfully transformed into a thanksgiving day and a peace jubilee.

There is no known copy extant of Governor Thomas Dudley's thanksgiving proclamation, of even date herewith, nor have we any assurance that he ever made one. There was indeed subsequent trouble between the English and Narragansetts respecting the performance of the provisions of this treaty until 1650 , but there was no war.

The magistrates and deputies renewed their struggle respectively for power this year. The discontent proceeded, as usual, from the deputies, however. There was at the same time a strong feeling against the government, on the part of those inhabitants who had not been admitted into church membership nor received the privileges of freemen.

1 Lowell's Among My Books, i. 262; Winthrop Papers, Mass. Hist. Coll., 4th series, vi. 65 .

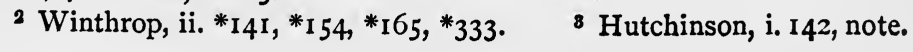


The newly acquired powers in their possession only excited these democratic representatives to extend the franchises already acquired by them. Enfranchised people are in general unhappy and turbulent until they are fully adjusted to their new condition, and discover the extreme boundary of their privileges. Macaulay has said, "In no form of government is there an absolute identity of interest between the different branches of any government."

The ministers were invited to mediate in this dispute, and through their pacific influence a temporary adjustment was secured, lasting into the next year. The subject-matter was not the identity of that ever-recurring and notable swine; the real issue and gravamen was still, however, the relative power of the two houses of the General Court, with the thought respecting the negative voice in the magistrates. Dudley and Bellingham, who were on opposite sides of the question of the identity of the sow, were hostile now, as usual, although they had once joined hand in hand as peacemakers, persuading the party who had justice on his side to yield his rights in the interest of harmony. ${ }^{1}$

Dudley was consistent in that earlier peaceful action with his usual conduct in his own private controversies, where no moral question was involved, but he could neither be seduced by bribery, nor be terrified by power, even of the British government, to depart one scintilla from his conviction of duty. Justice was to him one of the most sacred objects to be sought by intelligent Christian people.

The magistrates and deputies became deeply involved in another dispute of similar nature, in which the people manifested a fear, as they had so often done before, that the magistrates exercised too much power, and that their liberties were in danger; while the magistrates were on their part as anxious, fearing that "authority was overmuch slighted, which if not timely remedied, would endanger the commonwealth and bring it to a mere democracy."

This difficulty started in the town of Hingham, and in1 Hutchinson, i. 144. 
creased in bitterness until it resulted in making direct charges against Winthrop, the deputy governor. The Court assembled in the meeting-house at an appointed day to hear the complaint of certain petitioners and deputies against him.

The Standing Council for Life, composed of Winthrop, Dudley, and Endicott, possessed still the right of confirming the choice of inferior military officers. The council wished a vacancy in a company filled by the lieutenant. Winthrop became as usual the object of special vengeance on the part of Bellingham and Saltonstall of the magistrates, as well as of the majority of the deputies, and at once all the jealousies which the exercise of authority had created in the past between the two houses were fanned into a flame. Winthrop defended himself with great success, and finally made what he is pleased to call "a little speech" upon the subject of government in general, in which he set forth the liberty proper to the individual citizen, and the powers and duty of the government, in a very convincing manner. This speech has been referred to as a masterly production, involving a question of great general importance.

We cannot overlook the fact that Dudley, in his long service in the different departments of government, was never subjected to a similar humiliation, although he was a member of this council for life. This was certainly not because he was less firm or less outspoken. Did he possess more tact? Was he really more wise and "level-headed," in dealing with his fellow-citizens ? 1

Hutchinson says, "A great disturbance was caused in the colony, this year, both as to civil and ecclesiastical government, from the people in general." 2 It seems that since the action of the magistrates was sustained, and the deputy governor vindicated in the Hingham matter the previous year, certain discontented persons, the most prominent of whom

1 Winthrop, ii. *221-*236; Grahame's United States, i. 272, 273; Mass. Col. Rec., ii. II 4 ; English in America, i. 353, 354.

${ }^{2}$ Hutchinson, i. 145. 
were disfranchised because they were Episcopalians, or for other reasons deemed sufficient, now made a direct and insolent attack upon the existing government, which was begun here, but was intended really to accomplish its work in England, either by breaking down the authority of the magistrates and the doings of the government, or, which was the - same thing, by destroying it and placing in its stead a form of government direct from England, which was accomplished in 1684 by the destruction of the first charter, subverting the independent colonial government and its purposes.

This work was begun really in Plymouth in the October term of 1645 , but first appeared in the General Court of Massachusetts by what was styled a "Remonstrance and Humble Petition," etc., a copy of which may now be found in "New England's Jonas cast up at London," I647, supposed to have been written by William Vassal, though bearing the name of Major John Child. W. T. R. Marvin, in his introduction to an edition of this book, called attention to the fact that this petition was presented at the General Court, May 19, 1646, " but before any action could be taken upon it, copies were extensively dispersed, not only in the neighboring colonies of Plymouth and Connecticut, but also to the New Netherlands, Virginia, and the Bermudas, where persons who were ill-affected to the government of Massachusetts could ever be found. The course of the petitioners excited great feeling, and not a little anxiety among the colonial leaders." 1 This was natural, because it was evident that the petitioners were attempting to secure the judgment of the other colonies against Massachusetts, and by indirect methods to control her action. This was true, as we have said, not only in this country, but it was intended chiefly to secure the attention of the home government.

These people were Episcopalians, but there was also a Presbyterian influence centred in it from Hingham, of which Hobart was the chief exponent. The national religion of England had now become, by action of Parliament,

1 New England's Jonas, xxvii.; Mass. Hist. Coll., 5th series, 148, note. 
Presbyterian. This undoubtedly increased the fears of the Massachusetts government. These petitioners appeared against the colony in England, but were met by Governor Winslow, its able agent.

The petition was finally embodied in a pamphlet, as we have said, and brought to the notice of the government without any injurious results to Massachusetts, so far as appears. Winthrop says, "As for those who went over to procure us trouble, God met with them all." 1

It has been sometimes thought that the resistance of the colony to Episcopalians at this time indicates that they were not sincere when they wrote from the Arbella, April 7, 1630, to their brethren in and of the Church of England, that we "esteem it our honor to call the Church of England, from whence we rise, our dear mother." But they had received great light, and had great experience and responsibilities which taxed their utmost expedients in church and state since that day, during sixteen years of doubt and suffering. It is only needful to consider the progress and change in England itself during the same period, particularly in the mother church, to disarm strictures on the changes in opinions in Boston, Massachusetts. The state religion of England had gone from Episcopacy to Presbyterianism, and a powerful faction of it under Cromwell even to Independency as rank as the Massachusetts sort. It may easily be admitted that Massachusetts led in the revolt for liberty against the church and state, and everything else. It is a way she always had. Archbishop Laud once suggested to send a bishop to her with "forces to compel if he were not otherwise able to persuade obedience." 2 It was feudalism in church and state that the Independents were at war with, in Episcopacy, Catholicism, and indeed in Presbyterianism. It was the responsibility of the individual church and individual man that they proclaimed in the ears of all the world. And this was the direct highway to democracy in politics, which

1 Winthrop, ii. *32r.

2 Heylin's Life of Laud. 
end of the way they did not at first so much regard in their religious zeal until Winthrop and Dudley found themselves in it, with no possible retreat, if at first they wished it. Harold the Saxon was at the front and feudalism in the rear. 


\section{CHAPTER XXIX}

THERE was on the part of the government a deepening solicitude respecting the final results of the revolution now going on in England, and which was then far more nearly approaching its end than was known at that time. How and in what way would it affect America? And what wise middle course would place the colony in the best position in the event of the success of either the Commonwealth or the Royal cause in England? The Puritan side was earnestly espoused by America at heart, while prudence required the least action here until the result was attained abroad. Winthrop says, "Some malignant spirits began to stir and declare themselves for the king, etc., whereupon an order was made to restrain such course and to prevent all such turbulent practices, either by action, word, or writing." 1

The Royalists and Parliamentary armies took the field in their last campaign of the great rebellion, in the May of this very year 1645, at about the time that Dudley was elected governor, and the defeat of Charles I. at Nasby, where he staked and lost the crown of England, took place on July I4. It is certain that the chief officers in the government of Massachusetts were weighed down with grave responsibilities respecting the colony, in the midst of a most perilous crisis. Dudley was again chosen, in 1645 , a commissioner to draft laws. He had assisted in creating the Body of Liberties in $164 \mathrm{I}$, and in forming the Articles of Confederation in 1643 , and had been on most of the committees for constructing laws from the beginning of the colony. This is very significant, and assures us still more of his importance

1 Winthrop, ii. *21 2. 
and standing among his contemporaries in early Massachusetts. ${ }^{1}$

The Puritans regarded the Anabaptists as equally dangerous to true religion with the fanatical Familists of Münster in Germany. Moreover, if their teachings on the subject of baptism were correct, the baptism, and administration of the same, upon which the church of New England rested, which also was one of the sacraments which was the gateway to enfranchisement and political power, was void and of no effect. They might with reason regard the Baptists as determined on the destruction of their entire enterprise and policy. The Court refused in October, 1645, to alter at all, or explain its laws against Anabaptists. ${ }^{2}$ This year of Dudley's gubernatorial experience had been an eventful one, in establishing educational institutions, in uttering a vigorous protest against slavery, in settling the old feud between the Mohegans and Narragansetts, and in the struggles between the government and the people and between the departments of government.

It was also, as we have already observed, the period of the collapse of the British monarchy, and the culmination of the great rebellion.

Dudley secured and held the esteem and confidence of his fellow-citizens this year as always before, as is well shown in many ways. The General Court passed the following order during the subsequent autumn: "The Court doth thankfully acknowledge the good service our honored deputy governor [Thomas Dudley] hath done in the place of governor the last year [1645], and are not a little troubled that the pressing and many urgent necessities and necessary charges of this colony are such as to intervene between his deserved merits and the just recompense which this Court is used to allow; but believing he is no less sensible of the premises than ourselves, we doubt not of his loving acceptance of so slender an acknowledgment, have thought meet to order that

1 Mass. Col. Rec., ii. I09; Colonial Laws, 73.

2 Mass. Col. Rec., ii. I4I. 
our honored deputy governor [Thomas Dudley] shall be allowed out of the next levy the sum of sixty pounds." 1

The Assembly of Divines met in the choir of Westminster Abbey, July I, 1643, and sat in the chapel of Henry VII., or the Jerusalem Chamber, until the autumn of 1647 . Indeed, it never dissolved, but ceased to be in 1653 under the iron hand of Cromwell, the Independent, influenced in the order of its going at last by the same irresistible power which turned the Long Parliament out into the cold world.

This assembly and the House of Commons sat, both bodies, September 25, 1643, in St. Margaret's Church, near the Abbey, and adopted a "Solemn League and Covenant," pledging the nation to the abolition of Episcopacy and the establishment of Presbyterianism in its place. The Commons usually was holding its sittings then in the Chapter House of the Abbey. ${ }^{2}$

It enacted an ordinance, January 6,1643 , that the "Book of Common Prayer be abolished." It created a system of rigid Presbyterian discipline, and set forth a Confession of Faith, which bears the name adopted by Parliament in 1646 as the Creed of the English Church, and lastly a longer and shorter Catechism.

But the home government could not secure unqualified obedience. Large numbers of English people adhered to Episcopacy and others of the Irish to the Roman Catholic faith; only Scotland was devoted, constant, and loyal, and to-day it is steadfast, immovable, always abounding in Presbyterianism : while the Independents, who were desiring to escape from the restraints and dictations of arbitrary church government, and were more and more democratic in politics, were rapidly gaining ascendency in the British army under Parliament. Presbyterianism was made to appear, perhaps justly, to this restless, seeking multitude of people, to be only a subterfuge little removed, in effect, from the

1 Mass. Col. Rec., ii. 165.

${ }^{2}$ For a description of this assembly see Letters and Journals of Robert Baillie, ii. ro7-I09; Life of Bishop Sanderson, by Izaak Walton. 
hierarchies of Episcopacy or of Rome. The coveted freedom was no more secure, they thought, under presbyteries than under bishops.

It was quite different in America. The new Independent Church system had been on trial here many years before Presbyterianism became the national religion of England. Churches of the Independent order and states were merged and closely joined in their operations, so as to advance together with amazing success. Here at least the age of experiment was over, and there was every reason for keeping aloof from this unfortunate religious visitation and adversity which for a time overwhelmed the mother country.

The influence of New England in restraining the progress of Presbyterianism in England, and in extending the system of Independency among her people and the rank and file of the army of the Commonwealth, was measureless.

"Cromwell and Vane and Fieness and St. John used the tracts of Cotton and Hooker and Norton, and other New England ministers, as being for a thousand reasons the best weapons in their arsenal." 1

"In the year I642, letters came to Mr. Cotton, of Boston, Mr. Hooker, of Hartford, and Mr. Davenport, of New Haven, signed by several of the nobility, divers members of the House of Commons, and some ministers, to call them, or some of them, if all could not come, to assist in the Assembly of Divines at Westminster." 2

Hooker was a very distinguished writer upon the subject of Independency, and was well prepared to maintain his cause before any body of men, but he was too wise to take part in a convention, the conclusions of which in important particulars he was certain ever afterwards to be forced to antagonize. Moreover the assembly was of political origin, and the prudent policy for Americans, the very safety of their cherished institutions, both civil and ecclesiastical, had always depended upon severance from England.

1 E. E. Hale, Mass. Early Hist., Lowell Inst. Lectures, 457.

${ }^{2}$ Hutchinson, i. I 15. 
Their independence in religion and politics, their refusal to allow appeals to the throne or courts of England, was the germ of our nationality developed in the Revolution. Hooker avoided in this spirit all foreign jurisdiction, and, with his associates here behind the eternal barriers of the ocean, while England was overwhelmed with her own calamities, proceeded to construct in America the ideal state, freed largely from the useless trumpery which has adhered to and incumbered old and worn-out systems of church and state. Thus they flourished, while the throne of Charles I. toppled over, and the British people "gart kings ken that they had a lith in their necks," amid the shattering of armies, the quelling of factions, and the overthrow of creeds in fatherland. No Americans took part in the Assembly of Divines. Its Confession was adopted here; its Discipline was rejected.

Winthrop informs us that in 1643 "there was an assembly at Cambridge of all the elders in the country (about fifty in all). . . . They sat in the college and had their diet there, after the manner of scholars' commons, but somewhat better, yet so ordered as it came not to above six pence the meal for a person.

"Mr. Cotton and Mr. Hooker were chosen moderators. The principal occasion was because some of the elders went about to set up some things according to the Presbytery, as of Newbury, etc. The assembly concluded against some parts of the Presbyterial way, and the Newbury ministers took time to consider the arguments," etc. ${ }^{1}$

This synod at its last and important session, August 6, 1648, approved of the Westminster Confession of Faith, but not the Presbyterian Discipline. It created what was called a Platform of Church Discipline, "to be presented to the churches and the General Court for their acceptance in the Lord."

This action, it will be remembered, was ten years previous to the conference at the Savoy Palace in London, which

${ }^{1}$ Winthrop, ii. ${ }^{\prime}{ }_{3} 6, * 137$. 
did similar constructive work for Congregationalism in that country in 1658 .

The General Court commended the Platform to the churches for consideration one year. Their prolonged, patient, thoughtful deliberation was wise and exemplary, and after two years, in I65I, October I4, they gave "their testimony to the said Book of Discipline that, for the substance thereof, it was that they had practiced and did believe." 1 It had thus been more than five years in coming to maturity and perfection. Governor Winthrop did not survive to witness this final act of the Court.

Governor Dudley and Increase Nowell were the only assistants in 1651 who were present at the last meeting at Southampton, March I8, 1629-30; and Dudley and his sonin-law, Governor Simon Bradstreet, were the only assistants now present who were at the meeting on the Arbella, March 23. These three persons are all that remained in the Court in $165 \mathrm{I}$, of the assistants who first met at Charlestown in America, August 23, I630. It is quite certain that while Dudley lived his influence was far greater than that of any other assistant except Winthrop.

We may therefore well conceive his satisfaction when at last the Court had placed upon New England Congregationalism its final crowning seal and testimony. He might now with conscious joy and complacency review the beginning, progress through sufferings, and the outcome already before him in society, church, and state. He might behold with pride cultivated farms, thriving towns, and prosperous villages. He could not then see, as we see, the transformation which in two and one half centuries was to compass the earth, and that that freedom to which they contributed so much would like leaven develop public thought and opinion, and that the chainless mind would in science, art, politics, religion, and in many things pertaining to human life, with irresistible force and sweep, change all things, creating almost a new heaven and a new earth for our abode and con-

1 Mass. Col. Rec., ii. 285 ; iii. $177,240$. 
scious existence here. Neither need we plume ourselves with undue pride and arrogance, for the end of human progress is not yet.

The government of Massachusetts was almost constantly disturbed by the intrigues and scheming of persons in England, who had been here, and did not take kindly to Puritan methods or colonial justice, and possessed often an influence which rendered them dangerous to the colony and to its leading citizens. Public affairs were in such a state of turmoil much of the time that it was possible for persons of little importance in themselves, being so far removed from the scene of the complaint, to do considerable mischief before the remedy could be applied to heal the injury.

Gorton, Child, and others published tracts in England with the purpose of doing all that they could to weaken and destroy whatever confidence in Massachusetts and her methods and purposes the English people and government might entertain.

The colony secured the valuable services and the great influence of Governor Edward Winslow as its agent in England, as we have mentioned, who did for it an excellent service; and among other things prepared and issued two very comprehensive and valuable tracts in answer to those fulminated against the colony and its proceedings.

Winslow, ${ }^{1}$ as he was departing for England as the agent of Massachusetts, to represent, among other services, the colony before the commissioners of foreign plantations, in answer to the petition of Samuel Gorton, of Rhode Island, and others, received from the Court a written answer to be used, also his own commission giving him authority and full instructions.

1 Rev. John Eliot said in 1646, "Gorton found favor in England, having none to inform against him what he was, but Mr. Winslow was sent over, whom the Lord direct, protect, and prosper." (Hist..Gen. Reg., xxxiii. 65.) He says further in 1647 , "God so graciously prospered Mr. Winslow's endeavors in England, against Gorton and his accomplices, that all their great hopes were dashed; and they, among us, a little pulled in their heads, and held their peace." (Ib., 238.) 
But his private instructions are far more interesting and important to us than the public instructions, as they reveal the real and genuine interpretation of their charter rights as the Court then held them.

It is safe to say that no persons ever had a better opportunity to know the facts than themselves, no one knew all the details more thoroughly, no one had more at stake in the issue, and they here express themselves to themselves, in simple confidence.

They say, "If you shall be demanded about these particulars :-

"Obj. I. Why we make not out our process in the king's name? You shall answer:-

"I. That we should thereby waive the power of our government granted to us, for we claim not as by commission, but by a free donation of absolute government. 2. For avoiding appeals, etc.

"Obj. 2. That our government is arbitrary.

"Ans. We have four or five hundred express laws, as near the laws of England as may be ; and yearly we make more, and where we have no law, we judge by the word of God, as near as we can.

"Obj. 3. About enlarging our limits, etc.

"Ans. Such Indians as are willing to come under our government we know no reason to refuse. Some Indians we have subdued by just war, as the Pequods. Some English also, having purchased lands of the Indians, have submitted to our government.

"Obj. 4. About our subjection to England.

"Ans. I. We are to pay the one fifth part of ore of gold and silver.

" 2 . In being faithful and firm to the state of England, endeavoring to walk with God in upholding his truth, etc., and praying for it.

" 3 . In framing our government according to our patent, so near as we may.

"Obj. 5. About exercising admiral jurisdiction. 
"Ans. I. We are not restrained by our charter.

" 2 . We have power given us to rule, punish, pardon, etc., in all cases, ergo in maritime.

" 3 . We have power granted us to defend ourselves and offend our enemies, as well by sea as by land, ergo we must needs have power to judge of such cases.

" 4. Without this, neither our own people nor strangers could have justice from us in such cases.

"Obj. 6. About our independency upon that state.

"Ans. Our dependency is in these points : I. We have received our government and other privileges by our charter. 2. We owe allegiance and fidelity to that state. 3. In erecting a government here accordingly, and subjecting thereto, we therein yield subjection to that state. 4. In rendering one fifth part of ore, etc. 5. We depend upon that state for protection and immunities as freeborn Englishmen.

"Obj. 7. Seeing we hold of East Greenwich, etc., why every freeholder of forty shillings per annum have not votes in elections, etc., as in England.

"Ans. Our charter gives that liberty expressly to the freemen only.

"Obj. 8. By your charter, such as we transport are to live under his majesty's allegiance.

"Ans. So they all do, and so intended, so far as we know.

"Obj. 9. About a general governor.

"Ans. I. Our charter gives us absolute power of government. 2. On the terms above specified, we conceive, the patent hath no such thing in it, neither expressed nor implied. 3. We had not transported ourselves and our families upon such terms. 4. Other plantations have been undertaken at the charge of others in England, and the planters have their dependence upon the companies there, and those planters go and come chiefly for matter of profit; but we come to abide here, and to plant the gospel, and people the country, and herein hath God marvelously blessed us." 1

1 Winthrop, ii. *296-*30I. 
This short catechism presents the position of the Puritans and their charter rights with more clearness and force than many pages of authors in this immediate period, who have had much to say about the subject which appeared to be wise and true to them, no doubt, but which was probably neither.

The firm and abiding friendship of Cromwell and of the Independents in England was an impediment that neither hatred, revenge, nor jealousy could remove or do away with, and it served until the colony had passed its first generation of adolescence, and in its mature independence asked for no parental tenderness towards it.

It was provided by the Court early in this year, whether wisely or not, persons will differ, "that it shall be lawful for any man that is on his journey (and remote from any house five miles) to take tobacco, so that thereby he sets not the woods on fire to the damage of any man." 1

The early records of Roxbury, the home of Dudley, furnish us an account of what may have been a visitation by the army worm, which occurred in 1646 . "This year, about the end of the Fifth Month, we had a very strong hand of God upon us, for upon a sudden innumerable armies of caterpillars filled the country all over all the English plantations, which devoured some whole meadows of grass, and greatly devoured barley, being the most grown, and tender corn, eating off all the blades and beards, but left the corn, only many ears they quite eat off by eating the green straw asunder below the ear, so that barley was generally half spoiled; likewise they much hurt wheat, by eating the blades off, but wheat had the less hurt because it was a little forwarder than barley, or harder and dryer, and they less meddled with it. As for rye, it was so hard and near ripe, that they touched it not. But above all grains they devoured oats. And in some places they fell upon Indian corn, and quite devoured it; in other places they touched it not. They would cross highways by one thousand.

1 Mass. Col. Rec., ii. 15 I. 
"Much prayer there was made to God about it, and fasting in divers places, and the Lord heard, and on a sudden took them all away again in all parts of the country, to the wonderment of all men. It was the Lord, for it was done suddenly." 1 This record continues to be interesting. It informs us that "this winter of 1646 was one of the mildest we ever had; no snow all winter long; nor sharp weather. We never had a bad day to go preach to the Indians all this winter, praised be the Lord." 2

The New England colonies were for a long time disturbed with encroachments of the French on the north and east, and not much less by the Dutch on the west, and were at the same time required to give constant attention to the Indians all about them.

There were two rival French governors of Acadia, which included Nova Scotia, New Brunswick, and a part of Maine. Their names were La Tour and D'Aulnay. They both claimed high authority from the French government, assuring the Court of Massachusetts that they were each able to be of great service to them, or, on the other hand, most dangerous enemies, with the throne of France to enforce their mischievous designs.

La Tour pretended to be a Huguenot to gain his points with the Puritans, but he had not religion enough of any sort to embarrass his work in wickedness. They both in turn at different times were entertained with distinguished honor by the authorities in Boston, as the representatives of a powerful European state, and neighbors whose friendship and commercial importance demanded the attention of the public, with the bestowal of every civility and considerate courtesy. They both betrayed the confidence reposed in them. They both managed to keep Massachusetts in a state of anxiety by charging her with too great attentions to the interests of the other man.

The issue finally entered the politics of the colony. The

1 C. M. Ellis's Hist. of Roxbury, 75, 76.

8 Ib., 76. 
agricultural and country people thought that Boston, in its over-zeal for traffic, was making far too intimate "friends of the mammon of unrighteousness," Popish idolaters. They had no confidence in the foreigners,-nor in the worldly wisdom which cultivated their friendship. Winthrop lost popularity in the country, and was forced to bear the reproach of neglecting the rest of the colony while he fostered the commerce of Boston.

La Tour appears first in our history in 1633 , and one or the other comes into the foreground frequently during the succeeding fifteen years. Finally D'Aulnay died, after he had ruined La Tour and blasted his prosperity, but La Tour married the widow of D'Aulnay and secured the wealth of his enemy and his own. This recalls the south sea island cannibal who quieted his title to real estate by consuming the man who was in possession before.

No portion of this account, as we have said, of the doings of the fathers of Massachusetts in their intercourse with these two Frenchmen is of greater historic significance than the self-contained manner in which they assumed absolute and sovereign authority to treat with the agents of a foreign state without the least thought of the home government, and without, so far as we know, ever reporting their doings in the premises to her, or recognizing any duty whatever to do so. Thus one event after another reveals to us that soon or late, the rupture and severance from England would be inevitable. They were already acting the part of an independent state, and this was certain to be only preliminary to the creation of the state itself.

Dudley had a commission, with other persons from the General Court, to proceed as agent or minister plenipotentiary to the home and country of D'Aulnay at Penobscot, and make treaties of settlement and of peace respecting all matters in dispute. D'Aulnay regarded very greatly the dignity and high official standing of these commissioners, and was now certain that Massachusetts intended to accomplish something, and perfect the treaties. He would accept, 
he said, the honor and courtesy, and not requiring the visit to himself would send his agents to Boston instead, with authority to make the treaties, which he accordingly did after some delay. It is said that he changed the place of meeting to Boston adroitly, to avoid the heavy expense of entertaining these dignitaries in a manner equal to his own former hospitable receptions in the capital of Massachusetts.

It is evident that the Court considered this mission important, since they appointed almost their leading man, at seventy years of age, to go to Penobscot to be exposed to the peril of capture, and to other dangers.

The words of the Court are charged with affectionate regard and appreciation. They say, "We have hereby authorized and appointed our much honored and right trusty and well beloved Thomas Dudley, Esq., the deputy governor of this jurisdiction," etc. And later they say, "This Court considering that the deputy governor, in regard of his age, may (through sickness, or other bodily infirmity) be disabled for the voyage at such time as the commissioners are to go to Penobscot, in which event his son-in-law, Governor Simon Bradstreet, is to be his substitute." 1

We cannot reflect upon the exposure of Boston to the guns of these French ships, with their unscrupulous and piratical commanders, and call to mind other visitors at other times of the same evil quality, without appreciating the foresight and wisdom of Dudley in desiring to place the capital interior, at Cambridge, until they were strong enough to fortify the harbor of Boston against the artillery of Europe. Winthrop evidently regarded their escape from these rovers of the sea as quite remarkable. ${ }^{2}$

1 Mass. Col. Rec., ii. I 58, I 59.

2 The following quotation from a letter of Governor Edward Winslow of Plymouth to Winthrop shows how much both colonies regarded and relied on Dudley: "I trust when Mr. Dudley goeth to Mr. D'Aulnay, he will put an end also to our controversy with him, and make but one work of both. ... Yours as ever, EDWARD WINSLOw." (Mass. Hist. Coll., 4th series, vi.) 


\section{CHAPTER XXX}

THE earnestness and sincerity of the Puritan fathers in soundness of the faith, enlightened by thorough scholarship, is marked and everywhere evident in their work. To their credit be it said, they planted the tree of knowledge in church and state, for the saving of society.

They laid, with patriotic, religious fervor, the groundwork of fair Harvard, and of the New England common schools, which, like the mid-day sun of August that clears the morning mists, swept in time from their broad foundations the dust of superstition, inseparable from their age.

They say in 1646, "This Court, being sensible of the necessity and singular use of good literature in managing the things of greatest concernment in this commonwealth, as also perceiving the fewness of persons accomplished to such employments, especially for future times [let us with grateful veneration regard these words], have thought meet to propose to all and every of reverend elders and brethren, that due care be had from time to time to improve and exercise such students, especially in divinity, as through the good hand of God may issue forth of the colleges, that so for want of employment or maintenance they be not forced from us, and we left destitute of help that way." 1

It is far more satisfactory, in attempting to study the thoughts and methods of any people, to let them speak for themselves. The following extracts from the records of the commissioners of the United Colonies in 1646 seem to be instructive. These words are not the expressed opinions of Massachusetts alone, but of the confederacy.

"Upon serious consideration of the spreading nature of 1 Mass. Col. Rec., ii. 167. 
error, the dangerous growth, and effects thereof in other places, and particularly how the purity and power, both of religion and of civil order, is already much complained (corrupted) if not wholly lost in a part of New England by a licentious liberty granted and settled, whereby many, casting off the rule of the word, profess and practice what is good in their own eyes; and upon information of what petitions have been lately put up in some of the colonies, against the good and strait ways of Christ, both in the churches and in the commonwealth, the commissioners remembering that those colonies, for themselves and their posterity, did enter into this firm and perpetual league, as for other respects, so for mutual advice, that the truth and liberties of the gospel might be preserved, and propagated, thought it their duty seriously to commend it to the care and consideration of each General Court within these United Colonies, that as they have laid their foundations and measured the temple of God, the worship and worshipers by that strait reed God hath put into their hands, so they would walk on and build up (all discouragements and difficulties notwithstanding) with an undaunted heart, an unwearied hand, according to the same rules and patterns.

"That a due watch be kept and continued at the doors of God's house, that none be admitted as members of the body of Christ but such as hold forth effectual calling and thereby union with Christ the head, and that those whom Christ hath received are to enter by an express covenant to attend and observe the laws and duties of that spiritual corporation, that Baptism, the seal of the covenant, be administered only to such members and their immediate seed, that Anabaptism, Familism, Antinomianism, and generally all errors of like nature which oppose and undermine, and slight either the Scriptures, the Sabbath, or other ordinances of God, and bring in and cry up unwarranted revelations, inventions of men, or any carnal liberty, under a deceitful color of liberty of conscience, may be seasonably and duly suppressed, though they wish as much forbearance and respect may be 
had of tender conscience seeking light as may stand with the purity of religion and peace of the churches. (The commissioners of Plymouth desire further consideration concerning this advice given to the General Courts.)

"And lastly, that some serious provision be speedily made against oppression, whether in commodities or wages, against excess and disorder in apparel, drink, and all other loose and sinful miscarriages not fit to be named amongst Christians, by which the name of our holy God is much dishonored, and the churches of Christ in those parts are much reproached, as if they were strict in their forms only, or had respect only to one of the tables of God's law, their fruits in reference to the other being nothing better than the wild vines and brambles in the wilderness.

"If thus we be for God, he will certainly be with us. And though the God of the world (as he is styled) be worshiped, and by usurpation set upon his throne, in the main the greatest part of America, yet this small part and portion may be vindicated as by the right hand of Jehovah, and justly called Emanuel's land."

The foregoing conclusions were agreed upon by the commissioners of the United Colonies, September I 8, I646. ${ }^{1}$

The following words, by the same commissioners, at the same time, are full of experience, pathos, and beauty, which must appeal to the heart of every American :-

"Whereas our good God hath from the first done great things for his people in these colonies, in sundry respects worthy to be written in our hearts, with a deep and charactered impression not to be blotted out and forgotten, and to be transmitted to posterity, that they may know the Lord, and how he hath glorified his grace and mercy in our foundations and beginnings, that they also may trust in him, and walk with a right foot before him without warping and declining. It is desired by the commissioners, that all the colonies (as they may) would collect and gather up the many special providences of God towards them, since their arrival

1 Plymouth Col. Rec., ix. 81, 82. 
and settling in these parts, how he hath made room for them, how his hand hath been with them in laying their foundations in church and commonwealth, how he hath cast the dread of his people (weak in themselves) upon the Indians, and scattered their counsels, broken their plots and attempts, and continued our peace (notwithstanding their insolences, rage, and malice), made glorious provisions for us, and in all respects hath been a sun and shield to us, and that memorials being made, they may be duly communicated and seriously considered, that no thing be mistaken, but that history may be compiled according to truth with due weight, by some able and fit man appointed thereunto." 1

As we follow these statements of their anxieties and hopes, as these Puritans themselves recount them, we instinctively turn back to the beginnings of the colony, and to those pathetic recitals of Dudley himself in the most important letter in early American history.

"If any come hither to plant for worldly ends, that can live well at home, he commits an error, of which he will soon repent him. . . . In a word we have little to be envied; but endure much to be pitied, in the sickness and mortality of our people." And then says Mr. Justice Story: "In the conclusion of this letter, he breaks out with the unconquerable spirit of Puritanism. 'We are left, a people poor and contemptible, yet such as trust in God; and are contented with our own condition, being well assured, that he will not fail us, nor forsake us.'" Judge Story continues, after recounting these words of Dudley, "Men who were thus prepared to encounter such distresses, were prepared for everything. The stake had no terrors for them; and earth had no rewards which could; for a moment, withdraw them from the dictates of conscience and duty." He says further, "They laid the foundations of empire in these northern regions, with slow and thoughtful labor. Our reverence for their services should rest, not upon the fictions of fancy, but upon a close survey of their means and their ends, their

1 Plymouth Col. Rec., ix. 82. 
motives and their lives, their characters and their actions. And I am much mistaken, if that close survey does not invigorate our patriotism, confirm our principles, and deepen and widen the channels of our gratitude." 1

Our Puritan fathers were steadfast Calvinists, who are finely described by James Anthony Froude: "These men were possessed of all the qualities which give nobility and grandeur to human nature - men whose life was as upright as their intellect was commanding, and their public aims untainted with selfishness; unalterably just where duty required them to be stern, but with the tenderness of a woman in their hearts; frank, true, cheerful, humorous, as unlike sour fanatics as it is possible to imagine any one, and able in some way to sound the keynote to which every brave and faithful heart in Europe instinctively vibrated. This is the problem, grapes do not grow on bramble-bushes." 2

The Court informs us that "one end in planting these parts was to propagate the true religion unto the Indians." 3 This worthy object was the cause, no doubt, of the following statute:-

"It is ordered decreed by this Court, that no Indian shall at any time powwow, or perform outward worship to their false gods, or to the devil, in any part of our jurisdiction, whether they be such as dwell here, or shall come hither. If any shall transgress this law, the powwower to pay five pounds, the procurer five pounds, and every assistant countenancing, by his presence or otherwise (being of age of discretion), twenty shillings." 4

The Court proceeds next to make a declaration more liberal and full of soul liberty than they have been represented as having entertained: "Though no human power be Lord over the faith and consciences of men, and therefore may not constrain them to believe or profess against their conscience, yet, because such as bring in damnable heresies,

1 Centennial Discourse, 46, 49.

2 "Calvinism," in Short Studies on Great Subjects, 2d series, xiv. 52.

${ }^{8}$ Mass. Col. Rec., ii. 178.

4 Ib., ii. I77. 
tending to the subversion of the Christian faith, and the destruction of the souls of men, ought duly to be restrained from such notorious impiety. ... Forasmuch as in these countries, where the churches of Christ are seated, the prosperity of the civil state is much advanced and blessed of God, when the ordinances of true religion and public worship of God do find free passage in purity and peace, therefore, though we do not judge it meet to compel any to enter into the fellowship of the church, nor force them to partake in the ordinances peculiar to the church (which do require voluntary subjection thereunto), yet, seeing that the word is of general and common behoof to all sorts of people, as being the ordinary means to subdue the hearts of hearers, not only to the faith, and obedience to the Lord Jesus, but also to civil obedience, and allegiance unto magistracy, and to just and honest conversation towards all men - it was ordered, therefore, that all persons must attend where churches are established." 1

There can be no doubt that such laws in this age in any civilized country would be resisted as an invasion of the domain of personal liberty and of natural, inalienable human privilege of choice and conduct. And yet when we have said that, we feel somehow a deep sympathy with the fundamental thought and purpose of these persons. We may reject their methods, but we should be glad to see a state in this world where religious principles with a lively execution of the golden rule dominated politics; and self-seeking on the part of persons who hold sacred trusts of power should never be allowed to antagonize the public interest or the welfare of constituents.

Priestcraft is the worst element in politics, because a wolf in sheep's clothing is a concealed peril ; but pure and undefiled religion is the tremendous need to-day to resist and neutralize political corruption everywhere. For view it as we will, the Puritans were correct, that religion and the state are not to be sundered. Human society itself, indeed, is

1 Mass. Col. Rec., ii. I77, I 78. 
inseparable from religion. The great leaders in our national struggles have been noble, godlike, religious men, of firm principle, founded on the Eternal, and the people could and did trust them, and were not betrayed by greed or petty personal ambition, heedless of the public welfare. No! religion is the chief cornerstone of the state, and the Puritans knew it as well as we do, and possibly better. Their methods and means were somewhat rigid and arbitrary, but their thought that righteousness exalteth a nation was essential; and human government, after ages of experience in the devious cycles of error and municipal corruptions, will in the end find much to admire in the simple integrity and steadfast honor of these immortal founders of New England.

It is certainly questionable whether, of all the harsh laws made by these stern people, the following does not mark, with more striking contrast than any other, the difference between public sentiment then, respecting the relation of parents to children, and their bearing toward them now, in this humane, submissive, and tender age, wherein blooming youth rule the court, the camp, almost from their cradle to the final demise of their father and mother :-

"If any child or children, above sixteen years old, and of sufficient understanding, shall curse or smite their natural father or mother, he or she shall be put to death." Unless certain faults named were attached to the parent. "If a man have a stubborn or rebellious son, of sufficient years and understanding, namely, sixteen, which will not obey the voice of his father or the voice of his mother, and that when they have chastened him will not hearken unto them, then shall his father and mother, being his natural parents, lay hold on him, and bring him to the magistrates, assembled in Court, and testify unto them, by sufficient evidence, that this their son is stubborn and rebellious, and will not obey their voice and chastisement, but lives in sundry notorious crimes, such a son shall be put to death." 1

The most cheerful feature about these laws is that they

1 Mass. Col. Rec., ii. 179, 180. 
do not appear ever to have been executed. The Puritans ran back more than forty centuries, and made these statutes the voice of authority from the highest court, without the exercise of reason or human sympathy.

We may, within certain limits, reverence that stoicism which, martyr-like, discharges its duty utterly regardless of sentiment or affection, or indeed of consequences, performing the supposed will of Heaven as blind to influences on one side or the other as ideal justice herself, but it is difficult to conceive of a parent so divested of natural feeling as to destroy his own offspring, even under the iron doctrine of early Calvinism. It is possible to fanaticism, - mothers cast their children into the Ganges, - where right reason and affection are insanely overthrown. But these people were not fanatics. Fortunately we do not have to apologize for the Puritans; they were never guilty, as we have observed, of the execution of these cruel statutes.

Dudley had two hundred and seventy-four acres of land laid out to him, December 25, I646, near Dedham. ${ }^{1}$

Winthrop was chosen governor, Dudley deputy governor and commissioner ${ }^{2}$ of the United Colonies, May 26, I647. There was only one new assistant elected. This election

1 Mass. Col. Rec., ii. I84.

2 Mass. Archives, ii. 30I. "At a General Court holden at Boston for the jurisdiction of the Massachusetts the 26th of the 3 Mo. 1647 .

"Thomas Dudley Esq. and John Endicott Esq. were chosen Commissioners for this Colony for a full and complete year, as any occasion or exigents may require, and particularly for the next meeting at Boston the 26th of the 5th Month next, and were invested with full power and authority to treat of, and conclude of all things according to the true tenor and meaning of the Articles of Confederation of the United Colonies of New England concluded at Boston the Igth of the 3 Mo. I643, and in case either of them be hindered in this business either by sickness, or any other (the like) providence, that then Mr. Bradstreet may supply his place.

"By the General Court, INCREASE NOWELL, Sec."

"Commonwealth of Massachusetts, Office of the Secretary, Boston, Jan. 28, I898. Compared with the original and found correctly copied. WM. M. Olin, Sec'y." 
evidently gave great satisfaction to Winthrop, because his enemies had attempted to overturn the old government, and signally failed to accomplish their purpose. ${ }^{1}$

"An epidemical sickness was through the country among Indians and English, French and Dutch." Forty or fifty died in Massachusetts, and nearly as many in Connecticut. "But that which made the stroke more sensible and grievous, both to them and to all the country, was the death of that faithful servant of the Lord, Thomas Hooker, pastor of the church in Hartford, who, for piety, prudence, wisdom, zeal, learning, and what else might make him serviceable in the place and time he lived in, might be compared with men of greatest note; and he shall need no other praise: the fruits of his labors in both Englands shall preserve an honorable and happy remembrance of him forever." 2

Hooker has always seemed nearer to Dudley, for the reason that he first had his home in America at the house of Dudley in Cambridge. He and Dudley were, we think, more or less united in politics early against Winthrop and Cotton. Dudley seems to have been tempted to go with Hooker to Connecticut, but resisted and went to Ipswich because he did not care to go so far, and not long after was so closely united to Winthrop by the marriage of their children and otherwise as to be nevermore severed in politics, religion, friendship, or policy. John Fiske says that "Mr. Hooker deserves more than any other man to be called the father of American democracy." There were, however, other progenitors of the American republic.

"In this sickness of the governor's wife [Mrs. Winthrop], daughter of Sir John Tindal, Knight, left this world for a better, being about fifty-six years of age : a woman of singular virtue, prudence, modesty, and piety, and especially

1 Winthrop, ii. *307.

2 Ib., ii. *310. Rev. John Eliot said, that "generally those that died were of the choicest flowers, and most precious saints. Among others that were then taken to rest was that worthy and blessed light, Mr. Hooker." (Hist. Gen. Rec., xxxiii. 238.). 
beloved and honored of all the country." 1 The light thus departed from the home of Winthrop never to return, and in a few brief months he himself followed her. We doubt not that the charmed circle around the Winthrop hearthstone often included the social, warm-hearted, and welcome Governor Dudley and his family from Roxbury.

In this sad bereavement very much had gone also out of Dudley's life, and by this shadow his own home had been forever darkened. These people must have been endeared to each other by the vivid experiences of many eventful years, and the loss of each of the tried and the true, in this constantly contracting circle, must have been deeply felt by the survivors.

"It is ordered, that ten pounds should be given Mr. Eliot, as a gratuity from this Court, in respect to his great pains and charge in instructing the Indians in the knowledge of God, and that order be taken that the twenty pounds per annum, given by the Lady Armin for that purpose, may be called for and employed accordingly; and it is desired that some care may be taken of the Indians on the Lord's days." 2

Winthrop relates that "mention was made before of some beginning to instruct the Indians, etc. Mr. John Eliot, teacher of the church of Roxbury, found such encouragement as he took great pains to get their language, and in a few months could speak of the things of God to their understanding; and God prospered his endeavors, so as he kept a constant lecture to them in two places, one week at the wigwam of one Wabon, a new sachem near Watertown mill, and the other the next week in the wigwam of Cutshamekin, near Dorchester mill." 3

Dudley and Eliot were no doubt at this time very intimate and dear to each other. We need to keep in mind that one of the influences which drew Dudley to Roxbury was his

1 Winthrop, ii. *310.

2 Mass. Col. Rec., ii. I89.

${ }^{3}$ Winthrop, ii. *303-*305. 
wish to be under the instruction of Eliot, whom he sincerely appreciated. He had moved to Boston in England for a similar reason, that he might be under the ministrations of the Rev. John Cotton there. Neither were these the only instances in which he changed his residence to bring himself and family into near touch with eminent scholarly ministers.

Cotton Mather has called attention to Dudley's solicitude in selecting the purest, the greatest, and the best teachers; an evidence, as we have before noticed, of what he himself was. The dwellings, families, and homes of these two excellent, ever-memorable heroes, we have seen, were on opposite sides of the same street in Roxbury, near to the old meetinghouse, the sacred temple where together they worshiped God with a reverence, sincerity, and weightiness of spirit, not very much transcended, we suspect, by their more enlightened, liberal, but sometimes indifferent posterity.

Ellis, the historian of Roxbury, evidently regards these two men, rightly no doubt, as the most notable persons of the period in that town. He cannot resist the temptation to estimate and compare one with the other over and over again, which we esteem a compliment to both of these worthies. He says, "Mr. John Eliot, the next person whose name we meet, was the counterpart of Thomas Dudley." 1 And later, "How could Eliot be measured, for instance, with Thomas Dudley? One was a public man, loaded with honors, a rich man, a zealous defender of the faith! The other went quietly to work, almost alone, spending all he had, encountering danger and earning reproach. In their characters all is contrasted. One was a man of the world. The other was spiritual, living out what he used to say, 'Heaven is here.'" 2

We are not quite prepared to accept the candid judgment of Ellis here. We fear that he holds the balances of the sanctuary with a strong bias towards the gentle, loving John, the apostle to the Indians, and may not quite appreciate the soldier, jurist, statesman, - that strong soul who had also

1 Hist. Roxbury, I04.

2 Ib., 117. 
risked all things, suffered all things, and fought a good fight and kept the faith, laid the foundation of a free state in the wilderness, with the help of others, and worshiped God always with a pure heart and a willing mind.

Men often think that gentle, inoffensive, lamb-like persons, whose daily lives and conduct reveal only sweetness and light, are nearer to the kingdom of heaven and the pattern of the Master, than the more rugged heroes like Luther, Cromwell, and Dudley, who, as valiant soldiers, without hesitation, take a share in the conflicts of this world, full of zeal for the good, and righteous indignation towards wrong and oppression everywhere. Is it not possible that in the sight of Heaven both may be equally justified? Were they not each faithful stewards of the manifold grace of God, whose life works were severally set apart and acceptably performed?

May not the contrite delver and ditcher serve in the busy hive of this world as truly as the saint who ministers at altars and darkens arch or aisle or cornice with clouds of incense? Priests, ministers, and sacred teachers are not the only approved servants of God. It is they "who love their fellow-men" who demonstrate that they first loved God.

The Court, in common with other Protestant powers, took alarm at the progress of the Jesuits, and constructed a statute to exclude them: "This Court taking into consideration the great wars, combustions, and divisions which are this day in Europe, and that the same are observed to be chiefly raised and fomented by the secret underminings and solicitations of those of the Jesuitical order, men brought up and devoted to the religion and court of Rome, which has occasioned divers states to expel them from their territories." They thence make a law that they shall not be allowed to reside in their jurisdiction.

Persons who condemn the Court of Massachusetts with great vigor for excluding Antinomians and other religious and political agitators because they deemed them dangerous 
to the state, or enemies to good government, have no words of censure for this statute. Here was a bird of a different feather, who made even Roger Williams quail in spirit and speech. But fortunately he was never in his day required to test the strength of "soul liberty" to any extent by fostering Jesuits. He did not write sweetly about them or seem to admire them.

The Court, out of the goodness of its heart, remembered the spiritual fathers who were at Cambridge, puzzled and perplexed in constructing a platform of Doctrine to avoid the errors of Westminster, and retain the essentials of sound doctrine.

"The Court think it convenient that order be given to the auditor to send twelve gallons of sack and six gallons of white wine, as a small testimony of the Court's respect, to the reverend assembly of elders at Cambridge." 1

The Court recognized the justice at last of allowing persons not church members, and therefore not freemen, to sit on juries, hold minor town offices, and vote within certain limits for selectmen and on assessment, since they were subject to the laws equally with the freemen, and had a chronic grievance respecting their rights and powers. This action was certainly wise and prudent, a step forward towards universal American citizenship. ${ }^{2}$

1 Mass. Col. Rec., ii. 194, 195.

${ }^{2}$ Ib., ii. 197. 


\section{CHAPTER XXXI}

THE General Court extended a helping hand to Harvard College in 1647 , by assisting it to receive money due to it, and to secure its financial stability.

It assisted the medical school, in a way which has been imitated in many States recently, and which seems not only to have aided science but to have prevented crime. "We conceive it very necessary that such as study physic or surgery may have liberty to read anatomy, and to anatomize once in four years some malefactor, in case there be such as the Court may allow of." 1

But the system of public instruction which included then and now all the children of the commonwealth, instituted by law in 1647 , has reflected greater glory upon the founders, and done more to exalt the dignity and character of Massachusetts and secure her lasting prosperity, than any other fact in her history. Palfrey has finely said, "Not a word of such legislation as the following must be withheld from the reader. Since the seventeenth year of Massachusetts, no child of hers has been able to say, that to him poverty has closed the book of knowledge or the way to honor."

"It being one chief project of that old deluder, Satan, to keep men from the knowledge of the Scriptures as in former times by keeping them in an unknown tongue, so in these latter times by persuading from the use of tongues, that so at least the true sense and meaning of the original might be clouded by false glosses of saint-seeming deceivers, - that learning may not be buried in the grave of our fathers in the church and commonweath, the Lord assisting our endeavors, -

1 Mass. Col. Rec., ii. 20 I. 
"It is therefore ordered, that every township in this jurisdiction, after the Lord hath increased them to the number of fifty householders, shall then forthwith appoint one within their town to teach all such children as shall resort to him, to write and read, whose wages shall be paid either by the parents or masters of such children, or by the inhabitants in general, by way of supply, as the major part of those that order the prudentials of the town shall appoint; provided these that send their children be not oppressed by paying much more than they can have them taught for in other towns; and it is further ordered, that where any town shall increase to the number of one hundred families or householders, they shall set up a grammar school [where Greek and Latin were taught], the master thereof being able to instruct youth so far as they may be fitted for the university, provided, if any town neglect the performance hereof above one year, that every such town shall pay five pounds to the next school till they shall perform this order." 1

Moses Coit Tyler has said that "probably no other community of pioneers ever so honored study, so reverenced the symbols and instruments of learning. Theirs was a social structure with its cornerstone resting on a book. Universal education seemed to them to be a universal necessity." 2

"Is there," said Rufus Choate, "a surer way of achieving the boast of Themistocles that he knew how to make a small state a great one, than by making it wise, bright, knowing, apprehensive, quick-witted, ingenious, thoughtful."

These wonderful people, whose foresight penetrated to far-off consequences, embarked upon this enterprise while they were yet poor, unprotected, persecuted at home and abroad, and in peril on every hand.

We extol the philanthropy and eminent public services of individuals who endow schools and colleges; we recognize them as instinct with a deep love of their fellow-men, of other generations also, for this work is lasting; but here, not upon a foundation of charity, but as a municipal obligation,
1 Mass. Col. Rec., ii. 203.
${ }^{2}$ Hist. Amer. Lit., i. 99. 
the state or the town makes a grant tendering to all its youth freely, without money and without price, the living waters of learning, not for one day, but forever. It is not strange that this act has elicited the admiration of the world.

The following words of Lord Macaulay, in the House of Commons in 1847 , just two centuries after this act became a law, commended it in burning words which ought to be dear to every American, because they are so true, so beautiful, and so just to the memory of those brave, unselfish pioneers and their work. Consider for one moment, the orator, the place, the occasion.

"I say therefore, that the education of the people ought to be the first concern of a state. . . . This is my deliberate conviction; and in this opinion I am fortified by thinking that it is also the opinion of all the great legislators, of all the great statesmen, of all the great political philosophers, of all ages and of all nations. ... . Sir, it is the opinion of all the greatest champions of civil and religious liberty in the Old World and in the New; and of none - I hesitate not to say it - more emphatically than of those whose names are held in the highest estimation by the Protestant Nonconformists of England.

"Assuredly, if there be any class of men whom the Protestant Nonconformists of England respect more highly than another, - if any whose memory they hold in deeper veneration, - it is that class of men, of high spirit and unconquerable principles, who, in the days of Archbishop Laud, preferred leaving their native country, and living in the savage solitudes of a wilderness, rather than to live in a land of prosperity and plenty, where they could not enjoy the privilege of worshiping their Maker freely, according to the dictates of their conscience. Those men, illustrious forever in history, were the founders of the Commonwealth of Massachusetts; but though their love of freedom of conscience was illimitable and indestructible, they could see nothing servile or degrading in the principle that the state should take upon itself the charge of the education of the people. 
"In the year 1647 they passed their first legislative enactment on this subject; in the preamble of which they distinctly pledged themselves to this principle, that education was a matter of the deepest possible importance and the greatest possible interest to all nations and to all communities ; and that, as such, it was, in an eminent degree deserving of the peculiar attention of the State." 1

James Russell Lowell has contributed his estimate of this foundation structure of the fathers :-

"But it was in making education not only common to all, but in some sense compulsory on all, that the destiny of the free republics of America was practically settled. Every man was to be trained, not only to the use of arms, but of his wits also; and it is these which alone make the others effective weapons for the maintenance of freedom. . . . It is quite true that our Republic is the heir of the English Commonwealth; but as we trace events backward to their causes, we shall find it true also, that what made our Revolution a foregone conclusion was that act of the General Court, passed in May, I647, which established the system of common schools." 2

Douglas Campbell assures us that "rejuvenated England has followed America in her system of popular education, freedom of religion, freedom of the press, the secret ballot, prison reform, and the entire reformation of her legal system." 3 But he evidently thinks that we did not invent; that our ancestors only discovered all things in the Netherlands. There is, however, not much new under the sun. We owe very much to Holland, it is certain; she in turn received light from Athens, Jerusalem, Rome, from the masterly educational services of the Saracens in the Middle Ages; and Germany, before the Thirty Years' War, was leading the world in scholarship, as she has been in recent times.

We are "the heir of all the ages, in the foremost files of

1 Macaulay's Speeches, ii. 334, 335, Redfield's ed.

2 Among My Books, i. 239-242.

3 The Puritan in Holland, England, and America, ii. 404, 410-414. 
time." Our fathers had the wisdom and discretion to take, as bees select their honeyed sweets, from sources many, strange, and curious, but they always secured the useful, lifesaving, life-sustaining thing for their hives.

Nothing can detract from the honor of this great service to mankind, rendered now and here by these wise masterbuilders. They who have thrown light upon the path of men, and have so secured the vital oil to their lamp that its flame shall never be extinguished, have earned and shall receive the praises of all time.

We ought not to take our leave of the subject of education without averting at least to the provision made by the Court in 1642 that children shall have trades and education in business, and be brought, up with an occupation; if neglected by parents and guardians, then it was the duty of the selectmen of the town to see to the training in industry of the refuse and waste of society. ${ }^{1}$

This was a simple and very efficient way to accustom all citizens to labor; to give to every one a trade or occupation; to reduce the number of the unemployed, also the amount of vice and crime born of ignorance and still more of idleness. We in this day are slowly coming to understand that training of the eye, the hand, the judgment, in mechanic arts, in handicrafts, is for the larger portion of the community the most important education next to morals, while skill in agriculture and in the rotation of crops and qualities of soil and their needs calls for special training. And yet again, schools in textiles and dyeing and the various arts of manufacture are demanded, for the age of apprentices is at an end.

Here again the practical wisdom, thrift, and business capacity of these men were manifested. They were determined to have no drones in their hive, no tramps in their streets, no poor on the towns.

Care was taken by the Court respecting the boundary lines of private estates and also of the towns. The subject of weights and measures was also under consideration, and

1 Mass. Col. Rec., ii. 6, 7. 
provision made to secure uniform and accurate standards in both.

Burglars received attention in the following statute: "Whereas no provision hath hitherto been made against burglary, and other violent assaults against men's persons and goods, the want whereof may expose many, especially travellers and inland inhabitants, both by day and night, to the rage and cruelty of men of Belial, whether Indians or others, for self-defense he is justified in destroying them, and shall be holden blameless." 1

The General Court, with its committees, was making deliberate preparation for a very correct compilation of colonial laws, which was published in 1649 , and for that reason, among others, they sought the great authorities in the English common law. "It is agreed by the Court, to the end we may have the better light for making and proceeding about laws, that there shall be these books following procured for the use of the Court from time to time: Two of Sir Edward Coke upon Littleton; two of the books of Entries; two of Sir Edward Coke upon Magna Charta; two of the New Terms of the Law; two Dalton's Justice of Peace ; two of Sir Edward Coke's Reports." 2

These books are said to have been the beginning of the state library in the State House in Boston.

A little reflection upon the industry and efforts of the colonists in making laws, importing law books, and providing intellectual and industrial education for the whole people, together with moral and religious instruction, will lead our attention naturally to the remarkable manner in which $\mathrm{Sir}$ William Jones gathered it all up in his replete and vigorous lines, full to the brim with suggestion :-

"What constitutes a state?

Men who their duties know,

But know their rights, and knowing, dare maintain,

Prevent the long-aimed blow,

1 Mass. Col. Rec., ii. 210-21 2.

2 Ib., ii. 2 r2. 
And crush the tyrant while they rend the chain;

These constitute a state ;

And sovereign law, that state's collected will,

O'er thrones and globes elate

Sits empress, crowning good, repressing ill."

They order, in November, 1647, that hereafter in each succeeding year the towns shall, at an annual town meeting in the Fifth Month, choose a commissioner, who, with the selectmen, shall constitute a board of assessors, whose duty it shall be to estimate the true valuation of all real and personal estates for the purpose of assessing the taxes, and thereupon to make such assessment according to law.

The prices of corn, for the rate to be gathered, are ordered by the Court to be: wheat, four shillings and sixpence; barley, four shillings; rye and peas, three shillings and sixpence; Indian, three shillings per bushel. ${ }^{1}$

The Court is troubled to furnish ways and means to support Governor Winslow, its "honored and industrious" agent, in England. ${ }^{2}$

It also ordered leather guns from England, "found to answer," in $1778 .^{3}$

The Court ordered that ballots thereafter at elections should be of beans, with the same purpose of the Australian ballots, and by various devices they tried to secure more perfect protection to the secret choice and purpose of the independent voter.

How many of the practical questions in every day's experience came before them for judgment and action!

It was ordered that all magistrates, deputies, officers of the Court, elders and deacons, the president, fellows, students, and officers of Harvard College, and others, shall be exempt from trainings, and night and day watching and warding.

The provision for giving alarm at the approach of an enemy, night or day, is so complete and particular that it

1 Mass. Col. Rec., ii. 213, 2 I 5. 2 Ib., ii. 2 I 8.

8 Hayden's Dict. of Dates (Leather). 
gives a vivid idea of the peril and exposure on every hand of these feebly protected people, who, with unsurpassed bravery, consummate wisdom, and unshaken faith in the divine oracles of God, were fashioning a free government for a free people. ${ }^{1}$

There were, at the end of 1647 , thirty-three settled towns in Massachusetts. This does not include Plymouth, not yet annexed. Every other colony in New England was only an incident, compared with the growth and progress here. Massachusetts led from the start in development, in education, among the United Colonies, in the Revolution, in the Civil War, and still leads in extent of noble charities and advanced legislation; and in a natural, well-earned selfimportance manifests even in her sons and daughters of this generation a feeling of superiority.

Dudley was one of the commissioners of the United Colonies and president of the confederacy this year, although Endicott was his colleague. It seems quite certain, until age had impaired Dudley's efficiency, that he outranked Endicott in importance in the General Court and in the councils of the United Colonies. Endicott seems to follow next.

Palfrey says: "The confederacy of the four colonies was an humble but substantial power in the world. It was known to be such by its French, Dutch, and savage neighbors; by the alienated communities on Narragansett Bay; and by the rulers of the mother country." 2

It was in this year 1647 , on the 29 th of May, that Governor Peter Stuyvesant, the last of the Dutch governors of New Netherland, succeeded the former Governor Kieft. He has been so facetiously set forth by Washington Irving in his "History of New York," that the really strong qualities of his character have sustained a loss at the hands of this genial master of humor; as the profession of schoolteacher will not in years escape from the influence of the

1 Mass. Col. Rec., ii. 223.

2 Palfrey, ii. 271, 272. 
simple, witless Ichabod Crane, a product of the same matchless, kindly wit.

The commissioners of the United Colonies, Dudley being their president, at once paid their respects to Governor Stuyvesant, with congratulations upon his accession to office, not forgetting to mention certain grievances and injuries inflicted on them by his unscrupulous predecessor, such as confiscation of English vessels under false pretenses of revenue charges, finally giving a relish to their diplomacy by suggesting that they hoped to obtain from him full indemnification for their past misfortunes at the hands of his people.

Governor Stuyvesant was easily convinced of the faults of the former administration, but instead of consenting to any indemnity or restitution, made a counter-demand for the restoration of portions of Connecticut and New Haven, which he said the English had unjustly wrested from the Dutch. Soon after this a short-lived treaty was concluded between them and the council. Trouble was, however, soon fomented again, and continued until, in 1664, Governor Stuyvesant surrendered with tact and wisdom to an overpowering British force, without bloodshed, and New Netherland henceforth became New York, some day not far off to be the metropolis of the world. '

Winthrop was chosen governor, and Dudley deputy governor, in May, 1648, and Dudley was also chosen substitute commissioner of the United Colonies. This proved to be the last year of Governor Winthrop's official life. He lived until March, I649, but not until another election of governor, which was in the following May. Dudley was, we suppose, acting governor from the demise of Winthrop, on the 26th of March, until the $2 \mathrm{~d}$ of May, one month and six days.

The permit of the Court was reluctantly granted to Samuel Gorton to pass through Massachusetts, upon the request of the Earl of Warwick. This license was clothed in such carefully guarded words, and was so instinct with disdain towards him, and chagrin and humiliation in the submission of the 
Court to a requisition which it did not feel at liberty to withstand, that we cannot avoid quoting it in full :-

"The Court did consent that Samuel Gorton, now on shipboard, upon the request of the Earl of Warwick, hath one full week after the date hereof allowed him, for the transportation of himself and his goods, through our jurisdiction, to the place of his dwelling, he demeaning himself inoffensively, according to the contents of the said earl's letter; and that the marshal, or some other, be appointed to show him a copy of this order, or to fix it to the mainmast of the ship in which he is." 1

The Court, in May, I648, appointed a committee of ten, with Winthrop and Dudley at" the head of it, "to peruse the Articles of our Confederation with the United Colonies, as also the acts that have passed the commissioners, which may seem either to confound the power of our General Court or so interfere with it, as may in a short time prove not only prejudicial but exceedingly uncomfortable." 2

This committee suggested that the powers of the United Colonies should not "extend to limit or interrupt the civil government or church affairs within any of the colonies." They raised questions about having meetings less often. And since Massachusetts bore five times the expenses that any other colony did, could she not have three commissioners and the others two each? It proceeds to say that certain decisions of the commissioners are not mandatory but only advisory; this last and only essential point to be directed at a claim of right on the part of Connecticut to collect imposts from Massachusetts people who dwelt upon the banks of the Connecticut River, at Springfield, Mass., and in the adjacent country, including Westfield and other towns, such toll to be taken at the mouth of the river, to construct or repair the fort at Saybrook, or to pay Mr. Fenwick the cost price of the estate.

Massachusetts had already submitted this question to the commissioners, and it had been before them and argued over

1 Mass. Col. Rec., ii. 242, 243.

2 Ib., ii. 245. 
and over, from I645 to I648; and Massachusetts, or her citizens, had finally been directed to pay said duties assessed at Saybrook upon merchandise coming down the river from Massachusetts. It now wished the judgment understood as advisory, not mandatory. Here at the very start these people, who were working away at the foundation of things, had to meet a question that has since attracted the attention of diplomatists throughout the commercial world; and although many opinions have been expressed, and many arguments made on both sides, the balance of authority seems to incline towards the right of a state at the mouth of a river to dictate terms and collect duties, unless that right has been extinguished by treaty provisions.

The first river to be set free was the Rhine, on the demand of the French, in 1804, more than a century and a half after this question was raised on the Connecticut. In I 880 the Elbe and the Rhine were again restricted, and vessels must present themselves at the custom-house on each frontier. The great rivers have all been subjects of treaty in this respect, - the Danube, the Scheldt, the Amazon, the La Plata, the Mississippi, the Rio Grande, the St. Lawrence, the three great rivers of Alaska, and the Congo and Niger. This has all transpired during this century. Thus enlightened policy - not obedience to law, but the general good of mankind - has in a great measure created treaties and set the rivers free from tolls and exactions. The demands of an ever-widening commerce will at length set the great highways to the sea as free and chainless as the ocean itself ; then Massachusetts will be vindicated. ${ }^{1}$

It ought not to escape our notice that an early contention had existed between Massachusetts and Connecticut as to whether Springfield and Westfield were in one colony or the other, in which controversy the commissioners decided in favor of Massachusetts. This may have added energy to the action of Connecticut. The colony had purchased the

1 Internat. Law, W. E. Hall, 116-125; Internat. Law, Woolsey, 7983; Wheaton, ii. $4, \S 15$. 
land about the mouth of the Connecticut of George Fenwick in 1644, and the colony of Connecticut claimed under him.

But Massachusetts had contended earlier with Fenwick about this title and boundary. "Mr. Fenwick desired in I643, that if he did not prove, and make it appear to the commissioners at the next meeting, that his line, by an ancienter patent than ours, and an authentic one, doth take in Wooronock [Westfield], then our line to stand, and that trading house to be subject to our orders." 1

We find the following in a letter from Fenwick to Governor Winthrop, October, I639: “For other matters, as they are of great consequence and near concernment to others as well as myself, I can at present say thus much duly, that if there be anything betwixt you and the towns above, about bounds, whatsoever is concluded without us here, I shall account invalid and must protest against it. I speak not this out of any fear either of wrong or neglect from you or them, but to tell you in short (having many other business) what I hold myself bound to do in that particular, and when there shall be a fit time for anything betwixt us you shall find us in all things to submit to right and good conscience." 2

It is evident from the Mass. Col. Rec., ii. 264, 268, that this question of boundary lines was unsettled in 1649 , that Fenwick failed to send any one to join Massachusetts in running the south line, and that the commissioners, assuming the Massachusetts line to be the correct one, awarded Westfield and Springfield to them.

We have entered more carefully into this question because we find in Mass. Col. Rec., i. 319, the following: "Mr. Dudley was entreated to answer Mr. Fenwick's letter, according to the directions indorsed." We had, until the present time, no means of knowing the subject-matter of this letter, but recently we have learned, as will appear else-

1 Mass. Col. Rec., ii. 44.

- ${ }^{2}$ Hutchinson Papers, published by the Prince Society, i. I2I. 
where, ${ }^{1}$ that the general course of controversy between Fenwick and Massachusetts was agitated, and that Dudley was directed to set forth in the said answer the definite opinions of the Court respecting the southern boundary line of Massachusetts, including Springfield, within the colony.

The immediate connection of Dudley with this affair will be apparent, if we consider that he was governor of the colony in 1640 and $I 645$, that he was commissioner in 1643 , and president of the confederacy in 1647 , and a prominent member of the present committee of 1648 , during all which time this matter of boundary and right of free passage through the Connecticut River to the sea was under consideration.

There seems to have been immediate connection between the above question of boundary and the following one of the jurisdiction of Massachusetts over Indians in the neighborhood of Springfield. William Pynchon, at Springfield, had written a letter dated the $5^{\text {th }}$ of Fifth Month, I648, to Dudley, the purport of which was that certain murders in his neighborhood, committed by the Indians, were probably not the work of the Indians within their jurisdiction. The following quotation, in this connection, illustrates the relation of Winthrop, Dudley, and Eliot, in the government. It appears in this how much Governor Winthrop relied upon Dudley in emergencies; and, on the other hand, the clear, methodical, judicial answer of Dudley shows to us abundant reason for Winthrop's confidence in him. "Haste, haste. For his loving brother, the deputy governor, with speed." On receipt of this letter, the deputy governor, Dudley, sent it with this address : "To his honored friend Mr. John Winthrop, governor, at his house in Boston, deliver it with all speed." Governor Winthrop writes upon it : "SIR, I pray acquaint Mr. Eliot with this letter, and let me have your advice about it speedily. So I rest your loving brother, JoHn Winthrop, governor. 9th of 5 th month, I648." 2

1 Page 283, this volume.

2 The following letter of Dudley and notes of Winthrop exhibit in a 
Eliot was acquainted with these Indians and, as we have seen, lived opposite the house of Dudley. Dudley answered the above as follows. We copy it in full because every line of his composition is cherished by us, and it also shows his style and his method:-

"Upon reading this letter and conference with Mr. Eliot, I give my advice (which you require) for a pause in the business, before proceeding any further in it.

" I. For that the ground and warrant of our meddling in it is by this letter taken away, it being denied that the strong light their relations to each other and to the government, at an earlier date, in another matter.

To the Right Worshipful John Winthrop, EsQ., Governor.

Sir, - In answer to yours, and to what Mr. Coddington hath by word mentioned, I say as followeth, that I am content himself, Mr. Wilbore, Mr. Coggeshall, Goodman Freeborn, and Richard Carder, shall have license to depart out of this Patent within a month from hence following, and after to return at their pleasure to remove their families, so it be within half a year from this day, - only Mr. Coddington and Mr. Wilbore are to come and go, and trade and commerce, and take their own time for removal of their families. Likewise for Sergeant Hutchinson and Sergeant Baulston, and for John Porter, I consent to their departure and the release of their fines, provided that they shall depart before the thirteenth day of the next month, and not return any more, which if they do, they are to be liable to the payment of their fines and all three to such further censure as the Court shall think meet. Thus with my service remembered, I take leave and rest,

I9 of the 12,1637 .

Yours at command,

Tho: Dudley.

The following order, in the handwriting of Governor Winthrop, is found on the next leaf of this letter.

"Mr. Wm. Coddington, Mr. Jo: Coggeshall, and Mr. Wilbore, are licensed to depart out of this Jurisdiction, and they have liberty to remove their families, and dispose of their estates here in convenient time, at their own liberty, and to go and come at their liberty, except they, or any of them shall be otherwise limited by the General Court.

"Wm: Baulston and Edward Hutchinson have license to depart out of this Jurisdiction, provided that they submit to the order of the next General Court in regard of the censure they lie under."

Indorsed by Governor Winthrop, "Brother Dudley." (Masss. Hist. Coll., 4th series, vii. 109.) 
murdered were our subjects or the murderers within our jurisdiction.

" 2 . If the murderers should be apprehended and brought to us, the party escaping is, for aught we yet know, all the witness against them, he affirming he knows their faces, which yet is doubtful, the murder being done in the night.

“ 3. It is like in Mr. Pynchon's opinion to draw a war upon us, which, if (as he saith) it be provoked by us voluntarily, not necessarily, we shall incur blame at home and with our confederate English, and want the [aid ?] from heaven in it and comfort in prosecuting it.

"4. The charge and difficulty which the sending men out in hay and harvest time would be considered.

" 5. A pause will advantage us in hearing what the Narragansetts will do upon Uncas, whom we must defend.

" 6 . And if so, it cannot be wisdom in us to stir up other Indians against us to join with the Narragansetts.

"I have forgotten two other reasons while I was setting down these. I think a messenger would be dispatched to Mr. Pynchon to let such Indians loose, if any should be apprehended, which I think will not be, they who have promised not being like to do it, or if Mr. Pynchon see cause to do otherwise, to leave it to him.

\section{"Thomas Dudley." 1}

It is evident that Winthrop was very affectionate in his nature, while he was capable of being aroused to the acme of momentary passion. His early letters to his wife are remarkable for their expressions of feeling. We cannot fail to note his constant reference to Dudley as "my brother Dudley" or "my dear brother Dudley," not only in communications between them, but in writing also to other persons respecting him, which makes it still more evident. ${ }^{2}$ For example, in a letter to his son this year, he says, "I

1 Winthrop, ii. 470, 471, App.

2 The importance of this we know is diminished by the custom of the period. 
understand by my brother Dudley, that his son $\mathrm{D},{ }^{1}$ finding that Mr. B. is offended with his teaching at New Town, is now resolved to remove, and if he have a call from your people and assurance of reasonable maintenance at present, and what likelihood of competency afterward, he will come to you." 2

Robert C. Winthrop, referring to the last election of Winthrop and his associates in office, says, with great feeling and good sense, "Winthrop, Dudley, Endicott, Bradstreet, - how much of the best history of Massachusetts is connected with these names! For length of service; for steadfast devotion to New England, whether in prosperity or adversity ; for ability and integrity; for moral and religious excellence, - we may search the civil history of the colony in vain for a nobler quaternion than that represented by the names which are thus closely grouped together in Governor Winthrop's last entry of a Massachusetts election." 3

1 We do not know who he may mean by "D."

2 Winthrop's Life and Letters of John Winthrop, ii. 385.

8 Ib., ii. $374,375$. 


\section{CHAPTER XXXII}

WE regret very much to be forced to admit that the melancholy delusion of witchcraft took its start in Massachusetts in the lifetime of Winthrop and Dudley, while we are thankful that the great burden of disgraceful record, by chance or otherwise, falls upon later administrations in Massachusetts.

It was in 1691 and 1692 that there came a panic under the influence of Cotton Mather's "Memorable Providences." "Censure is deserved by all those who speak of Salem witchcraft as if it were a special, peculiar, and unique product of the Massachusetts theocracy, the flowering out and full fruitage of Puritanism. The delusions and atrocities connected with that distressing episode in our history had no relation whatever to the distinctive qualities of Puritanism, but involved in a common share in superstitions and cruelties all classes and ranks of men and women, of every party in religion, Papal or Protestant, and of no religion." 1

A little investigation will show to us the influence of this delusion, and the terrible atrocities resulting from it many years before throughout Europe. Winthrop says, Fourth Month, 4th, 1648: "At this Court one Margaret Jones of Charlestown was indicted and found guilty of witchcraft and hanged for it." $2 \mathrm{He}$ proceeds to give a revolting description of the evidence against her, which is not creditable to him, ${ }^{3}$ and shows him, as we have heretofore noticed, to have been in no manner above the superstitions of his age.

It is difficult, even with the above allowance, for us to understand how a man could have been so intelligent and

1 George E. Ellis's Puritan Age in Massachusetts, 557.

2 Winthrop, ii. *326.

8 From our standpoint; but we must judge him from his own. 
wise, and yet entertain such whimsical superstitions. We can understand his accepting the scriptural teaching in these matters, and his obedience to what he conceived to be the divine authority which bound him both in religion and laws. But the mystery still remains why he should take apparent satisfaction in the sickening details of this, Mrs. Dyer's, and other cases. ${ }^{1}$

Some of these instances cause us to question whether Winthrop was so entirely fortunate in having kept a diary, while his associate neglected it, in which, while his great and amiable qualities appear, his defects by our standards also have been transmitted to posterity.

These very 'defects contribute to our conviction of his honesty and sincerity, as the good and bad intermixed in the worthies of the Old Testament, without concealment, add to our faith in their character and work. They are nevertheless defects.

It seems that this was not the first instance of the execution of a witch in New England, but it was the first in Massachusetts, and the only one in that period of its history which we are required to consider. We find, in Winthrop's Journal (1646), the following: "One [blank] of Windsor arraigned and executed at Hartford for a witch." 2 Savage, in his note to this, evidently takes great satisfaction in saying, "The Connecticut law, December, I642, may be read in three lines of Trumbull, Col. Rec., i. 77. Including the authorities from Exodus, Leviticus, and Deuteronomy, Massachusetts borrowed every letter of the text and comment." But it is only just to say that Massachusetts had an earlier law, being number two, under her capital laws of I64 I, in the Body of Liberties, of the same import, although in the statute of 1649 she seems to have taken the words of the Connecticut statute. Dudley cannot escape from his share in connection with this miserable business, both in making of the laws and in the case of Margaret Jones, but there is no other record of his approval of this delusion.

1 Winthrop, ii. *26I-*264. * 2 Ib., ii. *307. 
W. E. H. Lecky has, no doubt truly, said of witchcraft: "Arising amid the ignorance of an early civilization, it was quickened into an intenser life by a theological struggle which allied terrorism with credulity, and it declined under the influence of that great rationalistic movement which, since the seventeenth century, has been on all sides encroaching on theology. ... It is impossible to leave the history of witchcraft without reflecting how vast an amount of suffering has, in at least this respect, been removed by the progress of a rationalistic civilization." 1 Mr. Lecky's entire chapter is full of instruction upon this painful subject. We cannot be too grateful that we have escaped many things which afflicted our ancestors.

History has gathered only a few unrejoicing berries from fields of antiquity, while the unmeasured and unknown ages, we may be certain, were in darkness, gross ignorance, and despair; bitter in superstition, cruelty, and heartless tyranny.

John Winthrop, after one month's confinement with fever, departed this life the 26th of March, I649; not, however, until the great experiment in civil government, which has no superior in its importance to mankind, had been here put to the proof and not found wanting. Winthrop, by the consensus of all men, is regarded as the illustrious father of Massachusetts. No greater honor can attach to any name in these modern centuries than this. Dudley was, as we have said, only second to him, in responsibility, in selfconsecration, fortitude, and constancy. They both entertained the same impossible ideal of government, drawn from the very oracles of God, bearing the superscription, as they unflinchingly believed, of the all-knowing God and Father of us all.

But while they trusted too much in the letter which killeth, they nevertheless surpassed all before them in deducing from that volume of truth, coupled with Calvinism, with their sincere scholarship, their remarkable common sense, and

1 Hist. of Rationalism in Europe, i. 152, 153. 
their new experience, the foundation, lasting and firm, of the noblest superstructure in government yet evolved. Winthrop has been duly honored by state and nation as he deserves. It will, we trust, always be a sacred duty, reverently called to remembrance by the people of Massachusetts, to make known to every succeeding generation of its citizens the matchless services of Winthrop to the commonwealth.

We do not seek to buttress the character of Dudley by the strong personal record and qualities of Winthrop, or to raise him above his own just merit and honest desert. Many a government has been able, and attracted influence, when it possessed in its cabinet a wise, far-seeing, stable minister.

Many a war has been waged with success, because in prominent second command stood a great lieutenant or able marshal. Subordinates may not win the honors and may be discredited with the mistakes of the campaign, and yet be the very bone and sinew in the forward movement of the victorious column. Whoever else was absent from the councils of state, we have found both Winthrop and Dudley there; and in all but the first years, up to 1636 , they were of the same opinion and party. We have seen how they took counsel together about public matters in critical moments. Why should they not also be united in the tribute and praise, in the homage, of a valiant and grateful people which owes so much to their steadfast fortitude, their measureless sufferings and stupendous sacrifices? This is the work that we have left undone; herein we have signally failed. We have exalted Winthrop, and have been inattentive, even hostile, to his great associate and coequal in command in the fierce conflict out of which Massachusetts came forth full-armed and endued with that energy and those originative principles which have made her great and unique among states.

We need only to refer to one matter already mentioned, ${ }^{1}$ to show how unjust to Dudley most writers have been. We do not overlook the fact that earlier in this volume we have adverted to this matter, but it is impossible to do it too often

1 Page 208, this volume. 
when we contend with such an innumerable host of able writers through two centuries and a half of constant repetition. Hutchinson says briefly, "Some writers say that, upon his death-bed, when Mr. Dudley pressed him to sign an order of banishment of an heterodox person, he refused, saying, 'he had done too much of that already.'

Dudley here, as it is usually understood, was the willing representative and type of the narrow, bigoted, red-handed Puritan; and Winthrop, on the other hand, under a great new light and change, had at the approach of his final departure been translated out of his generation, into the humane Christian convictions of our own times.

If Dudley ever did take an order to Winthrop, it was an order of Court, and not his own scheme, or snare, for the unorthodox offender. He was doing, in an official capacity, what he had sworn to do in the execution of the laws; it was the act of the Court and not of Dudley in a personal sense, and Winthrop, unless too feeble, was bound to sign the order. He had no veto power, or power to neglect or refuse. But the answer to this tradition, conclusive and full, is that the Rev. Marmaduke Matthews, the heretic in question, was at the date of Winthrop's death a minister in Hull in good standing, later in Malden; that he came under some dealing by the Court afterwards, but the record shows what was done in his case, and no order of banishment issued, so none was taken to Winthrop by Dudley, and the whole story rests on a pernicious tradition which found its way into "New England Judged," by George Bishop, page 226. ${ }^{1}$ Matthews was before the Court in the next administration of Endicott, May, 1649, ${ }^{2}$ for the first time, not upon a question of banishment, and was only to be admonished by Governor Endicott. ${ }^{3}$

1 Felt's Eccl. Hist., i. 364. See Wonder-Working Providence, lib. iii. c. vii., or Poole's edition, pp. 21 I, 212, cix., cxi.; Mass. Col. Rec., iii. 29-32.

2 Felt's Eccl. Hist., ii. I8, 42, 43, 53, 54, 60, 62, 69, 136.

8 Mass. Col. Rec., ii. 276; Winthrop, i. ${ }^{*} 273$, note, ii. ${ }^{*}{ }_{175}$, note. 
From this conclusive evidence of the record, this odious comparative estimate of these two foremost men at the beginning of Massachusetts, to the enduring reproach of Dudley, ought to perish, and history ought to do him that tardy justice which it has declined to render to him for nearly two and one half centuries. These dear brothers were, during the last thirteen years of their companionship, - years of unsurpassed importance in Massachusetts, - one in purpose, one in their ideal of the commonwealth, which was to come forth from their righteous planting. They "were lovely and pleasant in their lives, and in death they were not divided." 1

Endicott succeeded Winthrop, in May, 1649, as governor. Hutchinson says: "I fancy that about this time the scrupulosity of the good people of the colony was at its height. Soon after Mr. Winthrop's death, Mr. Endicott, the most rigid of any of the magistrates, being governor, he joined with the other assistants in an association against long hair." 2

There has been no period in history which has not shown a variety of indifferent acts or matters to have been adjudged evil, and to have received utter disapproval, and their adher-

12 Samuel, chap. i. ver. 23.

2 Hutchinson, i. 15I. The following are the words of Agreement and Association, which we quote, because Dudley was a party to it, and because it is no doubt the better method to let these people speak for themselves when it is possible to do so:-

"Forasmuch as the wearing of long hair, after the manner of ruffians and barbarous Indians, has begun to invade New England, contrary to the rule of God's word, which says it is a shame for a man to wear long hair (I Cor. xi. 14), as also the commendable custom generally of all the godly of our nation, until within this few years.

"We the magistrates who have subscribed this paper (for the showing of our innocency in this behalf) do declare and manifest our dislike and detestation against the wearing of such long hair, as against a thing uncivil and unmanly, whereby men do deform themselves and offend sober and modest men, and do corrupt good manners. We do thereby earnestly entreat all the elders of this jurisdiction (as often as they shall see cause) to manifest their zeal against it in their public administrations, and to take care that the members of their respective churches 
ents the persecution, at least the ostracism, of those in power.

Governor Endicott seems to have been very punctilious and much in distress about these unimportant matters. $\mathrm{He}$ began by supporting Roger Williams in requiring "all the women of his congregation to wear veils," in 1634, and in the same year he cut the red cross out of the king's colors, because it was donated to the king by the Pope and was idolatrous, and now he begins a crusade against long hair among the first acts of his administration in 1649 , as governor.

It would not be just to Endicott to assume that he was the only man who was vigilant in this cause. The names to the document forbid that; but he has the credit of being the chief to enforce it.

Even the sweet soul of Eliot, the apostle to the Indians, was aroused to high tension by this strange departure from rectitude, regarding it a "luxurious feminine prolixity for men to wear their hair long." An opinion which most sensible people nowadays would heartily approve of, although on other grounds, long hair for men being allowed by common consent in these days, as a special favor to weak persons with poetical tendencies, or to those persons whose exacting business engagements afford no time in which to protect themselves against this capillary enormity.

Eliot was especially scandalized by the brethren of his

be not defiled therewith; that so, such as shall prove obstinate and will not reform themselves, may have God and man to witness against them. The third month, Ioth day, 1649 .

\footnotetext{
"Jo. EndicotT, Governor, Tho. Dudley, Dep. Gov., Rich. Bellingham, RichaRd SALTONSTALL, INCREASE NOWELL, William HibBins, Thomas Flint, ROBERT BRIDGES, SIMON BRADSTREET."
} (Hutchinson, i. I 52.) 
own profession. It grieved him beyond measure that they " ruffled their heads in excesses of this kind." But with the lofty resignation of Mrs. Partington armed with her mop, in powerless conflict with the Atlantic, and with a philosophy worthy of a great cause, he at last concludes, "The lust is insuperable." 1 Hutchinson says the rule in New England was, "no hair below the ears," ministers to go patentibus auribus. ${ }^{2}$

Dudley was again, in I649, appointed commissioner of the United Colonies for the last time. $\mathrm{He}$ was seventy-three years of age, but he was at once chosen president of the confederacy. He was, however, prevented to some extent by ill health from attending its sessions. This attracts our attention more, because he was always present at the General Court, and discharged with distinguished fidelity all of his official obligations. We are forced to regard this illness as a premonition that his great life work was approaching its termination. It was the beginning of the end. ${ }^{3}$

It was stated early in this work, as the testimony of some of the best informed, that the great burden and responsibility of the government rested upon the two conspicuous leaders, Winthrop and Dudley. And we are convinced it might as truly be said that when Winthrop was gone, then the chief place came to Dudley; and Mather has related that after the death of Dudley, the notice and respect of the colony fell chiefly on Endicott. ${ }^{4}$

We do not forget that they proceeded in 1649 to choose Endicott, and not Dudley, governor. But Dudley's five years did not come around until the next year, when he was chosen governor for the last time.

He was, in I649, deputy governor and president of the confederacy. As we have noticed, he was ill; we know

1 Mass. Hist. Coll., viii. 27; J. B. Moore's Memoirs of Am. Governors, 359, note.

${ }^{2}$ Hutchinson, i. I 52.

8 Plymouth Col. Rec., ix. 149, 160.

4 Mather's Magnalia. 
nothing of that sickness except that it deprived the confederacy of his services.

There is reason to believe that events of the greatest importance, both in England and America, must have contributed much with his advancing years towards the aggravation of his sickness. The sense of loneliness and responsibility in a great national crisis, his strong, intense nature, which had endured so many hardships and surmounted so many difficulties, and survived in the midst of fallen associates in so many struggles, was in this critical juncture consuming itself with overwhelming anxiety.

The irreparable loss of Winthrop was hardly realized by him when news not less startling, possibly more sensational and potent in peril, came from England that the people in their majesty and might had beheaded Charles I. Or, in the spirit but not the words of an eminent Scotchman, they had made kings know that they had a joint in their necks.

His sympathies had been with the people against the king, but he may well have stood aghast in presence of this final catastrophe, which had exceeded in bold and daring execution any thought that he had entertained respecting the revolution. We do not know how he viewed it, but we do know that the first feeling with the public, in America as in England, was one of consternation, and then of wonder as to the next consequences to follow this violent taking off of a king.

It is needful to keep in mind that the church doctrine of the divine right of kings was commonly accepted, and that they were not amenable to human tribunals. It required another half a century and another revolution to explode that theory and to settle forever that the king himself is of the people, by the people, and for the people, and amenable to the people. But the theory of the divine right had received a mortal blow in the destruction of Charles I., from which it had no chance of recovery.

Consider for a moment the thoughts and feelings of the subjects of the king, three thousand miles away, who had 
not the daily excitement in London to stir them up to mutiny and prepare them, step by step, for the final event. They had been taught, and their ancestors before them for many generations, that it was treason in a subject to impeach the motives or question the conduct of a king. It is a proverb expressing the convictions of men for ages, and even now it is held in a Pickwickian sense, that "the king can do no wrong;" evil is solely from the ministry.

A powerful recoil had returned to America, whence much of the energy and leaven which had permeated England, and had wrought this daring deed, had originated without a dream of its fatal outcome.

What would be the issue of this dreadful affair in England? in America? was the question. Winthrop is thought never to have known of the execution. The leaders must hold on their course without his wise counsel, without that confidence his sound judgment always inspired, without his foresight and prudence, taking upon themselves his great share of public responsibility.

It could hardly be expected that Dudley so late in life could suffer this accumulation of sorrows, perils, and responsibilities, without being overcome, and feeling more than he had ever done before the extreme necessity to cherish his resources of health and strength, and "husband out life's taper at the close."

The Book of Discipline produced by the synod of Cambridge in 1647 , was in 1649 commended to the consideration of the churches by the General Court for their approval, before the action of the Court thereon. ${ }^{1}$ The Book of the General Laws and Liberties concerning the inhabitants of Massachusetts, collected out of the records of the General Court for the several years wherein they were made and established, was in May, I649, revised by the Court, and "disposed into an alphabetical order and published." 2

1 Mass. Col. Rec., ii. 285.

2 W. H. Whitmore's Col. Laws of Mass., 79, I19; Mass. Col. Rec., ii. 286. 
We are certain that great interest must always be found in the changes in the courts and administration of justice in this constructive period, wherein everything, including laws and customs, was rounding into form; and it is a matter of constant surprise how many of their expedients in legal practice and otherwise, then first tested and tried, became permanent, and have continued to this day useful and with little change. Their laws grew out of daily experience and necessity in human society, which after all has much in common from age to age, and therefore whatever method is well adapted to a useful purpose easily becomes permanent.

Not long after the death of the king, the public mind of England was moved in behalf of the Indians in New England through the correspondence of John Eliot, aided by the great influence of Governor Winslow. Parliament was induced on July 27, I649, to pass an act "for promoting and propagating the Gospel of Jesus Christ in New England." 1

"This," says Mr. Drake, in his "History and Antiquities of Boston," page 3I6, "was the origin of the Society for Propagating the Gospel among the Indians, - a society of great importance so long as the race for which it was instituted were of any account. And it is specially noticed here 'because it 'has all along had its commissioners at Boston.' " The Hon. Robert Boyle, appointed by Charles II., was its first governor in I662. We mention this because it is pleasant to connect his name with philanthropic work in America, since no person after Lord Bacon had in England such a reputation in scientific scholarship. ${ }^{2}$

1 Parliamentary Hist. of Eng., xix. I 56.

2 Boerhaave declared that "we owe to him the secrets of fire, air, water, animals, plants, and fossils." He contributed generously to the funds of the above-mentioned society, and left a bequest to it in his will. The correspondence between Boyle and the commissioners of the United Colonies, in his official relation as governor, is very instrucive. (Hazard, ii. $453,470,49$ I.) 


\section{CHAPTER XXXIII}

DUdLEy was for the fourth and last time elected governor, May 22, I650. It was now twenty years since "the great emigration" had come to America under the leadership of Winthrop and himself. What a change in that twenty years had taken place in New England. What a large amount of territory had been settled and brought under cultivation; what an extent of constructive work had been accomplished, in laws, in the government of towns, in the holding of courts, in legal practice, in customs of society, in a hundred forms distinctly American; and lastly, what an individualism, and democratic spirit, and independency had leavened the whole community, and taken it far on the road towards the thought of "liberty, equality, and fraternity," the battle-cry of a subsequent revolution.

These twenty years of experience and testing of principles, on a new continent, with a new and free environment, were initiatory in that general revolution on both sides of the sea which was determined on the overthrow of hierarchies, kingcraft, and priestcraft, with every form of feudalism.

It was the beginning of the most quiet but most potent revolt of the people in the interests of liberty which the world had seen, and was followed by consequences of which no one had then a conception.

As we read in the records of the General Court that it granted the request of Dudley and others, executors to the last will of Isaac Johnson, respecting a certain amount of land, we are drawn back instinctively to the early days of the colony, with a mingled feeling of sadness, and of delightful recollections of the ship Arbella and of her distinguished 
passengers, of Isaac Johnson and the Lady Arbella, the sister of the Earl of Lincoln, "who took America on her way to Heaven." Dudley was an original executor to this will, a position of honor which his connection with the family during many years may in some measure have brought to him. ${ }^{1}$

The inhabitants of Boston wisely petitioned the General Court to repeal the payment of duties on the part of the inhabitants of the other colonies exporting from, or importing goods into the colony of Massachusetts, because Connecticut had suspended the taking of customs at Saybrook, at the mouth of the Connecticut River. The Court granted this petition, and was no doubt glad to find itself out of the entanglement of a retaliatory act, by which it had, not to its credit, involved the other colonies in its attempt to punish Connecticut. ${ }^{2}$

The most important act by far of the General Court in the year 1650 was the charter granted by it to Harvard College, which, by a strange succession of circumstances hereinbefore mentioned, still remains to this day, to be the charter of the University.

Governor Joseph Dudley, as we have seen, had a bold and conspicuous part to perform in connection with this matter. It is certainly no small honor to Governor Thomas Dudley that as executive his name is attached to this illustrious and ever-memorable document, no matter how perfunctory the act of signing may have been. ${ }^{3}$

Plymouth relinquished to Massachusetts its claim upon the Warwick and Pawtuxet district, now of Rhode Island, the subject of long contention, involving Samuel Gorton, Benedict Arnold, and divers Indians. It was annexed to the county of Suffolk. ${ }^{4}$

Two days later the Court made preparation to try the question of the right and title of Massachusetts to the aforesaid district in dispute, with Gorton's company, inviting dif-
1 Mass. Col. Rec., iv. 7.
2 Ib., iv. II.
3 Ib., iv. 13.
4 Ib., iv. 17, 19; Palfrey, ii. 362,363 . 



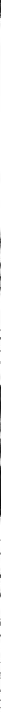





ferent judges and a jury to determine the points of difference, "that so mutual peace and love may be preserved amongst us." This does not look like a wicked purpose on the part of Massachusetts to hold this territory in any event, rightfully or otherwise. We are well persuaded that the Massachusetts government meant to be just and equitable in its dealings with its neighbors; and that if its conduct did not seem consistent with that view at all times, if it appeared to be selfish and self-seeking, at those times in general it was contending for its supposed self-preservation, or protecting the weak and innocent against the violence of wicked men.

Strangers have liberty granted to them to try actions one with another in the courts of Massachusetts.

Marmaduke Matthews had an opportunity given to him to explain his heresy, and to give satisfaction on June 28,1650 , fifteen months after the decease of Winthrop, and there is no order of banishment yet in the case; it had not even reached its concluding hearings and final judgment, nor did it for a long time ; and when judgment did come, as we have noticed, it was not of banishment. ${ }^{1}$

No one thing, it may reasonably be said, so thoroughly registers the advancement of a people in rationalism, in business, in morals, in culture, and in the comforts of life, as the laws they make and are able faithfully to execute, thus proving that the public sentiment of their age approves of and is abreast of the legislation.

The General Court appointed a committee to examine a certain book which had appeared, and was entitled "Lex Mercatoria," or a treatise on the Law Merchant, then existing. This committee was directed to select from the book those provisions needful in the commerce of the colony, particularly with reference to maritime affairs. They have discovered that such laws have been made and published in England, France, and other kingdoms and commonwealths. ${ }^{2}$

This is significant, for it informs us that the colony was entering the commerce of the world, which is the next step ${ }^{1}$ Mass. Col. Rec., iv. 21.

2 Ib., iii. 193, 252 ; iv. 10, 69. 
to entering the sisterhood of nations. ${ }^{1}$ It no longer subsists on what it can produce, in poverty and want, omitting the comforts and luxuries of life. It seeks now all that the earth can give. It produces more than it needs, and seeks a market over the sea for the surplus.

A strong desire and felt need for this department of law, more extended and far-reaching in its use and effects than the statutes found in the Body of Liberties, forcibly shows us how very much they had already advanced towards national life and national requirements, to meet on the highways of trade the subjects of foreign nations.

Bozoun Allen of earlier fame reappears on the record. It will be remembered that he was in 1645 the rival of Anthony Eames, indeed, the deputies' candidate against the magistrates', for the position of captain of a militia company in Hingham; and that in this contest at last Winthrop was impeached, but triumphed finally over all of his opponents in a "little speech," which has been greatly commended.

It seems that this Bozoun Allen had the audacity or effrontery to attack Dudley early in 1650, making charges directly to Governor Dudley himself, that he had falsified and made misstatements regarding Hingham people, and the agitation of Cotton and Wilson respecting them at Weymouth. He seems, from his apology left on the record, to have aroused a somewhat vigorous adverse party, who did not take the trouble to soothe him with "little speeches" and the sweet reasonableness of actions and law, but set him at once to eat humble pie.

It is only just to say of this misguided man, that he disclaimed any intention to be discourteous, although the evi-

1 Mr. Justice Kent says, "When Lord Mansfield mentioned the Law Merchant as being a branch of public law, it was because that law did not rest essentially for its character and authority on the positive institutions and local customs of any particular country, but consisted of certain principles of equity and usages of trade, which general convenience and a common sense of justice had established, to regulate the dealing of merchants and mariners in all the commercial countries of the civilized world." (Kent's Comm., iii. 2.) 
dence showed that he had been. We are only interested in that portion of his gentle and beautiful apology which describes Governor Dudley, and Allen's estimate of him, under the circumstances, or it may be in fact. He says, with humility mingled with sadness, "and most of all to defame him whom I know and acknowledge to be, and have been, so eminently serviceable unto, and tender of, the good of this country, and do, in very deed, account it a matter of grief unto my very soul that he should be reproached or the least eclipsed by any, and much more that I should be, or apprehended to be, an occasion thereof. Secondly, I do solemnly profess that I neither have, nor then had, such a thought in my heart, nor I trust ever shall harbor such a thought; as if he, viz., our Honored Governor, did, or would, willingly speak or relate anything untrue or false; nor know I any ground for myself, or any man, so to conceive, much less to conclude or affirm, concerning him.

"Thirdly, my humble request to this honored Court, and in particular to our Honored Governor, is, that I may be favorably construed according to my upright and sincere acknowledgment and protestation, and that whatsoever in any of my expressions on the occasion aforesaid was justly offensive, in one respect or other, may be remitted and covered with the mantle of love, which hopes, believes, and suffereth much.

" Fourthly, for vindication of our Honored Governor from all appearance of reproach by my occasion, my humble request is, that this acknowledgment may be publicly read before the Court ; so, desiring your prayers to God for me, that I may be more circumspect and inoffensive in all points for time to come, I humbly subscribe myself, willing, in all I may, to serve and honor you.

\section{"Bozoun Allen." 1}

Allen may have used these conciliatory and appreciative words under constraint from the magistrates, but neither he

1 Mass. Col. Rec., iii. 25, 26, 206, 207. 
nor they are open to a suspicion of premeditated adulation. There was a grave sincerity in the words and lives of all of them, which assures us that the kind words said of Dudley were then thought by the magistrates and the public not to exceed his just merits. And therefore this document was spread upon the records by the Court with their distinguished approval, as a sort of public indorsement of Dudley by his contemporaries.

The Court now ordered that no man shall strike his wife, nor any woman her husband, under a penalty not exceeding ten pounds or corporal punishment. This was a humane and righteous law.

William Pynchon, of Springfield, published a book entitled "The Meritorious Price of our Redemption, Justification," etc., which appeared in New England in 1650, and created a great commotion in church and state. The effect of the heresy was more dangerous, and created greater consternation, because Pynchon was a highly esteemed citizen, and had been long an assistant and influential person in Massachusetts. He had in his remote home been pondering with the assistants over the works of the great biblical scholars, of many lands and different periods, the central thought of Orthodox Christianity, and had become bewildered in the blinding mists of heterodoxy, in the opinion of the sound, well-seasoned divines and leaders in Christian thought in Massachusetts at that time.

The General Court ordered his book to be burned in the market-place in Boston by the common executioner, and proceeded to cure Pynchon of his errors, employing the learned John Norton to answer his book and furnish an antidote full and ample to its heretical virus. Pynchon soon retired to England, not to return, and the colony lost a valuable citizen.

History for more than two centuries clearly indicates to us the utter folly of the action of the Court in Pynchon's case. But they had not our advantage, and they acted up to the light they had. There are not wanting to-day people 
of the same ideas, spirit, and purpose of the Court then, but their methods are more concealed and subtle. ${ }^{1}$

Governor D'Aillebout, of Canada, had labored since 1648 , by correspondence, messengers, and otherwise, to secure the alliance and affiliation of New England with Canada, including reciprocity in commerce. The government of Massachusetts wisely and constantly declined all overtures. ${ }^{2}$ Father Druillette, a zealous Jesuit missionary, came in 1650 on one of those diplomatic visits. He informs us that he was received in Boston by Major-General Gibbons, who, he says, "gave me a key of an apartment in his house, where I might freely pray and go through the services of my religion; and besought me to make his house my home while I continued in Boston." The general went with him to "a village called Roxbury," to call upon Governor Dudley. He was invited by the governor to dine in that home which, as we have seen, is said to have had more distinguished strangers beneath its roof than any other in the commonwealth.

He was subsequently dined in like manner at the home of Governor Bradford, at Plymouth. But the friend and hospitality that he most valued were over the way from Dudley's house, in the residence of Eliot, a brother Indian missionary, not of the Latin church, but of the church universal.

Governor Dudley and other citizens of Massachusetts must have been perplexed and disconcerted in extending courtesies to this Jesuit Father, with the law of 1647 , which they had constructed themselves, confronting them. "No Jesuit or ecclesiastical person ordained by the authority of the Pope shall henceforth come within our jurisdiction." 3

They may have consoled themselves with the opinion that his official agency, representing New France, eliminated his religion and personality for the time being, and left him only a commissioner of his country. Dudley seems to have been wary of him and of his proposals and schemes.

1 Mass. Col. Rec., iii. 21 5, 230; The Puritans in England and New England, by Byington, I85, 281 .

2 Hazard, 182.

8 Mass. Col. Rec., iii. II2. 
This concluding year of Dudley's gubernatorial life had been full of important events, both in England and America, and now it had reached its close, and he was about to depart from his great office, never to return, full of years, full of honors, still holding in undiminished strength the affection and confidence of his fellow-citizens, who had never distrusted him nor been false to him.

We may justly apply to Governor Dudley in his official life the beautiful words of Tacitus, respecting Agricola: "Scorning to disguise his sentiments, he acted always with a generous warmth, at the hazard of making enemies." 1

The following is the testimonial of the Court on his services, in 1650: "This Court doth with all thankfulness acknowledge the good service of Thomas Dudley, Esq., our late honored governor, in respect of his great care and faithfulness in the discharge of that trust which was committed unto him, and do in the behalf of the country render him hearty thanks for the same, and desire his kind acceptance of one hundred marks [ $£ 66$ I3s. 4d.] as a slender manifestation of our due respect unto him, until we shall be better enabled to declare the same, which we order shall be paid him by the treasurer out of the next county levy." 2

Endicott was elected governor in May, 165I, and Dudley, for the twelfth time, deputy governor.

Dudley now received a letter from Governor Edward Winslow, the agent of the colony in England, to the effect that all warrants and processes in the colony should hereafter be issued in the name of Parliament, or "of the keepers of the liberties of England," instead of the name Colony of Massachusetts, or the Governor and Company of Massachusetts, or that there should be a modification of their charter which should acknowledge the de facto government in England. These propositions at once raised the issue of their quasi independence, which had so often been called to their notice by the British government during their history, and as often

1 Life of Agricola, by Tacitus, chap. xxii.

2 Mass. Col. Rec., iii. 226, 227. 
by tact and skillful diplomacy harmlessly laid to rest, while the government went on its course unnoticed and undisturbed. This time they were not dealing with Loyalists, but with Independents and Puritans of like faith with themselves, and they could and did appeal with confidence to them, setting forth their common interest in a common cause, and their own steadfast loyalty to that cause in their record and conduct.

It is needless to say that this was effectual. They complied with neither request, but went on their way under their charter unchanged, and were unmolested. We cannot in any other manner enter so fully into their feelings and purposes as by studying their petition to Parliament on this question, signed by Endicott, Dudley, and Edward Rawson, secretary, in the name and behalf of the General Court.1

1 Copy of a petition to the Parliament in 1651 :-

"To the Most Honorable the Parliament of the Commonwealth of England, the Supreme Authority, Greeting.

"The humble petition of the General Court of the Massachusetts Bay in New England.

"There coming to our hands, not long since, a printed proclamation prohibiting trade with Virginia, Barbadoes, Bermuda, and Antigua, of which we were observant (though to the great loss and prejudice of the whole Colony), about the end thereof we found, that the Parliament had given power to the Council of State to place governors and commissioners (without exception) in all the colonies of the English in America, wherein we finding ourselves comprehended as wrapped up in one bundle with all the other colonies. [This possibility of a foreign governor not of their own election and choice was an embarrassment constantly returning to trouble them, since it would be destructive of their holy experiment in church and state.] Our case being different from all other English colonies in America for aught we know, or have heard: Also since receiving information by Mr. Winslow, our agent, that it is the Parliament's pleasure that we should take a new patent from them and keep our Courts, and issue our warrants in their name, which we have not used either in the late King's time or since, not being able to discern the need of such an injunction: These things make us doubt and fear what is intended towards us. [Their charter was satisfactory to themselves; they did not care to risk changes in it, or experiments with it, fearing that they might tend to limitation and restraint of their priceless liberties.] Let it therefore please you, most 
Another attempt was made this year to make the colony useful to England, by transporting it in whole or in part to

Honorable, we humbly entreat, to take notice, hereby, what were our orders, upon what conditions and with what authority we came hither, and what we have done since our coming. We were the first movers and undertakers of so great an attempt, being men able enough to live in England with our neighbors, and being helpful to others, and not needing the help of any for outward things, about three or four and twenty years since, seeing just cause to fear the persecution of the then bishops and high commission, for not conforming to the ceremonies then pressed upon the consciences of those under their power, we thought it our safest course to get to this outside of the world, out of their view and beyond their reach. Yet before we resolved upon so great an undertaking, wherein should be hazarded not only all our estates, but also the lives of ourselves and our posterity, both in the voyage at sea (wherewith we were unacquainted) and in coming into a wilderness uninhabited (unless in some few places by heathen, barbarous Indians), we thought it necessary to procure a patent from the late King, who then ruled all, to warrant our removal and prevent future inconvenience, and so do. By which patent, liberty and power was granted to us to live under the government of a governor, magistrates of our own choosing, and under laws of our own making (not being repugnant to the laws of England), according to which patent we have governed ourselves above this twenty-three years, we coming hither at our proper charges, without the help of the state, an acknowledgment of the freedom of our goods from custom, and having expended, first and last, in our transportation, building, fencing, war with the Indians, fortifying, subduing the earth in making it fit for culture, divers hundreds of thousand pounds; and have now made the place so habitable that we are enabled to live in a mean and low condition, and also to furnish other places with corn, beef, pork, masts, clapboards, pipe staves, fish, beaver, otter, and other commodities, and hoped that our posterity should reap the fruit of our labor, and enjoy the liberties and privileges we had obtained for them, and for which we have paid so dear, and run so great hazards.

"And for our carriage and demeanor to the honorable Parliament for these ten years, since the first beginning of your differences with the late King and the war that after ensued, we have constantly adhered to you, not withdrawing ourselves in your weakest condition and doubtfulest times, but by our fasting and prayers for your good success, and our thanksgiving after the same was attained, in days of solemnity set apart for that purpose, as also by our sending over useful men (others also going voluntarily from us to help you) who have been of good use, 
Ireland, to repeople that country, which Cromwell had desolated by war, with the thought that a resolute self-governing

and done good, acceptable services to the army, declaring to the world hereby, that such was the duty and love we bear unto the Parliament, that we were ready to rise and fall with them; for which we have suffered the hatred and threats of other English colonies, now in rebellion against you, as also the loss of divers of our ships and goods taken by the King's party that is dead, by others commissioned by the King of Scots, and by the Portuguese. All which, if you shall please justly and favorably to consider, we cannot but hope, but that as you have formerly conferred many favors upon us, so it shall go no worse with us than it did under the late King; and that the frame of our government shall not be changed, and instead of governor and magistrates yearly by ourselves chosen, have other imposed upon us against our wills; wherein if our hopes should deceive us (which God forbid) we shall have cause to say we have fallen into hard times, and sit down and sigh out our too late repentance for our coming hither, and patiently bear what shall be imposed upon us; our adversity in such a case being the greater, because some of us are too old, and all our estates grown too weak (except a very few) to seek out a new corner of the world to inhabit in. But, as we said before, we hope that this most honorable Parliament will not cast such as have adhered to you and depended upon you, as we have done, into so deep despair, from the fear of which we humbly desire to be speedily freed by a just and gracious answer, which will freshly bind us to pray and use all lawful endeavors for the blessing of God upon you and the present government.

"We will conclude, most Honorable, our humble petition with the hearty acknowledgments of the goodness of God towards us, who hath put into your hearts graciously to confer upon us so many undeserved favors and great privileges, from time to time, in helping on the great work of God here amongst us, in taking off the customs from us, in enlarging your fund of bounty towards us for the propagating of the gospel amongst the natives with us, which work God prospereth beyond expectation in so few years; in doing us that justice in stopping all appeals from hence to you, in sending over many servants to us, in vouchsafing to have a tender care over us upon all occasions; for these, and for all other manifold encouragements received from the most honorable court of Parliament, as we are bound to praise and magnify the name of our good God, so we acknowledge it our bounden duty, not only to be heartily thankful to the most honorable court, but ever to pray, that the Lord (if it be his good pleasure) will so establish you the supreme authority of that Commonwealth, that, all your enemies 
body of Puritans from Massachusetts would keep in subjection the conquered Irish, and possibly step by step might extinguish the Roman idolatry, as they considered it, in that beautiful but benighted country.

The lord general, Oliver Cromwell, on the 29th of May, 1650, embarked at Youghall in Ireland, for England, after an extraordinary conquest of that country, requiring only nine months, at the end of a war of nine years, in which country the ruins of castles, churches, monasteries, and other establishments yet remain as abundant memorials of the havoc and desolation which he wrought, without mercy, upon that unfortunate country and people. The present feeling towards Cromwell and his memory is well expressed by the following language of a native: "So Ossian went, and he wondered grately to see such a many ould castles in ruins for ye see, your honors, 't was after Cromwell went through the country like a blast; bad luck to his seed, breed, and generation : Amin!"

The lord general having offered to these Massachusetts people, forlorn and desolate, in the wilderness of America, an exchange of home in the Emerald Isle, already conquered, prostrate, and productive as a garden, was no doubt amazed at their answer to his tempting proposition.

They praise his great achievements; they give to him seven reasons why in their opinion such a change will not tend to the glory of God.

First. They came to enjoy the liberties of the gospel, which they have done for twenty-three years, "so that there being subdued, you may rule in peace and prosperity to his glory and your own comfort here on earth, and everlastingly reign with him in glory hereafter, which are the earnest desires and fervent prayers of

"Most Honorable,

"Your humble servants,

"J. E. [John EndicotT.]

T. D. [Thomas Dudley.]

ED. R. [EDward Rawson, Secretary.]

"In the name and of the Court."

(Hutchinson, i. I76, 516 ; Mass. Col. Rec., iv. 72, 73.) 
is no solid ground for any defect therein that we know, that should occasion a remove."

Second. God has blest them with food, "so that poverty cannot truly be alleged to be a ground of removal."

Third. Not a more healthy place exists; want of health is no ground.

Fourth. Peace abounds; war is no cause of departure.

Fifth. The ordinances both in church and commonwealth are maintained; spreading errors in judgment are suppressed; therefore no defect in these.

Sixth. Indians are converted; they cannot turn their backs upon so hopeful and glorious a work.

Lastly. "The great noise and report of so many invited, and intending to transplant themselves into Ireland," have injured the reputation of the colony as to the productiveness of its territory, and people are not mindful of the good gifts of God to them during these many years. Yet there is freedom under the law to depart; they do not hinder, but they give them their feelings and opinions.

"Furthermore, we humbly petition your' Excellence to be pleased, to show us what favor God shall be pleased to direct you unto on our behalf, to the most Honorable Parliament, unto whom we have now presented a petition. The copy of it verbatim, we are bold to send herewith, that, if God so please, we may not be hindered in our comfortable proceedings in the work of God here in this wilderness. [Such as issue warrants in any name but that of Massachusetts or suffer an amendment of the charter.] Wherein, as for other favors we shall be bound to pray, that the Captain of the host of Israel may be with you and your whole army, in all your great enterprises, to the glory of God, the subduing of his and your enemies, and your everlasting peace and comfort in Jesus Christ. In whom, we are, Right Honorable,

"Your most obliged servants,

$$
\text { "J. E." [Јонn Endicotт.] }
$$

This letter was on behalf of the General Court. ${ }^{1}$

1 Hutchinson, i. 520. 


\section{CHAPTER XXXIV}

THE record informs us that Dudley, by order of the General Court, has the extent of his fifteen hundred acres of land on the Concord River determined from the bounds established by himself and Winthrop at the "Two Brothers " by the river side. ${ }^{1}$

The Rev. Mr. John Norton receives a recompense of reward of twenty pounds, May 22, for smiting William Pynchon's Book and extinguishing its heresy.

The Court on the same day gives its attention to a day of fast and humiliation, for good and sufficient reasons duly set forth in the order, as follows :-

"This Court, taking into consideration how far Satan prevails amongst us in respect of witchcraft, as also by drawing away some from the truth to the profession and practice of strange opinions, and also considering the state and condition of England, Ireland, and Scotland, and the great things now in hand there, conceive it necessary that there be a day of humiliation throughout our jurisdiction in all the churches, and do therefore desire and order, that the eighteenth day of the Fourth Month [June] shall be set apart for that end and purpose, and that the deputies of the several towns give notice to the several elders of their churches of the Court's desire herein." 2

The Book of Discipline, begun in the Cambridge synod of 1646 , having been five years under consideration and criticism by all the churches, or offered to them for comment, and the objections which appeared, cast pell-mell into the alembic of the minds of the elders, and having come forth pure and unadulterated, with all its amendments and

1 Mass. Col. Rec., iii. 247.

2 Ib., iii. 239. 
accrued perfections attached, then on the fourteenth day of October, 1651, received the testimony of the Court "that for the substance thereof it is that we have practiced and do believe." 1

"To the end that good and wholesome beer be brewed, it is ordered that no person shall undertake the calling or work of brewing beer for sale, but only such as are known to have sufficient skill and knowledge in the art or mystery of a brewer." 2

"Upon information of divers loose, vain, and corrupt persons, both such as come from foreign parts and also some others, here inhabiting and residing, which insinuate themselves into the fellowship of the young people of this country, drawing them both by night and by day from their calling, studies, honest occupations, and lodging places, to the great dishonor of God, grief of their parents, masters, teachers, tutors, guardians, overseers, and such like," it is ordered that persons who do such things shall not go unpunished. ${ }^{3}$

A controversy of considerable importance arose in relation to baptism, in July, I65 I. As we have already observed, the colony had abundant reason to fear Anabaptists of the German or John Leyden sort, but they had to deal now with another order of Baptists, who in a very important particular entertained doctrines hostile at once to their church and state.

The Anabaptism they had in the past been contending with had a wicked, anarchistic record, well known and easily available in resisting them, but the Baptists now confronting them were men without reproach, while their doctrine of baptism was subversive of the Puritan church constitution, and of their ideal of citizenship in the state. The Puritans denied the sacrament of baptism to the children of all persons who were not themselves in covenant with one of their churches. But the offspring of persons in such covenant took a Christian inheritance, as an estate falls to an heir. Baptism was held to be the sign of admission to the church,
1 Mass. Col. Rec., iii. 240.
${ }^{2}$ Ib., iii. 24 I.
8 Ib., iii. 242. 
the vehicle of God's grace, without actual faith except of sponsors, because of the covenant and not otherwise.

The revolutionary Baptists, on the other hand, held that personal conversion and personal faith were essential, which none but persons capable of thought and meditation could attain to. Hence infant baptism was useless and wicked, a remnant of church tradition and superstition.

The General Court has set forth its complaint against Baptists. "Where the said persons did in open Court assert their former practice to have been according to the mind of God, .. . . with making infant baptism a nullity, and thereby making us all to be unbaptized persons, and so consequently no regular churches, ministry, or ordinances, and also renouncing all our churches as being so bad and corrupt that they are not fit to be held communion with, denying to submit to the government of Christ in the church, and entertaining of those that are under church censure, thereby making the discipline of Christ in his churches to be of none effect ... all which to allow, would be the setting up a free school for seduction into ways of error, and casting off the government of Christ Jesus, in his own appointments, with a high hand, and opening a door for all sorts of abominations to come in among us, not only to the disturbance of our ecclesiastical enjoyments, but also contempt of our civil order and the authority here established." 1

The issue was now, about July 31 , 165 I, raised against the government by the distinguished John Clarke, of Newport, R. I., John Crandall, and Obadiah Holmes, who appeared as teachers of the heresy of baptism in Massachusetts, and were found guilty under the law, and duly sentenced. Friends paid the fines of two of them, and would have done so for Holmes, but he declined their generous assistance, and was duly whipped. It has been argued that this incursion into Massachusetts by Clarke was to achieve fame as a man persecuted for righteousness' sake, to be used in England politically against Coddington, in a contest which immediately 1 Mass. Col. Rec., iv. part ii. 374; Hutch. Coll., i. *216. 
followed this one. ${ }^{1} \mathrm{~J}$. A. Doyle scouts this as far-fetched, because no contemporary had ever discovered it. The character of Clarke makes this unreasonable. But distance often enables one, with a better perspective and greater knowledge of facts, to see what was unobserved by persons in the conflict.

Public sentiment has gone strongly against the Puritans in our humane and compassionate era. But no unprejudiced person can read the above story of the encounter of the government with these men, as stated by it, and not feel that the Puritan had every reason to regard their holy experiment of government, and their most sacred church organization, in real danger of being overrun and destroyed. Indeed, everything that they had struggled for in this wilderness was to be blotted out unless they conquered in this battle. Neither was the war their own; it was, in their judgment, the conflict of light with darkness, Christ with Belial.

The Puritans were therefore persecuted in this onset. The three men, unless impelled by conscience, which we do not deny, might retire or never have appeared, but the government had to stand its ground and take the shock, or perish. As Abraham Lincoln said ${ }^{2}$ to the erring South, "You have no oath registered in heaven to destroy the government, while I shall have the most solemn one to preserve, protect, and defend it." While this is true, we may, and ought to say, that it is the duty of all to obey the voice of God, and if the three worthies were under the higher law, thrones, principalities, and powers ought to be no hindrance to them, and martyrdom a holy privilege. God pity them both and pity us all, who have to contend blindly, seeing through a glass darkly, no matter how certain we are that we see clearly.

Clarke had an offer of disputation not open and satisfactory, but it interests us, for Thomas Dudley's signature is among the others, dated the I Ith of Sixth Month, I65 I. ${ }^{3}$

1 Palfrey, ii. 35 I.

2 First Inaugural Address, I86I.

8 Backus's Hist. Baptists, i. I85. The Right Rev. Jeremy Taylor 
The General Court is much disturbed again respecting extravagance in dress. "Although we acknowledge it to be a matter of much difficulty, in regard of the blindness of men's minds and the stubbornness of their wills, to set down exact rules to confine all sorts of persons, yet we cannot but account it our duty to commend unto all sorts of persons a sober and moderate use of those blessings which beyond our expectations the Lord hath been pleased to afford to us in this wilderness, and also to declare our utter detestation and dislike that men or women of mean condition, education, and callings should take upon themselves the garb of gentlemen, by wearing of gold or silver lace, or buttons, or points at their knees, to walk in great boots; or women of the same rank to wear silk or tiffany hoods or scarfs, which though allowable to persons of greater estates or more liberal education, yet we cannot but judge it intolerable in persons of such like condition." It is therefore ordered by the Court that people shall dress according to their means, education, and rank, with many particulars respecting the same.

This has a special interest for us because we can already discern the dissolving in this democratic atmosphere, this new social life, of the outward emblems and distinctions of ranks and orders and of previous conditions of servitude, arising from generations of poverty, or ignorance, or plebeian extraction. The offenders here, the law-makers, not so rapidly, however, for they had little or nothing to gain, were being ushered into hitherto unknown liberty, and had caught a foregleam of the song of Burns :-

said, in 1647 , "There may be no toleration inconsistent with the public good. . . . And therefore here they are to be restrained from preaching such doctrine, if they mean to preserve their government, and the necessity of the thing will justify the lawfulness of the thing. If they think it to themselves, that cannot be helped, so long it is innocent as much as concerns the public; but if they preach it, they may be accounted authors of all the consequent inconveniences, and punished accordingly. No doctrine that destroys government is to be endured." (Discourse of the Liberty of Prophesying, § 19, Works of Jeremy Taylor, v. 589, 590.) 
"Is there for honest poverty

That hangs his head, an' a' that?

The coward slave, we pass him by -

We dare be poor for a' that!

For a' that, an' a' that:

Our toils obscure, an' a' that,

The rank is but the guinea's stamp,

The man 's the gowd ${ }^{1}$ for a' that."

The United States has, from its first settlement, been the retreat of the oppressed of all nations and races; men have been leveled up and down to a common honorable citizenship, where men of light complexion, at least, were equal before God and the law.

Education has been the barrier against-aristocracy, aided by the free alienation of land and the unbounded domain open to all. Here for many years an Arcadian simplicity, purity in morals, and fraternal equal fellowship existed, rights of persons and of property were respected, homes needed no defense by day, and doors were not bolted by night.

It was determined by the Court that blasphemous expressions uttered in mid-ocean, half way to England, were beyond the jurisdiction of the Court. ${ }^{2}$

The annual election was held in Boston, May 22, I652, at which Endicott was chosen governor, and Dudley, for the thirteenth and last time, deputy governor. He had, during the twenty-two years of his being in the colony, been either in the first or second office in the gift of the people for seventeen years, and a magistrate all the time, and an overseer of Harvard College from its foundation. He was now seventy-six years old, and having endured many hardships it was right that he should have a brief respite from care and duty before his final departure, and that he should relinquish his hold upon the helm of state, committing it into the hands of his successors.

The Court at this session made a statute affirming its faith in the Bible, and its purpose to punish all persons who should be guilty of denying its genuineness or authority.
1 Gold.
2 Mass. Hist. Coll., iii. 257. 
"The Holy Scriptures of the Old and New Testament being written by the Prophets, Apostles, and holy men of God, inspired by the Holy Ghost, containing in them the infallible and whole will of God, which he purposed to make known to mankind, both for his own worship and service, and also for the instruction, obedience, faith, and salvation of man, which yet by heretics in former ages, and now of late by others, have been oppugned and denied so to be, which if connived at, would manifestly tend to the overthrow of all true religion and salvation, for the prevention of so heinous a crime, it is therefore hereby ordered and enacted," that such persons shall be punished as therein set forth. ${ }^{1}$

We must esteem it fortunate that Dudley, so near the end of his career, united with his associates in this testimony to the Bible, which had been their great statute book, the source, higher than the English common law, whence they had drawn most of their Body of Liberties. By this also they had been guided in the wilderness, when the way was doubtful and their charter gave no light to them, in the creation and government of a state which was to be a beacon light in civilization for centuries.

If by theocracy it is intended that the exercise of political authority in Massachusetts was by priests, as representing the Deity, it is an error clear and certain. The ministers were totally excluded from direct political place or power. They were called as scientific experts sometimes, indeed often, to declare the meaning of the written word as applied to the case in issue. The executive of a State may require the Supreme Court to interpret statutes; no other body is so well qualified to do that service. But it would hardly be correct to say that the executive with his council, the Senate and House, or legislature, and all other departments were set aside while the Supreme Court governed the commonwealth. We know very well that Dudley and others did not hesitate to tell the ministers to mind their calling when they exceeded their professional duties.

1 Mass. Col. Rec., iii. 259. 
If by theocracy is meant a Christian government in which God reigns, and his will is done, we hope it is still the sort of government which the American people confides in and desires above all things. God is not named in the Constitution, neither need he be, but it is important that he be reverenced as surely by the citizens of our country to-day as by the Massachusetts fathers, and that a sense of responsibility to the Divine Governor of all things be instilled in childhood, to create citizens who will be obedient to law and duty.

The righteousness of the Old Testament and the gospel of the New Testament are as essential to government to-day as ever. Political corruption stalks away with bated breath where the golden rule prevails.

The reliance of the General Court upon the infallible literalism of the Old Testament, the Biblical commonwealth, was an error which a greater light and " higher criticism" have made evident to us. The open Bible had only just reached the people in their day. But their faith in the Eternal, and that the Bible and a devout spirit were the sure and only ways to know his will, were essential facts which they accepted and acted upon with full assurance.

The colony undertook this year the coinage of money, a thing it is said never attempted by a colony before. This was little regarded at the time in England, or by the British government; they had quite enough on their hands at home. But when, finally, proceedings were undertaken by charges of Randolph, which vacated the charter of Massachusetts in I684, he was careful to say in item thirteen, "They persist in coining money, though they had asked forgiveness for that offense." 1

The coining of money has always been a sovereign prerogative, and this is thought to be the first instance in history of such colonial action; and no one act of the colony more definitely asserts their assumed and growing independence of the mother country than this. It is not quite clear

1 Palfrey, iii. 376 , note. 
to us why certain shilling pieces of New England, as represented in the "Illustrated History of the United States Mint at Philadelphia," by George G. Evans, should bear the date 1650 , if the first shillings were coined, as it is claimed, at the house of John Hull, in Sheaffe Street, Boston, in 1652. These were the old pine-tree shillings. Is it possible that New England shillings were coined in the Bermudas in I650 and known as "Sommer money," as all seem to agree that the first coinage in this country was in 1652 ?

The wife of this John Hull was Judith, the daughter of Edmund Quincy, after whom Point Judith in Rhode Island was named, and their daughter, Hannah Hull, received from her father for her wedding portion her weight in pine-tree shillings, or $£ 30,000$.

If the first shillings were made in the Bermudas in 1650 , it was the administration of Dudley which first undertook to supply the colony with the much-needed, pure silver coin, which we are not yet prepared to declare; but we think his courage was equal to it, if he deemed the need sufficient and the action wise. At any rate, there the shillings are with 1650 clearly on their face, and no account of them yet found in the authorities. ${ }^{1}$

"Forasmuch as divers inhabitants within this jurisdiction, who have long continued amongst us receiving protection from this government, have, as we are informed, uttered offensive speeches whereby their fidelity to this government may justly be suspected, and also that divers strangers of foreign parts, of whose fidelity we have not the assurance which is commonly required by all governments, it is therefore ordered" that the oath of fidelity be administered to such. $^{2}$

The Court appoints a committee, under God's blessing, to be a council to consider of all sorts of trading and to consult about the best ways of improving the same. ${ }^{3}$ The militia

1 Mass. Col. Rec., iv. 84, I04; G. G. Evans's U. S. Mint, 57; S. G. Drake's Hist. and Antiquities of Boston, 329.

2 Mass. Col. Rec., iii. 263. 8 Ib., iii. 267. 
regulations were carefully established in 1652 . "The husband of Elizabeth Fairfield, being long since judged for some miscarriage of his to wear a rope about his neck during the Court's pleasure, upon her request to this Court, hath liberty granted him to lay the rope aside."

Harvard College seeks money from England.

"Mrs. Dorothy Pester, whose husband went into England some ten years since, and was never to this day heard of, upon her petition to this Court, hath liberty granted her to marry when God by his providence shall afford her an opportunity." 1

"A declaration concerning the advancement of learning in New England by the General Court. If it should be granted that learning, namely skill in the tongues and liberal arts, is not absolutely necessary for the being of a commonwealth and churches, yet we conceive that the judgment of the godly wise, it is beyond all question, not only laudable, but necessary for the being of the same. And although New England (blessed be God) is competently furnished (for this present age) with men in place, and, upon occasion of death or otherwise, to make supply of magistrates, associates in Courts, physicians, and officers in the commonwealth, and of teaching elders in churches, yet for the better discharge of our trust for the next generation, and so to posterity, being the first founders do wear away apace, and that it grows more and more difficult to fill places of most eminence as they are empty or wanting, and this Court finding by manifest experience, that though the number of scholars at our college doth increase, yet as soon as they are grown up, ready for public use, they leave the country, and seek for and accept of employment elsewhere, so that if timely provision be not made it will tend much to the disparagement, if not to the ruin of this commonwealth. It is therefore ordered" that collections of money be taken to support the president of Harvard and certain fellows and poor scholars. ${ }^{2}$

1 Mass. Col. Rec., iii. 277.

2 Ib., iii. 279, 280. 
It was ordered that verbal contracts for the sale of houses and land must be discontinued, and such bargains henceforth be by deed in writing, acknowledged and recorded. ${ }^{1} \mathrm{~A}$ patent right is issued by the Court to John Clarke for three years, on an "invention for saving of firewood and warming of rooms with little cost."

"This Court taking into consideration sundry reasons why the churches should set apart a solemn day of humiliation, especially for three reasons following: The loss of many persons by unwonted diseases; secondly, in respect of unusual storms and continued rains ; thirdly, want of supply of meet persons for public service ; fourthly, for the worldly-mindedness, oppression, and hard-heartedness feared to be amongst us; as also in regard of England and the wars there, the increase of heresies and errors, \&c., and that God would give us favor in the hearts of the Parliament, \&c. In conclusion, that God would supply us with such commodities as are wanting, \&c. This day to be observed, Ioth : 9th next." 2

It seems that one Powell was thought by the Court to be wanting in education to preach or exercise his gift in Boston, and his case reveals the fact that New England had testified to the English Puritans respecting their neglect of learning, for the Court says, "and considering the humor of the times in England inclining to discourage learning, against which we have borne testimony, this Court, in our petition to the Parliament, which we should contradict if we should approve of such proceedings amongst ourselves," as allowing an uneducated man to occupy a pulpit.

The following seems to be as funny as an Irish bull of the first quality. "Martha Brenton desiring an Irish boy and girl, about the age of twelve years, for servants, hath her request granted, so as the parties are proved before two magistrates to be born of English parents." 3

The name of Thomas Dudley disappears from the record in the year 1653 , excepting the following entry in honor of his memory :-

1 Mass. Col. Rec., iii. 280. $\quad{ }^{2}$ Ib., iii. 287, $288 . \quad{ }^{3}$ Ib., iii. 294. 
"It is ordered by this Court, that the treasurer shall pay unto the present secretary six pounds for powder sold unto the captain of the castle, expended at Mr. Dudley's funeral, and that, according to a former agreement with him, both for price and pay, this to be paid out of this country rate now in being, and the captain of the castle is to take up his bond." 1

Dudley died Sunday night, July 31, I653, and his funeral took place at Roxbury on the 6th of August following. ${ }^{2} \mathrm{He}$ was in the seventy-seventh year of his age.

$\mathrm{He}$ was buried in one of the oldest cemeteries in New England, at the corner of Washington and Eustis streets, in Roxbury.

"On entering the cemetery the first tomb that meets the eye, and the one upon the highest ground, is covered with an oval slab of white marble bearing the name of Dudley. In it were laid the remains of Governors Thomas and Joseph Dudley, Chief Justice Paul Dudley, and Colonel William Dudley, a prominent political leader a century and a half ago. The original inscription plate is said to have been of pewter, and to have been taken out and run into bullets by the provincial soldiers during the siege of Boston."

Dudley has suffered in his reputation by the writers of poetry, and, strange to say, without any intention on their part to defame his memory, but to eulogize him. The most noted of these effusions is as follows :-

"Here lies Thomas Dudley, that trusty old stud, A bargain's a bargain, and must be made good."

These lines no doubt came from the original inscription on the pewter plate on his tomb.

Most persons who read them receive two unfortunate impressions respecting their meaning, and assuming that they express the opinions of his contemporaries, do not care to

1 Mass. Col. Rec., iii. 329.

2 Rec. of Rev. S. Danforth of the First Church in Roxbury; New England Genealog. and Antiq. Reg., xxxiv. 86. 
know much more about him. Furthermore, these lines have long been deemed necessary to a good description of Dudley. The first thought which the ordinary reader gains is that Dudley was such a brute of a man that, by metaphor, he is described as a horse, ugly and ungovernable. The second line suggests the character of Shylock, - a man who entangles his fellow-men in unjust contracts, as spiders snare insects in webs, intent upon their destruction without mercy. Such interpretation is an error.

Mr. James Savage, in his note on these lines, ${ }^{1}$ says they were the work of Governor Belcher. ${ }^{2}$ They are not the

1 Winthrop, i. *5o.

2 Jonathan Belcher was governor of Massachusetts and of New Hampshire from 1730 to 1741 . The States were then united. He was governor of New Jersey in 1747. He was born in 1681, twenty-eight years after the death of Governor Dudley, and the probability of his having written his epitaph, being without personal knowledge of him, is certainly very small. It would not have been done by him before he was twenty years old; and if he did thus write it after the lapse of half a century, it ought to have no weight or importance. But his use of it seems to carry abundant evidence that he did not write it, and leave a reasonable assurance that he is quoting from another. He no doubt quoted from the ancient inscription on Dudley's tomb in Roxbury.

Belcher was in $\mathbf{1} 732$ an extensive owner in the Simsbury copper mines, now in East Granby, Conn., about eighteen miles northwest of Hartford. These mines are worthy of a little note. The company, it is said, was organized under the first charter for mining in this country. Belcher, it is said, disbursed in this enterprise about sixty thousand dollars. Trumbull says that "the mine at Simsbury was dug until the veins of copper ceased. A prodigious cavity was made, which has since become the famous prison called Newgate. This has been of much greater advantage to the State than all the copper dug out of it." (Trumbull's Conn., ii. 45.) It is claimed that the first coinage of money in this country was accomplished at this mine ; but doubtless the Massachusetts pine-tree shilling in $\mathbf{1} 652$ was earlier. The mine was transformed to a prison about 1750 . It was one of the excuses in all the colonies for their unusual punishments, that they had no places of sufficient strength to secure and retain prisoners. This use of this dismal place marks at that period a change in the treatment of criminals in Connecticut. Here, deep down into the earth, were sent in the Revolutionary War the Royalists, some of the best men of Connecticut, who 
composition of Governor Belcher. ${ }^{1} \mathrm{He}$ quoted them in admiration of the illustrious character of Dudley, whom he esteemed as reliable in his generation as Washington was regarded in a later age. Belcher, because he was weary with treacherous servants and with breaches of contracts, which ought to be sacred (indeed, the Constitution of the United States took the power away from sovereign States even to impair existing contracts), mentions as an illustration that Dudley was accounted worthy to have these memorable lines placed on his tomb, which Belcher conceived to be in the highest degree eulogistic. Let us then read the lines as he interpreted them. "Stud," as here used, means pillar, support, or prop. "The church of the living God, the pillar and the ground of truth." 2 The word had at that time a very appropriate use as the trunk, stem, or stick of a tree.

had long had the confidence of the home government. (Trumbull's Conn., ii. 40-45 ; Lippinc., xxvii. 290 ; Mag. Amer. Hist., xv. 321.)

It appears in the Belcher Papers, Mass. Hist. Coll., 6th series, vi. part i. 450, 459, 464, 466, 467, 471, 472, 474, 478, 479, that Belcher, during the years 1731 and 1732 , at which time he was governor of Massachusetts, and resided in Boston, was in constant trouble with the laborers in Simsbury mine. He charges them very often with villainy, theft, and dishonor. It seems to be a perpetual story of bad faith and failure to perform contracts, and in his extreme vexation with the treacherous miners he wrote a letter to Joseph Pitkin, an officer or agent at the mine, from which we make the following extracts : He writes of the "villainy of the men. . . . My consideration was not whether they could live by the bargain, but whether I could. I knew it was not my business to maintain a crew of rogues to my ruin. . . . And another thing, you have practiced to my hurt, viz.: too great a fear and compassion least you should hurt poor men; and this is hardly justifiable while you acted for another, and not for yourself. A man may do as he pleases for himself ; but where a man is in trust for another, in matters of dealing, strict justice is the rule, without any consideration of the circumstances of the parties. It was wrote over Governor Thomas Dudley's tomb." And he then quotes the lines given on page 417 , placing quotation marks over them. Here is the strongest evidence that he was not the author; since he quotes the lines, he does not claim them, but distinctly quotes in 1732 from another, - he says from the tomb.

1 See Belcher Papers, 479.

2 I Tim. iii. I 5. 
Dudley was one of the trunks which held up the goodly tree of the Massachusetts commonwealth during its first twentythree years.

Edmund Spenser, who was a contemporary with Dudley, wrote :-

"Seest not thilke same Hawthorne studde,

How bragly it beginnes to budde,

And utter his tender head?" 1

The word "trusty" means a reliable pillar, safe in an emergency, as a trusty servant or friend. The upright post was really a good metaphor to suggest the firm, upright, and reliable character of Dudley. Governor Belcher affirmed that so great, good, and exemplary a man as Dudley held to the sacred and inviolable obligations of contracts, and that without this no business could be transacted, for no man could otherwise make business calculations; there could be no such thing as credit, the present foundation of all the business in the world. Dudley had the distinguished honor, when he had departed this life, to have some appreciative friends, in memory of his great example, tenderly and reverently place those lines upon his tomb ${ }^{2}$ as a monumental tribute to the stability and integrity of his character, that all the world hereafter might know of his illustrious record, and imitate it. These were the thoughts of Governor Belcher, when in the next generation he pointed out the notable example of Governor Dudley to his irresponsible associates. They have in recent years been read backwards, and their meaning distorted from homage and eulogy to odium and reproach.

1 Shep. Cal. March.

${ }^{2}$ Charles M. Ellis, in the History of Roxbury, p. 102, relates that "It is said there was on his tomb in the graveyard at the corner of Eustis and Washington streets (Roxbury) a leaden plate that had an epitaph upon it [consisting of the lines under consideration], which was torn off and run up into bullets in the Revolution." If the tradition had foundation, the seeming desecration was the work of American patriots, in a moment of pressing need, in the defense of freedom in Massachusetts, and the act was hallowed by the cause and the hour. 
"Here, side by side with the apostle Eliot and Robert Calef, were laid the Dudleys, the Warrens, and others of lesser note." 1

1 Memorial Hist. of Boston, i. 4I8. Mention of Mr. Dudley's home in Roxbury has already been made in this work (page 258).

"Within the compass of this lustre [five years] was the Massachusetts deprived of two eminent and worthy persons, the one in the magistracy [Governor Dudley], the other in the ministry [Rev. John Cotton]; which loss was the more to be lamented, in that they left neither of them any one in each of their capacities, equal with themselves.

"Mr. Dudley, an ancient gentleman, one of the principal founders and pillars of the Massachusetts colony, was called from his station, July 31,1653 , in the 77 th year of his age, eminently qualified with those choice virtues fit for the discharge of the trust, to which he was oft called, and wherein he always approved himself a lover of justice, and friend of truth, an enemy of all disorder, and that always bore a special antipathy against all heresy and corrupt doctrine; which made him conclude his own epitaph with this character of himself, 'I died no libertine;' and which gave occasion to a reverend person of the clergy [Rev. Nathaniel Rogers - Mather says 'E. R.,' (Mag., i. 124) Ezekiel Rogers, but Hubbard is probably correct; he was the son-in-law of Nathaniel, and was contemporary with Dudley; Nathaniel was famous for Latin poetry, and was Dudley's pastor at Ipswich] to honor him with this double encomium, as well of English as Latin poesy.

\section{THOMAS DUDLEY.}

Hold, mast, we dy.

When swelling gusts of Antinomian breath, Had well nigh wreck'd this little bark to death, When oars 'gan crack, and anchors, then we cry, Hold firm, brave mast, thy stand, or else we die. Our orth'dox mast did hold, we did not die; Our mast now roll'd by th' board (poor bark,) we cry, Courage, our pilot, lives, who stills the waves, Or midst the surges still his bark he saves.

\section{EPITAPHIUM.}

Heluo librorum, lectorum bibliotheca Communis, sacræ syllabus historiæ. Ad mensam comes, hinc facundus, rostra disertus, Non cumulus verbis, pondus acumen erat, Morum acris censor, validus defensor amansque, Et sanæ, et canæ, catholicæ fidei. Angli-novi columen, summum decus, atque senatus, Thomas Dudleius conditur hoc tumulo. 
Mrs. Catherine Dudley, the widow of Governor Dudley, and eight of his children survived him, as follows: Rev. Samuel Dudley, Mrs. Anne Bradstreet, Mrs. Patience Dennison, Mrs. Sarah Pacey, and Mrs. Mercy Woodbridge, by his first wife, Dorothy; and Mrs. Deborah Wade, Governor Joseph Dudley, and Paul Dudley, by his last wife Catherine. ${ }^{1}$ He left, it seems, the largest estate in Roxbury, three hundred and fifty-six acres. ${ }^{2}$

[Translation of the above, as follows: A devourer of books, in himself a choice collector; a compend of sacred history ; a companion for the table, hence eloquent; a master of rhetoric, not merely a mass of words; he was weighty, keen, a sharp censor of morals, a strong and loving defender of a rational and pure catholic faith, the sturdiest support and ornament of New England; Thomas Dudley lies buried within this tomb.]

"He was the most resolved champion of the truth, above all the gentlemen in the country, in the years 1636 and 1637 , at which time was New England's crisis; when many, under pretense of crying up the free grace of God in the work of man's salvation, had well-nigh cashiered all the grace of God out of their hearts, endeavoring to vilify the grace of sanctification, that thereby they might exalt the grace of justification." (Rev. Wm. Hubbard's General Hist. of New Eng., Mass. Hist. Soc. Coll., 2d series, vi. chap. 1xii. 552, 553.)

These words of Hubbard have contributed unjustly to make Dudley, single and alone, the victim of Antinomian vengeance in recent years.

An epitaph on Thomas Dudley by his daughter, Anne Bradstreet:-

\section{HIS EPITAPH.}

Within this tomb a Patriot lies

That was both pious, just and wise,

To truth a shield, to right a wall,

To sectaries a whip and maul,

A magazine of history,

A prizer of good company,

In manners pleasant and severe;

The good him lov'd, the bad did fear,

And when his time with years was spent,

If some rejoic'd, more did lament.

1 Dean Dudley's Hist. Dudley Family, i. 276. See Appendix B, C, D, E, F, G, H, I.

${ }^{2}$ Early records of Roxbury, N. E. Genealog. and Antiq. Reg., ii. 54. 
His will was in his own handwriting, and is duly recorded and preserved in the Suffolk probate office, Boston, Mass. $\mathrm{He}$ named his "worthy and beloved friends, John Eliot, teacher of the church at Roxbury, and Samuel Danforth, pastor of the said church," among his executors. He invoked in them that just and equitable spirit which had been the rule of his life. He says : "Entreating them, as my last request, that they will do for me and mine as I would have done for them and theirs in the like case." The last codicil to this will was only thirteen days before his decease. But previous dates in April and May attached to the will assure us that he realized that his departure was near. He was in office as deputy governor until May I8, only two months and thirteen days previous to his death, and his absence from office is conclusive evidence that he was ill, or too feeble for service.

The following lines from the will are of great public interest, like the dying words of the Commander to the Old Guard. Some persons will read nothing in them but narrowness and bigotry. It was the day of small things, but it was the seed-sowing, the planting, of a nation possibly to be greater than any other in the previous history of the world :

"For my soul I commend it into the hand of my God, in whom I have believed, whom I have loved, which he hath promised to receive in Jesus Christ, my Redeemer and Saviour, with whom I desire ever to be, leaving this testimony behind me, for the use and example of my posterity, and any other upon whom it may work, that I have hated and do hate every false way in religion, not only the old idolatry and superstition of Popery, which is wearing away, but much more (as being much worse) the new heresies, blasphemies, and errors of late sprung up in our native country of England, and secretly received and fostered more than I wish they were here." This document, from beginning to end, is written in that clear, terse language which well sustains his early reputation for skill in drafting public papers. 
He certainly had no superior in this respect among his associates in the government. His sincere conviction of the danger from heresy to their work in church and state is vigorously and weightily stated here, in his last appeal to his countrymen. Public sentiment has long been against his theory of the true method of action by which to keep a church and state pure and safe ; a larger territory and population has contributed to the change; it welcomes now, instead, free speech and a free press, to the very verge of libel and slander, and tolerates nearly every doctrine under the sun, in science and religion.

There is great and ancient authority for letting both the tares and the wheat grow together, but there have been times when the only possible way of saving the wheat was by violence and revolution; or, in other words, a reversal in public sentiment which set the other way with the force of a tide in the ocean. 


\section{CONCLUSION}

THE assumption which is the groundwork of the American portion of this biography of Thomas Dudley is that he and the colony of Massachusetts were inseparable during the period from 1630 to 1653 .

If Lord Byron correctly said, -

"I live not in myself, but I become

Portion of that around me;" 1

if Lord Tennyson properly affirmed, -

"I am a part of all that I have met;" 2

then for stronger, more essential reasons a person may be said to be an integral part of his acts, and Thomas Dudley inseparable from every important event in this period of the history of Massachusetts. His handiwork, in common with that of Winthrop and others, lies at the beginning of the institutions of Massachusetts, and attended them beyond the period of her adolescence to the fixed development which has made her character memorable in history.

Neither he nor Winthrop entertained the autocratic idea of Louis XIV. of France, when he exclaimed, "I am the state," although many persons have seemed to regard Winthrop as such. This was their work in company with their associates, among whom they were the two most conspicuous.

There is an inscription in Latin to Sir Christopher Wren, the architect of Saint Paul's Cathedral, in London, over its north porch, ending with these words, which comprehend

1 Childe Harold, chap. iii.

2 Ulysses. 
his merit and his fame: "If thou seekest his monument, look around." The greatest orator Massachusetts ever had (we might as truly say, or any other modern state) in a memorable moment, when her character was assailed in the national capitol, exclaimed, "There she is. Behold her, and judge for yourselves. There is her history ; the world knows it by heart. The past at least is secure."

Massachusetts is herself the memorial of her founders ; to comprehend her annals is to know, appreciate, and admire them.

In the hands of Winthrop, Dudley, and their associates she grew to be almost a sovereign commonwealth; she determined without foreign advice the issues of war and of peace; she joined in a confederation with sister colonies; she exercised the sovereign prerogative of coining money; while without hesitation she taxed her citizens and their estates, she contributed nothing to the treasury of England, she created her own laws, with a respectful acknowledgment of their subordination to the supreme authority of the laws of England, but resisted and disclaimed all rights of appeal to foreign jurisdiction; she had in the Body of Liberties twelve capital laws, involving the issues of life and death; and in her Laws and Liberties, published in 1649 , is a statute against rebellion, conspiracy, invasion, and insurrection, in effect, including treason, with a death penalty attached to the violation of the law; she raised armies and equipped them, and fortified her ports, and collected tribute of her neighbors ; she received agents of France and of Holland, and appointed agents to negotiate with them and make treaties of peace and consult about alliances for mutual protection; when she felt that her liberties were in peril from British intervention, she always resorted to a Fabian policy, and to fasting and prayer, and thus retained her first charter, as a bulwark against English supremacy, until I684. ${ }^{1}$

There were thirty-one towns, or units, of our system, represented in the General Court at the decease of Dudley, in

1 Maverick's Description of N. E., 1660, 19. 
1653. The government of Massachusetts was a representative republic, with the departments of executive, judiciary, and legislative authority. The ministers had no political power; they had, however, great influence because of their extensive knowledge and excellent character. They were also very numerous early in the history of the colony.

Massachusetts established a common school system at that time in advance of all the world, supported by public money, and enforced attendance to the schools was exacted by law.

It is well to remember, also, her relative importance in the New England colonies. More than half of the population of the entire confederacy was in Massachusetts, and more than half of the wealth. She was the mother of states, Rhode Island and Connecticut being her offspring, while Maine and New Hampshire were an integral portion of her, and Vermont was not yet settled.

Plymouth Rock was the beginning, in 1620 , without which the other colonies might never have existed, while without the "great emigration" to Massachusetts, in 1630, the Plymouth Colony might have perished. ${ }^{1}$

Plymouth was the first in American church independency, ${ }^{2}$ and her people endured greater privations and suffering than those of any other New England colony. But she was not otherwise conspicuous. She has contributed her full share towards making Massachusetts great and strong, but after all she has been tributary and incidental, and not the trunk and main body of character and influence, ${ }^{3}$ the orators of Forefathers' Day to the contrary notwithstanding. She was as sound in the faith as Massachusetts, but more tender towards Mrs. Hutchinson, the Baptists, and Quakers.

Massachusetts not only took the lead in population and wealth, but in education, in political organization, ${ }^{4}$ in its code of laws, ${ }^{5}$ in that unconquerable energy which captured Louisburg on Cape Breton Island, which brought the colony

1 Hutchinson, ii. 476, 477.

4 Ib., ii. 467.
2 Ib., ii. 467.

5 Ib., ii. 463 .
8 Ib., ii. 468,469 . . 
to the front in King Philip's War (though Plymouth suffered fearfully), and made the State most prominent in the War of the Revolution ${ }^{1}$ and in the Civil War, and later in philanthropy, in charities, and in literature. The leadership has emanated from Boston, the "Hub," and not from Plymouth.

What Governor Hutchinson has said of the distinguished men of Plymouth applies with still greater force to the eminent founders of Massachusetts. "I am not preserving from oblivion the names of heroes, whose chief merit is the overthrow of cities, provinces, and empires, but the names of the founders of flourishing towns and a colony, if not of the whole British empire in America." 2

The existence of these English colonies for a time was uncertain, as they were beset with enemies. The Dutch were on the west, the French on the east and north, the Spaniards on the west and south, and the Indians everywhere. If the story of our country is the story of the growth of modern liberty, the importance of the Massachusetts colony at this critical juncture is measureless.

We have thus briefly presented a few characteristics of Massachusetts as she came forth from the hands of her great master builders; her progress we have been following through these pages in the life of one of the greatest of her founders. Lord Macaulay said, "The Puritans were perhaps the most remarkable body of men the world has ever known." Here certainly was their greatest and most permanent work. Royalty overwhelmed them in England, but both they and the remarkable productions of their labors survive here, since the democratic republic still exists.

We are ungrateful children if, with the magnificent inheritance which they have transmitted to us, we, without becoming candor, deride their bigotry or make light of their zeal; if we measure them by the standard of civilization and public opinion of our age.

Edward Everett said, "I reverence, this side of idolatry,

1 Anglo-Saxon Freedom, Hosmer, 216, note I.

2 Hutchinson, ii. 463. 
the wisdom and fortitude of the revolutionary and constitutional leaders, but I believe we ought to go back beyond them all for the real framers of the commonwealth. I believe that its foundation stones, like those of the capitol of Rome, lie deep and solid, out of sight at the bottom of the wall ; Cyclopean work - the work of the Pilgrims [Puritans] - with nothing below them but the rock of ages." 1

We have noticed in an early portion of this work the very' creditable career of Thomas Dudley in England before he came to America, at the age of fifty-four years. We then congratulated ourselves that at that mature period in life the remainder of his journey would be secure, and that we might safely conclude that he would be guided by the same wisdom and sound judgment which had distinguished his course in the past. We were then sure that what he had already achieved, his well-established principle, manifest tendencies, and that genuine character which inspires confidence in all of us were guarantees of his great future in America.

Nothing less than the testimony of two witnesses to any overt act of wrong-doing, charged against him in the face of this record, can carry conviction to the minds of those who are informed respecting him. Winthrop's Journal, unsupported in matters of controversy, is to be read thoughtfully. Such is the force and influence of well-established and thoroughly grounded character in human society. We firmly believe that his American record sustains our expectations thus early formed, and that our confidence in his future was not then misplaced.

The nations of antiquity deified the founders of their states, but there are indifferent citizens in the old commonwealth who detract from the just merits of her heroes and planters with every refinement of severity. "God sifted a whole nation that he might send choice grain over into this wilderness," said the Rev. William Stoughton in 1669. "God had sifted three kingdoms to find wheat for this planting,"

1 Oration on the Settlement of Mass., 243. 
sang H. W. Longfellow. Emerson has said that "to be great is to be misunderstood."

Dudley belonged to that immediate age after the Bible came to the English common people. He was never blessed with the light of "higher criticism," but read the Bible in childlike simplicity and belief. He was also a sincere, earnest Calvinist. He breathed the same air, read the same literature, and heard the same ministers preach as his associates. He delighted in the preaching of the greatest and most learned Puritan divines, both in England and in America.

The author is convinced, after careful examination, that the incidents and poems which have been the stock material for writers during many years, used, repeated, and enlarged upon to discredit the name and character of Governor Dudley, have been misconstrued and misunderstood. "Let not the land once proud of him insult him now." The aim and purpose to do justice, tardy indeed, to the life and character of Governor Dudley has been an important incident in our work, as we intimated at the beginning that it would be. It has been our earnest purpose to have the truth spoken at last respecting him.

Those lines found in Dudley's pocket after his death, which we have given, are usually quoted to prove his bigotry, respecting which one author says, "wherein the intolerance of that age is neatly summed up." This author uses certain of these grim epithets, and then says in effect that these lines by Dudley "neatly sum up the intolerance of that age." If we understand him, Dudley is no more intolerant in his verses, at least, than his neighbors in their opinions; and if the lines do really express the height and depth of their intolerant thought, he ought not to be selected to receive from this age vicarious punishment for all the heapedup sins in bigotry of his period. If, on the other hand, it is the purpose of these critics to single out Dudley as the foremost Puritan, more truly representative of his age than any one else, then we claim that before the casting of stones at 
him began, it should have been publicly announced that he suffered in the stead and behalf of his most illustrious contemporaries and for the errors of an intolerant age, as its special hero.

The fact is, as we have shown, that his lines were intended to call attention to public danger from fanatics. For two reasons: people were more exposed then to danger than we are. They had no. prisons or asylums ; and society was then so limited in extent that a few ungovernable people could do greater harm than would be possible to-day in the midst of millions of inhabitants. ${ }^{1}$

Mr. Savage says, in effect, that Dudley was penurious. But he had judgments of the Court against Winthrop and freely gave the claims to him. He placed a bond upon his estate and headed the list of subscriptions to secure the permanency of the Roxbury Latin School. Morton says that he served the public many years at his own cost. These are a few instances, and more might be cited with a confirmation from his written words, to show that he was not selfish or mean, but on the other hand in a high degree public-spirited. His emigration itself confutes the accusation.

\footnotetext{
"One of thy Founders, him New-England know, Who staid thy feeble sides when thou wast low, Who spent his estate, his strength, and years with care That After-comers in them might have share. True patriot of this little Commonweal, Who is't can tax thee aught, but for thy zeal?" 2
}

1 These hostile writers seem, through centuries, to have hung on Governor Thomas Dudley, "as if increase of appetite had grown by what it fed upon." This is an ancient as well as modern experience. A Roman poet two centuries before Christ discovered it, "for enemies carry about slander not in the form in which it took its rise." But a nobler Roman said, "There is nothing which wings its flight so swiftly as calumny, nothing which is uttered with more ease; nothing is listened to with more readiness, nothing dispersed more widely;" and Shakespeare declares, "Whose breath rides on the posting winds and doth belie all corners of the world."

2 Anne Bradstreet. 
The opinions formed of Dudley in his lifetime by his fellow-citizens, as we have said, are the only conclusive ones for or against him, since he has left little in writing by which to judge of his sentiments. These opinions, so far as we have discovered, are uniformly and strongly in his favor, with the slight exception of a few sentences in Winthrop's Journal, written in the heat of personal encounter. But in later years and cooler moments Winthrop has given his testimony greatly to the credit of Dudley. He knew Dudley more thoroughly than any one else.

He says of him, "This gentleman was a man of approved wisdom and godliness and of much good service to the country, and therefore it was his due to serve in such honor and benefit as the country had to bestow." 1

These words, "approved wisdom and godliness," possess an excellent flavor, considering their source; and moreover they then had been ten years together in authority, in the most difficult and responsible period, consulting each other at every step, not always agreeing, but in those differences Dudley was, perhaps in every instance, approved by the Court and people. Their early bickerings were now passed and gone, they had settled down to their business of statecraft in earnest.

We have through the diary of Winthrop the contemporary testimony in 1635 of Sir Harry Vane, supported by that of Governor John Haynes, Richard Bellingham, Cotton, Hooker, and Wilson, that "Dudley and Winthrop were those upon whom the weight of the affairs did lie," etc. ${ }^{2}$

1 Winthrop, ii. *3.

2 Ib., i. *I77. Increase Mather, president of Harvard University, a contemporary of Thomas Dudley, pronounced him "a principal founder and pillar of the colony of Massachusetts, and as a nursing father of the churches." (Hist. Harv. Univ., by Josiah Quincy, i. I 52.) Even Roger Williams, in 1640 , when his trials in Massachusetts were ended, writes to Winthrop of his "much honored brother, Mr. Governor" [Dudley.] (Pub. Narr. Club, vi. I38.)

The testimony of Dudley's neighbor, Nathaniel Morton, of Plymouth, is of great value. Morton, from his professional life of secretary of the 
It is highly probable that the temporary unpopularity in Massachusetts of Governor Joseph Dudley, ${ }^{1}$ the efficient

Court, was in the very best position to estimate the value of men. His work, "New England's Memorial," has the approval of historians. He says : "Mr. Dudley, who was a principal founder and pillar of the colony of the Massachusetts, in New England, and sundry times governor and deputy governor of that jurisdiction, died at his home in Roxbury, July 31, I653, in the seventy-seventh year of his age. $\mathrm{He}$ was a person of quick understanding and solid judgment in the fear of the Lord. He was a lover of justice, order, the people, Christian religion, - the supreme virtues of a good magistrate.

"I. His love to justice appeared at all times, and in special upon the judgment-seat, without respect of persons in judgment; and in his own particular transactions with all men he was exact and exemplary.

"II. His zeal to order appeared in contriving good laws and faithfully executing them upon criminal offenders, heretics, and underminers of true religion. He had a piercing judgment to discover the wolf, though clothed with a sheepskin.

"III. His love to the people was evident in serving them in a public. capacity many years, at his own cost, and that as a nursing father to the churches of Christ.

"IV. He loved the true Christian religion, and the pure worship of God, and cherished as in his bosom all godly ministers and Christians. He was exact in the practice of piety, in his person and family, all his life. In a word, he lived desired, and died lamented by all good men." (Nathaniel Morton's New England's Memorial, 166.)

What a need there is in executive chairs, in legislative halls, and on the benches of justice for such able and upright public men!

Another personal acquaintance of Dudley was Captain Edward Johnson, who came with him in the "great emigration" in 1630 , and represented the town of Woburn in the General Court every year until I67I, except I643. They were thus officially connected in the government nine years, and were probably acquainted as long as Mr. Dudley lived in the colony.

Johnson says of him, that in 1632 "The ancient Thomas Dudley, Esq., was deputy governor, a man of a sound judgment in matters of religion and well read, bestowing much labor that way, of whom as followeth: The honored, aged, stable, and sincere servant of Christ, zealous for his truth, Thomas Dudley, Esq., four times governor of the English nation in the Massachusetts, and first major-general of the military forces." He says again, "In 1647 the honored John Win- 
friend of Harvard, but also an ally of royalty and Andros, may have without reason diminished public respect for the family, and left the robust character of his father unguarded and exposed, in the tumult of politics, to deductions, and inferences from that portion of Winthrop's Journal which covers the brief period when he and Winthrop were not good friends.

If we compare the men who were most prominent in the founding of Massachusetts, we shall find that Governor Endicott was a more reckless man than Governor Dudley, as shown by his contempt of Court in $1635,{ }^{1}$ and by his cutting the red cross out of the king's colors ; more vindictive, as was evident in his treatment of Baptists, ${ }^{2}$ and later of the Quaker martyrs. ${ }^{3}$

Governor Winthrop was more morbid and superstitious, as appears in his own account of Mary Dyer and Ann Hutchinson, and in other writings by him, ${ }^{4}$ and was more

throp, Esq., was chosen governor, and the like honored Thomas Dudley, Esq., deputy governor." (Wonder-Working Providence, 68, 207.)

The General Court, in I646, speaks of "our much-honored and right trusty and well-beloved Thomas Dudley, Esq."

William Hubbard, who came to Massachusetts in 1635 and graduated at Harvard in 1642 in its first class, knew Governor Dudley and the public estimate of him, and he says in his New England History that when he died he left not his equal behind in the magistracy. (Mass. Hist. Soc. Coll., 2 d series, vi. chap. 1xii. 552.)

Cotton Mather was born ten years after the decease of Dudley, and must have known many persons who knew him, including his own distinguished father, Increase Mather. $\mathrm{He}$ informs us that " $\mathrm{He}$ was a man of great spirit as well as of a great understanding; suitable to the family he was by his father descended from; and envy itself cannot deny him a place amongst the first three that ever were called to intermeddle in the affairs of the Massachusetts. He was endowed with many excellent abilities that qualified him thereunto." (Proc. Mass. Hist. Soc. 1870,220 .)

1 Mass. Col. Rec., i. 157.

${ }^{2}$ Backus's Hist. Bapt., i. I8r.

${ }^{3}$ Dudley had deceased three years before any Friends arrived in Boston.

4 E. Eggleston's Beginnings of a Nation, 340, 34I. 
contracted in his political ideas, as was seen in his opposition to Governors Vane and Dudley in the matter of spreading the king's colors at Castle Island. ${ }^{1}$

He was not so frank and open as Dudley, as appeared in his method of removing his house from Cambridge, which was disapproved of by the Court ; more intriguing, as manifested in letting the officers go to Salem to arrest Roger Williams, when he had reason to believe that under his own advice he had already gone to Rhode Island, the particular movement by Williams which the Court feared, and wished to prevent.

He did no more constructive work in the committees in framing the laws than Dudley. He and Dudley were each twice president of the confederacy, and no other person was president when either of them was a commissioner. Dudley was commissioner in 1643,1647 , and 1649. They both assisted in forming the Articles of Confederation, and for nine or ten of the last years of their lives were brothers beloved, of one political faith, and if they had personal differences they kept them to themselves. There was one striking contrast between them: Dudley, as we have noticed, took no care for posthumous fame; and what is more strange, with one exception, concealed his ancestry, which was eminent. If he had said more about himself he probably would have left less opportunity for misrepresentation of his character. Winthrop left a diary, was the first governor and founder, and in recent years his statue is erected in Boston, at Mount Auburn, and in the Capitol at Washington, justly proclaiming him as the founder of Massachusetts; but he was not alone in that immortal service, and should share the honor with his worthy colleague. ${ }^{2}$

1 Winthrop, i. * I $89 ;$ ii. * 42 I.

2 The omission of Dudley from that companionship of illustrious names which encircles the hall of representatives in the capitol of Massachusetts is a matter for anxious thought. Dudley was in any event, however otherwise bounded or described, hardly second in weight and influence in the beginning of the colony. His career furnishes no 
We trust that the commonwealth which Dudley helped to found will at last in sincere gratitude, after these tardy years, place his statue, a thing he never sought, in her great public squares, that the world may know that she delights without respect of persons to honor her illustrious men, and to extend the influence of noble character and honorable public service to the coming generations of her citizens.

Dudley had little personal ambition for fame. His politics seemed to be guided by his idea of the higher law. He was considering conscience more and fostering reputation less. He was not casting about to discover what he was to get out of political action or what niche in earthly renown would reward him.

We are convinced that for sterling worth and ability, for downright manliness, for that true grandeur of righteous character and Christian virtue which we admire in Washington and in Lincoln, Thomas Dudley was the peer of any man among the founders of New England.

excuse for neglect, like the too bold words of Byron, which excluded his ashes from Westminster Abbey, as if in realization of his prophetic lines:-

\footnotetext{
"If my fame should be, as my fortunes are, Of hasty growth and blight, and dull Oblivion bar My name from out the temple where the dead Are honor'd by the nations - let it be And light the laurels on a loftier head! And be the Spartan's epitaph on me 'Sparta hath many a worthier son than he.'"
}

(Childe Harold, Canto iv. 8o-86.)

This oversight of Dudley is sunfortunately only one among many evidences that true grandeur of character may be rejected by the people who sometimes subsequently erect monuments to its undying worth. La Fontaine wisely said, "If you really wish to prevent the commission of injustice, you must first remove error and prejudice." 


\section{APPENDIX A \\ GOVERNOR THOMAS DUDLEY'S LETTER ${ }^{2}$}

To the Right Honorable, my very good Lady, the Lady BRidGet, Countess of Lincoln :

Madam, - Your letters (which are not common nor cheap), following me hither into New England, and bringing with them renewed testimonies of the accustomed favors you honored me with in the Old, have drawn from me this narrative retribution, which (in respect of your proper interest in some persons of great note amongst us) was the thankfullest present I had to send over the seas. Therefore I humbly entreat your Honor this be accepted as payment from him who neither hath nor is any more than

Your Honor's old thankful servant,

Boston, in New-England, March I2th, 1630.

T. D.

For the satisfaction of your honor and some friends, and for the use of such as shall hereafter intend to increase our Plantation in New England, I have, in the throng of domestic, and not altogether free from public business, thought fit to commit to memory our present condition, and what hath befallen us since our arrival here; which I will do shortly, after my usual manner,

1 Samuel E. Drake says, "I should not be pardoned by any intelligent reader, I think, were I not to allow a man of Governor Dudley's importance to tell things as he saw and knew them; being one of those who wrote 'with his hands to the plow, and tells us things nowhere else to be found. He wrote within the year of settlement. ... With this paragraph ends the invaluable Letter of Dudley. No document in the annals of Boston will compare in importance with it, and no one can successfully study this period of its history without it." (Drake's Hist. and Antiq. of Boston, 91, 122, 123, notes.) Alexander Young pronounces it "the most interesting as well as authentic document in our early annals." (Young's Chron., 340, note.) James Savage says, "The high authority of Governor Dudley's Narrative (Mass. Hist. Coll., Ist series, viii. 37) makes it vanish." (Winthrop, i. *43.) One of the best annotated copies of this letter is in Young's Chronicles, 303-34I. 
and must do rudely, having yet no table nor other room to write in than by the fireside upon my knee, in this sharp winter; to which my family must have leave to resort, though they break good manners, and make me many times forget what I would say, and say what I would not.

. . . sachim in New-England, whom I saw the last summer. Upon the river of Naponset, near to the Mattachusetts fields, dwelleth Chickatalbott, who hath between fifty and sixty subjects. This man least favoreth the English of any sagamore (for so are the kings with us called, as they are sachims southwards) we are acquainted with, by reason of the old quarrel between him and those of Plymouth, wherein he lost seven of his best men; yet he lodged one night the last winter at my house in friendly manner. About seventy or eighty miles westward from these are seated the Nipnett men, whose sagamore we know not, but we hear their numbers exceed any but the Pequods and the Narragansets, and they are the only people we yet hear of in the inland country. Upon the river of Mistick is seated sagamore John, and upon the river of Saugus sagamore James, his brother, both so named by the English. The elder brother, John, is a handsome young man, [one line missing] conversant with us, affecting English apparel and houses, and speaking well of our God. His brother James is of a far worse disposition, yet repaireth often to us. Both these brothers command not above thirty or forty men, for aught I can learn. Near to Salem dwelleth two or three families, subject to the sagamore of Agawam, whose name he told me, but I have forgotten it. This sagamore hath but few subjects, and them and himself tributary to sagamore James, having been before the last year (in James's minority) tributary to Chickatalbott. Upon the river Merrimack is seated sagamore Piscataqua, having under his command four or five hundred men, being esteemed by his countrymen a false fellow, and by us a witch. For any more northerly, I know not, but leave it to after Relations.

Having thus briefly and disorderly, especially in my description of the bays and rivers, set down what is come to hand touching the [one line missing].

Now concerning the English that are planted here, I find that about the year 1620 certain English set out from Leyden, in Holland, intending their course for Hudson's river, the mouth 
whereof lieth south of the river of the Pequods, but ariseth, as I am informed, northwards in about $43^{\circ}$, and so a good part of it within the compass of our patent. These, being much weather-beaten and wearied with seeking the river, after a most tedious voyage arrived at length in a small bay lying northeast from Cape Cod; where landing about the month of December, by the favor of a calm winter, such as was never seen here since, began to build their dwellings in that place which now is called New Plymouth; where, after much sickness, famine, poverty, and great mortality (through all which God by an unwonted providence carried them), they are now grown up to a people healthful, wealthy, politic, and religious; such things doth the Lord for those that wait for his mercies. These of Plymouth came with patents from King James, and have since obtained others from our sovereign, King Charles, having a governor and council of their own.

There was about the same time one Mr. Weston, an English merchant, who sent divers men to plant and trade, who sat down by the river of Wesaguscus. But these coming not for so good ends as those of Plymouth, sped not so well ; for the most of them dying and languishing away, they who survived were rescued by those of Plymouth out of the hands of Chickatalbott and his Indians, who oppressed these weak English and intended to have destroyed them, and the Plymotheans also, as is set down in a tract written by Mr. Winslow, of Plymouth.

Also, since, one Captain Wollaston, with some thirty with him, came near to the same place, and built on a hill which he named Mount Wollaston. . But being not supplied with renewed provisions, they vanished away, as the former did.

Also divers merchants of Bristow, and some other places, have yearly for these eight years, or thereabouts, sent ships hither at the fishing times to trade for beaver; where their factors dishonestly, for their gains, have furnished the Indians with guns, swords, powder and shot.

Touching the Plantation which we here have begun, it fell out thus. About the year 1627 , some friends being together in Lincolnshire, fell into discourse about New-England, and the planting of the Gospel there ; and after some deliberation we imparted our reasons, by letters and messages, to some in London and the west country; where it was likewise deliberately thought upon, and at length with often negotiation so ripened, that in the year 
I628 we procured a patent from his Majesty for our planting between the Massachusetts Bay and Charles river on the south, and the river of Merrimack on the north, and three miles on either side of those rivers and bay; as also for the government of those who did or should inhabit within that compass. And the same year we sent Mr. John Endicott, and some with him, to begin a Plantation, and to strengthen such as he should find there, which we sent thither from Dorchester and some places adjoining. From whom the same year receiving hopeful news, the next year, 1629, we sent divers ships over, with about three hundred people, and some cows, goats, and horses, many of which arrived safely.

These, by their too large commendations of the country and the commodities thereof, invited us so strongly to go on, that Mr. Winthrop, of Suffolk (who was well known in his own country, and well approved here for his piety, liberality, wisdom, and gravity), coming in to us, we came to such resolution, that in April, 1630, we set sail from Old England with four good ships. And in May following eight more followed; two having gone before in February and March, and two more following in June and August, besides another set out by a private merchant. These seventeen ships arrived all safe in New-England, for the increase of the Plantation here this year, 1630, but made a long, a troublesome, and costly voyage, being all wind-bound long in England, and hindered with contrary winds after they set sail, and so scattered with mists and tempests that few of them arrived together. Our four ships which set out in April arrived here in June and July, where we found the Colony in a sad and unexpected condition, above eighty of them being dead the winter before, and many of those alive weak and sick; all the corn and bread amongst them all hardly sufficient to feed them a fortnight, insomuch that the remainder of a hundred and eighty servants we had the two years before sent over, coming to us for victuals to sustain them, we found ourselves wholly unable to feed them, by reason that the provisions shipped for them were taken out of the ship they were put in, and they who were trusted to ship them in another failed us and left them behind, whereupon necessity enforced us, to our extreme loss, to give them all liberty, who had cost us about $£ \mathrm{I} 6$ or $£ 20$ a person, furnishing and sending over. 
But bearing these things as we might, we began to consult of the place of our sitting down; for Salem, where we landed, pleased us not. And to that purpose, some were sent to the Bay, to search up the rivers for a convenient place; who, upon their return, reported to have found a good place upon Mistick; but some others of us, seconding these, to approve or dislike of their judgment, we found a place [that] liked us better, three leagues up Charles river; and thereupon unshipped our goods into other vessels, and with much cost and labor brought them in July to Charlestown. But there receiving advertisements, by some of the late arrived ships, from London and Amsterdam, of some French preparations against us (many of our people brought with us being sick of fevers and the scurvy, and we thereby unable to carry up our ordnance and baggage so far), we were forced to change counsel, and for our present shelter to plant dispersedly, some at Charlestown, which standeth on the north side of the mouth of Charles river; some on the south side thereof, which place we named Boston (as we intended to have done the place we first resolved on); some of us upon Mistick, which we named Medford; some of us westwards on Charles river, four miles from Charlestown, which place we named Watertown; others of us two miles from Boston, in a place we named Roxbury; others upon the river of Saugus, between Salem and Charlestown; and the western men four miles south from Boston, at a place we named Dorchester.

This dispersion troubled some of us; but help it we could not, wanting ability to remove to any place fit to build a town upon, and the time too short to deliberate any longer, lest the winter should surprise us before we had builded our houses. The best counsel we could find out was to build a fort to retire to, in some convenient place, if any enemy pressed us thereunto, after we should have fortified ourselves against the injuries of wet and cold. So ceasing to consult further for that time, they who had health to labor fell to building, wherein many were interrupted with sickness, and many died weekly, yea, almost daily. Amongst whom were Mrs. Pynchon, Mrs. Coddington, Mrs. Phillips, and Mrs. Alcock, a sister of Mr. Hooker's. Insomuch that the ships being now upon their return, some for England, some for Ireland, there was, as I take it, not much less than a hundred (some think many more), partly out of dislike of our government, which 
restrained and punished their excesses, and partly through fear of famine, not seeing other means than by their labor to feed themselves, which returned back again; and glad were we so to be rid of them. Others also, afterwards hearing of men of their own disposition, which were planted at Piscataqua, went from us to them, whereby though our numbers were lessened, yet we accounted ourselves nothing weakened by their removal. Before the departure of the ships, we contracted with Mr. Peirce, master of the Lion, of Bristow, to return to us with all speed with fresh supplies of victuals, and gave him directions accordingly. With this ship returned Mr. Revell, one of the five undertakers here for the joint stock of the company, and Mr. Vassall, one of the Assistants, and his family, and also Mr. Bright, a minister sent hither the year before.

The ships being gone, victuals wasting, and mortality increasing, we held divers fasts in our several congregations. But the Lord would not yet be deprecated; for about the beginning of September died Mr. Gager, a right godly man, a skilful chirurgeon, and one of the deacons of our congregation; and Mr. Higginson, one of the ministers of Salem, a zealous and a profitable preacher - this of a consumption, that of a fever; and on the 3 oth of September died Mr. Johnson, another of the five undertakers (the Lady Arbella, his wife, being dead a month before). This gentleman was a prime man amongst us, having the best estate of any, zealous for religion, and the greatest furtherer of this Plantation. He made a most godly end, dying willingly, professing his life better spent in promoting this Plantation than it could have been any other way. He left to us a loss greater than the most conceived. Within a month after, died Mr. Rossiter, another of our Assistants, a godly man, and of a good estate, which still weakened us more. So that now there were left of the five undertakers but the governor, Sir Richard Saltonstall, and myself, and seven other of the Assistants. And of the people who came over with us, from the time of their setting sail from England in April, r630, until December following, there died by estimation about two hundred at the least; so low hath the Lord brought us!

Well, yet they who survived were not discouraged, but bearing God's corrections with humility and trusting in his mercies, and considering how, after a lower ebb, he had raised up our 
neighbours at Plymouth, we began again in December to consult about a fit place to build a town upon, leaving all thoughts of a fort, because upon any invasion we were necessarily to lose our houses, when we should retire thereinto. So after divers meetings at Boston, Roxbury, and Watertown, on the 28th of December we grew to this resolution, to bind all the Assistants (Mr. Endicott and Mr. Sharpe excepted, which last purposeth to return by the next ship into England) to build houses at a place a mile east from Watertown, near Charles river, the next spring, and to winter there the next year; that so by our examples, and by removing the ordnance and munition thither, all who were able might be drawn thither, and such as shall come to us hereafter, to their advantage be compelled so to do; and.so, if God would, a fortified town might there grow up, the place fitting reasonably well thereto.

I should have mentioned how both the English and Indian corn being at ten shillings a strike, and beaver being valued at six shillings a pound, we made laws to restrain the selling of corn to the Indians, and to leave the price of beaver at liberty, which was presently sold for ten and twenty shillings a pound. I should also have remembered, how the half of our cows and almost all our mares and goats, sent us out of England, died at sea in their passage hither, and that those intended to be sent us out of Ireland were not sent at all; all which, together with the loss of our six months' building, occasioned by our intended removal to a town to be fortified, weakened our estates, especially the estates of the undertakers, who were 3 or $£ 4000$ engaged in the joint stock, which was now not above so many hundreds. Yet many of us labored to bear it as comfortably as we could, remembering the end of our coming hither, and knowing the power of God, who can support and raise us again, and useth to bring his servants low that the meek may be made glorious by deliverance.

In the end of this December departed from us the ship Handmaid, of London, by which we sent away one Thomas Morton, a proud, insolent man, who has lived here divers years, and had been an attorney in the west countries while he lived in England. Multitude of complaints were received against him for injuries done by him both to the English and Indians; and amongst others, for shooting hailshot at a troop of Indians for not bring- 
ing a canoe unto him to cross a river withal, whereby he hurt one, and shot through the garments of another. For the satisfaction of the Indians wherein, and that it might appear to them and to the English that we meant to do justice impartially, we caused his hands to be bound behind him, and set his feet in the bilboes, and burned his house to the ground, all in the sight of the Indians, and so kept him prisoner till we sent him for England; whither we sent him, for that my Lord Chief Justice there so required, that he might punish him capitally for fouler misdemeanours there perpetrated, as we were informed.

I have no leisure to review and insert things forgotten, but out of due time and order must set them down as they come to memory. About the end of October this year, 1630, I joined with the governor and Mr. Mavereck in sending out our pinnace to the Narragansetts, to trade for corn to supply our wants ; but after the pinnace had doubled Cape Cod, she put into the next harbour she found, and there meeting with Indians, who showed their willingness to truck, she made her voyage there, and brought us a hundred bushels of corn, at about four shillings a bushel, which helped us somewhat. From the coast where they traded, they saw a very large island, four leagues to the east, which the Indians commended as a fruitful place, full of good vines, and free from sharp frosts, having one only entrance into it, by a navigable river, inhabited by a few Indians, which for a trifle would leave the island, if the English would set them upon the main; but the pinnace, having no direction for discovery, returned without sailing to it, which in two hours they might have done. Upon this coast they found store of vines full of grapes dead ripe, the season being past; whither we purpose to send the next year sooner, to make some small quantity of wine, if God enable us; the vines growing thin with us, and we not having yet any leisure to plant vineyards.

But now having some leisure to discourse of the motives for other men's coming to this place, or their abstaining from it, after my brief manner I say this: that if any come hither to plant for worldly ends, that can live well at home, he commits an error, of which he will soon repent him; but if for spiritual, and that no particular obstacle hinder his removal, he may find here what may well content him, viz., materials to build, fuel to burn, ground to plant, seas and rivers to fish in, a pure air to breathe in, good 
water to drink, till wine or beer can be made; which, together with the cows, hogs, and goats brought hither already, may suffice for food; for as for fowl and venison, they are dainties here as well as in England. For clothes and bedding, they must bring them with them, till time and industry produce them here. In a word, we yet enjoy little to be envied, but endure much to be pitied in the sickness and mortality of our people. And I do the more willingly use this open and plain dealing, lest other men should fall short of their expectations when they come hither, as we to our great prejudice did, by means of letters sent us from hence into England, wherein honest men, out of a desire to draw over others to them, wrote somewhat hyperbolically of many things here. If any godly men, out of religious ends, will come over to help us in the good work we are about, I think they cannot dispose of themselves nor of their estates more to God's glory and the furtherance of their own reckoning. But they. must not be of the poorer sort yet, for divers years; for we have found by experience that they have hindered, not furthered the work. And for profane and debauched persons, their oversight in coming hither is wondered at, where they shall find nothing to content them. If there be any endued with grace, and furnished with means to feed themselves and theirs for eighteen months, and to build and plant, let them come over into our Macedonia and help us, and not spend themselves and their estates in a less profitable employment. For others, I conceive they are not yet fitted for this business.

Touching the discouragement which the sickness and mortality which every first year hath seized upon us and those of Plymouth, as appeareth before, may give to such who have cast any thoughts this way (of which mortality it may be said of us almost as of the Egyptians, that there is not a house where there is not one dead, and in some houses many), the natural causes seem to be in the want of warm lodging and good diet, to which Englishmen are habituated at home, and in the sudden increase of heat which they endure that are landed here in summer, the salt meats at sea having prepared their bodies thereto; for those only these two last years died of fevers who landed in June and July; as those of Plymouth, who landed in winter, died of the scurvy; as did our poorer sort, whose houses and bedding kept them not sufficiently warm, nor their diet sufficiently in heart. 
Other causes God may have, as our faithful minister, Mr. Wilson, lately handling that point, showed unto us, which I forbear to mention, leaving this matter to the further dispute of physicians and divines.

Wherefore to return, upon the $3 \mathrm{~d}$ of January died the daughter of Mr. Sharpe, a godly virgin, making a comfortable end, after a long sickness. The Plantation here received not the like loss of any woman since we came hither, and therefore she well deserves to be remembered in this place.

And to add to our sorrows, upon the $5^{\text {th }}$ day came letters to us from Plymouth, advertising us of this sad accident following: About a fortnight before, there went from us in a shallop to Plymouth six men and a girl, who, in an hour or two before night, on the same day they went forth, came near to the mouth of Plymouth bay; but the wind, then coming strongly from the shore, kept them from entering, and drove them to sea-wards; and they having no better means to help themselves, let down their killock, that so they might drive the more slowly, and be nearer land when the storm should cease. But the stone slipping out of the killock, and thereby they driving faster than they thought all the night, in the morning, when they looked out, they found themselves out of sight of land, which so astonished them (the frost being extreme, and their hands so benumbed with cold that they could not handle their oars, neither had any compass to steer by), that they gave themselves for lost, and lay down to die quietly. Only one man, who had more natural heat and courage remaining than the rest, continued so long looking for land that, the morning waxing clearer, he discovered land, and with difficulty hoisted the sail; and so the wind a little turning, two days after they were driven from Plymouth bay, they arrived at a shore unknown unto them. The stronger helped the weaker out of the boat, and taking their sail on shore, made a shelter thereof, and made a fire. But the frost had so pierced their bodies, that one of them died about three days after their landing, and most of the others grew worse, both in body and courage, no hope of relief being within their view. Well, yet the Lord pitying them, and two of them, who only could use their legs, going abroad rather to seek than to hope to find help, they met first with two Indian women, who sent unto them an Indian man, who informed them that Plymouth was within fifty miles, and 
offered together to procure relief for them, which they gladly accepting, he performed, and brought them three men from Plymouth (the governor and Council of Plymouth liberally rewarding the Indian, and took care for the safety of. our people), who brought them all alive in their boat thither, save one man, who, with a guide, chose rather to go over land; but quickly fell lame by the way, and getting harbour at a trucking-house the Plymotheans had in those parts, there he yet abides. At the others' landing at Plymouth, one of them died as he was taken out of the boat. Another, and he the worst in the company, rotted from the feet upwards, where the frost had gotten most hold, and so died within a few days. The other three, after God had blessed the chirurgeon's skill used towards them, returned safe to us. I set down this the more largely, partly because the first man that died was a godly man of our congregation, one Richard Garrad, who, at the time of his death, more feared he should dishonor God than cared for his own life; as also because divers boats have been in manifest peril this year, yet the Lord preserved them all, this one excepted.

Amongst those who died about the end of this January, there was a girl of eleven years old, the daughter of one John Ruggles of whose family and kindred died so many, that for some reason it was matter of observation amongst us; who, in the time of her sickness, expressed to the minister, and to those about her, so much faith and assurance of salvation as is rarely found in any of that age; which I thought not unworthy here to commit to memory. And if any tax me for wasting paper with recording these small matters, such may consider that little mothers bring forth little children; small commonwealths, matters of small moment, the reading whereof yet is not to be despised by the judjcious, because small things in the beginning of natural or politic bodies are as remarkable as greater in bodies full grown.

Upon the $5^{\text {th }}$ of February arrived here Mr. Peirce, with the ship Lion, of Bristow, with supplies of victuals from England, who had set forth from Bristow the Ist of December before. $\mathrm{He}$ had a stormy passage hither, and lost one of his sailors not far from our shore, who in a tempest having helped to take in the spritsail, lost his hold as he was coming down, and fell into the sea, where, after long swimming, he was drowned, to the great dolor of those in the ship, who beheld so lamentable a spectacle 
without being able to minister help to him, the sea was so high, and the ship drove so fast before the wind, though her sails were taken down. By this ship we understood of the fight of three of our ships and two English men-of-war coming out of the Straits, with fourteen Dunkirkers, upon the coast of England, as they returned from us in the end of the last summer; who, through God's goodness, with the loss of some thirteen or fourteen men out of our three ships, and I know not how many out of the two men-of-war, got at length clear of them; the Charles, one of our three, a stout ship of three hundred tons, being so torn, that she had not much of her left whole above water. By this ship we also understood the death of many of those who went from us the last year to Old England, as likewise of the mortality there; whereby we see there are graves in other places as well as with us.

Also, to increase the heap of our sorrows, we received advertisement by letters from our friends in England, and by the reports of those who came hither in this ship to abide with us (who were about twenty-six), that they who went discontentedly from us the last year, out of their evil affections towards us, have raised many false and scandalous reports against us, affirming us to be Brownists in religion, and ill affected to our state at home, and that these vile reports have won credit with some who formerly wished us well. But we do desire, and cannot but hope, that wise and impartial men will at length consider that such malecontents have ever pursued this manner of casting dirt, to make others seem as foul as themselves, and that our godly friends, to whom we have been known, will not easily believe that we are so soon turned from the profession we so long have made in our native country. And for our further clearing, I truly affirm, that I know no one person, who came over with us the last year, to be altered in judgment and affection, either in ecclesiastical or civil respects, since our coming hither. But we do continue to pray daily for our sovereign lord the King, the Queen, the Prince, the royal blood, the council and whole state, as duty binds us to do, and reason persuades others to believe. For how ungodly and unthankful should we be, if we should not thus do, who came hither by virtue of his Majesty's letters patent, and under his gracious protection, under which shelter we hope to live safely, and from whose kingdom and sub- 
jects we now have received and hereafter expect relief. Let our friends therefore give no credit to such malicious aspersions, but be more ready to answer for us than we hear they have been. We are not like those which have dispensations to lie; but as we were free enough in Old England to turn our insides outwards, sometimes to our disadvantage, very unlike is it that now, being procul a fulmine, we should be so unlike ourselves. Let therefore this be sufficient for us to say, and others to hear in this matter.

Amongst others who died about this time was Mr. Robert Welden, whom, in the time of his sickness, we had chosen to be captain of a hundred foot; but before he took possession of his place, he died, the r6th of this February, and was buried as a soldier, with three volleys of shot.

Upon the $22 \mathrm{~d}$ of February we held a general day of Thanksgiving throughout the whole colony for the safe arrival of the ship which came last with our provisions.

About this time we apprehended one Robert Wright, who had been sometimes a linen draper in Newgate market, and after that a brewer on the Bank side and on Thames street. This man, we lately understood, had made an escape in London from those who came to his house to apprehend him for clipping the King's coin [one or two words missing] had stolen after us. Upon his examination he confessed the fact, and his escape, but affirmed he had the King's pardon for it under the broad seal; which he yet not being able to prove, and one to whom he was known charging him with untruth in some of his answers, we therefore committed him to prison, to be sent by the next ship into England.

Likewise we were lately informed that one Mr. Gardiner, who arrived here a month before us, and who had passed here for a knight, by the name of Sir Christopher Gardiner, all this while was no knight, but instead thereof had two wives now living in a house at London, one of which came about September last from Paris in France (where her husband had left her years before) to London, where she had heard her husband had married a second wife, and whom, by inquiring, she found out. And they both condoling each other's estate, wrote both their letters to the governor (by Mr. Peirce, who had conference with both women in the presence of Mr. Allerton, of Plymouth), his first wife desiring 
his return and conversion, his second his destruction for his foul abuse, and for robbing her of her estate, of a part whereof she sent an inventory hither, comprising therein many rich jewels, much plate, and costly linen. This man had in his family (and yet hath) a gentlewoman, whom he called his kinswoman, and whom one of his wives in her letter names Mary Grove, affirming her to be a known harlot, whose sending back into Old England she also desired, together with her husband. Shortly after this intelligence, we sent to the house of the said Gardiner (which was seven miles from us), to apprehend him and his woman, with a purpose to send them both to London to his wives there. But the man, who, having heard some rumor from some who came in the ship, that letters were come to the governor, requiring justice against him, was readily prepared for flight, so soon as he should see any crossing the river, or likely to apprehend him; which he accordingly performed. For he dwelling alone, easily discerned such who were sent to take him, half a mile before they approached his house, and with his piece on his neck, went his way, as most men think, northwards, hoping to find some English there like to himself. But likely enough it is, which way soever he went, he will lose himself in the woods, and be stopped with some rivers in his passing, notwithstanding his compass in his pocket, and so with hunger and cold will perish before he find the place he seeks. His woman was brought unto us, and confessed her name, and that her mother dwells eight miles from Boirdly, in Salopshire, and that Gardiner's father dwells in or near Gloucester, and was (as she said) brother to Stephen Gardiner, bishop of Winchester, and did disinherit his son for his twenty-six years' absence in his travels in France, Italy, Germany, and Turkey; that he had (as he told her) married a wife in his travels, from whom he was divorced, and the woman long since dead; that both herself and Gardiner were Catholics till of late, but were now Protestants; that she takes him to be a knight, but never heard when he was knighted. The woman was impenitent and close, confessing no more than was wrested from her by her own contradictions. So we have taken order to send her to the two wives in Old England, to search her further.

Upon the 8th of March, from after it was fair daylight until about eight of the clock in the forenoon, there flew over all the towns in our plantations so many flocks of doves, each flock con- 
taining many thousands, and some so many that they obscured the light, that it passeth credit, if but the truth should be written; and the thing was the more strange, because I scarce remember to have seen ten doves since I came into the country. They were all turtles, as appeared by divers of them we killed flying, somewhat bigger than those of Europe, and they flew from the northeast to the southwest; but what it portends, I know not.

The ship now waits but for wind, which when it blows, there are ready to go aboard therein for England, Sir Richard Salton: stall, Mr. Sharpe, Mr. Coddington, and many others; the most whereof purpose to return to us again, if God will. In the mean time, we are left a people poor and contemptible, yet such as trust in God, and are contented with our condition, being well assured that he will not fail us nor forsake us.

I had almost forgotten to add this, that the wheat we received by this last ship stands us in thirteen or fourteen shillings a strike, and the pease about eleven shillings a strike, besides the adventure, which is worth three or four shillings a strike, which is a higher price than I ever tasted bread of before.

Thus, Madam, I have, as I can, told your Honor all our matters, knowing your wisdom can make good use thereof. If I live not to perform the like office of my duty hereafter, likely it is some other will do it better.

Before the departure of the ship (which yet was wind-bound), there came unto us Sagamore John and one of his subjects, requiring satisfaction for the burning of two wigwams by some of the English, which wigwams were not inhabited, but stood in a place convenient for their shelter, when upon occasion they should travel that way. By examination we found that some English fowlers, having retired into that which belonged to the subject, and leaving a fire therein carelessly, which they had kindled to warm them, were the cause of burning thereof. For that which was the sagamore's, we could find no certain proof how it was fired; yet, lest he should think us not sedulous enough to find it out, and so should depart discontentedly from us, we gave both him and his subject satisfaction for them both.

The like accident of fire also befell Mr. Sharpe and Mr. Colborne upon the I $^{\text {th }}$ of this March, both whose houses (which were as good and as well furnished as the most in the Plantation) were in two hours' space burned to the ground, together with 
much of their household stuff, apparel, and other things; as also some goods of others who sojourned with them in their houses, God so pleasing to exercise us with corrections of this kind, as he hath done with others. For the prevention whereof in our new town, intended this summer to be builded, we have ordered that no man there shall build his chimney with wood, nor cover his house with thatch, which was readily assented unto, for that divers other houses have been burned since our arrival (the fire always beginning in the wooden chimneys), and some English wigwams, which have taken fire in the roofs covered with thatch or boughs.

And that this ship might return into Old England with heavy news, upon the r8th day of March came one from Salem, and told us that upon the ${ }_{5} 5^{\text {th }}$ thereof there died Mrs. Skelton, the wife of the other minister there; who, about eighteen or twenty days before, handling cold things in a sharp morning, put herself into a most violent fit of the wind colic and vomiting, which continuing, she at length fell into a fever, and so died, as before. She was a godly and a helpful woman, and indeed the main pillar of her family, having left behind her a husband and four children, weak and helpless, who can scarce tell how to live without her. She lived desired, and died lamented, and well deserves to be honorably remembered.

Upon the $25^{\text {th }}$ of this March, one of Watertown having lost a calf, and about ten of the clock at night hearing the howling of some wolves not far off, raised many of his neighbours out of their beds, that, by discharging their muskets near about the place where he heard the wolves, he might so put the wolves to flight, and save his calf. The wind serving fit to carry the report of the muskets to Roxbury, three miles off, at such a time, the inhabitants there took an alarm, beat up their drum, armed themselves, and sent in post to us to Boston, to raise us also. So in the morning, the calf being found safe, the wolves affrighted, and our danger past, we went merrily to breakfast.

I thought to have ended before; but the stay of the ship, and my desire to inform your Honor of all I can, hath caused this addition; and every one having warned to prepare for the ship's departure to-morrow, I am now, this 28th of March, I63I, sealing my letters. 


\section{APPENDIX B}

\section{GOVERNOR JOSEPH DUDLEY}

It is incumbent upon us in writing the Life of Governor Thomas Dudley, to make mention of his very able and distinguished son, Joseph Dudley, also in due time both president and governor of Massachusetts, receiving at different times many other positions of trust and responsibility from the crown and colony. This concerns us more because he was conspicuous in a colonial revolution involving the religion and politics of England and New England, in which the conflict was so deep and the public mind so disturbed that intervening generations have preserved and cherished considerable of the partisan vigor and championship of the various coteries.

He was the son of Thomas Dudley by his second wife. $\mathrm{He}$ was born in Roxbury, September 23, 1647 , and as his father died in 1653 , at seventy-seven years of age, it is evident that he had very little to do with the education of his son, who survived his father, living at the old homestead in Roxbury until April 2, I 720 .

$\mathrm{He}$ graduated at Harvard in $166_{5}$, and studied theology. Hutchinson says that, "If various dignities had been known in the New England churches, possibly he would have lived and died a clergyman; but without this, nothing could be more dissonant from his genius. He soon turned his thoughts to civil affairs ; was first a deputy or representative of the town of Roxbury; then an assistant; then agent for the colony in England, where he laid a foundation for a commission, soon after appointing him president of the council, first for Massachusetts Bay only, but, under Andros, for all New England." 1 He, was, until he went to England, admired and sought by everybody. He was influential because of his father and also because of his own great ability and culture. When he was thirty-four years old, in $\mathbf{r} 68 \mathrm{I}$, he had then been four years commissioner of the United Colonies. He was in the battle of the Narragansetts in 1675 , and gave an account of it which still exists.

When he went to England in 1682, as the agent of the colony, with an associate to protect and save the old charter that Win-

1 Hutchinson, Hist. Mass., ii. 2 r3. 
throp and his father had brought over in the Arbella in 1630 , he seemed to carry with him the hopes and confidence of his fellowcitizens without distinctions of party. It was at once evident that the mission was useless ; that the restoration of Charles II., the destruction of the Commonwealth, and of the powerful Puritan party which had cherished the government of Massachusetts and its religion, had each and all contributed to this result. The throne of the Stuarts and the Church of England were supreme, with a fixed purpose that Massachusetts should conform, and no longer assume, under an ancient charter, the liberties, civil and religious, of an independent state.

Dudley at once found himself in a revolution, which he did not create, which he could neither thwart nor direct. It was as irresistible as fate, a sequence of the growth and progress on both sides of the sea for half a century. The existing leaven in church and state must extend throughout the kingdom, creating conformity and homogeneous dominion everywhere.

Edward Randolph was the evil genius who, as early as October I2, 1676 , aroused the attention of the home government to the independent tendencies of the New England colonies, and their antipathy to the Church of England. ${ }^{1}$

Thoughtful Americans were then forced at once to decide between loyalty to the throne or rebellion. A similar question was presented to the Southern people in our Civil War : allegiance to the State or loyalty to the United States. The divine right of rebellion is conceded, but it was not yet expedient; all things were in preparation, but it would require nearly one hundred years of growth to perfect everything for the Declaration of Independence, - for Bunker Hill, Saratoga, and Yorktown. Yet there were even then, in 1776 , multitudes of the best people who took the same ground that Dudley had done earlier, continued to be tories and loyal to the crown.

Dudley made friends in England, as he had the good fortune always to do. He had the quick perception and intelligence to discover at once the manifest tendency of events, and the wisdom not to contend in a battle already hopelessly lost. There is no charge that he did not accomplish in this agency all that could have been done, or that he betrayed the cause of the colony or gave aid and comfort to its enemies in his official position. Wil-

1 Perry's Hist. of the Church in Mass., I-24. 
liam Stoughton wrote to him in London in August, I683, "Great revolutions, I see, are hastening everywhere; and since our poor corporation is like to outlive the charter of so famous a city as London, we must compose ourselves with the less regret to expect and entertain our own dissolution." Dudley was the means of diffusing a broader nationality, of creating through closer contact with Europe, especially with the mother country in her wars and struggles, a strong and well-sustained public confidence, which grew, and found New England prepared in 1776 to assert her nationality. If she had entered this conflict earlier and without the experiences of these years, the consequences to liberty on this continent might have been disastrous; but liberty the world over has in recent years received its greatest impulse from America.

He returned to Boston, October 23, I683. He lost his election of assistant in 1684 , but secured it again the next year. He was commissioned by James II., September $27, \mathbf{1 6 8 5}$, as president of Massachusetts, New Hampshire, Maine, and Rhode Island; he served nearly seven months, when Andros arrived and took his place, because he was not satisfactory to the crown nor acceptable to the people. A native who could be a servant of the king then was in about the same position to his neighbors as the Jew, nineteen centuries ago, who collected taxes for Rome from his countrymen. He was made a member of the council of Andros, and became president of it, and resisted the attacks of Andros upon the titles of the land in defense of the people, but sustained the hated government.

When the government of Andros was overturned, in r689, he and Dudley were both retained in prison twenty weeks in Boston, and then sent to England. This evidently rendered Dudley popular in London, and the next year but one he was created chief justice of New York (May 15, r69r), but was removed because he was not a resident, in $16922^{1}$ He returned to Eng-

1 Hutchinson states that Dudley "was charged with dispensing summum jus to [Jacob] Leisler [in New York in 1691], and incurring an aggravated guilt of blood beyond that of a common murderer. The other party, no doubt, would have charged the failure of justice upon him, if Leisler had been acquitted." (Hutchinson, ii. 214.)

Leisler was a weak man, intoxicated with the love of power, and refused at the proper time to deliver up the government to the new governor, Henry Sloughter, on March 19, 169I. (Valentine's Hist. City of N. Y., 20I ; New 
land in 1693 , and remained there until 1702 , when he came to New England bearing the commission of Queen Anne appointing him governor of Massachusetts, an office which he now held continuously during the remainder of her life, for about thirteen years, or until he was seventy years old, with a stormy administration in the beginning, but with popularity and success in its closing years.

York Hist. Soc. Coll., Ist series, iv. 96.) Valentine says the government called a special court of oyer and terminer, before which Leisler was brought about April 9, 1691, "on the charge of traitorously levying war against the sovereign" (Hist. City of N. Y., 204), and found guilty. "On the 14th of May the council requested the governor to carry the sentence into effect, and thus allay the ferment in. the public mind, which was every day increasing." (Ib., 205.) Two days after, the Assembly of New York declared their approbation of the execution, which took place on the 16 th. (Ib., 205.) There is an unsupported tradition that Sloughter was intoxicated when he signed the warrant. (N. Y. Hist. Soc. Coll., Ist series, iv. I03, 104.)

Bancroft says, "Joseph Dudley, of New England, now chief justice in New York, giving the opinion that Leisler had had no legal authority whatever." (Bancroft's Hist., iii. 54.) Dudley was not chief justice of New York when Leisler was tried, April 9. He was appointed chief justice May 15, 1691. Dudley was a member of the council, with six others, whose names are given in New York Hist. Soc. Coll., Ist series, iv. 96. The lords commissioners of trade in England reported on the whole matter, March II, I692, "that they were humbly of opinion that Jacob Leisler and Jacob Milborne, deceased, were condemned and suffered according to law." (New York Hist. Coll., Ist series, iv. 104.)

There had been a political revolution in New York, in which either party, if it succeeded, was determined upon the destruction of the other. Dudley was on the side of prerogative and the British authority, while his enemies in Massachusetts were on the other side, and have never ceased to manifest their displeasure with him. The court (of which we do not find that he was a member), the council, of which he was a member, the assembly, of which he was not a member, were all directly involved in promoting the execution, which in our period of prisons and of greater humanity would have been avoided. There can be no justice in heaping the great burden of discredit upon him who, in any event, must share it with many others if there is blame.

In 1695 Parliament reversed the attainder, which was a concomitant then to a conviction of treason, and restored the property to the children. This is quite different from voting an indemnity or assailing the original conviction of treason. (New York Hist. Soc. Coll., Ist series, iv. 104.) This was a simple act of humanity and justice. Our fathers, with the same tender compassion for innocent, defenseless children, ordained in the Constitution of the United States that there shall be no attainder of treason beyond the "life of the person attainted." (Sparks's Am. Biog., 2d series, iii. r8r ; Appleton's Biog. Dict. ; Moore's Mem. Amer. Governors, 390.) 
Dudley had been, during his last visit to England, eight years lieutenant-governor of the Isle of Wight, and "for several of those years the representative in Parliament of one of the island boroughs." 1 He must have been now an Episcopalian under the Test Act of 1673 to 1828 , to have had a seat in Parliament. $\mathrm{He}$ is said to have been the first native-born American who ever sat in Parliament. The date of his first church connection we have not found. He joined the society in Boston at King's Chapel in 1702 , and became an active vestryman the same year that he became governor. ${ }^{2}$ Dudley's important connection with the English church in Boston is shown by his correspondence in Perry's Hist. of the Church in Massachusetts, 74-108.

This religious position of a native-born Massachusetts man, with such an inheritance, from such a father, who was the very apostle of Puritanism fifty years before, steadfast and resolute, and he a loyal governor in these degenerate times, was more than enough to set both of the Mathers into a towering rage and fill them, as they sat at the head of surviving Puritanism, with the "rancor of theological hatred" and bitter jealousy in the midst of Dudley's triumphs.

This furnishes a key to the bitter correspondence between the Mathers and Dudley in the Mass. Hist. Coll., ist series, vol. iii.

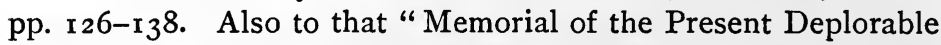
State of New England," published in 1707 , and another in 5708 , with which the Mathers were believed to be more or less connected. ${ }^{8}$ The answer to the first of these pamphlets is "A Modest Enquiry," etc., associated with it in the same vol. iii. p. 66*. The editors of the Historical Society in this volume have made some very pertinent remarks in their Introductory Note, p. $30^{*}$.

"In view of these pamphlets, we may perhaps conclude that the dissimulation was the other way. It looks rather as if Cotton Mather, aspiring to the presidency of the college, had pretended friendship to Governor Dudley; and, concluding that the election would be settled in 1707 , he gave vent to his malice by sending to England the manuscript of this first pamphlet."

1 Mass. Hist. Soc. Proc., 2d series, ii. 172.

2 Quincy's Hist. Harvard Univ., i. 359.

${ }^{8}$ Mass. Hist. Coll., 5th series, vi. 27*-1 31*; Doyle's English in America, ii. 472. 
There are two charges made against Dudley in these pamphlets, and reiterated since that day, First, that he was ambitious ; second, that he was inordinately selfish, and took and gave bribes in office, which is not proven, and since the presumption of innocency protects him it may be regarded as false. The first we have no doubt was strictly true; without strong ambition he could not have attained to the great trusts imposed on him. We must regard the times, to be just to Dudley, and consider that in the midst of ardent friends he was surrounded by powerful enemies who exaggerated faults and misrepresented events. Governor Hutchinson, writing only half a century later, with these pamphlets before him, from which he has quoted freely, says of Dudley, "The visible increase of his substance made some incredible reports of gross bribery and corruption to be very easily received; but, in times when party spirit prevails, what will not a governor's enemies believe, however injurious and absurd ? . . . Few men have been pursued by their enemies with greater virulence, and few have been supported by their friends with greater zeal." 1

It is a frequent method in our own times to measure the integrity and good faith of public men by their poverty. Nothing can be more absurd, as the sources of fortunes are so many and various. It has been recently asserted that no man of wealth has been, or ever can be, president of the United States, with the free and full consent of the American people. Moreover, that we take extreme care to keep them poor, to guarantee their purity and virtue.

Josiah Quincy informs us that "the friends of the college and of Dudley did not fail to appear in his defense, and to express publicly their reprobation of the conduct of the Mathers." The clergy also took sides on the occasion.

The pulpit, according to the too frequent custom of the period, was made the organ of crimination and recrimination. The Mathers "preached and prayed about their contest with the governor." Mr. Pemberton "resented Cotton Mather's letter," and said that "if he were Dudley, he would humble him, though it cost him his head." And Colman, preaching at the lecture in Boston, treated the topics of "envy and revenge," in connection with the question whether "the spirit was truly regenerated or 
no," in a manner to be "reckoned that he lashed" the Mathers and their party. ${ }^{1}$

Mr. J. A. Doyle, who has recently entered with true historic spirit into this distracted period and its controversies, says, "No one can read the pamphlets against Dudley and not trace the hand of Cotton Mather," - the hero and centre of the witchcraft delusion. "At the same time it was clear that the attacks on the governor had produced little effect in England." ${ }^{2}$ He says further, that "there is no distinct evidence that Dudley was a corrupt man. It would seem rather as if, in his case, cupidity was overruled and subdued by ambition. To tower over his countrymen as the representative of English ideas and interests, raised above petty provincial views, seems to have been Dudley's guiding object. . . . Nor is there anything to forbid the belief that he at least connived at corruption, though he did not himself profit by it." The burden of proof is on the person who suggests this allegation of connivance without evidence. The presumption of innocence remains strong and unbroken. Who would in recent times have the audacity to hold up presidents of the republic, governors of States, or generals of the army, as accessaries and confederates of treasonable, corrupt army contractors? or disloyal men who in time of war barter with the enemy? Is the mere fact that such high crimes are committed by men in important official position to be deemed sufficient, without other evidence, to blast the character of their superiors in office? If this be so, no administration can escape condemnation, for none has been without them which had a revolution on its hands. History affords few examples, if any, of chief magistrates charged with great responsibilities fighting both for and against the common enemy. Dudley was never bad enough or weak enough for that sort of an enterprise. This slanderous and disreputable stricture upon the otherwise good name of Dudley seems to have been the offspring of envy, jealousy, surmise, distrust, and malice, of which the sad story of witchcraft has shown the authors to have been fully capable.

One fact relieves these disreputable opinions. It is that his son Paul was coupled with him in wrong-doing by the Mathers; but fortunately we have his distinguished record apart from his

1 Hist. Harvard Univ., i. 202, 203.

2 The English in America, ii. 472. 
father's, and can judge for ourselves. Paul Dudley was attorney, general of Massachusetts during nearly the entire governorship of his father, and three years more, until 1718 , when he was raised to be a judge in the highest court, and held that position for twenty-seven years ; when, in $\mathbf{1 7 4 5}$, he was created chief justice of the same court, and continued till his death in $175 \mathrm{I}$, covering in all a period of forty-nine years, in which, excepting the Mather insinuations, he seems to have been respected and highly honored; and yet with all this record he could not escape calumny from this source. Quincy says, "But the talent and independence he exhibited in the offices he subsequently held gradually restored him to the favor of the people. In I 7 I 8 he was raised to the bench, and was finally made chief justice of the province, in which office his conduct obtained universal approbation." 1 Men grow better, and sometimes worse, we admit, but this record shows the mental and moral constitution of the man. "Do men gather grapes of thorns, or figs of thistles?" He was, with Franklin and others, "a leading student of nature in this country." 2

Perhaps I cannot do better than to quote the words of some of Joseph Dudley's contemporaries, to show how he was esteemed, since we have seen how he has been ungraciously treated by a portion of them.

Mr. Dean Dudley has furnished us with an extract from the writings of Rev. Benjamin Colman, of the class of 1692 at Harvard, first minister of Brattle Street Church, Boston, Mass. Mr. Colman was visiting England, evidently some time after I70I, since he calls him Colonel Dudley, a title he acquired during his government in the Isle of Wight. He says, "I am, myself, a witness of the honor and esteem he was in there, and his country not a little for his sake, among wise and learned men, both at London and at Cambridge. He was then in the prime of his life, and shone at the very court and among the philosophers of the age."

He continues, "When I was at Cambridge, England, as soon and as often as I had occasion to say that I came from New England, I was eagerly asked if I knew Colonel Dudley, who had lately appeared there with my Lord Cutts, and one and another

1 Hist. Harvard Univ., ii. 139.

2 Tyler's Hist. Am. Lit., ii. 317. See Paul Dudley, Eliot's Dict. 
spoke with such admiration of the man, as the modesty and humility of my country will not allow me to repeat." The veracity and judgment of Mr. Colman cannot be questioned, as he was the author of three volumes of evangelical sermons.

It was certainly a confirmation of the existence of these distinguished friendships ${ }^{1}$ for Dudley in England that he received such special favors from Major-General Lord John Cutts, one of the illustrious commanders at the battles of Boyne, Namur, and Blenheim, and governor of the Isle of Wight when Dudley was lieutenant-governor, during eight years, through his influence no doubt. Sir Richard Steele, subsequently distinguished as the founder of the British Essayist, and the "father of periodical writing" in the Augustan age of English literature, was in 1695 taken into the household of Lord Cutts and made his secretary; thus for about five years he and Dudley were companions, and are said to have been friends, with congenial interests and sympathies. Steele was twenty-five years younger, we are informed, ${ }^{2}$ and was attentive to the counsel and opinions of Dudley.

Dudley's last days in office, after the storm of revolution had subsided and people had accepted the national government in place of the local, were his best and most popular in the colony. The Boston Nezws-Letter, for many years the one newspaper in Boston, gave in No. 834 of its issue the following comprehensive and glowing estimate of him, which could not have been satisfactory to all readers of the paper; but since the smoke of that inevitable conflict has blown away, it may not be found

1 J. A. Doyle's Eng. in Amer., ii. 407, 408.

2 Letter of Richard Steele to Joseph Dudley :-

June, 25, 1700. it ; you excuse my not doing that in your observation of the loss of my brains, but the circumstances of that matter are such, that you yourself, as wise as you really are, would have done the same thing. You cannot imagine the sincere pleasure Mrs. Lawrence's Pity gave me. I always had an honor for her, and knew she had, at the bottom, a generous disposition.

I am just come of Hampton Court Guard. You already know Lord Jersey is Chamberlain, Lord Rumney, Groom of the Stole [first lord of the bedchamber in the royal household]. 'T is expected Lord Pembroke will be Lieutenant of Ireland, Lord Lexington, or Mr. Hill, Secretary in Lord Jersey's room.

You shall always find me, Dear Sir, your most obedient, ready humble servant,

R. STEele.

(Proc. Mass. Hist. Soc., 2d series, Jan. I887, 20r.) 
so extravagant in praise. " $\mathrm{He}$ was a man of rare endowments and shining accomplishments; a singular honor to his country, and in many respects the glory of it. He was early its darling, always its ornament, and in his age its crown. The scholar, ${ }^{1}$ the divine, the philosopher, and the lawyer all met in him. $\mathrm{He}$ was visibly formed for government ; and under his administration, by the blessing of Almighty God, we enjoyed great quietness, and were safely steered through a long and difficult French and Indian war." 2

This was contemporary Massachusetts testimony of the press, which, if servile, was nevertheless solicitous for its reputation with its readers, and would not venture far away from existing public sentiment.

The family of Governor Thomas Dudley was at the end of three quarters of a century in complete, undisputed ascendency in Massachusetts. No other family had such a hold on the government and the high places of power before or since. But, as Governor Washburn says, "the name has yielded to the republican tendencies of our institutions, and is not now to be found among those in place and power in our commonwealth." ${ }^{8}$ The father was governor; his son Paul attorney-general ; and his son William in public service in an embassy to Canada, and a military expedition against Port Royal. These sons were both very influential for many years in Massachusetts. ${ }^{4}$

1 Tyler's Hist. Am. Lit., ii. 312, 313, $3^{1} 7$.

2 Governor Emory Washburn said of him in 1840, "No native of New England had passed through so many scenes and enjoyed so many public honors and offices as Governor Dudley.

" Had he remained in private life, he would have been justly eminent as a philosopher and scholar, a divine or lawyer. He was, in fact, to no small extent all these, even amidst the cares and perplexities of public life.

"In private life he was amiable, affable and polite, elegant in his manners, and courteous and gentlemanly in his intercourse with all classes. His person was large, and his countenance open, dignified, and intelligent. He had been familiar with the court, and his address and conversation were uncommonly graceful and pleasing. As a judge he was distinguished for gravity, dignity, and on ordinary occasions mildness of manner. As a chief magistrate, none could doubt his capacity to govern, and the prudence with which he managed the affairs of the province disarmed even the opposition of his enemies. . . . He was justly regarded as an honor to Massachusetts." (Jud. Hist. Mass., 1 19, I 20; History of Dudley Family, i. 163-196, 313-336.)

8 Jud. Hist. Mass., I 20.

4 Washburn's Jud. Hist. Mass., 283, 326; Hutch., Hist. Mass., i. I 54, note. 
Joseph Dudley, forgetful of the sturdy independence of his father, was thought by some persons to be too loyal to the crown, too fond of the English church, too selfish and ambitious for public trust. $^{1}$

Dudley, from 1683 to $17{ }_{15}$, recognizing his influence at home and his prestige in England, and being an accomplished gentleman and politician, deemed it, as others before and since have done, to be his privilege and duty to take and hold office for the good of Massachusetts, not forgetting the honor which ought to attend faithful service.

A remarkable change both in the politics of England and of Massachusetts had given a new turn to affairs. That ignoring of the English government, which had distinguished the administrations of Winthrop and of his father, was no longer possible. The province was now of sufficient importance to attract the attention of the covetous and powerful Louis XIV. and other European sovereigns, while hostile Indians on every side created anxiety.

There was only one course open to Dudley as matters then stood : that was to cling loyally to the service and protection of the mother country. An attempt at revolt then would have been fatal ; the era for the Revolution had not arrived. Neither would the crown tolerate half-hearted service; he must do his duty, or a foreigner would take his place. It would have been worse than criminal then to have awakened the wrath of England, with no sympathetic Puritan party to assist, with the hierarchy and the Stuarts in power, without army or navy, and with growing bitter-

1 It has been said in the same spirit, in recent years, that the magnificent patriotism of Daniel Webster, so conspicuous at Plymouth Rock, at Bunker Hill, and in the Senate, was quenched in 1850 by his unworthy ambition to be president. "So fallen! so lost! the light withdrawn which once he wore." The political situation devoted him to political destruction, to which he advanced with the same love of country, cherishing with the deepest and most sincere affections of his heart the Constitution and the Union, imploring his fellow-citizens of every section of the nation to pause, consider, lay aside passion, and listen to reason. It was one of the remarkable incidents of the Civil War that the generation of men from the North, who fought it, had been trained to love the Union, and educated to comprehend its marvelous significance, by declaiming at school the masterly utterances of Webster. His wisdom, his thoughts, had penetrated to the heart of the nation, and filled its life currents with one great overmastering conviction, "Liberty and Union, now and forever, one and inseparable." $\mathrm{He}$ and John Brown marched at the head of the advance column of the army of the Union. 
ness constantly extending between Old and New England, which was at last to result in independence. His ardent love for Massachusetts was fully attested. He was an able man, long in public life, and created by his positive career strong friends and bitter enemies. His public record, as we have noticed, received both severe criticism and the highest commendation from his contemporaries ; and the time may yet come - and our faith in justice at last prompts us to say that it will come - when the exalted patriotism of Dudley and Webster will receive universal encomium.

It is difficult to do justice to the magnificent men who, as the final severance from England came, were found on the loyal side in politics. Judges of the greatest influence, scholars of the first rank, men with the purest character, with consciences void of offense, with unflinching fidelity clung to fatherland, and with great sufferings and sacrifices held their true allegiance to the British throne to the end. Examine the spotless records of judges like Peter Oliver, and a multitude of others, whose only reproach was that they were on the wrong side of politics, for which they were exiled or ostracized, and it will assist us to realize the political environment of Dudley earlier, and prepare us to meet the discreditable charges of his bitter rivals and enemies. We ourselves followed near enough to the Revolution to have an almost irrepressible hatred of England in our childhood, which we are much pleased to have outgrown, but that hostility embraced every person, without reason or mercy, who was not on the political side with the fathers.

The time will come, if it has not, when both sides of the situation may be regarded without passion or prejudice, and the obloquy which has been thrown upon the memory of some of the ablest and best Americans of the past will disappear from the history of our country.

\section{APPENDIX C}

GOVERNOR SIMON BRADSTREET AND HIS WIFE, ANNE

Anne Bradstreet, the oldest daughter of Governor Thomas Dudley, was born in Northamptonshire, England, about r6r2, while her father was with Judge Nicolls, and died at Andover, Mass., September 16, 1672. She married Governor Simon Brad- 
street, who was nine years older than herself, in 1628 , and went with him and with her father and his family on the Arbella, to New England, in 1630 .

Anne was only sixteen years old when she married Mr. Bradstreet. They must have had an excellent opportunity to become acquainted with each other during the eight years that. Bradstreet was "under the direction of" her father at Sempringham, in the family of the Earl of Lincoln, "the best family of any nobleman then in England," from his sixteenth to his twenty-fourth year. It adds another interest to the Church of St. Andrew's that these young people went in and out of it as we see it now, and may have been married within its ancient walls. ${ }^{1}$

Mrs. Bradstreet was the mother of eight children. She was the author of the first volume of poems written in America, published in 1640 . Both her poetry and her prose have received merited praise. Tyler says, "Somehow, during her busy lifetime, she contrived to put upon record compositions numerous enough to fill a royal octavo volume of four hundred pages, - compositions which entice and reward our reading of them two hundred years after she lived." 2 Bradstreet was governor from 1679 to $\mathbf{I 6 8 6}$, and from $\mathbf{1 6 8 9}$ to $\mathbf{1 6 9 2}$. He was for many years a commissioner of the United Colonies. $\mathrm{He}$ was the Nestor of New England; born in 1603 , died 1697 . He was the youngest of the original assistants, and survived them all, continuing in that office from 1630 for forty-nine years. He was educated at Emanuel College, Cambridge, Eng. He married for his second wife the sister of Sir George Downing. ${ }^{8}$

\section{APPENDIX D}

MAJOR-GENERAL DENNISON AND HIS WIFE, PATIENCE

Dudley's second daughter, Patience, was born in England, and died at Ipswich, Mass., February 8, r689-90. She married at Cambridge, Mass., Major-General Daniel Dennison, a very distin-

1 Mather's Mag., i. bk. ii. 126.

2 Hist. of Amer. Lit., i. 28o: Allibone's Dict., i. 236; John Harvard Ellis's Works of Anne Bradstreet in Prose and Verse, 1867; Duyckinck's Cyclo. of Amer. Lit., i. 52.

3 Young's Chron, 125. 
guished person in the colony. He was born in England in $\mathbf{r}_{6} \mathbf{1}_{3}$, and died at Ipswich, Mass., September 20, 1682. He came to America the next year after the emigration of his wife, viz., in 1631. They removed with Thomas Dudley to Ipswich in r635. $^{\circ}$ He was a commissioner, as we have seen, to treat with D'Aulnay in 1646 at Penobscot, and was after that major-general of the colonial forces for ten years. He was speaker of the House in 1649 and in $1651-52$. He was secretary of the colony in 1653 , and justice of the Quarterly Court in 1658 . He was commissioner of the United Colonies in 1654-62 inclusive, and substitute commissioner in $1671,1673,1674-75$, and 1679 . He and Bradstreet were the two commissioners from Massachusetts from 1654 to 1662 , with the single exception that John Endicott took his place in $165^{8}$. Either Dennison or Bradstreet, or both of them, were commissioners or substitutes from the decease of Dudley until 1680, with the exception of $1667-68,1676$, and 1678 , in which last year Joseph Dudley took the position, and continued in it, excepting 1682 and 1683 , until 1685 , or nearly to the end of the first charter. Dennison was an assistant from 1653 , the date of Dudley's death, until 1667. If we take into account the fact that Bradstreet was governor from 1679 to 1686 , and assistant from 1668 until 1678 , and that he was not only a son-in-law of Dudley, but began his active life with him at Sempringham and subordinate to him; and further, that Joseph Dudley followed them into power and continued in it until old age, in $171_{5}$, with little interruption, we shall be sure that the Dudley family was more intimately associated with the first century of Massachusetts history than the family of any other one of the distinguished immigrants of 1630 , or of their predecessors, to this country. Such summary ought also to include Paul and William Dudley.

Dennison has the distinction also of having made the revision of the Code of 1660 and the index to it. ${ }^{1}$ Johnson says of Dennison, "Their first Major, who now commandeth this Regiment, is the proper and valiant Major Daniel Dennison, a good soldier, and of a quick capacity, not inferior to any other of these chief officers; his own company are well instructed in feats of warlike activity." 2

1 See Col. Laws of Mass. supervised by Whitmore, 119-216, also Introduc. to same, 99; Poole's edition of Johnson's Wonder-Working Providence, cvii.

2 Whitmore's Col. Laws, I92. 
$\mathrm{He}$ was the author of a curious tract, with the title "Irenicon, or Salve for New England's Sore." 1

\section{APPENDIX E}

\section{REV. SAMUEL DUDLEY}

Rev. Samuel Dudley, son of Thomas, was born in Northamptonshire, England, about 1608, while his father was clerk of Judge Nicolls, and died February 10, 1683, at Exeter; N. H. He came with his father to America in the Arbella in 1630 . He was married, in $\mathbf{1 6}_{32}$, to Mary, the daughter of Governor Winthrop. He erected a house which stood at or near the corner of Dunster and Mount Auburn streets, in Cambridge. He removed to Ipswich in 1635 , in company with his father. $\mathrm{He}$ founded with others the town of Salisbury in 1638 . He represented Salisbury in the General Court in $1642,1643,1644$, and 1645. He was associate judge for the year 1649 with Richard Bellingham, and Samuel Simonds for the county of Norfolk. ${ }^{2}$ His wife, Mary, after eleven years of companionship with him, died April 12, 1643, at Salisbury. ${ }^{8}$ He married Mary Byley, of Salisbury, in 1643 . Mr. Dudley was the pastor at Exeter, N. H., in $165^{\circ}$. He asked the town in 1655 to reduce his salary, it being a year of hardship and misfortune. In 1659 he preached at Portsmouth, N. H., upon invitation, and received a call to settle there, with an offer of eighty pounds a year, which he declined, and continued at Exeter, at a smaller salary. $\mathrm{He}$ took an interest in mills and farming. Dean Dudley says that "he seems to have been the first in this country to attempt to improve the breed of horses, cattle, and sheep." He met with the loss of his second wife in 1651 , and later married his last wife, Elizabeth. His children, so far as known, numbered eighteen. He seems to have retained public confidence to the age of seventy-five years, and died with the affectionate regard of all who knew him, and his memory has been kindly cherished by every writer since his day:

1 Winthrop, ii. *259.

2 Mass. Col. Rec., ii. 266 ; see, also, 242.

8 Life and Letters of Winthrop; ii. $32 \mathrm{I}$. 


\section{APPENDIX F}

REV. JOHN WOODBRIDGE AND HIS WIFE, MERCY.

Rev. John Woodbridge, son-in-law of Dudley, was born in Stanton, Wiltshire, England, in 16r4, and died in Newbury, Mass., March I7, I695. He was sent to Oxford, where he remained " until the oath of conformity came to be required of him, which, neither his father nor his conscience approving, he removed thence into a course of more private studies." He came to America in the ship Mary and John, in 1634, and settled in Newbury, Mass., of which he was town clerk in $1634-38$, and surveyor of arms in 1637 . In 1639 he married Mercy, the youngest daughter of Thomas Dudley by his first wife. She had crossed the ocean with her father in the Arbella, in 1630. There were twelve children by this marriage. He taught in Boston in 1643 , following the advice of his father, Dudley, given in a letter dated November $28,1642 .{ }^{1}$ Still further following the advice of said letter, he was chosen the first minister of Andover, Mass., and ordained September 4, 1647 , according to Mather. He, with others, purchased the land from the Indians on which that town was built. He returned to England in 1647 , and was chaplain to the parliamentary commissioners who made a treaty with the king at the Isle of Wight. He was afterwards a minister at various places, until he was rejected after the Restoration. He returned to New England in r663, and served as an assistant to Rev. Thomas Parker until November 30, 1670. He was an assistant in $1683-84$. There is an island named for him near the mouth of the Merrimac River. "He was observably overwhelmed by the death of his most religious, prudent, and faithful consort, when she was, July I, 169 I, fifty years after his first marriage unto her, torn away from the desire of his eyes. His value of the whole world was, after a manner, extinguished in this loss, of what was to him the best part of it; and he sometimes declared himself desirous to be gone, whenever the Lord of Heaven should be pleased to call him thither." ${ }^{2}$ Savage says he had seen a letter from Dudley dated July 8, I648, to him, "Preacher of the word of God at Andover in Wiltshire," advising of the means he would follow

1 See p. 287 of this volume.

2 Mather's Mag., i. 542-544. 
to send his wife and children. ${ }^{1}$ We have been unable to find this letter.

\section{APPENDIX G}

\section{CAPTAIN JONATHAN WADE AND HIS WIFE, DEBORAH}

Thomas Dudley's youngest daughter, Deborah, was born February 27,1645 , and died November 1,1683 . She married Jonathan Wade, whose native place was Ipswich, but he removed to Medford, Mass. He was admitted a freeman in I669. He was captain of the "Three County Troop of Horse." $\mathrm{He}$ died November, 24, 1689. ${ }^{2}$

\section{APPENDIX H}

\section{SARAH PACEY}

Sarah, the third daughter of Thomas Dudley, was baptized July 23, 1620, at Sempringham, England, as we are informed by Dean Dudley, and died in Roxbury, Mass., in 1659, Savage says, "very poor." 3 She was married, September I, I638, to Major Benjamin Keayne, the son of Captain Robert Keayne, the first commander of the Ancient and Honorable Artillery Company. They had one child, Ann or Hannah, who seems to have been respected during her life, although her grandfather Keayne, in the most remarkable will extant for length and irrelevant matter, manifested such distrust of her that it might well, when read by strangers, cast a shade upon her character. So that we are inclined to think that any reflection upon her in literature is an exhalation from that will.

We should willingly avoid entering upon the sad story of Mrs. Benjamin Keayne, were it not for the fact that her brothers and sisters have been considered, and it seems due to her memory to trace her career, of which very little is known. Her husband deserted her and went to England in disgust, Savage says, in 1645. It seems that Keayne had an estate in Lynn, Mass., and that he made an assignment of his property to his wife and his father after his departure to England, or immediately previous, and the Court thought that the assignment might be detrimental

1 Winthrop, ii. *253. See, also, Mather's Mag., i. 542, and Second Reunion of the Dudley Association, October 17, 1893, p. $3^{8 .}$

2 N. E. Genealog. Reg., iv. 378.

3 Winthrop, ii. 4 , note. 
to the claim of certain orphans upon the estate of Keayne, and it ordered that the Lynn "farm shall not be alienated." It seems quite possible that Keayne went to England to avoid his American creditors. He left his wife behind him, who was loyal enough to him to gather all she could, with the help, no doubt, of her coassignee, and take it with her to England. She was unfortunate, and lost the property by the perils of the sea, or, as it was said, "all her goods miscarried and she escaped only with her life." 1

It is quite possible that if she had succeeded in taking money to England she would have been more welcome to her husband. But when she came with only her life and no visible means of support, he at once repudiated her. If he was in fact an honest bankrupt he had very little money, because we may conclude that she was in London in 1646 , within a year of his going, and while the assignment of his property in Massachusetts was in force. Keayne wrote three disgusting letters about his wife in March, I646, from London, as follows: March i2, to the Rev. John Cotton; March I 5 , to the Rev. Mr. Wilson; March I8, to Thomas Dudley, all of Massachusetts. These letters are recorded in Boston, Mass., with Suffolk Deeds, i. 83, 84 .

$\mathrm{He}$ charges her with unfaithfulness to him, but admits that he has no legal evidence. Dudley drew from him in a letter exactly what he wanted, viz.: "I do plainly declare my resolution, never again to live with her as a husband."

This letter to Mr. Dudley seems to have been recorded September I3, I647. Savage says that she was disciplined November, 1646 , for irregular prophesying. If it was in America, which is probable, "the Puritans maintained frequent religious exercises, in which texts of Scripture were interpreted or discussed, one speaking to the subject after another, in an orderly method." ${ }_{2}$ This was prophesying. What her irregular conduct was does not appear, or the extent of the discipline, or the tribunal which enforced the discipline. Savage says further that she was excommunicated in October, 1647. Again we have no particulars of the charge, complaint, church, or tribunal. And we do not know whether it is worthy of consideration or not.

All this is from an unfriendly source.

1 Letter of Gurdon to John Winthrop, June 6, I649. Mass. Hist. Coll., 4th series, vi. 568 .

2 Neal in New England's Memorial, 171, note. 
She married Thomas Pacey, of Boston, Mass., about r649. This fact carries with it a great amount of relief in the case, because she had no fortune to tempt him, and he must have had confidence in her; because she could not have married unless she had been divorced, and also had leave to marry by the Court. ${ }^{1}$ The desertion was proven by the letter to Mr. Dudley, quoted above. If the Court had believed the charges of her husband, it would never have granted the divorce. The crime would have been punishable with death. ${ }^{2}$ The fact that the letters are recorded would seem to indicate that Dudley regarded Benjamin Keayne as an unprincipled man who ought to be shown up to the world as nothing but his own composition could do it.

$\mathrm{Mr}$. Savage has called this last a marriage of convenience. $\mathrm{He}$ seems to regard it as not altogether creditable. Dudley was a member of the Court of the highest integrity. He calls her Mrs. Pacey in his will, and at other times. Mr. Robert Keayne, who was very hostile to her, calls her Mrs. Pacey in his will. She is mentioned frequently as Mrs. Pacey by many persons at different times. It was then a bona fide marriage, whether convenient or otherwise. We can discover no ground for flinging disagreeable insinuations at her. Savage says at last that she "was sadly degraded." There seems to be no other foundation for this statement than her poverty. Her father left to her the income of about

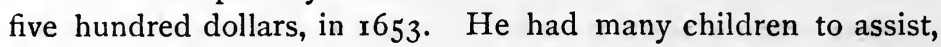
and may have given her portion to her earlier. He assisted her to a home in Roxbury in 1647 . The town of Boston was careful that she be not received as an inhabitant without security that she would not become a charge, which was furnished. But they followed hundreds of excellent people, as the record shows, with the same solicitude. It is no sin to be poor. The noblest and best who have passed through this world have experienced poverty; even "He whose morning appetite would have gladly fed on green figs between Bethany and Jerusalem." Martin Luther devoutly prayed, "Lord God, I thank thee that thou hast been pleased to make me a poor and indigent man upon earth. I have neither house nor lands nor money to leave behind me."

"The honest man, though e'er sae poor,

Is king o' men for a' that!"

1 See case of Mrs. Pester, Mass. Col. Rec., iii. 277.

2 Body of Liberties, I64I. Capital Laws, p. 94, I 9. 


\section{APPENDIX I}

PAUL DUDLEY

Paul Dudley, the third son of Governor Thomas Dudley, was born September 8, I650, and died December r, I68r. He was about three years old when his father died. He married Mary, the daughter of Governor John Leverett, and thus connected two very influential families.

Mr. Dean Dudley says that "Mr. Paul Dudley was a merchant and collector of customs at the port of Boston and Charlestown. His dwelling-house stood on the town street leading to the dock. The dock was where Faneuil Hall stands; Dock Square was so named from the dock." 1 He was for a brief period judge of probate of Suffolk County, Mass.

$\mathrm{He}$ and his brother Joseph became members of the Ancient and Honorable Artillery Company in 1677 . He appears to have been contented with private life, and to have left the precarious turmoil of politics to his brother Joseph, who evidently reveled in its turbulent storms.

\section{APPENDIX J}

CHIEF JUSTICE PAUL DUDLEY, GRANDSON OF THOMAS DUDLEY

The Chief Justice Paul Dudley, son of Governor Joseph Dudley and grandson of Governor Thomas Dudley, seems to be entitled to consideration here both on account of the eminence he secured for his family and because of the great services he rendered to Massachusetts.

$\mathrm{He}$ was born at Roxbury, Mass., September 3, I675, and resided there throughout his life. He took his first degree at Harvard in 1690 , when he was fourteen years old, and is said to have been the youngest student ever graduated from the university, being younger by one year than Cotton Mather and the late Andrew Preston Peabody.

His father gave an attractive glimpse of his genial nature in his letter to the university offering Paul as a student in the following words :-

1 History of Dudley Family, i. 337. 
"April 26, I686. I have humbly to offer to you a little, sober, and well disposed son, who though very young, if he may have the favor of admittance, I hope his learning may be tolerable; and for him I will promise that by your and my care, his own industry and the blessing of God, his mother the University shall not be ashamed to allow him the place of a son at seven years end. Appoint a time when he may be examined."

$\mathrm{He}$ read law several years in America after graduation, and then went to England to finish his studies at the Temple. ${ }^{1}$

$\mathrm{He}$ returned to America in $\mathbf{I} 702$ with a commission from the Queen as attorney-general of Massachusetts, which office he held for sixteen years, until he was appointed a judge of the Superior Court, the highest court in the province then, where he continued twenty-seven years to administer justice. He became chief justice in 1745 , and remained in that office six years, until his decease in $175 \mathrm{I}$.

$\mathrm{He}$ was thus in judicial office during forty-nine years, nearly half a century, including his entire active career. $\mathrm{He}$ adhered at first to the throne and prerogative like his father, but later entered more and more the popular current and became Americanized, to the great joy of his fellow-citizens.

He was a representative to the General Court several years, and speaker in 1739 , and had a seat at the council board. Judge Sewall, who was a justice of the same court, and knew Mr. Justice Dudley well, says : "Here [on the bench] he displayed his admirable talents, his quick apprehension, his uncommon strength of memory and extensive knowledge. . . . When he spoke, it was with such authority and peculiar energy of expression as never failed to command attention, and deeply impress the minds of all who heard him; and his sentiments of law and evidence, in all cases before the court, had generally a determining weight with those who were charged with the trial of them."

Eliot, in his Biographical Dictionary, says that "he was a very learned theologian, and wrote a book upon the 'merchandise of souls,' being an exposition of certain passages in the book of Revelations." This essay was an attempt chiefly to present the perils that were impending over the world from the Roman Catholic Church, setting forth solemnly and zealously

1 Hist. Geneal. Reg., x. 338, 343; Diary of Paul Dudley, Ib., xxxv. 28. 
its errors. ${ }^{1}$ It was a work of much learning, but of little use in this mild and liberal age.

The very next year after he was elevated to the bench, his attention was drawn to Baconian, experimental investigation of the phenomena of nature. He contributed to the Transactions of the Royal Society of London, papers on Niagara Falls, Rattlesnakes, Poison-wood, New England Plants, and many other subjects.

He maintained this correspondence with the society fifteen years. Some of his letters appear in vols. 31, 33.34, and 39 of the Transactions of the society. He had the great honor conferred on him of being elected a Fellow of the Royal Society, November 2, I 72 r, an attention shown to very few Americans of his period. Sir Isaac Newton was at this time president of it, and it had recently included Sir Robert Boyle among its fellows.

Dudley was welcomed into this companionship, and, what was more, his papers entered into the proceedings of the society. Some persons regard his subjects and theories as simple and child-like, but it is a fate which, in the progress of science, will attend very much which has passed current as human wisdom. The answer to such criticism is the contemporary approval both of him and his work by that august body which in its time had under its supervision the whole range of science.

This ancient worthy, with his own good steed, traversed year after year his judicial circuit, all the way from Cape Cod around to the wilds of Maine, meditating on the issues in court, holding communion with the visible forms of nature, and collecting facts with which to enlighten the savants in London.

Some of his conclusions have passed all of the fire-ordeals of modern science, and added to the permanent stock of knowledge. $\mathrm{He}$ is never to be brought into comparison with students whose energies have been devoted exclusively to natural science. This was only a pastime to relieve his mind from the exacting demands of his real vocation, which finally so absorbed his attention that the haunts of nature were neglected or ceased to find description through him.

He was a benefactor of the town of Roxbury. He gave to it the Upper Stone Bridge over Smelt Brook, the milestones from Boston to Roxbury, and scattered over the town, marked P. D.

1 There are two copies of this book in the Boston Athenæum. 
$\mathrm{He}$ also gave freely to the Roxbury Latin School. He was one of the founders of the town of Dudley, Mass. A grant of most of the land of the town excepting the Indian Reservation had been made to his father, Governor Joseph Dudley, and Judge Dudley and his brother Colonel William, with a certain Colonel Fitch, held most of it in 1732 . The town took its name no doubt from the family. The two brothers gave at about this time five hundred dollars and one hundred acres of land "as a parsonage or settlement for the first minister." 1 The chief justice died January $25, \mathrm{I} 75 \mathrm{I}$, and was buried in the family tomb with his father and grandfather at Roxbury. He established by his will lectures at Harvard upon four subjects, some of which are antiquated, and have in recent years troubled the university, Natural Religion, Revealed Religion, The Corruptions of the Church of Rome, The Validity of Presbyterian Ordination. He was great and honorable in his day, and made a profound impression upon the Commonwealth, which he dearly loved, and which held him during life in its high places of power and trust.

\section{APPENDIX $\mathrm{K}$}

\section{COLONEL WILLIAM DUDLEY, GRANDSON OF THOMAS DUDLEY}

Colonel William Dudley, brother of Chief Justice Paul Dudley, was born in Roxbury, October 20, 1686, and always resided there. He was graduated at the head of his class at Harvard in 1704. He was high sheriff of Suffolk County several years, a major in the Ancient and Honorable Artillery Company of Boston, and was during thirty-seven years, from 17 Io to 1747 , colonel of the First Suffolk County Regiment. He was sent in 1705 , when nineteen years of age, the year after his graduation, as a commissioner with Captain Vetch to Canada, to negotiate an exchange of prisoners, in which mission he was successful.

He brought back the Rev. John Williams, who had the year before been captured by the Indians at Deerfield, Mass. Williams was the first minister in that town, and his wife and two of his children were slain by the savages, while one daughter,

1 Town Rec. of Dudley, 38, 46, and Hist. Notices of Dudley, by Joshua Bates, 54. 
Eunice, was never recovered from captivity. This was in Queen Anne's War. It was said that "young Dudley managed the business with no small address, and by his manner of negotiating kept the frontiers from being pillaged. This was doubtless the policy of his father [Governor Joseph Dudley], but he gained credit by the execution." 1 Colonel Dudley was at last, in I 7 Io, a distinguished officer in the final successful expedition against Nova Scotia; and from that day to this the English flag has floated at Annapolis, which before had been called Port Royal. There were thirty New England vessels and four New England regiments in this conflict, besides the British troops.

Mr. Dudley was, at a later period, a justice of the Court of Common Pleas, and also a representative for Roxbury in the General Court. Eliot says : "He always had great influence in a public assembly, being an admirable speaker, and possessing strong intellectual powers as well as a brilliant fancy. The opposition to his father's administration felt the weight of his talents. He could render himself very popular, and was for several years Speaker of the House of Representatives," beginning in $1724 .^{2}$

In 1729 he was chosen one of His Majesty's Council, and was very serviceable to the community. Douglas says that "he was more acquainted with Provincial affairs than any other man, especially that he understood landed property." He died August Io, I 743, at the age of fifty-six years, in the midst of his usefulness, with all his honors thick upon him. He was, as we have already seen, together with his brother, a founder of the town of Dudley, Mass.

1 Eliot's Dictionary, I60.

2 Hist. Geneal. Reg., x. 338. 
INDEX 



\section{INDEX}

Abscinden from the charter, government of Massachusetts in England, 68.

Adventurers without principle vex the emigrants in the beginning, 117.

African slavery, 330 .

Agreement, Cambridge, 72.

Alcock, Mrs., sister of Rev. Mr. Hooker, death of, 85 .

Alden, John, prisoner in Boston, 173-1 75 .

Alfred the Great, grave of, and the emigration, 57; will of, and English freedom, 57 .

Allen, Bozoun, and Dudley, trouble between, 396.

Almanac, early literature in New England, 256.

Amiens, cathedral of, 21 ; siege of, 20-23.

Anabaptists and Puritans, 219, 341, 407, 408.

Anagram by Mr. Eliot, 329.

Ancestry, not much regarded in America, 9, 10;

Dudley and other Puritans careless of, 91 .

Ancient and Honorable Artillery of Boston, 253.

Andrews, Richard, donations of, 326.

Andrew's, St., church, 37, 38, 465, 469 .

Andros, Sir Edmund, and Joseph Dudley, 453.

Antinomian controversy, 2 r 9.

Antinomians and Dudley, 226, 232.

Antinomians and United Colonies, 222.

Antinomians, Winthrop, and the name, 228.

Antinous, page of Hadrian, 17.

Apparel, laws respecting, 186.

Appeals to England refused, 344

Aquiday (Rhode Island) and Dudley's answer, 275.

Arbella, Lady, $37,46,53,58,60,64$.

Arbella, the ship, $58,66,74$; bears the first charter of Massachusetts to America, 66.

Aristocracy and poverty, 4 Io.

Arms, coats of, Thomas Dudley and Joseph Dudley, 5.

Army worms, 349.

Arnold, Benedict, 300 .

Arnold, S. G., strictures on Dudley, 278; opinion of Dudley, 284

Arnold, William, 300 .

Articles of Confederation, 298.

Ashby Castle, home of Dudley, r, $13,14$.

Assembly of Westminster divines, 342.

Assistarts, reduced in number, 88 ; are made representatives of the people and of the freemen, 94, 95, 118.

Assistants and deputies contest, 1643, 189.

Assistants, Court of, last one in England, 59; first court of, Charlestown, $9 \mathbf{r}$; a court of judicature, 93 ; judicial powers transferred to, 255 .

BACON, LORD, 9, 18, 27, 28.
Ballot, introduced, 165 ; beans used for, 372 .

Baptism, not the true and political power, $34^{1}$; in 1651 , dangers to the colony, 407 .

Bargains in poetry, 417 .

Bay Psalm Book, 256, 275.

Bay of Massachusetts, 79,80 .

Beaumont and Fletcher, 18.

Becket, Thomas à, 36 .

Beer, wholesome, 407.

Belcher, Gov. Jonathan, 418.

Bellingham, Richard, in law-making, 266, 280, 282 ; governor, 1641, and unpopular, 279; married, 280 ; resigns, 282 ; compared with Dudley, 282 ; admonished by the Court, 281 ; and Saltonstall oppose the assistants, 294 ; reconciled to the magistrates, 294; and Saltonstall against the magistrates in the sow business, 315 .

Bible, the, in politics, 190 ; supreme law, 265 ; in Massachusetts, 412 .

Bigotry in Massachusetts, 353 ; of Thomas Dudley, 279, 423.

Blackstone, Mr., and Boston, Mass., 84.

Blasphemy and Roger Williams, $136,137$.

Body of Liberties, 203, 265, 285, 286.

Book of discipline, 344 .

Books on the law, 371 .

Boston, England, home of Dudley, 31, 34, 49 .

Boston, Massachusetts, Puritans in, 66 ; formerly Trimountain, 79; settlement of, 85 ; name of, 92 ; made the permanent capital of Massachusetts, 92 ; or Cambridge to be the capital, 155 ; and Ann Hutchinson, 224 ; disturbed by Captain Stagg, 323 .

Botolph, St., church of, 49 .

Boyle, Hon. Robert, and the gospel in Massachusetts, 392.

Boys, military drill of, 328 .

Bradstreet, Anne, 4, 464; and her father, 247 : earliest poet, 262 .

Bradstreet, Simon, 58, 84, 464; steward of Earl of Lincoln, 47; first winter in Boston, 84 ; selectman of Cambridge in $1634^{-5}, 132$.

Brenton, Martha, desiring an Irish boy and girl, request granted, $4 \mathrm{I} 6$.

British monarchy, collapse of, $34 \mathrm{r}$.

Browne, John and Samuel, sent to England, 81.

Bunyan, John, 18.

Burdett, George, and Dudley, 240.

Burglars, 371.

Business habits of Dudley, 289.

Byron and Westminster Abbey, 436.

Calef, Robert, $42 \mathrm{I}$.

Calvinism, its influence for liberty in England, 47 ; in Massachusetts, 357,384 . 
Cam and the Isis, influence from, in America, rgo.

Cambridge, England, University, Puritan influence of, 31 ; home of Puritanism, 48 ; influence of, in America, 191 ; men in America, 256.

Cambridge and Oxford, 287.

Cambridge agreement, 72.

Cambridge, Massachusetts, first intended to be the capital, 92 ; founded by Thomas Dudley, 123 ; an early capital of Massachusetts, 123,124 ; canal in, 124 ; fortification of, 125 , 127 ; provision to secure beauty and safety of, 130, 131; early description of, 130-132; selectmen of, 132 ; or Boston to be the capital, 95, 96, 132, 135; the capital, $1634,15^{8}$; Cambridge faction, 190, 319 ; settlers from, in Connecticut, 210 ; synod of, 223,344 ; famous election at, 234; and the United Colonies, 326.

Capital crimes, 266.

Capital punishment and Miantonomoh, 312.

Carpenter, Willianı, 300.

Castle Island, Boston, 183 .

Catechism, shorter and longer, 342.

Cathedral service, $8 \mathbf{8 2}$.

Catholics, Roman, and Roger Williams, 137.

Caterpillars, 349.

Caucus, 170, 296.

Character of Dudley with the Earl of Lincoln, 34, 40, 41; established in England, unchanged in America, 102-104, 429.

Charles I., 33, 35; death of, and Dudley, 390.

Charles River and Dudley's land, 133.

Charlestown, Massachusetts, 78, 79, 83, 84 .

Charta, Magna, 30, 265, 17 I.

Charter of Harvard College, 243 ; in 1650 , 394.

Charter of Massachusetts, granted, 55 ; the question of its transfer to America considered, $52,70-75,145$; how regarded by the people, go; freemen and the, 94 ; removal to America, 66, 75, 145; writ of quo warranto, 185 ; ordered to be returned to England, 185 ; powers of, 348 .

Child, Major John, 337; a disturber in England, 346.

Child and parent, 359.

Children of Dudley by first marriage, there were five, $25,464,465,467,468,469$.

Children, protection of, 407 .

Christianity, planting of, in America, 76, 77 .

Chuff, Indian, and Roger Williams, $3 \times 3$.

Church of Sempringham, the old, 37,38 .

Church of England, and the Humble Request, 6o-63.

Church, First, $81-83$

Church in America, need of simple services in, 82 .

Church and state united, 20.

Church and the drama in Massachusetts, 267.

Church in New England, 260.

Church members only to be freemen, rig.

Church membership restriction limited, 365 .

Churches established on the model of that at Salem, I 6 .

Citizens not church members allowed to hold office, 365.

Clarke, Dr. John, second charter of Rhode Island, 201: soul liberty, 201; father of Rhode Island, 201.

Cleever, Rev. Mr., minister and friend of Dudley, 24 .

Clinton, Theophilus, fourth Earl of Lincoln, 31.
Clipsham, 49, 53.

Cloth : linen, cotton, and woolen, 272.

Clothing and the General Court, 254.

Coats of arms, Thomas and Joseph Dudley, 5.

Coddington, William, and wife, passengers on the Arbella, 58; letter of, to Dudley, 276 .

Coddington, Mrs. William, death of, 85

Coining money in Massachusetts, $4^{13}$.

Coke, Lord, 18, 26, 27, 5 r.

Cole, Robert, 300 .

College, the, committee appointed to take order for, 242.

Colony in distress upon arrival of Puritans, 77.

Common Pleas, Court of, and Dudley, 26, 2? 29, 51.

Common Prayer Book, disuse of, in America, $8 r$.

Common schools in Massachusetts, 255, 256, 366,367 .

Commonwealths in England and America, 289.

Compton family, friendly to Dudley family, 14.

Compton, Henry, or Baron Compton, $\mathrm{r}$.

Compton, William, family of, 12 .

Comptons not Puritans, 14.

Compton-Winyates, home of Dudley, 12.

Conant, Roger, at Salem, Mass., 55 .

Concord, land of Dudley at, $251-253$.

Confederacy of New England, 1643, 22 ; of colonies, 298 ; and familism, 354 ; the power of, in the world, 373 ; Dudley president of, in 1649, 389; and Massachusetts, 427.

Confession of Faith, 342, 344 .

Congregationalism in America, 82, 345.

Connecticut, settled from Massachusetts, 210 river, rights on, 283; Massachusetts and, in trouble, 376 ; river, retaliatory act, 394 .

Conscience and suffrage, 164 ; rights of, in Massachusetts, 357,358 .

Constitution of United States and Henry IV. of France, 22.

Conveyances, fraudulent, 272.

Corn, Dudley's trades in, vindicated, 111 ; prices of, 372.

Corn Hill, Boston, 155.

Cotton, Rev. John, minister of Dudley, 49; antagonistic to Hooker, 156 ; friend of Winthrop, 160 ; sermon on the stability of office, r6r; code of, not approved, 203; and the Council for Life, 212; and Wheelwright recant from Antinomian error, 224 ; letter from Sir Richard Saltonstall to, $24 \mathrm{I}$; letter of Dudley to, 257; the ministry of, 269; and Gorton, 305; and Hooker and Norton, influence of, in England, 343 .

Council for Life, Dudley of, 213 ; in the Hingham case, 336 .

Council of Plymouth, 55.

Council, the Standing, Dudley chosen member of, 213 .

Countess of Lincoln, 42, 77

Court of Common Pleas, England, 26, 27, 29, 51.

Court records, 255

Courts, the, acts of, revealed public opinion, 153 ; four General Courts to be held yearly, I70; county created, 215 ; General, time of, fixed, 215 ; county, 255 ; courts of Massachusetts, 392.

Cowes, Isle of Wight, Puritans at, 59.

Cradock, Matthew, 55; farewell of, to the Puritans, 60.

Cromwell, Oliver, 50 ; attempted emigration to America, 250; friendship of, to Massachusetts, 349; his attempt to colonize Ireland from America, 404. 
Cross cut out of the ensign by Endicott, 152 . Cruel punishments in Massachusetts, 139, 140. Cutshamekin, 302.

Cutts, Major-General Lord John, 461 .

Dana, Richard H., 8.

Dana, Richard H., Jr., 8.

Danforth, Rev. S., 417.

D'Aulnay, 350, $35 \mathrm{I}$.

Deeds, acknowledgment of, 272.

Democracy an early subject of solicitude, 94 ; dangers from, 171 ; and Massachusetts, 317 ; in Massachusetts, 335 .

Dennison, Daniel, 258, 465 ; Mrs. Patience, ${ }_{4}^{6} 5$; William, 258.

Deputies and assistants contest, 1643,189 .

Dexter, Thomas, relative importance of towns, 153 ; in the bilboes, 153.

Diary of Dudley, none, 91 .

Disability to hold office not limited to the Puritan state, 120, 121.

Discipline of the Assembly, rejected in America, 344 ; of the synod and the churches, 391 ; book of, adopted, 406.

Divine riglit of kings, 27.

Dod, Rev. Mr., minister and friend of Dudley, 24, 32.

Dogmatism in Massachusetts, 353.

Donne, John, 18.

Dorchester, settlement of, 85 .

Downing, Emanuel, at Sempringham, 44 ; and slavery, 333 .

Doyle, J. A., strictures on Dudley, 277.

Drama, immoral influence of, 267.

Dress, Court made rules upon, 186 ; superfluity in, 254 ; and rank, 4 ro.

Druillette, Father, in Boston, 399.

Dryden, John, 18.

Dudley Castle, 6, 7 .

Dudley family, friendly to Compton family, 14.

Dudley mansion, destroyed at Roxbury, 262.

Dudley, Anne (Bradstreet), 58, 464 .

Dudley, Baron, 6 .

Dudley, Dean, 3,4

Dudley, Deborah (Wade), 469.

Dudley, Dorothy, death of, 3 I 7 .

Dudley, Gov. Joseph, 8, 453; Harvard College and, 243-245; tomb of, 417; unpopularity of, injurious to Thomas Dudley, 434 ; agent to England, 454; president of New England, 455; prisoner in Boston, 455; Episcopalian, 457; quarrel with the Mathers, 458 ; and Richard Steele, $46 \mathbf{1}$; lieutenant-governor Isle of Wight, 461 ; exalted opinions respecting, 461,462 .

Dudley, Nercy, 58, 468; married John Woodbridge, 287.

Dudley, Paul, Chief Justice, 8,459 ; benefactor of the college, 243,417 ; sketch of, 472 .

Dudley, Paul, son of Thomas Dudley, 472 .

Dudley, Patience, (Dennison), 58, 465 .

Dudley, Robert, Earl of Leicester, 3.

Dudley, Roger, father of Thomas Dudley, 2, 3 ; connected by birth with Sir Philip Sidney, $2,3$.

Dudley, Samuel, 4, 58, 467 .

Dudley, Sarah (Keayne and Pacey), 58, 469.

Dudley, Thomas, birth of, 1 ; descended from the same ancestry as the Duke of Northum. berland, 3, 4, 6; name of, honored, 8, 9; more remarkable for life work than ancestry, 8, 9; a Puritan, not interested in ancestry, 9, 10; parents and childhood of, 1o; sister of, ro; family on side of mother probably
Puritan, but not thought to have been on father's side, ro; a Latin scholar, 11 ; and Mrs. Puefroy, $x 1$; associations in England, 13-18; courteous manners of, 15; was in Europe at a very important era, 18; joins the army, is made a captain, 17, 19, 20; popular in youth, 19 ; return to England from the war, 23, 24; married to Dorothy Yorke, 24; of gentle blood, 25 ; clerk of Judge Nicolls, 25 ; skillful in drawing legal papers, 25; was probably with Lord Compton until 1597,25 ; in London, 27-30; in service of the Earl of Lincoln, 31; Dudley and the Englislı statutes in opposition to the loan, 35 ; stewardship of Earl of Lincoln's estate, 39,40 ; conscientious, 40 ; character with the Earl of Lincoln, 40, 4I; a thorough business man, 4I : secured a match between the Earl of Lincoln and Lady Bridget, Countess of Lincoln, 42; his friends in England, 38, 40, 50; his associations in England, influence upon his character, 50-53; motives for emigrating, $5 \mathrm{r}$; considering the separations and sacrifices resulting from emigration, 52,53 ; Dudley and family passengers on the Arbella, 58; his history that of his country, 75, 91,425 ; would not emigrate without the charter, 52, 70-75; Dudley and Winthrop explore for places to settle, 78 ; Dudley and First Church covenant, 80 ; Dudley and family, first winter in Boston, 84 ; constant in attendance at church, 91 ; principal founder of Cambridge, 95,123 ; Dudley and Winthrop have a disagreement respecting the removal by Winthrop of his house from Cambridge, 96-98, 102, 104, 105; Dudley and family settled at Cambridge, 96; military knowledge. 96,97 ; character of, has suffered from the diary of Winthrop, 97 ; is said to have resigned his place as assistant in anger towards Winthrop, 97,98 ; represented unjustly as over-rash, 98,99 ; thought to have been strict with Roger Williams, 99 ; wisdom approved, 100; champion for the truth, roo; abuse of, roo; trusty pillar, roo; unjust epithets applied to him, 100; high praise from Winthrop and other contemporaries, roo; great forbearance of, ror ; consideration as to the propriety of his resignation, 101; resignation of, 101, 104; trades in corn criticised by Winthrop, 102; house of, not extravagant, 103, 104 ; the peacemaker, I01, ro4; no charges against, ro7; Dudley and Winthrop quarrel, 106-1 ro; said to have been in passion, 109; has the support of the mediators, rro-ri2; thrifty, r1 1 ; falsely represented as penurious, 11 I, 135; ministers sustain Dudley against Winthrop, 112 ; Dudley and the fort at Boston, 113,114 , 155, 156; Dudley and Winthrop at peace, 115; possessed a sincere, rugged character, II5; letter with reference to the sufferings of the first winter in Boston, 116 ; founded Cambridge, 123 ; residence of, in Cambridge, 123, 124; two hundred acres of land in Cambridge, 133 ; to exercise prophecy, 134; severe temper, 135; affectionate, 135 ; answer to Gardiner, $145^{-149}$; Dudley and the bishops, 147, 149; Dudley and the descent of Christ into hell, 146, 148; Dudley and impenetrable minds, 146, 149; not bigoted or intolerant, 149 ; not superstitious, 149 ; compared with Winthrop, 150, 194; Dudley and the cross in the ensign, $150-152$; controversy with Winthrop, 155; overcome by Boston 
faction, 157 ; absent from Court, 157 ; emigrates to Ipswich, 158 ; Winthrop and Dudley, importance of, in the colony, 159 ; governor, 1634, 160: with the people, 172; relation of, to Plymouth misunderstood, 173-181; Dudley and John Hocking, 173180; letter of, respecting Plymouth, 177, 179 ; Dudley and Winthrop in the Plymouth trouble, 181 ; as a soldier, 184 ; never had charges made against his administration of affairs, 186; Dudley and the negative voice, 189 ; patience of, 189 ; governorship of, and rotation in office, 190; Dudley and John Cotton, 190; entertainment of the Court in Cambridge, r92; Dudley and the cross in the ensign, 193; not fanatical, 194: Endicott compared with, 193; opinıon of Roger Williams, r94 ; charge of bigotry in Roger Williams case, 198 ; bitter things said of, 198 ; narrowness and bigotry of, 198; compared with Roger Williams, 200 ; courage of, 200 ; Dudley and the laws, 202; Dudley and fishing trade, 204; business qualities of, 204 ; severe strictures upon, 207 ; high opinion of Harry Vane, Mr. Peters, and Mr. Haynes respecting, 209; went to reside in Ipswich in 1635,211 ; wrote no tracts: Massachusetts is his answer and proof of his labor, 2 ro; vindication of himself, $21_{3}, 214$; popular, 214 ; loss of Hooker and Haynes sustained by, 217 ; obedience to conviction, 217 ; ensign on the fort, 217 ; much quoted, poetry of, 227 ; Mrs. Hutchinson and Dudley, 226-232; political liberality suggests religious liberality, 231 ; lieutenant-colonel, 233; foreign wars and Dudley, 236; letters of, to Winthrop, 236-238; Dudley and Lech. ford's book, 238; George Burdett and Dudley, 240; deliberation of, 240; Dudley and Harvard College, 242; generosity of, 246 , 247 ; Dudley and the Roxbury Latin School, 247; Dudley and the construction of the laws, 248; on the committee for making laws, 248; Dudley and Winthrop reconciled at Concord, $252 ;$ visit with Winthrop to Concord, 251-253; home at Roxbury, 256262 ; letter to John Cotton, 257 ; library of, 259-26r ; most eminent citizen of colonial Roxbury, 262 ; mansion destroyed, 262 ; constantly a magistrate, 263 ; Dudley and others deputed to make a draft of laws, 264 ; lawmaking, 264; Dudley and Winthrop compared, 271; governor in $1640,270,271$; quotations from contemporaries respecting him, 270, 271; approved by Wintlirop and others, 270, 271; Dudley and the ambitious ministers, 271 ; Dudley and Miantonomoh, 273 ; farm granted to, at Ipswich, 275 ; severely blamed for excluding Coddington and others in his answer, 276; Dudley and a letter of Eaton and others, 276; refusal to treat with Rhode Island, 276 ; strictures on, by Savage, Arnold, and J. A. Doyle, 277, 278 ; letter to Winthrop, 279; suit against Mr. Howe, 280 ; Winthrop and Dudley, first in dignity and importance, 209,282 ; resigns, 281; Dudley and Bellingham compared, 282 ; strictures on, by Arnold, 284 ; letter to John Woodbridge, 287 ; not sordid, 289; heart-burning of, in 1642,290 ; not disappointed in election, 290 ; defends the Standing Council, 294 ; literary style of, 297 ; Dudley and United Colonies, 298, 299 ; a foremost leader, 308; Dudley and Miantonomoh, 314: states his conviction to Rev. Mr.
Rogers, 316; second marriage to Catharine Hackburn, 319 ; Dudley and Winthrop party 319; major-general, 325 ; to receive public letters and donations, 326 ; Dudley and acknowledgment of gifts, 326; Dudley and Eliot neighbors in Roxbury, 328 ; Winthrop party triumph, 328 ; firmness of, 335 ; tact of, 336; Dudley and the English Revolution, 340; Dudley and the laws, 340 ; Dudley and the Body of Liberties, 340; Nowell, Bradstreet, only old assistants, 345 ; commissioner to Penobscot, 351, 352; commissioner of United Colonies, 360 ; Dudley and Hooker, friendship of, $36 \mathbf{r}$; Dudley and Rev. Mr. Eliot, friends, 362 ; Dudley and Eliot compared, 363 ; outranks Endicott, 373 ; deputy governor, 1648, 374; Dudley and Fenwick, 377; Dudley and Pynchon's letter, 378 ; reliance of Winthrop upon, 379 Dudley and Winthrop, friendship of, 380 381 ; relations of Dudley and Winthrop, 384 ; dependence of Winthrop upon, 384 ; tradition respecting last visit to Winthrop an error, 386; Dudley and long hair, 387 ; conmissioner in 1649 for the last time, 389 illness of, ${ }_{3} 89$; Dudley and the Confederation, 389 ; next to Winthrop, 389; Dudley and death of Charles I., 390 ; governor, 1650, 393 ; experience of, in America, 393 Dudley and Isaac Johnson, 394; Dudley and Bozoun Allen, 396 ; Dudley and Father Druillette, 399 ; testimony of the Court to, 400 ; letter of Gov. Winslow to, 400 ; signs petition to Parliament, $40 \mathrm{r}$; in office and out, 411 ; death of, 417 ; funeral of, 417 ; grave of, $4^{1} 7$; inscription on tomb, $417 ;$ Dudley and contracts, 417 ; trusty old stud, 417 ; a trusty pillar, 4 I9; children of, 422,453 , $464,465,467-469,472$; epitaph on, by Anne Bradstreet, 422; will of, 423 ; Dudley and heresy, 423; Dudley and Massachusetts inseparable, 425; Dudley and the Bible, 430; character in England and America considered, 430; poetry of, and fanatics, 430 ; Dudley and his critics, $43 \circ, 431$; not penurious, 431 ; good opinions by his contemporaries, 432-435; Increase Mather's opinion of, 432 ; fame impaired by Joseph Dudley, 433 ; president of the Confederacy, 435 ; name of, left out of the hall of representatives, 435 ; careless of his fame, 435; Dudley and Winthrop one in party and in faith, 435: Dudley and the higher law, 436; to public recognition in modern times, 436 ; sterling worth of, 436 ; the peer of any among the founders, 436 ; family of, distinguished, 462 ; letter of, to Countess of Lincoln, 437 .

Dudley, Mrs. Thomas, death of, at Roxbury, Mass., 1643,317 ; high praise of, from Winthrop and other contemporaries, 317 .

Dudley, Colonel William, $4^{17}$; sketch of, 475 . Dunkirkers, 64

Dutch, the, in Massachusetts, 299; of New Netherland, 374 .

Duties, repeal of, on goods of other colonies, 394 .

EDGE Hill, 12.

Educated ministry, 415.

Education in Massachusetts, 255, 329, 353 . 366 ; ancient and modern ideas of, 411 ; importance of, 415 .

Elders, the, and Roger Williams, 194.

Election sermon, 327 . 
Elections, change of method, 285 .

Electors, system of tens, 285 .

Eliot, Rev. John, and Dudley, 258; Eliot and Dudley neighbors in Roxbury, 328 ; anagram on Dudley, 329 ; opinion of Gorton, 346; Dudley and Eliot friends, 362; Dudley compared with, 363 ; Eliot and long hair, 388 ; grave of, 421 .

Emigrants, sick from hardships upon arrival, 77; return to England discouraged, 86.

Emigration from eastern counties to Massachusetts, 56; from America prevented, 139 ; from England ceased in 1640,274 ; to America, $54,250$.

Endicott, John, emigration to America, 56 Endicott and the cross in the ensign, 152 ; compared with Dudley, 193; Dudley and Endicott, 282 ; second to Dudley, 373; governor, 387 ; Endicott and the king's colors 388 ; Endicott and long hair, 388 ; rash and vindictive, 434 .

Enfranchised people, 335

England, Church of, in America, 8x.

England, government of Massachusetts in, abscinded from the charter, 68; Puritans in America, honest towards, 82 ; the Botany Bay of the colony, 92 ; appealed to, 263.

English Church and Williams, 136 .

English Revolution felt in America, 289.

Entertainment, place of, 268.

Enthusiasts, 210.

Episcopacy, 342.

Episcopal Church and the Humble Request, $60-63$.

Episcopalians and Roger Williams, 136; in Massachusetts, 337.

Epithets, some specimens applied to Dudley, 100.

Essex faction, 320 .

Estates in care of Dudley, 39.

Evelyn, John, i8.

Everett, Edward, touching words respecting the early emigration to America, 88 .

Fairfax, Lord Thomas, 50.

Faith, Confession of, 342,344

Familists, 2 ro.

Fanatics and Dudley's stanzas, 430.

Farewell to England of the emigrants, 59.

Fashion in the dress of women, 254.

Fashions, laws respecting, 186 .

Fast day brings rain, 270 .

Fasting and prayer, 325 .

Fens of Lincolnshire, $37,49,50$.

Fenwick, George, answer to letter of, 283 ; and

Saybrook, 375; and Massachusetts, 378 .

Feudal servitudes, 266.

Feudal system and New England, 57.

Fendalism extinguished, 286 ; in church, 338 ; in Masssachusetts, 393.

Fidelity, oath of, 414 .

Fiennes, William, Lord Saye and Sele, father of Bridget, Countess of Lincoln, 46 .

First Table of the Law and Williams, 136.

Fishing trade of Massachusetts, 204.

Fiske, Mr. John, strictures on the Dudley name, 7 .

Flemings, influence of, in England, 48.

Fort in Boston, finishing of, and palisade at Cambridge, $\mathrm{II}_{3}, \mathrm{x} 55$.

Fort Hill in Boston, 155 .

Fotheringay Castle, 20.

Franchise, limit of, 120, 121, 317; extreme boundary of, 335 .

Fraudulent conveyances, 272.
Freemen, one hundred and eighteen admitted, 93 ; cause of anxiety to the government, 93 ; by reason of modesty, delegate their powers, II8; to be church members, I19; become suspicious of the governor and assistants, 128; agitated over Winthrop, 162; important change in the oath of, 164 .

French on the north and east, 350 .

French, the, in Massachusetts, 299.

Friends arrive in Boston after decease of Dudley, 434 .

Funeral of Dudley, 417.

Galileo, 18.

Gardiner, Sir Christopher, 140, 141, 142, 144 ; answer to the petition of, $145^{-152}$.

General Court, construction of, 93 ; time of, fixed, 215; judicial powers taken from, 255.

Generosity of Dudley, 246, 247 .

Geraldine, wife of the first Earl of Lincoln,

37.

Gilbert, St., 36, 37, 43 .

Gilbertines, Order of, 36, 37 .

Goldman, Emma, sent to Massachusetts, 138 .

Gorges, Sir Ferdinando, 142, 144; Lady Frances, sister of Earl of Lincoln, 46 .

Gorton, Samuel, and Miantonomoh, 273 ; at Pawtuxet, 300 ; religious opinions of, 305 , 306 ; and Cotton, 305 ; admirers of, 312 ; a disturber in England, 346; allowed to pass through Massachusetts, 375 .

Gospel, the, propagating of, in Massachusetts, 392.

Gothic art, 21 .

Government of Massachusetts, construction of, 93 .

Governor and company, letter to brethren of the church, on departure for America, 60 .

Governor, the, and deputy, with assistants, to make the laws, 118 .

Grave of Thomas Dudley, 417 .

Graves, Thomas, 79 .

"Great House," the, Charlestown, 79, 80, 9r.

Great Tavern, 79.

Great Rebellion, 340.

Grove, Mary, 14I, 143.

Guns, leather, $37^{2}$.

Hackburn, Mrs. Catharing, matriage of, to Dudley, 319.

Halberts and swords, persons with, to attend the governor, 187 .

Hampden, John, 5o; attempted emigration to America, 250.

Harold at the battle of Hastings, and $\mathrm{New}$ England, 57.

Harvard College, founded, 225 ; the Dudley family and Harvard College, 243; public education and Harvard College, 255 ; Dudley and Harvard College, 286, 297; admission to, 287; the United Colonies and Harvard College, 326 ; in Massachusetts, 353; assisted 366 ; charter of, in 1650,394 ; donations to, 415 .

Haselrig, Sir Arthur, attempted emigration to America, 250.

Hastings, battle of, and Massachusetts, 57 .

Hawthorne, Nathaniel, description of Concord River, 252.

Haynes, Hon. John, in the family of Governor Dudley at one time, 124; in Cambridge, 130, 132 ; emigrates to Connecticut 158 ; friend of Dudley, 190 ; high opinion of Dudley, 209. 
Henry II., 36.

Henry IV. of France (Navarre), 3, 20-23.

Henry VIII., 12, 13; Lincolnshire and Henry VIII., 48 .

Herbert, George, 18.

Heresy, Scripture antidote for, 224.

Heroism of the Puritans, 86.

Herrick, Robert, 18.

Higginson, Rev. Francis, 55.

Higginson, T. W., 125.

Highways improved, 255 ; selectmen and highways, 293.

Hildersham, Arthur, minister of Dudley, 31 .

Hingham difficulty, 335 ; and Winthrop, 336.

Hobbes, Thomas, 18.

Hocking, John, slain at Kennebec, 173; Hocking and Dudley, 173-r8r.

Hogs, become of interest in securing the friendship of Winthrop and Dudley, 114; the cause of an important revolution, 162, 167, 168.

Holland, its influence on Lincolnshire and England, 48, 49 .

Holmes, Oliver Wendell, descended from Dudley, 8.

Hooker, Richard, 18

Hooker, Rev. Thomas, in the family of Dudley at one time, 124; first pastor at Cambridge, 132; antagonistic to Cotton, 156; emigration to Connecticut, 158, 188, 2 10, 217 . president of the Cambridge Synod, 223 ; the ministry of, 270; influence of, in Fngland, 343 ; Hooker and Dudley, friendship of, $36 \mathrm{x}$; death of, $36 \mathrm{r}$.

Hotels in America, 242.

Howard, Thomas, Earl of Surrey, 37.

Howe, Mr., title to a mill, 281 .

Hubbard, Rev. William, eulogy on Dudley, 422 ; opinion of Dudley, 434.

Humble Request, 60, 63 .

Humphrey, Lady Susan, sister of Earl of Lincoln, 46 .

Hutchinson, Mrs. Ann, 218 ; new heresies, 284.

Hypocrisie Unmasked, 311 .

IDOLATRY and Roger Williams, 136.

Immigration into Massachusetts in $1640,274$.

Independency in Massachusetts, 338 ; and Presbyterianism, 342.

Independent spirit in America, 289.

Indians, not permitted to bear arms, 92 ; to christianize, one of the great objects of the emigration, 117 ; care of, in Massachusetts, 272 ; kindness to, 76,275 ; the cursed race of Ham, 275; conspiracy of, 312 ; preaching to, 350 ; worship resisted, 357 ; Indians and Eliot, 362; Indians and the gospel in Massachusetts, 392.

Intemperance in general, 355 .

Intolerance of Dudley, 278 .

Ipswich, Dudley resided there from 1635 to 1639,211 .

Ireland, colonization of, from America declined, 404.

Irish, prejudice against, $4 \mathrm{I} 6$.

Ironsides of Cromwell, 50.

Ivry, battle of, 2, 3 .

JAMES I., 13.

Jeffrey, Lord, 18

Jesuits in Massachusetts, 365 ; in Boston, 399

Johnson, Lady Arbella, passenger on the Arbella, 58 ; on English soil for the last time, $60 ;$ in danger at sea, 64,$65 ;$ death of, 86 , 87; Dudley and Lady Johnson, 394.
Johnson, Edward, 303 ; opinion of Dudley, 433.

Jolinson, Isaac, and Lady Arbella, 37, 45, 58 ; the largest financial adventurer, 46 ; Johnson and Dudley, 49, 53 ; the Humble Request, 63 ; would not emigrate without the charter, 73 ; First Church covenant, 80,81 ; death of, 86,87 .

Jones, Margaret, a witch, 382 .

Jonson, Ben, $15,18$.

Judges, power of, $\mathbf{7} 7 \mathbf{I}$.

Judicial powers changed, 255.

Judith, Point, in Rhode Island, 4I4

Jurisdiction, foreign, 344 .

Jury, trial by, 171, 266.

Justice, distribution of, 215 .

Keayne, Benjamin, 253, 469.

Keayne, Captain Robert, commander of Ancient and Honorable Artillery in Boston, 253 ; and the sow, 314.

Keayne, Mrs. Sarah, 253, 469.

King Philip of Mount Hope, the successor of Miantonomoh in his purposes, 273 .

Kings, anointed, and Dudley, 149.

Knollys, Rev. Mr., Antinomian, profligacy of, 220.

LABOR, wages, and prices, $118,253$.

Land, contracts for, in writing, $4 \mathrm{I} 6$.

Land, free, and intolerance in Massachusetts, $272,273$.

Landholders in Massachusetts, 272.

La Tour, 350, 35 $\mathrm{r}$.

Laud, Archbishop, stirs up English government against Massachusetts, r8r; feared in Massachusetts, 223 ; Massachusetts and, 338.

Law, the First Table of the, 136 .

Law-making, 248, 264 ; books, 371 ; merchant, 395.

Laws of a people, indicate their progress, 9o, 395; made by governor and assistants, I 18; positive need of, 202; historic importance of, 248 ; laws of the colony, how made, 248 , 249 ; written, need of, 248 ; general, system of, 264 ; code of, in Massachusetts, 266; the first code of, in New England, 320; book of 1649,391 .

Lawyers in Massachusetts not popular, 203.

Learning, advancement of, 4 I 5 .

Leather, production of, 296 ; guns, 372 .

Lechford, Thomas M., 238.

Lecture to begin at one o'clock, 154 .

Legislation of Puritans in America, 90.

Legislative power in the hands of the governor and assistants, 95 .

Legislature, representative, of Massachusetts, its remarkable origin, 128 .

Leisler, Jacob, 455.

Letter of Dudley to the Countess of Lincoln, 42, 437; of Dudley to John Cotton, 257 ; Humble Request to English Church, 6o-63 ; of Sir Richard Saltonstall to Mr. Wilson and Mr. Cotton, 24.

Leyden, John of, 219.

Liberties, Body of, 203.

Libertines, Dudley's opinion of, 228,423 .

Liberty, new era of, in Massachusetts, 249; and the Puritans, 274; in Massachusetts, 393.

Liberty of thought, but not of action, 230 .

Library of Dudley, 259-26r.

Lincoln, Earl of, family of, $3 \mathrm{I}-42,46,47$; in the Palatinate, $34,3^{8}$; prisoner in the Tower, 36, 43. 
Lincoln family and Massachusetts, 45-47.

Lincoln, fourth Earl, and Dudley, 40, 41.

Lincoln, Countess of, and Dudley, 42, 77, 437.

Lincolnshire and Henry VIII., 48.

Literature in Massachusetts, 353.

Liturgy, set aside, $8 \mathrm{r}$.

Loans, forced, Charles I., 35.

Locke, John, 18.

Long hair in Massachusetts, 387 .

Long Parliament, 274 .

Longfellow, H. W., and Dudley's land, 133

Lowell, James Russell, on the narrowness of the Puritans, 99 ; poem respecting Hampden and Cromwell, 250; free land, free thouglit, in Massachusetts, 273 ; and the intolerant Puritans, 272.

Loyalty of the Puritans to the Church of England, 6o-64.

Luther and Antinomians, $222,232$.

MACAur.ay, statement of the political condition at the close of the French war, 22.

"Macedonian cry" suggested to the Puritans, 76 .

Magistrate, Dudley always one, 263.

Magna Charta, 265.

Malden, 78 .

Malefactors may be dissected, 366 .

Manners of Dudley, 15, 180 .

Mansfeld, Count, 34 .

Mansion House, Charlestown, 79.

Manual training, 370 .

Manufactures in England and the Flemings, 48; encouraged, 272.

Marlowe, Christopher, 18.

Mason, John, closed Pequot war, 218.

Massachusetts, and family of Lincoln, 45-47; charter of, granted, 55 ; people, from eastern counties of England, 56 ; charter, transfer to America considered, 66-75, 145; government of, in England, abscinded from the charter, 68 ; founders, honest in their use of the first charter, 70, 72, 90; history of, that of Dudley, 75-91; and Plymouth, 173-181, 427; early prosperity of, 249 ; severance of, early, in spirit from the mother country, 295; the strongest colony, 1643, 300,427 ; and persons outside of her territory, 299, 300; controversy with persons in Rhode Island, 30r; and Gorton, 305; a model in government, 308 ; foundation of her government, 309 ; and English civil war, 324 ; and slavery, 330 ; progress of, 355,356 ; founders not in search of gold, 356 ; leader in progress, $373,427,428$; in conflict with the United Colonies, 375 ; and Connecticut in trouble, 376; and the death of Charles I., 390; and Canada, 399; and Dudley inseparable, 425 ; the monument of Thomas Dudley, 426; her early construction, 426; and Plymouth compared, 427 .

Masters before the Court for the improper treatment of servants, 118 .

Mather, Cotton, opinion of Dudley's letter, I76; and Joseph Dudley, 457.

Matthews, Marmaduke, false account of, 208 ; and his heresy, 395 ; not banished, 395 .

Mayflower, the, 57

Medford, 85 .

Medicine, quack, prices of commodities determined by the Court, 118 .

Merchant, law, 395.

Miantonomoh, at the home of Dudley, 259, 273; fear of, in Massachusetts, 296; Gorton and, 305 ; and Uncas, 3 ro.
Midsummer Night's Dream performed in London on Sunday, 267.

Military knowledge of Dudley, 96 ; organization, 233 ; drill of boys, 328 .

Milton, John, 18, 50.

Ministers, maintenance of, first business in the colony, 91 ; not in civil authority, 120 ; determine who shall be freemen, 120: and the code, 203 ; ambition of, and Dudley, 271; and the government, 412 ; and political power, 427.

Ministry, educated, 415

Mistick, changed to Malden, 78 .

Money, need of, 272 ; coining of, in Massachusetts, $4^{13}$

Moral standard of servants, low in many instances, 118 .

Morals in Massachusetts in 1639, 267.

More, Sir Thomas, 6, 29.

Morton, Nathaniel, good opinion of Dudley, $388,432,433$.

Morton, Thomas, 92, 142, 324

Münster, fanatics of, 219 ; and Puritans, 311 .

Musselburgh, victory of, and Earl of Lincoln, 37.

NANTES, Edict of, 22.

Narragansetts, peace with, 334

Navarre, Henry of, $3,20,22$.

Needles, the, passed by the Arbella, 64 .

Negative voice in legislation, $189,317,335$ and the magistrates, 327 .

Netherlands, influence on Lincolnshire and England, $4^{8}$.

New England's Jonas, 337.

Newgate in Connecticut, 418 .

Newton, Sir Isaac, 18.

Newtown, approved, 78 ; first intended to be the capital, 92 ; chosen for the capital, 1630 , $92,95,98$; fortified, 1631,96 ; refuses to help on the fort at Boston, 113 .

Nicolls, Augustine, 4, 25, 27, 31 ; character and occupation of, 26,27 .

Nonconformists in the ascendency in Lincolnshire, $39,45,48$.

Normans against Saxons in Lincolnshire, 37.

Northampton, Dudley's residence at, 24 .

Northampton, Earl of, 1 ; Dudley the page of, $1,12$.

Norton, Charles Eliot, descended from Dudley, 8.

Nova Scotia, civil war in, 286.

OArH of freemen and suffrage, 164 ; not to be tendered to an nnregenerate man, Williams, 194 ; of allegiance to the king, 289; of allegiance omits the king, 289, 290.

Office, disability to hold, very general, $\mathbf{x 2 0}$ 121 ; rotation in, and Dudley, 161 .

Oldman, John, killed, 2 i 7.

Oligarchy, government not an, 94,95 .

Ordnance in Bcston, moved by Winthrop.

Oxford, England, influence of, in America, 101.

Oxford men in America, 256.

Pacey, Mrs. Thomas, 469.

Page, duties of a, 15-17.

Palatinate, expedition to the, 34,38 .

Palisade about Newtown (Cambridge) made by Dudley, 96,125 ; at Cambridge and the fort in Poston, $114,155,156$; of Dudley at Cambridge, the cause of representative legislature in Massachusetts, 127, 128, $155^{\circ}$ 
Parent and child, 359.

Parliament, petition to, 401 .

Patent, 55.

Paw'tuxet and Gorton, 300 .

Peace with the Narragansetts, 334; in 1645, 334.

Penobscot, 351, 352.

People, the, how far to be trusted, 93 .

Pepys. Samuel, 18.

Perjury and Roger Williams, 136, 137.

Pequot war, 217 .

Pesecus, warlike, 334.

Pester, Dorothy, leave to marry, 415.

Peter the Great and lawyers, 203 .

Peter the Hermit and Amiens, 20

Peters, Mr., high opinion of Dudley, 209.

Philip II. of Spain, 2 r.

Philip, King, of Mount Hope, the successor of Miantonomoh in his purposes, 273.

Phillips, Wendell, descended from Dudley, 8.

Piers Plowman, 26r.

Plymouth, Council of, 55 .

Plymouth and Massachusetts, 173-181, 427

Poetry of Dudley much quoted, 227, 430 .

Politicians and Massachusetts, 320 .

Politics and religion, 358 .

Polygamy is not tolerated, 229.

Powwow, Indian, 357 .

Prayer and fasting, 325, 416.

Prayer Book, 81, 342 .

Presbyterianism, $\mathbf{3 4 2}$.

Presbyterians of Hingham, 338.

Preston, Dr., influence with the Earl of Lincoln and Dudley, $34,35,38$.

Prices of commodities set at liberty, 153 ; wages and labor, 253 .

Priestcraft, worst element in politics, 358 .

Priesthoods and the government, 412.

Printing press, the, in America, 256; at Cambridge in 1639,275 .

Prisons, lack of, in America, 200, 418.

Privy Council, charges before, 144; favors Massachusetts, 144, 145.

Prohibitory law, 154.

Prosperity of Massachusetts, 154, 155, 249.

Providence, overruling, 326.

Puefroy, Mrs., and Thomas Dudley, Ir.

Puefroys, connected with Dudleys by marriage, $\mathbf{I r}$.

Pumham and Sacononoco against Gorton, 301.

Punishment in Massachusetts vindictive, 139, 140.

Puritan emigration to America of 1630, 54-66 ; strictness vindicated, 249.

Puritans not interested in ancestry, 9 , 10; in England, 39; letter of, to their brethren of the church on departing, $60-63$; in distress, 1630, 80 ; honest towards the Church of England in America, 82; adhere to the English Church, 120 ; had little confidence in persons without religion, 122 ; in England retaiued there in 1640,274 ; not fanatical, 274 ; and liberty, 274; in Massachusetts, 428, 429.

Pym, John, 50; attenipted emigration to America, 250.

Pynchon, William, and Springfield, Mass., 283 ; Pynchon's book, 398, 406 ; letter of, and Indians, 378 .

Pynchon, Mrs. William, death of, 85 .

QuARRel between Winthrop and Dudley, 97-105, 155, 156.

RAIN produced by fasting, 270 .

Raleigh, Sir Walter, 18.
Randolph, Edward, 454.

Ratcliffe, Philip, punished, 139.

Records of marriages, births, and deaths, 255 .

Religion and the state, 119-122, 327, 338, 342, 344,413 ; in politics, 358 ; foundation of the state, 359

Religious and political freedom, 23I ; stability in America, 343.

Representative government in Massachusetts, 285.

Representatives chosen, 93 ; House of, result of palisade, 155 .

Request, Humble, and the English Church, $60-63$.

Revelations, Antinomian, $22 \mathrm{~J}$.

Revolution, the, and an earlier one, 183 .

Rhode Island, Dr. John Clarke father of, 201; refusal by Massachusetts to treat with, $276,277$.

Richmond Hill, 30 .

Roads improved, 255.

Rogers, Rev. Ezekiel, 42 I.

Rogers, Rev. Nathaniel, kind woris of, respecting Dudley, 26r ; and Dudley, plain words, 316 ; encomium on Dudley, 412 .

Ross, Robert de, 30 .

Roxbury, 85 ; residence of Dudley, 256-262 ; Latin school, 259; free scliool, 329 ; tomb of Dudley at, 420.

Ruskin, Jolin, and the cathedral at Amiens, 21.

Russell, Lord Williain, 29.

SABbath-BREAKING and Roger Williams, 136.

Sacononoco, 301 .

Salem, arrival of the Puritans at, 77; did not please them, 77 .

Saltonstall, Sir Richard, passenger on the Arbella, 58; would not emigrate without the charter, 73; and a few others survived, 88; fined for absence from Court, 92 ; letter to Wilson and Cotton, $24 \mathrm{r}$.

Saltonstall, Richard, and the Council for Life, 213; and Bellingham against the assistants, 282, 294; book of, 293, 294; and Bellinghan against the magistrates in the sow business, 315.

Satan and the Scriptures, 366.

Savage, Mr. James, approves of Dudley's trades in corn, 102, 103; strictures on Dudley, 135; possible mistake of, 206; his defense of Wintlirop on the use of the word Antinomian, 228; note of, upon Dudley and Miantonomoh, 273; and bigotry, 276.

Saxon kings, graves of, and the emigration to America, 57.

Saxon in the Commonwealth of Massachusetts, 262 ; at the front, 339 .

Saxons against Normans in Lincolnshire, 37.

Say and Sele, Lord, daughter of, Countess of Lincoln, 42, 46.

Saybrook, the fort at, 375 ; settlement of, dispute at, 394 .

Schools; common, 255, 256, 366, 367, 427.

Scilly Isles and Sir Harry Vane, 65 .

Scots, Mary, Queen of, 20.

Scriptures, Holy, in Massachusetts, 412.

Sea, the, overcome in the lowlands of Lin. colnshire, 48 .

Seal on Gov. Thomas Dudley's will, 5-7.

Selden, John, 18.

Selectmen of Cambridge, 132.

Selectmen of towns, 266, 293. 



\section{RETURN CIRCULATION DEPARTMENT}

TO $\longrightarrow 202$ Main Library

\begin{tabular}{l|l|l}
\hline $\begin{array}{c}\text { LOAN PERIOD 1 } \\
\text { HOME USE }\end{array}$ & 2 & 3 \\
\hline 4 & 5 & 6 \\
\hline
\end{tabular}

ALL BOOKS MAY BE RECALLED AFTER 7 DAYS

1. month loans may be renewed by calling 642.3405

6-month loans may be recharged by bringing books to Circulation Desk

Renewals and recharges may be made 4 days prior to due date

\section{DUE AS STAMPED BELOW}

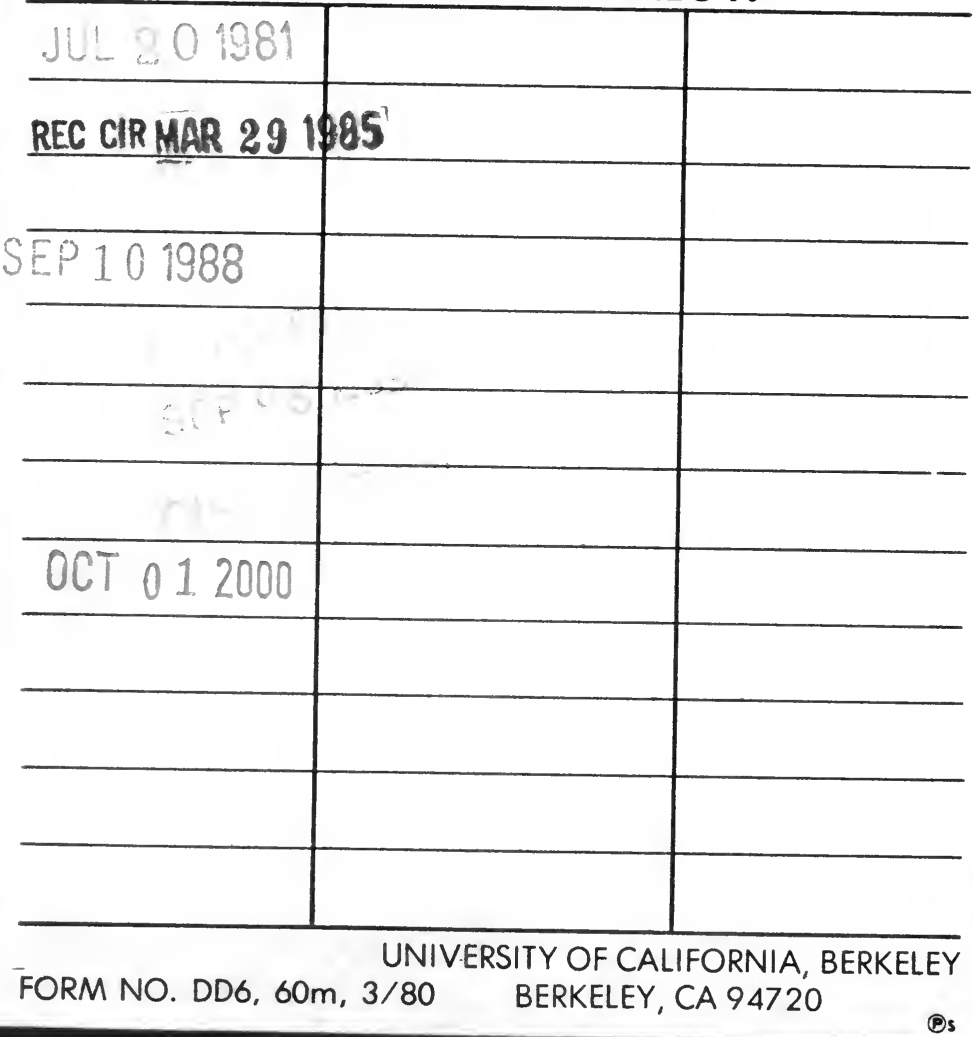




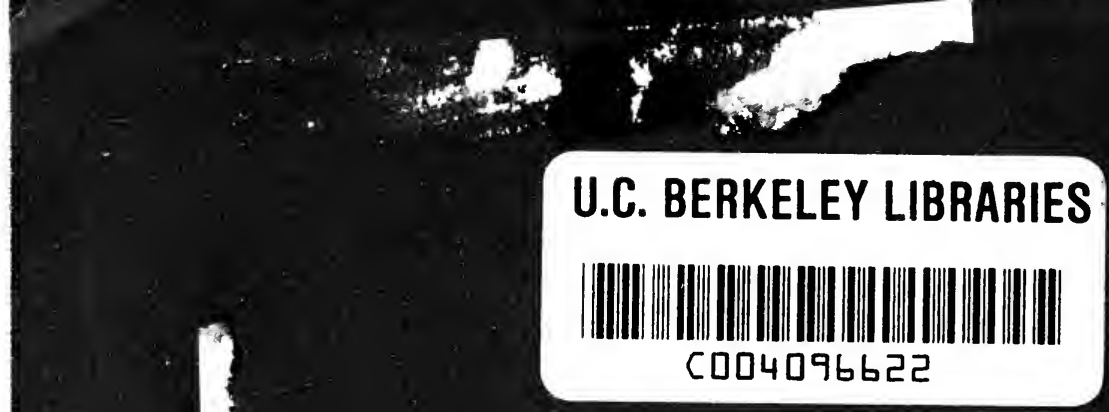

THE UNIVERSITY OF CALIFORNIA LIBRARY 
